Davi Fagundes Leal

\title{
Sobre perfis de aço formados a frio compostos por dupla cantoneira com seção "T" submetidos à compressão
}

\begin{abstract}
Dissertação apresentada à Escola de Engenharia de São Carlos da Universidade de São Paulo como parte dos requisitos necessários à obtenção do Título de Mestre em Engenharia de Estruturas.
\end{abstract}

Área de concentração: Estruturas Metálicas

Orientador: Prof. Dr. Jorge Munaiar Neto

\section{Versão Corrigida}

A versão original encontra-se na Escola de Engenharia de São Carlos - EESC / USP

São Carlos 
Aos meus pais, Ilton Curty Leal e Ione Fagundes Leal, e aos meus irmãos Ilton Jr., Fábio, Isaias e Flávia, com amor e gratidão. 
AUTORIZO A REPRODUÇÃO E DIVULGAÇÃO TOTAL OU PARCIAL DESTE TRABALHO, POR QUALQUER MEIO CONVENCIONAL OU ELETRÔNICO, PARA FINS DE ESTUDO E PESQUISA, DESDE QUE CITADA A FONTE.

Ficha catalográfica preparada pela Seção de Tratamento da Informação do Serviço de Biblioteca - EESC/USP

\begin{tabular}{|c|c|}
\hline \multirow[t]{3}{*}{$\mathrm{L} 435 \mathrm{~s}$} & $\begin{array}{l}\text { Leal, Davi Fagundes } \\
\text { Sobre perfis de aço formados a frio compostos por } \\
\text { dupla cantoneira com seção "T" submetidos à compressão / } \\
\text { Davi Fagundes Leal ; orientador Jorge Munaiar Neto. -- } \\
\text { São Carlos, } 2011 .\end{array}$ \\
\hline & $\begin{array}{l}\text { Dissertação (Mestrado-Programa de Pós-Graduação e Área } \\
\text { de Concentração em Engenharia de Estruturas) -- Escola de } \\
\text { Engenharia de São Carlos da Universidade de São Paulo, } \\
2011 \text {. }\end{array}$ \\
\hline & $\begin{array}{l}\text { 1. Estrutura de aço. 2. Elementos de aço formados a } \\
\text { frio. 3. Compressão. 4. Estabilidade estrutural. } \\
\text { 5. Incêndio. 6. Análise numérica. 7. Análise térmica. } \\
\text { 8. Análise não-linear. I. Título. }\end{array}$ \\
\hline
\end{tabular}




\section{FOLHA DE JULGAMENTO}

Candidato: Engenheiro DAVI FAGUNDES LEAL

Título da dissertação: Sobre perfis de aço formados a frio compostos por dupla cantoneira com seção "T" submetidos à compressão.

Data da defesa: 20/10/2011:

\section{Comissão Julgadora:}

Prof. Dr. Jorge Munaiar Neto (Orientador)

(Escola de Engenharia de São Carlos/EESC)

Prof. Dr. Rodrigo Ribeiro Paccola

(Escola de Engenharia de São Carlos/EESC)

Prof. Dr. Alex Sander Clemente de Souza

(Universidade Federal de São Carlos/UFSCar)

\section{Resultado:}

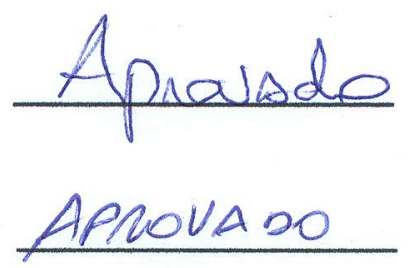

APROUADO

Coordenador do Programa de Pós-Graduação em Engenharia Civil (Engenharia de Estruturas):

Profa. Associada Ana Lucia Homce de Cresce El Debs

Presidente da Comissão de Pós-Graduação:

Prof. Associado Paulo Cesar Lima Segantine 
Primeiramente, agradeço aos meus pais, Ilton e Ione, verdadeiros exemplos de caráter, honestidade e dedicação para com a família. Só Deus sabe o quanto eu os amo!

Aos meus irmãos, Ilton Jr., Fábio, Isaias e Flávia, pela amizade e pelo incentivo nos estudos. Aos meus avós, Maria Aparecida de Medeiros e Antônio.

À minha namorada, Larissa, pelo carinho e cuidado.

Aos meus grandes amigos Diego, Rafael e Geraldo e ao meu primo Adriano, os quais considero como irmãos!

Ao meu orientador, Jorge Munaiar Neto, pela confiança, paciência e por estar sempre à disposição para ajudar.

Ao professor Maximiliano Malite, pelo apoio no desenvolvimento da pesquisa.

Aos amigos Wanderson e Saulo, pela grande ajuda na realização deste trabalho.

Aos professores da Universidade Federal de Viçosa (UFV), em especial à professora Rita de Cássia Alvarenga e aos professores José Luiz Rangel, Gustavo Veríssimo e José Carlos Bohnenberger.

Ao meu professor de Biologia no ensino médio, Régis, pelas palavras de incentivo que despertaram em mim o interesse pelos estudos.

Aos amigos da saudosa “Sala 7A” do SET (Rafael Eclache, Rafael “Maceió”, Rafael Tamanini e Emerson) e demais colegas do Departamento de Engenharia de Estruturas e do Departamento de Engenharia de Transportes da EESC/USP, pelo companheirismo e pelos momentos de diversão. 
Aos amigos que tive a felicidade de conhecer na Igreja Assembléia de Deus de São Carlos.

Ao Conselho Nacional de Desenvolvimento Científico e Tecnológico, CNPq, pela bolsa de estudos concedida.

E, acima de tudo e de todos, agradeço a Deus, pelas bênçãos que me tem concedido.

“Bendize, ó minha alma ao senhor, e tudo o que há em mim bendiga o Seu santo nome.” Salmos 103, 1 - Bíblia Sagrada "Porque desde a antiguidade não se ouviu, nem com ouvidos se percebeu, nem com os olhos se viu um Deus além de Ti, que trabalhe para aquele que nele espera.” Isaías 64, 4-Bíblia Sagrada 
"O temor do Senhor é o princípio da sabedoria..."

Provérbios 9, 10 - Bíblia Sagrada 
LEAL, D. F. (2011). Sobre perfis de aço formados a frio compostos por dupla cantoneira com seção “T” submetidos à compressão. Dissertação (Mestrado) - Escola de Engenharia de São Carlos, Universidade de São Paulo, São Carlos, 2011.

Atualmente, dentre os perfis de aço formados a frio (PFF) mais utilizados em sistemas estruturais correntes, merecem destaque aqueles compostos por duas cantoneiras ligadas entre si por meio de presilhas, apresentando seção na forma de “T”. Embora tenha utilização bastante difundida, pouco se sabe sobre o comportamento estrutural deste tipo de perfil, principalmente em relação aos modos de instabilidade a ele associados. No presente trabalho, são desenvolvidos, com base em ferramentas disponibilizadas no código computacional ANSYS, modelos numéricos em elementos finitos com a finalidade de se investigar o comportamento estrutural dos referidos perfis submetidos à compressão e, com isso, contribuir para futuras revisões nas especificações da ABNT NBR 14762:2010 referentes aos PFF compostos. Por meio de análises não-lineares, foi investigada a influência de diversos fatores na resposta estrutural dos perfis, como: a forma de introdução do carregamento (compressão centrada ou excêntrica), as condições de vinculação, a esbeltez global, as imperfeições geométricas iniciais, a espessura das cantoneiras e o número de presilhas. Os resultados numéricos indicam que os valores de força normal de compressão resistente, obtidos conforme a ABNT NBR 14762:2010, podem resultar bastantes conservadores, principalmente nos casos de menor esbeltez global. Adicionalmente, a quantidade e a distribuição das presilhas se mostram bastante influentes, tanto na capacidade resistente como nos modos de instabilidade predominantes dos perfis. Por fim, o trabalho prevê uma investigação introdutória sobre os perfis dupla cantoneira sob temperaturas elevadas, a fim de se verificar, em caráter exploratório, o seu desempenho em situação de incêndio. As análises termoestruturais realizadas apresentaram como resultado tempos de resistência ao fogo bem abaixo do valor mínimo especificado pela ABNT NBR 14432:2001, apontando à necessidade do uso de revestimento térmico nesses perfis e de estudos mais aprofundados sobre o assunto.

Palavras-chave: Estruturas de aço, Elementos de aço formados a frio, Compressão, Estabilidade estrutural, Incêndio, Análise numérica, Análise térmica, Análise não-linear. 
LEAL, D. F. (2011). About cold-formed double angles back-to-back under compression. Dissertation (Master) - Engineering School of São Carlos, University of São Paulo, São Carlos, São Paulo, Brazil, 2011.

Nowadays, among cold-formed steel members (PFF) commonly used in current structural systems, deserve to be highlighted those composed by two angles connected through intermediate fastener (stitch-fillers) forming a "T" section. Although its widespread use, little is known about its structural behavior, especially in what concerns instability modes. In this study, based on tools available on the ANSYS code, numerical finite element models were developed in order to investigate the structural behavior of these profiles under compression to contribute to future revisions of the ABNT NBR 14762:2010 specifications regarding PFF compounds. By using non-linear analysis, we investigated the influence of various factors in the structural response, namely, the loading introduction (compression-centric or eccentric), the boundary conditions, the global slenderness, the geometric imperfections, the angle thickness and the number stitch-fillers. The numerical results indicated that the compression resistance, obtained according to ABNT NBR 14762:2010, it is quite conservative, especially in cases of small global slenderness. Additionally, the stitch-fillers distribution proved its great influence both in the bearing capacity as in the determination of the instability modes. Finally, the study makes an introductory research on double angle profiles under high temperatures, in order to verify its performance under fire. The thermal analysis showed fire resistance results inferior to the minimum specified by ABNT NBR 14432:2001, indicating the need of using fire protection and further studies this subject.

Key-words: Steel structures, Cold-formed steel members, Compression, Structural stability, Fire, Numerical analysis, Thermal analysis, Nonlinear analysis. 

1 INTRODUÇÃO 1

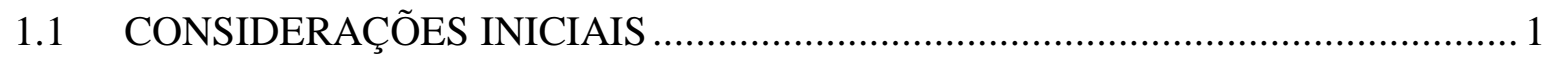

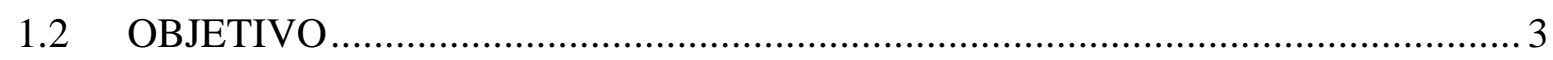

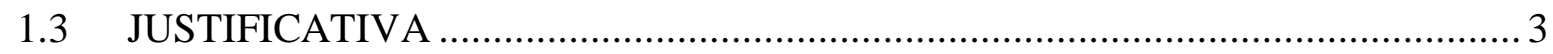

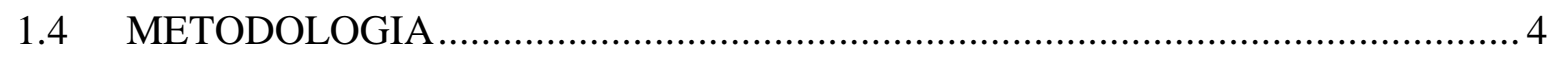

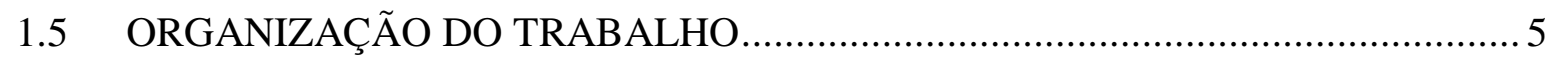

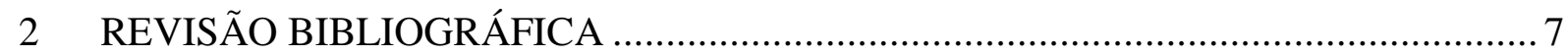

2.1 PERFIS DE AÇO SUBMETIDOS À COMPRESSÃO............................................ 7

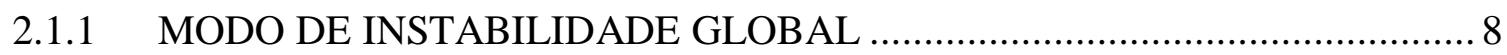

2.1.1.1 Instabilidade global por flexão ………………….................................. 8

2.1.1.2 Instabilidade global por torção ou flexo-torção ……………………………... 9

2.1.2 MODO DE INSTABILIDADE LOCAL ……………………........................ 12

2.1.3 MODO DE INSTABILIDADE DISTORCIONAL ...........................................17

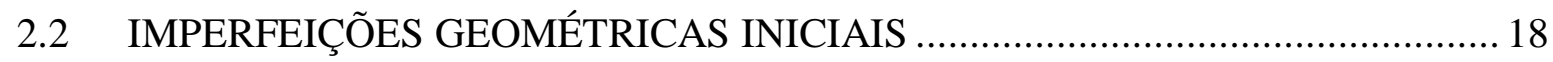

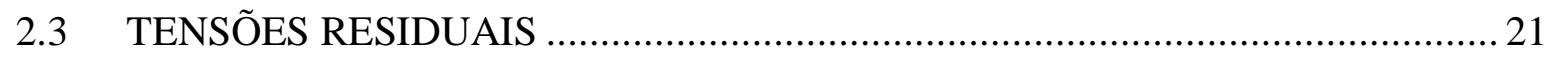

2.4 CANTONEIRA SIMPLES x DUPLA CANTONEIRA …......................................... 25

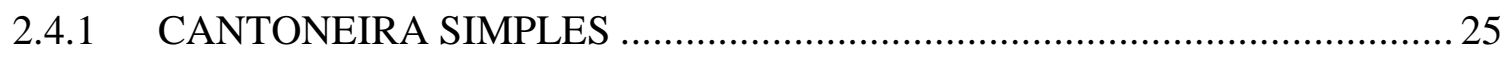

2.4.2 DUPLA CANTONEIRA ……………………………………………..... 27

2.5 SOBRE AS PRESCRIÇÕES NORMATIVAS - Breves comentários........................ 29

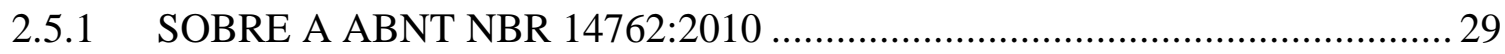

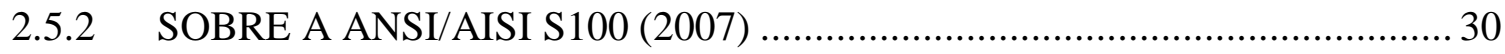

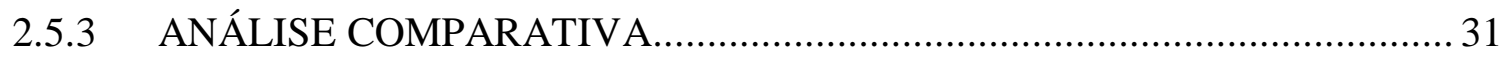

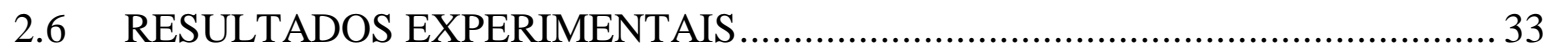

2.6.1 CHODRAUI (2006) - Resultados ........................................................................ 33

2.6.2 VISHNUVARDHAN \& SAMUEL KNIGHT (2008) - Resultados.................... 34 
2.7.1 PROPRIEDADES DO AÇO SOB TEMPERATURAS ELEVADAS ............... 38

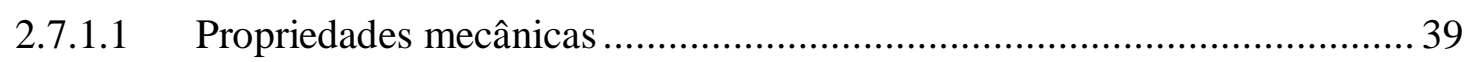

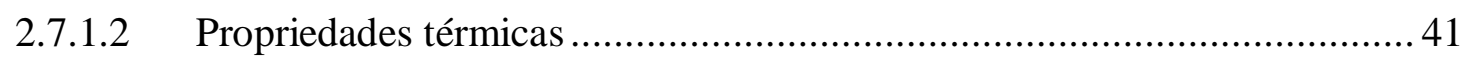

2.7.2 FORMAS DE TRANSFERÊNCIA DE CALOR ........................................... 43

2.7.3 MODELOS DE INCÊNDIO - Breve abordagem........................................ 45

2.7.4 TEMPO DE RESISTÊNCIA AO FOGO................................................... 48

3 ASPECTOS REFERENTES À MODELAGEM NUMÉRICA …............................... 51

3.1 ANÁLISES À TEMPERATURA AMBIENTE ................................................ 51

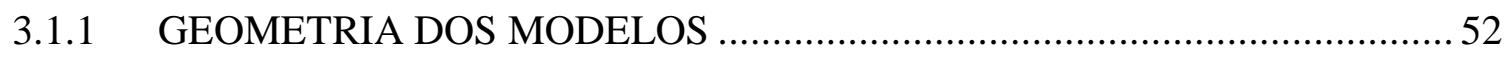

3.1.2 MALHA E ELEMENTOS FINITOS UTILIZADOS ................................... 58

3.1.3 CONDIÇÕES DE VINCULAÇÃO E DE CARREGAMENTO .......................63

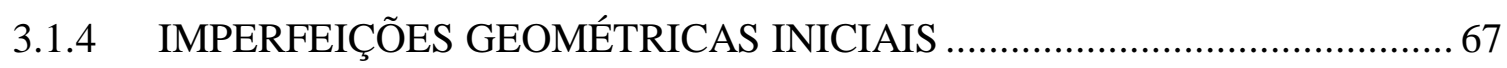

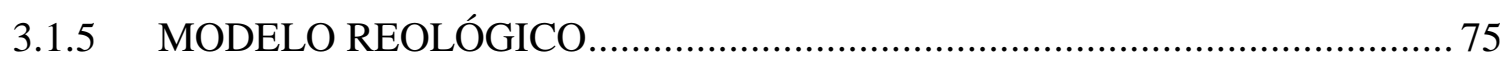

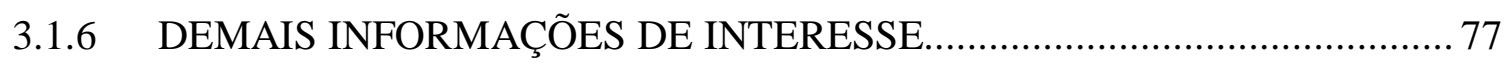

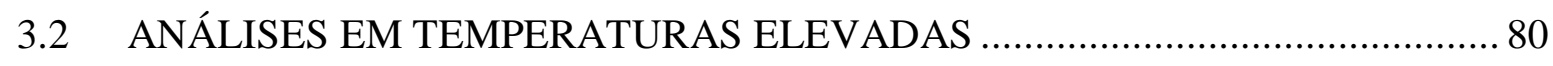

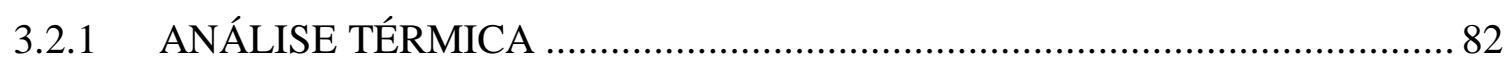

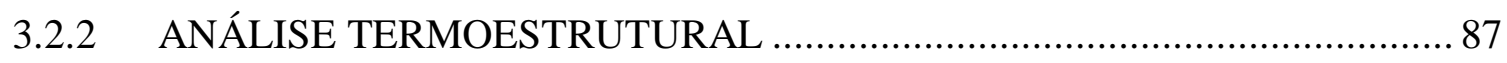

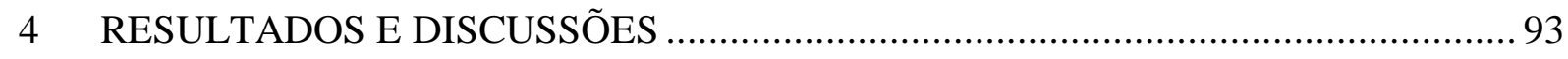

4.1 ANÁLISES À TEMPERATURA AMBIENTE ............................................ 93

4.1.1 COMPRESSÃO CENTRADA............................................................... 94

4.1.1.1 Análise de sensibilidade às imperfeições geométricas ............................ 94

4.1.1.2 Modelos finais: comparação com resultados teóricos e experimentais .... 107

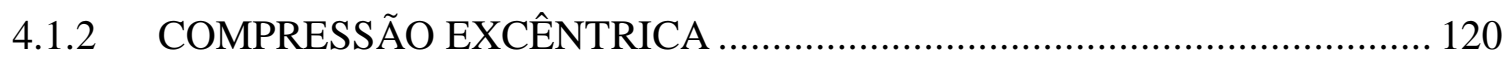

4.1.2.1 Análise de sensibilidade às imperfeições geométricas ........................... 120

4.1.2.2 Modelos finais: comparação com resultados teóricos ............................ 123

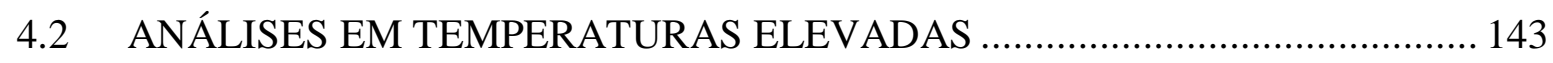


5 CONCLUSÕES

5.1 QUANTO ÀS ANÁLISES À TEMPERATURA AMBIENTE............................ 153

5.2 QUANTO ÀS ANÁLISES EM TEMPERATURAS ELEVADAS ...................... 156

5.3 SUGESTÕES PARA TRABALHOS FUTUROS ............................................ 157

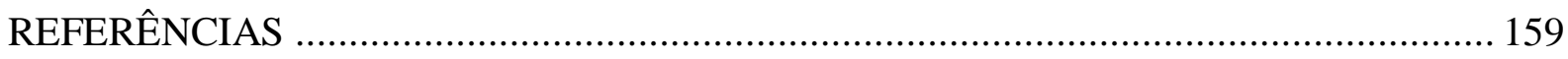

APÊNDICE A - Scripts para as análises à temperatura ambiente: compressão centrada...... 165 APÊNDICE B - Scripts para as análises à temperatura ambiente: compressão excêntrica ... 184 APÊNDICE C - Scripts para as análises em temperaturas elevadas ................................. 212 APÊNDICE D - Resultados das análises à temperatura ambiente: compressão centrada ..... 245 APÊNDICE E - Resultados das análises à temperatura ambiente: compressão excêntrica... 262 APÊNDICE F - Resultados das análises em temperaturas elevadas 310 



\section{CAPÍTULO}

\section{INTRODUÇÃO}

\subsection{CONSIDERAÇÕES INICIAIS}

A constante busca por estruturas mais leves e econômicas, aliado ao desenvolvimento de tecnologias que permitem a produção de aços com melhores propriedades mecânicas, tem impulsionado a aplicação dos chamados Perfis de Aço Formados a Frio em diversos tipos de sistemas estruturais, uma vez que estes apresentam elevada relação inércia/peso e podem, ainda, ser empregados com diversas formas de seção transversal.

Como o próprio nome indica, os Perfis de Aço Formados a Frio (PFF) são elementos estruturais obtidos por meio de algum processo de conformação à temperatura ambiente, seja por dobramento, em uma prensa dobradeira; ou por perfilagem, em um conjunto de matrizes rotativas. Assim, geralmente, são utilizadas chapas finas de aço para a sua produção (da ordem de 0,4 mm a 4,75 mm), o que permite obter perfis com relações largura/espessura dos elementos que compõem a seção transversal maiores se comparadas àquelas geralmente encontradas em perfis soldados ou laminados.

Tratando mais especificamente de peças solicitadas à compressão, essa elevada esbeltez local traz grande influência no comportamento estrutural do perfil, pois o torna ainda mais susceptível à ocorrência dos modos de instabilidades dos tipos local e distorcional (quando aplicável), além do clássico modo de instabilidade global (por flexão, torção ou flexo-torção). Em SCHAFER (1997) se ressalta que, devido a problemas de instabilidade, é comum que estes perfis de paredes finas atinjam o fim da sua capacidade resistente mesmo apresentando valores de tensões inferiores à resistência ao escoamento do material.

Dentre as seções mais utilizadas em PFF submetidos à compressão, destacam-se aquelas compostas por duas cantoneiras, ligadas entre si por meio de chapas intermitentes (chapas separadoras ou presilhas), dando origem a uma seção na forma de “T”. Este tipo de perfil é comumente empregado em componentes de treliças, estruturas tridimensionais para coberturas, sistemas de contraventamento etc., conforme os exemplos mostrados na Figura 1.1 e na Figura 1.2. Porém, apesar da sua larga utilização, pouco se sabe sobre o comportamento estrutural destes perfis, principalmente no que se refere aos modos de instabilidade a ele 
associados. Tal desconhecimento sobre o assunto acaba limitando as normas de PFF no que se refere à especificação de procedimentos de cálculo para o projeto deste tipo de perfil.
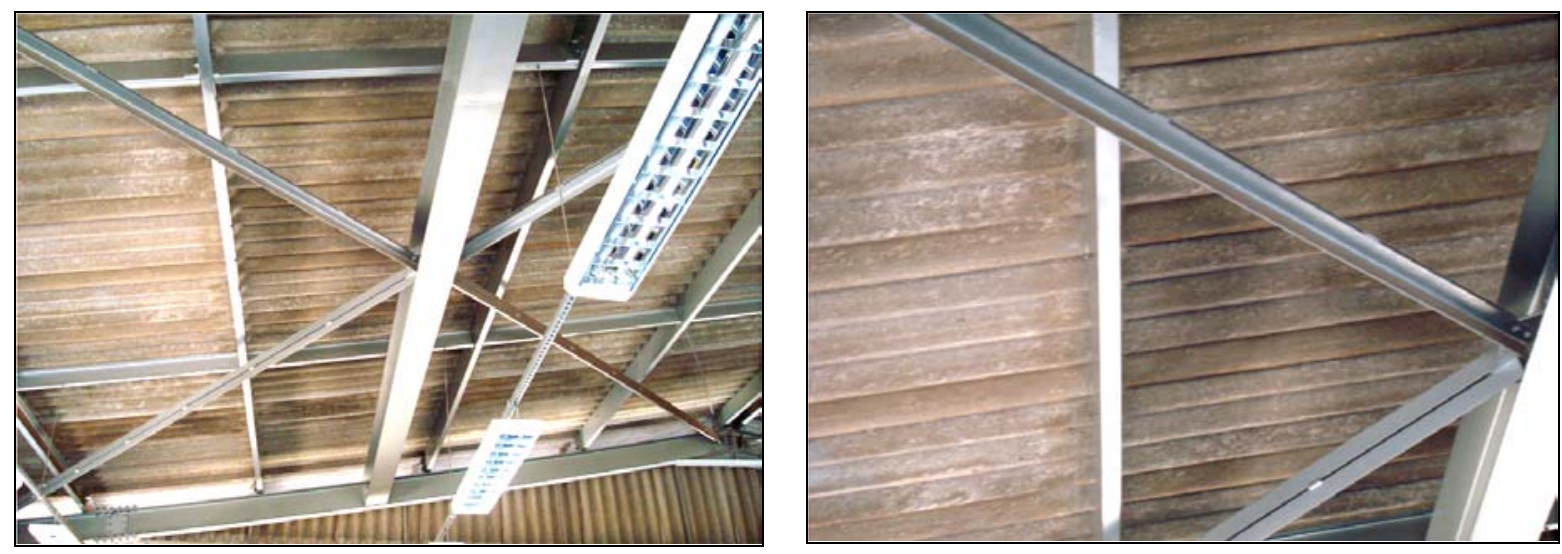

Figura 1.1 - Aplicação de PFF compostos por dupla cantoneira em "T” em um sistema de contraventamento de cobertura.
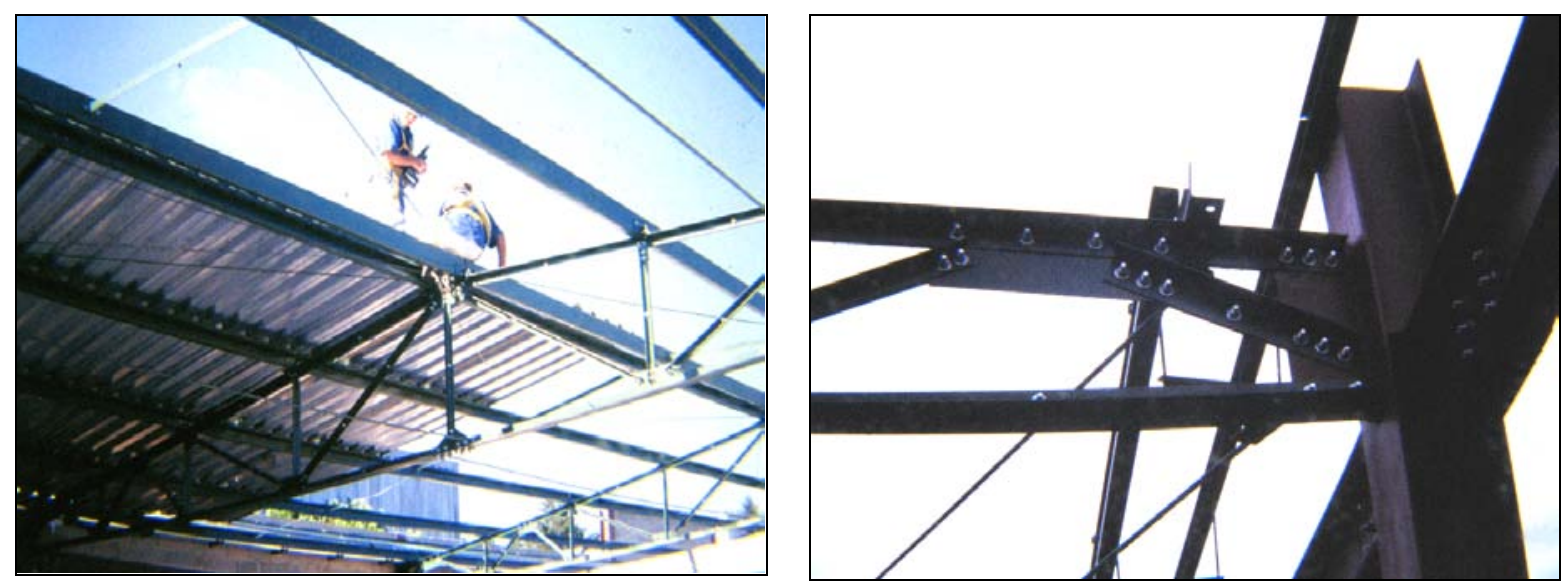

Figura 1.2 - Aplicação de PFF compostos por dupla cantoneira em “T” em uma treliça plana.

Além disso, em MAIA et al. (2008) e em MAIA et al (2009) é mencionado que cantoneiras simples submetidas à compressão apresentam comportamento estrutural bem particular quando comparadas aos demais perfis, nas quais se observam dois modos críticos na análise de estabilidade elástica: um modo global de flexão, no caso de barras mais longas; e um modo coincidente local-chapa/global de flexo-torção, que é crítico para barras de menor comprimento.

Desta forma, passa a ser interessante realizar estudos mais aprofundados sobre o comportamento de barras de PFF compostas por dupla cantoneira, uma vez que, além dos modos de instabilidade referentes às cantoneiras isoladas, poderão ocorrer modos de instabilidade associados à barra composta em função da presença das chapas separadoras (presilhas), que tendem a modificar o comportamento do sistema. 


\subsection{OBJETIVO}

O presente trabalho tem por objetivo desenvolver, por meio de modelos numéricos, estudos que visam caracterizar o comportamento estrutural de perfis de aço formados a frio compostos por dupla cantoneira com seção transversal na forma de “T” em temperatura ambiente, de forma a se verificar, dentre outros resultados, as suas respectivas resistências à compressão e os modos de instabilidade predominantes. Este estudo visa, ainda, averiguar se os valores da força normal de compressão resistente, obtidos de acordo com as prescrições da ABNT NBR 14762:2010, resultam satisfatórios. Por fim, o trabalho prevê uma investigação introdutória sobre os perfis em questão submetidos a temperaturas elevadas, a fim de se obter uma estimativa, ainda que em caráter exploratório, do tempo de resistência ao fogo e da temperatura em que ocorre o colapso dos mesmos.

\subsection{JUSTIFICATIVA}

Conforme exposto anteriormente, os PFF compostos por dupla cantoneira com seção “T” têm seu uso bastante difundido em sistemas estruturais diversos, tais como aqueles apresentados nas Figura 1.1 e Figura 1.2. No entanto, historicamente, a aplicação dos PFF na construção civil antecedeu às pesquisas sobre o comportamento estrutural dos mesmos. Mesmos nos dias atuais, apesar de as inúmeras pesquisas realizadas já terem tornado relativamente bem conhecidos os fenômenos de instabilidade, existem ainda muitas dúvidas sobre o comportamento dos PFF em geral, sobretudo em relação à interação entre os modos de instabilidade e os seus efeitos na resistência dos perfis.

A situação é ainda mais complexa para esses casos de perfis compostos, uma vez que o comportamento do conjunto depende não somente do comportamento de um perfil isolado, mas também da interação entre dois (ou mais) perfis devido à presença das presilhas. Alguns estudos já foram desenvolvidos para barras compostas por perfis pesados, incluindo a composição de cantoneiras laminadas; porém, a quantidade de pesquisas voltadas para os perfis formados a frio do tipo dupla cantoneira é ainda muito pequena, tanto no campo experimental quanto no numérico. Desta forma, são necessários estudos mais aprofundados sobre esses perfis para um melhor entendimento do seu comportamento estrutural e, com isso, dar base para novas especificações normativas e para a melhoria das já existentes. 


\subsection{METODOLOGIA}

Os estudos aqui desenvolvidos se baseiam em modelos numéricos discretizados em elementos finitos e construídos por meio da utilização do código computacional ANSYS, sendo consideradas as não-linearidades geométrica e de material nas análises. Tomaram-se como base, principalmente, as estratégias adotadas em ALMEIDA (2007) e em MAIA (2008), ajustando os modelos às particularidades dos perfis aqui estudados.

Primeiramente, foram feitas análises à temperatura ambiente dos perfis submetidos à compressão centrada, com as mesmas características dos ensaios apresentados em CHODRAUI (2006), de forma a comparar os resultados obtidos e, com isso, calibrar os modelos numéricos criados. Para tanto, foram realizados inicialmente diversos testes na modelagem, tais como: refinamento da malha de elementos finitos, redução do passo de carga, uso de ferramentas e opções de processamento disponibilizadas pelo ANSYS, aplicação de elementos de contato em locais estratégicos e uma ampla análise de sensibilidade às imperfeições geométricas iniciais.

Em seguida, passou-se ao estudo, também à temperatura ambiente, dos perfis submetidos à compressão excêntrica, situação mais comumente encontrada na prática. Esta etapa também contou com uma análise de sensibilidade às imperfeições geométricas, visando selecionar imperfeições coerentes e que exercem maior influência na resistência dos perfis (situação mais desfavorável). Foram criados modelos para duas espessuras da chapa que compõem as cantoneiras (3,0 mm e 1,5mm), fazendo-se variar a esbeltez global do perfil e o número de chapas separadoras (presilhas).

Por fim, foi realizado um estudo introdutório dos perfis submetidos à compressão em temperaturas elevadas, com base na estratégia empregada em REGOBELLO (2007) e aperfeiçoada em SANTOS (2009), KIMURA (2009) e DORR (2010). Este estudo consiste em análises termoestruturais dos perfis submetidos à compressão centrada nos quais é aplicado um gradiente térmico, visando estimar, para um determinado nível de carregamento, o tempo de resistência ao fogo e a temperatura em que ocorre o colapso. 


\subsection{ORGANIZAÇÃO DO TRABALHO}

A presente dissertação está organizada em cinco capítulos, nos quais são apresentados assuntos de interesse e os detalhes da pesquisa aqui desenvolvida. Segue uma breve descrição de cada um dos capítulos.

- Capítulo 1: é o atual capítulo, onde é feita uma introdução para contextualizar o leitor com o assunto aqui estudado. Os principais objetivos do trabalho também são apresentados, seguido das justificativas para a realização da pesquisa desenvolvida e de um resumo da metodologia empregada na mesma.

- Capítulo 2: neste capítulo, é feita uma revisão da bibliografia que trata de temas relacionados ao presente trabalho, no intuito de se fazer um resumo dos conceitos envolvidos no estudo dos perfis formados a frio submetidos à compressão, tanto em temperatura ambiente como em temperaturas elevadas.

- Capítulo 3: neste capítulo, é descrita toda a metodologia utilizada para a modelagem numérica em elementos finitos, detalhando os aspectos referentes à construção dos modelos e as diferentes análises numéricas envolvidas (análises elásticas, análise térmica, análise nãolinear em temperatura ambiente e análise termo-estrutural).

- Capítulo 4: é onde estão apresentados todos os resultados obtidos por meio das análises numéricas, a partir dos quais são feitas comparações com os resultados experimentais existentes na literatura e com as atuais prescrições normativas.

- Capítulo 5: este capítulo traz as conclusões referentes ao presente trabalho, além de sugestões para pesquisas futuras. 



\section{CAPÍTULO}

\section{REVISÃO BIBLIOGRÁFICA}

\subsection{PERFIS DE AÇO SUBMETIDOS À COMPRESSÃO}

Em geral, os perfis de aço são empregados como elementos estruturais com seções transversais compostas de chapas finas, o que permite aumentar a inércia da seção por meio da forma e, conseqüentemente, reduzir o peso da estrutura. Porém, esta característica pode alterar significativamente o comportamento estrutural das barras quando submetidas a esforços de compressão, uma vez que passa a envolver possíveis instabilidades das chapas que compõem o perfil e instabilidades relacionadas à torção da barra como um todo.

Isso é ainda mais evidente nos perfis formados a frio (PFF), pois estes geralmente possuem relações largura/espessura dos elementos componentes da seção ainda maiores do que aquelas apresentadas pelos perfis soldados ou laminados. Dessa forma, em vez da plastificação da seção, os PFF são mais propensos a entrarem em colapso devido à ocorrência dos chamados modos de instabilidade local, distorcional (em perfis com enrijecedor de borda) ou global; ou, ainda, numa situação em que há a interação entre esses modos, onde um modo induz o aparecimento do outro.

Segundo YU (2000), a ocorrência dos diferentes modos de instabilidade depende, dentre outros fatores, das características geométricas do perfil, como: forma da seção transversal, esbeltez global da barra e esbeltez local dos elementos que compõem a seção transversal. Além destes, na última referência se destaca, também, a grande influência de imperfeições geométricas iniciais, propriedades do material, excentricidades de carregamento e condições de vinculação da barra.

A seguir, é apresentada uma breve revisão teórica sobre os modos de instabilidade aos quais estão sujeitos os PFF sob compressão. Neste trabalho, por vezes será utilizado o termo flambagem (que está associado a problemas de bifurcação de equilíbrio em sistemas ideais) para se referir a um fenômeno mais amplo denominado instabilidade, que é o que ocorre na prática. Embora conceitualmente diferentes, ambos os termos têm sido utilizados para identificar problemas de instabilidade. 


\subsubsection{MODO DE INSTABILIDADE GLOBAL}

Trata-se de um modo de instabilidade na barra como um todo, podendo, de acordo com as propriedades geométricas do perfil e suas condições de vinculação, se apresentar sob três formas diferentes: instabilidade global por flexão, por torção ou por flexo-torção.

\subsubsection{Instabilidade global por flexão}

A instabilidade global por flexão é caracterizada pelo movimento de corpo rígido da seção transversal em resposta ao deslocamento transversal do eixo da barra, o qual assume uma configuração curva. Trata-se da ocorrência de flexão em torno de um dos eixos principais de inércia da seção transversal devido a um esforço de compressão maior do que o crítico.

Na Figura 2.1 é ilustrado um caso geral de flambagem elástica por flexão dos PFF compostos por dupla cantoneira, cuja seção, com a forma de “T”, possui apenas um eixo de simetria (monossimétrica). Neste caso, a flambagem por flexão ocorre em torno do eixo-x de menor inércia (eixo de não-simetria), sendo representada na figura pela translação $\delta$ da seção transversal.
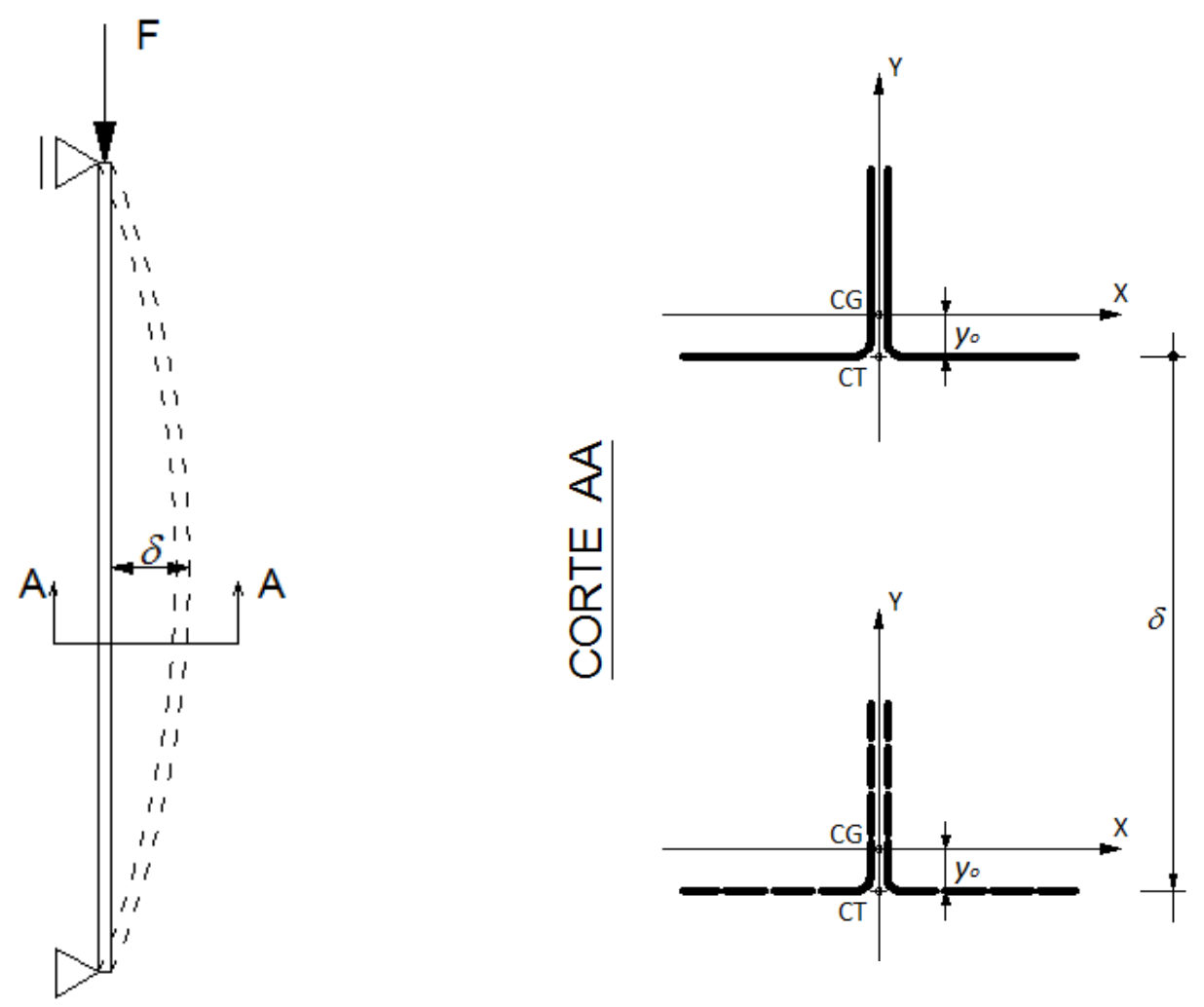

Figura 2.1 - Instabilidade global por flexão do perfil dupla cantoneira com seção “T”. 
Considerando o caso de flambagem elástica, na qual as tensões atuantes não ultrapassam a tensão de proporcionalidade, a força normal crítica é dada pela clássica expressão deduzida por Euler, conforme as Equações (2.1) e (2.2).

$$
\begin{aligned}
& N_{e x}=\frac{\pi^{2} E I_{x}}{\left(K_{x} L_{x}\right)^{2}} \\
& N_{e y}=\frac{\pi^{2} E I_{y}}{\left(K_{y} L_{y}\right)^{2}}
\end{aligned}
$$

Onde:

$N_{e x}$ - é a força normal de flambagem elástica por flexão em relação ao eixo x;

$N_{e y}$ - é a força normal de flambagem elástica por flexão em relação ao eixo y;

$I_{X}$ - é o momento de inércia em relação ao eixo x;

$I_{y}$ - é o momento de inércia em relação ao eixo y;

$K_{x} L_{x}$ - é o comprimento efetivo de flambagem por flexão em relação ao eixo x;

$K_{y} L_{y}$ - é o comprimento efetivo de flambagem por flexão em relação ao eixo y;

$E$ - é o módulo de elasticidade longitudinal.

Em casos de tensões atuantes acima da tensão de proporcionalidade, que está diretamente ligada às tensões residuais $\left(f_{p}=f_{y}-f_{r}\right)$, a flambagem ocorre em regime elastoplástico, o que exige um ajuste nas equações da força normal crítica a fim de se considerar o comportamento inelástico do material. Para isso, podem ser utilizados os conceitos do Módulo de Elasticidade Tangente $\left(E_{t}\right)$ ou do Módulo de Elasticidade Reduzido $\left(E_{r}\right)$, que passam a substituir o módulo de elasticidade longitudinal (E) nas Equações (2.1) e (2.2). Maiores informações sobre a teoria que envolve os módulos de elasticidade tangente e reduzido são apresentadas em GALAMBOS \& SUROVEK (2008) e em YU (2000).

\subsubsection{Instabilidade global por torção ou flexo-torção}

Ao contrário das barras com seção fechada, que possuem elevada rigidez à torção, as barras submetidas à compressão centrada com seção transversal aberta, com ou sem simetria, e composta de chapas finas estão sujeitas à instabilidade global por torção, que é 
caracterizada pela rotação da seção transversal em torno do seu centro de torção (centro de cisalhamento) sem sofrer deformações no plano da mesma.

Para o caso mais específico de barras com seção monossimétrica, a posição do centróide (CG) não coincide com a posição do centro de torção (CT), o que as torna susceptíveis à ocorrência do modo de instabilidade global por flexo-torção quando submetidas a uma força de compressão atuante em seu CG. Nesta situação, além da rotação da seção em torno do CT, ocorre ainda a translação da mesma em resposta ao aparecimento simultâneo dos esforços de torção e flexão na barra.

A Figura 2.2 ilustra um caso geral de instabilidade por flexo-torção de PFF compostos por dupla cantoneira com seção " $\mathrm{T}$ ”, que se enquadram na categoria dos perfis monossimétricos. Neste caso, sendo o eixo-y o eixo de simetria da seção transversal, a força de compressão $(F)$ aplicada no CG gera ou flexão em torno do eixo-x de menor inércia (situação explicada no item 2.1.1.1) ou torção $(\phi)$ associada a uma flexão $(\delta)$ em torno do eixo-y de maior inércia (eixo de simetria), ou seja, a barra fica submetida à flexo-torção.
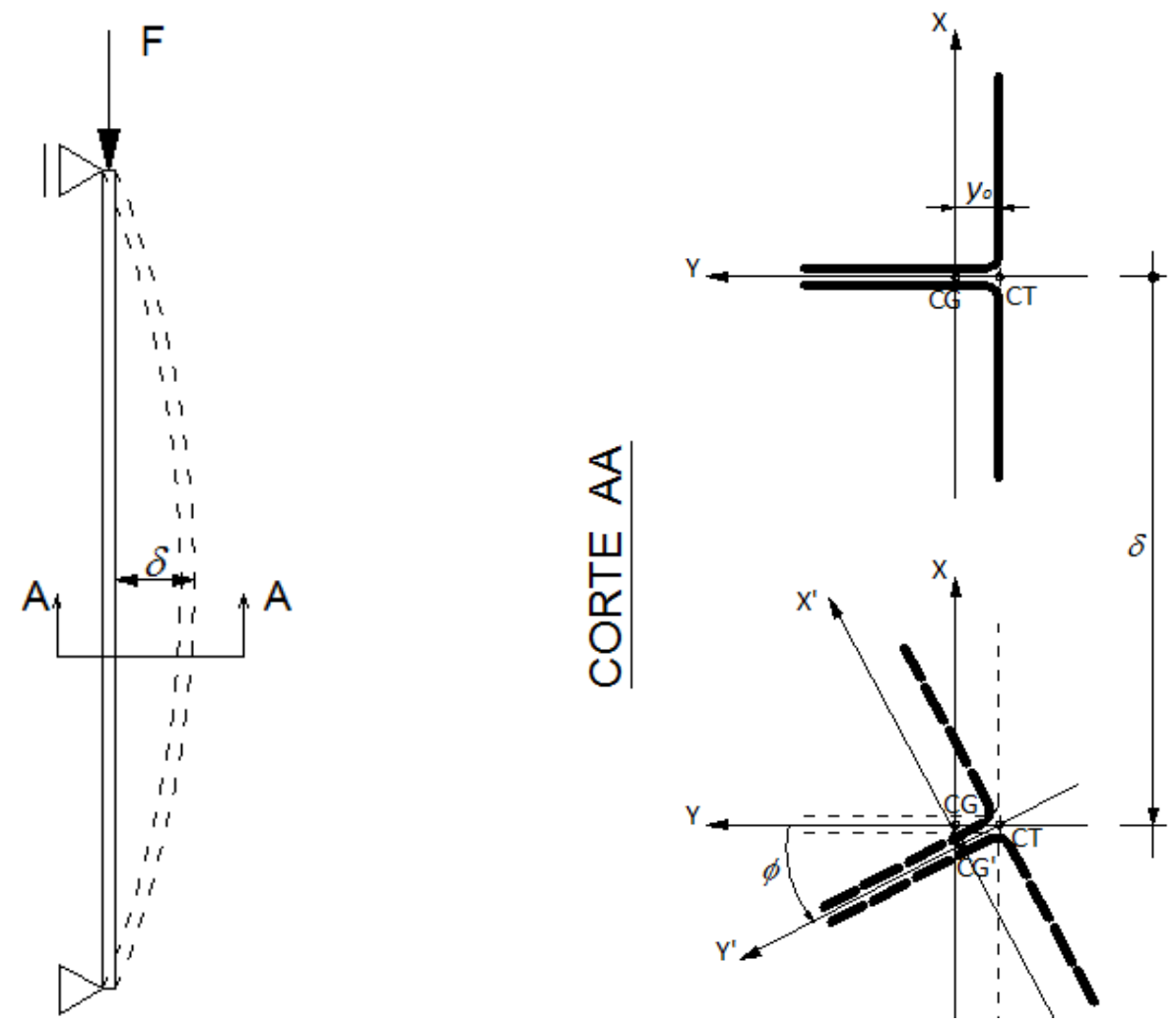

Figura 2.2 - Instabilidade global por flexo-torção do perfil dupla cantoneira com seção “T”.

Por meio da Teoria de Estabilidade Elástica (TIMOSHENKO \& GERE, 1961; CHAGES \& WINTER, 1965) é possível obter equações para o cálculo da força normal de 
flambagem por torção e de flambagem por flexo-torção de uma barra com seção monossimétrica sob compressão centrada, conforme as Equações (2.3) e (2.4), respectivamente, sendo y o eixo de simetria da seção transversal.

$$
\begin{aligned}
& N_{e z}=\frac{1}{r_{0}^{2}}\left[\frac{\pi^{2} E C_{w}}{\left(K_{z} L_{z}\right)^{2}}+G I_{t}\right] \\
& N_{e y z}=\frac{N_{e y}-N_{e z}}{2\left[1-\left(y_{0} / r_{0}\right)^{2}\right]}\left[1-\sqrt{1-\frac{4 N_{e y} N_{e z}\left[1-\left(y_{0} / r_{0}\right)^{2}\right]}{\left(N_{e y}+N_{e z}\right)^{2}}}\right]
\end{aligned}
$$

Onde:

$N_{e y}$ - é a força normal de flambagem elástica por flexão em relação ao eixo y;

$N_{e z}$ - é a força normal de flambagem elástica por torção;

$N_{\text {eyz }}$ - é a força normal de flambagem elástica por flexo-torção;

$y_{0}$ - é a distância do centro de gravidade ao centro de torção;

$r_{0}$ - é o raio polar de giração;

$I_{y}$ - é o momento de inércia em relação ao eixo y;

$K_{y} L_{y}$ - é o comprimento efetivo de flambagem por flexão em relação ao eixo y;

$K_{z} L_{z}$ - é o comprimento efetivo de flambagem por torção;

$I_{t}$ - é o momento de inércia à torção uniforme;

$C_{w}$ - é a constante de empenamento da seção ( $C_{w} \cong 0$ para dupla cantoneira em “T”);

$E$ - é o módulo de elasticidade longitudinal;

$G$ - é o módulo de elasticidade transversal.

Tendo exposto o conceito dos três modos de instabilidade global (por flexão, torção ou flexo-torção), resta identificar para quais faixas de esbeltez cada um deles é predominante. Apresenta-se na Figura 2.3, para uma visualização inicial, um exemplo de análise global de estabilidade elástica de um PFF composto por dupla cantoneira com seção “T” (2L 60x3,00), com extremidades rotuladas e submetido à compressão centrada. O gráfico esquematiza as curvas obtidas por meio das Equações (2.1), (2.2), (2.3) e (2.4), onde se relaciona a força crítica de flambagem elástica ao comprimento do perfil em questão. 


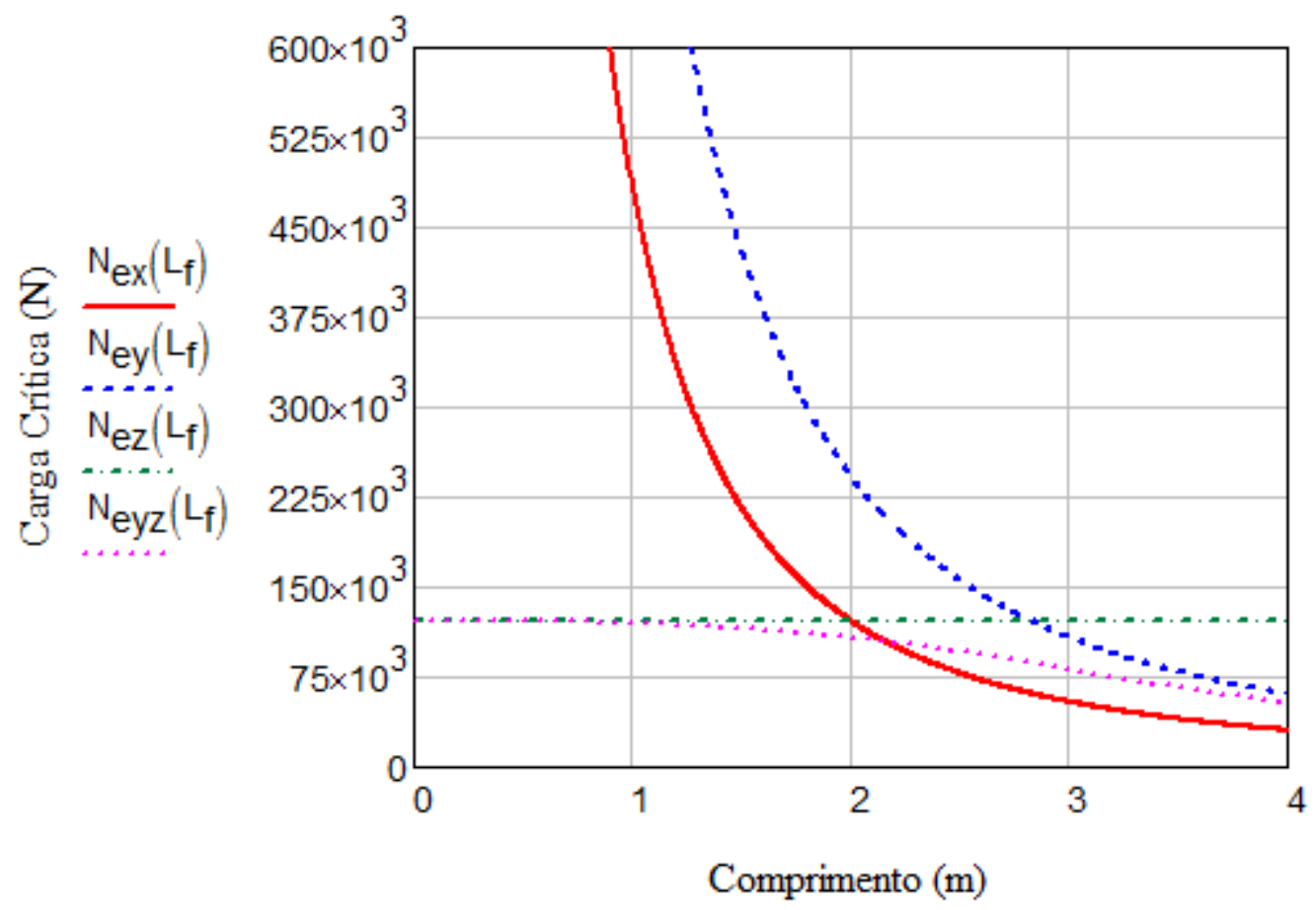

Figura 2.3 - Análise de estabilidade elástica para o perfil 2L 60x3,00.

Nota-se que, para os perfis com comprimento reduzido (até 2,1m, aproximadamente), o modo de flexo-torção $\left(N_{\text {eyz }}\right)$ comanda o dimensionamento, uma vez que apresenta valores de força crítica inferiores aos demais. A partir desse ponto, quem passa a comandar é o modo de flexão em torno do eixo de menor inércia do perfil $\left(N_{e x}\right)$. Vale ressaltar que, como neste tipo de perfil a constante de empenamento é aproximadamente igual a zero $\left(\mathrm{C}_{\mathrm{w}} \approx 0\right)$, tem-se $N_{e z}$ independente do comprimento da barra, fazendo com que $N_{\text {eyz }}$ tenda a um valor constante para barras menos esbeltas. Logicamente, ao se considerar as não-linearidades física (ou de material) e geométrica, o comportamento do perfil tende a sofrer alguma mudança, podendo até mesmo um modo de instabilidade precipitar a ocorrência de outro.

\subsubsection{MODO DE INSTABILIDADE LOCAL}

Conceitualmente, flambagem local (ou modo de instabilidade local) refere-se à perda de estabilidade de uma ou mais chapas componentes de um perfil de aço submetido a esforços de compressão, resultando em ondulações ao longo de seu comprimento. Uma característica importante da flambagem local, e que a diferencia da flambagem distorcional (será apresentada e explicada no item subseqüente) é que a deformação da seção transversal ocorre sem que haja deslocamento ou mudança nos ângulos formados nas arestas entre os elementos que compõem a seção transversal (Figura 2.4). 

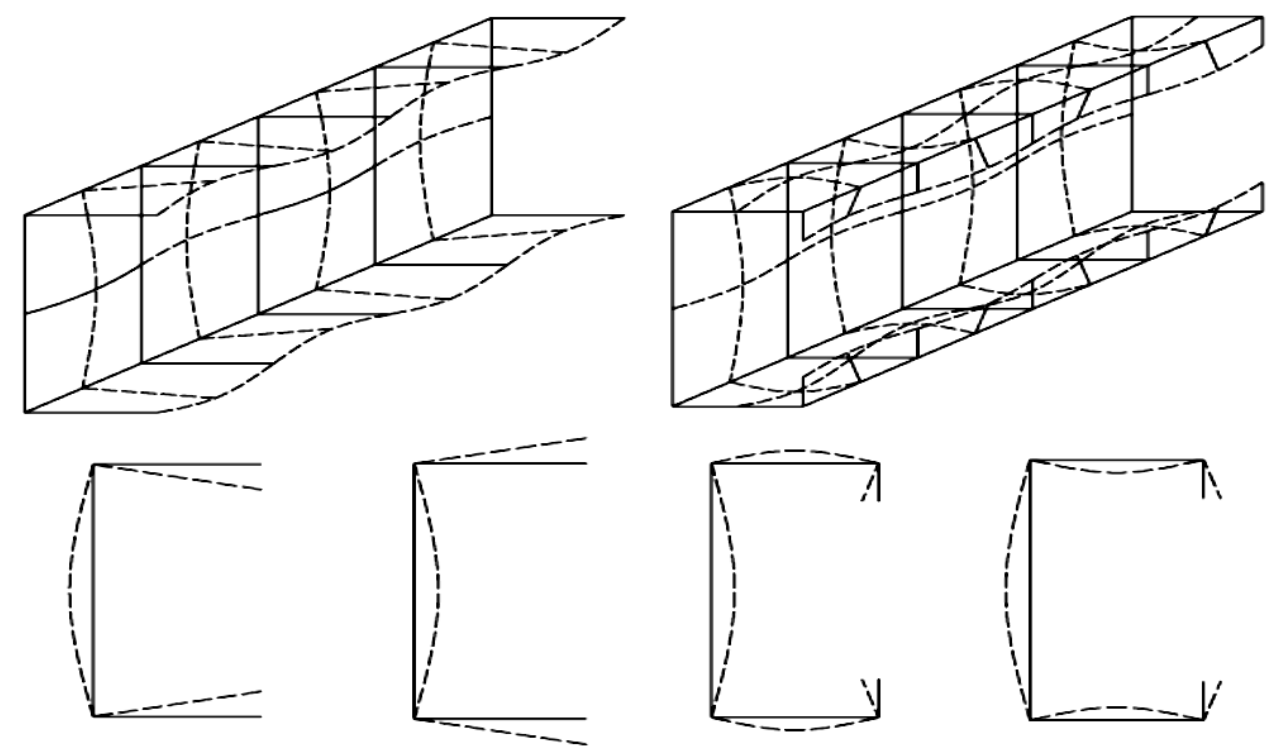

Figura 2.4 - Exemplos de ocorrência do modo de instabilidade local em perfil U e U enrijecido. Fonte: ALMEIDA (2007).

Pela teoria clássica de estabilidade de chapas, para uma chapa retangular simplesmente apoiada em seus quatro bordos e submetida à compressão uniforme, o tamanho da meia onda $(\lambda)$ gerada pela flambagem é da ordem de grandeza da largura $(b)$ da chapa, como ilustrado na Figura 2.5. Porém, por serem as chapas dos perfis ligadas umas às outras (elementos AA), ou mesmo com um dos bordos livre (elementos $\mathrm{AL}$ ), a condição real de vinculação acaba sendo diferente da situação anteriormente idealizada, de tal forma que o comprimento de meia onda não resulta exatamente igual ao valor de $b$, conforme exposto em SALMON \& JOHNSON (1996).

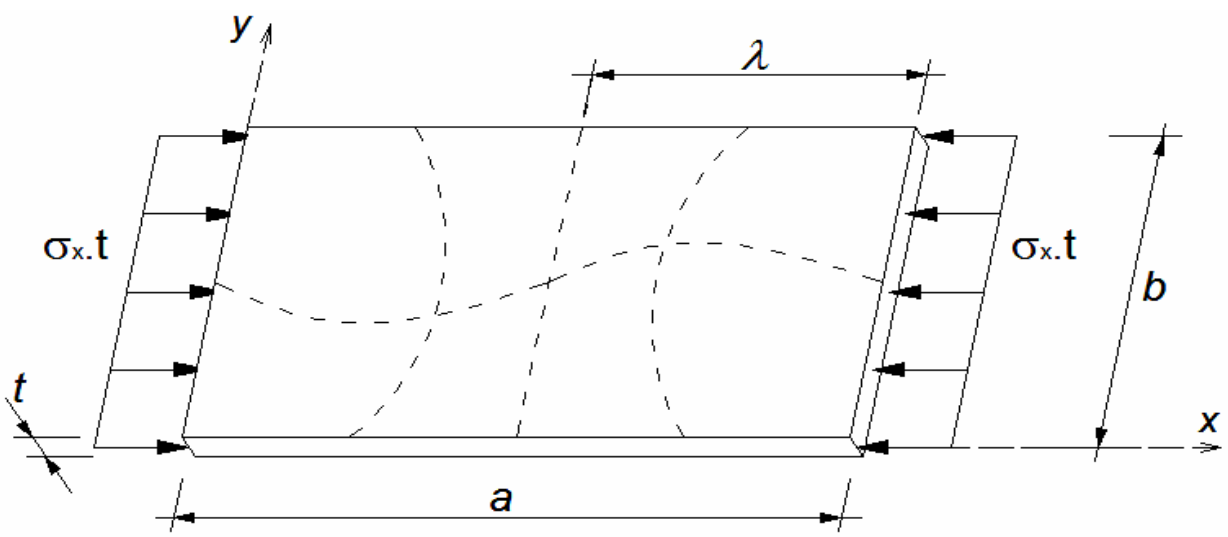

Figura 2.5 - Chapa retangular com bordos apoiados e submetida à compressão uniforme.

Fonte: adaptado de ANGST (2003). 
Como se trata de um típico caso de instabilidade de chapa, todo o desenvolvimento das formulações que caracterizam modo de instabilidade local está fundamentado na teoria de flambagem elástica de chapas. O comportamento de uma chapa ideal em regime elástico e submetida à compressão é descrito pela equação diferencial (Equação (2.5)) proposta em BRYAN (1891) apud GALAMBOS (1998), considerando-se a hipótese de pequenos deslocamentos.

$$
\frac{\partial^{4} w}{\partial x^{4}}+2 \frac{\partial^{4} w}{\partial x^{2} \partial y^{2}}+\frac{\partial^{4} w}{\partial y^{4}}+\frac{f_{x} t}{D} \frac{\partial^{2} w}{\partial x^{2}}=0
$$

Onde:

$\mathrm{D}=\mathrm{E} \cdot \mathrm{t}^{3} /\left[12 .\left(1-v^{2}\right)\right]$

$E$ - é o módulo de elasticidade longitudinal;

$v$ - é o Coeficiente de Poisson;

$w$ - é o deslocamento da chapa perpendicular ao seu plano;

$f_{x}$ - é a tensão de compressão na direção de x;

$t$ - é a espessura da chapa.

A partir da resolução da Equação (2.5), conforme TIMOSHENKO \& GERE (1961), se obtém a formulação utilizada para o cálculo da tensão crítica de flambagem elástica de chapas, no caso, a Equação (2.6). Para os casos em que a tensão atuante ultrapassa o limite de proporcionalidade, a flambagem ocorre em regime elasto-plástico e a referida equação passa a não ser mais aplicável. Em BLEICH (1924) se faz a consideração do problema da nãolinearidade de material por meio da introdução do conceito do módulo de elasticidade tangente $\left(E_{t}\right)$ na equação diferencial proposta por Bryan (Equação (2.5)), resultando na Equação (2.7).

$$
\begin{aligned}
& \sigma_{c r}=k \frac{\pi^{2} E}{12\left(1-v^{2}\right)}\left(\frac{t}{b}\right)^{2} \\
& \sigma_{c r}=k \frac{\pi^{2} E \sqrt{\eta}}{12\left(1-v^{2}\right)}\left(\frac{t}{b}\right)^{2}
\end{aligned}
$$


Onde:

$\eta=E_{t} / E$

$k$ - é o coeficiente de flambagem local, que depende das condições de vínculo das bordas da chapa, da relação $a / b$ (Figura 2.5) e da solicitação;

$E$ - é o módulo de elasticidade longitudinal;

$E_{t}$ - é o módulo de elasticidade tangente;

$v$ - é o Coeficiente de Poisson;

$t$ - é a espessura da chapa;

$b$ - é a largura da chapa.

Porém, diferentemente dos modos de instabilidade globais de barra, a flambagem local geralmente não resulta no colapso da chapa, pois, a partir da tensão crítica de flambagem, ocorre uma redistribuição de tensões para as partes mais enrijecidas da chapa, o que permite a absorção de acréscimos de tensão.

Esse fenômeno, conhecido como resistência pós-flambagem (ou comportamento póscrítico), pode ser entendido a partir da visualização da Figura 2.6, que mostra a evolução na distribuição de tensões normais em uma chapa com bordas apoiadas submetida à compressão. Enquanto as tensões atuantes são menores do que a tensão crítica de flambagem (caso (a)), tem-se uma distribuição uniforme ao longo da largura $b$. Acima de $\sigma_{c r}$, os cantos da chapa passam a absorver tensões maiores por serem regiões enrijecidas pelos apoios (caso (b)). Com o aumento gradativo da solicitação, as tensões atingem então a resistência ao escoamento $\left(f_{y}\right)$ do material, alcançando, com isso, o fim da capacidade resistente da chapa (caso (c)).

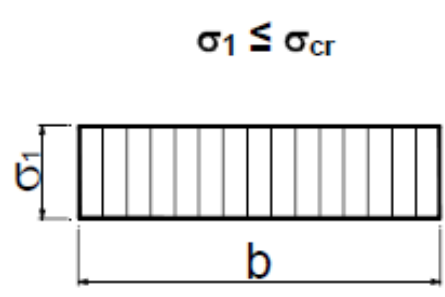

(a)

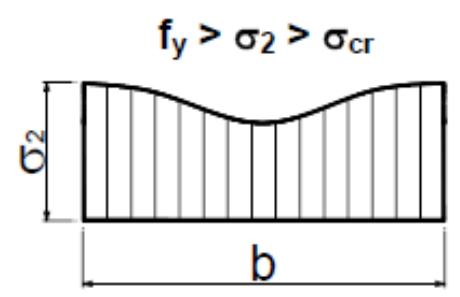

(b)

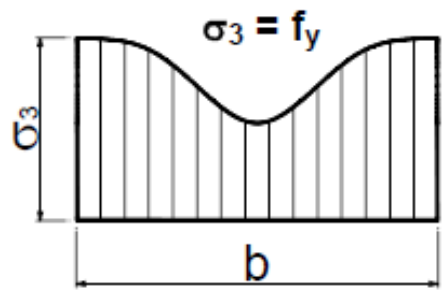

(c)

Figura 2.6 - Distribuição de tensões em chapa sob compressão e com bordas apoiadas. Fonte: YU (2000).

Com o intuito de equacionar esse comportamento pós-crítico, em VON KARMAN (1932) foi introduzido o conceito das larguras efetivas, que consiste na redução da rigidez da 
chapa por meio da substituição da chapa original de largura $b$ por uma chapa com largura $b_{e f}$ (largura efetiva), sendo $b_{e f}<b$. Dessa forma, em vez de considerar a distribuição nãouniforme de tensões sobre toda a largura $b$, é assumido que a resultante de tensões da situação real é absorvida, numa situação fictícia, pela largura efetiva $b_{\text {ef }}$ sujeita a uma distribuição uniforme de tensões igual ao valor máximo atuante $\left(\sigma_{\max }\right)$, conforme ilustrado na Figura 2.7.

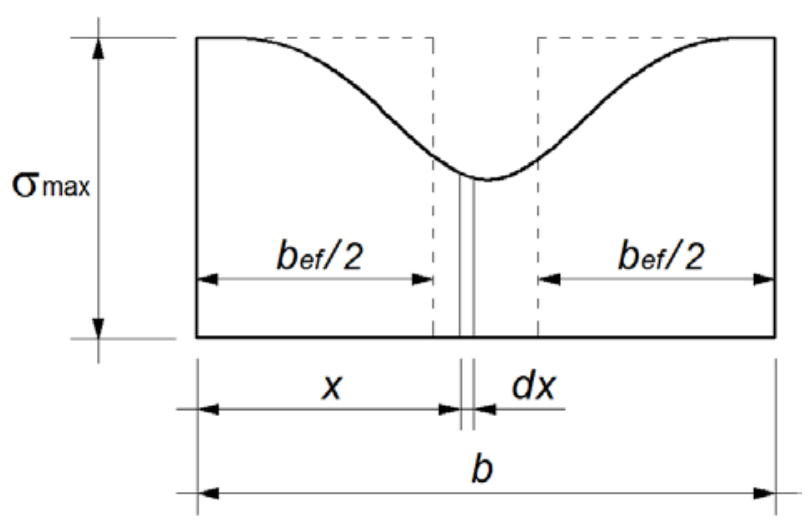

Figura 2.7 - Largura efetiva em chapa sob compressão e com bordas apoiadas. Fonte: adaptado de CHODRAUI (2006).

Para a obtenção da largura efetiva, é imposta então a igualdade das resultantes da situação real e da situação fictícia, ou seja, a área sob a curva de distribuição de tensões nãouniforme deve ser igual à soma das áreas referentes à distribuição de tensões $\sigma_{\max }$ em $b_{e f}$, conforme a Equação (2.8).

$$
\int_{0}^{b} \sigma \cdot t d x=b_{e f} \cdot t . \sigma_{\max }
$$

Vários pesquisadores desenvolveram estudos teóricos e experimentais para a avaliação e calibração da formulação proposta em VON KARMAN (1932), incluindo a consideração dos efeitos das imperfeições geométricas e de material. Destaca-se o trabalho experimental apresentado em WINTER (1947), que resultou na expressão adotada pela ABNT NBR 14762:2010, cuja forma parametrizada é apresentada na Equação (2.9).

$$
b_{e f}=\frac{b}{\lambda_{p}}\left(1-\frac{0,22}{\lambda_{p}}\right)
$$




$$
\lambda_{p}=\frac{b / t}{0,95(k E / \sigma)^{0,5}}
$$

Onde:

$b$ - é a largura do elemento;

$t$ - é a espessura do elemento;

$\lambda_{p}$ - é o índice de esbeltez reduzido do elemento.

Vale ressaltar que VON KARMAN (1932) propôs a formulação das larguras efetivas para os elementos com bordas apoiadas (elementos AA), cuja aplicação foi extrapolada posteriormente para os elementos com uma borda livre (elementos $A L$ ), para os quais aparentemente também apresenta bons resultados, conforme verificado em KALYANARAMAN et al (1977). A Figura 2.8 ilustra a distribuição de tensões em elementos AL, bem como a aplicação do Método das Larguras Efetivas para os mesmos.

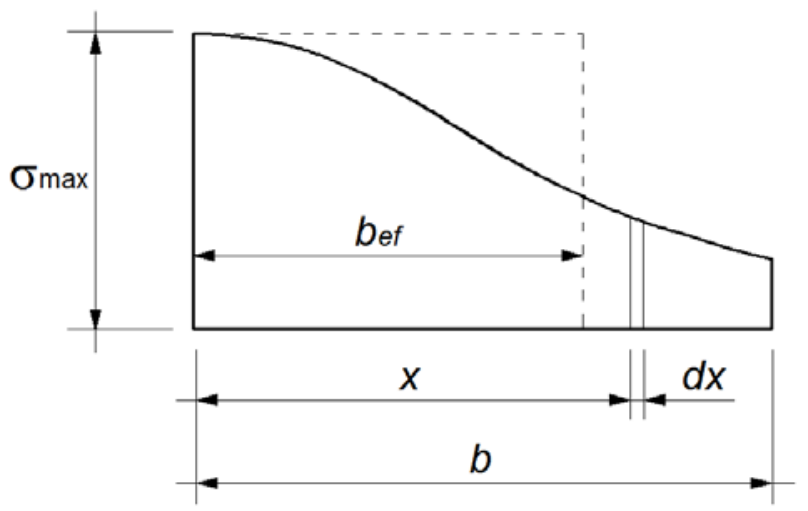

Figura 2.8 - Método das larguras efetivas para elementos AL.

\subsubsection{MODO DE INSTABILIDADE DISTORCIONAL}

Além dos clássicos fenômenos de instabilidade global e local, há também a possibilidade de ocorrência de outro modo de instabilidade, associado à distorção da seção transversal, que é característico dos perfis com enrijecedores de borda - perfis do tipo U e Z enrijecidos, perfis cartola e perfis "rack" - sendo ainda mais pronunciado no caso de aços com elevada resistência mecânica.

O modo distorcional caracteriza-se pela rotação e possível translação do conjunto formado pelo elemento comprimido e seu enrijecedor de borda devido à perda de estabilidade, 
alterando a forma inicial da seção (Figura 2.9), ao contrário da instabilidade local, na qual se admite a conservação da posição original dos cantos da seção e dos ângulos formados entre elementos adjacentes.

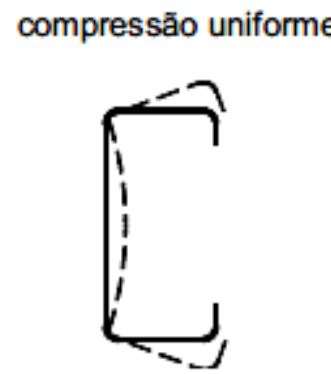

a) Seção tipo $U$ enrijecido

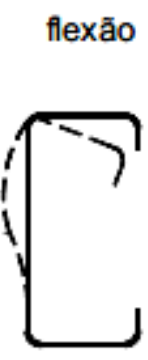

compressão uniforme

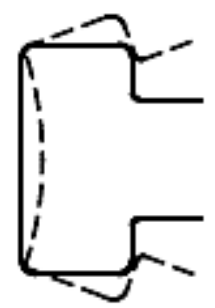

b) Seção tipo rack flexão

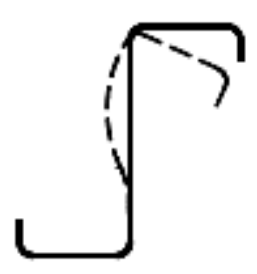

c) Seção tipo Z enrijecido

Figura 2.9 - Instabilidade por distorção da seção transversal. Fonte: ABNT NBR 14762:2010.

No caso dos PFF compostos por dupla cantoneira com seção “T”, que não possuem enrijecedores de borda, o modo distorcional não resulta crítico, pois a instabilidade local é preponderante pelo fato de o elemento possuir apenas uma borda apoiada, conforme relatado em CHODRAUI (2003) e em CHODRAUI et al. (2006b). Por isso, o modo de instabilidade distorcional não será tratado aqui com maiores detalhes. Informações complementares sobre o assunto podem ser encontradas nas referências citadas neste parágrafo e ainda em GALAMBOS (1998) e em YU (2000).

\subsection{IMPERFEIÇÕES GEOMÉTRICAS INICIAIS}

Entende-se por imperfeições geométricas iniciais a diferença entre as geometrias de uma barra perfeita e de outra dita real antes de se aplicarem os carregamentos. Consistem em ondulações presentes nos elementos da barra (almas e mesas) e ao longo de seu comprimento, abrangendo o empenamento da seção, torção, desvio do eixo longitudinal e ondulações locais (ALMEIDA, 2007). Essas imperfeições podem ser originadas por diversos fatores, tais como: transporte das barras; montagem da estrutura; furação ou soldagem para alocação de presilhas ou fixação das ligações; ou ainda resultantes do processo de fabricação.

Devido a essas imperfeições, até mesmo as barras solicitadas por compressão centrada resultam, na verdade, flexo-comprimidas. As ondulações nas chapas dos perfis e os desvios em relação ao eixo longitudinal da barra consistem em excentricidades que geram esforços 
adicionais, podendo comprometer a capacidade resistente do elemento e a segurança da estrutura.

Muitos estudos teóricos e experimentais vêm sendo desenvolvidos ao longo dos anos com o intuito de se mapear as imperfeições geométricas iniciais presentes nos perfis metálicos, sobretudo em relação à forma e à magnitude com que se apresentam. No entanto, a grande variabilidade destes parâmetros torna difícil a tarefa de se padronizar um procedimento para a consideração das imperfeições geométricas na análise da estrutura.

A importância deste fato se torna ainda mais evidente a partir das análises de sensibilidade às imperfeições geométricas iniciais realizadas em ALMEIDA (2007) e MAIA (2008), cujos resultados mostraram que a forma e a magnitude das imperfeições tendem a alterar a capacidade resistente dos PFF e os modos de instabilidade referentes ao colapso dos mesmos quando submetidos à compressão.

Uma das primeiras propostas para a maneira de se considerar as imperfeições geométricas foi feita por Young, em 1807, onde foi sugerida a utilização de uma função senoidal para representar a imperfeição global do eixo da barra, considerando amplitude máxima localizada na metade do seu comprimento (Figura 2.10). Apesar de não representar necessariamente a realidade, a proposta de Young foi recebida como uma boa aproximação, dada a grande variabilidade das imperfeições. Porém, o grande problema é que esse procedimento leva em consideração apenas a imperfeição global de flexão da barra, não abordando as imperfeições localizadas das chapas que compõem o perfil.

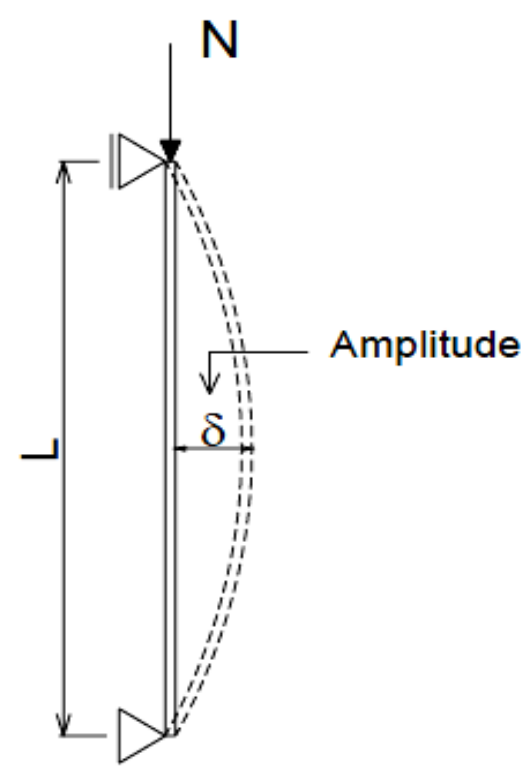

Figura 2.10 - Imperfeição global proposta por Young. Fonte: adaptado de ALMEIDA (2007). 
Com o passar dos anos, muitas pesquisas foram realizadas buscando formulações para a inserção das imperfeições nas análises das estruturas, como explicado em GALAMBOS (2008). Atualmente, o desenvolvimento da tecnologia tem tornado viável a utilização de ferramentas numéricas em modelos computacionais que permitem considerar não somente as imperfeições globais, mas também aquelas relacionadas ao empenamento, à distorção da seção transversal e às ondulações nas chapas componentes dos perfis. Desta forma, é possível verificar variadas amplitudes e formas para as imperfeições em análises de sensibilidade. A Figura 2.11 mostra alguns exemplos de imperfeições geométricas iniciais, obtidas por meio dos modelos numéricos criados no presente trabalho, que podem ser adotadas para perfis compostos por dupla cantoneira com seção “T”.
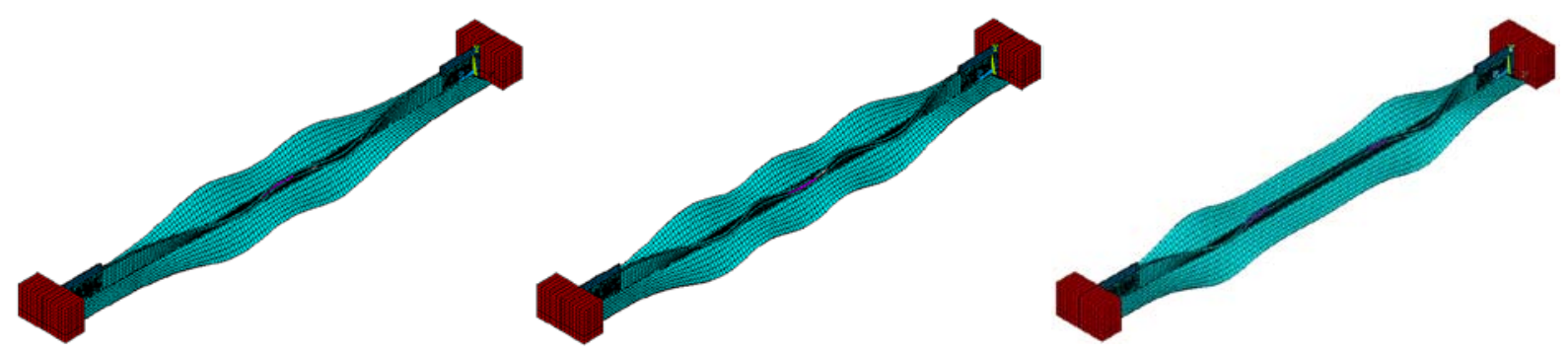

Figura 2.11 - Exemplos de imperfeições geométricas iniciais para dupla cantoneira (em escala ampliada) obtidas por meio de modelos numéricos em Elementos Finitos.

Em relação à magnitude das imperfeições geométricas iniciais, é consenso nos meios técnico e científico que os valores iguais a L/1000 ou L/1500, aplicados na metade do comprimento da barra (Figura 2.10), são razoáveis para serem adotados em investigações voltadas às imperfeições globais. Os valores encontrados experimentalmente para diferentes tipos de perfis resultam da mesma ordem de grandeza que os supracitados (ALMEIDA, 2007) e, além disso, essas amplitudes sugeridas são menores do que o limite de L/500 prescrito pela ABNT NBR 6355:2003.

Já para as imperfeições localizadas, em SCHAFER \& PEKÖZ (1998) se realizou uma ampla análise de dados coletados em vários trabalhos referentes às imperfeições em elementos com bordas apoiadas e com borda livre. Por meio de um tratamento estatístico dos dados, estimou-se a probabilidade de que um valor de imperfeição selecionado aleatoriamente $(\Delta)$ exceda um valor de imperfeição discreto determinístico (d), ou seja, a probabilidade de que os valores de imperfeição geométrica inicial medidos na prática sejam maiores do que os sugeridos para serem adotados nos modelos numéricos $[\mathrm{P}(\Delta>\mathrm{d})]$. A Tabela 2.1 resume, de 
forma adaptada, os valores de imperfeições locais $d_{1}$ e $d_{2}$ (conforme Figura 2.12) sugeridos pelos autores e suas respectivas probabilidades $\mathrm{P}(\Delta>\mathrm{d})$.

Tabela 2.1 - Magnitudes de imperfeições locais associadas às análises probabilísticas. Fonte: adaptado de SCHAFER \& PEKÖZ (1998).

\begin{tabular}{|c|c|c|}
\hline $\mathbf{P}(\boldsymbol{\Delta}>\mathbf{d})$ & $\begin{array}{c}\text { Tipo 1 } \\
\mathbf{d}_{\mathbf{1}} / \mathbf{t}\end{array}$ & $\begin{array}{c}\text { Tipo 2 } \\
\mathbf{d}_{\mathbf{2}} / \mathbf{t}\end{array}$ \\
\hline 0,75 & 0,14 & 0,64 \\
\hline 0,50 & 0,34 & 0,94 \\
\hline 0,25 & 0,66 & 1,55 \\
\hline 0,05 & 1,35 & 3,44 \\
\hline 0,01 & 3,87 & 4,47 \\
\hline $\begin{array}{l}\text { t }- \text { espessura da chapa; } \\
\mathrm{d}_{1} \text { e d }\end{array}$ \\
\hline
\end{tabular}
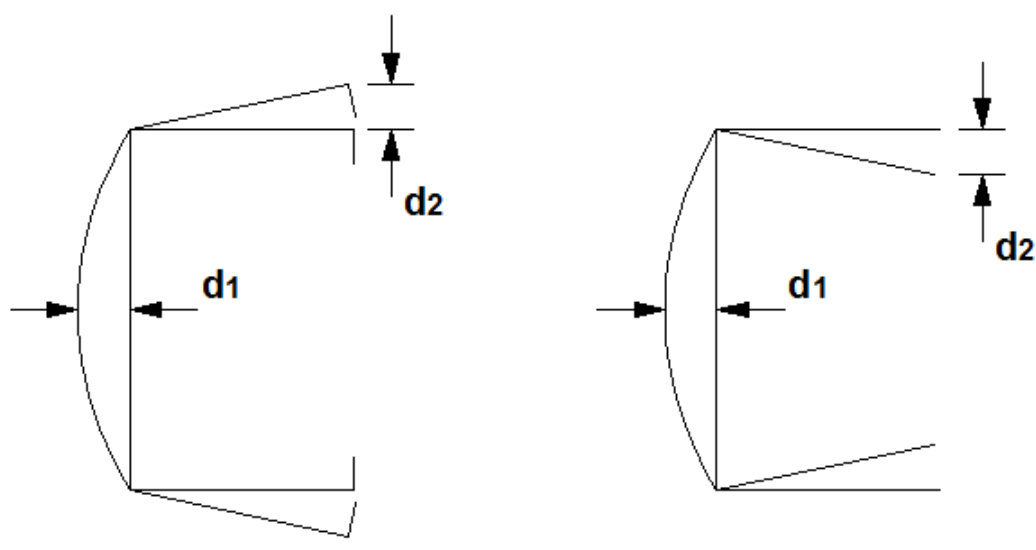

Figura 2.12 - Imperfeições geométricas locais.

Fonte: adaptado de SCHAFER \& PEKÖZ (1998).

\subsection{TENSÕES RESIDUAIS}

Mesmo antes de serem colocados em uso os perfis de aço em geral já estão submetidos a tensões denominadas tensões residuais, que tendem a reduzir sua capacidade resistente. Essas tensões são originadas a partir de diversos fatores inerentes ao processo de fabricação dos perfis, tais como: diferenças no resfriamento das chapas de aço após a laminação a quente, conformação a frio, soldagem, cortes e puncionamento. Portanto, as tensões residuais são resultado de deformações plásticas provenientes da fabricação do perfil, seja por ação mecânica ou por resfriamento desigual das chapas. 
Desta forma, perfis laminados, soldados ou conformados a frio possuem tensões residuais diferentes uns dos outros, tanto na distribuição ao longo da seção transversal quanto nos valores máximos apresentados. Para os perfis laminados, as tensões residuais surgem após o processo de laminação, quando as partes mais expostas dos perfis (como as extremidades das mesas e o meio da alma, por exemplo) se resfriam mais rápido e posteriormente, para conter o resfriamento do restante do perfil, essas partes ficam comprimidas e as demais, para equilibrar o sistema, resultam tracionadas.

Nos perfis soldados, as tensões residuais também têm origem térmica. Porém, o gradiente de temperatura surge, neste caso, devido ao processo de soldagem das chapas que compõem o perfil. Estas tensões se sobrepõem então àquelas resultantes do processo de fabricação das chapas, trazendo como resultado um panorama de tensões residuais bem diferente daquele apresentado pelos perfis laminados, conforme exposto em SALMON \& JOHNSON (1996).

No caso dos perfis formados a frio, as tensões residuais surgem devido ao trabalho mecânico de dobra das chapas de aço. Assim como nos perfis soldados, nas chapas utilizadas para a produção dos PFF já constam tensões residuais advindas da sua fabricação, sendo estas superpostas àquelas resultantes do trabalho de conformação a frio.

Em WENG \& PEKÖZ (1990) se conclui, a partir de resultados experimentais, que a forma geral de distribuição das tensões residuais nos perfis formados a frio segue um mesmo padrão para qualquer seção transversal, com tração na superfície externa e compressão na superfície interna das chapas. Em SCHAFER (1997) e em SCHAFER \& PEKÖZ (1998) se explica que esse gradiente de tensões ao longo da espessura da chapa é devido à superposição de duas parcelas que constituem as tensões residuais em PFF, a saber: tensão de membrana e tensão de flexão, conforme Figura 2.13.

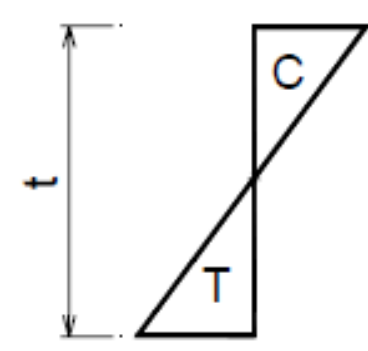

flexão

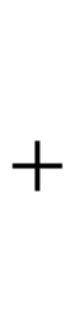

\section{membrana}

Figura 2.13 - Parcelas constituintes das tensões residuais em PFF: de membrana e de flexão. Fonte: adaptado de SCHAFER \& PEKÖZ (1998). 
Como as tensões de membrana e de flexão variam ao longo da seção, tem-se uma distribuição de tensões residuais não constante na linha de esqueleto da seção transversal. Um fato interessante constatado em SCHAFER (1997) é que, em geral, os perfis fabricados por perfilagem em mesas de roletes apresentam valores de tensões residuais mais uniformes ao longo da seção, porém com valores mais elevados nas partes planas se comparados com aqueles fabricados em prensas dobradeiras.

Em YOUNG (2005) apud MAIA (2008) são apresentados resultados de medições das tensões residuais em cantoneiras formadas a frio simples e enrijecidas. Os resultados deste trabalho estão resumidos na Figura 2.14 e na Figura 2.15, nas quais as tensões residuais são ilustradas em função da tensão de escoamento do aço utilizado e distribuídas de acordo com seus valores médios (os sinais positivo e negativo indicam tração e compressão, respectivamente). É importante salientar que os valores referem-se às medições feitas nas faces internas dos perfis, porém, para melhor visualização, estão representados nas externas.

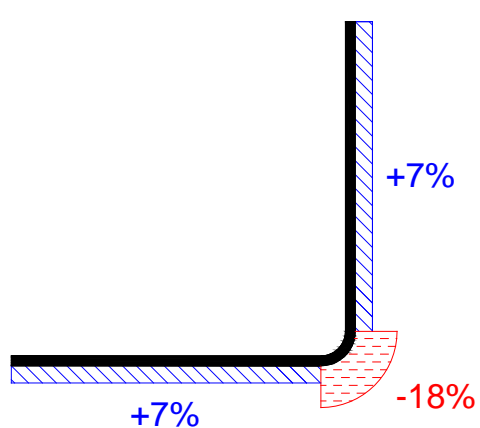

Membrana

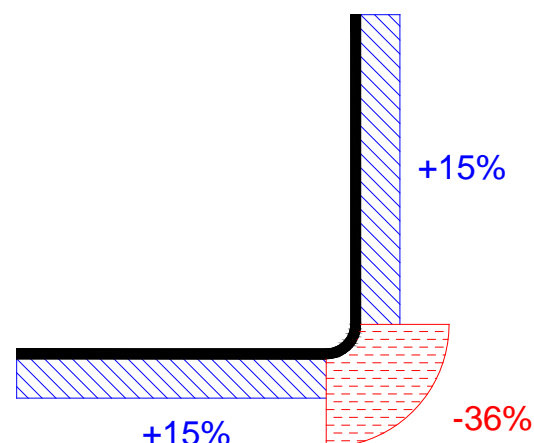

Flexão

Figura 2.14 - Tensões residuais médias em cantoneira simples: porcentagem de $f_{y}$. Fonte: MAIA (2008)

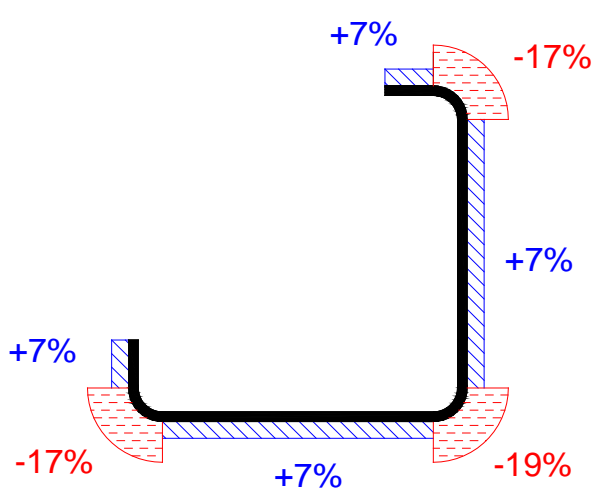

Membrana

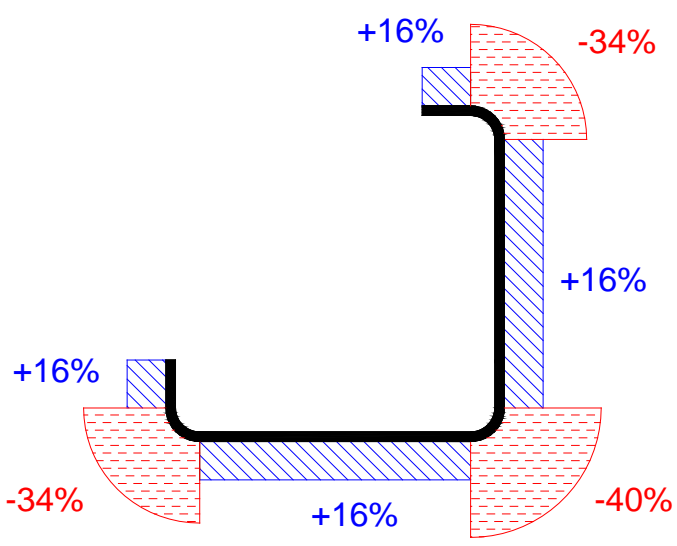

Flexão

Figura 2.15 - Tensões residuais médias em cantoneira enrijecida: porcentagem de $f_{y}$. Fonte: MAIA (2008) 
Entretanto, em CHODRAUI (2006) é enfatizado que, em função da variabilidade, não há um consenso sobre a distribuição e a magnitude das tensões residuais a serem adotadas em modelos numéricos. Para se ter uma idéia, em WENG \& PEKÖZ (1990) são apresentados valores de tensões residuais variando entre $25 \%$ e $75 \%$ da resistência ao escoamento do aço virgem. Além disso, ainda existe um ganho de resistência do aço nas regiões das dobras devido ao trabalho a frio, o que de certa forma "compensa” os efeitos das tensões residuais nesses pontos.

Neste sentido, em SCHAFER \& PEKÖZ (1998) é apresentada uma metodologia para a consideração das tensões residuais em modelagens numéricas de PFF. A proposta consiste em aplicar apenas as tensões residuais de flexão com uma distribuição média semelhante àquelas apresentadas na Figura 2.14 e na Figura 2.15, uma vez que a tensão de membrana em perfis formados a frio é bem menor se comparada àquela de flexão, e ocorrem especialmente nas regiões das dobras, conforme levantamento feito em SCHAFER (1997).

Como alternativa à modelagem explícita das tensões residuais, em SCHAFER (1997) é sugerida a utilização de um diagrama “tensão x deformação” modificado a partir do modelo bilinear (Figura 2.16), com vistas a tentar reproduzir o efeito de tais tensões no modelo reológico do material. O problema desse método é que, considerando as tensões residuais constantes em toda a seção e ao longo da espessura, possíveis plastificações prematuras em alguns trechos da seção não são avaliadas.

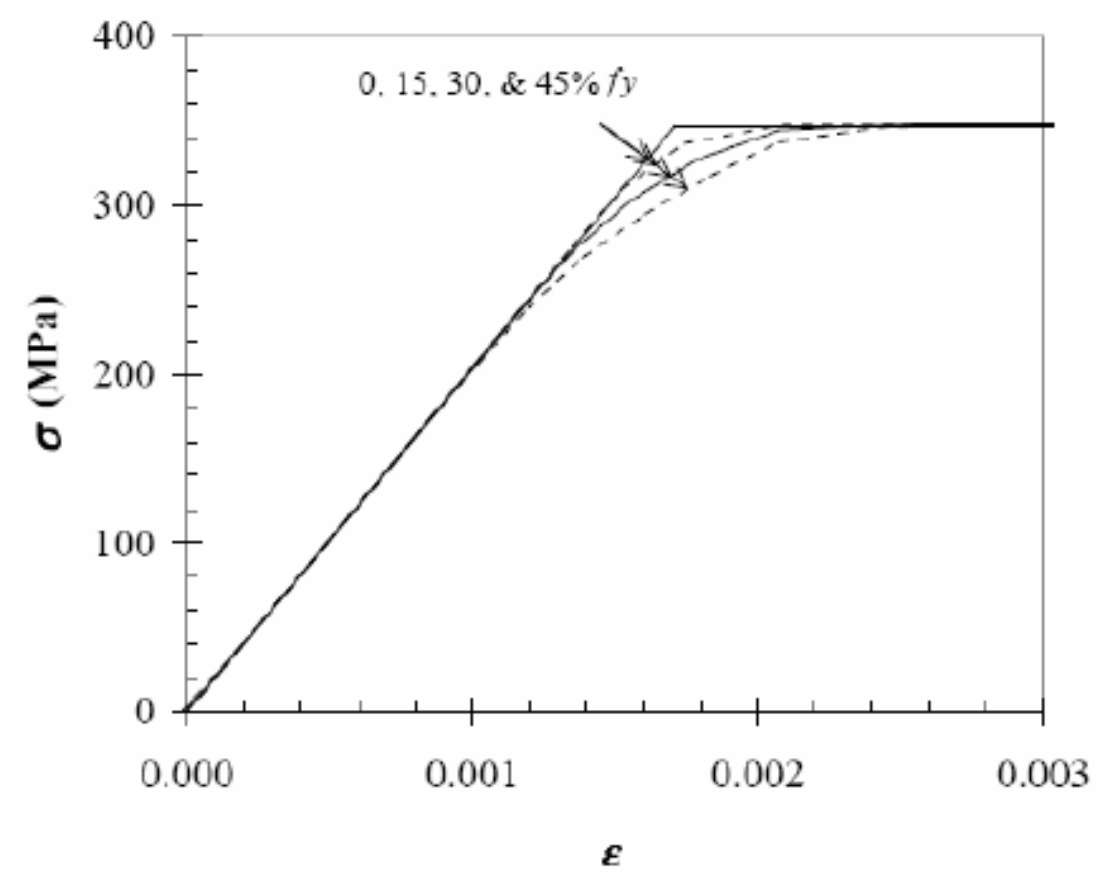

Figura 2.16 - Influência das tensões residuais no diagrama tensão x deformação do aço. Fonte: SCHAFER (1997) 
Com a finalidade de se verificar o efeito das tensões residuais na resistência à compressão dos PFF, CHODRAUI (2006) aplicou a metodologia proposta em SCHAFER \& PEKÖZ (1998) descrita anteriormente, com tração na face externa e compressão na face interna das chapas. Os resultados das simulações numéricas não apontaram para uma influência significativa das tensões residuais na capacidade resistente, levando o autor a desconsiderá-las em seus modelos. Em CHODRAUI (2006) são citados, ainda, outros trabalhos envolvendo a consideração das tensões residuais em modelagem numérica de PFF, onde também se verificou a pouca influência nos resultados. Desta forma, a decisão foi de não se considerar as tensões residuais nos modelos numéricos desenvolvidos no presente trabalho.

\subsection{CANTONEIRA SIMPLES X DUPLA CANTONEIRA}

\subsubsection{CANTONEIRA SIMPLES}

As cantoneiras simples de aço são perfis largamente utilizados em sistemas estruturais correntes, geralmente empregadas em elementos sujeitos a esforços de tração ou de compressão, como em barras de contraventamento e em estruturas treliçadas em geral. GALAMBOS (1998) cita que um dos motivos da grande popularidade das cantoneiras é a facilidade em conectá-las a outros componentes estruturais, além da menor complexidade no processo de produção destes perfis.

Porém, as vantagens construtivas destes perfis e a simplicidade de sua forma contrastam com seu complexo comportamento estrutural quando submetidos à compressão, principalmente no caso das cantoneiras formadas a frio, que geralmente possuem paredes muito delgadas. Em MAIA (2008) é enfatizada a elevada sensibilidade das cantoneiras formadas a frio às imperfeições geométricas e a grande interação entre os modos locais e globais de flambagem. Dessa forma, é consenso entre os pesquisadores que o correto dimensionamento deste tipo de perfil não é tão simples quanto aparenta ser.

Por ser um perfil com seção monossimétrica (em relação aos eixos principais), as cantoneiras simples não compactas submetidas à compressão estão sujeitas aos seguintes modos de instabilidade global: flambagem por flexão, em torno do eixo de não-simetria (eixo de menor inércia), ou flambagem por flexo-torção, conforme ilustrado na Figura 2.17. 


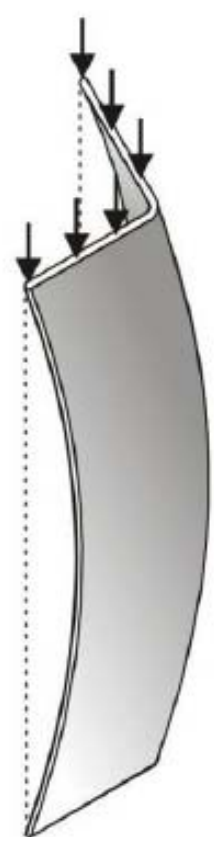

(a)

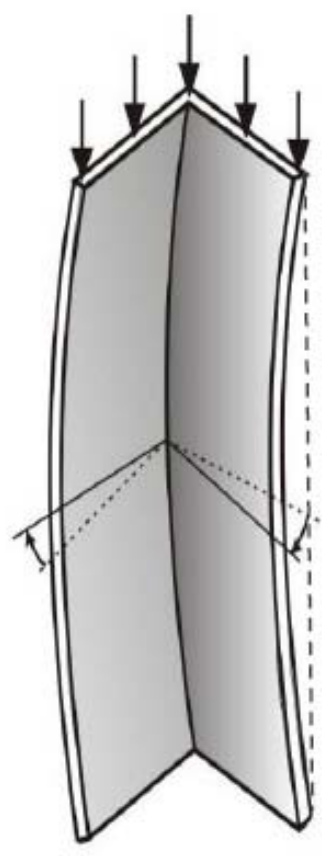

(b)

Figura 2.17 - Instabilidade em cantoneira simples: (a) por flexão e (b) por flexo-torção.

No entanto, existe uma grande discussão a respeito do modo global por flexo-torção, uma vez que o mesmo pode ser entendido como um modo local associado a um global por torção, denominado local/torsional por alguns pesquisadores. Para melhor explicar tal situação, CHODRAUI (2006) apresenta uma análise de estabilidade elástica de uma cantoneira (60x60x2,38mm) por meio da utilização de um código computacional denominado CUFSM (www.ce.jhu.edu/bschafer/cufsm), a partir da qual são observados os dois modos anteriormente citados, identificados pelas linhas cheias na Figura 2.18.

Vale destacar que o primeiro modo (local/torsional) não apresenta ponto de mínimo, como é comum em outros perfis, bem como apresenta coincidência nos modos local e global por torção (daí o nome “local/torsional”). Esta coincidência é apresentada explicitamente em RASMUSSEN (2003), onde pode ser visto que esses modos são matematicamente idênticos para cantoneiras de abas iguais e espessura constante. Em CHODRAUI (2006) se conclui que este fato causa confusão nos pesquisadores quanto à possível consideração “duplicada” nos procedimentos de cálculo com este modo local/torsional, uma vez que pode ser considerado como um modo local e também como um modo global, ou ainda a interação de ambos. 


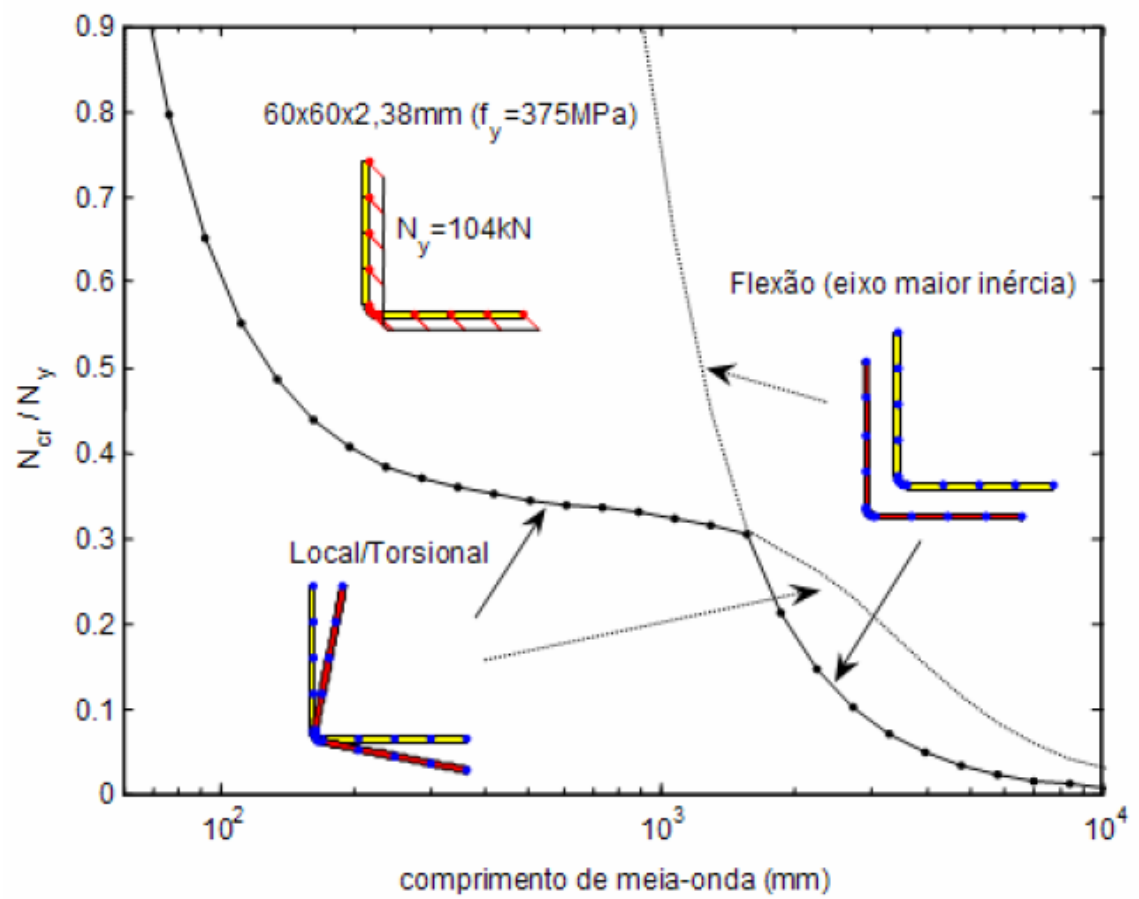

Figura 2.18 - Análise de estabilidade elástica via CUFSM: cantoneira sob compressão. Fonte: CHODRAUI (2006).

Em MAIA (2008) se verificou, por meio de resultados numéricos e experimentais, que considerar no cálculo da força normal resistente apenas o modo global de flexão conduz a resultados contra a segurança e, por outro lado, considerar também o modo de flexo-torção implica em resultados conservadores. Enfim, fica claro que não se trata de um problema trivial e que este tipo de perfil tende a continuar sendo estudado.

Toda essa discussão em torno das cantoneiras se mostra de grande importância neste trabalho, visto que os perfis aqui estudados são compostos por cantoneiras simples, ou seja, o comportamento do conjunto está diretamente relacionado ao comportamento das cantoneiras isoladas entre presilhas.

\subsubsection{DUPLA CANTONEIRA}

O aumento progressivo dos esforços de compressão conduz à situação em que a utilização da cantoneira simples passa a ser inviável financeiramente, bem como sob o aspecto da produção, pois o perfil resultará com seções transversais cada vez mais robustas (maiores dimensões). Uma alternativa interessante, neste caso, é utilizar os perfis compostos por duas cantoneiras simples ligadas entre si por meio de chapas intermitentes (denominadas chapas separadoras, ou presilhas, ou ainda interconectores). 
Estes perfis dupla cantoneira podem ser empregados sob diferentes configurações, como aquelas mostradas na Figura 2.19. A utilização de uma ou de outra configuração está relacionada às vantagens e desvantagens que cada uma apresenta, sendo a dupla cantoneira com seção “T” a mais comumente encontrada, segundo GALAMBOS (1998).
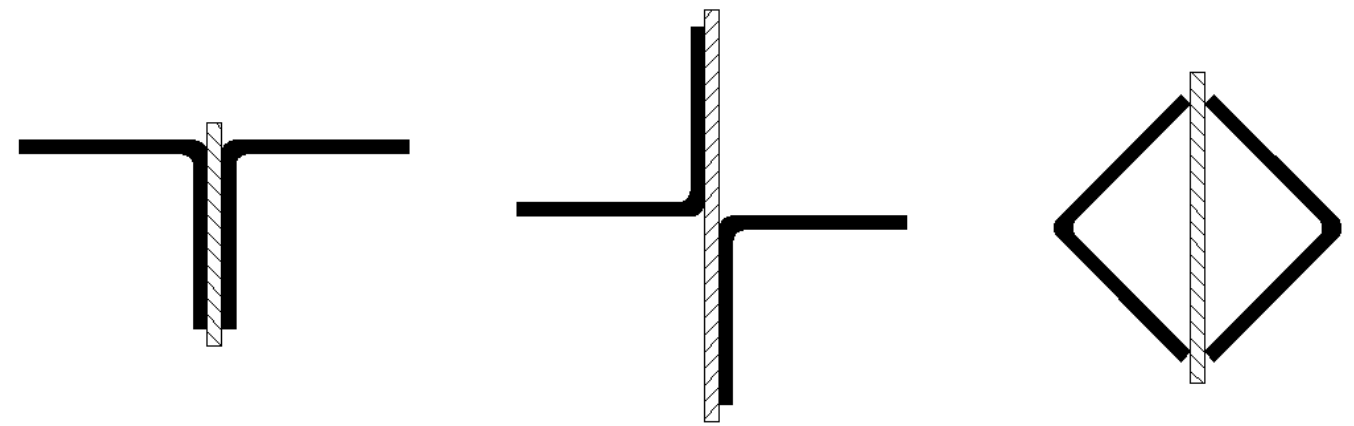

Figura 2.19 - Exemplos de perfis dupla cantoneira: (a) seção T, (b) seção Cruz e (c) seção Quadrada.

O comportamento estrutural desses perfis está diretamente relacionado ao número e à disposição das presilhas ao longo do seu comprimento, as quais podem exercer influência tanto na resistência do perfil quanto nos modos de instabilidade predominantes. A função destas presilhas é reduzir a esbeltez das cantoneiras que compõem o perfil e fazer com que elas trabalhem em conjunto, o que tende a resultar em ganhos na capacidade resistente do elemento estrutural quando comparado com uma situação sem presilhas, ou seja, tendo duas cantoneiras simples atuando isoladamente.

Em TEMPLE et al (1986), TEMPLE et al (1987) e TEMPLE e TAN (1988) são apresentados resultados de estudos com perfis laminados com seções semelhantes às mostradas na Figura 2.19, com os quais foram realizados ensaios de compressão fazendo-se variar o número de presilhas. Os resultados apontaram mudanças no modo de falha e um significativo ganho de resistência dos perfis com seção “Cruz” e com seção "Quadrada” quando o número de presilhas passou de um para dois, no caso de perfis mais esbeltos $(L / r=$ 122). Acima de duas presilhas, os resultados de resistência não foram tão influenciados. Para os perfis com menor esbeltez $(L / r=80$ ou 40), não foi constatada muita diferença na capacidade resistente destes perfis, alterando, no entanto, o modo de falha.

No caso de dupla cantoneira com seção “ $T$ ”, os resultados experimentais indicaram que a utilização de apenas uma presilha no meio do comprimento é o suficiente para que os perfis apresentem resistência compatível com as prescrições normativas. Além disso, outra constatação interessante desta pesquisa é que a espessura das presilhas não influencia na 
resistência dos perfis, sendo elas solicitadas por esforços muito pequenos se comparados àqueles identificados nas cantoneiras.

Estes perfis ainda carecem de estudos mais aprofundados, sobretudo nos casos em que as chapas componentes dos perfis são muito delgadas, como é o caso dos perfis formados a frio, de forma a avaliar a influência da variação no número de presilhas em conjunto com a elevada esbeltez local na resistência e nos modos de falha.

\subsection{SOBRE AS PRESCRIÇÕES NORMATIVAS - Breves comentários}

\subsubsection{SOBRE A ABNT NBR 14762:2010}

Apresenta-se, no que segue, as prescrições normativas da ABNT NBR 14762:2010 para o dimensionamento dos perfis dupla cantoneira com seção “T” submetidos à compressão, que são semelhantes àquelas apresentadas pelo ANSI/AISI S100 (2007), salvo alguns detalhes que serão mostrados posteriormente. A força axial de compressão resistente nominal $\left(N_{c, R}\right)$ é obtida por meio da Equação (2.11):

$$
N_{c, R}=\chi \cdot A_{e f} \cdot f_{y}
$$

Nesta equação, $f_{y}$ é a tensão de escoamento do aço utilizado e $\chi$ é o fator de redução associado à flambagem global, que varia em função do índice de esbeltez reduzido $\left(\lambda_{0}\right)$ do perfil, conforme as Equações (2.12) e (2.13).

$$
\begin{aligned}
& \chi=0,658^{\lambda_{0}^{2}} \rightarrow \text { para } \lambda_{0} \leq 1,5 \\
& \chi=\frac{0,877}{\lambda_{0}^{2}} \rightarrow \text { para } \lambda_{0}>1,5
\end{aligned}
$$

O índice de esbeltez reduzido é obtido por meio da Equação (2.14), em que $A$ é a área bruta da seção transversal da barra. 


$$
\lambda_{0}=\sqrt{\frac{A \cdot f_{y}}{N_{e}}}
$$

Para o cálculo da força global de flambagem elástica $\left(N_{e}\right)$ de perfis dupla cantoneira com seção “T”, utilizam-se as expressões referentes a perfis monossimétricos, conforme explicado nos itens 2.1.1.1 e 2.1.1.2. $N_{e}$ é tomado então como o menor valor entre as cargas críticas de flambagem à flexão $\left(N_{e x}\right)$ e à flexo-torção $\left(N_{e y z}\right)$, obtidas através das Equações (2.1) e (2.4).

Finalmente, para o cálculo da área efetiva da seção transversal da barra $\left(A_{e f}\right)$ a ABNT NBR 14762:2010 disponibiliza duas opções, que são baseadas no Método das Larguras Efetivas e no Método da Seção Efetiva, respectivamente. Porém, não é possível a utilização do segundo método para os perfis dupla cantoneira aqui estudados, pois nem todos os parâmetros envolvidos na formulação estão calibrados para estes perfis. Sendo assim, calcula-se $A_{e f}$ a partir das larguras efetivas da seção transversal $\left(b_{e f}\right)$.

A referida norma brasileira traz, ainda, considerações quanto à limitação da esbeltez total da barra composta (que deve ser no máximo igual a 200) e também das cantoneiras simples que compõem o perfil, que deve ser inferior à metade do índice de esbeltez máximo do conjunto, quando da utilização de presilhas.

\subsubsection{SOBRE A ANSI/AISI S100 (2007)}

Como exposto anteriormente, a ABNT NBR 14762:2010 possui um procedimento de cálculo semelhante ao do ANSI/AISI S100 (2007) para barras sob compressão. No entanto, a norma norte-americana traz uma particularidade para barras compostas por perfis ligados entre si por meio de presilhas, como é o caso dos perfis dupla cantoneira com seção "T”.

Esta particularidade está relacionada à reduzida rigidez ao cisalhamento deste tipo de perfil, conforme explicado em GALAMBOS (1998). A influência desta baixa resistência ao cisalhamento nas tensões de flambagem é levada em consideração por meio do Índice de Esbeltez Modificado, cuja formulação (Equação (2.15)) teve como base os estudos apresentados em BLEICH (1952).

$$
\left(\frac{K . L}{r}\right)_{m}=\sqrt{\left(\frac{K . L}{r}\right)_{o}^{2}+\left(\frac{a}{r_{i}}\right)^{2}}
$$


Onde:

$(K . L / r)_{m}$ - é o índice de esbeltez modificado da barra;

$(K . L / r)_{o}$ - é o índice de esbeltez da barra composta considerando eficiência total;

$r_{i}$ - é o raio de giração mínimo da cantoneira isolada;

$a$ - é a distância entre as presilhas (fixada a partir da limitação da esbeltez).

Nota-se, pela última equação, que ao índice de esbeltez do conjunto é somada uma parcela referente à esbeltez das cantoneiras isoladas entre presilhas. Sendo assim, o índice de esbeltez modificado resulta maior do que se fosse desconsiderada a eficiência das presilhas, fazendo com que a força normal resistente de cálculo seja menor do que aquela obtida por meio da norma brasileira ABNT NBR 14762:2010.

É importante ressaltar que as presilhas só são mobilizadas para o caso de flexão da dupla cantoneira com seção “T” em torno do eixo-y de maior inércia (eixo de simetria). Neste caso, o esforço cortante é transmitido de uma barra para outra através das ligações feitas com as presilhas. Portanto, a força crítica de flambagem $N_{e x}$ não é afetada pela referida baixa rigidez ao cisalhamento, ao contrário da força crítica de flambagem $N_{e y}$, que deve ser calculada fazendo-se uso do índice de esbeltez modificado. Como conseqüência, há também uma redução na força de flambagem por flexo-torção $\left(N_{\text {eyz }}\right)$, pois, como se sabe, esta é diretamente dependente de $N_{e y}$.

\subsubsection{ANÁLISE COMPARATIVA}

A Figura 2.20 e a Figura 2.21 mostram dois gráficos para a comparação entre os resultados obtidos pela ABNT NBR 14762:2010 e pelo ANSI/AISI S100 (2007) para o dimensionamento de PFF compostos por dupla cantoneira em "T" com seções de 60x60x3,0mm e 60x60x1,5mm, respectivamente. Em cada um dos gráficos são mostradas as curvas para o dimensionamento considerando apenas a flambagem por flexão $N_{e x}$ (curvas NBR-F e AISI-F) e as curvas referentes ao dimensionamento considerando também a flexotorção $N_{\text {eyz }}$ (curvas NBR-FT e AISI-FT). 


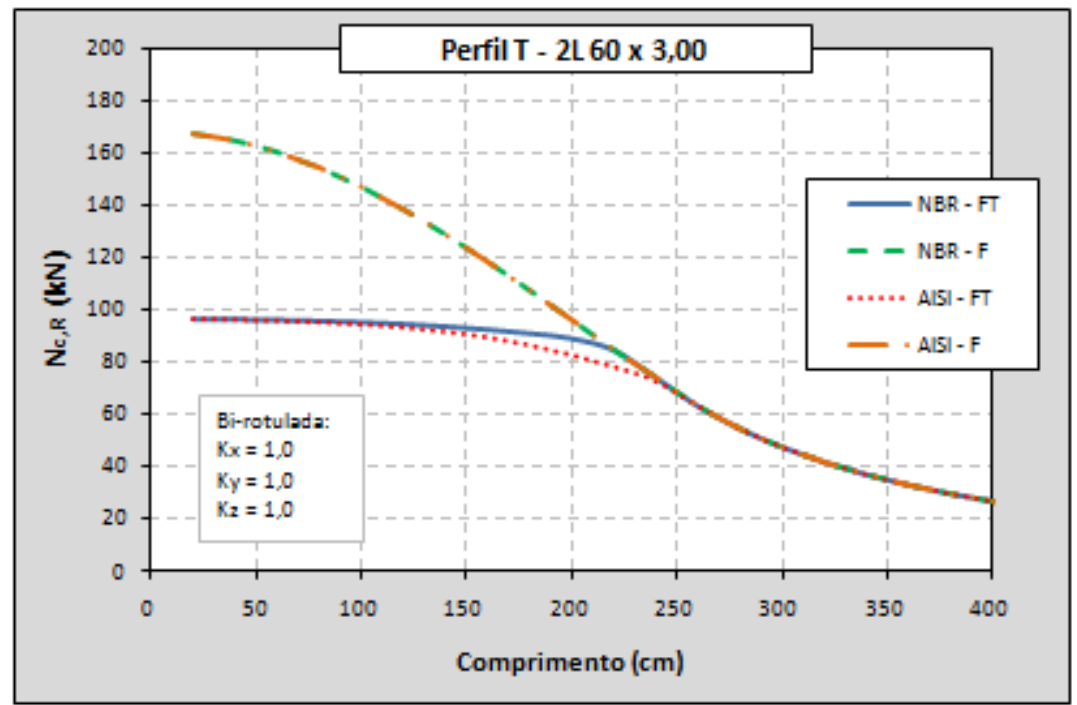

Figura 2.20 - Dimensionamento do perfil dupla cantoneira com seção 60x60x3,0mm.

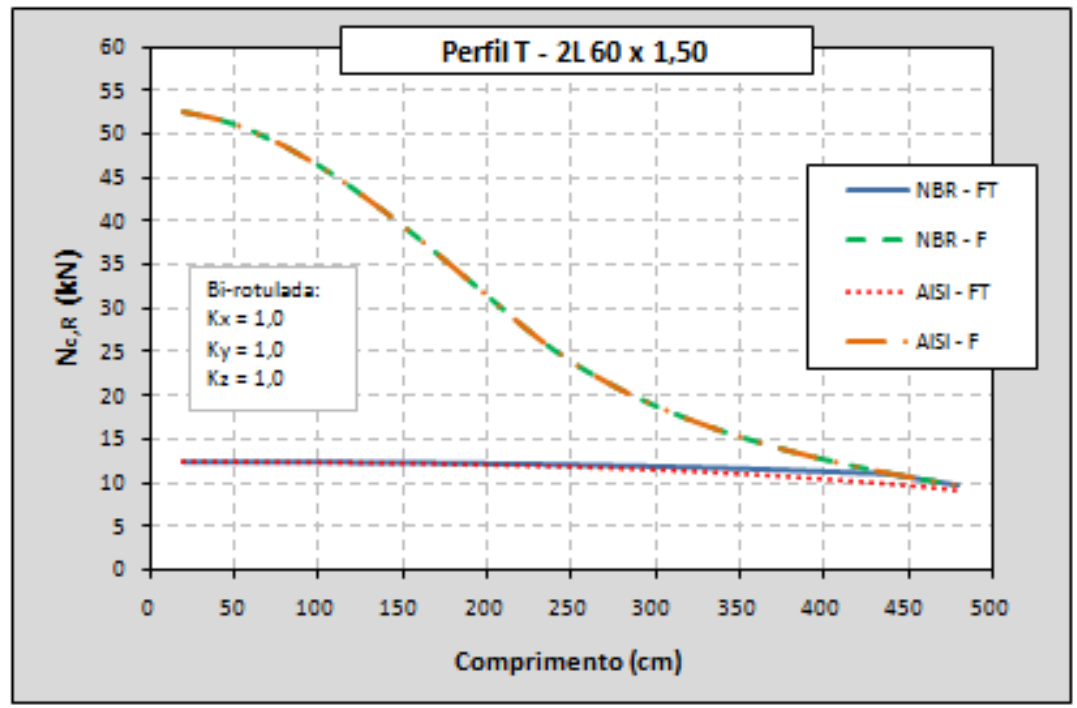

Figura 2.21 - Dimensionamento do perfil dupla cantoneira com seção 60x60x1,5mm.

A partir dos gráficos, como já esperado, percebe-se que não há qualquer diferença entre os resultados das duas normas quando se considera apenas a flambagem por flexão no dimensionamento. Porém, levando-se em consideração a flambagem por flexo-torção (que é o que recomendam ambas as normas) nota-se certa alteração nos resultados, principalmente no perfil com chapa mais espessa $(3,0 \mathrm{~mm})$.

No caso dos perfis aqui estudados, a utilização do índice de esbeltez modificado não influenciou significativamente a força normal resistente, conforme se observa nos gráficos apresentados na Figura 2.20 e na Figura 2.21, o que pode significar que a redução da rigidez ao cisalhamento devido à presença das presilhas não é tão importante nestes perfis quanto pode ser em outros tipos de perfis compostos. 


\subsection{RESULTADOS EXPERIMENTAIS}

São apresentados neste item resultados de estudos experimentais de perfis de aço formados a frio compostos por dupla cantoneira com seção “T” submetidos à compressão. Por se tratar de uma seção ainda pouco estudada, a quantidade de resultados experimentais deste tipo de perfil presentes na literatura é muito pequena. A seguir, são apresentados os principais resultados das pesquisas desenvolvidas em CHODRAUI (2006) e em VISHNUVARDHAN \& SAMUEL KNIGHT (2008).

\subsubsection{CHODRAUI (2006) - Resultados}

Os ensaios realizados nessa referência consistiram na aplicação de uma compressão centrada em um total de oito corpos-de-prova, tendo sido fixadas as dimensões da seção transversal das cantoneiras em 60x60x2,38mm. Com isso, a avaliação da influência da esbeltez global foi possível por meio da variação do comprimento do perfil. A Figura 2.22 mostra um dos perfis ensaiados e um detalhe da vinculação utilizadas em suas extremidades.
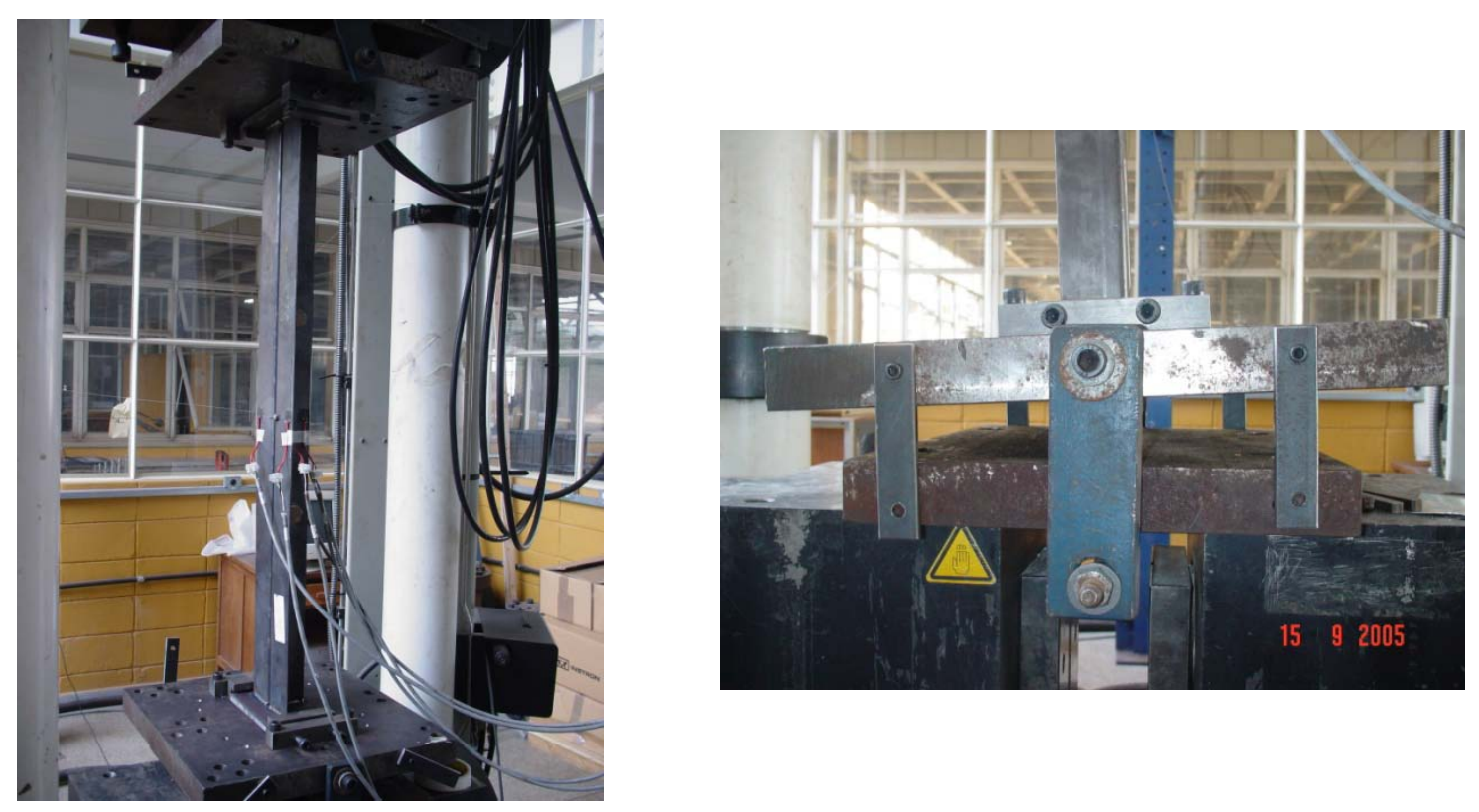

Figura 2.22 - Ensaios em perfis dupla cantoneira.

Fonte: CHODRAUI (2006)

Para a aplicação do carregamento centrado, foram utilizados dispositivos de apoio do tipo "rótula cilíndrica" posicionados no centróide da seção transversal de ambas as extremidades. Este tipo de apoio tem a característica de permitir o giro da seção apenas em 
torno de um dos eixos baricêntricos (x ou y), conforme esquematizado na Figura 2.23. Assim, dos oito corpos-de-prova, quatro foram ensaiados com as rótulas cilíndricas posicionadas no eixo-y da seção (eixo de simetria) e quatro no eixo-x (eixo de não-simetria).

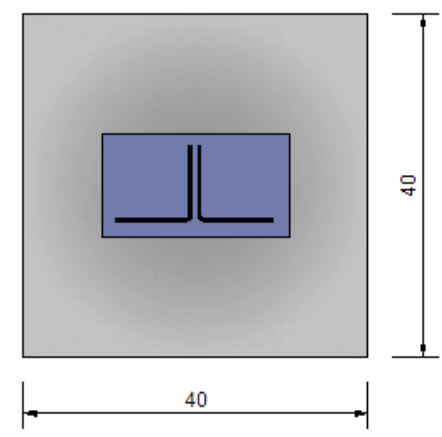

VISTA SUPERIOR
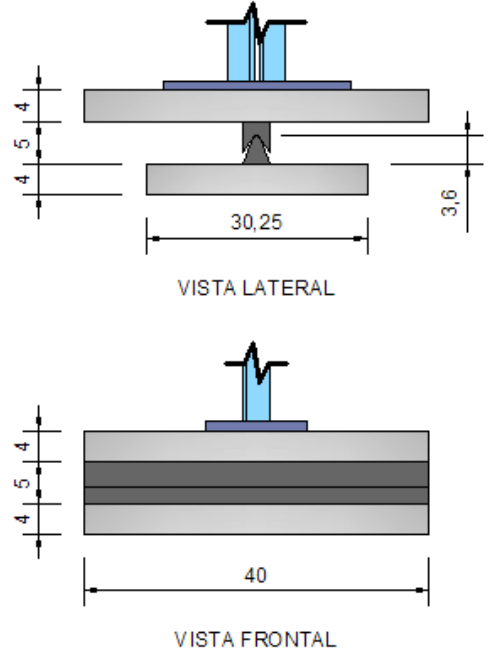

(a)
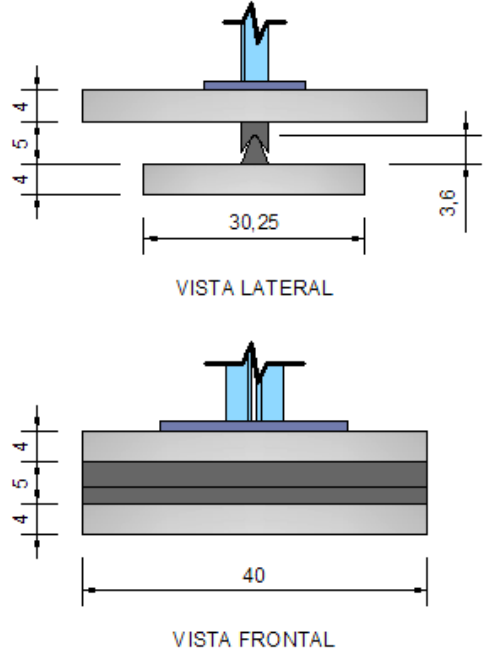

(b)

Figura 2.23 - Dispositivos de apoio: (a) rótula cilíndrica em y e (b) rótula cilíndrica em x dimensões em centímetros.

Como se trata de um perfil composto, o número de presilhas utilizadas foi definido de acordo com o espaçamento máximo sugerido pela ABNT NBR 14762, tendo um total de duas e três presilhas para os perfis com a rótula no eixo-x e no eixo-y, respectivamente. A distância entre as cantoneiras simples que compõem os perfis (espessura das presilhas) foi definida em 5,0 mm e a espessura das chapas das mesmas foi de 2,38mm, como já informado. Além disso, ensaios em corpos-de-prova para a caracterização do material resultaram em: $f_{y}=375 \mathrm{MPa}$ (resistência ao escoamento) e $f_{u}=513 \mathrm{MPa}$ (resistência à ruptura).

Algumas das propriedades geométricas dos perfis e um resumo dos resultados dos ensaios realizados estão apresentados na Tabela 2.2. Conforme constatação do autor, independentemente da esbeltez da peça, houve a predominância de um modo que ele chamou de "local/torcional”, que a rigor se trata do modo global de flexo-torção.

\subsubsection{VISHNUVARDHAN \& SAMUEL KNIGHT (2008) - Resultados}

Segundo os autores, os perfis ensaiados nesse trabalho foram fabricados para duas espessuras das chapas $(2,00 \mathrm{~mm}$ e $3,15 \mathrm{~mm})$ e utilizando-se aços com diferentes propriedades mecânicas, conforme Tabela 2.3. A pesquisa focou apenas no ensaio de colunas curtas, com o índice de esbeltez variando entre 10 e 30, razão pela qual nenhuma presilha foi utilizada. 
Tabela 2.2 - Propriedades geométricas dos perfis e resumo dos resultados dos ensaios.

Fonte: adaptado de CHODRAUI (2006)

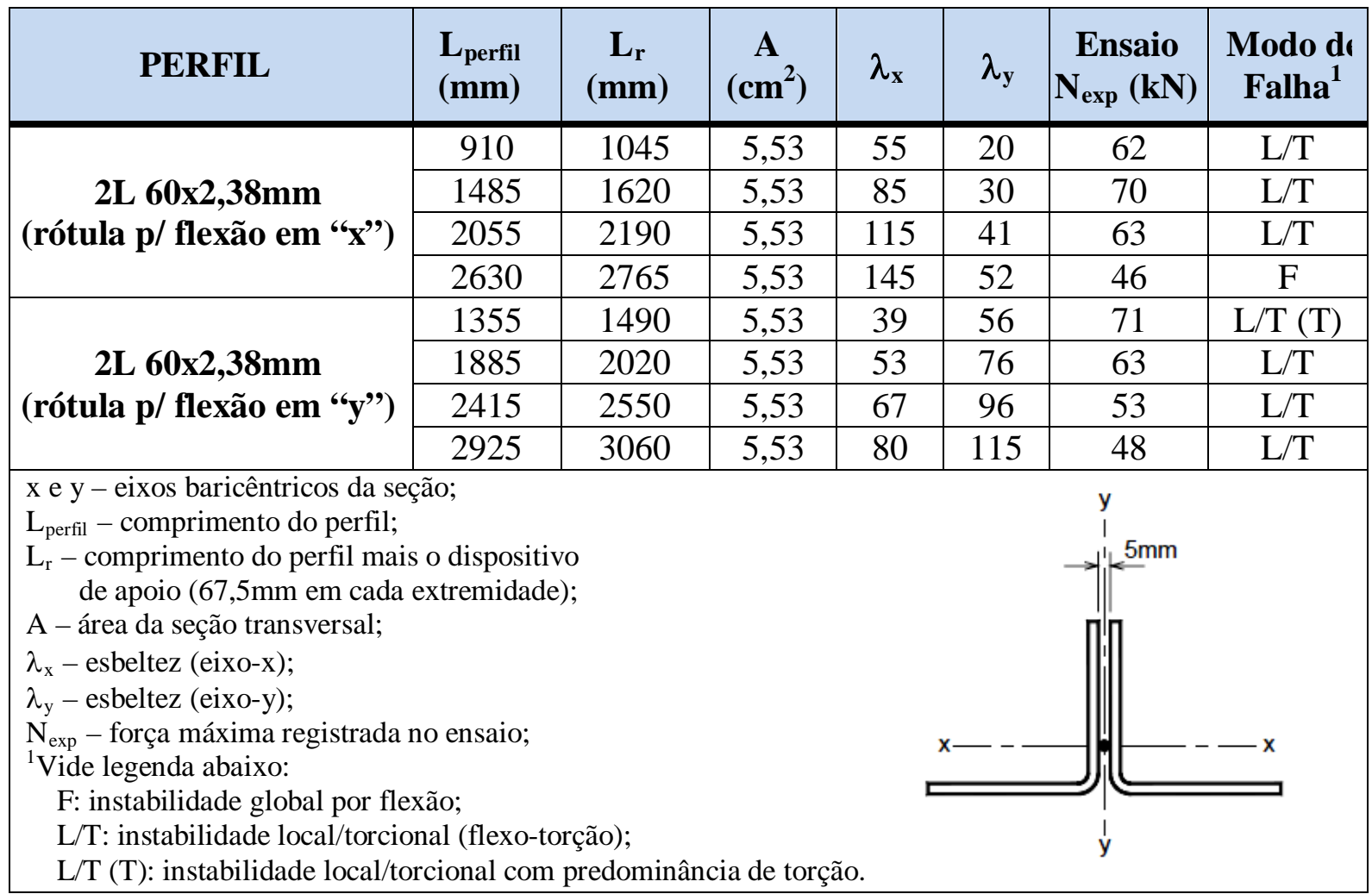

Tabela 2.3 - Propriedades do aço utilizado nos perfis.

Fonte: adaptado de VISHNUVARDHAN \& SAMUEL KNIGHT (2008)

\begin{tabular}{|c|c|c|c|c|c|}
\hline $\begin{array}{l}\text { Tipo de } \\
\text { aço }\end{array}$ & $\begin{array}{c}\mathrm{t} \\
(\mathrm{mm})\end{array}$ & $\begin{array}{c}E \\
(\mathbf{M P a})\end{array}$ & $\begin{array}{c}f_{y} \\
\text { (MPa) }\end{array}$ & $\begin{array}{c}f_{u} \\
(\mathbf{M P a})\end{array}$ & $f_{u} / f_{y}$ \\
\hline 1 & 2,00 & 182000 & 345 & 440 & 1,28 \\
\hline 2 & 2,00 & 211000 & 425 & 495 & 1,20 \\
\hline 3 & 3,15 & 201000 & 250 & 350 & 1,40 \\
\hline 4 & 2,00 & 179000 & 205 & 300 & 1,46 \\
\hline 5 & 2,00 & 210000 & 310 & 410 & 1,32 \\
\hline 6 & 3,15 & 208000 & 250 & 365 & 1,46 \\
\hline \multicolumn{6}{|c|}{$\begin{array}{l}\text { Onde: } \\
\text { t - espessura da chapa; } \\
\text { E - módulo de elasticidade longitudinal; } \\
f_{y} \text { - resistência ao escoamento do aço; } \\
f_{u} \text { - resistência à ruptura do aço. }\end{array}$} \\
\hline
\end{tabular}

A Figura 2.24 ilustra os três tipos de apoios diferentes empregados nos ensaios, a saber: (a) rótula esférica, que permite a rotação em torno de qualquer eixo; (b) ligação com chapa soldada em apenas uma aba das cantoneiras que compõem o perfil, aplicando, com isso, uma compressão excêntrica; e (c) ligação parafusada nas duas abas de cada uma das cantoneiras que compõem o perfil. Na Tabela 2.4 estão resumidas as propriedades 
geométricas dos corpos-de-prova, o tipo de aço empregado em cada um deles e os respectivos tipos de dispositivos de apoio.

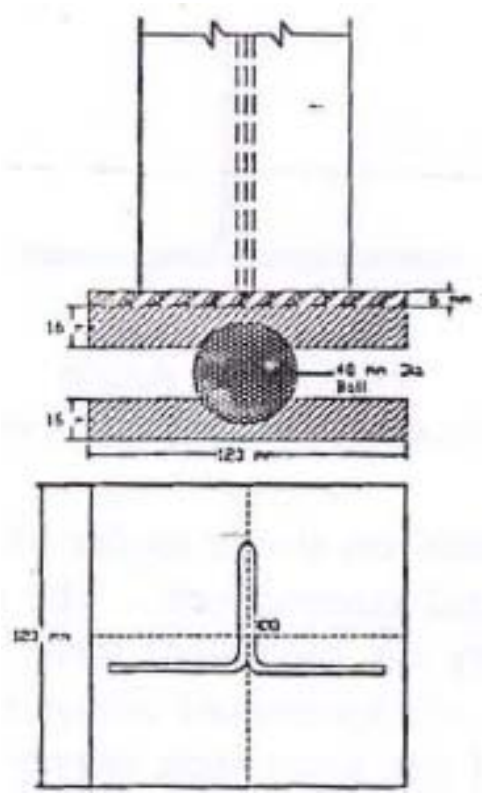

(a)

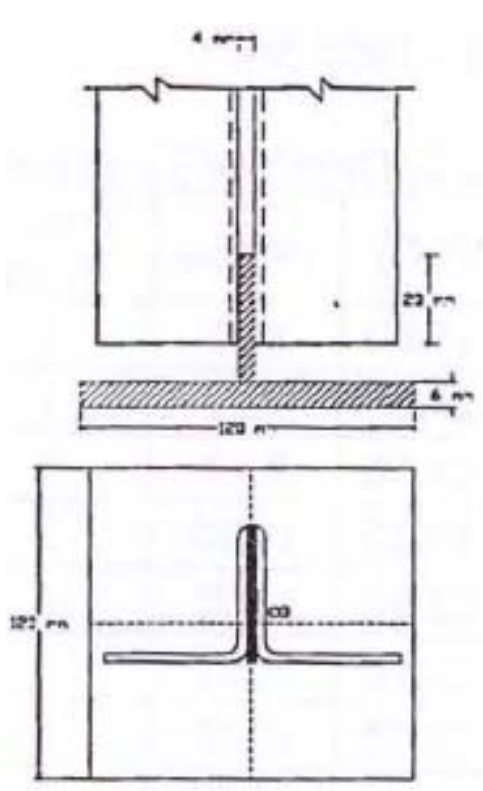

(b)

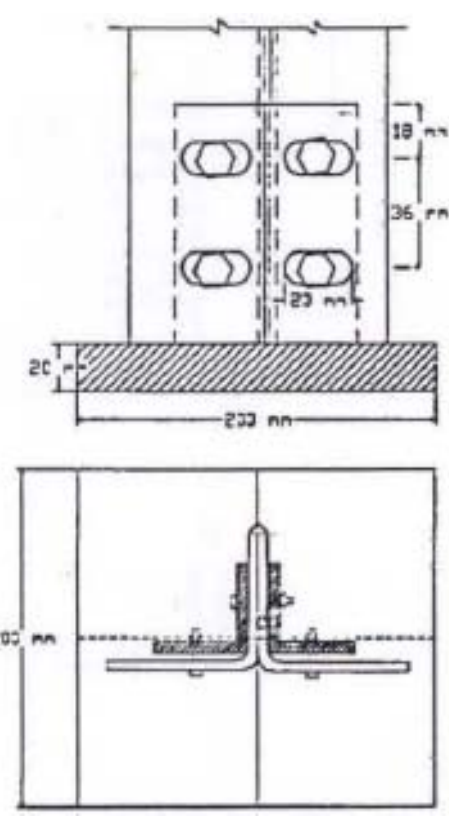

(c)

Figura 2.24 - Dispositivos de apoio: (a) rótula esférica, (b) chapa soldada e (c) parafusada. Fonte: VISHNUVARDHAN \& SAMUEL KNIGHT (2008)

Tabela 2.4 - Características dos corpos-de-prova.

Fonte: adaptado de VISHNUVARDHAN \& SAMUEL KNIGHT (2008)

\begin{tabular}{|c|c|c|c|c|c|c|}
\hline Peça $n^{\circ}$ & $\begin{array}{l}\text { Seção } \\
(\mathbf{m m})\end{array}$ & $(w / t)$ & $(w / t)_{\lim }$ & $\begin{array}{l}\text { Tipo de } \\
\text { aço }\end{array}$ & $\lambda$ & Apoios \\
\hline 1 & $35 \times 35 \times 2,00$ & 15,00 & 9,02 & 1 & $15,20,25$ & Rótula esférica \\
\hline 2 & $45 \times 45 \times 2,00$ & 20,00 & 9,02 & 1 & $15,20,25$ & Rótula esférica \\
\hline 3 & $40 \times 40 \times 2,00$ & 17,50 & 8,23 & 2 & 15,30 & Rótula esférica \\
\hline 4 & $40 \times 40 \times 3,15$ & 10,20 & 10,60 & 3 & 15,30 & Rótula esférica \\
\hline 5 & $50 \times 50 \times 2,00$ & 22,50 & 11,71 & 4 & $10,15,20$ & Chapa soldada \\
\hline 6 & $60 \times 60 \times 2,00$ & 27,50 & 9,52 & 5 & 20,30 & Abas parafusadas \\
\hline 7 & $60 \times 60 \times 3,15$ & 16,55 & 10,60 & 6 & 20,30 & Abas parafusadas \\
\hline 8 & $70 \times 70 \times 3,15$ & 19,72 & 10,60 & 6 & 20,30 & Abas parafusadas \\
\hline \multicolumn{7}{|c|}{$\begin{array}{l}\text { Onde: } \\
\lambda \text { - esbeltez global do perfil composto; } \\
\text { w - largura da chapa (aba); } \\
\text { t - espessura da chapa (aba). }\end{array}$} \\
\hline
\end{tabular}

Finalmente, são apresentados na Tabela 2.5 os resultados obtidos nos ensaios de compressão dos perfis dupla cantoneira, a partir dos quais os autores fazem uma comparação 
com os resultados de resistência à compressão das cantoneiras simples que compõem os perfis.

Tabela 2.5 - Resultados dos ensaios.

Fonte: adaptado de VISHNUVARDHAN \& SAMUEL KNIGHT (2008)

\begin{tabular}{|c|c|c|c|c|}
\hline \multirow{2}{*}{$\begin{array}{l}\text { Seção } \\
(\mathbf{m m})\end{array}$} & \multirow[b]{2}{*}{$\lambda$} & \multicolumn{2}{|c|}{ Resistência $\mathbf{N}_{\mathrm{c}, \mathrm{R}}(\mathbf{k N})$} & \multirow{2}{*}{$\begin{array}{c}\mathbf{N}_{\mathbf{c}, \mathbf{R} \text { simples }} \\
\text { / } \\
\mathbf{N}_{\mathbf{c}, \mathbf{R} \text { dupla }}\end{array}$} \\
\hline & & $\begin{array}{l}\text { Jantoneira } \\
\text { simples }\end{array}$ & $\begin{array}{c}\text { Dupla } \\
\text { cantoneira }\end{array}$ & \\
\hline \multicolumn{5}{|c|}{ Rótula esférica } \\
\hline \multirow{3}{*}{$35 \times 35 \times 2,00$} & 15 & 32,03 & 76,09 & 2,38 \\
\hline & 20 & 31,59 & 73,87 & 2,34 \\
\hline & 25 & 29,37 & 69,42 & 2,36 \\
\hline \multirow{3}{*}{$45 \times 45 \times 2,00$} & 15 & 40,05 & 80,28 & 2,00 \\
\hline & 20 & 32,69 & 75,46 & 2,31 \\
\hline & 25 & 27,02 & 70,49 & 2,61 \\
\hline \multirow{2}{*}{$40 \times 40 \times 2,00$} & 15 & 48,47 & 69,14 & 1,43 \\
\hline & 30 & 46,90 & 65,10 & 1,39 \\
\hline \multirow{2}{*}{$40 \times 40 \times 3,15$} & 15 & 62,12 & 127,30 & 2,05 \\
\hline & 30 & 59,20 & 123,50 & 2,09 \\
\hline \multicolumn{5}{|c|}{ Chapa soldada } \\
\hline \multirow{3}{*}{$50 \times 50 \times 2,00$} & 10 & 26,00 & 58,50 & 2,25 \\
\hline & 15 & 25,75 & 55,00 & 2,14 \\
\hline & 20 & 24,50 & 49,20 & 2,01 \\
\hline \multicolumn{5}{|c|}{ Abas parafusadas } \\
\hline \multirow{2}{*}{$60 \times 60 \times 2,00$} & 20 & 31,15 & 64,52 & 2,07 \\
\hline & 30 & 28,49 & 59,30 & 2,08 \\
\hline \multirow{2}{*}{$60 \times 60 \times 3,15$} & 20 & 68,97 & 127,71 & 1,85 \\
\hline & 30 & 52,51 & 123,23 & 2,35 \\
\hline \multirow{2}{*}{$70 \times 70 \times 3,15$} & 20 & 73,42 & 128,38 & 1,75 \\
\hline & 30 & 58,29 & 101,65 & 1,74 \\
\hline
\end{tabular}

\subsection{PFF EM SITUAÇÃO DE INCÊNDIO}

Como já exposto anteriormente, os perfis de aço formados a frio (PFF) vêm sendo empregados com bastante freqüência em diversos tipos de sistemas estruturais nas últimas décadas. Suas propriedades mecânicas e a facilidade na produção tem os tornado bastante competitivos no mercado da construção civil, uma vez que tendem a resultar em estruturas mais leves e, conseqüentemente, mais econômicas. No entanto, historicamente, a aplicação dos PFF antecedeu o desenvolvimento de estudos sobre o comportamento estrutural dos mesmos, contrariando a lógica da segurança das estruturas. 
Com o avanço das pesquisas, alguns aspectos de grande relevância para os PFF, como, por exemplo, os fenômenos da flambagem global, local e por distorção, se tornaram razoavelmente conhecidos em temperatura ambiente, muito embora mais pesquisas ainda estejam sendo desenvolvidas com o objetivo de aprimorar este conhecimento. Por outro lado, pesquisas realizadas a respeito dos PFF em temperaturas elevadas são bastante recentes em contexto nacional e internacional, sendo o seu comportamento estrutural em situação de incêndio muito pouco conhecido até o presente momento.

De acordo com KAITILA (2000), essa falta de subsídios teóricos acaba refletindo nos procedimentos normativos para a segurança destas estruturas em situação de incêndio, conduzindo a especificações conservadoras, antieconômicas e pouco ecológicas para proteção térmica. Neste sentido, estudos teórico-numéricos e experimentais vêm sendo desenvolvidos visando melhor conhecer o comportamento dos PFF também em temperaturas elevadas, de forma a melhorar as condições de segurança das estruturas e otimizar o emprego de materiais de proteção contra incêndios.

WANG (2002) ressalta que ensaios experimentais de estruturas em situação de incêndio são geralmente caros e demandam grande quantidade de tempo para sua preparação e execução. Assim, com o desenvolvimento de ferramentas numéricas capazes de reproduzir de forma satisfatória o comportamento das estruturas sob ação térmica, as análises termoestruturais em modelos numéricos têm sido cada vez mais utilizadas para o estudo de elementos isolados, e até mesmo de sistemas estruturais completos, em situação de incêndio.

Para isto, existe todo um embasamento teórico presente em conteúdos normativos que abrange desde a caracterização do incêndio até o dimensionamento das estruturas em temperaturas elevadas. Segue um breve comentário sobre temas de interesse para o estudo de perfis de aço em situação de incêndio e que serviram como base para os estudos aqui realizados.

\subsubsection{PROPRIEDADES DO AÇO SOB TEMPERATURAS ELEVADAS}

A importância de se estudar as estruturas em situação de incêndio é evidenciada pelo fato de os materiais, em geral, apresentarem significativas mudanças quando submetidos a temperaturas elevadas. O principal efeito da ação térmica nas estruturas em aço está associado à alteração das propriedades térmicas e mecânicas do material, que resulta em deformações adicionais referentes à dilatação térmica e na redução da capacidade resistente do sistema estrutural. 


\subsubsection{Propriedades mecânicas}

Como se sabe, o aço possui excelentes propriedades mecânicas em temperatura ambiente, porém, a grande elevação da temperatura provoca quedas acentuadas em sua resistência e em seu módulo de elasticidade. Para um melhor entendimento, YU (2000) apresenta graficamente um caso geral da redução das propriedades mecânicas do aço quando submetido ação térmica, conforme ilustrado na Figura 2.25.

A partir desse gráfico, percebe-se que os valores da resistência ao escoamento ( $F_{y}$ na figura), da resistência última ( $F_{u}$ na figura) e do módulo de elasticidade ( $E$ na figura) especificados pelas normas de projeto, como a ABNT NBR 8800:2008 e a ABNT NBR 14762:2010, passam a não ser mais representativos em situação de incêndio, necessitando de ajustes que considerem tais modificações.

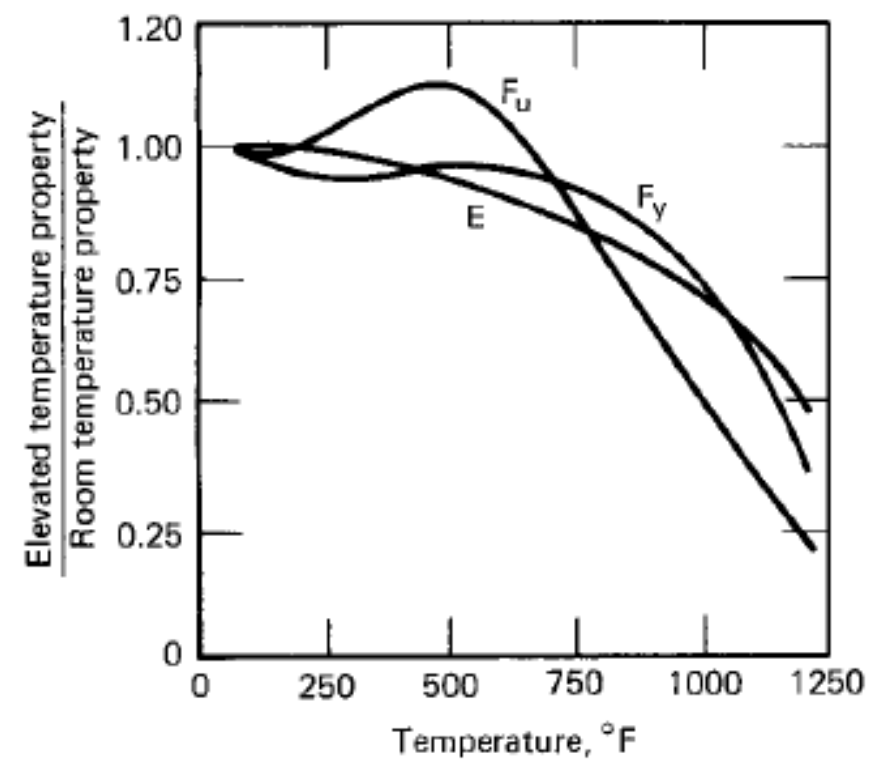

Figura 2.25 - Redução das propriedades mecânicas do aço sob ação térmica.

Fonte: YU (2000)

Os efeitos da ação térmica nas propriedades mecânicas do aço podem ser considerados então por meio dos procedimentos prescritos pelas normas ABNT NBR 14323:1999 e EN 1993-1-2:2010, que especificam coeficientes de redução para a resistência ao escoamento, para o limite de proporcionalidade e para o módulo de elasticidade $\left(\mathrm{k}_{\mathrm{y}, \theta}, \mathrm{k}_{\mathrm{p}, \theta}\right.$ e $\mathrm{k}_{\mathrm{E}, \theta}$, respectivamente) a serem utilizados na análise estrutural. Os valores destes coeficientes são calculados em função dos valores das respectivas propriedades mecânicas a $20^{\circ} \mathrm{C}$ e variam 
com a temperatura $(\theta)$, conforme apresentado na Tabela 2.6. A Figura 2.26 mostra graficamente a variação dos referidos fatores de redução em função da temperatura.

Tabela 2.6 - Fatores de redução das propriedades mecânicas do aço carbono.

Fonte: adaptado de EN 1993-1-2:2010

\begin{tabular}{|c|c|c|c|}
\hline $\begin{array}{c}\boldsymbol{\theta} \\
\left({ }^{\circ} \mathbf{C}\right)\end{array}$ & $\begin{array}{c}\mathbf{k}_{\mathbf{y}, \boldsymbol{\theta}} \\
\left(\boldsymbol{f}_{\boldsymbol{y}, \boldsymbol{\theta}} / \boldsymbol{f}_{\boldsymbol{y}}\right)\end{array}$ & $\begin{array}{c}\mathbf{k}_{\mathbf{p}, \boldsymbol{\theta}} \\
\left(\boldsymbol{f}_{\boldsymbol{p}, \boldsymbol{\theta}} / \boldsymbol{f}_{\boldsymbol{p}}\right)\end{array}$ & $\begin{array}{c}\mathbf{k}_{\mathrm{E}, \boldsymbol{\theta}} \\
\left(\boldsymbol{E}_{\boldsymbol{a}, \boldsymbol{\theta}} / \boldsymbol{E}_{\boldsymbol{a}}\right)\end{array}$ \\
\hline 20 & 1,000 & 1,000 & 1,000 \\
\hline 100 & 1,000 & 1,000 & 1,000 \\
\hline 200 & 1,000 & 0,807 & 0,900 \\
\hline 300 & 1,000 & 0,613 & 0,800 \\
\hline 400 & 1,000 & 0,420 & 0,700 \\
\hline 500 & 0,780 & 0,360 & 0,600 \\
\hline 600 & 0,470 & 0,180 & 0,310 \\
\hline 700 & 0,230 & 0,075 & 0,130 \\
\hline 800 & 0,110 & 0,050 & 0,090 \\
\hline 900 & 0,060 & 0,0375 & 0,0675 \\
\hline 1000 & 0,040 & 0,0250 & 0,0450 \\
\hline 1100 & 0,020 & 0,0125 & 0,0225 \\
\hline 1200 & 0,000 & 0,000 & 0,000 \\
\hline $\begin{array}{l}\text { Nota: } \\
\text { Para valores intermediários de temperatura, pode ser feita } \\
\text { interpolação linear. }\end{array}$ \\
\hline
\end{tabular}

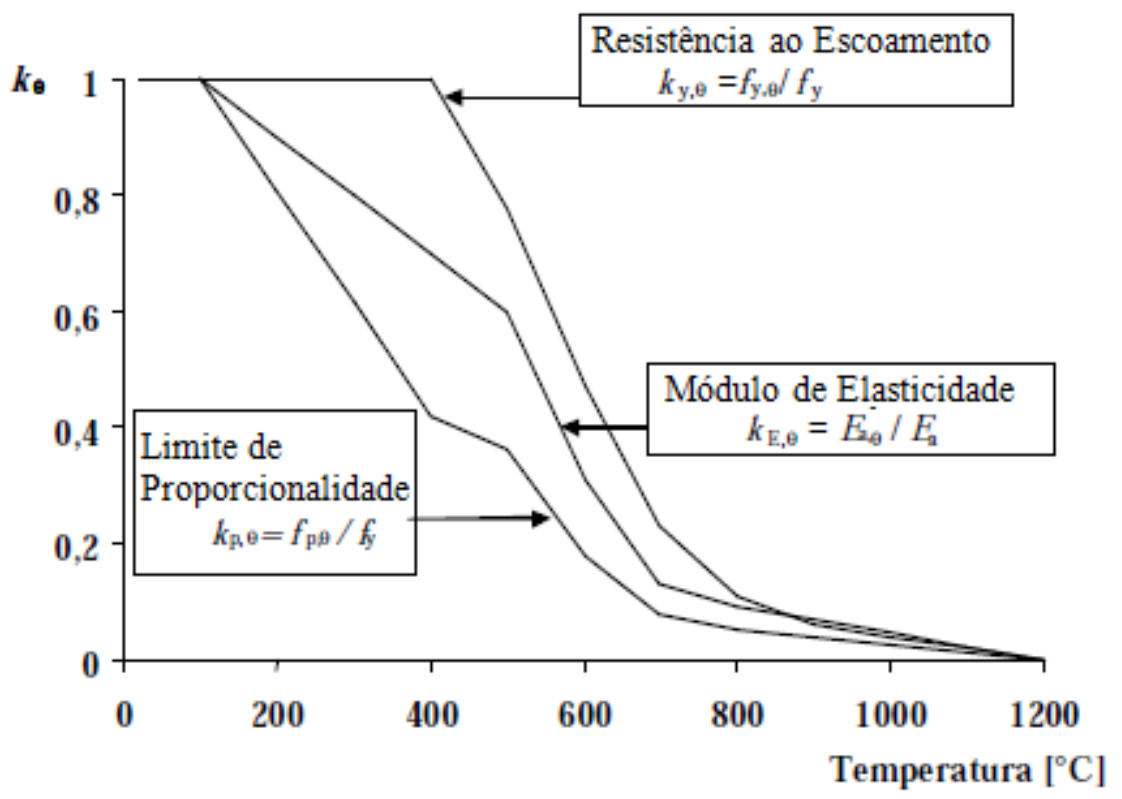

Figura 2.26 - Variação dos fatores de redução em função da temperatura.

Fonte: adaptado de EN 1993-1-2:2010 


\subsubsection{Propriedades térmicas}

As propriedades térmicas do aço que são de interesse na análise estrutural são basicamente três: a condutividade térmica, o calor específico e a dilatação térmica. Elas estão diretamente relacionadas com a taxa de aquecimento do elemento estrutural em situação de incêndio e, conseqüentemente, com a velocidade em que ocorre a perda da sua capacidade resistente, além das tensões e deformações advindas da expansão térmica dos mesmos.

A condutividade térmica pode ser calculada com base nas expressões da EN 1993-12:2010, cujo valor (em $\mathrm{W} / \mathrm{m}^{\circ} \mathrm{C}$ ) varia em função da temperatura $\left(\theta_{\mathrm{a}}\right)$, conforme as Equações (2.16). A ABNT NBR 14323:1999 especifica as mesmas expressões para o cálculo da condutividade térmica, porém, para fins de aplicação de um procedimento simplificado para o dimensionamento, a norma brasileira permite que se adote o valor constante de $45 \mathrm{~W} / \mathrm{m}^{\circ} \mathrm{C}$.

$$
\lambda_{a}\left(\theta_{a}\right)=\left\{\begin{aligned}
54-3,33.10^{-2} \theta_{a} & \rightarrow 20^{\circ} \mathrm{C} \leq \theta_{a}<800^{\circ} \mathrm{C} \\
27,3 & \rightarrow 800^{\circ} \mathrm{C} \leq \theta_{a}<1200^{\circ} \mathrm{C}
\end{aligned}\right.
$$

Na Figura 2.27 é apresentado um gráfico que ilustra a comparação entre os valores de condutividade térmica obtidos por meio das Equações (2.16) e aquele constante recomendado pela norma brasileira em caso de análises simplificadas.

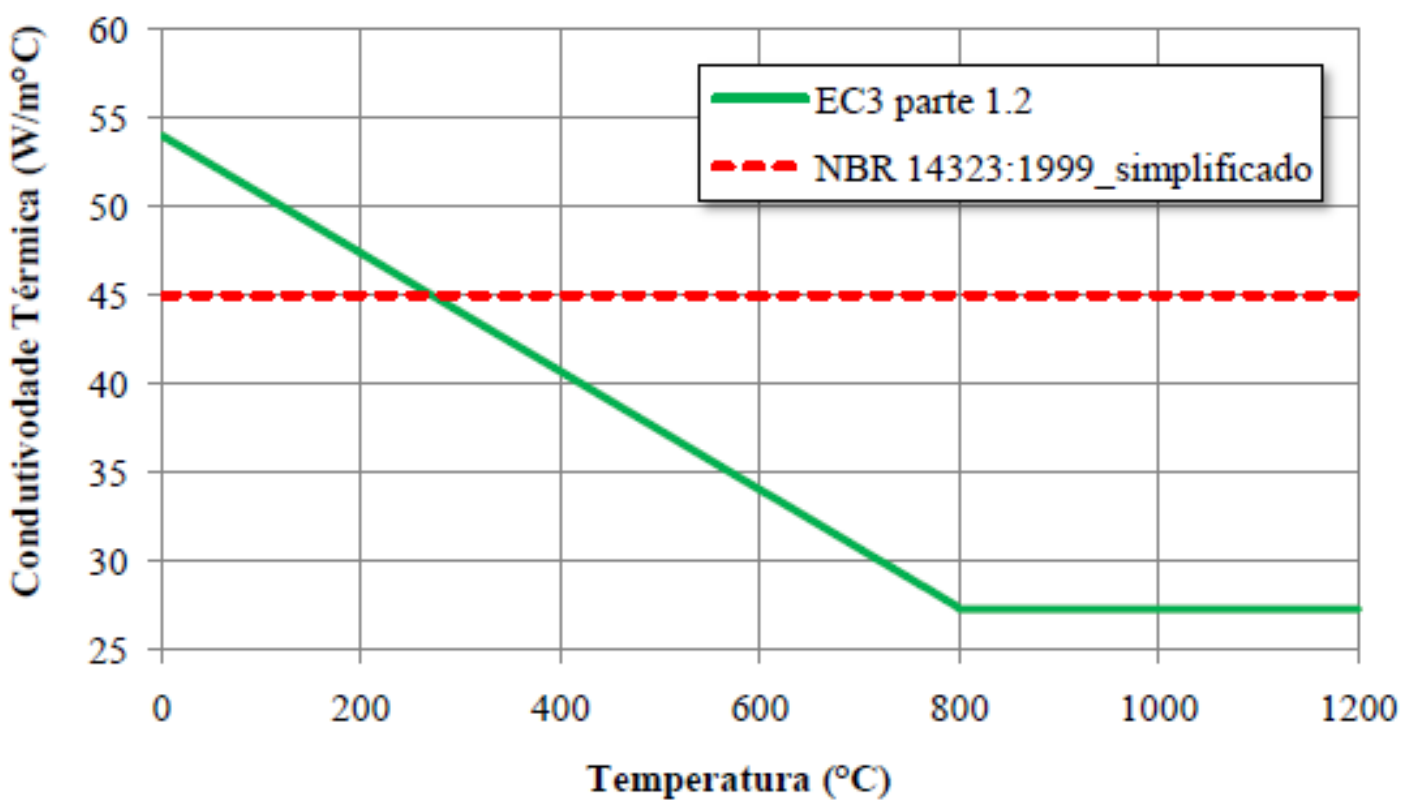

Figura 2.27 - Valores para a condutividade térmica de aços estruturais. Fonte: DORR (2010) 
Para o cálculo do calor específico, a ABNT NBR 14323:1999 e a EN 1993-1-2:2010 sugerem a utilização do conjunto de Equações (2.17), cujos resultados são dados em $\mathrm{J} / \mathrm{kg}^{\circ} \mathrm{C}$. Também neste caso, a norma brasileira permite a utilização de um valor constante de 600 $\mathrm{J} / \mathrm{kg}^{\circ} \mathrm{C}$ para análises simplificadas.

$$
C_{a}\left(\theta_{a}\right)= \begin{cases}425-7,73.10^{-1} \theta_{a}-1,69.10^{-3} \theta_{a}{ }^{2}+2,22.10^{-6} \theta_{a}^{3} & \rightarrow 20^{\circ} \mathrm{C} \leq \theta_{a}<600^{\circ} \mathrm{C} \\ 666+\frac{13002}{738-\theta_{a}} & \rightarrow 600^{\circ} \mathrm{C} \leq \theta_{a}<735^{\circ} \mathrm{C} \\ 545+\frac{17820}{\theta_{a}-731} & \rightarrow 735^{\circ} \mathrm{C} \leq \theta_{a}<900^{\circ} \mathrm{C} \\ 650 & \rightarrow 900^{\circ} \mathrm{C} \leq \theta_{a}<1200^{\circ} \mathrm{C}\end{cases}
$$

A Figura 2.28 apresenta um gráfico que ilustra a comparação entre os valores de calor específico obtidos por meio das Equações (2.17) e aquele constante recomendado pela norma brasileira em caso de análises simplificadas.

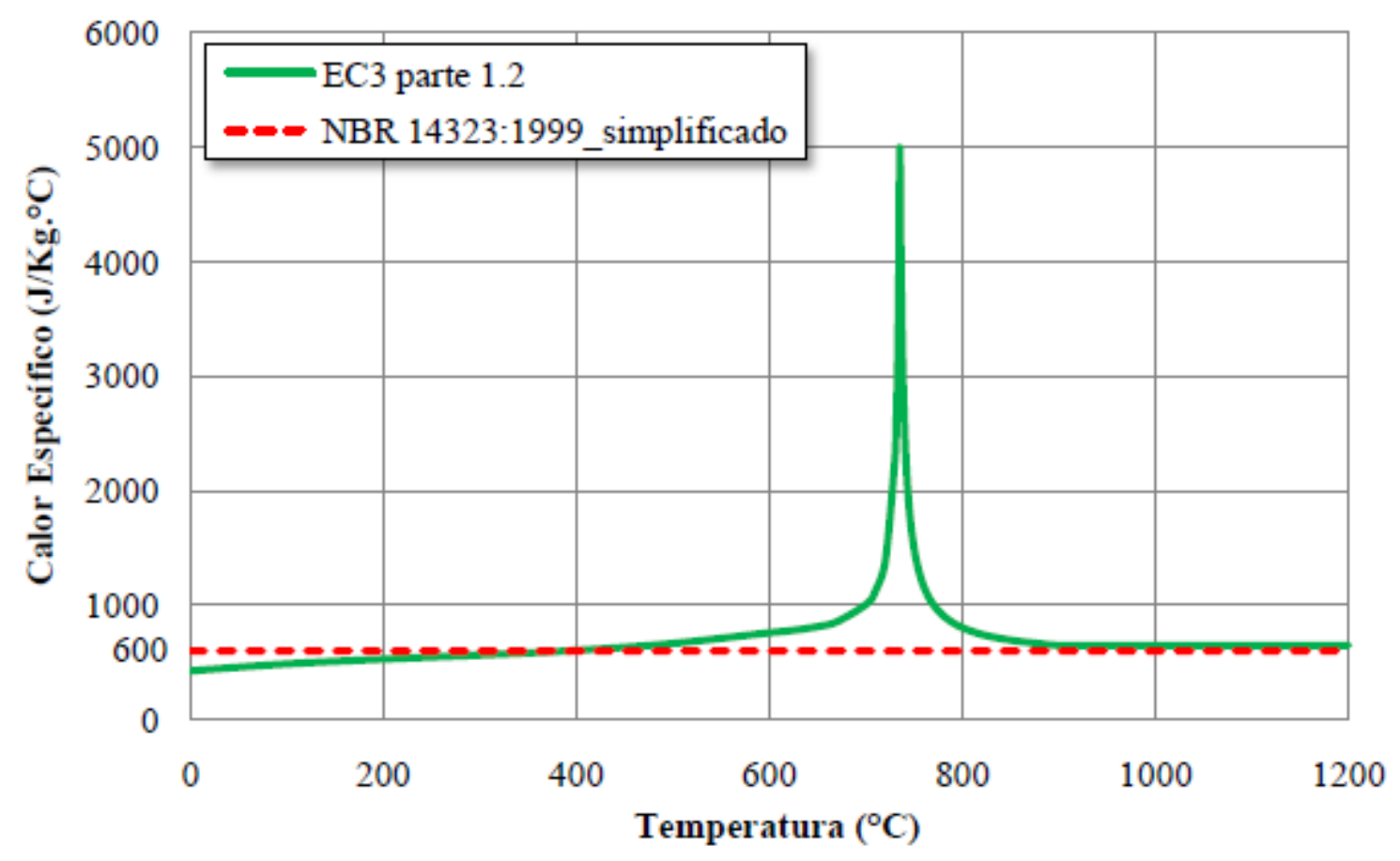

Figura 2.28 - Valores para o calor específico de aços estruturais. Fonte: DORR (2010)

Por fim, a dilatação térmica dos aços estruturais também pode ser determinada por meio do conjunto de Equações (2.18) ou pela Equação (2.19), que são referentes às 
especificações de cálculo da EN 1993-1-2:2010 e da ABNT NBR 14323:1999 (no caso de análises simplificadas), respectivamente. Nestas equações, $\ell$ é o comprimento a $20^{\circ} \mathrm{C}, \Delta \ell$ é a dilatação térmica e $\theta_{\mathrm{a}}$ é a temperatura do aço.

$$
\begin{aligned}
& \frac{\Delta \ell}{\ell}\left(\theta_{a}\right)= \begin{cases}1,2.10^{-5} \theta_{a}-0,4.10^{-8} \theta_{a}{ }^{2}+2,416.10^{-4} & \rightarrow 20^{\circ} \mathrm{C} \leq \theta_{a}<750^{\circ} \mathrm{C} \\
1,1.10^{-2} & \rightarrow 750^{\circ} \mathrm{C} \leq \theta_{a}<860^{\circ} \mathrm{C} \\
2.10^{-5} \theta_{a}-6,2.10^{-6} & \rightarrow 860^{\circ} \mathrm{C} \leq \theta_{a}<1200^{\circ} \mathrm{C}\end{cases} \\
& \frac{\Delta \ell}{\ell}\left(\theta_{a}\right)=1,4.10^{-5}\left(\theta_{a}-20\right)
\end{aligned}
$$

A Figura 2.29 demonstra graficamente a variação do valor adimensional da dilatação térmica $(\Delta \ell / \ell)$ em função da temperatura do aço, conforme as Equações (2.18) e (2.19) especificadas pelas respectivas normas.

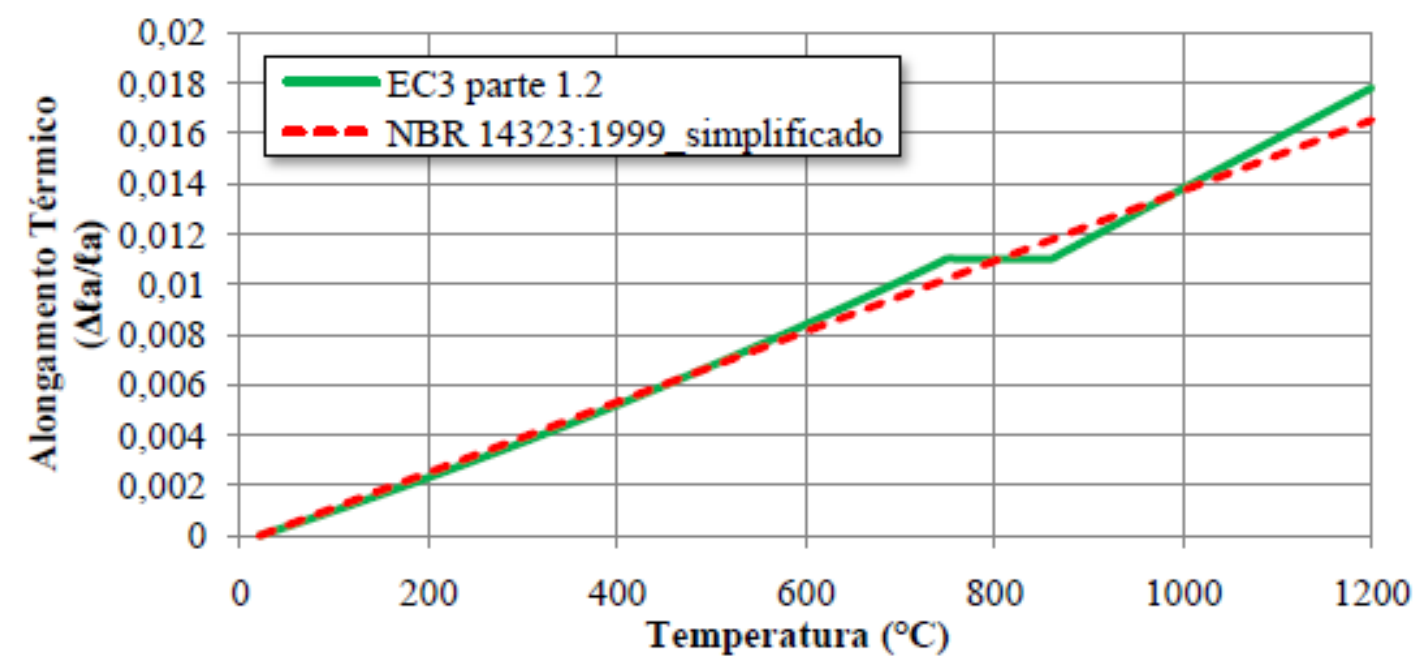

Figura 2.29 - Valores para a dilatação térmica de aços estruturais. Fonte: DORR (2010)

\subsubsection{FORMAS DE TRANSFERÊNCIA DE CALOR}

Por definição, calor é a energia em trânsito entre dois ou mais sistemas em virtude da diferença de temperatura entre eles. Existindo este gradiente térmico, em um sistema isolado, o calor flui da massa com maior temperatura para a de menor temperatura até que haja o 
equilíbrio térmico, ou seja, quando a temperatura passa a ser igual em todo o sistema. Desta forma, o termo "transferência de calor" passa a ser redundante, uma vez que a palavra "calor" já define um fluxo de energia. No entanto, esse termo é freqüentemente utilizado em estudos sobre o comportamento das estruturas em situação de incêndio, justificando o seu emprego neste trabalho.

Partindo dessa definição, percebe-se que, numa edificação em situação de incêndio, a temperatura dos elementos estruturais tende a se aproximar da temperatura dos gases quentes do ambiente. Como a capacidade resistente das estruturas de aço está diretamente relacionada com a temperatura dos seus elementos, conforme explicado anteriormente, passa a ser necessário conhecer as três possíveis formas de transferência de calor envolvidas, a saber: transferência por condução, por convecção e por radiação. Conhecidas estas formas de transferência de calor é possível prever a taxa de aquecimento dos elementos estruturais e, com isso, estimar o tempo que uma dada estrutura resistiria a um determinado incêndio.

A condução é um mecanismo de transferência de calor característico dos materiais sólidos. É por meio deste que o calor se propaga de uma extremidade para outra e ao longo da seção de um elemento estrutural ou, ainda, entre elementos estruturais que estejam em contato físico entre si. Assim, a condução é uma forma de transferência de calor que necessita de um meio físico para que ocorra e está diretamente relacionada com as propriedades térmicas descritas no item anterior (condutividade térmica e calor específico) e com a densidade do material. Portanto, a taxa de aquecimento devido à condução é variável de um material para outro.

No mecanismo de convecção, a transferência de calor é gerada pela diferença de temperatura em um fluido, seja ele gasoso ou líquido. Como a densidade de um fluido varia em função da sua temperatura, em um ambiente em chamas, por exemplo, os gases mais aquecidos se tornam menos densos e tendem a ocupar a atmosfera superior, enquanto que os gases mais frios (ou menos aquecidos), por terem maior densidade, tendem a se movimentar para a atmosfera inferior do ambiente. Esse movimento contínuo cria um fluxo convectivo que promove o rápido aquecimento do ambiente, incluindo os elementos estruturais presentes no mesmo. A ABNT NBR 14323:1999 especifica o valor de $25 \mathrm{~W} / \mathrm{m}^{2}{ }^{\circ} \mathrm{C}$ para o coeficiente de transferência de calor por convecção, valor este que será utilizado nos modelos numéricos do presente trabalho.

Por fim, a forma de transferência de calor por radiação se dá por meio da propagação de ondas eletromagnéticas, tal como a luz do Sol, que se propaga no vácuo e irradia calor para o nosso planeta. Portanto, ao contrário da condução e da convecção, o mecanismo de radiação 
não depende de um meio físico para que ocorra. Para os parâmetros referentes à radiação a serem considerados nos modelos numéricos aqui propostos, serão adotados os valores especificados pelas normas EN 1993-1-2:2010 e ABNT NBR 14323:1999 e empregados nas análises de DORR (2010). São eles: coeficiente de emissividade igual a 0,7 e constante de Stefan-Boltzmann igual a $5,67.10^{-8} \mathrm{~W} / \mathrm{m}^{2} \mathrm{~K}^{4}$.

\subsubsection{MODELOS DE INCÊNDIO - Breve abordagem}

Um dos aspectos mais importantes para o dimensionamento de estruturas submetidas a temperaturas elevadas é o prévio conhecimento dos fenômenos envolvidos em uma situação de incêndio. Neste sentido, a criação e propagação das chamas estão condicionadas à existência simultânea de três fatores básicos: a fonte de calor, o material combustível (papel, madeira, tecido etc.) e o comburente (que é o oxigênio). O incêndio tem início, então, quando a mistura combustível/oxigênio está suficientemente aquecida para que haja a combustão.

A elevação da temperatura em um compartimento em situação de incêndio é usualmente representada pelas chamadas curvas temperatura-tempo. Na Figura 2.30 é apresentada a curva temperatura-tempo típica de um modelo de incêndio real, na qual são identificadas três fases distintas que se sucedem: a ignição, o aquecimento e o resfriamento. Segue uma breve descrição, extraída e adaptada de REGOBELLO (2007), de cada uma destas fases.

- Ignição: fase durante a qual as temperaturas permanecem baixas, não tendo nenhuma influência no comportamento estrutural das edificações. Embora não seja incluída nas curvas temperatura-tempo das normas de dimensionamento, essa fase é a mais crítica no que se refere à vida humana devido à alta produção de gases tóxicos.

- Aquecimento: esta fase, iniciada pela “inflamação generalizada” ou "flashover", é caracterizada pelo rápido aumento da temperatura e ocorre quando todo o material combustível presente no ambiente entra em combustão. A duração desta fase está diretamente relacionada com a disponibilidade de combustível no ambiente e à sua taxa de queima.

- Resfriamento: nesta fase, ocorre a diminuição progressiva da temperatura dos gases pela falta de carga combustível ou oxigênio, ou ainda pela intervenção humana para o controle das chamas. 


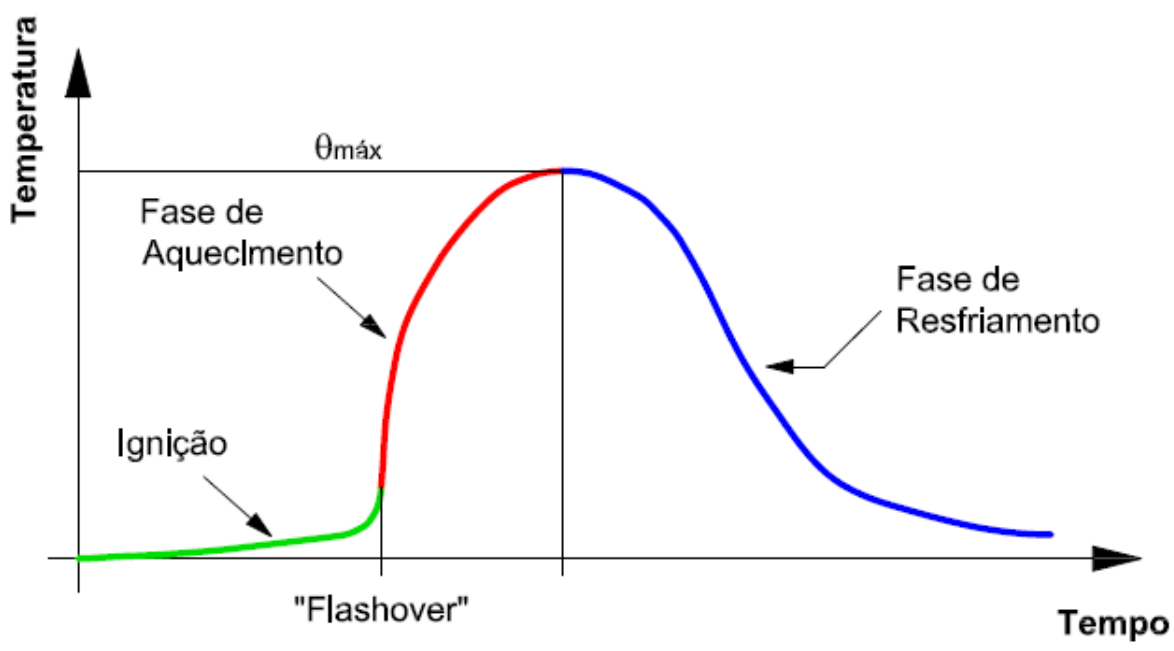

Figura 2.30 - Curva temperatura-tempo típica de um incêndio real.

Fonte: adaptado de REGOBELLO (2007)

No entanto, a curva representativa de um incêndio real é de difícil determinação, uma vez que os parâmetros que definem cada uma de suas fases apresentam grande variabilidade. Mesmo intuitivamente, é fácil perceber que parâmetros como os tempos de ignição, de aquecimento e de resfriamento, além da temperatura máxima atingida, dependem de uma série de fatores que apresentam diferenças de uma edificação para outra, tais como a compartimentação, quantidade e tipo de material combustível, disposição das aberturas e grau de ventilação, dentre outros.

Para solucionar esse problema, foram criadas curvas simplificadas para fins de modelagem de estruturas sob ação térmica, dentre as quais se destacam as chamadas curvas de incêndio natural e as curvas de incêndio-padrão. Vale informar que as formulações dos modelos que serão aqui citados e as suas respectivas definições são apresentadas detalhadamente em KIMURA (2009), onde podem ser obtidas maiores informações sobre o assunto.

No modelo de incêndio natural é desconsiderada a fase de ignição (por se entender que, nesta fase, as temperaturas atingidas não afetam a capacidade resistente da estrutura) e a fase de resfriamento é ajustada por meio de uma reta decrescente, conforme ilustrado na Figura 2.31. Portanto, buscando reproduzir os mesmos efeitos do incêndio real na estrutura, a curva temperatura-tempo do modelo de incêndio natural aborda tanto a fase de aquecimento após o "flashover" como a fase de resfriamento dos gases, sendo previstas, pela sua formulação, alterações dos parâmetros inerentes ao incêndio (Figura 2.31). 


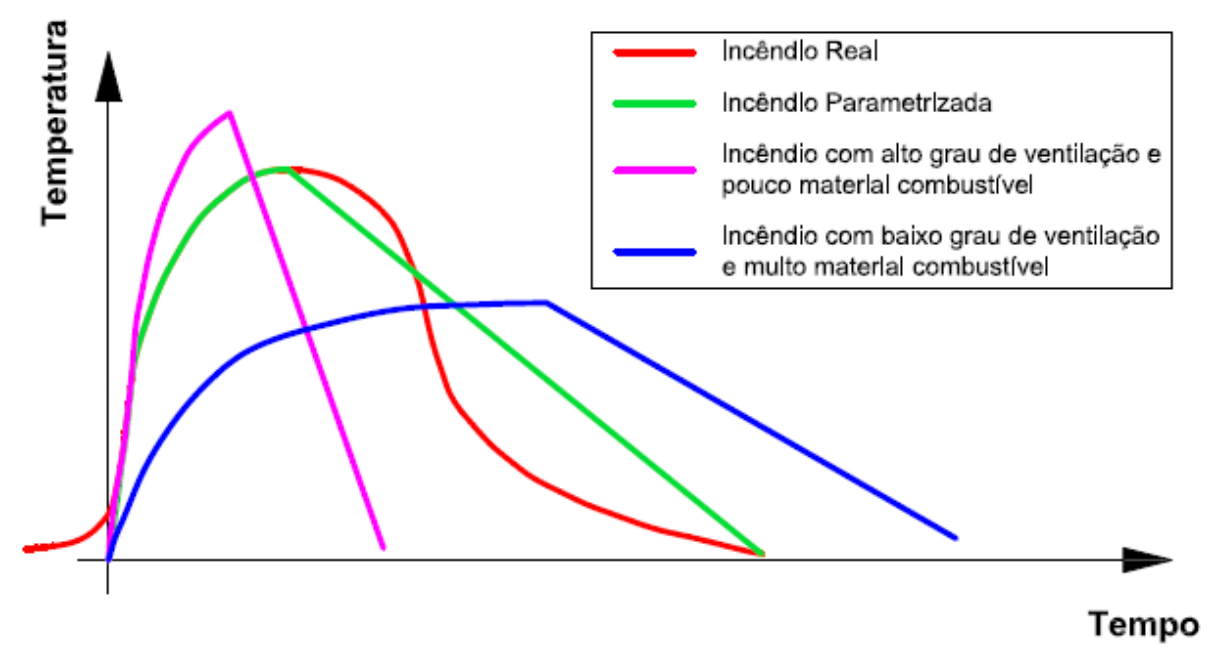

Figura 2.31 - Curva temperatura-tempo do modelo de incêndio natural. Fonte: adaptado de DORR (2010)

Tendo em vista, portanto, que a curva temperatura-tempo do incêndio natural se altera para cada situação, na intenção de padronizar as análises de estruturas em situação de incêndio no que diz respeito à curva de aquecimento dos gases, tanto em contexto experimental quanto numérico, convencionou-se adotar uma curva padronizada proposta pela norma ISO 834-1:1999, conhecida como modelo de incêndio-padrão (DORR, 2010). Essa curva, que tem sua forma geral apresentada na Figura 2.32, é semelhante àquelas propostas por outras normas, como a ASTM E119:2000 e a própria norma brasileira ABNT NBR 5628:2001.

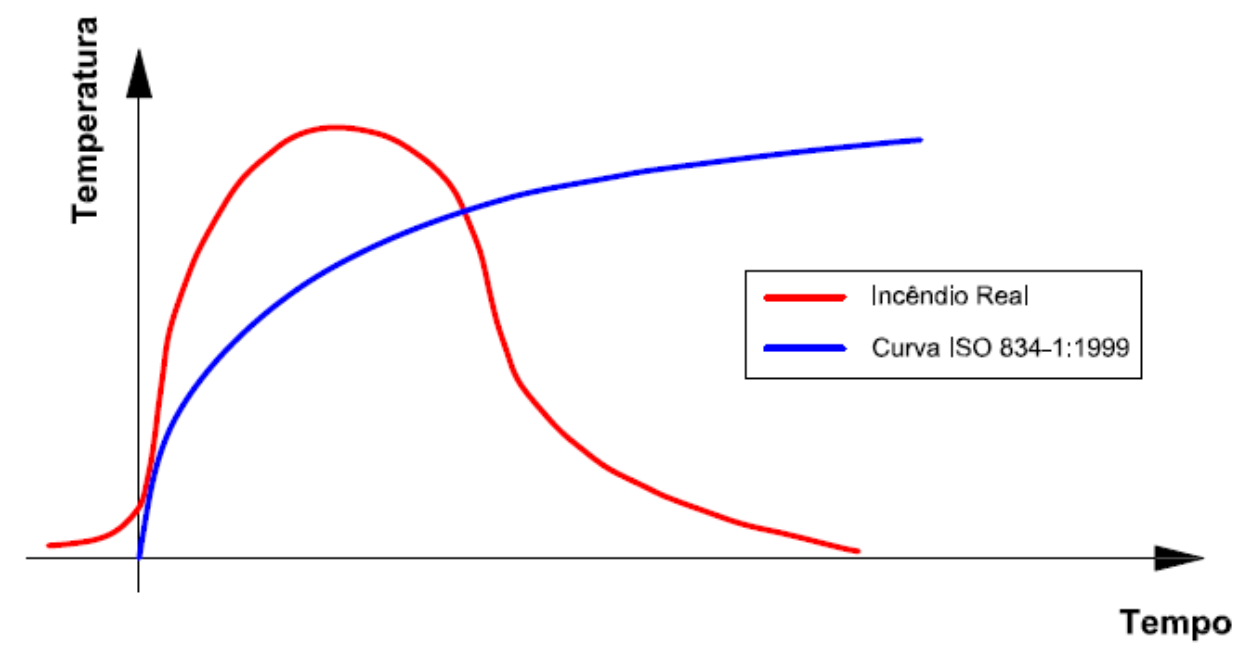

Figura 2.32 - Curva temperatura-tempo do modelo de incêndio-padrão. Fonte: adaptado de DORR (2010) 
Portanto, foi utilizada, no presente trabalho, a curva do modelo de incêndio-padrão da ISO 834-1:1999, cuja construção é feita por meio da Equação (2.20), onde $\theta_{g}$ é a temperatura dos gases do ambiente em chamas (dada em ${ }^{\circ} \mathrm{C}$ ) e $t$ é o respectivo tempo em segundos.

$$
\theta_{g}=345 \cdot \log _{10}(8 t+1)+20^{\circ} \mathrm{C}
$$

\subsubsection{TEMPO DE RESISTÊNCIA AO FOGO}

Segundo MENDES (2004), com a publicação da ABNT NBR 14323:1999 (atualmente em processo de revisão), percebeu-se a necessidade de um documento normativo que permitisse estabelecer um intervalo de tempo em que um sistema estrutural, mesmo em situação de incêndio, garantisse a sua capacidade portante no sentido de se conseguir a desocupação dos edifícios e a preservação de vidas humanas.

De encontro a essa necessidade, foi publicada então a norma brasileira ABNT NBR 14432:2001, a qual define exigências no que se refere à resistência dos elementos estruturais ao fogo, tais como o chamado Tempo Requerido de Resistência ao Fogo (TRRF). Segundo a definição da referida norma, TRRF é o tempo mínimo de resistência de um elemento construtivo quando sujeito ao incêndio-padrão. Na Tabela 2.7 são apresentados, de forma resumida, os valores especificados pela ABNT NBR 14432:2001 para o TRRF, que indica, teoricamente, o tempo mínimo de resistência ao fogo exigido para um elemento estrutural quando sujeito ao incêndio-padrão (ALVES, 2006).

Tabela 2.7 - Tempo Requerido de Resistência ao Fogo (TRRF). Fonte: ABNT NBR 14432:2001

\begin{tabular}{|l|c|c|c|c|c|}
\hline \multirow{2}{*}{ Ocupação / Uso } & \multicolumn{5}{|c|}{ ALTURA DA EDIFICAÇ̃̃o } \\
\cline { 2 - 6 } & $\mathbf{h}<\mathbf{6 m}$ & $\mathbf{6} \leq \mathbf{h}<\mathbf{1 2} \mathbf{m}$ & $\mathbf{1 2} \leq \mathbf{h}<\mathbf{2 3 m}$ & $\mathbf{2 3} \leq \mathbf{h}<\mathbf{3 0 m}$ & $\mathbf{h} \geq \mathbf{3 0 m}$ \\
\hline Residência & 30 & 30 & 60 & 90 & 120 \\
\hline Hotel & 30 & 60 & 60 & 90 & 120 \\
\hline Supermercado & 60 & 60 & 60 & 90 & 120 \\
\hline Escritório & 30 & 60 & 60 & 90 & 120 \\
\hline Shopping & 60 & 60 & 60 & 90 & 120 \\
\hline Escola & 30 & 30 & 60 & 90 & 120 \\
\hline Hospital & 30 & 60 & 60 & 90 & 120 \\
\hline Igreja & 60 & 60 & 60 & 90 & 120 \\
\hline
\end{tabular}


A partir do tipo e das características da edificação é especificado um valor para o $T R R F$, conforme indica a Tabela 2.7. Associando-se esse tempo à curva de incêndio-padrão, como a da norma ISO 834-1:1999, é possível obter a temperatura máxima teórica à qual a estrutura estará submetida e para a qual deverá apresentar capacidade portante suficiente para garantir a desocupação da edificação. 



\section{ASPECTOS REFERENTES À MODELAGEM NUMÉRICA}

\section{CAPÍTULO}

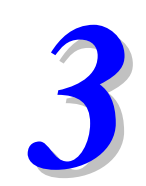

Os estudos apresentados no presente trabalho baseiam-se em modelos numéricos discretizados em elementos finitos e construídos por meio da utilização do código computacional ANSYS, visando um melhor entendimento sobre o comportamento estrutural de PFF compostos por dupla cantoneira, com seção transversal na forma de “T”, submetidos à compressão.

Inicialmente, foram realizadas análises numéricas não-lineares dos referidos perfis à temperatura ambiente, a partir das quais foi possível obter, dentre outros resultados, a capacidade resistente e os modos de instabilidade referentes ao colapso. Em seguida, os perfis em questão também foram avaliados, apenas em caráter exploratório, sob temperaturas elevadas, a fim de se ter uma estimativa do seu tempo de resistência ao fogo e da temperatura em que ocorre o fim de sua capacidade resistente para determinados níveis de carregamento.

A seguir, são descritos, de forma detalhada, a estratégia adotada para a modelagem numérica aqui desenvolvida e os recursos do programa ANSYS empregados nas análises à temperatura ambiente e em temperaturas elevadas.

\subsection{ANÁLISES À TEMPERATURA AMBIENTE}

Apesar de também envolver análises em temperaturas elevadas, o presente trabalho tem como foco principal o conhecimento do comportamento estrutural dos perfis em questão à temperatura ambiente. Para tanto, foram desenvolvidos modelos numéricos para a simulação de dois tipos de carregamento nos perfis: compressão centrada e compressão excêntrica.

As análises iniciais foram feitas para os modelos sob compressão centrada, a partir dos quais foram calibrados, com base nos resultados experimentais citados no item 2.6.1, todos os parâmetros da modelagem para a posterior análise dos mesmos perfis sob compressão excêntrica, que é a situação mais comumente encontrada na prática.

Vale ressaltar que a modelagem numérica aqui apresentada foi desenvolvida baseando-se, principalmente, nas estratégias adotadas em ALMEIDA (2007) e em MAIA 
(2008), que envolvem, para cada modelo, as seguintes etapas: (i) uma análise elástica para a obtenção da imperfeição geométrica inicial global; (ii) uma análise elástica de autovalor para a seleção das imperfeições geométricas iniciais locais; e (iii) uma análise considerando as não-linearidades geométricas e de material.

\subsubsection{GEOMETRIA DOS MODELOS}

\section{- Compressão centrada}

Para os modelos submetidos à compressão centrada, foram criadas geometrias semelhantes àquelas adotadas nos ensaios apresentados em CHODRAUI (2006) - ver item 2.6.1 - visto que a idéia inicial foi verificar se o modelo numérico criado apresentaria resultados coerentes com a situação de ensaio.

Sendo assim, foram fixadas as dimensões da seção transversal das cantoneiras que compõem o perfil, tendo abas com $60 \mathrm{~mm}$ e espessura da chapa igual a 2,38mm (60x60x2,38mm). A distância entre as cantoneiras, que corresponde à espessura das presilhas, também foi fixada em todas as análises com o valor igual a 5,0mm. Ainda em relação à seção transversal, os cantos arredondados, resultantes do processo de fabricação do perfil, foram modelados de acordo com as prescrições da ABNT NBR 6355:2003, com raio médio de dobramento igual a 1,5 vezes a espessura da chapa $\left(t=2,38 \mathrm{~mm} \leq 6,3 \mathrm{~mm} \rightarrow \mathrm{r}_{\mathrm{m}}=1,5 . \mathrm{t}\right)$. A Figura 3.1 ilustra a seção transversal utilizada nos modelos sob compressão centrada.

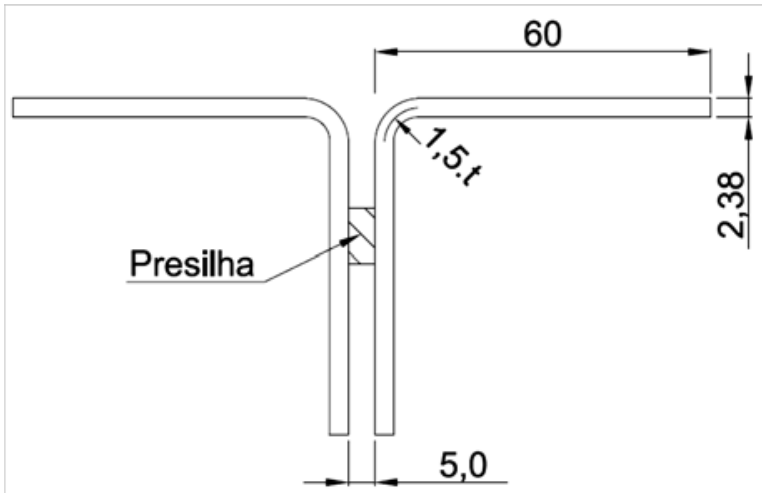

Figura 3.1 - Seção transversal adotada para os modelos sob compressão centrada.

Mantidas as dimensões da seção transversal, a avaliação da influência da esbeltez na capacidade resistente e no modo de colapso foi verificada por meio da variação do comprimento do perfil composto. Foram modelados, então, perfis com os mesmos índices de 
esbeltez dos perfis ensaiados em CHODRAUI (2006), conforme apresentado na Tabela 2.2 e na Tabela 3.1, tanto para a rótula cilíndrica posicionada no eixo-x como no eixo-y (a modelagem destes dispositivos de apoio será explicada com maiores detalhes adiante).

Tabela 3.1 - Propriedades geométricas dos perfis modelados sob compressão centrada.

\begin{tabular}{|c|c|c|c|c|c|c|c|c|c|}
\hline PERFIL & $\begin{array}{l}\mathbf{L}_{\text {perfil }} \\
(\mathbf{m m})\end{array}$ & $\underset{(\mathbf{m m})}{\mathbf{L}_{\mathbf{r}}}$ & $\begin{array}{c}I_{x} \\
\left(\mathrm{~cm}^{4}\right)\end{array}$ & $\begin{array}{c}I_{y} \\
\left(\mathrm{~cm}^{4}\right)\end{array}$ & $\begin{array}{c}A \\
\left(\mathrm{~cm}^{2}\right)\end{array}$ & $\begin{array}{c}\mathbf{r}_{\mathrm{x}} \\
(\mathbf{c m})\end{array}$ & $\begin{array}{c}r_{y} \\
(\mathbf{c m})\end{array}$ & $\lambda_{x}$ & $\lambda_{\mathrm{y}}$ \\
\hline \multirow{4}{*}{$\begin{array}{c}2 \mathrm{~L} \text { 60x2,38mm } \\
\text { (rótula no eixo-x) } \\
\mathrm{K}_{\mathrm{x}}=1,0 \text { e } \mathrm{K}_{\mathrm{y}}=0,5\end{array}$} & 910 & 1045 & 19,97 & 39,08 & 5,53 & 1,90 & 2,66 & 55 & 20 \\
\hline & 1485 & 1620 & 19,97 & 39,08 & 5,53 & 1,90 & 2,66 & 85 & 30 \\
\hline & 2055 & 2190 & 19,97 & 39,08 & 5,53 & 1,90 & 2,66 & 115 & 41 \\
\hline & 2630 & 2765 & 19,97 & 39,08 & 5,53 & 1,90 & 2,66 & 145 & 52 \\
\hline \multirow{4}{*}{$\begin{array}{c}\text { 2L 60x2,38mm } \\
\text { (rótula no eixo-y) } \\
K_{x}=0,5 \text { e } K_{y}=1,0\end{array}$} & 1355 & 1490 & 19,97 & 39,08 & 5,53 & 1,90 & 2,66 & 39 & 56 \\
\hline & 1885 & 2020 & 19,97 & 39,08 & 5,53 & 1,90 & 2,66 & 53 & 76 \\
\hline & 2415 & 2550 & 19,97 & 39,08 & 5,53 & 1,90 & 2,66 & 67 & 96 \\
\hline & 2925 & 3060 & 19,97 & 39,08 & 5,53 & 1,90 & 2,66 & 80 & 115 \\
\hline \multicolumn{10}{|c|}{$\begin{array}{l}\text { x e y - eixos baricêntricos da seção; } \\
\mathrm{L}_{\text {perfil }} \text { - comprimento do perfil; } \\
\mathrm{L}_{\mathrm{r}} \text { - comprimento do perfil mais o dispositivo de apoio (67,5mm em cada extremidade); } \\
\mathrm{I}_{x}, \mathrm{I}_{\mathrm{y}} \text { - momento de inércia em relação ao eixo-x e ao eixo-y, respectivamente; } \\
\mathrm{r}_{x}, \mathrm{r}_{\mathrm{y}} \text { - raio de giração em relação ao eixo-x e ao eixo-y, respectivamente; } \\
\text { A - área da seção transversal; } \\
\lambda_{x} \text { - índice de esbeltez em relação ao eixo-x; } \\
\lambda_{y} \text { - índice de esbeltez em relação ao eixo-y; }\end{array}$} \\
\hline
\end{tabular}

Analogamente às definições dos ensaios, o número de presilhas nos modelos numéricos foi definido de acordo com os limites prescritos pela ABNT NBR 14762:2010 para a esbeltez de perfis compostos sob compressão. Com isso, foram utilizadas duas presilhas para os perfis com a rótula cilíndrica posicionada segundo o eixo-x e três presilhas para aqueles com a rótula cilíndrica posicionada segundo o eixo-y, sendo igualmente espaçadas ao longo do comprimento em ambos os casos. As presilhas foram inseridas com dimensões de 20x20x5mm e posicionadas conforme ilustrado na Figura 3.1.

Para representar as condições de vinculação, foram modelados sólidos de topo equivalentes nas extremidades das barras. A dimensão longitudinal desses sólidos foi adotada como sendo a soma da espessura dos dispositivos de apoio (55mm) utilizados nos ensaios com a espessura da chapa de topo que foi soldada ao perfil $(12,5 \mathrm{~mm})$, resultando numa espessura total de 67,5mm para cada extremidade (ver Figura 2.22 e Figura 2.23).

A Figura 3.2 apresenta a geometria completa de um dos perfis analisados sob compressão centrada, onde podem ser observadas as cantoneiras que compõem o perfil, o posicionamento das presilhas e os sólidos de topo equivalentes. 


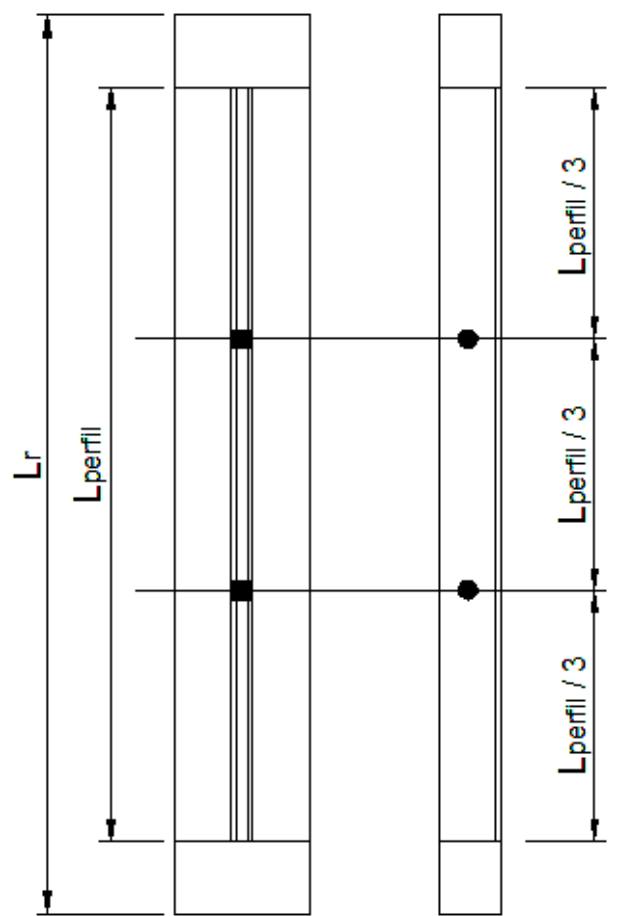

(a)

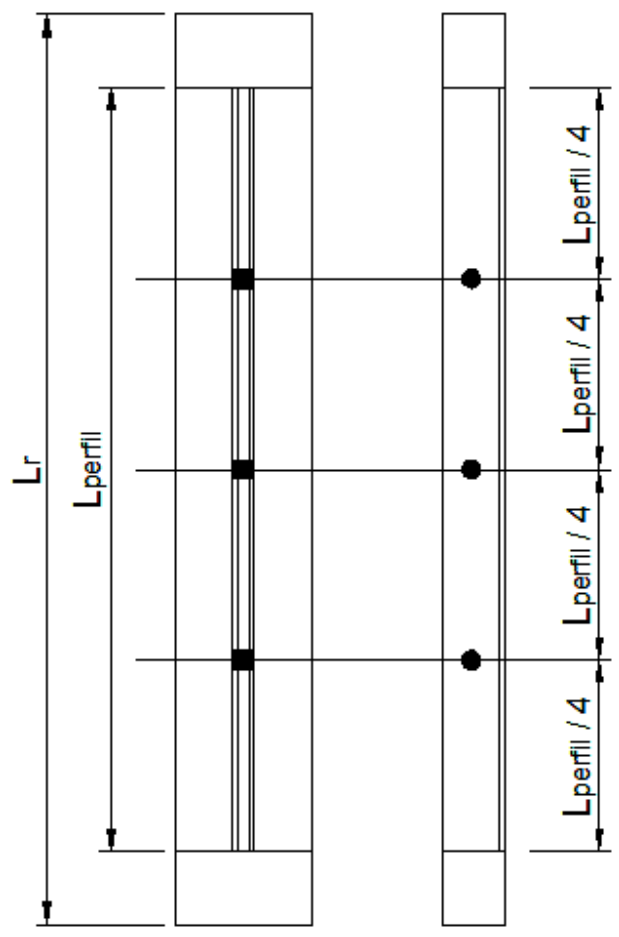

(b)

Figura 3.2 - Geometria dos modelos sob compressão centrada: (a) Rótula no eixo-x e (b) Rótula no eixo-y.

\section{- Compressão excêntrica}

Para os modelos submetidos à compressão excêntrica, foram empregadas duas seções transversais diferentes, sendo mantidas as abas das cantoneiras com $60 \mathrm{~mm}$ e variando a espessura de suas chapas entre os valores 1,5mm e 3,0mm (seções 60x60x1,5mm e 60x60x3,0mm), conforme ilustrado na Figura 3.3. Com esta variação na espessura da chapa das cantoneiras foi possível avaliar a influência da esbeltez local no comportamento do perfil.

Semelhantemente aos modelos sob compressão centrada, a distância entre as cantoneiras que compõem o perfil (espessura das presilhas) foi fixada em 5,0mm em todas as análises. Da mesma forma, o raio médio de dobramento, resultante do processo de fabricação dos perfis, também foi modelado com o valor de 1,5 vezes a espessura da chapa $(\mathrm{t}=1,5 \mathrm{~mm}$ ou $\left.3,0 \mathrm{~mm} \leq 6,3 \mathrm{~mm} \rightarrow \mathrm{r}_{\mathrm{m}}=1,5 . \mathrm{t}\right)$. 

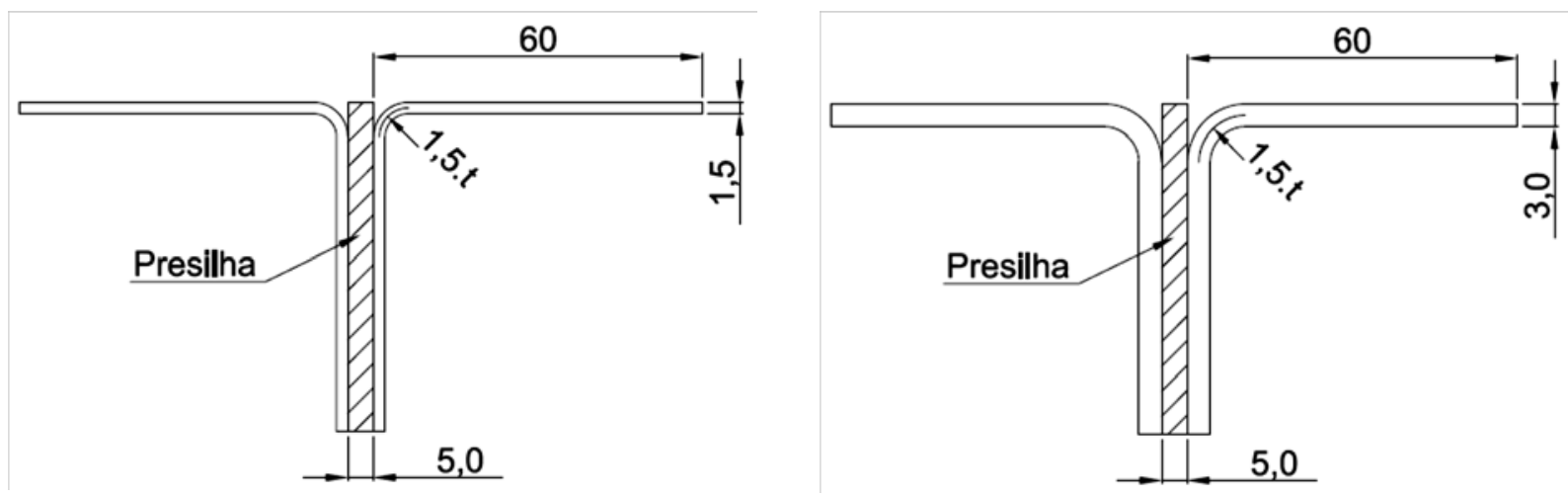

Figura 3.3 - Seções transversais adotadas para os modelos sob compressão excêntrica.

A avaliação da esbeltez global no comportamento do perfil foi feita, então, por meio da variação do seu comprimento, cujos valores foram estrategicamente escolhidos de forma a se fazer uma varredura na faixa de comprimentos usuais do perfil em questão. A Tabela 3.2 apresenta os índices de esbeltez para os quais foram modelados os perfis sob compressão excêntrica e algumas das propriedades geométricas para as duas seções avaliadas (60x60x1,5mm e 60x60x3,0mm). Vale ressaltar que todas as propriedades geométricas dos perfis foram calculadas de acordo com ABNT NBR 6355:2003 e por meio de formulações deduzidas com base no “método linear”, cuja definição se encontra na referida norma.

Tabela 3.2 - Propriedades geométricas dos perfis modelados sob compressão excêntrica.

\begin{tabular}{|c|c|c|c|c|c|c|c|c|c|}
\hline PERFIL & $\begin{array}{l}\mathbf{L}_{\text {perfil }} \\
(\mathbf{m m})\end{array}$ & $\underset{(\mathbf{m m})}{\mathbf{L}_{\mathbf{r}}}$ & $\begin{array}{c}I_{x} \\
\left(\mathrm{~cm}^{4}\right)\end{array}$ & $\begin{array}{c}I_{y} \\
\left(\mathrm{~cm}^{4}\right)\end{array}$ & $\begin{array}{c}A \\
\left(\mathrm{~cm}^{2}\right)\end{array}$ & $\begin{array}{c}\mathbf{r}_{\mathbf{x}} \\
(\mathbf{c m})\end{array}$ & $\begin{array}{c}r_{y} \\
(\mathbf{c m})\end{array}$ & $\lambda_{x}$ & $\lambda_{y}$ \\
\hline \multirow{5}{*}{$\begin{array}{l}\mathbf{2 L} \mathbf{6 0 x 1 , 5 m m} \\
K_{x}=1,0 \text { e } K_{y}=1,0\end{array}$} & 695 & 575 & 12,91 & 24,58 & 3,54 & 1,91 & 2,64 & 30 & 22 \\
\hline & 1175 & 1055 & 12,91 & 24,58 & 3,54 & 1,91 & 2,64 & 55 & 40 \\
\hline & 1745 & 1625 & 12,91 & 24,58 & 3,54 & 1,91 & 2,64 & 85 & 62 \\
\hline & 2320 & 2200 & 12,91 & 24,58 & 3,54 & 1,91 & 2,64 & 115 & 83 \\
\hline & 2895 & 2775 & 12,91 & 24,58 & 3,54 & 1,91 & 2,64 & 145 & 105 \\
\hline \multirow{6}{*}{ 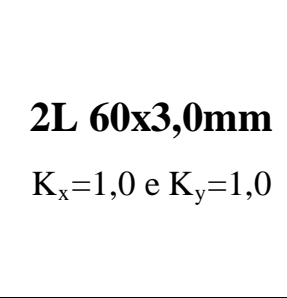 } & 500 & 380 & 24,72 & 49,33 & 6,90 & 1,89 & 2,67 & 20 & 14 \\
\hline & 875 & 755 & 24,72 & 49,33 & 6,90 & 1,89 & 2,67 & 40 & 28 \\
\hline & 1445 & 1325 & 24,72 & 49,33 & 6,90 & 1,89 & 2,67 & 70 & 50 \\
\hline & 2010 & 1890 & 24,72 & 49,33 & 6,90 & 1,89 & 2,67 & 100 & 71 \\
\hline & 2580 & 2460 & 24,72 & 49,33 & 6,90 & 1,89 & 2,67 & 130 & 92 \\
\hline & 3145 & 3030 & 24,72 & 49,33 & 6,90 & 1,89 & 2,67 & 160 & 113 \\
\hline \multicolumn{10}{|c|}{$\begin{array}{l}\text { x e y - eixos baricêntricos da seção; } \\
\mathrm{L}_{\text {perfil }} \text { - comprimento do perfil; } \\
\mathrm{L}_{\mathrm{r}} \text { - comprimento do perfil de centro a centro da ligação parafusada; } \\
\mathrm{I}_{\mathrm{x}}, \mathrm{I}_{\mathrm{y}} \text { - momento de inércia em relação ao eixo-x e ao eixo-y, respectivamente; } \\
\mathrm{r}_{\mathrm{x}}, \mathrm{r}_{\mathrm{y}} \text { - raio de giração em relação ao eixo-x e ao eixo-y, respectivamente; } \\
\text { A - área da seção transversal; } \\
\lambda_{x} \text { - índice de esbeltez em relação ao eixo-x; } \\
\lambda_{\mathrm{y}} \text { - índice de esbeltez em relação ao eixo-y; }\end{array}$} \\
\hline
\end{tabular}


Com a finalidade de se investigar a influência das presilhas (ou chapas separadoras) na capacidade resistente e no modo de colapso dos perfis estudados, fez-se variar a quantidade de presilhas ao longo do comprimento nas análises numéricas, conforme apresentado na Tabela 3.3. Para a definição do número de presilhas empregadas nos modelos, tomou-se como referência o valor especificado pela ABNT NBR 14762:2010 para perfis compostos e também a limitação de espaço para a alocação das mesmas nos perfis mais curtos. Assim, o número mínimo de presilhas utilizadas foi igual a zero (perfis sem presilhas, que é a situação em que as cantoneiras são unidas apenas através das chapas de ligação) e o número máximo foi aquele especificado pela referida norma mais duas, totalizando quatro presilhas.

Tabela 3.3 - Número de presilhas para os modelos sob compressão excêntrica.

\begin{tabular}{|c|c|c|c|c|}
\hline PERFIL & $\begin{array}{l}\mathbf{L}_{\text {perfil }} \\
(\mathbf{m m})\end{array}$ & $\begin{array}{c}\mathbf{L}_{\mathbf{r}} \\
(\mathbf{m m})\end{array}$ & $\lambda$ & $\begin{array}{l}\text { Número de presilhas } \\
\text { utilizadas }\end{array}$ \\
\hline \multirow{5}{*}{ 2L $60 \times 1,5 \mathrm{~mm}$} & 695 & 575 & 30 & 0,1 e 2 \\
\hline & 1175 & 1055 & 55 & $0,1,2$ e 3 \\
\hline & 1745 & 1625 & 85 & $0,1,2,3$ е 4 \\
\hline & 2320 & 2200 & 115 & $0,1,2,3$ е 4 \\
\hline & 2895 & 2775 & 145 & $0,1,2,3$ е 4 \\
\hline \multirow{6}{*}{$2 \mathrm{~L} \mathrm{60x3,0 \textrm {mm }}$} & 500 & 380 & 20 & 0,1 e 2 \\
\hline & 875 & 755 & 40 & 0,1 e 2 \\
\hline & 1445 & 1325 & 70 & $0,1,2$ e 3 \\
\hline & 2010 & 1890 & 100 & $0,1,2,3$ e 4 \\
\hline & 2580 & 2460 & 130 & $0,1,2,3$ e 4 \\
\hline & 3145 & 3030 & 160 & $0,1,2,3$ e 4 \\
\hline \multicolumn{5}{|c|}{$\begin{array}{l}\mathrm{L}_{\text {perfil }} \text { - comprimento do perfil; } \\
\mathrm{L}_{\mathrm{r}} \text { - comprimento do perfil de centro a centro da ligação parafusada; } \\
\lambda \text { - índice de esbeltez do perfil. }\end{array}$} \\
\hline
\end{tabular}

As dimensões das presilhas foram definidas com a mesma ordem de grandeza das abas das cantoneiras que compõem o perfil, sendo sua espessura mantida constante e igual a $5 \mathrm{~mm}$ (60x60x5,0mm) nas análises. Em todas as situações as presilhas foram igualmente espaçadas e, para a sua fixação nos perfis, optou-se pela utilização de um parafuso em cada uma delas, sendo o efeito dessa ligação considerado nos modelos numéricos por meio de acoplamentos ou união dos nós, conforme será exposto mais à frente.

Para os dispositivos de apoio do perfil, foram modelados sólidos de topo conectados a uma chapa de ligação em cada extremidade. A espessura dos sólidos de topo foi adotada como sendo a mesma dos modelos sob compressão centrada ( $55 \mathrm{~mm}+12,5 \mathrm{~mm}=67,5 \mathrm{~mm})$ e a chapa de ligação foi inserida com dimensões suficientes para o posicionamento de dois 
parafusos com $\phi 19 \mathrm{~mm}$ (diâmetro dos furos de $21 \mathrm{~mm}$ ), resultando em chapas de 60x120x5,0mm. Ao invés de um único parafuso, optou-se por se utilizar dois parafusos na ligação para evitar problemas de rasgamento ou esmagamento das chapas na região dos furos, o que fugiria do escopo do estudo.

É importante informar que, apesar de as dimensões terem sido fixadas com os valores informados, os "scripts” desenvolvidos no presente trabalho para automatização das análises permitem a alteração de todos os parâmetros de entrada referentes à geometria e demais propriedades dos modelos. A Figura 3.4 apresenta, de forma esquemática, a geometria de um dos perfis analisados sob compressão excêntrica, onde podem ser observadas as cantoneiras que compõem o perfil, as chapas de ligação, o posicionamento das presilhas e os sólidos de topo equivalentes.

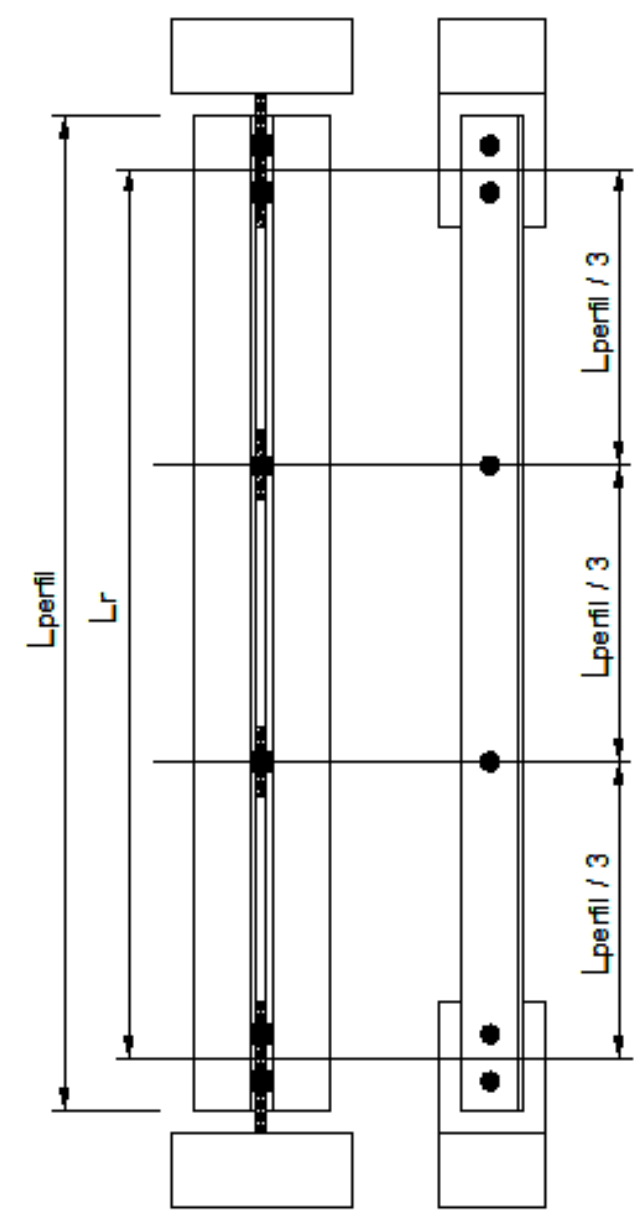

Figura 3.4 - Geometria de um dos modelos analisados sob compressão excêntrica (modelo com duas presilhas). 


\subsubsection{MALHA E ELEMENTOS FINITOS UTILIZADOS}

\section{- Compressão centrada}

A discretização dos perfis sob compressão centrada foi feita utilizando-se basicamente dois elementos finitos disponibilizados na biblioteca interna do ANSYS, denominados SHELL 181 e SOLID 45.

Para as chapas das cantoneiras foi empregado o elemento SHELL 181, que é um elemento finito descrito na biblioteca interna do ANSYS como ideal para análises nãolineares de cascas de pequena espessura e sujeitas a grandes deformações e rotações, o que se aplica bem aos PFF. Este elemento possui quatro nós com seis graus de liberdade por nó, que são referentes à translação na direção dos eixos cartesianos (Ux, Uy e Uz) e à rotação em torno destes mesmos eixos (ROTx, ROTy e ROTz).

A decisão de se empregar esse elemento nas chapas dos perfis aqui modelados teve como base, além de suas características interessantes para o problema em questão, os vários testes com elementos finitos apresentados em ALMEIDA (2007), onde se verificou que PFF sob compressão discretizados com o elemento SHELL 181 apresentam resultados coerentes e ainda reduzem o esforço computacional nas análises quando comparados a elementos sólidos.

No caso dos dispositivos de apoio, optou-se pela utilização do elemento SOLID 45, já que os mesmos foram modelados como sólidos de topo equivalente. Trata-se de um elemento sólido com quatro nós e três graus de liberdade por nó, que são referentes apenas à translação na direção dos eixos cartesianos (Ux, Uy e Uz). O elemento SOLID 45 também foi empregado na discretização das presilhas para facilitar a união entre as cantoneiras e as presilhas na região parafusada.

Tomando como referência as modelagens numéricas apresentadas em ALMEIDA (2007) e em MAIA (2008), foi inserida uma malha mapeada de aproximadamente $1 \mathrm{~cm}$ x $1 \mathrm{~cm}$ na discretização das presilhas e das cantoneiras que compõem os perfis, com a exceção das regiões curvas, cuja seção foi dividida em apenas dois elementos. Nos dispositivos de apoio, o tamanho dos elementos variou de forma a fazer coincidir os nós da região a ser unida ao perfil. Ressalta-se que a caracterização da malha e a escolha dos elementos finitos empregados no presente trabalho tomou como base os testes realizados nas referências supracitadas.

A Figura 3.5 mostra um dos modelos analisados indicando a malha e os elementos finitos utilizados nas cantoneiras, nas presilhas e nos dispositivos de apoio. 


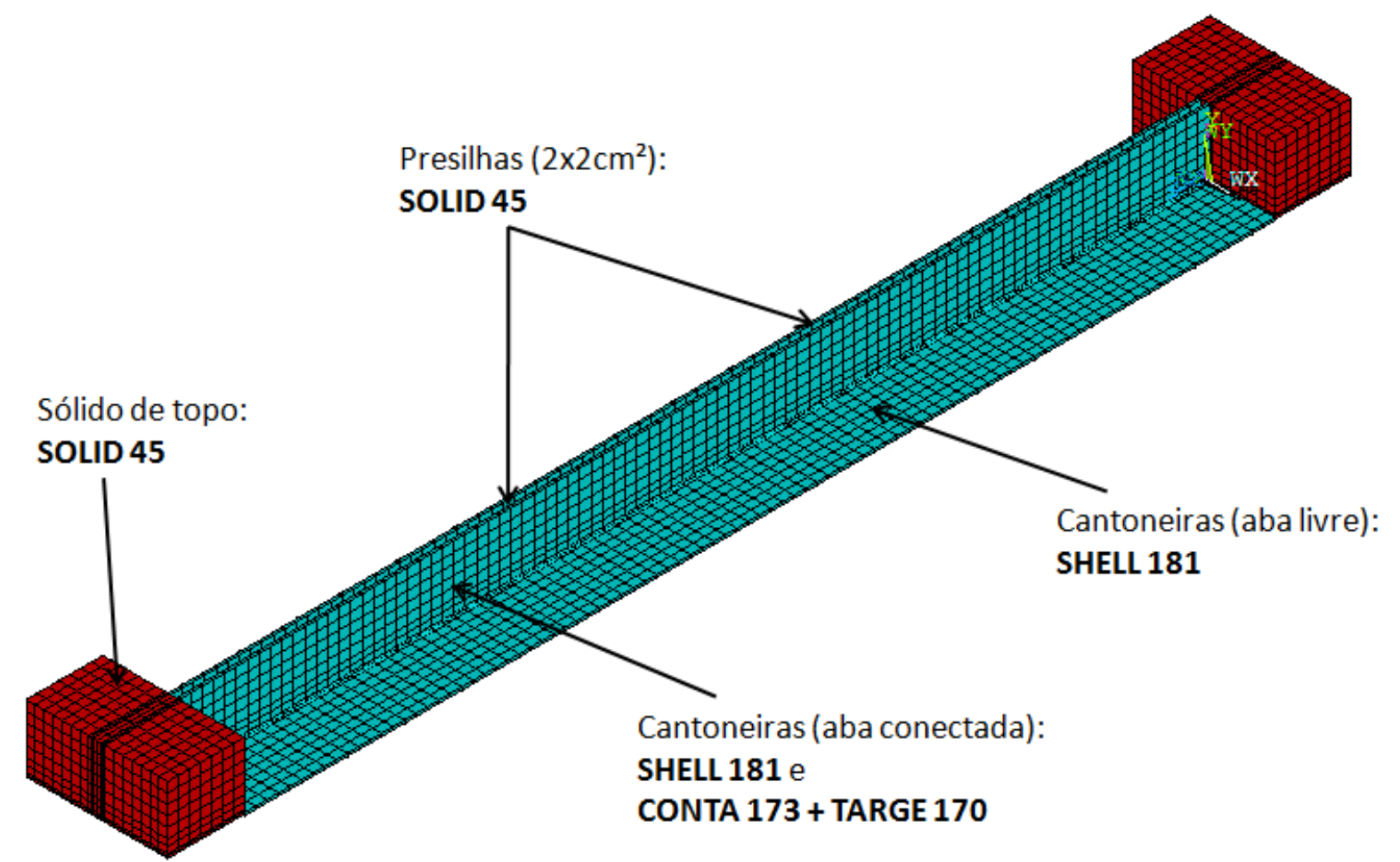

Figura 3.5 - Malha e elementos finitos utilizados nos modelos sob compressão centrada.

Além dos elementos citados, como alguns modelos passaram a apresentar interpenetração entre as chapas das cantoneiras e entre as cantoneiras e as presilhas devido às deformações, testou-se a utilização do par de elementos de contato CONTA 173 e TARGE 170. Estes elementos são inseridos por meio dos nós dos elementos SHELL 181 e SOLID 45 já existentes e seus graus de liberdade englobam a pressão de contato e o atrito entre as duas superfícies.

Realizaram-se inúmeros testes para a calibração dos parâmetros desses elementos, os quais foram posicionados nas faces internas das abas das cantoneiras e nas presilhas. Com isso, resolveram-se problemas de convergência e de interpenetração nos modelos, conforme ilustrado na Figura 3.6 e na Figura 3.7.

Maiores informações sobre os elementos de contato e sobre a forma de inserção dos mesmos nos modelos estão disponibilizadas na biblioteca interna do ANSYS (Manual Contact Technology Guide). Além disso, a estratégia para a alocação de tais elementos na modelagem desenvolvida no presente trabalho pode ser visualizada por meio dos scripts apresentados no APÊNDICE A e no APÊNDICE B desta dissertação. 


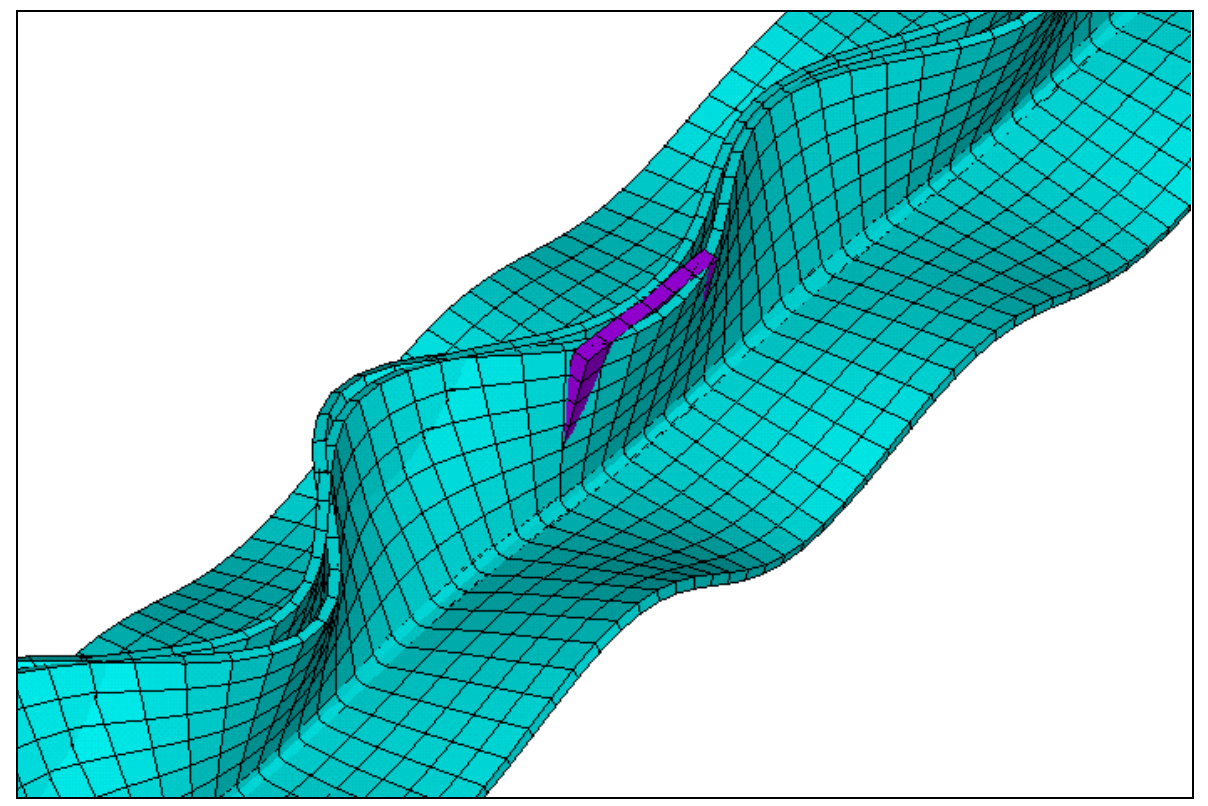

Figura 3.6 - Modelos sem elementos de contato: problemas de interpenetração das malhas (entre as chapas das cantoneiras e entre a presilha e a cantoneira) - escala aumentada.

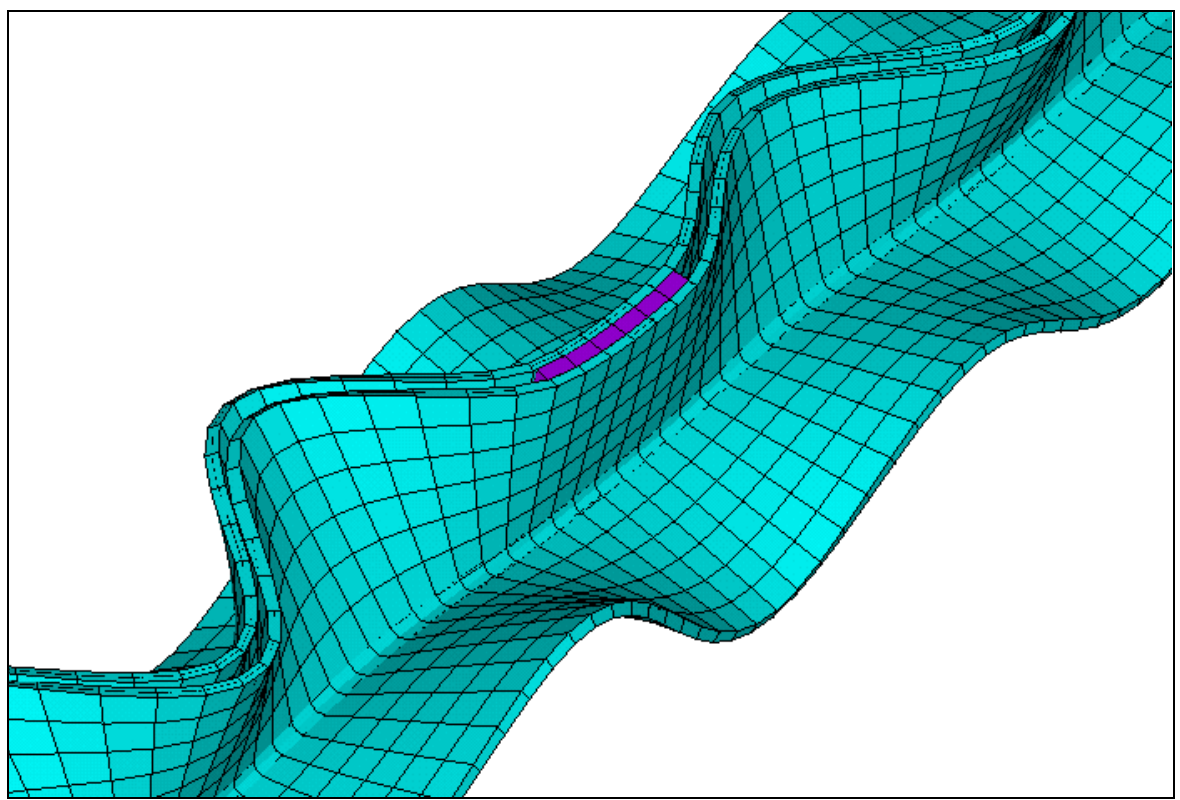

Figura 3.7 - Modelos com elementos de contato: eliminação dos problemas de interpenetração das malhas - escala aumentada.

\section{- Compressão excêntrica}

Para os perfis analisados sob compressão excêntrica, foram utilizados, além dos elementos SHELL 181 e SOLID45 empregados nos modelos sob compressão centrada, o elemento SOLID 95. 
Assim como as presilhas, as chapas de ligação foram modeladas como sólidos para facilitar os acoplamentos e a união de nós com as chapas das cantoneiras e os dispositivos de apoio. Porém, devido aos furos circulares referentes à ligação parafusada, foram encontrados problemas de forma quando da utilização do elemento SOLID 45 nessas regiões. Com isso, definiu-se a discretização das chapas de ligação com o elemento SOLID 95, uma vez que este possui nós intermediários que possibilitam a melhor definição do contorno dos furos. O SOLID 95 possui um total de até vinte nós com três graus de liberdade por nó, que são referentes à translação na direção dos eixos cartesianos (Ux, Uy e Uz).

As cantoneiras, as presilhas e os dispositivos de apoio foram discretizados de forma semelhante aos modelos sob compressão centrada, ou seja, com os elementos SHELL 181 e SOLID 45, respectivamente. A única diferença ficou por conta da malha na região das ligações, cujos elementos foram inseridos com forma triangular no contorno dos furos. A Figura 3.8 mostra um dos modelos analisados indicando a malha e os elementos finitos utilizados nas cantoneiras, nas presilhas, nos dispositivos de apoio e nas chapas de ligação.

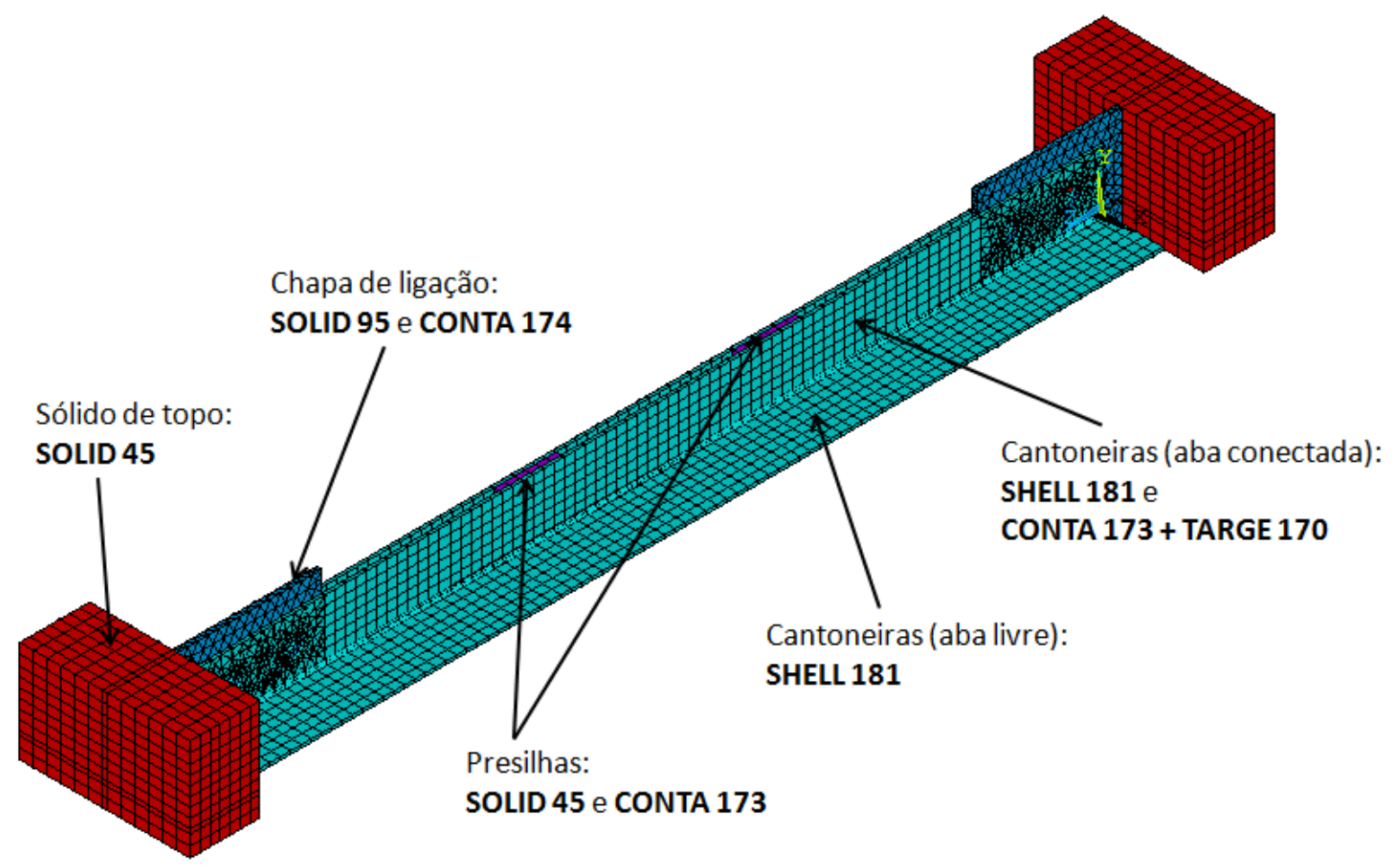

Figura 3.8 - Malha e elementos finitos utilizados nos modelos sob compressão excêntrica.

Como os problemas de interpenetração das malhas devidos às deformações persistiram também nos modelos sob compressão excêntrica, foram empregados os pares de elementos de contato equivalentes aos elementos base utilizados, a saber: o par CONTA 173 e TARGE 170 
para as malhas com os elementos SHELL 181 e SOLID 45; e o par CONTA 174 e TARGE 170 para as malhas com o elementos SOLID 95. A Figura 3.9 e a Figura 3.10 mostram a região da ligação para modelos sem e com elementos de contato, respectivamente.

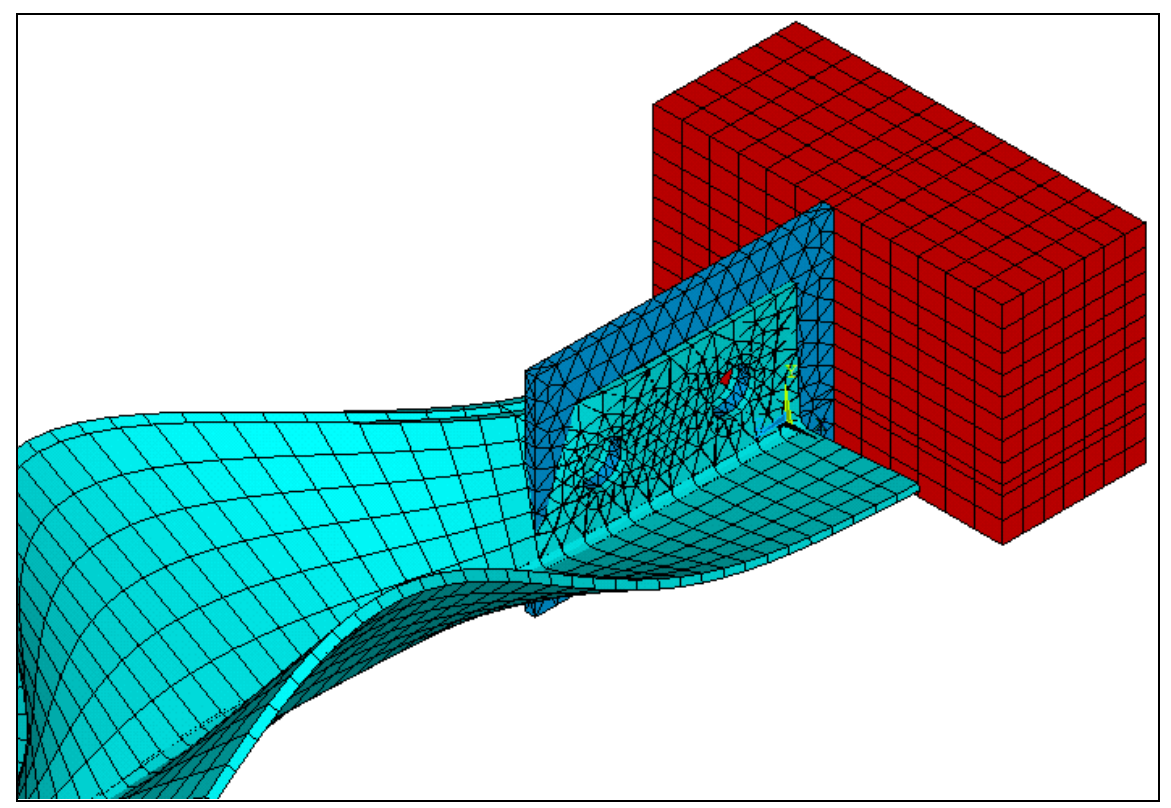

Figura 3.9 - Modelos sem elementos de contato: problemas de interpenetração das malhas na região da ligação - escala aumentada.

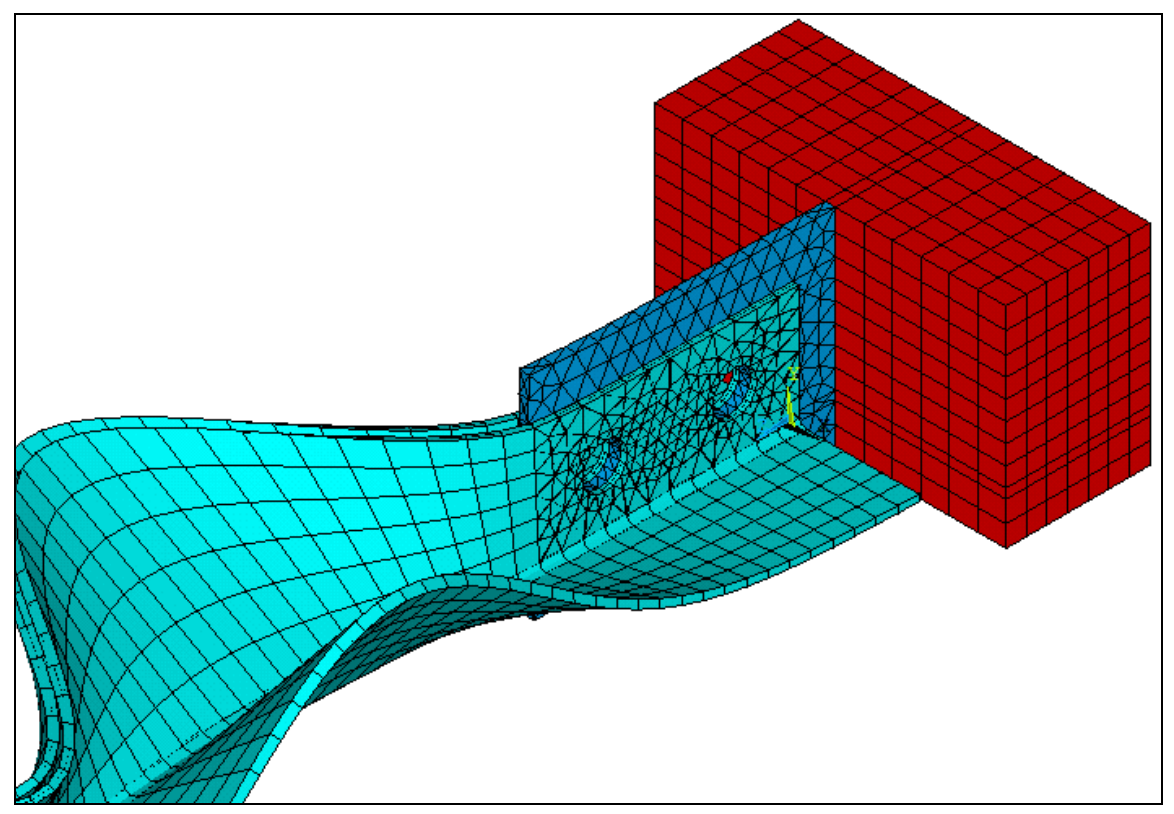

Figura 3.10 - Modelos com elementos de contato: eliminação dos problemas de interpenetração das malhas - escala aumentada. 


\subsubsection{CONDIÇÕES DE VINCULAÇÃO E DE CARREGAMENTO}

\section{- Compressão centrada}

Como informado anteriormente, os ensaios experimentais apresentados em CHODRAUI (2006) foram realizados fazendo-se uso de dispositivos de apoio do tipo rótula cilíndrica, as quais foram posicionadas nos eixos baricêntricos da seção a fim de se aplicar a compressão centrada nos perfis. Esta rótula tem como característica permitir apenas a rotação em torno do eixo que a contém, conforme pode ser percebido analisando o desenho esquemático da Figura 2.23.

Para representar essa situação, os modelos numéricos foram desenvolvidos considerando nos sólidos de topo equivalentes uma malha com duas linhas de nós coincidentes com os eixos baricêntricos da seção do perfil, de tal forma que o funcionamento dessas rótulas cilíndricas pudesse ser simulado por meio de restrições e acoplamentos dos nós pertencentes a essas linhas. Assim, foram liberados apenas a rotação em torno do eixo onde a rótula foi posicionada (rótula cilíndrica no eixo-x ou no eixo-y) e o deslocamento axial na extremidade do perfil em que foi aplicado o carregamento, conforme mostrado na Figura 3.11 e na Figura 3.12.

Além do acoplamento e restrições dos nós da rótula, foram aplicadas, ainda, as restrições nodais necessárias nos demais nós da extremidade dos dispositivos de apoio, conforme está resumido na Tabela 3.4. Feito isso, bastou aplicar o carregamento em um ponto da linha de nós que contém a rótula, denominado “nó mestre”, para se alcançar a compressão centrada desejada. É importante ressaltar que o carregamento foi aplicado nos modelos sob a forma de deslocamento prescrito no referido nó, de forma a se obter a força normal resistente do perfil, que corresponde ao pico da curva Reação de apoio x Deslocamento axial. 


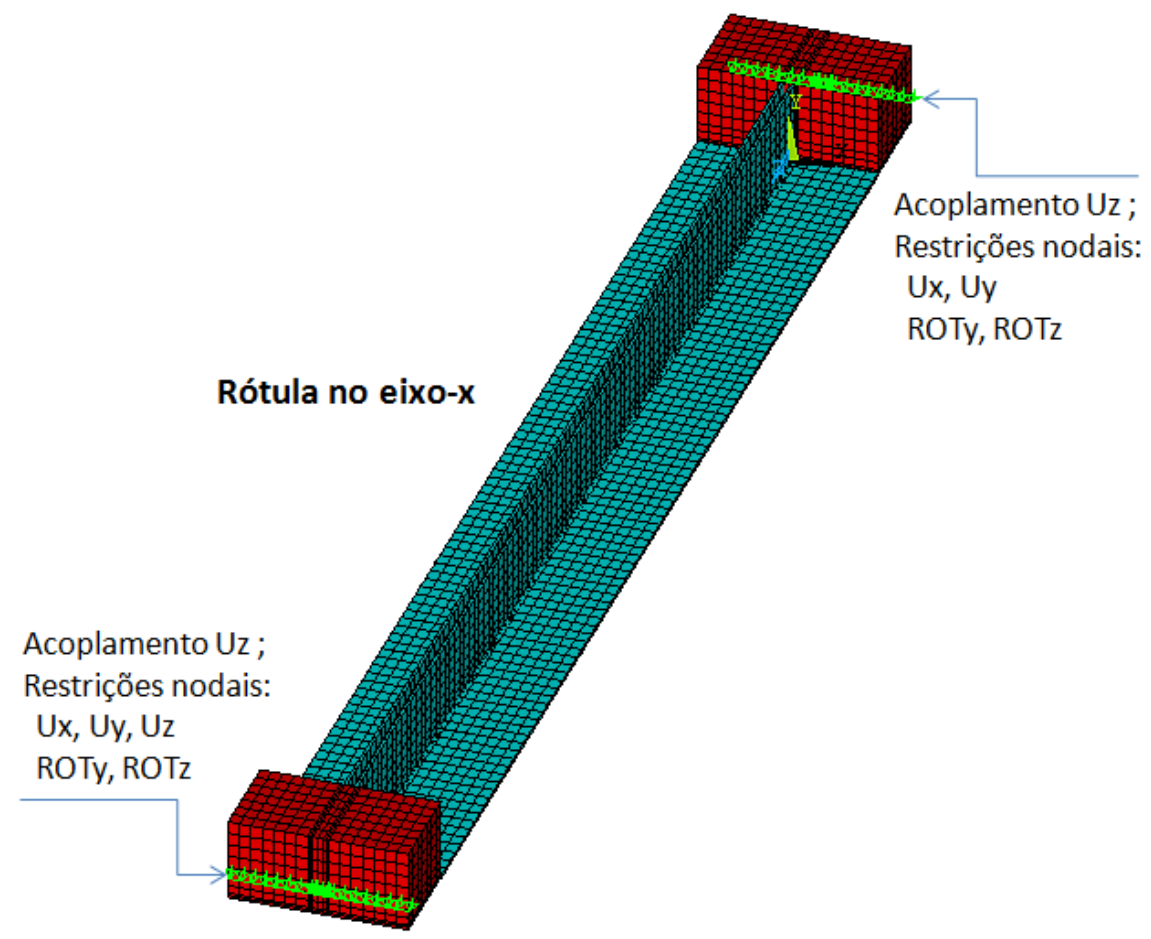

Figura 3.11 - Restrições nodais simulando a rótula cilíndrica posicionada no eixo- $\chi$ do centróide da seção.

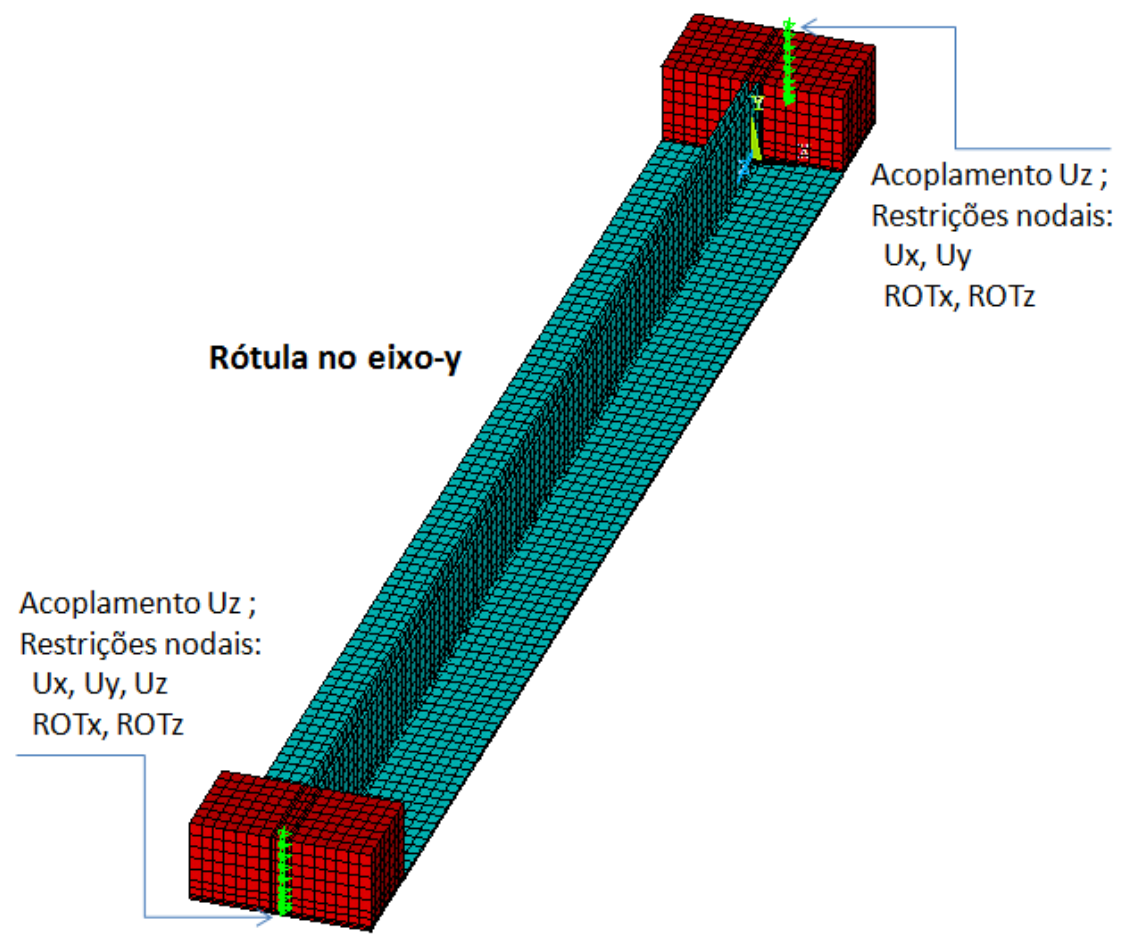

Figura 3.12 - Restrições nodais simulando a rótula cilíndrica posicionada no eixo-y do centróide da seção. 
Tabela 3.4 - Restrições nodais dos apoios para os perfis sob compressão centrada.

\begin{tabular}{|c|c|c|c|c|}
\hline Tipo de apoio & $\begin{array}{c}\text { Nós das duas } \\
\text { chapas de topo }\end{array}$ & $\begin{array}{c}\text { Nós dos eixos } \\
\text { baricêntricos } \\
\text { (rótula) das } \\
\text { chapas de topo }\end{array}$ & $\begin{array}{c}\text { Nós da rótula de } \\
\text { aplicação do } \\
\text { carregamento }\end{array}$ & $\begin{array}{c}\text { Nós da rótula } \\
\text { oposta à } \\
\text { aplicação do } \\
\text { carregamento }\end{array}$ \\
\hline Rótula em X & $\begin{array}{c}\text { Ux, ROTy, } \\
\text { ROTz }\end{array}$ & $\begin{array}{c}\text { Acoplamento } \\
\text { Uz }\end{array}$ & $\begin{array}{c}\text { Ux, Uy, } \\
\text { ROTy, ROTz }\end{array}$ & $\begin{array}{c}\text { Ux, Uy, Uz } \\
\text { ROTy, ROTz }\end{array}$ \\
\hline Rótula em Y & $\begin{array}{c}\text { Uy, ROTy, } \\
\text { ROTz }\end{array}$ & $\begin{array}{c}\text { Acoplamento } \\
\text { Uz }\end{array}$ & Ux, Uy, \\
ROTx, ROTz & Ux, Uy, Uz \\
ROTx, ROTz
\end{tabular}

Para a fixação das presilhas, foram utilizadas ferramentas do ANSYS para a união dos nós das mesmas com os das cantoneiras na região parafusada, que foi definida como sendo de, aproximadamente, $2 \mathrm{cmx} 2 \mathrm{~cm}$.

\section{- Compressão excêntrica}

Para os perfis analisados sob compressão excêntrica, os dispositivos de apoio foram modelados de forma a dar base para comparações com futuros ensaios experimentais dos perfis em questão igualmente carregados, sendo suas condições de vinculação bem diferentes daquelas aplicadas para os perfis analisados sob compressão centrada.

Neste caso, os dispositivos de apoio foram considerados engastados por meio da restrição de todos os graus de liberdade dos nós das chapas de topo, exceto o deslocamento na direção longitudinal (Uz) dos nós da extremidade onde foi aplicado o carregamento, os quais foram acoplados nessa direção.

Nas chapas de ligação, foram modelados dois furos com o intuito de se considerar os efeitos da ligação parafusada. Para a transferência do carregamento do dispositivo de apoio para o perfil, adotou-se a simplificação testada e apresentada em MAIA (2008), que consiste em simular a área de contato dos parafusos com as chapas das cantoneiras por meio do acoplamento na direção longitudinal (Uz) de um quarto dos nós dos furos (ver Figura 3.13). Segundo exposto na referência citada, esta estratégia fornece resultados coerentes e se aproximam mais da realidade do que numa situação em que haja o acoplamento de metade dos nós, em vez de um quarto. 
Completando o efeito da união entre as cantoneiras e a chapa de ligação promovida pelos parafusos, os deslocamentos Ux e Uy de todos os nós dos furos também foram acoplados. A Tabela 3.5 apresenta todas as restrições e acoplamentos nodais empregados nos dispositivos de apoio dos perfis modelados sob compressão excêntrica e, na Figura 3.13, é mostrada a ligação com um esquema ilustrando os acoplamentos adotados na região dos furos.

Tabela 3.5 - Restrições nodais dos apoios para os perfis sob compressão excêntrica.

\begin{tabular}{|l|c|c|c|c|}
\hline $\begin{array}{c}\text { Nós das duas } \\
\text { chapas de topo }\end{array}$ & $\begin{array}{c}\text { Nós da } \\
\text { extremidade de } \\
\text { aplicação do } \\
\text { carregamento }\end{array}$ & $\begin{array}{c}\text { Nós da } \\
\text { extremidade } \\
\text { oposta à aplicação } \\
\text { do carregamento }\end{array}$ & $\begin{array}{c}\text { Todos os nós } \\
\text { dos furos da } \\
\text { ligação } \\
\text { parafusada }\end{array}$ & $\begin{array}{c}\text { Nós de 1/4 dos } \\
\text { furos da ligação } \\
\text { parafusada }\end{array}$ \\
\hline $\begin{array}{c}\text { Acoplamento } \\
\text { Uz }\end{array}$ & $\begin{array}{c}\text { Ux, Uy, } \\
\text { ROTx, ROTy, } \\
\text { ROTz }\end{array}$ & $\begin{array}{c}\text { Ux, Uy, Uz } \\
\text { ROTx, ROTy, } \\
\text { ROTz }\end{array}$ & $\begin{array}{c}\text { Acoplamento } \\
\text { Ux e Uy }\end{array}$ & Acoplamento \\
Uz
\end{tabular}

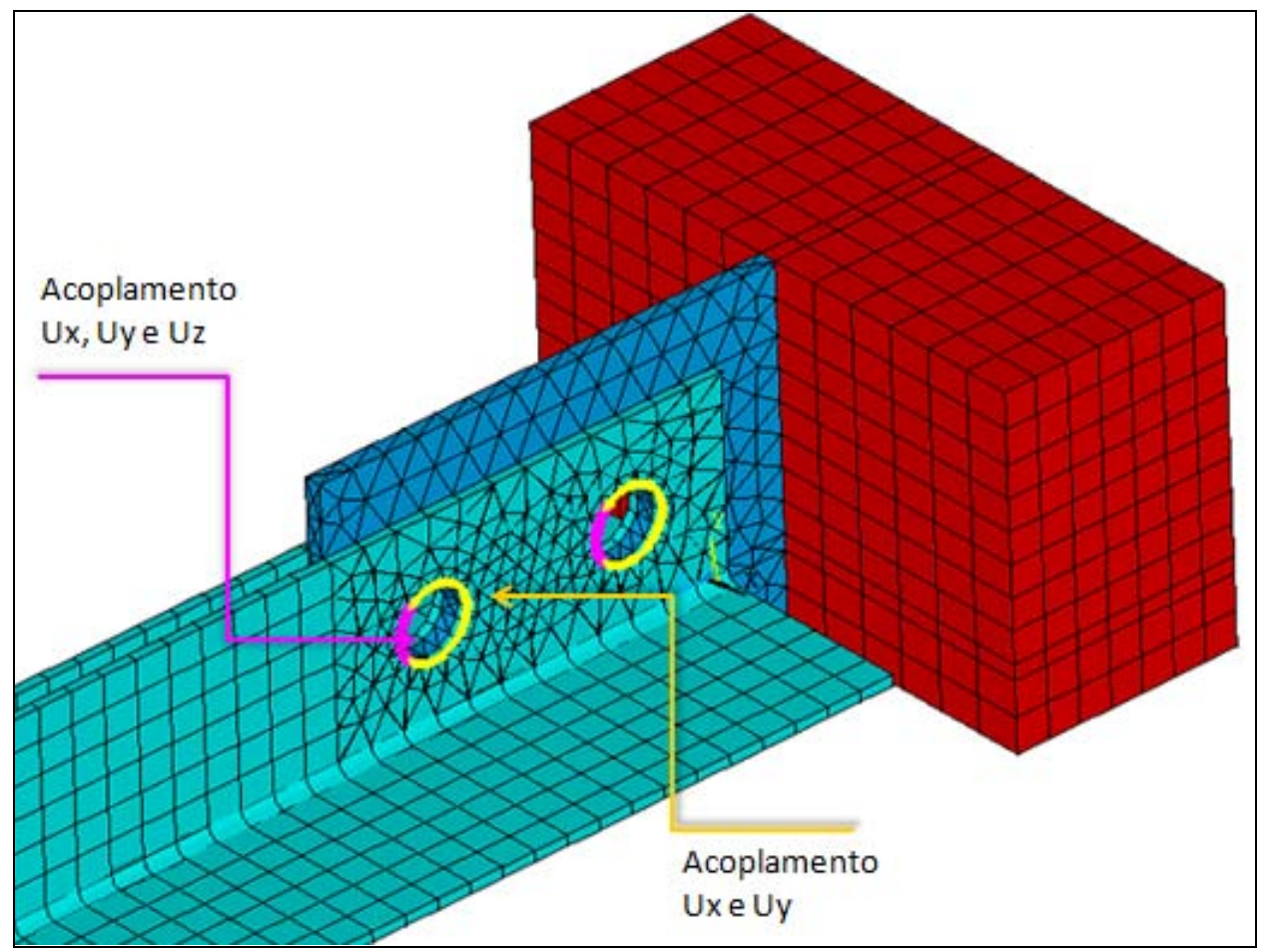

Figura 3.13 - Esquema ilustrativo dos acoplamentos dos nós nos furos da ligação parafusada. 
Semelhantemente aos modelos com compressão centrada, o carregamento também foi feito por meio da aplicação de um deslocamento prescrito visando à obtenção da maior força normal de compressão resistida pelos perfis. Pela estratégia, esse deslocamento é transferido para o perfil composto na forma de compressão excêntrica, já que os furos da ligação foram centralizados na metade da largura das abas e não no centróide da seção. Nestes modelos, as presilhas também foram fixadas nas cantoneiras por meio da união de nós numa região de, aproximadamente, $2 \mathrm{cmx} 2 \mathrm{~cm}$ (no meio das presilhas).

\subsubsection{IMPERFEIÇÕES GEOMÉTRICAS INICIAIS}

As imperfeições geométricas iniciais podem ser caracterizadas, basicamente, pela forma e pela magnitude com que se distribuem ao longo do perfil. Em perfis de aço formados a frio, que geralmente possuem elevada esbeltez local, diferentes panoramas de distribuição dessas imperfeições tendem a alterar de forma significativa a resistência e o modo de colapso dos mesmos. Por isso, realizou-se um estudo aprofundado no presente trabalho para a seleção de imperfeições geométricas que melhor descrevem o comportamento dos perfis dupla cantoneira nas análises numéricas, quando submetidos à compressão.

A estratégia para a consideração das imperfeições geométricas nos modelos numéricos foi a mesma para ambos os casos de carregamento (compressão centrada e compressão excêntrica). Primeiramente, as imperfeições foram geradas a partir de duas prévias análises elásticas feitas no ANSYS e, em seguida, as mesmas foram inseridas em modelos analisados considerando-se as não-linearidades geométricas e de material.

Numa das análises elásticas, buscou-se alcançar uma configuração deformada para os perfis tal que pudesse ser empregada como uma imperfeição geométrica inicial global na análise não-linear. Para isso, um carregamento unitário foi aplicado perpendicularmente ao eixo da barra na metade do seu comprimento. Já para a obtenção das imperfeições geométricas iniciais locais foi realizada uma análise elástica de autovalor, a partir da qual foi importada a deformada referente a um dos modos identificados como local dentre os cinqüenta modos requeridos na análise.

A seguir, são apresentados maiores detalhes sobre as imperfeições geométricas iniciais testadas nos modelos sob compressão centrada e nos modelos sob compressão excêntrica. 


\section{- Compressão centrada}

$\mathrm{Na}$ prática, as imperfeições geométricas iniciais podem se apresentar nas mais diferentes formas e magnitudes, mesmo em perfis com geometrias iguais e produzidos de forma semelhante. Como não existe um padrão, a consideração das imperfeições em modelos numéricos acaba se tornando uma tarefa sem uma sistemática completamente definida, geralmente envolvendo testes para a seleção de imperfeições que melhor retratam o comportamento do elemento estrutural.

Em função dessa grande variabilidade na distribuição das imperfeições geométricas iniciais, foi realizada, neste trabalho, uma ampla análise de sensibilidade dos perfis dupla cantoneira com seção “T” a essas imperfeições por meio de análises numéricas não-lineares, variando tanto a forma como a magnitude das imperfeições local e global. A calibração foi feita tomando-se como base de comparação os resultados experimentais apresentados em CHODRAUI (2006), sendo observados os resultados obtidos para a resistência e para o modo de colapso dos perfis.

No que se refere à forma, fez-se variar nos modelos sob compressão centrada o sinal da imperfeição global apenas para os perfis com a rótula cilíndrica posicionada no eixo-x (eixo de menor inércia), já que, por ser o eixo de não-simetria, a inversão de sinal da flexão pode influenciar o comportamento estrutural do perfil. Para os perfis com a rótula posicionada no eixo-y (eixo de maior inércia) não houve a necessidade de testar o sinal da imperfeição global devido à simetria em relação a esse eixo.

A Figura 3.14 e a Figura 3.15 mostram a forma geral das imperfeições geométricas iniciais globais empregadas nos modelos sob compressão excêntrica, onde os sinais positivo $e$ negativo referem-se a flexões que produzem, respectivamente, compressão e tração nas abas livres das cantoneiras que compõem o perfil. 


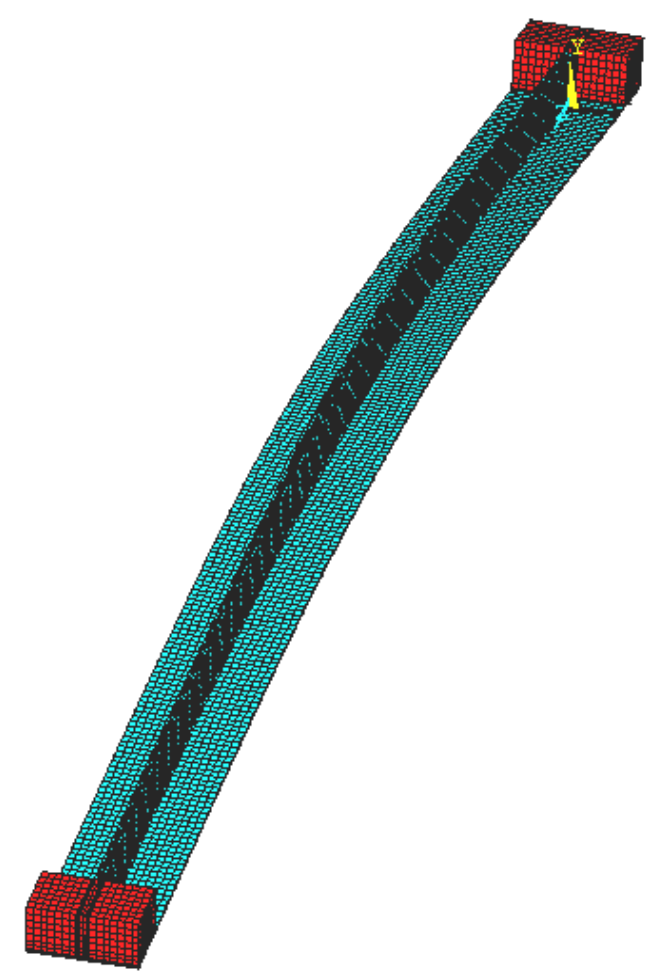

(a)

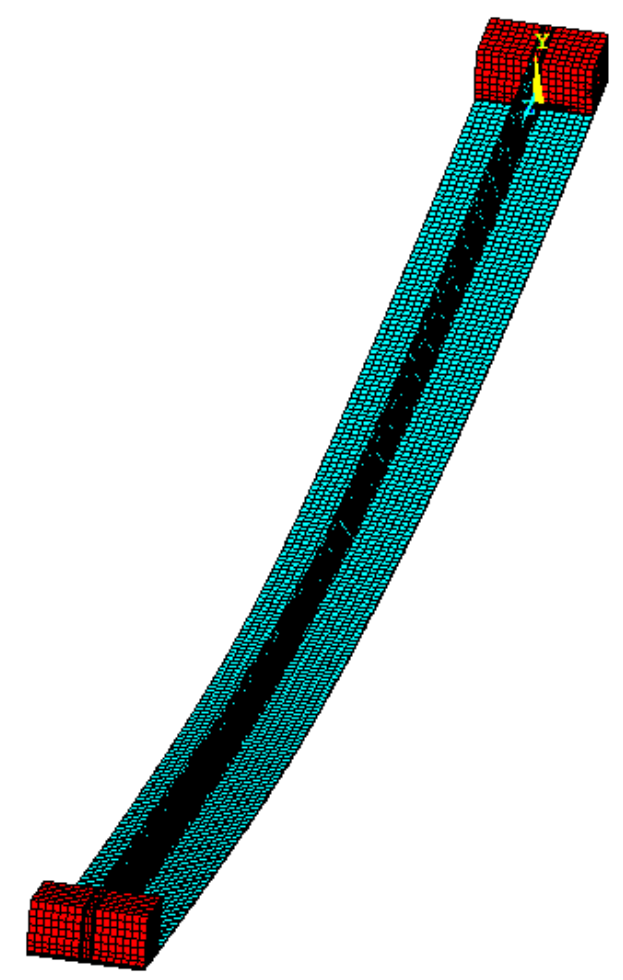

(b)

Figura 3.14 - Forma das imperfeições geométricas iniciais globais adotadas para os modelos com rótula posicionada no eixo-x: (a) sinal positivo e (b) sinal negativo.

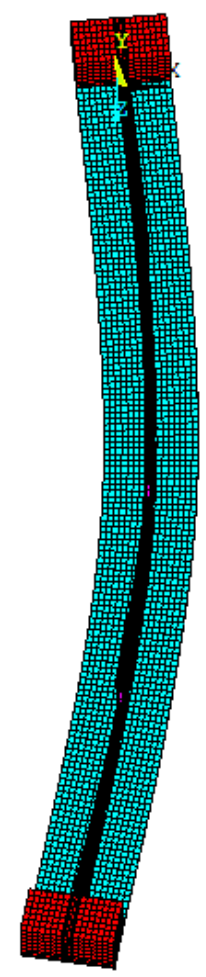

Figura 3.15 - Forma da imperfeição geométrica inicial global adotada para os modelos com rótula posicionada no eixo-y. 
A forma da imperfeição local também foi testada nas análises numéricas a partir da seleção de diferentes modos de instabilidade gerados na análise de autovalor. Foram realizadas, então, análises não-lineares com duas formas de imperfeições locais:

(a) na primeira, foi inserida uma deformada com várias semi-ondas ao longo do comprimento do perfil, o que pode ser entendido como um modo local puro do perfil composto ou um modo de flexo-torção das cantoneiras isoladas entre as presilhas;

(b) na segunda, inseriu-se uma deformada com algumas ondulações nas chapas das cantoneiras e ainda com uma torção do perfil composto, ou seja, de todo o conjunto.

Essas formas foram empregadas tanto para a rótula posicionada no eixo-x como no eixo-y, conforme os exemplos apresentados na Figura 3.16.

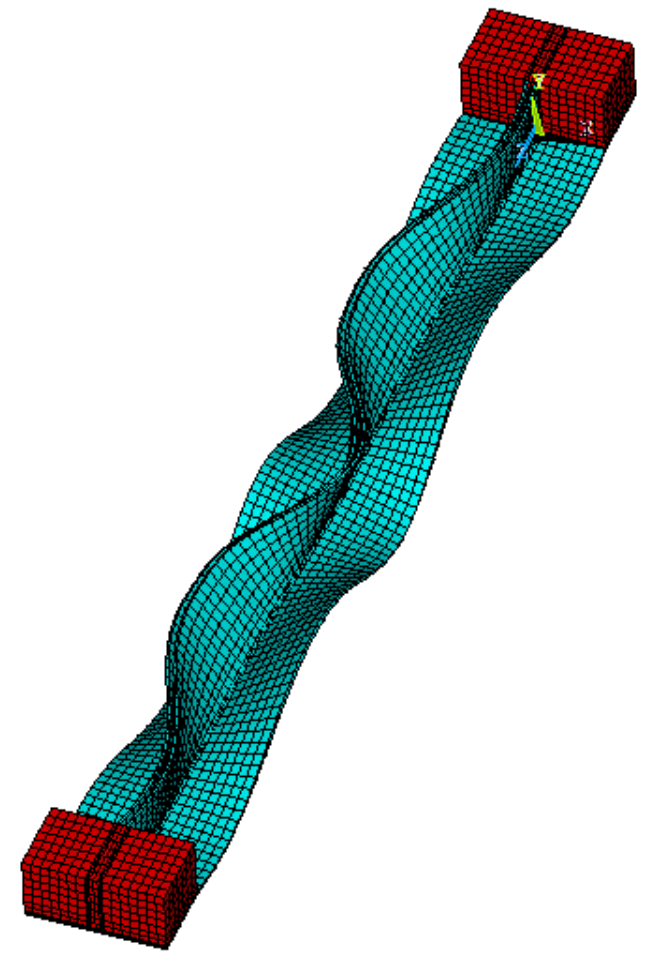

(a)

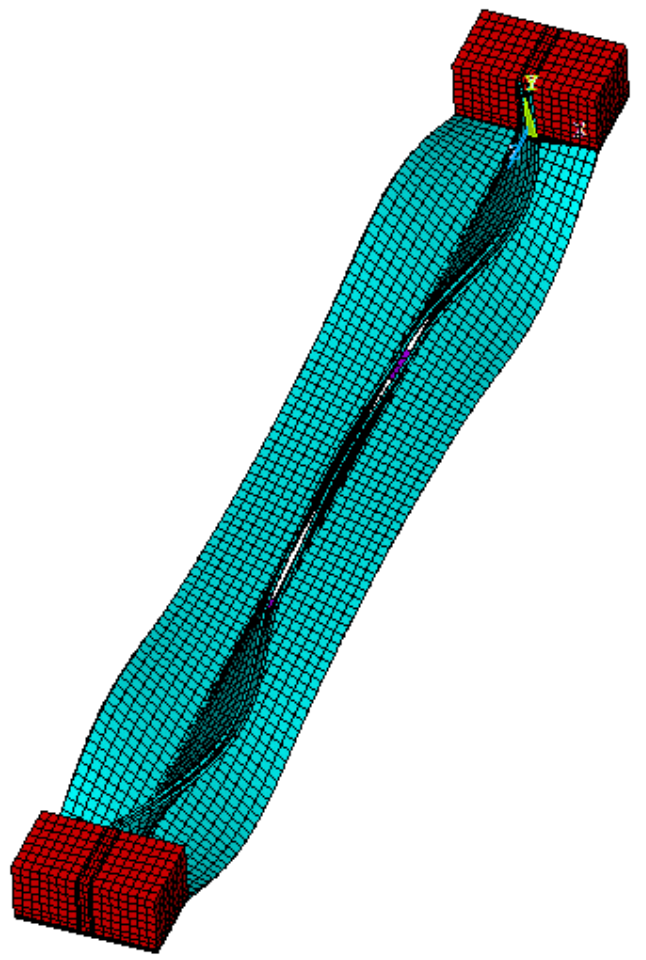

(b)

Figura 3.16 - Forma geral das imperfeições geométricas iniciais locais adotadas para os modelos sob compressão centrada.

Como informado anteriormente, a análise de sensibilidade envolveu não somente a forma, mas também a magnitude das imperfeições geométricas iniciais. Assim, para a imperfeição global, foram utilizados os valores de $\pm \mathbf{L} / \mathbf{1 0 0 0 0}$ (barra praticamente sem imperfeições), $\pm \mathbf{L} / \mathbf{5 0 0}$ e $\pm \mathbf{L} / \mathbf{3 5 0}$, além dos tradicionais valores das normas americanas e 
européias, que são: $\pm \mathbf{L} / \mathbf{1 5 0 0}$ e $\pm \mathbf{L} / \mathbf{1 0 0 0}$, respectivamente (onde L é o comprimento da barra e os símbolos de positivo e negativo referem-se ao sinal da imperfeição global).

No caso das imperfeições locais, foram adotados dois dos valores sugeridos em SCHAFER \& PEKÖZ (1998), conforme apresentado no item 2.2 deste trabalho, a saber: 0,64.t e 0,94.t (onde $t$ é a espessura das chapas das cantoneiras que compõem o perfil). Apenas esses valores de imperfeição local foram utilizados, pois, para as imperfeições maiores, o modelo já apresentava penetrações entre chapas antes mesmo de se iniciar a análise.

Os resultados da análise de sensibilidade às imperfeições geométricas para os perfis sob compressão centrada apontam para uma maior influência da imperfeição global nos perfis mais esbeltos, o que já era esperado, já que a magnitude da imperfeição é diretamente proporcional ao comprimento da barra. Outra resposta interessante dos modelos foi a tendência de um sinal crítico negativo para a imperfeição global (situação em que as abas conectadas pelas presilhas resultam comprimidas e as abas livres tracionadas), com o qual os perfis apresentaram valores de resistência menores do que nos casos de sinal positivo da imperfeição global.

A análise de sensibilidade indicou, ainda, que a forma das imperfeições locais pode exercer grande influência tanto na resistência quanto no modo de colapso dos perfis, principalmente nos casos com menor esbeltez global. No que se refere à magnitude das imperfeições locais, pouca influência foi percebida nos resultados alcançados com os níveis de imperfeições descritos anteriormente (0,64.t e 0,94.t). Esses resultados reforçam a necessidade das análises de sensibilidade às imperfeições e evidenciam a importância dos ensaios experimentais como referências para a calibração de modelos numéricos.

Partindo da comparação com os resultados experimentais apresentados em CHODRAUI (2006), concluiu-se que as imperfeições que melhor descreveram o comportamento dos perfis dupla cantoneira aqui estudados, do ponto de vista da resistência e do modo de colapso, foram: imperfeição global com sinal negativo (Figura 3.14b ou Figura 3.15) associada a uma imperfeição local que contenha ondulações nas chapas das cantoneiras e uma torção global do perfil composto (semelhante à Figura 3.16b). Para a magnitude, podem ser tomados os tradicionais valores de L/1000 ou L/1500, para a imperfeição global, e os mesmos valores aqui utilizados para a imperfeição local (0,64.t ou 0,94.t). 
Os resultados completos e as discussões sobre a análise de sensibilidade às imperfeições geométricas iniciais são apresentados no Capítulo 4.

\section{- Compressão excêntrica}

A análise de sensibilidade feita com os modelos sob compressão excêntrica foi um pouco mais restrita do que aquela realizada para os perfis submetidos à compressão centrada. A idéia foi investigar se o número de presilhas utilizadas (que é um parâmetro que não variou nos modelos sob compressão centrada) exerce influência significativa na sensibilidade dos perfis dupla cantoneira em questão às imperfeições geométricas iniciais. Além disso, as diferenças nos dispositivos de apoio e na introdução do carregamento reforçaram a necessidade desse tipo de investigação também nesses modelos com carga excêntrica. Ressalta-se que, para estes casos, todas as análises de sensibilidade foram realizadas em perfis com seção de 60x60x3,0mm e número de presilhas igual a 1 e 2 .

Primeiramente, a forma da imperfeição global foi testada por meio da variação de seu sinal nos modelos (o sinal da imperfeição global tem aqui o mesmo significado dos modelos sob compressão centrada), sendo empregada com os valores de $+\mathbf{L} / \mathbf{1 5 0 0}$ e $-\mathbf{L} / \mathbf{1 5 0 0}$ (onde L é o comprimento da barra). Visando avaliar apenas o efeito da imperfeição global, nenhuma imperfeição localizada foi inserida nessas análises.

A Figura 3.17(a e b) mostra as deformadas referentes a imperfeições globais positiva e negativa, respectivamente, empregadas na análise de sensibilidade. Os resultados mostraram pouca influência do sinal da imperfeição global nos resultados, onde a diferença máxima encontrada para os valores de resistência foi de 3\%. Isto já era esperado, já que a excentricidade da aplicação do carregamento é bem maior do que as imperfeições globais empregadas. O número de presilhas também não fez com que houvesse diferenças significativas nos resultados de resistência dos perfis (no que se refere ao sinal da imperfeição global).

Desta forma, optou-se pela utilização da imperfeição global negativa nos modelos finais, pois apresentou resultados para forças de compressão resistentes menores (embora com pouca diferença, como dito) e por se somar ao efeito da excentricidade do carregamento, que é a situação mais desfavorável. Os resultados dessas análises de sensibilidade estão apresentados no Capítulo 4. 


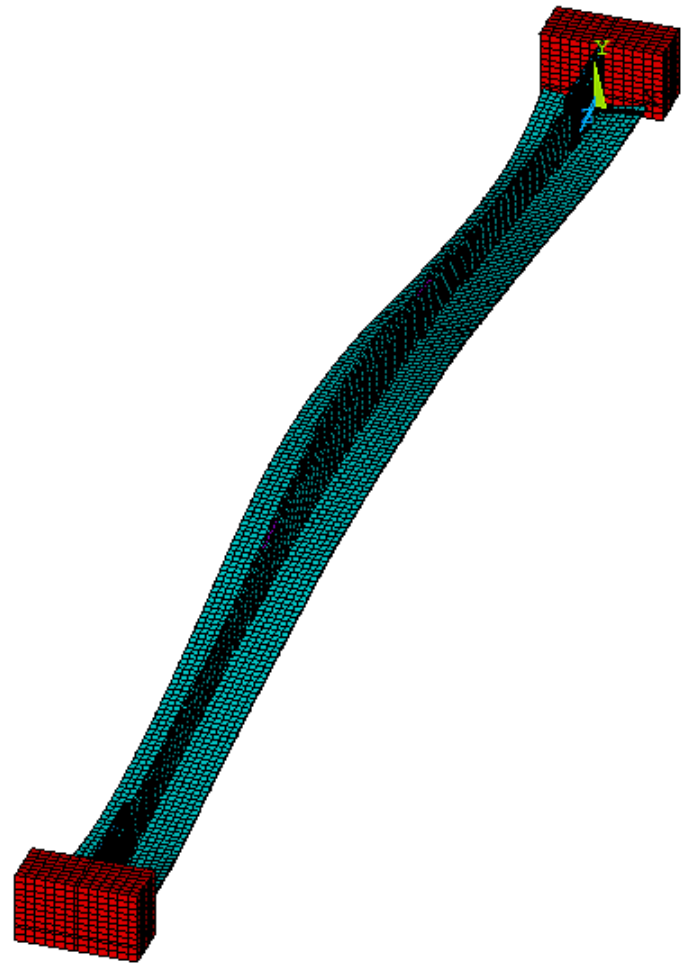

(a)

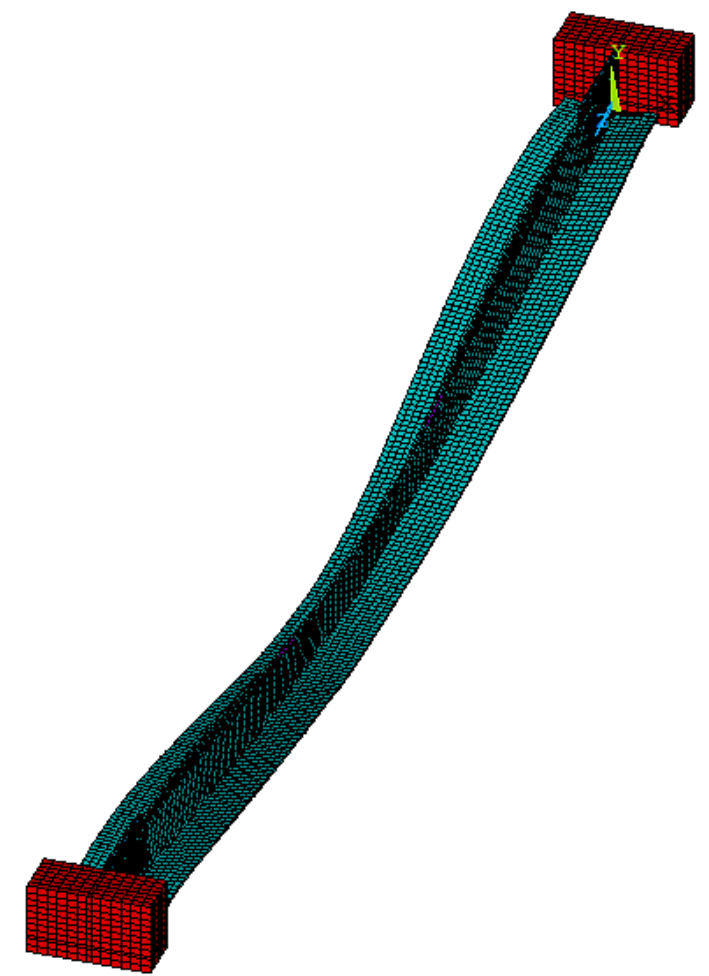

(b)

Figura 3.17 - Forma das imperfeições geométricas iniciais globais adotadas para os modelos sob compressão excêntrica: (a) sinal positivo e (b) sinal negativo.

Conhecida a imperfeição global mais desfavorável à resistência do perfil, passou-se então à análise de sensibilidade às imperfeições locais. Assim como nos modelos sob compressão centrada, foram selecionadas duas deformadas oriundas das análises de autovalor para se reproduzir os efeitos das imperfeições locais nas análises não-lineares. Neste caso, apenas as imperfeições locais associadas à torção do perfil composto foram empregadas, já que estas produziram resultados mais coerentes do que as imperfeições puramente locais nos modelos sob compressão centrada.

Sendo assim, a diferença entre as imperfeições testadas foi apenas no número e distribuição das semi-ondas ao longo do perfil ou, ainda, na associação dessas ondulações com a torção do conjunto. A Figura 3.18 mostra exemplos de duas imperfeições geométricas locais testadas para um dos perfis, de onde se pode perceber que ambas seguem um padrão de imperfeição, que pode ser considerada um modo de flexo-torção do perfil composto.

Novamente, as magnitudes adotadas para essas imperfeições foram os valores de 0,64.t e 0,94.t sugeridos em SCHAFER \& PEKÖZ (1998), sendo mantida a imperfeição global com -L/1500 em todas as análises. 


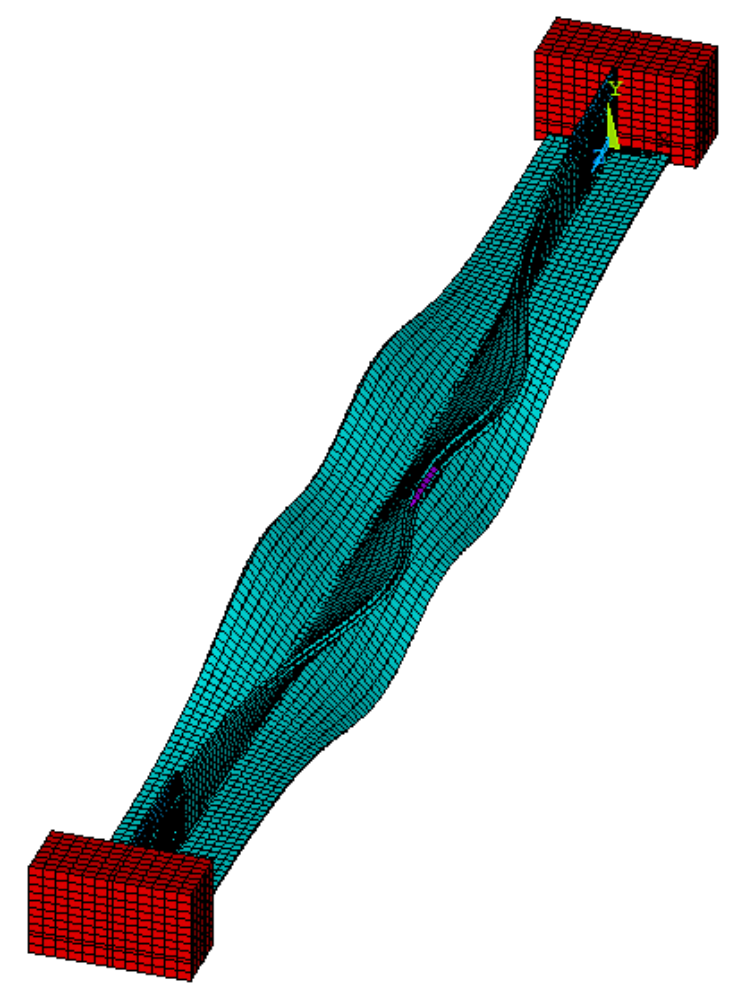

(a)

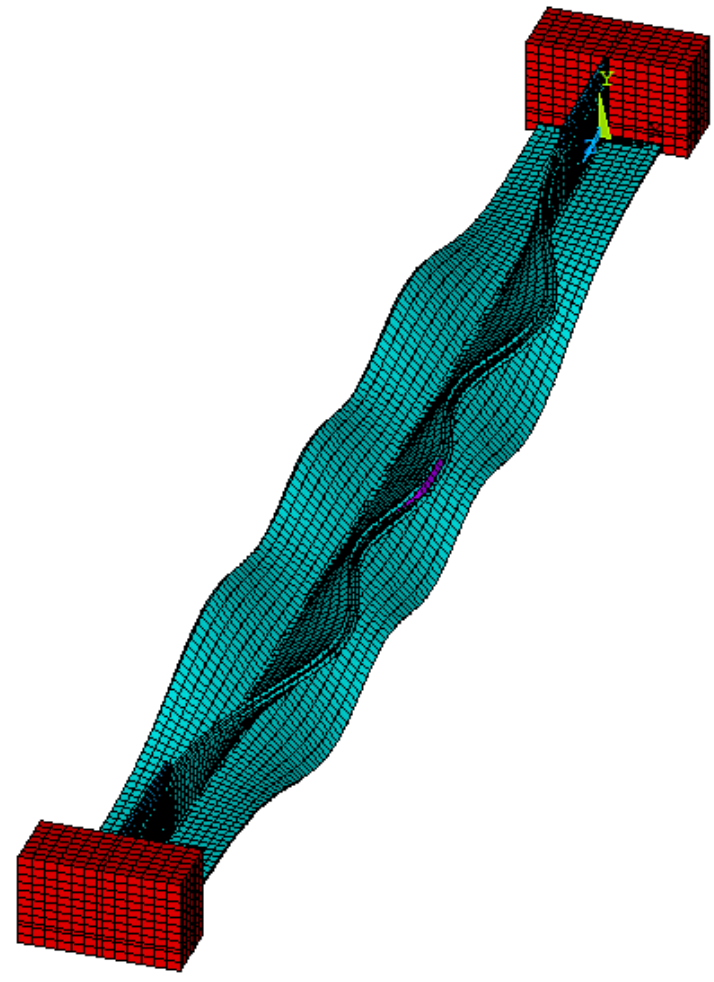

(b)

Figura 3.18 - Exemplos de imperfeições geométricas iniciais locais testadas para os modelos sob compressão excêntrica.

Assim como na imperfeição global, a forma da imperfeição local teve influência relativamente pequena nos resultados de resistência dos perfis, com uma diferença máxima alcançada de apenas 6\%. Notou-se, ainda, que os perfis menos esbeltos têm sua resistência mais afetada para imperfeições geométricas com mais ondulações nas chapas das cantoneiras. Já os perfis mais esbeltos, tendem a ser mais prejudicados por imperfeições geométricas com menos ondulações e mais torção do conjunto.

O modo de colapso também não sofreu mudanças significativas quando da utilização de uma ou outra imperfeição local, reforçando a idéia de que a excentricidade do carregamento aplicado acaba produzindo esforços muito maiores do que a parcela correspondente às imperfeições geométricas iniciais. Com isso, optou-se pela utilização da imperfeição local (associada à global, obviamente) mais desfavorável nos modelos finais, de forma a buscar a situação mais crítica.

Baseado nas conclusões obtidas por meio das análises de sensibilidade realizadas julgou-se coerente a adoção das seguintes imperfeições geométricas iniciais para todos os modelos sob compressão excêntrica: imperfeição global com sinal negativo (Figura 3.17b) associada a uma imperfeição local que contenha ondulações nas chapas das cantoneiras e 
uma torção global do perfil composto (semelhante à Figura 3.18a ou b, dependendo da esbeltez). Para a magnitude, foi utilizado o valor de L/1500 para a imperfeição global e os valores de 0,64.t ou 0,94.t para a imperfeição local.

Ressalta-se, novamente, que os resultados dessas análises de sensibilidade estão todos apresentados no Capítulo 4.

\subsubsection{MODELO REOLÓGICO}

As informações de interesse disponibilizadas em diagramas que apresentam a relação “Tensão x Deformação”, obtidos experimentalmente, geralmente se referem a valores aproximados, denominados “convencionais” ou engineering values, tendo em vista que essas mesmas tensões são medidas com base na área inicial do corpo de prova. No entanto, sabe-se que a área inicial, comumente utilizada como valor de referência, varia com o carregamento (como no caso da estricção do corpo-de-prova, por exemplo), o que pode ser relevante em análises dentro do campo das grandes deformações (ALMEIDA, 2007).

Com o intuito de se considerar essa alteração na área do corpo-de-prova, é apresentada em HANCOCK (2004) uma formulação que visa corrigir os valores convencionais calculados com base na área inicial, de forma a se obter valores "verdadeiros” para a curva Tensão x Deformação (true values). As Equações (3.1) e (3.2) apresentam a forma de cálculo para a obtenção dos valores ditos verdadeiros $\left(\sigma_{\text {true }}\right.$ e $\varepsilon_{\text {true }}$ ) a partir dos valores convencionais ( $\sigma_{\text {conv }}$ e $\left.\varepsilon_{\text {conv }}\right)$.

$$
\begin{gathered}
\sigma_{\text {true }}=\sigma_{\text {conv }}\left(1+\varepsilon_{\text {conv }}\right) \\
\varepsilon_{\text {true }}=\ln \left(1+\varepsilon_{\text {conv }}\right)
\end{gathered}
$$

Apesar de os PFF submetidos à compressão geralmente apresentarem tensões máximas solicitantes menores que a resistência ao escoamento devido a problemas de instabilidade e, portanto, trabalharem no campo das pequenas deformações, optou-se pela inserção da não-linearidade física nos modelos numéricos criados por se tratar de um procedimento mais correto. A seguir, são mostradas as curvas Tensão x Deformação adotadas nos modelos sob compressão centrada e sob compressão excêntrica (foram adotados os valores corrigidos nas análises numéricas). 


\section{- Compressão centrada}

Para os modelos sob compressão centrada aproveitaram-se, para fins de comparação, os resultados obtidos nos ensaios de caracterização do aço realizados em CHODRAUI (2006), com os quais se obteve resistência ao escoamento $f_{y}=375 \mathrm{MPa}$ e resistência à ruptura $f_{u}=$ 513MPa para o aço utilizado nas cantoneiras. A Figura 3.19 mostra as curvas Tensão $x$ Deformação referentes aos valores convencionais e também para aqueles corrigidos pela formulação anteriormente apresentada.

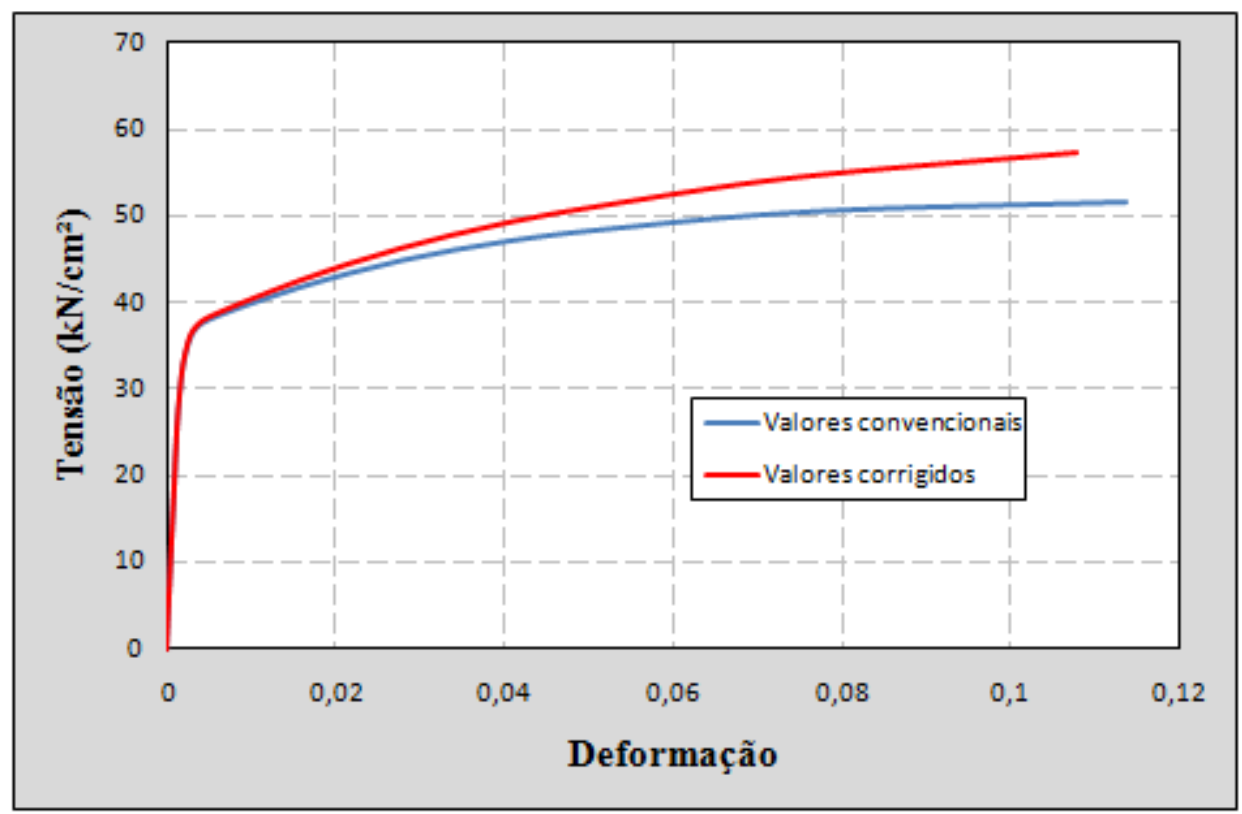

Figura 3.19 - Modelo reológico adotado para os modelos sob compressão centrada.

\section{- Compressão excêntrica}

No caso dos modelos cujos perfis foram submetidos à compressão excêntrica, foi utilizada a curva Tensão $x$ Deformação de um aço com resistência ao escoamento $f_{y}=$ $350 \mathrm{MPa}$ e resistência à ruptura $f_{u}=498 \mathrm{MPa}$, já que não foram encontrados resultados experimentais destes perfis com carga excêntrica para uma comparação direta. A Figura 3.20 apresenta a curva com os valores convencionais e com os valores corrigidos para o aço utilizado. 


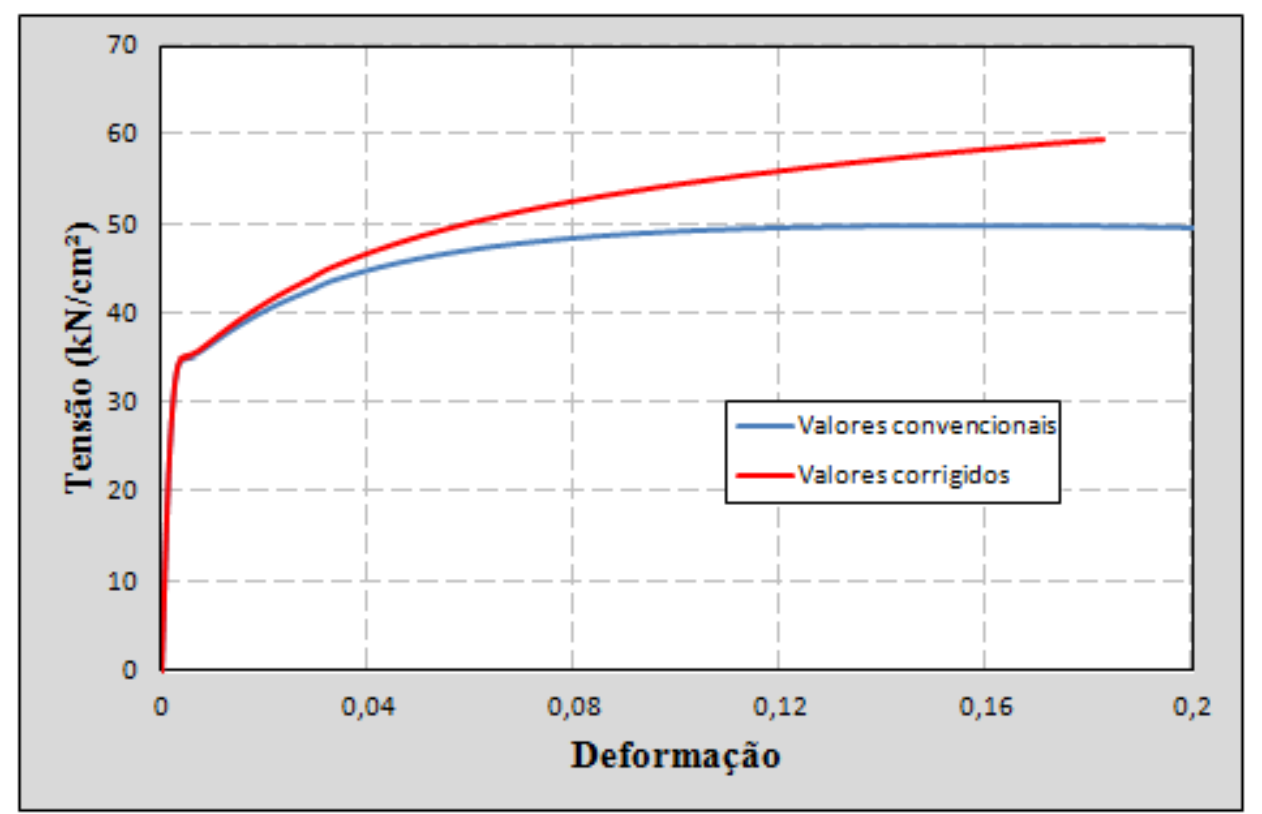

Figura 3.20 - Modelo reológico adotado para os modelos sob compressão excêntrica.

\subsubsection{DEMAIS INFORMAÇÕES DE INTERESSE}

Conforme já informado, os resultados de interesse para os perfis dupla cantoneira aqui estudados, como a resistência e o modo de colapso, foram obtidos por meio de análises nãolineares realizadas com os recursos da ferramenta computacional ANSYS. Para tanto, foram programadas linhas de comandos em arquivos de texto externos (conhecidos como "scripts"), as quais foram baseadas em funções básicas da linguagem FORTRAN e em códigos específicos do programa. Com isso, conseguiu-se automatizar a construção dos modelos e, assim, rodar um grande número de análises num curto espaço de tempo, já que os dados do modelo (dimensões do perfil, número de presilhas, malha, características do material etc.) podem ser facilmente alterados nos parâmetros de entrada dos scripts.

No APÊNDICE A e no APÊNDICE B são mostrados os scripts desenvolvidos para as análises elásticas e para as análises não-lineares à temperatura ambiente. Os apêndices são referentes aos modelos sob compressão centrada e excêntrica, respectivamente.

Finalizando a descrição da modelagem numérica, serão apresentadas, a seguir, as opções de processamento selecionadas nas análises e algumas ferramentas do programa ANSYS empregadas nos modelos desenvolvidos.

Para a resolução do sistema gerado na análise não-linear, foi utilizado o método iterativo Newton-Raphson Completo (“Newton-Raphson Full”), o qual busca a trajetória de equilíbrio para uma série de incrementos de carga. A definição desses incrementos de carga 
foi feita com o auxílio da ferramenta Automatic Load Stepping, que permite que o programa os atualize automaticamente a partir do fornecimento de uma estimativa inicial e dos limites superior e inferior para os passos de carregamento. Esses três parâmetros (passo inicial e limites superior e inferior) foram bem explorados em ALMEIDA (2007) para PFF com seção U sob compressão, cujos resultados serviram como base para a calibração dos valores aqui utilizados. O critério de convergência utilizado foi em termos de deslocamento, fixando-se a tolerância (ou erro máximo admitido) em 0,1\%.

A grande dificuldade na utilização de processos iterativos para a resolução de problemas não-lineares é o fato de não se conseguir a convergência da solução numérica a partir de qualquer configuração inicial. A definição de alguns parâmetros, como malha, geometria, imperfeições geométricas iniciais, passos de carregamento etc., podem contribuir para a perda de convergência nos modelos numéricos, e o ajuste ideal de todos esses parâmetros acaba se tornando uma tarefa trabalhosa e nem sempre viável.

Inicialmente, muitos dos modelos analisados no presente trabalho apresentaram os referidos problemas de convergência, principalmente no caso dos perfis solicitados à compressão centrada com a rótula cilíndrica posicionada no eixo-y (de maior inércia). Inúmeros testes foram realizados, então, em busca de soluções que conduzissem à convergência das análises numéricas. Como alguns dos parâmetros envolvidos não podiam ser alterados (como a geometria, o material e as imperfeições geométricas iniciais), a estratégia ficou focada apenas em testes com malha e passos de carregamento.

Para os testes realizados com o passo de carregamento, foi verificada a resposta dos modelos aos valores máximos do incremento de carga de DeslocP/100, DeslocP/200, DeslocP/300, DeslocP/400 e DeslocP/500 (onde DeslocP é o carregamento aplicado na forma de deslocamento prescrito). Os resultados indicaram uma pequena melhoria nas respostas, mas não o suficiente para se alcançar a convergência das análises. Além disso, a diferença entre resultados para cada um dos incrementos de carga testados foi muito pequena, tendo um aumento significativo no tempo de processamento. Dessa forma, optou-se pela utilização do valor de DeslocP/100 nos modelos finais, já que a redução do passo de carregamento não resolveu os problemas de convergência.

Em relação à malha, foi realizado um teste em um dos modelos com problema de convergência para o qual foi adotada uma malha com o dobro de elementos finitos nas chapas das cantoneiras em relação aos modelos iniciais. Mais uma vez, houve um aumento significativo do tempo de processamento sem, contudo, alcançar a convergência da análise numérica até o limite de resistência do perfil. 
Neste contexto, são disponibilizadas algumas ferramentas numéricas no ANSYS que visam auxiliar na resolução de sistemas não-lineares. Baseando-se nos modelos desenvolvidos em ALMEIDA (2007) e em MAIA (2008), foi explorado o uso da ferramenta "Line-Search”, que é empregado em conjunto com o Método Newton-Raphson para a resolução do sistema. Porém, essa alternativa não foi eficaz na solução dos problemas de convergência para a maioria das análises.

Finalmente, foi utilizada uma ferramenta numérica disponibilizada nas últimas versões do ANSYS que resolveu os problemas de convergência em quase todos os casos, sendo poucas as exceções. Trata-se do comando STABILIZE, um recurso que se aplica a apenas alguns tipos de elementos (dentre eles o SHELL 181) e que funciona muito bem em sistemas que envolvem problemas de flambagem e "snap-through".

São mostradas na Figura 3.21 as curvas Força x Deslocamento do apoio livre (apoio em que foi liberado o deslocamento longitudinal Uz) obtidas em duas das análises nãolineares realizadas no presente trabalho, uma com e outra sem a utilização da ferramenta STABILIZE. Percebe-se que a perda de convergência no modelo sem o STABILIZE, representada graficamente pela linha horizontal, ocorre bem antes de se alcançar o pico da curva, que corresponde à resistência à compressão do perfil. Em contrapartida, a utilização da referida ferramenta possibilitou alcançar o esforço máximo resistente e, ainda, um trecho considerável do comportamento pós-crítico.

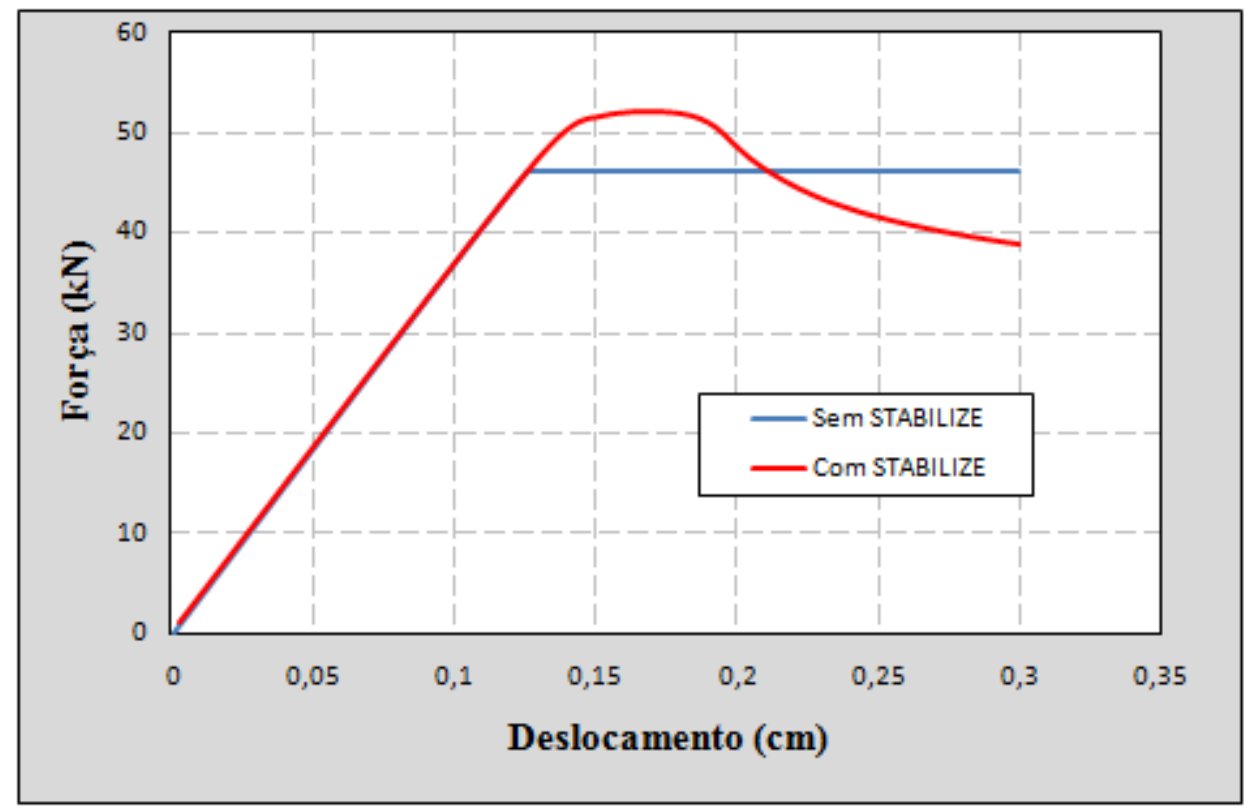

Figura 3.21 - Curvas Força x Deslocamento: comparação entre os resultados de análises com e sem a ferramenta STABILIZE (perfil 2L 60x60x2,38mm e L=2925mm). 
Para melhor entender o funcionamento da ferramenta STABILIZE, cabe aqui uma rápida explicação sobre um dos principais fatores que conduzem a problemas de convergência em modelos numéricos. Muitas das vezes, a dificuldade de convergência em análises nãolineares via Método dos Elementos Finitos está diretamente relacionada à ocorrência de grandes deslocamentos dos pontos nodais em resposta a pequenos incrementos de carga, tal como ocorre em problemas de instabilidade. A abrupta perda de rigidez de alguns elementos acaba zerando linhas da matriz de rigidez, tornando-a singular, o que impossibilita a resolução dos sistemas não-lineares gerados nas análises.

A idéia básica de funcionamento do comando STABILIZE consiste em adicionar um “elemento amortecedor artificial” em cada um dos nós dos elementos finitos que suportam a tecnologia (a lista completa dos elementos para os quais a ferramenta é aplicável está disponibilizada no Help do ANSYS), estabilizando os graus de liberdade desses elementos. Com isso, consegue-se sempre um resíduo na matriz de rigidez, eliminando o problema de singularidade nas etapas de carregamento em que ocorrem os problemas de instabilidade. Neste caso, deve-se tomar o cuidado de se calibrar bem os parâmetros que compõem a ferramenta, uma vez que há o risco de um enrijecimento exagerado do elemento estrutural como um todo.

\subsection{ANÁLISES EM TEMPERATURAS ELEVADAS}

O presente trabalho também teve como objetivo desenvolver modelos numéricos capazes de simular o comportamento dos PFF compostos por dupla cantoneira com seção "T” em temperaturas elevadas. Seguindo a mesma sistemática dos modelos desenvolvidos para as análises à temperatura ambiente, foram criados scripts com o intuito de se padronizar e automatizar a construção dos modelos, conforme apresentado no APÊNDICE C. Vale ressaltar que os estudos aqui realizados para os perfis em questão sob temperaturas elevadas se desenvolveram apenas em caráter exploratório, de forma a servir como base para pesquisas mais aprofundadas sobre o assunto.

Os modelos numéricos, discretizados em elementos finitos, também foram construídos por meio do código computacional ANSYS, tendo como base a estratégia adotada em REGOBELLO (2007) e aperfeiçoada conforme SANTOS (2009), KIMURA (2009) e DORR (2010), a qual consiste das seguintes etapas: (i) análise não-linear física e geométrica em temperatura ambiente, para a obtenção do esforço de compressão resistente das barras; (ii) 
análise térmica, para simular uma situação de incêndio através da aplicação de um campo térmico no perfil; e (iii) análise termo-estrutural, para a obtenção de uma estimativa do tempo de resistência ao fogo e da temperatura de colapso para perfis submetidos à compressão.

Basicamente, as solicitações existentes em um perfil em situação de incêndio são relativas à associação de ações térmicas e ações mecânicas, ou seja, além dos esforços resultantes das ações permanentes e variáveis, num ambiente em chamas os elementos estruturais sofrem ainda os efeitos provocados pela elevação da temperatura, que geram deformações adicionais e a redução das propriedades mecânicas do material.

Na modelagem numérica, o valor da ação mecânica introduzida (força de compressão) foi definido em termos percentuais da resistência $\left(N_{R}\right)$ obtida para cada perfil nas análises (i). Já a elevação da temperatura nas chapas e as implicações da ação térmica no elemento estrutural foram consideradas através da análise (ii). Finalmente, os efeitos gerados pela ação conjunta dessas duas solicitações foram então investigados por meio da análise termoestrutural (iii), sendo primeiramente inserida a força de compressão $\left(\% N_{R}\right)$ e, em seguida, aplicado o campo térmico resultante da análise (ii). Na Figura 3.22 é apresentada uma ilustração das etapas envolvidas na estratégia aqui adotada para a modelagem numérica.

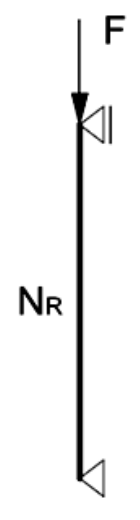

Análise em temperatura ambiente

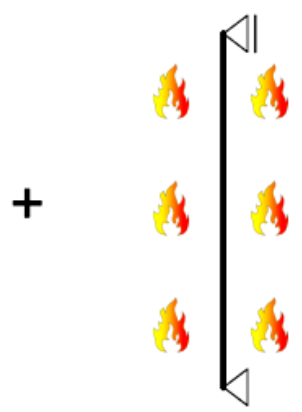

Análise térmica

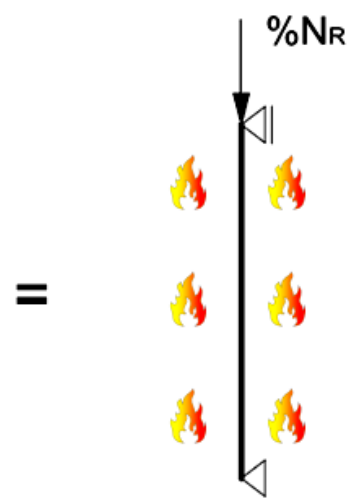

Análise termoestrutural

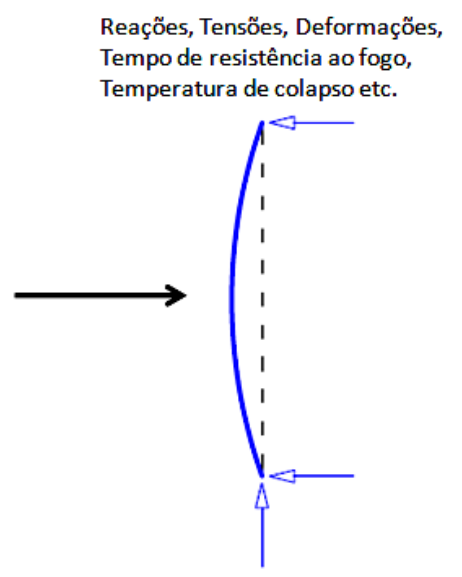

Resultados

Figura 3.22 - Ilustração das etapas envolvidas na modelagem numérica em temperaturas elevadas.

A geometria dos perfis e os dispositivos de apoio empregados nas análises em temperaturas elevadas foram os mesmos adotados para os perfis analisados sob compressão centrada à temperatura ambiente, para o caso da rótula cilíndrica posicionada no eixo-x (eixo 
de menor inércia) da seção transversal - ver itens 3.1.1 e 3.1.4. Assim, em resumo, os perfis foram modelados com seção transversal de 60x60x2,38mm, número de presilhas igual a dois e variando-se seu comprimento para valores do índice de esbeltez ( $\lambda$ ) iguais a 55, 85, 115 e 145. Portanto, os resultados obtidos para a resistência dos perfis nas análises anteriormente realizadas à temperatura ambiente puderam ser aproveitados para a definição do carregamento no modelo termoestrutural.

\subsubsection{ANÁLISE TÉRMICA}

Nas análises térmicas, o objetivo foi conseguir simular a elevação da temperatura nas chapas e presilhas que compõem o perfil, de forma a se reproduzir uma situação de incêndio sem compartimentação, já que os perfis dupla cantoneira em questão são geralmente empregados em locais não compartimentados, como em treliças e em sistemas de contraventamento de coberturas. Com isso, todas as faces dos perfis foram consideradas expostas à ação do incêndio simulado.

Para a discretização das cantoneiras e das presilhas, foi utilizada uma malha idêntica àquela empregada nos modelos analisados à temperatura ambiente, com elementos de aproximadamente $1 \times 1 \mathrm{~cm}^{2}$ nas partes planas e seção dividida em dois elementos nas regiões curvas (regiões de dobra). As diferenças ficam por conta dos elementos finitos utilizados, que, neste caso, foram os equivalentes térmicos dos elementos empregados nas análises à temperatura ambiente e no modelo termoestrutural, a saber: os elementos $S H E L L ~ 131$, para as chapas das cantoneiras; e SOLID 70, para as presilhas. Apenas a título de informação, são apresentados na Tabela 3.6 alguns equivalentes térmicos disponibilizados pelo ANSYS para vários tipos de elementos finitos, conforme exposto em DORR (2010).

Tabela 3.6 - Elementos compatíveis para análises acopladas. Fonte: ANSYS Guide

\begin{tabular}{|c|c|}
\hline ESTRUTURAL & TÉRMICO \\
\hline SOLID 45 & SOLID 70 \\
\hline SOLID 92 & SOLID 87 \\
\hline SOLID 95 & SOLID 90 \\
\hline PLANE 42 & PLANE 55 \\
\hline PLANE 82 & PLANE 77 \\
\hline SHELL 181 & SHELL 131 \\
\hline SHELL 91 e SHELL 93 & SHELL 132 \\
\hline LINK 8 & LINK 33 \\
\hline
\end{tabular}


O elemento SHELL 131 é um elemento finito do tipo casca que é ideal para ser utilizado em análises térmicas a serem acopladas em modelos termoestruturais discretizados com o elemento SHELL 181. É definido por quatro nós com até 32 graus de liberdade cada um, todos referentes à temperatura. A variação no número de graus de liberdade ocorre em função de uma importante característica desse elemento, que é a possibilidade de o mesmo poder ser dividido em várias camadas (layers) ao longo de sua espessura. No total, pode ser especificado um número máximo de camadas igual a 15 ou 31, dependendo se a variação da temperatura ao longo da espessura está definida como quadrática ou linear, respectivamente.

Para cada camada, podem ser definidas espessuras e propriedades inerentes ao material (ou aos materiais), dando, com isso, a possibilidade de serem considerados sistemas de proteção passiva contra incêndios nos modelos numéricos, tais como pintura intumescente ou revestimentos projetados. As propriedades a serem informadas para os materiais são: condutividade térmica, densidade e calor específico.

Baseando-se nos vários testes realizados em DORR (2010), foram adotadas apenas duas camadas para os elementos SHELL 131 utilizados nas análises térmicas, já que a pequena espessura das chapas dos perfis $(2,38 \mathrm{~mm})$, associada à elevada condutividade térmica do aço, acaba conduzindo a diferenças insignificantes de resultados quando da consideração de mais camadas. Além disso, um menor número de camadas deixa o modelo “mais leve” e permite reduzir o tempo de processamento das análises.

A distribuição da temperatura ao longo das camadas foi ajustada nos modelos com variação quadrática, que é a recomendada para situações em que se têm materiais muito sensíveis a gradientes térmicos, como é o caso do aço. As propriedades térmicas utilizadas nos modelos para o aço e suas variações em função da temperatura foram aquelas especificadas pelas normas, conforme detalhado no item 2.7.1.2, sendo adotado, ainda, o valor de $7850 \mathrm{~kg} / \mathrm{m}^{3}$ para a densidade do aço.

O outro elemento finito empregado nos modelos térmicos, o SOLID 70, é o elemento sólido que possui a compatibilidade necessária para análises termoestruturais acopladas que possuem elementos do tipo SOLID 45, situação em que se enquadra a discretização das presilhas aqui modeladas. Portanto, sua utilização se restringiu apenas à discretização das duas presilhas dos modelos, já que os dispositivos de apoio (onde também foi empregado o SOLID 45 nas análises termoestruturais e à temperatura ambiente) não são considerados nas análises térmicas. O SOLID 70 possui um total de oito nós, com um grau de liberdade, 
referente à temperatura, por nó. A Figura 3.23 apresenta a malha e os elementos finitos utilizados para a discretização dos perfis para as análises térmicas.

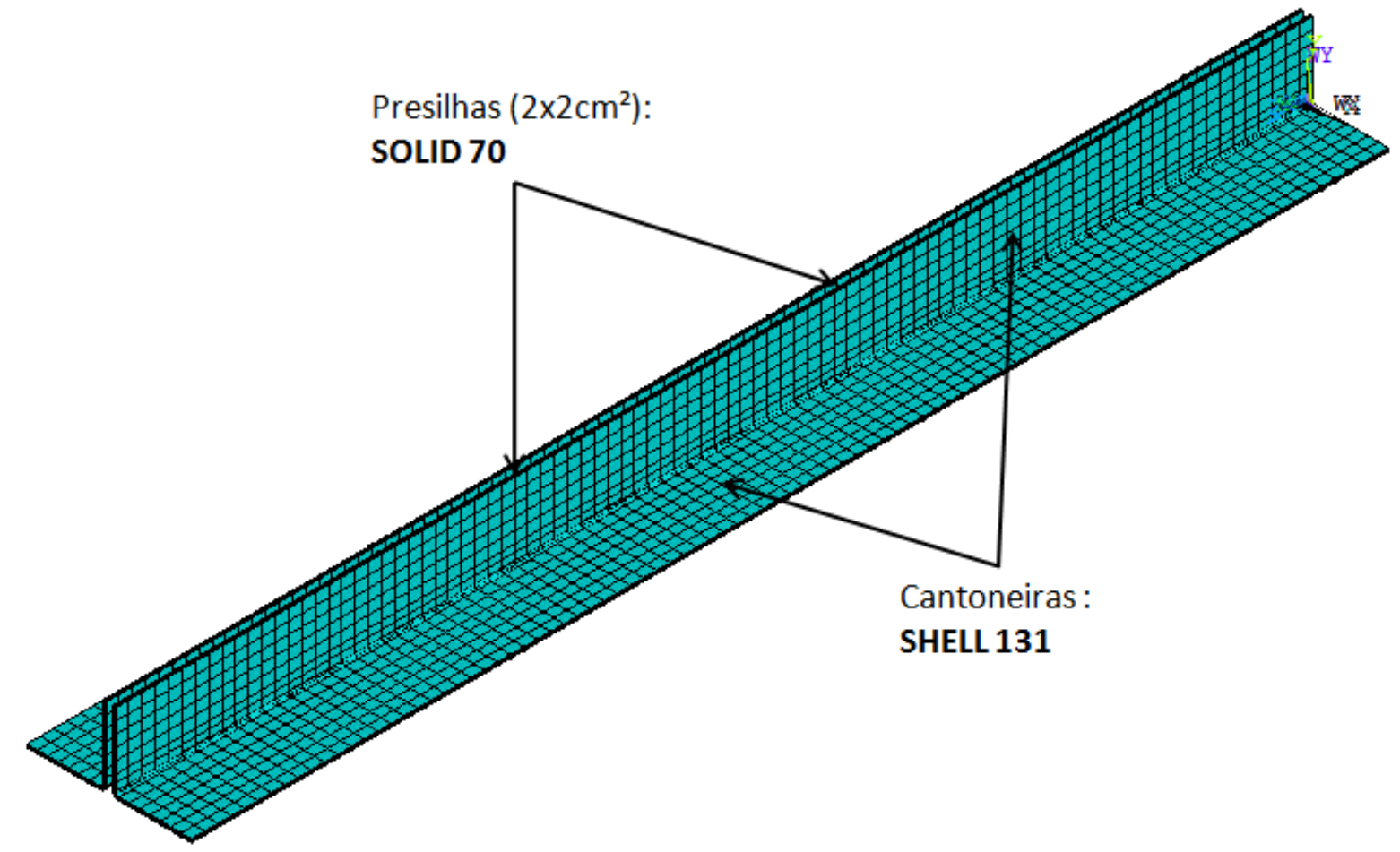

Figura 3.23 - Malha e elementos finitos utilizados nas análises térmicas.

Além dos elementos SHELL 131 e SOLID 70, que se destinam à transferência de calor por condução nas chapas do perfil, foi utilizado, também, um elemento finito para a consideração da transferência de calor por radiação e por convecção. Trata-se do elemento SURF 152, cuja geometria pode ser definida pela disposição de quatro a oito nós, tendo um grau de liberdade por nó, referente à temperatura. Opcionalmente, pode ser utilizado o chamado "nó extra", que se destina a representar a temperatura dos gases do ambiente e, assim, dar base para a transferência de calor por radiação e por convecção do ambiente para as superfícies expostas do perfil.

Como os modelos térmicos foram criados para representar um caso de incêndio sem compartimentação, foram dispostas malhas com o elemento SURF 152 em todas as faces das cantoneiras que compõem o perfil em questão, conforme ilustrado na Figura 3.24. Nota-se que há, na verdade, uma sobreposição dos filmes de radiação e convecção nas malhas de base compostas pelos elementos SHELL 131 e SOLID 70, de forma semelhante à alocação de elementos de contado anteriormente descrita. 
As propriedades do material a serem atribuídas ao elemento SURF 152 incluem o fator de emissividade, a constante de Stefan-Boltzmann e o coeficiente de transferência de calor por convecção, para os quais foram adotados os valores de $0,7,5,67.10^{-8} \mathrm{~W} / \mathrm{m}^{2} \mathrm{~K}^{4}$ e $25 \mathrm{~W} / \mathrm{m}^{2}{ }^{\circ} \mathrm{C}$, respectivamente (ver item 2.7.2).

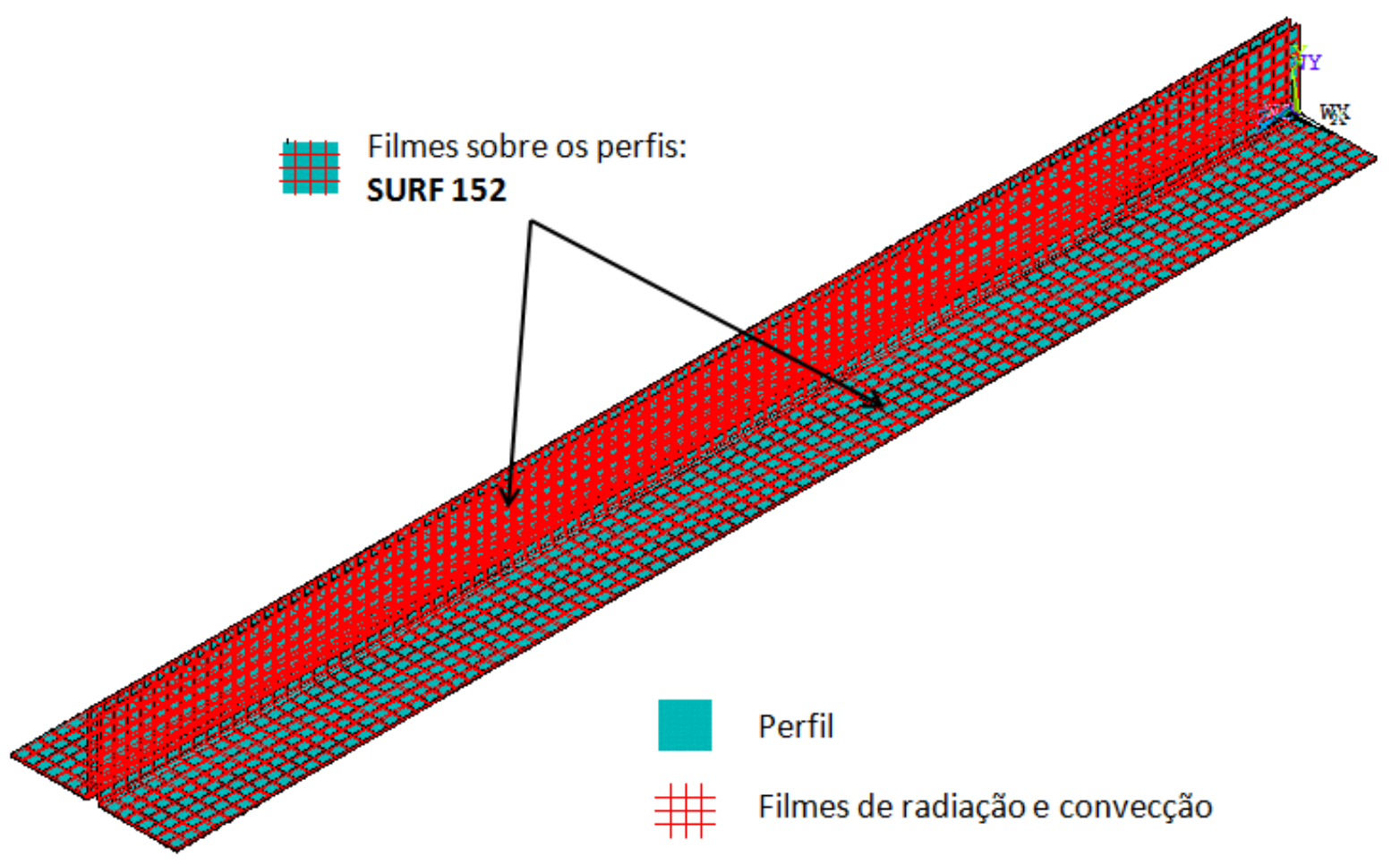

Figura 3.24 - Disposição dos filmes de radiação e convecção nas faces do perfil.

A evolução da temperatura dos gases do ambiente nos modelos construídos para a análise térmica foi regida pela exposição dos perfis ao Incêndio-Padrão proposto pela ISO 834-1:1999, conforme item 2.7.3, cuja relação Temperatura x Tempo foi atribuída ao nó mestre dos elementos SURF 152. O tempo máximo de exposição ao incêndio-padrão nas análises foi fixado em 60 minutos, o que conduziu a uma temperatura máxima de $945^{\circ} \mathrm{C}$ nas chapas dos perfis.

Por fim, para avaliar a confiabilidade dos resultados fornecidos pelas análises térmicas aqui desenvolvidas, foram realizados testes visando averiguar a distribuição da temperatura nas chapas do perfil e sua variação ao longo do tempo. Como as diferenças de temperatura na seção transversal dos perfis e ao longo de seu comprimento são muito pequenas, devido às elevadas esbeltez local e condutividade térmica, a visualização desse gradiente térmico só é possível nas etapas iniciais das análises. 
A Figura 3.25 esquematiza a etapa inicial de uma das análises térmicas realizadas, onde são destacadas as diferenças de temperatura na região das presilhas e na espessura das cantoneiras.

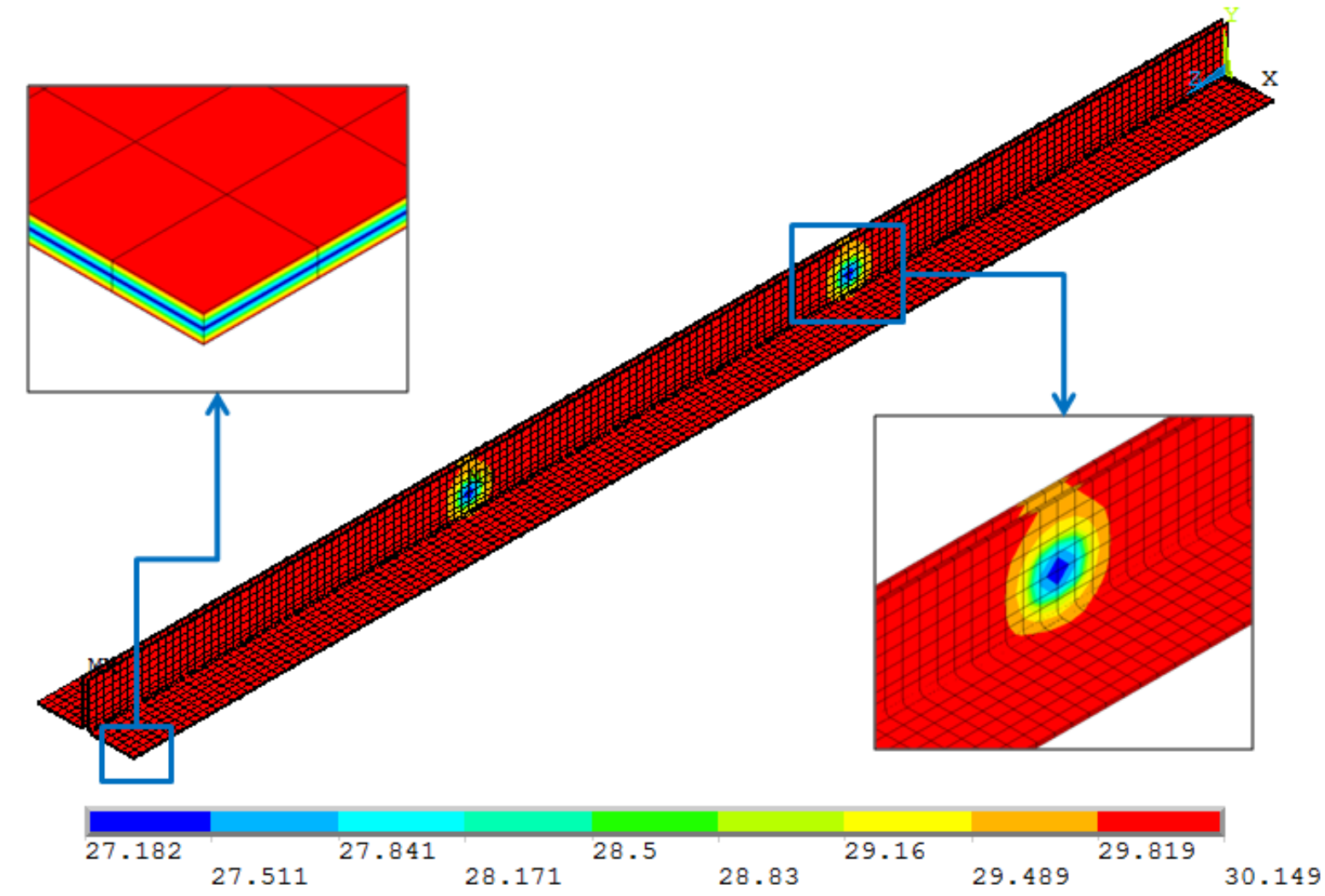

Figura 3.25 - Variação da temperatura $\left({ }^{\circ} \mathrm{C}\right)$ no perfil para a etapa inicial da análise térmica.

Apesar de a elevação da temperatura ser praticamente uniforme em PFF, a existência desse gradiente térmico (Figura 3.25) indica que a estratégia adotada neste trabalho para a análise térmica apresenta resultados qualitativamente coerentes com o que ocorre na prática. Com o passar do tempo de exposição ao fogo, as variações térmicas na espessura e ao longo do comprimento do perfil passam a praticamente não existir mais, uma vez que ocorre uma rápida uniformização da temperatura, principalmente nestes casos em que não há compartimentação. A Figura 3.26 mostra a última etapa da análise, indicando a temperatura máxima atingida no modelo. 


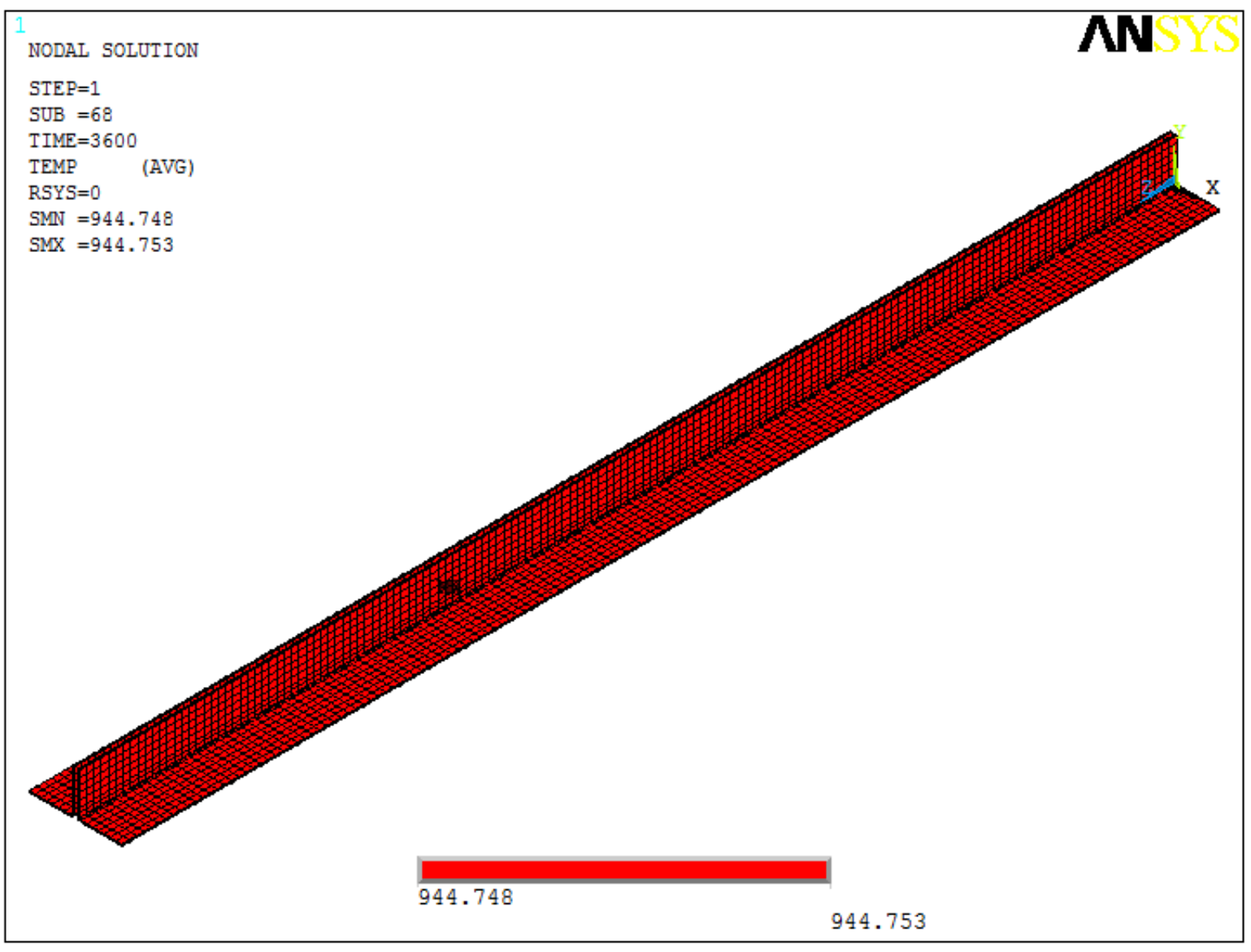

Figura 3.26 - Distribuição de temperatura no perfil para a última etapa da análise térmica.

\subsubsection{ANÁLISE TERMOESTRUTURAL}

As análises termoestruturais se destinam à investigação do comportamento estrutural dos perfis mediante a combinação de solicitações mecânicas e térmicas. Por meio dessas análises podem ser obtidos importantes resultados relacionados à segurança das estruturas em situação de incêndio, tais como os modos de falha predominantes, o tempo de resistência ao fogo e a temperatura máxima atingida no perfil em seu limite de resistência.

A estratégia numérica adotada no presente trabalho para a definição do carregamento mecânico e da variação da temperatura no perfil com o tempo envolve, como já dito, uma análise não-linear à temperatura ambiente e uma análise térmica, que são realizadas para cada um dos perfis. De posse dos resultados dessas análises, passa-se, então, às análises termoestruturais, cuja sistemática compreende a seguinte seqüência: primeiramente, é aplicada a ação mecânica (neste caso, o carregamento de compressão) e, em seguida, são considerados os efeitos da elevação de temperatura por meio do acoplamento com a análise térmica. Com isso, obtêm-se respostas à atuação simultânea de ambas as ações. 
Os modelos numéricos construídos para as análises termoestruturais são semelhantes àqueles analisados à temperatura ambiente, não somente em relação à geometria e às condições de vinculação, mas também sob os aspectos da discretização e dos elementos finitos utilizados. A única exceção fica por conta dos elementos de contato, que não foram aqui empregados.

Sendo assim, foi utilizada uma malha mapeada nas chapas dos perfis com as dimensões dos elementos de aproximadamente $1 \mathrm{x} 1 \mathrm{~cm}^{2}$ nas partes planas e seção dividida em dois elementos nas regiões curvas (regiões de dobra). Os dispositivos de apoio e as presilhas foram discretizados de forma a facilitar as uniões, os acoplamentos e as restrições nodais empregados para simular a interação entre as diferentes partes do perfil. Novamente, os elementos finitos utilizados foram o SHELL 181 (para as chapas das cantoneiras) e o SOLID 45 (para as presilhas e os sólidos de topo), conforme apresentado na Figura 3.27. Maiores informações sobre a geometria, a malha e os elementos finitos utilizados são apresentados no item 3.1.1 e 3.1.2.

Nesse contexto, cabe ressaltar a importância de se verificar a compatibilidade entre malhas e elementos finitos das análises térmicas e termoestruturais, já que o acoplamento das análises depende da igualdade nas discretização das duas malhas e da equivalência entre os elementos térmicos e estruturais, conforme exemplificado na Tabela 3.6.

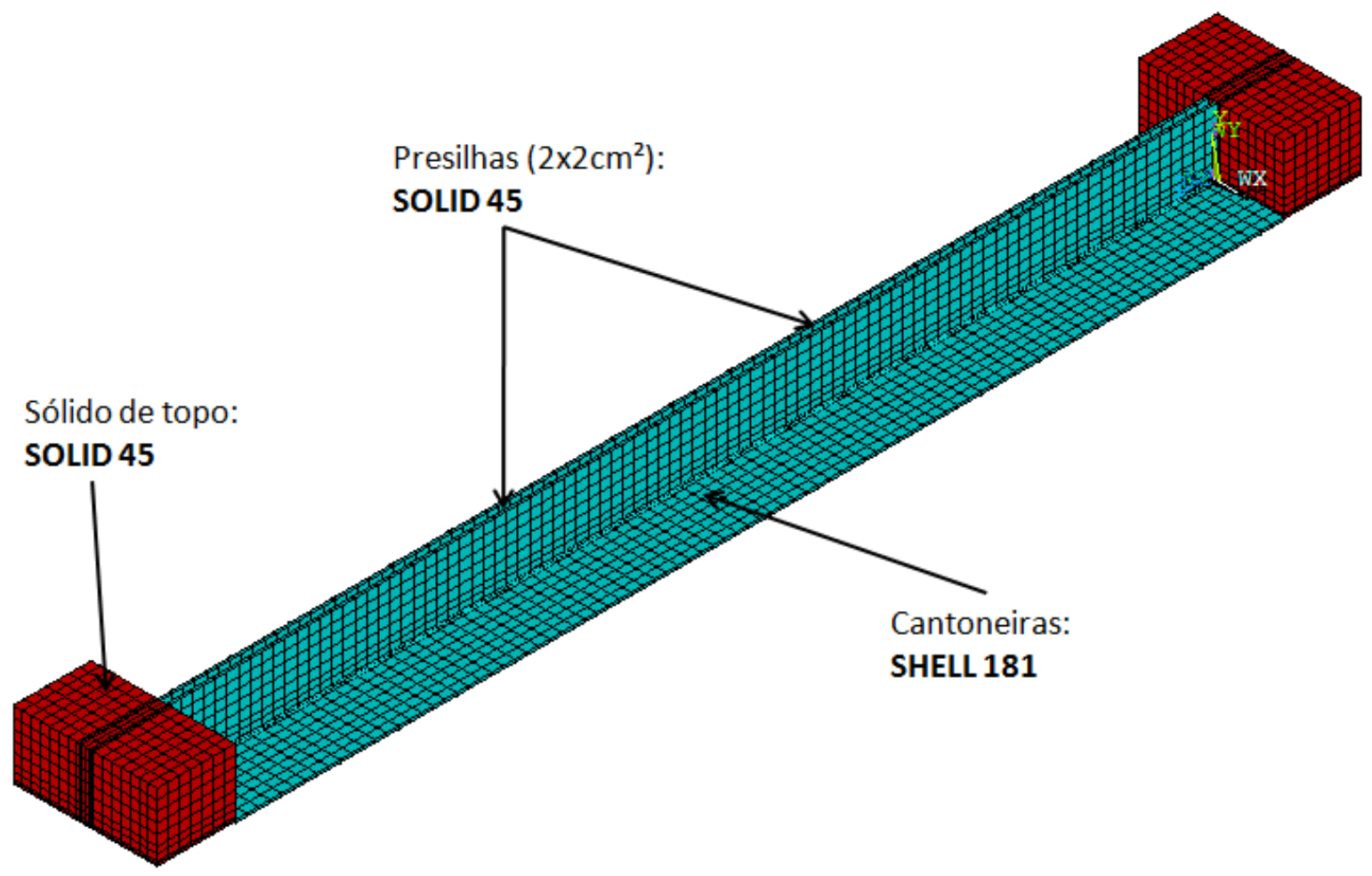

Figura 3.27 - Malha e elementos finitos utilizados nas análises termoestruturais. 
Sobre os dispositivos de apoio, cujas restrições nodais simulam o funcionamento de uma rótula cilíndrica posicionada no eixo de menor inércia da seção transversal (conforme Figura 3.11), uma importante informação é o fato de não ter sido considerada no modelo a restrição axial, que tenderia a reduzir a expansão resultante da ação térmica e, com isso, introduzir cargas adicionais no perfil. Pesquisas têm sido desenvolvidas visando fundamentar estratégias numéricas para a consideração dessas restrições axiais nos modelos, entre as quais se destacam os estudos apresentados em DORR (2010). Assim, fica como sugestão para trabalhos futuros a introdução de rotinas que considerem esses efeitos nos modelos aqui desenvolvidos.

As imperfeições geométricas iniciais também foram consideradas no modelo termoestrutural. As formas das imperfeições local e global seguiram o mesmo padrão dos modelos analisados em temperatura ambiente, conforme apresentado na Figura 3.14b e na Figura 3.16b, respectivamente. Para a magnitude, foram adotados os valores de 0,64.t para as locais e -L/1500 para as globais, tendo esta última sinal negativo por ter resultado na situação mais crítica nas análises à temperatura ambiente.

A relação constitutiva adotada para o aço, para fins de aplicação nos modelos numéricos em temperaturas elevadas, é aquela proposta na EN 1993-1-2:2010, para temperaturas variando entre $20^{\circ} \mathrm{C}$ e $1100{ }^{\circ} \mathrm{C}$. Com isso, os efeitos da ação térmica na análise da estrutura foram considerados por meio da aplicação dos coeficientes de redução das propriedades mecânicas do aço, cujas variações em função da temperatura são apresentadas na Tabela 2.6 e na Figura 2.26. Na Figura 3.28 são ilustrados, graficamente, os efeitos da redução das propriedades mecânicas (módulo de elasticidade, resistência ao escoamento e limite de proporcionalidade) na relação constitutiva do aço.

No que se refere ao carregamento mecânico, há uma diferença importante na forma de introdução do esforço de compressão no modelo termoestrutural quando comparado com aqueles analisados à temperatura ambiente. Enquanto lá o carregamento foi aplicado na forma de incrementos de deslocamentos, aqui o mesmo foi introduzido por meio de incrementos de força, já que essa estratégia é tida como mais coerente quando da associação com a ação térmica. 


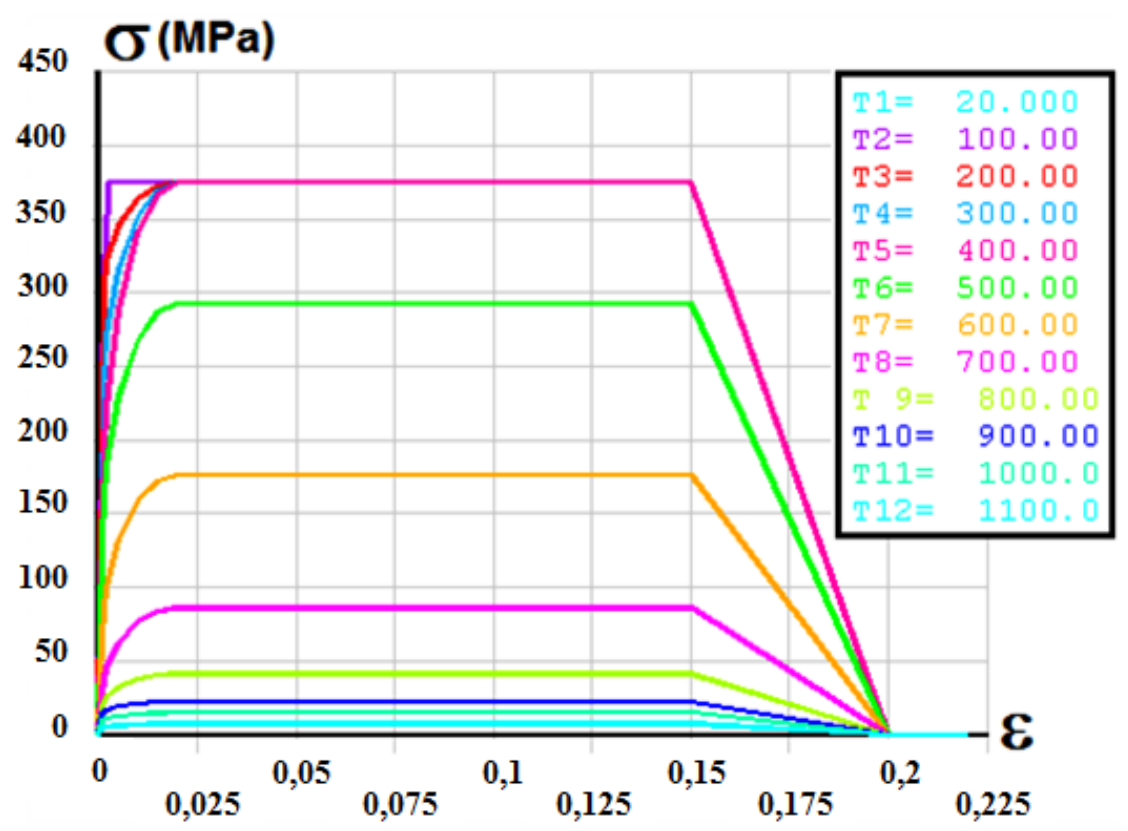

Figura 3.28 - Relações Tensão x Deformação adotadas para o aço, em função da temperatura. Fonte: adaptado de KIMURA (2009)

Assim, foram aplicados três níveis de carregamento (na forma de compressão centrada) em perfis com quatro índices de esbeltez diferentes, sendo estes carregamentos correspondentes a 30\%, 50\% e 70\% das resistências dos perfis obtidas nas análises realizadas à temperatura ambiente. A Tabela 3.7 apresenta os valores de força introduzidos nos modelos termoestruturais, com base nas resistências $\left(N_{R}\right)$ apresentadas pelos mesmos perfis analisados à temperatura ambiente.

Tabela 3.7 - Níveis de carregamento aplicados nas análises termoestruturais.

\begin{tabular}{|c|c|c|c|c|c|c|}
\hline \multirow{2}{*}{ PERFIL } & \multirow{2}{*}{$\begin{array}{l}\mathbf{L}_{\text {perfil }} \\
(\mathbf{m m})\end{array}$} & \multirow{2}{*}{$\lambda$} & \multirow{2}{*}{$\begin{array}{c}\mathbf{N}_{\mathrm{R}} \\
(\mathbf{k N})\end{array}$} & \multicolumn{3}{|c|}{ Força de compressão aplicada $(\mathbf{k N})$} \\
\hline & & & & $30 \% \mathbf{N}_{\mathrm{R}}$ & $50 \% \mathrm{~N}_{\mathrm{R}}$ & $70 \% \mathrm{~N}_{\mathrm{R}}$ \\
\hline \multirow{4}{*}{$\begin{array}{c}2 \mathrm{~L} \mathbf{6 0 x} 2,38 \mathrm{~mm} \\
\text { (rótula no eixo-x) } \\
\mathrm{K}_{\mathrm{x}}=1,0 \text { e } \mathrm{K}_{\mathrm{y}}=0,5\end{array}$} & 910 & 55 & 91,6 & 27,5 & 45,8 & 64,1 \\
\hline & 1485 & 85 & 77,7 & 23,3 & 38,9 & 54,4 \\
\hline & 2055 & 115 & 64,2 & 19,3 & 32,1 & 44,9 \\
\hline & 2630 & 145 & 48,6 & 14,6 & 24,3 & 34,0 \\
\hline
\end{tabular}

Tendo definidos todos os parâmetros da modelagem, passou-se, então, aos testes para verificação se os resultados apresentados pelas análises termoestruturais representavam de forma coerente o comportamento dos perfis em situação de incêndio. Porém, semelhantemente ao ocorrido nas análises à temperatura ambiente, muitos dos modelos apresentaram problemas de convergência nas análises termoestruturais. 
A Figura 3.29 mostra, para um dos exemplos-teste, o deslocamento axial do dispositivo de apoio em que foi aplicado o carregamento mecânico (força de compressão) em função do tempo de exposição ao incêndio-padrão simulado. Nota-se que, devido à prévia aplicação da força de compressão, o valor do deslocamento axial começa negativo, indicando um pequeno encurtamento do perfil resultante desse carregamento. Em seguida, na medida em que o tempo de exposição ao fogo vai crescendo (aumento na temperatura das chapas), ocorre a expansão da barra, representado graficamente pela curva ascendente. Até que, em um determinado momento (tempo de exposição igual a 4,5min, neste caso), ocorre a perda de convergência da análise numérica sem antes apresentar a esperada queda brusca na curva, resultante dos problemas de instabilidade.

Para resolver esse problema, foi novamente empregada a ferramenta STABILIZE nas análises, cuja influência nos resultados do exemplo-teste está ilustrada na Figura 3.30. Apesar de o avanço da curva não ter sido tão significativo em termos de tempo de resistência ao fogo, esses resultados se mostram interessantes por garantirem que o perfil chegou ao seu limite de resistência na análise. Mais uma vez, é importante informar que a utilização dessa ferramenta deve ser feita de forma cuidadosa, com seus parâmetros devidamente calibrados, para que não haja um enrijecimento exagerado no elemento estrutural (ver item 3.1.6).

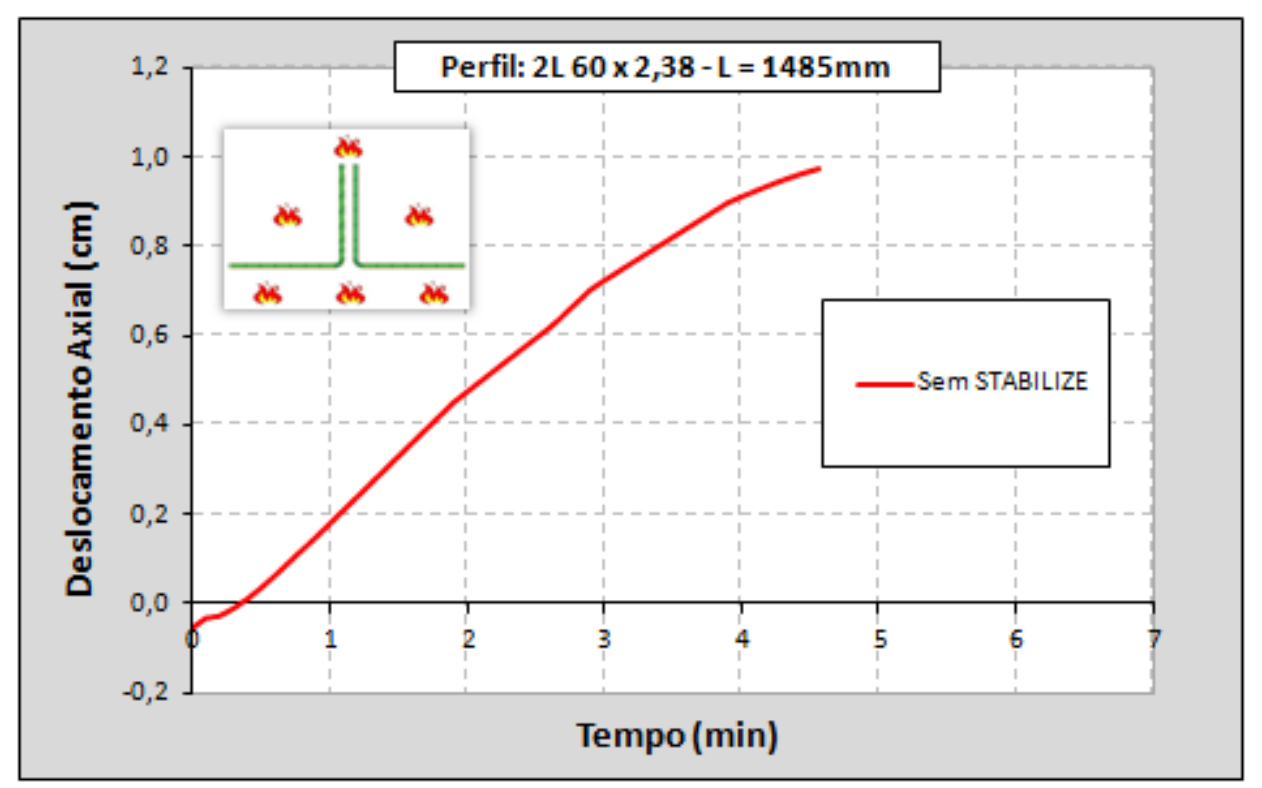

Figura 3.29 - Modelo termoestrutural sem a ferramenta STABILIZE. 


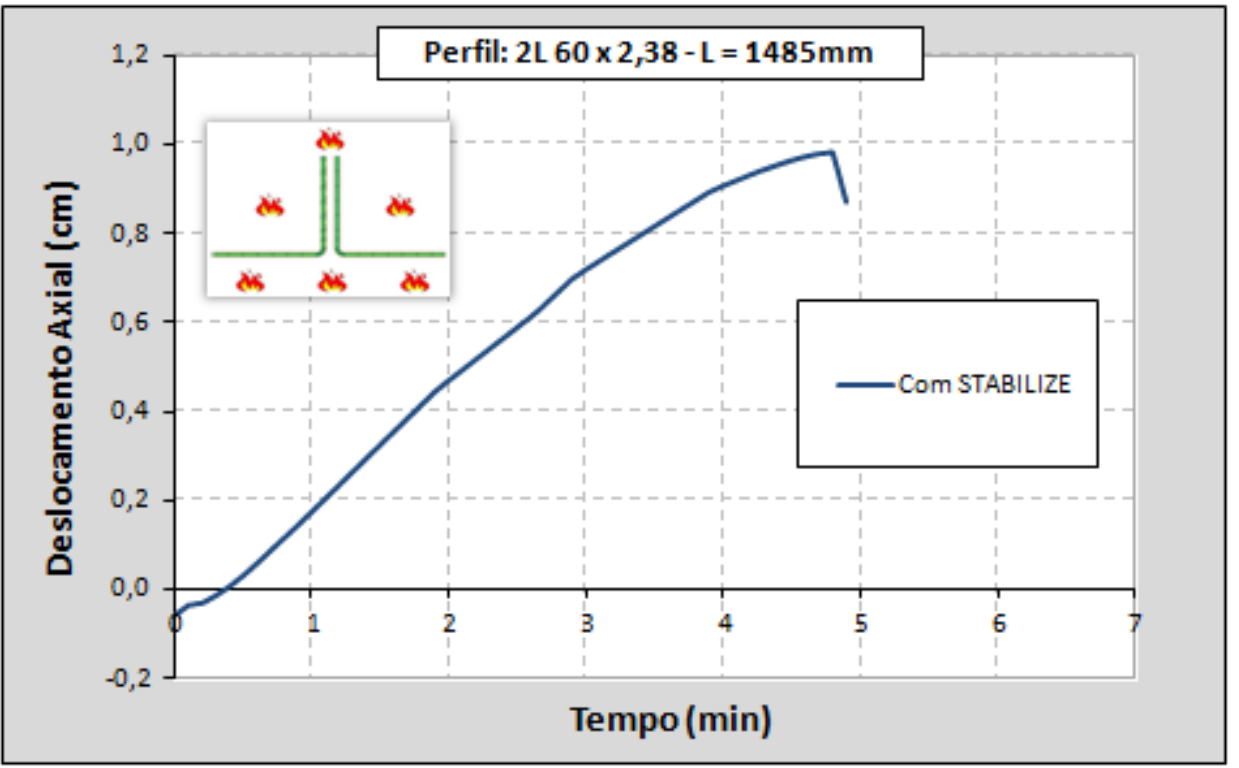

Figura 3.30 - Modelo termoestrutural com a ferramenta STABILIZE.

Vale ressaltar ainda que a perda de convergência em análises termoestruturais é, de certa forma, normal e até mesmo esperada, já que indica o colapso do elemento estrutural devido aos fenômenos de instabilidade. O problema é quando essa perda de convergência ocorre de forma precipitada, ou seja, antes de indicar a queda no deslocamento axial, conforme mostrado na Figura 3.29. 


\section{CAPÍTULO}

\section{RESULTADOS E DISCUSSÕES}

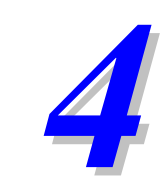

Neste capítulo, são apresentados e discutidos os resultados das modelagens numéricas realizadas no presente trabalho, conforme descrito no Capítulo 3. Seguindo a seqüência de desenvolvimento da presente pesquisa, serão analisados, primeiramente, os resultados obtidos por meio das análises à temperatura ambiente e, em seguida, aqueles extraídos das análises em temperaturas elevadas.

\subsection{ANÁLISES À TEMPERATURA AMBIENTE}

As análises à temperatura ambiente realizadas foram dividas em, basicamente, duas etapas. Na primeira, foi avaliado o comportamento estrutural dos perfis submetidos à compressão centrada, cujas análises numéricas também serviram para a calibração dos modelos criados mediante comparação com resultados experimentais presentes na literatura. $\mathrm{Na}$ segunda etapa, os perfis foram analisados sob compressão excêntrica, com ligações parafusadas em apenas uma das abas de cada cantoneira, que é a situação mais comumente encontrada na prática.

A idéia é analisar os resultados da modelagem sob aspectos quantitativos e qualitativos, principalmente no que se refere aos valores de resistência apresentados pelos modelos e aos respectivos modos de instabilidade responsáveis pelo colapso dos perfis. Nesse contexto, os resultados serão comparados também com aqueles obtidos por meio das prescrições da ABNT NBR 14762:2010 para dimensionamento de perfis compostos, de forma a contribuir para possíveis melhorias no referido documento normativo.

É importante ressaltar que uma das grandes dificuldades na caracterização do comportamento estrutural de perfis compostos é a identificação dos tais modos de instabilidade predominantes, uma vez que presença de presilhas intermitentes tende a conduzir a uma complexa configuração deformada, envolvendo uma associação do comportamento isolado dos perfis entre as presilhas com o da peça composta como um todo. 
Dessa forma, será adotada no presente trabalho uma nomenclatura para a descrição dos modos de instabilidade resultantes das análises numéricas, tanto para o perfil composto como para as cantoneiras simples nos trechos entre as presilhas. Além disso, são disponibilizadas nos APÊNDICES D e E as configurações deformadas obtidas nas análises finais realizadas via ANSYS para um melhor entendimento.

\subsubsection{COMPRESSÃO CENTRADA}

Tomando como base os resultados experimentais apresentados em CHODRAUI (2006), foram modelados os perfis dupla cantoneira descritos nos itens 2.6.1 e 3.1.1, tanto para a rótula cilíndrica posicionada no eixo-x (de menor inércia) como no eixo-y (de maior inércia - eixo de simetria).

Visando selecionar imperfeições geométricas iniciais que mais influenciam na capacidade resistente deste tipo de perfil e que, ao mesmo tempo, apresentem resultados nas análises numéricas coerentes com os resultados experimentais, foi realizada uma ampla análise de sensibilidade às imperfeições por meio dos modelos numéricos criados.

\subsubsection{Análise de sensibilidade às imperfeições geométricas}

\section{- Imperfeição global}

Inicialmente, o estudo envolveu a verificação da sensibilidade dos perfis em questão à imperfeição geométrica inicial global, sendo, para isso, realizadas análises numéricas sem a consideração das imperfeições locais e fazendo-se variar a imperfeição global.

Para os perfis com rótula cilíndrica no eixo-x (eixo de não-simetria) os testes envolveram o sinal e a magnitude da imperfeição global. No caso dos perfis com rótula cilíndrica posicionada no eixo-y (eixo de simetria), foi verificada apenas a influência da magnitude dessa imperfeição, já que, por ser o eixo de simetria, a variação do sinal não acarreta qualquer mudança no comportamento do perfil, neste caso.

Os resultados das análises não-lineares são apresentados na Tabela 4.1 e na Tabela 4.2, para a rótula no eixo-x e no eixo-y, respectivamente. 
Tabela 4.1 - Compressão centrada: resultados da análise de sensibilidade à imperfeição geométrica inicial global - Rótula no eixo-x.

\begin{tabular}{|c|c|c|c|c|c|c|}
\hline \multicolumn{7}{|c|}{ Perfil 60x60x2,38mm - Rótula cilíndrica no eixo-x } \\
\hline \multirow{2}{*}{$\begin{array}{l}\mathbf{L}_{\text {perfil }} \\
(\mathbf{m m})\end{array}$} & \multirow{2}{*}{$\begin{array}{l}N_{\text {exp }} \\
(k N)\end{array}$} & \multicolumn{4}{|c|}{ ANÁLISE NUMÉRICA } & \multirow{2}{*}{$\begin{array}{c}\mathbf{N}_{\exp } \\
/ \\
\mathbf{N}_{\text {FEM }}\end{array}$} \\
\hline & & $\begin{array}{l}\text { Imperfeições } \\
\text { local e global }\end{array}$ & $\begin{array}{c}N_{\text {FEM }} \\
(\mathbf{k N})\end{array}$ & $\begin{array}{l}\text { Modo } \\
\text { 2L }\end{array}$ & $\begin{array}{c}\text { Modo } \\
\text { L }\end{array}$ & \\
\hline \multirow{8}{*}{$\begin{array}{c}910 \\
\left(\lambda_{x}=55\right)\end{array}$} & \multirow{8}{*}{62,0} & $0 \mathrm{t} \mathrm{e}+\mathrm{L} / 10000$ & 92,3 & $\mathrm{~F}^{*}+\mathrm{L}$ & $\mathrm{T}$ & 0,67 \\
\hline & & 0t e -L/10000 & 92,3 & $\mathrm{~F}^{*}+\mathrm{L}$ & $\mathrm{T}$ & 0,67 \\
\hline & & 0t e $+\mathrm{L} / 1000$ & 91,6 & $\mathrm{~T}$ & $\mathrm{~T}^{*}$ & 0,68 \\
\hline & & 0t e -L/1000 & 92,0 & $\mathrm{~F}^{*}+\mathrm{L}$ & $\mathrm{T}$ & 0,67 \\
\hline & & $0 \mathrm{t} \mathrm{e}+\mathrm{L} / 500$ & 91,9 & $\mathrm{~T}$ & $\mathrm{~T}^{*}$ & 0,67 \\
\hline & & 0 t e -L/500 & 91,7 & $\mathrm{~F}^{*}+\mathrm{L}$ & $\mathrm{T}$ & 0,68 \\
\hline & & $0 \mathrm{t} \mathrm{e}+\mathrm{L} / 350$ & 92,2 & $\mathrm{~T}$ & $\mathrm{~T}^{*}$ & 0,67 \\
\hline & & 0 t e -L/350 & 90,8 & $\mathrm{~T}$ & $\mathrm{~T}^{*}$ & 0,68 \\
\hline \multirow{8}{*}{$\begin{array}{c}1485 \\
\left(\lambda_{x}=85\right)\end{array}$} & \multirow{8}{*}{70,0} & 20 t e $+\mathrm{L} / 10000$ & 81,1 & $\mathrm{~F}^{*+\mathrm{L}}$ & $\begin{array}{l}\text { FT } \\
\end{array}$ & 0,86 \\
\hline & & 0t e -L/10000 & 81,0 & $\mathrm{~F}^{*}+\mathrm{L}$ & FT & 0,86 \\
\hline & & $0 \mathrm{t} \mathrm{e}+\mathrm{L} / 1000$ & 79,6 & $\mathrm{~T}$ & $\mathrm{~T}^{*}$ & 0,88 \\
\hline & & 0t e -L/1000 & 78,7 & $F+L$ & FT & 0,89 \\
\hline & & 0 t e +L/500 & 80,0 & $\mathrm{~T}$ & $\mathrm{~T}^{*}$ & 0,88 \\
\hline & & $0 t$ e -L/500 & 78,0 & $\mathrm{~F}+\mathrm{L}$ & FT & 0,90 \\
\hline & & $0 \mathrm{t} \mathrm{e}+\mathrm{L} / 350$ & 80,3 & $\mathrm{~T}$ & $\mathrm{~T}^{*}$ & 0,87 \\
\hline & & 0t e -L/350 & 76,5 & $F+L$ & FT & 0,92 \\
\hline \multirow{8}{*}{$\begin{array}{c}2055 \\
\left(\lambda_{x}=115\right)\end{array}$} & \multirow{8}{*}{63,0} & 0t e +L/10000 & 76,0 & $F+T+L$ & FT & 0,83 \\
\hline & & 0t e -L/10000 & 72,5 & $F+T+L$ & FT & 0,87 \\
\hline & & $0 t \mathrm{e}+\mathrm{L} / 1000$ & 77,5 & $\mathrm{~F}+\mathrm{L}^{*}$ & FT* & 0,81 \\
\hline & & 0t e -L/1000 & 65,3 & $F+L$ & FT & 0,96 \\
\hline & & $0 \mathrm{t} \mathrm{e}+\mathrm{L} / 500$ & 78,6 & $\mathrm{~F}+\mathrm{L}^{*}$ & FT* & 0,80 \\
\hline & & 0t e -L/500 & 63,0 & $F+L$ & FT & 1,00 \\
\hline & & $0 \mathrm{t} \mathrm{e}+\mathrm{L} / 350$ & 79,4 & $\mathrm{~F}+\mathrm{L}^{*}$ & FT* & 0,79 \\
\hline & & 0t e -L/350 & 60,6 & $F+L$ & FT & 1,04 \\
\hline \multirow{8}{*}{$\begin{array}{c}2630 \\
\left(\lambda_{x}=145\right)\end{array}$} & \multirow{8}{*}{46,0} & 0 t e +L/10000 & 49,7 & $\overline{F+L^{*}}$ & FT* & $0,0,93$ \\
\hline & & 0t e -L/10000 & 50,0 & $\mathrm{~F}+\mathrm{L}^{*}$ & $\mathrm{FT}^{*}$ & 0,92 \\
\hline & & $0 \mathrm{t} \mathrm{e}+\mathrm{L} / 1000$ & 50,5 & $\mathrm{~F}+\mathrm{L}^{*}$ & $\mathrm{FT}^{*}$ & 0,91 \\
\hline & & 0t e -L/1000 & 48,4 & $\mathrm{~F}+\mathrm{L}^{*}$ & $\mathrm{FT}^{*}$ & 0,95 \\
\hline & & $0 \mathrm{t} \mathrm{e}+\mathrm{L} / 500$ & 52,3 & $\mathrm{~F}+\mathrm{L}^{*}$ & FT* $^{*}$ & 0,88 \\
\hline & & 0t e -L/500 & 45,1 & $\mathrm{~F}+\mathrm{L}^{*}$ & FT* & 1,02 \\
\hline & & $0 t$ e $+\mathrm{L} / 350$ & 53,8 & $\mathrm{~F}+\mathrm{L}^{*}$ & FT* $^{*}$ & 0,86 \\
\hline & & 0t e -L/350 & NC & - & - & - \\
\hline \multicolumn{7}{|c|}{$\begin{array}{l}\mathrm{t} \text { - espessura das chapas do perfil; } \\
\mathrm{L}_{\text {perfil }} \text { - comprimento do perfil; } \\
\lambda_{x} \text { - índice de esbeltez do perfil; } \\
\mathrm{N}_{\text {exp }} \text { - força de compressão resistente obtida em CHODRAUI (2006); } \\
\mathrm{N}_{\mathrm{FEM}} \text { - força de compressão resistente obtida na análise numérica (ANSYS); }\end{array}$} \\
\hline
\end{tabular}

continua na próxima página... 
... continuação da Tabela 4.1

Modo 2L - modo de instabilidade referente ao perfil composto;

Modo L - modo de instabilidade das cantoneiras isoladas entre presilhas;

$\mathrm{F}$ = instabilidade global por flexão em torno do eixo-x (de menor inércia);

$\mathrm{T}$ = instabilidade global por torção;

FT = instabilidade global por flexo-torção;

$\mathrm{L}=$ instabilidade local (de chapa);

* Modo de instabilidade pouco pronunciado;

$\mathrm{NC}$ = análise via MEF não convergiu.

Tabela 4.2 - Compressão centrada: resultados da análise de sensibilidade à imperfeição geométrica inicial global - Rótula no eixo-y.

\begin{tabular}{|c|c|c|c|c|c|c|}
\hline \multicolumn{7}{|c|}{ Perfil 60x60x2,38mm - Rótula cilíndrica no eixo-y } \\
\hline \multirow{2}{*}{$\begin{array}{l}\mathbf{L}_{\text {perfil }} \\
(\mathbf{m m})\end{array}$} & \multirow{2}{*}{$\begin{array}{l}\mathbf{N}_{\exp } \\
(\mathbf{k N})\end{array}$} & \multicolumn{4}{|c|}{ ANÁLISE NUMÉRICA } & \multirow{2}{*}{$\begin{array}{c}\mathbf{N}_{\text {exp }} \\
/ \\
\mathbf{N}_{\text {FEM }}\end{array}$} \\
\hline & & $\begin{array}{l}\text { Imperfeições } \\
\text { local e global }\end{array}$ & $\begin{array}{c}\mathbf{N}_{\text {FEM }} \\
(\mathbf{k N})\end{array}$ & $\begin{array}{l}\text { Modo } \\
\text { 2L }\end{array}$ & $\begin{array}{c}\text { Modo } \\
\text { L }\end{array}$ & \\
\hline \multirow{4}{*}{$\begin{array}{c}1355 \\
\left(\lambda_{y}=56\right)\end{array}$} & \multirow{4}{*}{71,0} & 0t e L/10000 & 83,7 & $\mathrm{FT}(\mathrm{T})+\mathrm{L}^{*}$ & $\mathrm{~T}^{*}$ & 0,85 \\
\hline & & 0t e L/1500 & 83,3 & $\mathrm{FT}(\mathrm{T})+\mathrm{L}^{*}$ & $\mathrm{~T}^{*}$ & 0,85 \\
\hline & & 0t e L/500 & 82,7 & $\mathrm{FT}(\mathrm{T})+\mathrm{L}^{*}$ & $\mathrm{~T}^{*}$ & 0,86 \\
\hline & & 0t e L/350 & 82,3 & $\mathrm{FT}(\mathrm{T})+\mathrm{L}^{*}$ & $\mathrm{~T}^{*}$ & 0,86 \\
\hline \multirow{4}{*}{$\begin{array}{c}1885 \\
\left(\lambda_{y}=76\right)\end{array}$} & \multirow{4}{*}{63,0} & 0t e L/10000 & 71,8 & $\mathrm{FT}(\mathrm{T})+\mathrm{L}^{*}$ & $\mathrm{~T}^{*}$ & 0,88 \\
\hline & & Ot e L/1500 & 71,6 & $\mathrm{FT}(\mathrm{T})+\mathrm{L}^{*}$ & $\mathrm{~T}^{*}$ & 0,88 \\
\hline & & 0t e L/500 & 72,2 & $\mathrm{FT}(\mathrm{T})+\mathrm{L}^{*}$ & $\mathrm{~T}^{*}$ & 0,87 \\
\hline & & 0t e L/350 & $\mathrm{NC}$ & - & - & - \\
\hline \multirow{4}{*}{$\begin{array}{c}2415 \\
\left(\lambda_{y}=96\right)\end{array}$} & \multirow{4}{*}{53,0} & "0t e L/10000 & 62,5 & FT & $\mathrm{T}^{*}$ & 0,85 \\
\hline & & 0t e L/1500 & 61,3 & FT & $\mathrm{T}^{*}$ & 0,86 \\
\hline & & 0t e L/500 & 62,5 & FT & $\mathrm{T}^{*}$ & 0,85 \\
\hline & & 0t e L/350 & 61,3 & $\mathrm{FT}$ & $\mathrm{T}^{*}$ & 0,86 \\
\hline \multirow{4}{*}{$\begin{array}{c}2925 \\
\left(\lambda_{y}=115\right)\end{array}$} & \multirow{4}{*}{48,0} & 0t e L/10000 & 54,8 & FT & $\mathrm{T}^{*}$ & 0,88 \\
\hline & & 0t e L/1500 & 52,3 & FT & $\mathrm{T}^{*}$ & 0,92 \\
\hline & & 0t e L/500 & NC & - & - & - \\
\hline & & 0t e L/350 & NC & - & - & - \\
\hline \multicolumn{7}{|c|}{$\begin{array}{l}\text { t - espessura das chapas do perfil; } \\
\mathrm{L}_{\text {perfil }} \text { - comprimento do perfil; } \\
\lambda_{y} \text { - índice de esbeltez do perfil; } \\
\mathrm{N}_{\text {exp }} \text { - força de compressão resistente obtida em CHODRAUI (2006); } \\
\mathrm{N}_{\text {FEM }} \text { - força de compressão resistente obtida na análise numérica (ANSYS); } \\
\text { Modo 2L - modo de instabilidade referente ao perfil composto; } \\
\text { Modo L - modo de instabilidade das cantoneiras isoladas entre presilhas; } \\
\\
\text { F = instabilidade global por flexão em torno do eixo-x (de menor inércia); } \\
\mathrm{T} \text { = instabilidade global por torção; } \\
\text { FT = instabilidade global por flexo-torção; } \\
\text { FT(T) = instabilidade global por flexo-torção com predominância de torção; } \\
\text { L = instabilidade local (de chapa); } \\
\text { * Modo de instabilidade pouco pronunciado; } \\
\text { NC = análise via MEF não convergiu. }\end{array}$} \\
\hline
\end{tabular}


Analisando, primeiro, os resultados dos modelos com rótula cilíndrica posicionada no eixo-x (Tabela 4.1), é possível identificar certa influência da imperfeição global no comportamento dos perfis em função da esbeltez dos mesmos. No que se refere à resistência, os perfis mais esbeltos apresentaram maior sensibilidade tanto à variação do sinal como da magnitude da imperfeição global, o que já era esperado, uma vez que essa imperfeição é diretamente proporcional ao comprimento das barras. Além disso, os perfis com imperfeição geométrica inicial global com sinal negativo (tracionando as abas sem presilhas) apresentaram, em quase todos os casos, resistências menores do que aqueles com imperfeição global positiva (comprimindo as abas sem presilhas), dando um indício de um "sinal crítico negativo" para este tipo de perfil.

Para facilitar a visualização dos resultados, é apresentado na Figura 4.1 um gráfico com os valores de resistência à compressão $\left(\mathrm{N}_{\mathrm{FEM}}\right)$, obtidos nas análises numéricas, para as respectivas imperfeições globais adotadas, conforme exposto na Tabela 4.1.

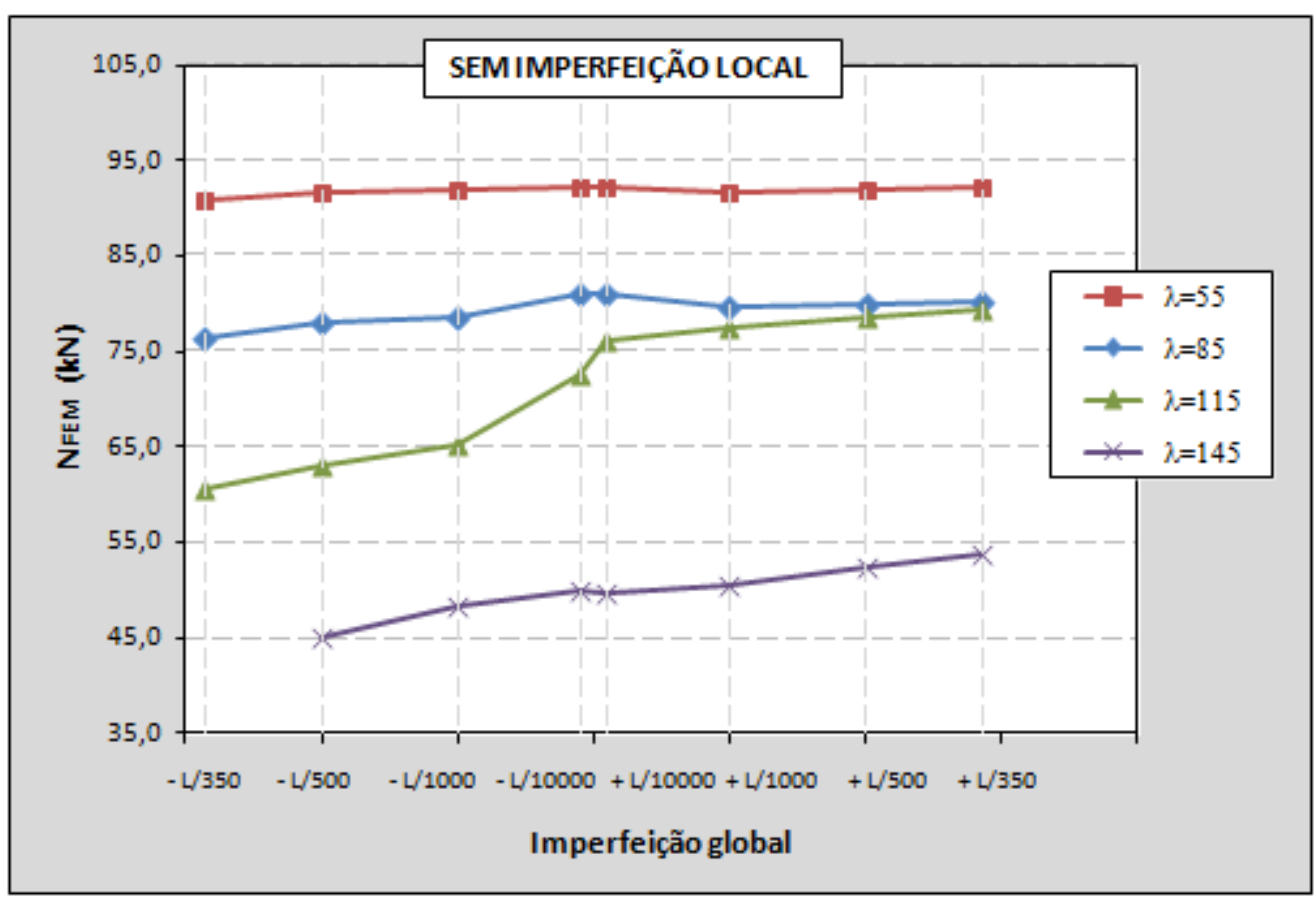

Figura 4.1 - Sensibilidade dos perfis à imperfeição geométrica global - Rótula no eixo-X.

Em relação aos modos de instabilidade referentes ao colapso dos perfis, os resultados revelam pouca influência do sinal e da magnitude dessas imperfeições globais neste tipo de perfil. A exceção fica por conta dos perfis menos esbeltos, que apresentaram significativas diferenças nas deformadas quando da variação apenas do sinal da imperfeição global, conforme mostrado na Tabela 4.1 e ilustrado na Figura 4.2. 
Obviamente, as conclusões finais sobre a resistência e sobre os modos de instabilidades predominantes para os perfis aqui estudados dependem ainda da composição com as imperfeições geométricas iniciais locais, que será tratada adiante. No entanto, as análises com as imperfeições globais “puras” se mostram muito interessantes no sentido de se investigar a real contribuição dessas imperfeições no comportamento dos perfis.

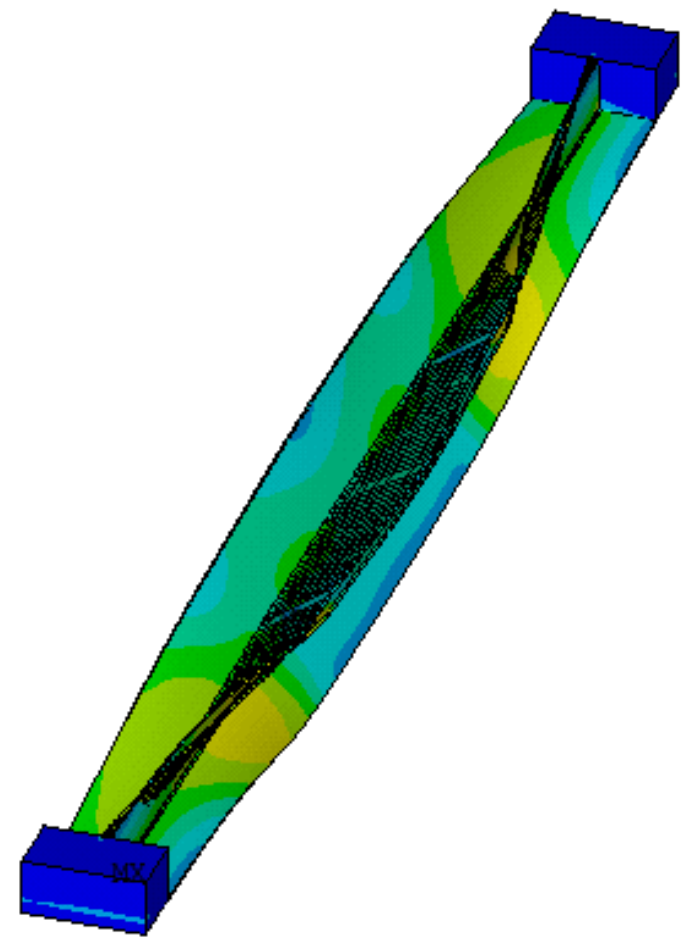

(a)

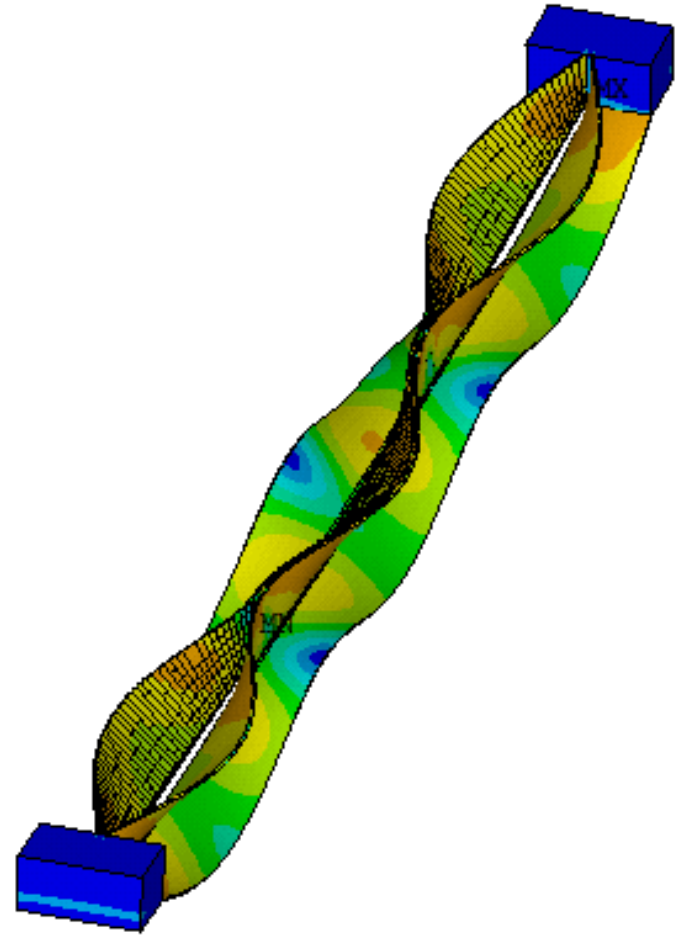

(b)

Figura 4.2 - Deformadas resultantes para o perfil com rótula no eixo-x $\left(\lambda_{x}=85\right)$ : imperfeição global de (a) +L/1000 e (b) -L/1000 - escala ampliada.

No caso dos perfis com a rótula cilíndrica posicionada no eixo-y (Tabela 4.2) os resultados das análises indicam uma influência quase insignificante da variação da imperfeição geométrica global na resistência e nos modos de instabilidade predominantes nos perfis. A Figura 4.3 apresenta, graficamente, os resultados de resistência $\left(\mathrm{N}_{\mathrm{FEM}}\right)$ obtidos nas análises com rótula no eixo-y, onde se pode observar a pouca variação na força de compressão resistente dos perfis quando da variação na magnitude da imperfeição global. 


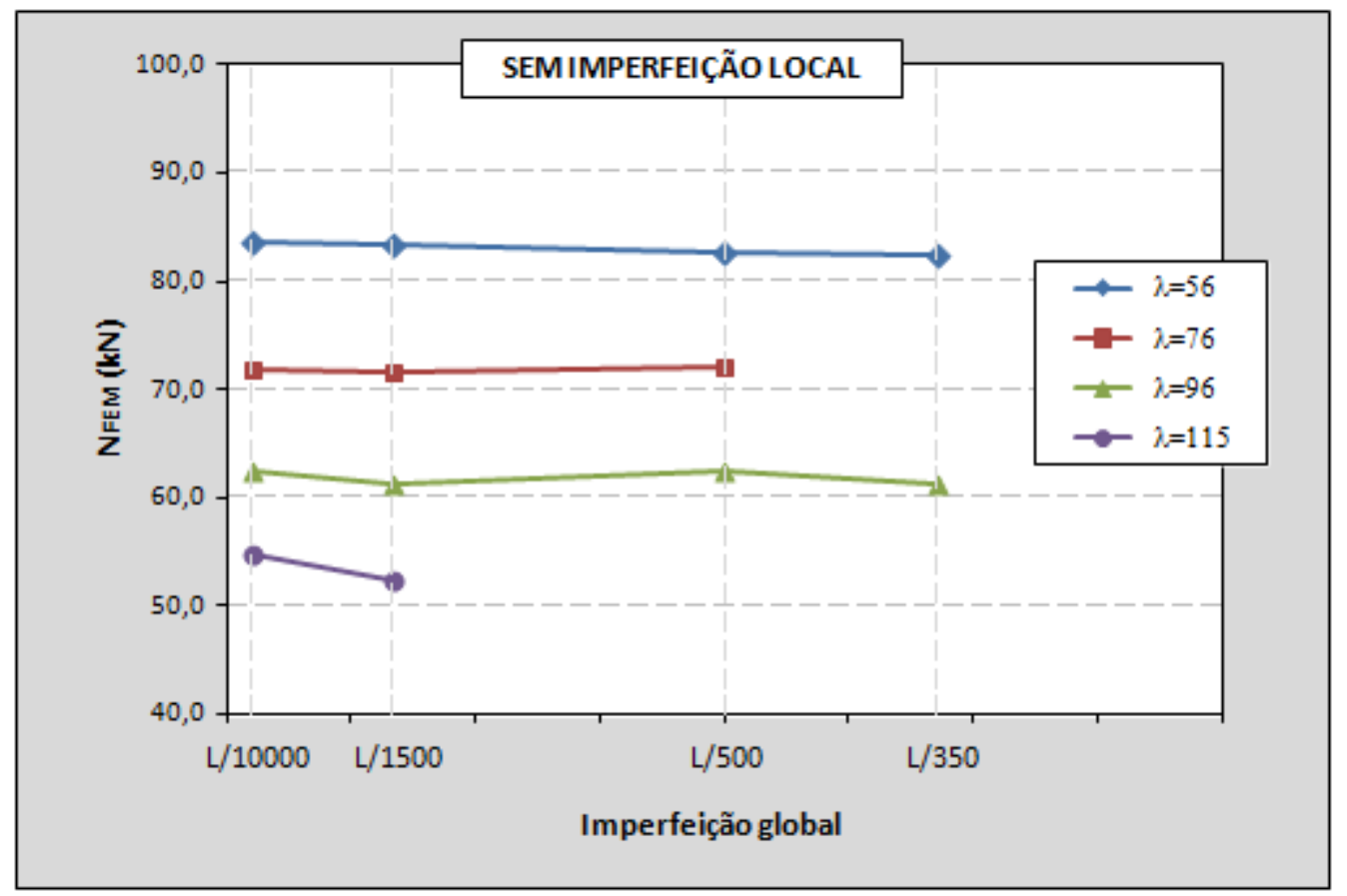

Figura 4.3 - Sensibilidade dos perfis à imperfeição geométrica global - Rótula no eixo-y.

\section{- Imperfeições locais}

Para a seleção das imperfeições geométricas iniciais locais foram testadas duas formas básicas obtidas nas análises elásticas de autovalor, conforme apresentado na Figura 3.16. Em ambas as imperfeições existem ondulações nas chapas ao longo do comprimento do perfil; a única diferença está na associação dessas ondulações localizadas a uma torção global do perfil composto no caso da Figura 3.16b. Para facilitar a citação no texto, as imperfeições locais caracterizadas por apenas ondulações nas chapas (Figura 3.16a) serão aqui denominadas Forma1 e aquelas compostas por ondulações localizadas e torção do conjunto (Figura 3.16b) serão referenciadas como Forma2.

A Tabela 4.3 mostra os resultados de análises de sensibilidade à forma das imperfeições locais realizadas com os perfis dupla cantoneira em questão. Os testes foram realizados nos perfis com índices de esbeltez $\lambda_{x}=85$ e $\lambda_{x}=115$, para o caso de rótula cilíndrica posicionada no eixo-x, e $\lambda_{y}=56$ e $\lambda_{y}=76$ para aqueles com a rótula no eixo-y. Além das referidas imperfeições locais, foram consideradas, ainda, as imperfeições globais iguais a $\pm \mathrm{L} / 1500$ nos modelos numéricos. 
Tabela 4.3 - Compressão centrada: resultados da análise de sensibilidade à forma das imperfeições geométricas iniciais locais.

\begin{tabular}{|c|c|c|c|c|c|c|}
\hline \multicolumn{7}{|c|}{ Perfil 60x60x2,38mm - Rótula cilíndrica no eixo-x } \\
\hline \multirow{2}{*}{$\begin{array}{l}\mathbf{L}_{\text {perfil }} \\
(\mathbf{m m})\end{array}$} & \multirow{2}{*}{$\begin{array}{l}N_{\exp } \\
(k N)\end{array}$} & \multicolumn{4}{|c|}{ ANÁLISE NUMÉRICA } & \multirow{2}{*}{$\begin{array}{c}\mathbf{N}_{\exp } \\
/ \\
\mathbf{N}_{\text {FEM }}\end{array}$} \\
\hline & & $\begin{array}{l}\text { Imperfeições } \\
\text { local e global }\end{array}$ & $\begin{array}{c}\mathbf{N}_{\text {FEM }} \\
(\mathbf{k N})\end{array}$ & $\begin{array}{l}\text { Modo } \\
\text { 2L }\end{array}$ & $\begin{array}{c}\text { Modo } \\
\text { L }\end{array}$ & \\
\hline \multirow{4}{*}{$\begin{array}{c}1485 \\
\left(\lambda_{x}=85\right)\end{array}$} & \multirow{4}{*}{70,0} & 0,64t (Forma2) e +L/1500 & 78,3 & $\mathrm{~F}^{*}+\mathrm{FT}+\mathrm{L}^{*}$ & $\mathrm{FT}^{*}$ & 0,89 \\
\hline & & 0,64t (Forma1) e +L/1500 & 73,6 & $\mathrm{~F}+\mathrm{L}$ & FT & 0,96 \\
\hline & & 0,64t (Forma2) e -L/1500 & 77,7 & $\mathrm{~F}^{*}+\mathrm{FT}+\mathrm{L}^{*}$ & $\mathrm{FT}^{*}$ & 0,90 \\
\hline & & 0,64t (Forma1) e -L/1500 & 72,6 & $F+L$ & FT & 0,96 \\
\hline \multirow{4}{*}{$\begin{array}{c}2055 \\
\left(\lambda_{x}=115\right)\end{array}$} & \multirow{4}{*}{63,0} & 0,64t (Forma2) e +L/1500 & 66,3 & $\mathrm{~F}+\mathrm{FT}^{*}+\mathrm{L}$ & FT & 0,95 \\
\hline & & 0,64t (Forma1) e +L/1500 & 63,0 & $\mathrm{~F}+\mathrm{L}$ & FT & 1,00 \\
\hline & & 0,64t (Forma2) e -L/1500 & 64,2 & $\mathrm{~F}+\mathrm{FT}^{*}+\mathrm{L}$ & FT & 0,98 \\
\hline & & 0,64t (Forma1) e -L/1500 & 61,0 & $\mathrm{~F}+\mathrm{L}$ & FT & 1,03 \\
\hline \multicolumn{7}{|c|}{ Perfil 60x60x2,38mm - Rótula cilíndrica no eixo-y } \\
\hline \multirow{2}{*}{$\begin{array}{c}1355 \\
\left(\lambda_{y}=56\right) \\
\end{array}$} & \multirow{2}{*}{71,0} & 0,64t (Forma2) e +L/1500 & 83,9 & $\mathrm{FT}(\mathrm{T})+\mathrm{L}^{*}$ & $\mathrm{~T}^{*}$ & 0,85 \\
\hline & & 0,64t (Forma1) e +L/1500 & 86,4 & $\mathrm{FT}(\mathrm{T})+\mathrm{L}$ & FT & 0,83 \\
\hline \multirow{2}{*}{$\begin{array}{c}1885 \\
\left(\lambda_{y}=76\right)\end{array}$} & \multirow{2}{*}{63,0} & 0,64t (Forma2) e +L/1500 & 72,2 & $\mathrm{FT}(\mathrm{T})+\mathrm{L}^{*}$ & $\mathrm{~T}^{*}$ & 0,87 \\
\hline & & 0,64t (Forma1) e +L/1500 & 72,3 & $\mathrm{FT}(\mathrm{T})+\mathrm{L}$ & FT & 0,87 \\
\hline \multicolumn{7}{|c|}{$\begin{array}{l}\text { t - espessura das chapas do perfil; } \\
\mathrm{L}_{\text {perfil }} \text { - comprimento do perfil; } \\
\lambda_{y} \text { - índice de esbeltez do perfil; } \\
\mathrm{N}_{\text {exp }} \text { - força de compressão resistente obtida em CHODRAUI (2006); } \\
\mathrm{N}_{\text {FEM }} \text { - força de compressão resistente obtida na análise numérica (ANSYS); } \\
\text { Modo 2L - modo de instabilidade referente ao perfil composto; } \\
\text { Modo L - modo de instabilidade das cantoneiras isoladas entre presilhas; }\end{array}$} \\
\hline
\end{tabular}

Comparando os resultados obtidos nas análises numéricas para a rótula posicionada no eixo-x com os resultados experimentais apresentados em CHODRAUI (2006), nota-se um fato interessante: no que se refere à resistência, a imperfeição local Forma1 resultou numa melhor aproximação entre os resultados numéricos e os experimentais; no entanto, foi com a imperfeição local Forma2 que os perfis apresentaram o modo de colapso por flexo-torção atingido e identificado nos ensaios. No caso dos perfis com a rótula posicionada no eixo-y, a forma das imperfeições locais não acarretou influência significativa nos resultados, nem na resistência e nem no modo de instabilidade resultante, gerando em ambos os casos boa aproximação com os resultados experimentais. 
Apesar de os modelos com a imperfeição local Forma1 terem apresentado resultados de resistência mais próximos dos valores alcançados nos ensaios, decidiu-se adotar a imperfeição local Forma2 nos modelos finais pelo fato de estas descreverem melhor a trajetória de deformações dos perfis com a evolução do carregamento. Além disso, pode-se considerar que os valores de resistência alcançados com esta imperfeição também tiveram boa aproximação com os resultados experimentais.

A Figura 4.4 e a Figura 4.5 mostram configurações deformadas dos perfis resultantes da aplicação das duas formas de imperfeições locais testadas. Como se pode perceber, os resultados revelam uma grande interação entre diferentes modos de instabilidade no momento da perda de capacidade resistente dos perfis, o que gera grande dificuldade para a identificação dos mesmos na estrutura deformada. Porém, essas figuras deixam claro que a escolha pela imperfeição local Forma2 conduziu a modos de instabilidade mais coerentes com os resultados dos ensaios apresentados em CHODRAUI (2006), denominados na referência como modo “local/torcional” (L/T), conforme apresentado no item 2.6.1.

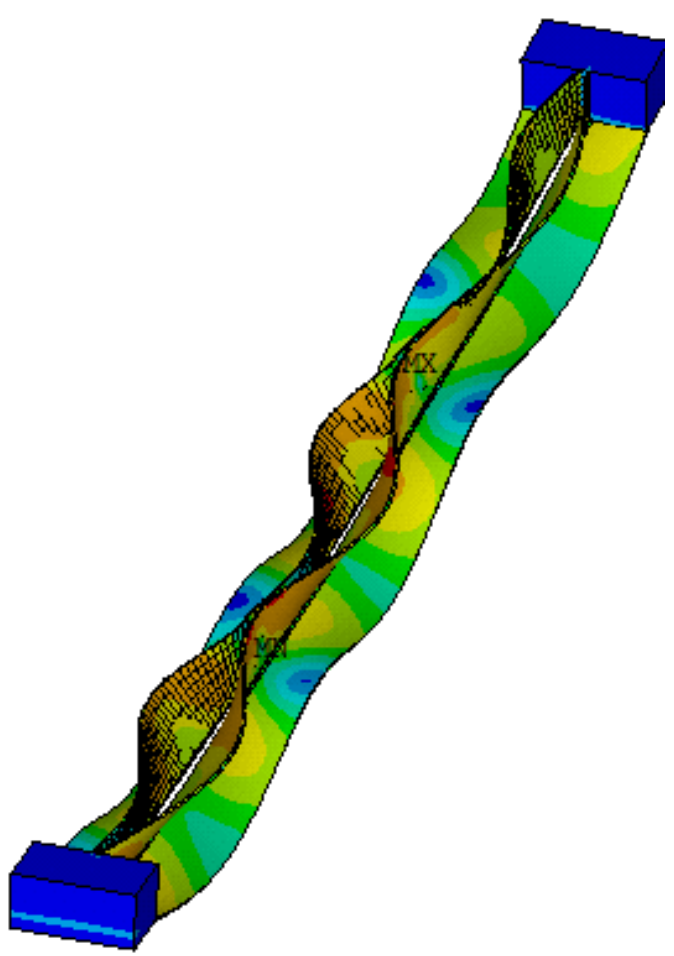

(a)

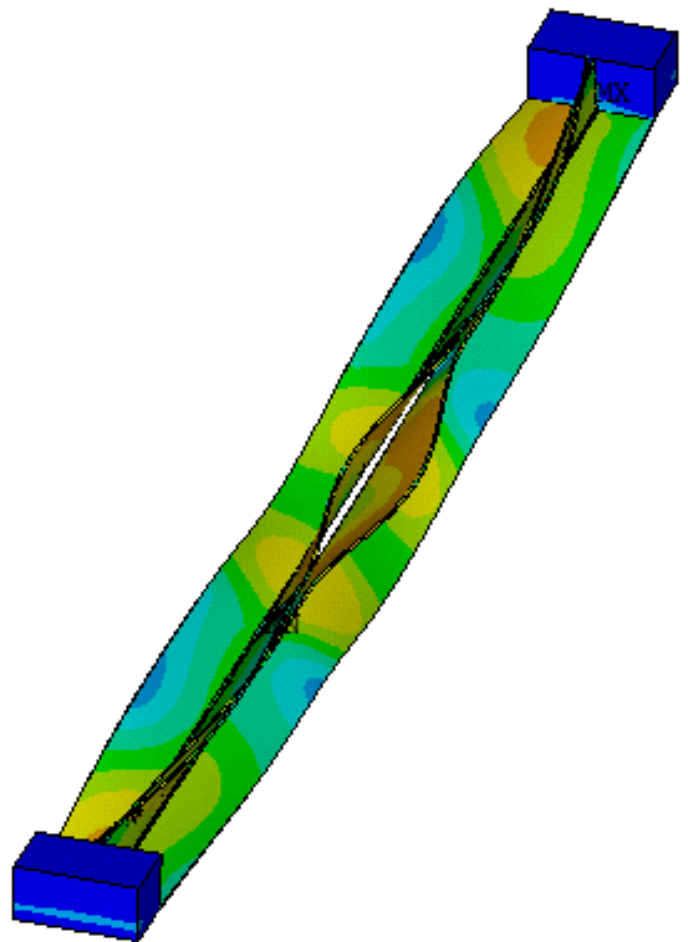

(b)

Figura 4.4 - Deformadas resultantes para o perfil com rótula no eixo-X $\left(\lambda_{x}=85\right)$ : imperfeição local (a) com a Forma1 e (b) com a Forma2 - escala ampliada. 


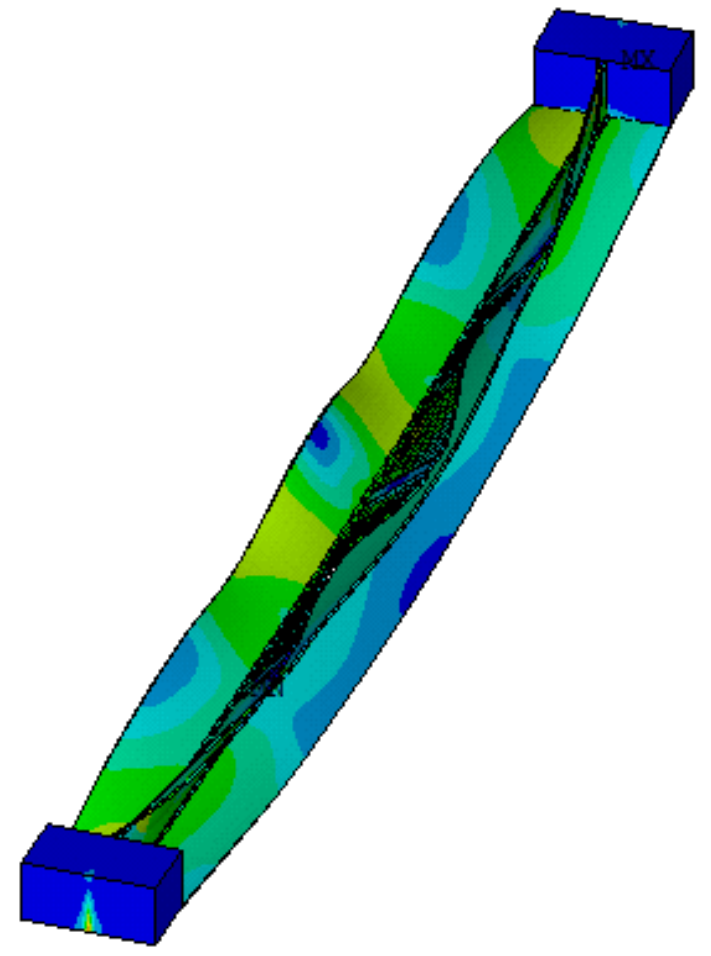

(a)

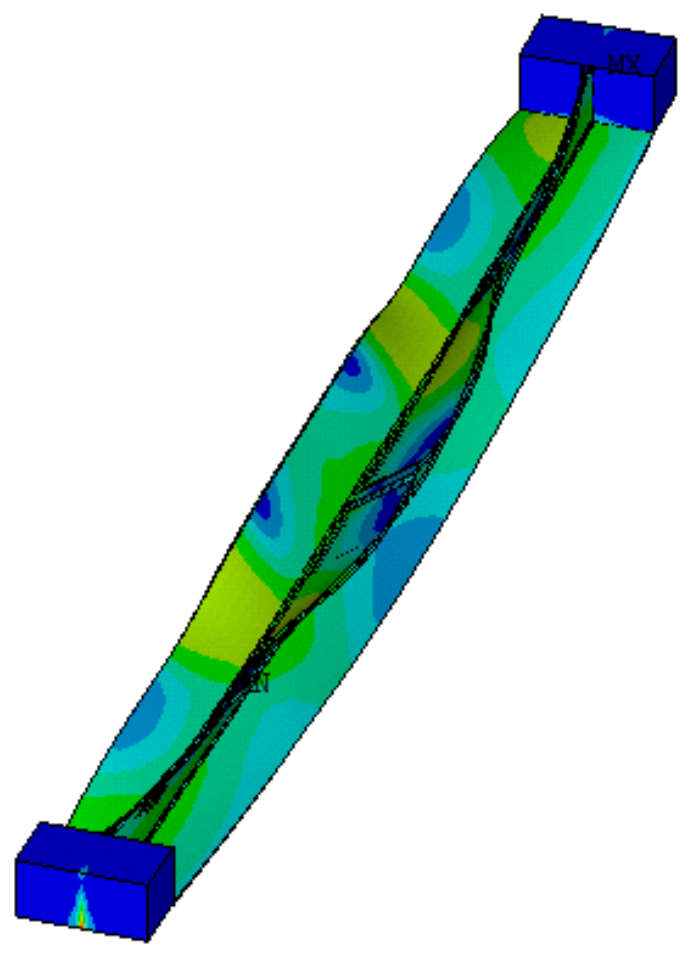

(b)

Figura 4.5 - Deformadas resultantes para o perfil com rótula no eixo-y $\left(\lambda_{y}=56\right)$ : imperfeição local (a) com a Forma1 e (b) com a Forma2 - escala ampliada.

Definida a forma da imperfeição local, passou-se à investigação da sensibilidade dos perfis à variação conjunta da magnitude das imperfeições locais e globais. Para tanto, foram utilizados os valores de imperfeições indicados no Capítulo 3, a saber: 0,64.t e 0,94.t para as imperfeições locais, bem como $\pm \mathrm{L} / 1500$ e $\pm \mathrm{L} / 1000$ para as imperfeições globais. A Tabela 4.4 e a Tabela 4.5 mostram, para modelos com rótula cilíndrica posicionada nos eixos x e y, respectivamente, os resultados das análises numéricas considerando-se tais imperfeições.

Tabela 4.4 - Compressão centrada: resultados da análise de sensibilidade à variação conjunta das imperfeições geométricas iniciais locais e globais - Rótula no eixo-X.

\begin{tabular}{|c|c|c|c|c|c|c|}
\hline \multicolumn{7}{|c|}{ Perfil 60x60x2,38mm - Rótula cilíndrica no eixo-x } \\
\hline \multirow{2}{*}{$\begin{array}{l}\mathbf{L}_{\text {perfil }} \\
(\mathbf{m m})\end{array}$} & \multirow{2}{*}{$\begin{array}{l}N_{\exp } \\
(\mathbf{k N})\end{array}$} & \multicolumn{4}{|c|}{ ANÁLISE NUMÉRICA } & \multirow{2}{*}{$\begin{array}{c}\mathbf{N}_{\text {exp }} \\
/ \\
\mathbf{N}_{\text {FEM }}\end{array}$} \\
\hline & & $\begin{array}{l}\text { Imperfeições } \\
\text { local e global }\end{array}$ & $\begin{array}{c}N_{\text {FEM }} \\
(\mathbf{k N})\end{array}$ & $\begin{array}{l}\text { Modo } \\
\text { 2L }\end{array}$ & $\begin{array}{c}\text { Modo } \\
\text { L }\end{array}$ & \\
\hline \multirow{5}{*}{$\begin{array}{c}910 \\
\left(\lambda_{x}=55\right)\end{array}$} & \multirow{5}{*}{62,0} & $0,64 t \mathrm{e}+\mathrm{L} / 1500$ & 92,0 & $\mathrm{~F}^{*}+\mathrm{T}+\mathrm{L}$ & $\mathrm{T}$ & 0,67 \\
\hline & & $0,64 \mathrm{t}$ e $-\mathrm{L} / 1500$ & 91,6 & $\mathrm{~F}^{*}+\mathrm{T}+\mathrm{L}$ & $\mathrm{T}$ & 0,68 \\
\hline & & $0,94 \mathrm{t} e+\mathrm{L} / 1500$ & 91,3 & $\mathrm{~F}^{*}+\mathrm{T}+\mathrm{L}$ & $\mathrm{T}$ & 0,68 \\
\hline & & $0,94 t$ e $-\mathrm{L} / 1500$ & 90,6 & $\mathrm{~F}^{*}+\mathrm{T}+\mathrm{L}$ & $\mathrm{T}$ & 0,68 \\
\hline & & $0,64 t \mathrm{e}+\mathrm{L} / 1000$ & 92,0 & $\mathrm{~F}^{*}+\mathrm{T}+\mathrm{L}$ & $\mathrm{T}$ & 0,67 \\
\hline
\end{tabular}

continua na próxima página... 
. continuação da Tabela 4.4

\begin{tabular}{|c|c|c|c|c|c|c|}
\hline $\begin{array}{l}\mathbf{L}_{\text {perfil }} \\
(\mathbf{m m})\end{array}$ & $\begin{array}{l}N_{\text {exp }} \\
(\mathbf{k N})\end{array}$ & $\begin{array}{l}\text { Imperfeições } \\
\text { local e global }\end{array}$ & $\begin{array}{c}N_{\text {FEM }} \\
(\mathbf{k N})\end{array}$ & $\begin{array}{l}\text { Modo } \\
\text { 2L }\end{array}$ & $\begin{array}{c}\text { Modo } \\
\text { L }\end{array}$ & $\begin{array}{c}\mathbf{N}_{\text {exp }} \\
/ \\
\mathbf{N}_{\text {FEM }}\end{array}$ \\
\hline \multirow{3}{*}{$\begin{array}{c}910 \\
\left(\lambda_{x}=55\right)\end{array}$} & \multirow{3}{*}{62,0} & $0,64 t$ e -L/1000 & 91,5 & $\mathrm{~F}^{*}+\mathrm{T}+\mathrm{L}$ & $\mathrm{T}$ & 0,68 \\
\hline & & $0,94 \mathrm{t} \mathrm{e}+\mathrm{L} / 1000$ & 91,5 & $\mathrm{~F}^{*}+\mathrm{T}+\mathrm{L}$ & $\mathrm{T}$ & 0,68 \\
\hline & & $0,94 t$ e -L/1000 & 90,4 & $\mathrm{~F}^{*}+\mathrm{T}+\mathrm{L}$ & $\mathrm{T}$ & 0,69 \\
\hline \multirow{8}{*}{$\begin{array}{c}1485 \\
\left(\lambda_{x}=85\right)\end{array}$} & \multirow{8}{*}{70,0} & $0,64 t \mathrm{e}+\mathrm{L} / 1500$ & 78,3 & $\mathrm{~F}^{*}+\mathrm{FT}+\mathrm{L}^{*}$ & FT* & 0,89 \\
\hline & & $0,64 t$ e -L/1500 & 77,7 & $\mathrm{~F}^{*}+\mathrm{FT}+\mathrm{L}^{*}$ & $\mathrm{FT}^{*}$ & 0,90 \\
\hline & & $0,94 \mathrm{t} e+\mathrm{L} / 1500$ & 78,8 & $\mathrm{~F}^{*}+\mathrm{FT}+\mathrm{L}$ & FT & 0,89 \\
\hline & & $0,94 \mathrm{t}$ e -L/1500 & 77,7 & $\mathrm{~F}^{*}+\mathrm{FT}+\mathrm{L}$ & FT & 0,90 \\
\hline & & $0,64 \mathrm{t} e+\mathrm{L} / 1000$ & 78,5 & $\mathrm{~F}^{*}+\mathrm{FT}+\mathrm{L}^{*}$ & $\mathrm{FT}^{*}$ & 0,89 \\
\hline & & $0,64 t$ e -L/1000 & 77,5 & $\mathrm{~F}^{*}+\mathrm{FT}+\mathrm{L}^{*}$ & FT* & 0,90 \\
\hline & & $0,94 \mathrm{t} e+\mathrm{L} / 1000$ & 79,1 & $\mathrm{~F}^{*}+\mathrm{FT}+\mathrm{L}$ & FT & 0,88 \\
\hline & & $0,94 \mathrm{t}$ e $-\mathrm{L} / 1000$ & 77,5 & $\mathrm{~F}^{*}+\mathrm{FT}+\mathrm{L}$ & FT & 0,90 \\
\hline \multirow{8}{*}{$\begin{array}{c}2055 \\
\left(\lambda_{x}=115\right)\end{array}$} & \multirow{8}{*}{63,0} & $0,64 t \mathrm{e}+\mathrm{L} / 1500$ & 666,3 & $\overline{F+F T^{*}+\mathrm{L}}$ & 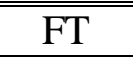 & 0,95 \\
\hline & & $0,64 t$ e -L/1500 & 64,2 & $\mathrm{~F}+\mathrm{FT}^{*}+\mathrm{L}$ & FT & 0,98 \\
\hline & & $0,94 \mathrm{t} \mathrm{e}+\mathrm{L} / 1500$ & 64,9 & $\mathrm{~F}+\mathrm{FT}^{*}+\mathrm{L}$ & FT & 0,97 \\
\hline & & $0,94 t$ e -L/1500 & 62,9 & $\mathrm{~F}+\mathrm{FT}^{*}+\mathrm{L}$ & FT & 1,00 \\
\hline & & $0,64 \mathrm{t} \mathrm{e}+\mathrm{L} / 1000$ & 66,9 & $\mathrm{~F}+\mathrm{FT}^{*}+\mathrm{L}$ & FT & 0,94 \\
\hline & & $0,64 t \mathrm{e}-\mathrm{L} / 1000$ & 63,7 & $\mathrm{~F}+\mathrm{FT}^{*}+\mathrm{L}$ & FT & 0,99 \\
\hline & & $0,94 \mathrm{t} e+\mathrm{L} / 1000$ & 65,3 & $\mathrm{~F}+\mathrm{FT}^{*}+\mathrm{L}$ & FT & 0,96 \\
\hline & & $0,94 \mathrm{t}$ e $-\mathrm{L} / 1000$ & 62,5 & $\mathrm{~F}+\mathrm{FT}^{*}+\mathrm{L}$ & FT & 1,01 \\
\hline \multirow{8}{*}{$\begin{array}{c}2630 \\
\left(\lambda_{x}=145\right)\end{array}$} & \multirow{8}{*}{46,0} & 0 0,64t e +L/1500 & 250,0 & $\overline{F+L^{*}}$ & FT* & 0,92 \\
\hline & & $0,64 t$ e -L/1500 & 48,6 & $\mathrm{~F}+\mathrm{L}^{*}$ & $\mathrm{FT}^{*}$ & 0,95 \\
\hline & & $0,94 \mathrm{t} \mathrm{e}+\mathrm{L} / 1500$ & 50,1 & $\mathrm{~F}+\mathrm{L}^{*}$ & FT* & 0,92 \\
\hline & & $0,94 \mathrm{t}$ e -L/1500 & 48,0 & $\mathrm{~F}+\mathrm{L}^{*}$ & $\mathrm{FT}^{*}$ & 0,96 \\
\hline & & $0,64 \mathrm{t} e+\mathrm{L} / 1000$ & 50,3 & $\mathrm{~F}+\mathrm{L}^{*}$ & FT* $^{*}$ & 0,91 \\
\hline & & $0,64 t$ e -L/1000 & 47,6 & $\mathrm{~F}+\mathrm{L}^{*}$ & FT* & 0,97 \\
\hline & & $0,94 \mathrm{t} \mathrm{e}+\mathrm{L} / 1000$ & 50,3 & $\mathrm{~F}+\mathrm{L}^{*}$ & FT* & 0,91 \\
\hline & & $0,94 \mathrm{t}$ e -L/1000 & 47,1 & $\mathrm{~F}+\mathrm{L}^{*}$ & FT* & 0,98 \\
\hline \multicolumn{7}{|c|}{$\begin{array}{l}\text { - espessura das chapas do perfil; } \\
\mathrm{L}_{\text {perfil }} \text { - comprimento do perfil; } \\
\lambda_{x} \text { - índice de esbeltez do perfil; } \\
\mathrm{N}_{\text {exp }} \text { - força de compressão resistente obtida em CHODRAUI (2006); } \\
\mathrm{N}_{\text {FEM }- \text { força de compressão resistente obtida na análise numérica (ANSYS); }} \text { Modo 2L - modo de instabilidade referente ao perfil composto; } \\
\text { Modo L - modo de instabilidade das cantoneiras isoladas entre presilhas; } \\
\\
\text { F = instabilidade global por flexão em torno do eixo-x (de menor inércia); } \\
\mathrm{T} \text { = instabilidade global por torção; } \\
\text { FT = instabilidade global por flexo-torção; } \\
\text { L = instabilidade local (de chapa); } \\
\text { * Modo de instabilidade pouco pronunciado; } \\
\text { NC = análise via MEF não convergiu. }\end{array}$} \\
\hline
\end{tabular}


Tabela 4.5 - Compressão centrada: resultados da análise de sensibilidade à variação conjunta das imperfeições geométricas iniciais locais e globais - Rótula no eixo-y.

\begin{tabular}{|c|c|c|c|c|c|c|}
\hline \multicolumn{7}{|c|}{ Perfil 60x60x2,38mm - Rótula cilíndrica no eixo-y } \\
\hline \multirow{2}{*}{$\begin{array}{l}\mathbf{L}_{\text {perfil }} \\
(\mathbf{m m})\end{array}$} & \multirow{2}{*}{$\begin{array}{l}\mathbf{N}_{\exp } \\
(\mathbf{k N})\end{array}$} & \multicolumn{4}{|c|}{ ANÁLISE NUMÉRICA } & \multirow{2}{*}{$\begin{array}{c}\mathbf{N}_{\text {exp }} \\
/ / \\
\mathbf{N}_{\text {FEM }}\end{array}$} \\
\hline & & $\begin{array}{l}\text { Imperfeições } \\
\text { local e global }\end{array}$ & $\begin{array}{c}\mathbf{N}_{\text {FEM }} \\
(\mathbf{k N})\end{array}$ & $\begin{array}{l}\text { Modo } \\
\text { 2L }\end{array}$ & $\begin{array}{c}\text { Modo } \\
\text { L }\end{array}$ & \\
\hline \multirow{4}{*}{$\begin{array}{c}1355 \\
\left(\lambda_{y}=56\right)\end{array}$} & \multirow{4}{*}{71,0} & $0,64 t \mathrm{e}+\mathrm{L} / 1500$ & 83,9 & $\mathrm{FT}(\mathrm{T})+\mathrm{L}^{*}$ & $\mathrm{~T}^{*}$ & 0,85 \\
\hline & & $0,94 \mathrm{t} \mathrm{e}+\mathrm{L} / 1500$ & 84,2 & $\mathrm{FT}(\mathrm{T})+\mathrm{L}^{*}$ & $\mathrm{~T}^{*}$ & 0,84 \\
\hline & & $0,64 \mathrm{t} e+\mathrm{L} / 1000$ & 83,7 & $\mathrm{FT}(\mathrm{T})+\mathrm{L}^{*}$ & $\mathrm{~T}^{*}$ & 0,85 \\
\hline & & $0,94 \mathrm{t} \mathrm{e}+\mathrm{L} / 1000$ & 84,0 & $\mathrm{FT}(\mathrm{T})+\mathrm{L}^{*}$ & $\mathrm{~T}^{*}$ & 0,85 \\
\hline \multirow{4}{*}{$\begin{array}{c}1885 \\
\left(\lambda_{y}=76\right)\end{array}$} & \multirow{4}{*}{63,0} & $0,64 \mathrm{t}$ e $+\mathrm{L} / 1500$ & 72,2 & $\overline{\mathrm{FT}}(\mathrm{T})+\mathrm{L}^{*}$ & $\mathrm{~T}^{*}$ & 0,87 \\
\hline & & $0,94 \mathrm{t} e+\mathrm{L} / 1500$ & 72,1 & $\mathrm{FT}(\mathrm{T})+\mathrm{L}^{*}$ & $\mathrm{~T}^{*}$ & 0,87 \\
\hline & & $0,64 \mathrm{t}$ e $+\mathrm{L} / 1000$ & 71,8 & $\mathrm{FT}(\mathrm{T})+\mathrm{L}^{*}$ & $\mathrm{~T}^{*}$ & 0,88 \\
\hline & & $0,94 \mathrm{t} e+\mathrm{L} / 1000$ & 71,6 & $\mathrm{FT}(\mathrm{T})+\mathrm{L}^{*}$ & $\mathrm{~T}^{*}$ & 0,88 \\
\hline \multirow{4}{*}{$\begin{array}{c}2415 \\
\left(\lambda_{y}=96\right)\end{array}$} & \multirow{4}{*}{53,0} & $0,64 \mathrm{t} e+\mathrm{L} / 1500$ & 62,1 & FT $+\mathrm{L}^{*}$ & $\mathrm{~T}^{*}$ & 0,85 \\
\hline & & $0,94 \mathrm{t} \mathrm{e}+\mathrm{L} / 1500$ & 62,3 & $\mathrm{FT}+\mathrm{L}^{*}$ & $\mathrm{~T}^{*}$ & 0,85 \\
\hline & & $0,64 t \mathrm{e}+\mathrm{L} / 1000$ & 61,9 & $\mathrm{FT}+\mathrm{L}^{*}$ & $\mathrm{~T}^{*}$ & 0,86 \\
\hline & & $0,94 \mathrm{t} e+\mathrm{L} / 1000$ & 62,1 & $\mathrm{FT}+\mathrm{L}^{*}$ & $\mathrm{~T}^{*}$ & 0,85 \\
\hline \multirow{4}{*}{$\begin{array}{c}2925 \\
\left(\lambda_{y}=115\right)\end{array}$} & \multirow{4}{*}{48,0} & $0,64 t \mathrm{e}+\mathrm{L} / 1500$ & 52,1 & FT & $\overline{\mathrm{T}^{*}}$ & 0,92 \\
\hline & & $0,94 \mathrm{t} \mathrm{e}+\mathrm{L} / 1500$ & 52,1 & FT & $\mathrm{T}^{*}$ & 0,92 \\
\hline & & $0,64 \mathrm{t} \mathrm{e}+\mathrm{L} / 1000$ & 52,2 & FT & $\mathrm{T}^{*}$ & 0,92 \\
\hline & & $0,94 \mathrm{t} e+\mathrm{L} / 1000$ & 52,3 & FT & $\mathrm{T}^{*}$ & 0,92 \\
\hline \multicolumn{7}{|c|}{$\begin{array}{l}\text { t - espessura das chapas do perfil; } \\
\mathrm{L}_{\text {perfil }} \text { - comprimento do perfil; } \\
\lambda_{y} \text { - índice de esbeltez do perfil; } \\
\mathrm{N}_{\text {exp }} \text { - força de compressão resistente obtida em CHODRAUI (2006); } \\
\mathrm{N}_{\text {FEM }} \text { - força de compressão resistente obtida na análise numérica (ANSYS); } \\
\text { Modo 2L - modo de instabilidade referente ao perfil composto; } \\
\text { Modo L - modo de instabilidade das cantoneiras isoladas entre presilhas; } \\
\text { F = instabilidade global por flexão em torno do eixo-x (de menor inércia); } \\
\mathrm{T}=\text { instabilidade global por torção; } \\
\text { FT = instabilidade global por flexo-torção; } \\
\text { FT(T) = instabilidade global por flexo-torção com predominância de torção; } \\
\mathrm{L}=\text { instabilidade local (de chapa); } \\
\text { * Modo de instabilidade pouco pronunciado; } \\
\text { NC = análise via MEF não convergiu. }\end{array}$} \\
\hline
\end{tabular}

Para melhor visualizar os efeitos da variação da magnitude das imperfeições locais e globais no comportamento dos perfis, são apresentados na Figura 4.6 e na Figura 4.7 gráficos com os resultados de resistência ( $\mathrm{N}_{\mathrm{FEM}}$ ) em função das imperfeições para os modelos com rótula cilíndrica no eixo-X. As variações um pouco mais pronunciadas nas curvas referentes aos perfis com índices de esbeltez $\lambda=115$ e $\lambda=145$ (comprimentos iguais a 2055mm e $2630 \mathrm{~mm}$ ) revelam, novamente, a maior sensibilidade dos perfis mais esbeltos às imperfeições globais quando comparados com os menos esbeltos (índices de esbeltez $\lambda=55$ e $\lambda=85-$ comprimentos iguais a $910 \mathrm{~mm}$ e $1485 \mathrm{~mm}$ ), embora as diferenças nos resultados não tenham 
sido tão significantes. Os modos de instabilidade, porém, se mantiveram os mesmos para todos os valores de imperfeição global adotados.

Quanto às imperfeições locais, poucas diferenças devidas à variação de sua magnitude $(0,64 t$ e $0,94 t)$ foram notadas nos resultados de resistência dos perfis. Da mesma forma, também os modos de instabilidade referentes ao colapso não foram alterados por essa variação nas imperfeições locais, conforme observado na Tabela 4.4.

Também no caso dos perfis modelados com a rótula cilíndrica no eixo-y, os resultados apresentados na Tabela 4.5 mostram que tanto a resistência quanto os modos de instabilidade resultantes praticamente não se alteram com a variação da magnitude das imperfeições locais e globais adotadas.

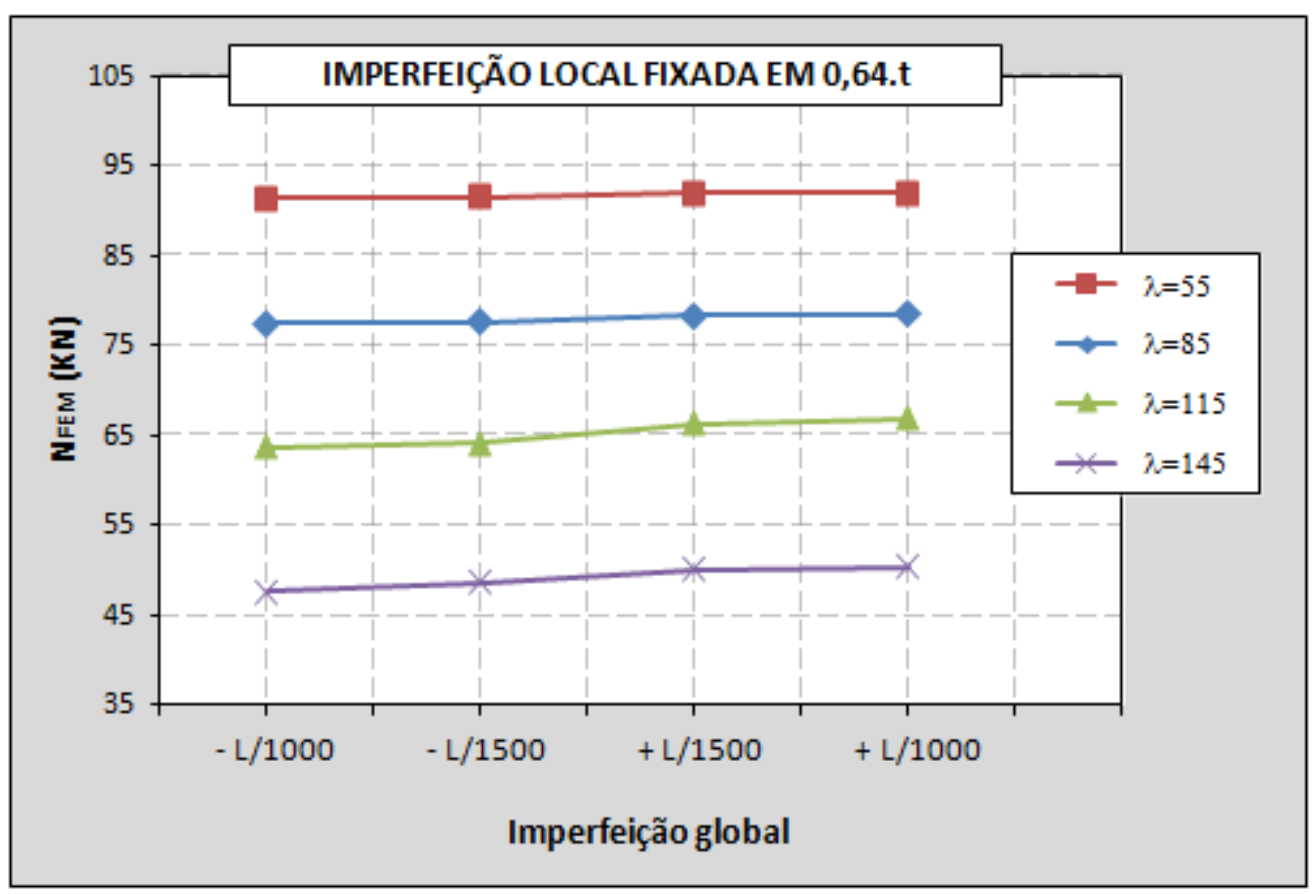

Figura 4.6 - Sensibilidade dos perfis às imperfeições geométricas iniciais locais $(\mathbf{0 , 6 4 t )}$ e globais $( \pm \mathrm{L} / 1500$ e $\pm \mathrm{L} / 1000)$ - Rótula no eixo-X. 


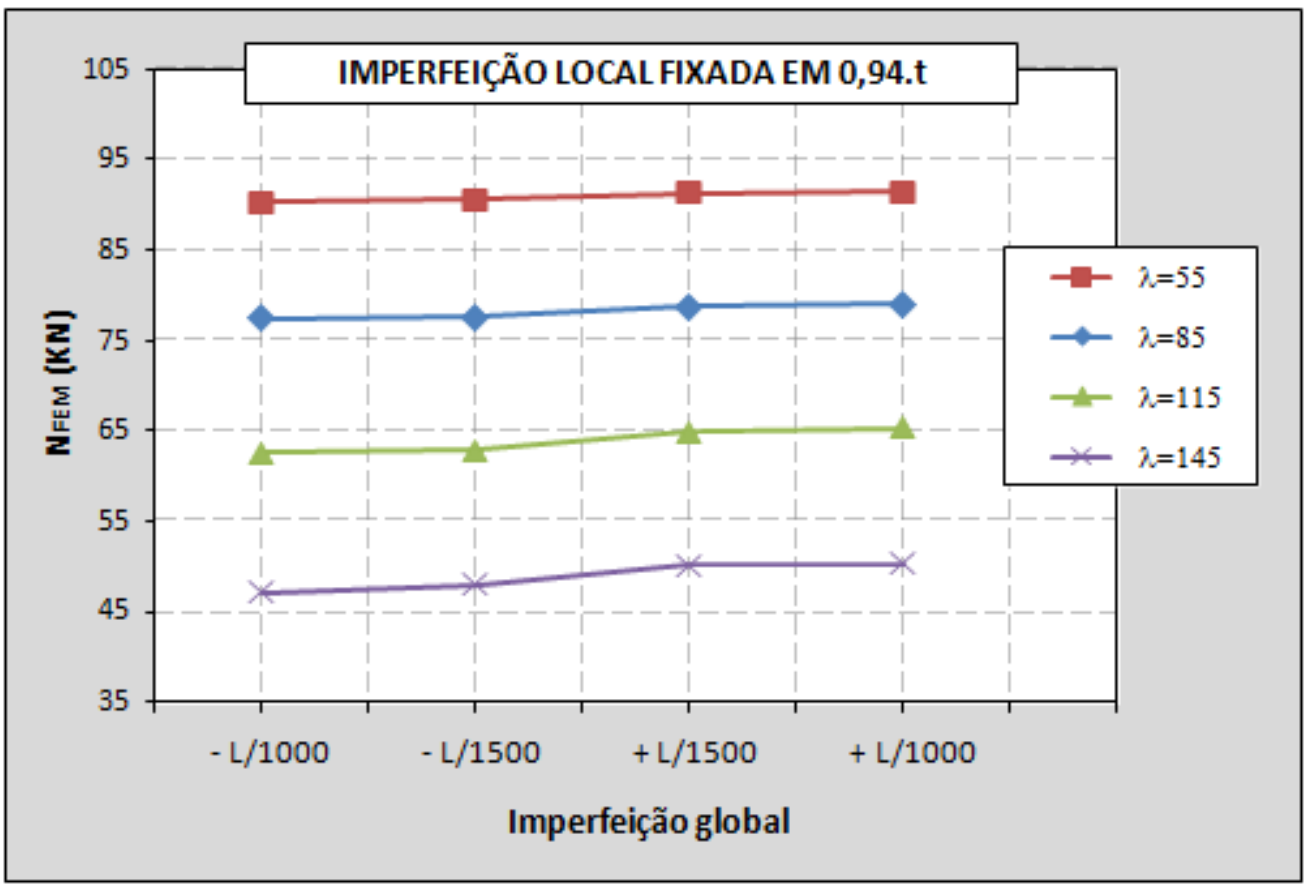

Figura 4.7 - Sensibilidade dos perfis às imperfeições geométricas iniciais locais $(\mathbf{0 , 9 4 t )}$ e globais $( \pm \mathrm{L} / 1500$ e $\pm \mathrm{L} / 1000)$ - Rótula no eixo-X.

\section{- Considerações finais a respeito da análise de sensibilidade}

Em resumo, com base nos resultados obtidos na análise de sensibilidade às imperfeições geométricas iniciais locais e globais combinadas (Tabela 4.3, Tabela 4.4 e Tabela 4.5), foi possível observar que para perfis cujos vínculos permitem apenas a rotação em torno do eixo de menor inércia da seção (rótula cilíndrica no eixo-x):

$\checkmark$ Forma das imperfeições locais - considerável influência tanto na resistência quanto nos modos de instabilidade dos perfis, principalmente nos casos de perfis mais esbeltos;

$\checkmark$ Magnitude das imperfeições locais - pouca influência na resistência e nos modos de instabilidade dos perfis, independentemente da esbeltez da barra;

$\checkmark$ Forma (Sinal) da imperfeição global - quando combinada às imperfeições locais, exercem pouca influência nos modos de instabilidade dos perfis. Quanto à resistência, apenas os perfis mais esbeltos apresentam variações consideráveis, resultando em valores de resistência menores nos casos de sinal negativo;

$\checkmark$ Magnitude da imperfeição global - quando empregada com valores normalmente utilizados em análises numéricas e combinada às imperfeições locais, exercem influência desprezível na resistência e nos modos de colapso dos perfis. 
No caso de perfis com vínculos que permitem apenas a rotação em torno do eixo de maior inércia da seção (rótula cilíndrica no eixo-y), os resultados das análises numéricas indicam que as imperfeições geométricas iniciais locais e globais praticamente não influenciam a resistência e os modos de instabilidade referentes ao colapso dos perfis em estudo. Tal constatação pode ser de grande valia para fins de projeto, uma vez que a configuração da ligação pode tornar esse tipo de perfil mais ou menos sensível às imperfeições geométricas iniciais, o que afeta a diretamente a confiabilidade do modelo e, conseqüentemente, o esforço de compressão resistente de cálculo.

Comparando os resultados obtidos nas análises numéricas com aqueles alcançados nos ensaios experimentais apresentados em CHODRAUI (2006), conclui-se também que as imperfeições que melhor descreveram o comportamento dos perfis dupla cantoneira aqui estudados, considerando a resistência e os modos de colapso, foram: imperfeição global com sinal negativo (Figura 3.14b ou Figura 3.15) associada a uma imperfeição local que contenha ondulações nas chapas das cantoneiras e uma torção global do perfil composto (semelhante à Figura 3.16b). Para a magnitude, podem ser tomados os tradicionais valores de L/1000 ou L/1500, para a imperfeição global, e os mesmos valores aqui utilizados para a imperfeição local $(0,64 . t$ ou $0,94 . t)$.

\subsubsection{Modelos finais: comparação com resultados teóricos e experimentais}

Com base na análise de sensibilidade, foram selecionadas as imperfeições geométricas iniciais que melhor se adequaram ao problema em questão e inseridas nos modelos finais, cujos resultados foram transcritos para a Tabela 4.6 e para a Tabela 4.7. A idéia é comparar resultados das análises numéricas e de ensaios experimentais com aqueles obtidos por meio de procedimentos normativos, em especial os da ABNT NBR 14762:2010, de forma a verificar se os valores de força de compressão resistente previstos nas normas resultam, de fato, coerentes para esse tipo de perfil. 
Tabela 4.6 - Modelos finais: resultados das análises numéricas e comparação com ensaios experimentais e previsões normativas - Rótula no eixo-X.

\begin{tabular}{|c|c|c|c|c|c|c|c|c|}
\hline \multicolumn{9}{|c|}{ Perfil 60x60x2,38mm - Rótula cilíndrica no eixo-x } \\
\hline \multirow[b]{2}{*}{$\begin{array}{l}\mathbf{L}_{\text {perfil }} \\
(\mathbf{m m})\end{array}$} & \multirow[b]{2}{*}{$\begin{array}{c}\mathbf{N}_{\mathbf{n}, \mathrm{NBR}} \\
(\mathbf{k N})\end{array}$} & \multirow[b]{2}{*}{$\begin{array}{l}N_{\text {exp }} \\
(\mathbf{k N})\end{array}$} & \multicolumn{4}{|c|}{ ANÁLISE NUMÉRICA } & \multirow{2}{*}{$\begin{array}{c}\mathbf{N}_{\mathbf{n}, \mathrm{NBR}} \\
/ \\
\mathbf{N}_{\text {FEM }}\end{array}$} & \multirow{2}{*}{$\begin{array}{c}\mathbf{N}_{\text {exp }} \\
/ \\
\mathbf{N}_{\text {FEM }} \\
\end{array}$} \\
\hline & & & $\begin{array}{l}\text { Imperfeições } \\
\text { local e global }\end{array}$ & $\begin{array}{l}\mathbf{N}_{\text {FEM }} \\
(\mathbf{k N})\end{array}$ & $\begin{array}{l}\text { Modo } \\
\text { 2L }\end{array}$ & $\begin{array}{c}\text { Modo } \\
\text { L }\end{array}$ & & \\
\hline \multirow{4}{*}{$\begin{array}{c}910 \\
\left(\lambda_{x}=55\right)\end{array}$} & \multirow{4}{*}{48,5} & \multirow{4}{*}{62,0} & $0,64 t$ e $-\mathrm{L} / 1500$ & 91,6 & $\mathrm{~F}^{*}+\mathrm{T}+\mathrm{L}$ & $\mathrm{T}$ & 0,53 & 0,68 \\
\hline & & & $0,94 t$ e $-\mathrm{L} / 1500$ & 90,6 & $\mathrm{~F}^{*}+\mathrm{T}+\mathrm{L}$ & $\mathrm{T}$ & 0,54 & 0,68 \\
\hline & & & $0,64 t$ e $-\mathrm{L} / 1000$ & 91,5 & $\mathrm{~F}^{*}+\mathrm{T}+\mathrm{L}$ & $\mathrm{T}$ & 0,53 & 0,68 \\
\hline & & & $0,94 \mathrm{t}$ e -L/1000 & 90,4 & $\mathrm{~F}^{*}+\mathrm{T}+\mathrm{L}$ & $\mathrm{T}$ & 0,54 & 0,69 \\
\hline \multirow{4}{*}{$\begin{array}{c}1485 \\
\left(\lambda_{x}=85\right)\end{array}$} & \multirow{4}{*}{48,3} & \multirow{4}{*}{70,0} & $0,64 t$ e -L/1500 & 77,7 & $\mathrm{~F}^{*}+\mathrm{FT}+\mathrm{L}^{*}$ & 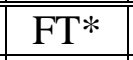 & 0,62 & 0,90 \\
\hline & & & $0,94 t$ e -L/1500 & 77,7 & $\mathrm{~F}^{*}+\mathrm{FT}+\mathrm{L}$ & FT & 0,62 & 0,90 \\
\hline & & & $0,64 t$ e -L/1000 & 77,5 & $\mathrm{~F}^{*}+\mathrm{FT}+\mathrm{L}^{*}$ & $\mathrm{FT}^{*}$ & 0,62 & 0,90 \\
\hline & & & $0,94 \mathrm{t}$ e $-\mathrm{L} / 1000$ & 77,5 & $\mathrm{~F}^{*}+\mathrm{FT}+\mathrm{L}$ & FT & 0,62 & 0,90 \\
\hline \multirow{4}{*}{$\begin{array}{c}2055 \\
\left(\lambda_{x}=115\right)\end{array}$} & \multirow{4}{*}{48,1} & \multirow{4}{*}{63,0} & "0,64t e -L/1500 & 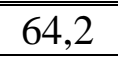 & $\bar{F}+\mathrm{FT}^{*}+\mathrm{L}$ & $\overline{\text { FT }}$ & 0,75 & 0,98 \\
\hline & & & $0,94 \mathrm{t}$ e -L/1500 & 62,9 & $\mathrm{~F}+\mathrm{FT}^{*}+\mathrm{L}$ & FT & 0,76 & 1,00 \\
\hline & & & $0,64 t$ e -L/1000 & 63,7 & $\mathrm{~F}+\mathrm{FT}^{*}+\mathrm{L}$ & FT & 0,76 & 0,99 \\
\hline & & & $0,94 \mathrm{t}$ e -L/1000 & 62,5 & $\mathrm{~F}+\mathrm{FT}^{*}+\mathrm{L}$ & $\mathrm{FT}$ & 0,77 & 1,01 \\
\hline \multirow{4}{*}{$\begin{array}{c}2630 \\
\left(\lambda_{x}=145\right)\end{array}$} & \multirow{4}{*}{42,6} & \multirow{4}{*}{46,0} & $0,64 t$ e -L/1500 & 48,6 & $\overline{F+L^{*}}$ & "FT* & 0,88 & 0,95 \\
\hline & & & $0,94 t$ e -L/1500 & 48,0 & $\mathrm{~F}+\mathrm{L}^{*}$ & $\mathrm{FT}^{*}$ & 0,89 & 0,96 \\
\hline & & & $0,64 t$ e -L/1000 & 47,6 & $\mathrm{~F}+\mathrm{L}^{*}$ & FT* & 0,89 & 0,97 \\
\hline & & & $0,94 \mathrm{t}$ e -L/1000 & 47,1 & $\mathrm{~F}+\mathrm{L}^{*}$ & FT* & 0,90 & 0,98 \\
\hline \multicolumn{9}{|c|}{$\begin{array}{l}\mathrm{t} \text { - espessura das chapas do perfil; } \\
\mathrm{L}_{\text {perfil }} \text { - comprimento do perfil; }\end{array}$} \\
\hline \multicolumn{9}{|c|}{$\begin{array}{l}\text { F = instabilidade global por flexão em torno do } \\
\text { T = instabilidade global por torção; } \\
\text { FT = instabilidade global por flexo-torção; } \\
\text { L = instabilidade local (de chapa); } \\
\text { * Modo de instabilidade pouco pronunciado; } \\
\text { NC = análise via MEF não convergiu. }\end{array}$} \\
\hline
\end{tabular}


Tabela 4.7 - Modelos finais: resultados das análises numéricas e comparação com ensaios experimentais e previsões normativas - Rótula no eixo-y.

\begin{tabular}{|c|c|c|c|c|c|c|c|c|}
\hline \multicolumn{9}{|c|}{ Perfil 60x60x2,38mm - Rótula cilíndrica no eixo-y } \\
\hline \multirow{2}{*}{$\begin{array}{l}\mathbf{L}_{\text {perfil }} \\
(\mathbf{m m})\end{array}$} & \multirow{2}{*}{$\begin{array}{c}\mathbf{N}_{\mathbf{n}, \mathrm{NBR}} \\
(\mathbf{k N})\end{array}$} & \multirow{2}{*}{$\begin{array}{l}N_{\text {exp }} \\
(k N)\end{array}$} & \multicolumn{4}{|c|}{ ANÁLISE NUMÉRICA } & \multirow{2}{*}{$\begin{array}{c}\mathbf{N}_{\mathbf{n}, \mathrm{NBR}} \\
/ \\
\mathbf{N}_{\text {FEM }}\end{array}$} & \multirow{2}{*}{$\begin{array}{c}\mathbf{N}_{\text {exp }} \\
/ \\
\mathbf{N}_{\text {FEM }}\end{array}$} \\
\hline & & & $\begin{array}{l}\text { Imperfeições } \\
\text { local e global }\end{array}$ & $\begin{array}{l}\mathbf{N}_{\text {FEM }} \\
(\mathbf{k N})\end{array}$ & $\begin{array}{l}\text { Modo } \\
\text { 2L }\end{array}$ & $\begin{array}{c}\text { Modo } \\
\text { L }\end{array}$ & & \\
\hline \multirow{4}{*}{$\begin{array}{c}1355 \\
\left(\lambda_{y}=56\right)\end{array}$} & \multirow{4}{*}{47,5} & \multirow{4}{*}{71,0} & $0,64 t \mathrm{e}+\mathrm{L} / 1500$ & 83,9 & $\mathrm{FT}(\mathrm{T})+\mathrm{L}^{*}$ & $\mathrm{~T}^{*}$ & 0,57 & 0,85 \\
\hline & & & $0,94 \mathrm{t}$ e $+\mathrm{L} / 1500$ & 84,2 & $\mathrm{FT}(\mathrm{T})+\mathrm{L}^{*}$ & $\mathrm{~T}^{*}$ & 0,56 & 0,84 \\
\hline & & & $0,64 t \mathrm{e}+\mathrm{L} / 1000$ & 83,7 & $\mathrm{FT}(\mathrm{T})+\mathrm{L}^{*}$ & $\mathrm{~T}^{*}$ & 0,57 & 0,85 \\
\hline & & & $0,94 \mathrm{t}$ e $+\mathrm{L} / 1000$ & 84,0 & $\mathrm{FT}(\mathrm{T})+\mathrm{L}^{*}$ & $\mathrm{~T}^{*}$ & 0,57 & 0,85 \\
\hline \multirow{4}{*}{$\begin{array}{c}1885 \\
\left(\lambda_{y}=76\right)\end{array}$} & \multirow{4}{*}{46,2} & \multirow{4}{*}{63,0} & $0,64 \mathrm{t}$ e $+\mathrm{L} / 1500$ & 72,2 & FT(T) $+\mathrm{L}^{*}$ & T* & 0,64 & 0,87 \\
\hline & & & $0,94 \mathrm{t}$ e $+\mathrm{L} / 1500$ & 72,1 & $\mathrm{FT}(\mathrm{T})+\mathrm{L}^{*}$ & $\mathrm{~T}^{*}$ & 0,64 & 0,87 \\
\hline & & & $0,64 \mathrm{t} \mathrm{e}+\mathrm{L} / 1000$ & 71,8 & $\mathrm{FT}(\mathrm{T})+\mathrm{L}^{*}$ & $\mathrm{~T}^{*}$ & 0,64 & 0,88 \\
\hline & & & $0,94 \mathrm{t}$ e $+\mathrm{L} / 1000$ & 71,6 & $\mathrm{FT}(\mathrm{T})+\mathrm{L}^{*}$ & $\mathrm{~T}^{*}$ & 0,65 & 0,88 \\
\hline \multirow{4}{*}{$\begin{array}{c}2415 \\
\left(\lambda_{y}=96\right)\end{array}$} & \multirow{4}{*}{44,2} & \multirow{4}{*}{53,0} & $0,64 \mathrm{t}$ e $+\mathrm{L} / 1500$ & 62,1 & $\overline{\mathrm{FT}+\mathrm{L}^{*}}$ & T* & 0,71 & 0,85 \\
\hline & & & $0,94 \mathrm{t}$ e $+\mathrm{L} / 1500$ & 62,3 & $\mathrm{FT}+\mathrm{L}^{*}$ & $\mathrm{~T}^{*}$ & 0,71 & 0,85 \\
\hline & & & $0,64 \mathrm{t} \mathrm{e}+\mathrm{L} / 1000$ & 61,9 & $\mathrm{FT}+\mathrm{L}^{*}$ & $\mathrm{~T}^{*}$ & 0,71 & 0,86 \\
\hline & & & $0,94 \mathrm{t} \mathrm{e}+\mathrm{L} / 1000$ & 62,1 & $\mathrm{FT}+\mathrm{L}^{*}$ & $\mathrm{~T}^{*}$ & 0,71 & 0,85 \\
\hline \multirow{4}{*}{$\begin{array}{c}2925 \\
\left(\lambda_{y}=115\right)\end{array}$} & \multirow{4}{*}{41,3} & \multirow{4}{*}{48,0} & $0,64 \mathrm{t}$ e $+\mathrm{L} / 1500$ & 252,1 & FT & $\overline{\mathrm{T}^{*}}$ & 0,79 & 0,92 \\
\hline & & & $0,94 \mathrm{t}$ e $+\mathrm{L} / 1500$ & 52,1 & FT & $\mathrm{T}^{*}$ & 0,79 & 0,92 \\
\hline & & & $0,64 t \mathrm{e}+\mathrm{L} / 1000$ & 52,2 & FT & $\mathrm{T}^{*}$ & 0,79 & 0,92 \\
\hline & & & $0,94 \mathrm{t}$ e $+\mathrm{L} / 1000$ & 52,3 & FT & $\mathrm{T}^{*}$ & 0,79 & 0,92 \\
\hline \multicolumn{9}{|c|}{$\begin{array}{l}\mathrm{t} \text { - espessura das chapas do perfil; } \\
\mathrm{L}_{\text {perfil }} \text { - comprimento do perfil; }\end{array}$} \\
\hline $\begin{array}{l}\mathrm{F}=\text { instabi } \\
\mathrm{T}=\text { instabi } \\
\mathrm{FT}=\text { insta } \\
\mathrm{FT}(\mathrm{T})=\text { in } \\
\mathrm{L}=\text { instabi } \\
\text { * Modo de } \\
\text { NC = anál }\end{array}$ & $\begin{array}{l}\text { lidade glob } \\
\text { lidade glot } \\
\text { bilidade gl } \\
\text { stabilidade } \\
\text { lidade loca } \\
\text { instabilide } \\
\text { ise via ME }\end{array}$ & $\begin{array}{l}\text { al por } \mathrm{f} \\
\text { al por } \mathrm{t} \\
\text { bal por } \\
\text { global } \\
\text { l (de ch } \\
\text { de pouc }\end{array}$ & $\begin{array}{l}\text { zão em torno do eixo- } \\
\text { ção; } \\
\text { exo-torção; } \\
\text { r flexo-torção com pr } \\
\text { a); } \\
\text { pronunciado; } \\
\text { fergiu. }\end{array}$ & de menor & $\begin{array}{l}\text { ércia); } \\
\text { e torção; }\end{array}$ & & & \\
\hline
\end{tabular}

Para melhor entendimento dos modos de instabilidade resultantes das análises numéricas e descritos nas tabelas anteriores, são apresentadas, da Figura 4.8 à Figura 4.15, as configurações deformadas dos perfis no instante em que ocorre a perda de sua capacidade resistente. Além das deformações, as referidas figuras mostram ainda a distribuição de tensões equivalentes (von Mises) nas chapas dos perfis.

Conforme se pode perceber, a identificação dos modos de instabilidade predominantes neste tipo de perfil não é uma tarefa simples. A grande interação entre diferentes modos de 
instabilidade resulta muitas das vezes em estados de deformação complexos, principalmente nesses casos em que os perfis são compostos por dois ou mais elementos conectados entre si por meio de chapas intermitentes, os quais geralmente resultam em situações intermediárias entre o comportamento do conjunto como um todo e o de perfis simples nos trechos entre presilhas.

A situação é ainda mais crítica quando os perfis são compostos por cantoneiras, que, apesar da forma simples, ainda causam muitas dúvidas no meio científico quanto ao seu comportamento estrutural, conforme mencionado no item 2.4. Por isso, os resultados das análises numéricas são aqui apresentados de forma a identificar não só os modos de instabilidade da peça como um todo, mas levando em consideração também as possíveis instabilidades das cantoneiras simples isoladas entre as presilhas. Nesse contexto, é possível perceber que os modos de instabilidade globais por flexo-torção das cantoneiras muitas vezes se confundem com instabilidades locais do perfil composto (vide Figura 4.8 à Figura 4.15), ou seja, são duas formas diferentes de descrever o mesmo fenômeno.

Apesar da complexidade que envolve o assunto, nota-se que os resultados das análises numéricas apontam para certas tendências quanto aos modos de instabilidade nos perfis dupla cantoneira aqui estudados. Em geral, para compressão centrada, pode-se dizer que o modo de instabilidade global por flexo-torção da seção composta, associado a instabilidades localizadas (flexo-torção da cantoneira simples), é quem determina o colapso deste tipo de perfil, exceto para situações em que a esbeltez em relação ao eixo de menor inércia é muito elevada, que tendem a resultar em modos globais por flexão.

O mesmo comportamento foi também observado nos ensaios experimentais realizados em CHODRAUI (2006), conforme apresentado no item 2.6.1. A Figura 4.16 e a Figura 4.17 mostram os resultados desses ensaios para alguns dos perfis analisados, os quais apresentam configurações deformadas semelhantes àquelas extraídas das análises numéricas. 


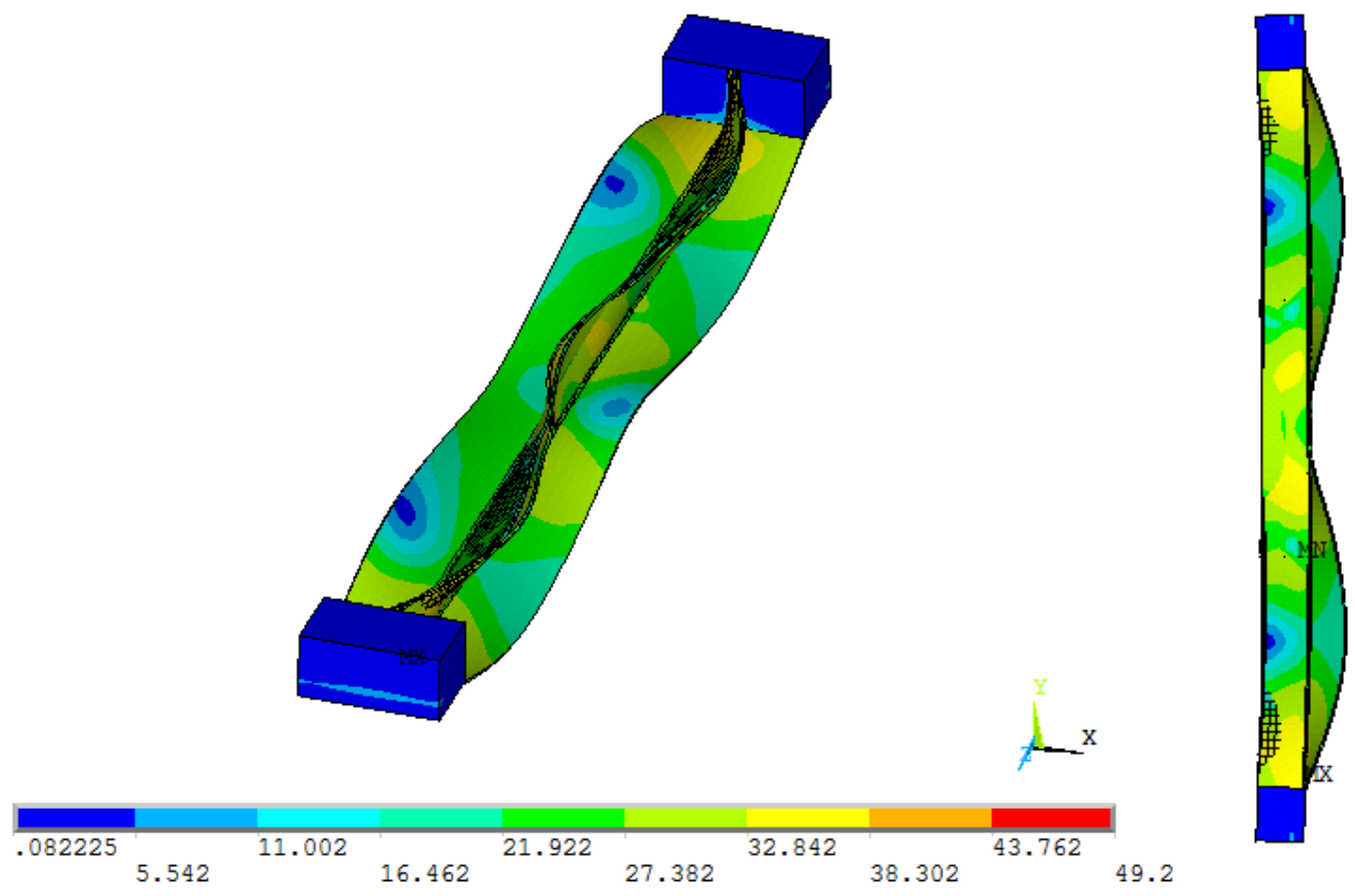

Figura 4.8 - Tensões de von Mises $\left(\mathrm{kN} / \mathrm{cm}^{2}\right)$ e deformadas (escala aumentada) no limite da capacidade resistente do perfil com $\mathbf{L}_{\text {perfil }}=\mathbf{9 1 0} \mathbf{m m}$ - Rótula no eixo-X.
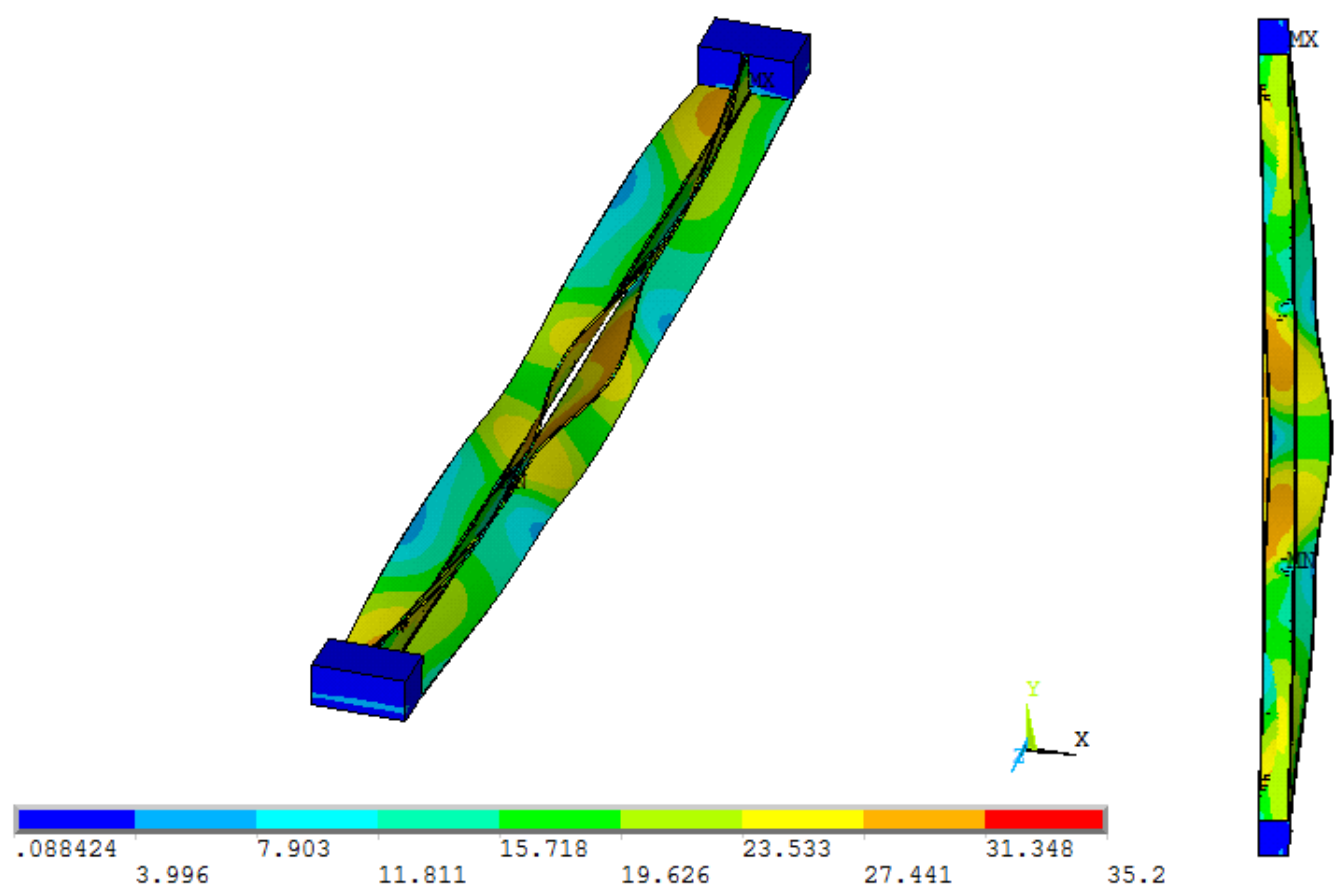

Figura 4.9 - Tensões de von Mises $\left(\mathrm{kN} / \mathrm{cm}^{2}\right)$ e deformadas (escala aumentada) no limite da capacidade resistente do perfil com $\mathbf{L}_{\text {perfil }}=\mathbf{1 4 8 5} \mathbf{m m}$ - Rótula no eixo-X. 


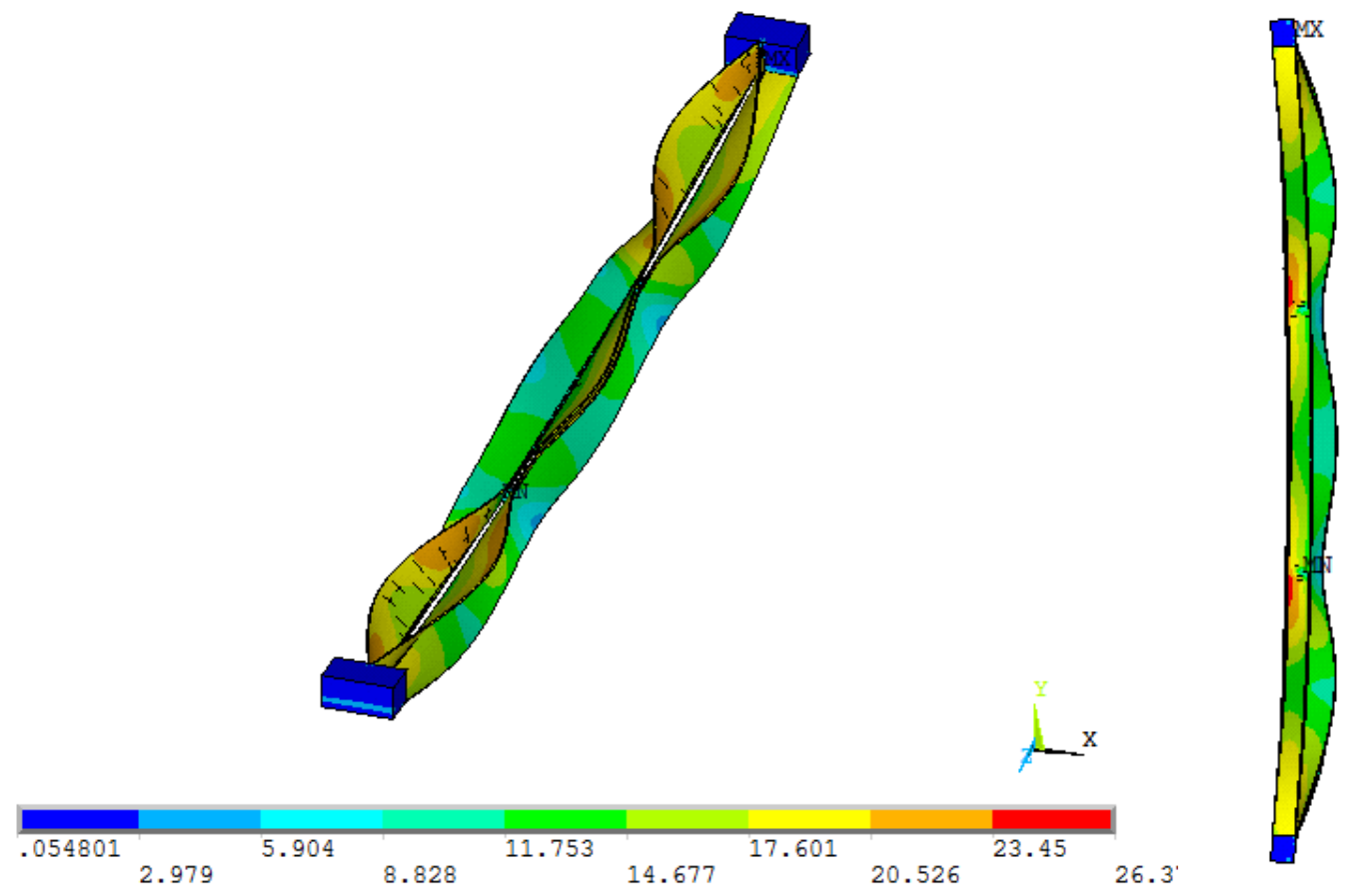

Figura 4.10 - Tensões de von Mises $\left(\mathrm{kN} / \mathrm{cm}^{2}\right)$ e deformadas (escala aumentada) no limite da capacidade resistente do perfil com $\mathbf{L}_{\text {perfil }}=\mathbf{2 0 5 5} \mathbf{m m}$ - Rótula no eixo-X.

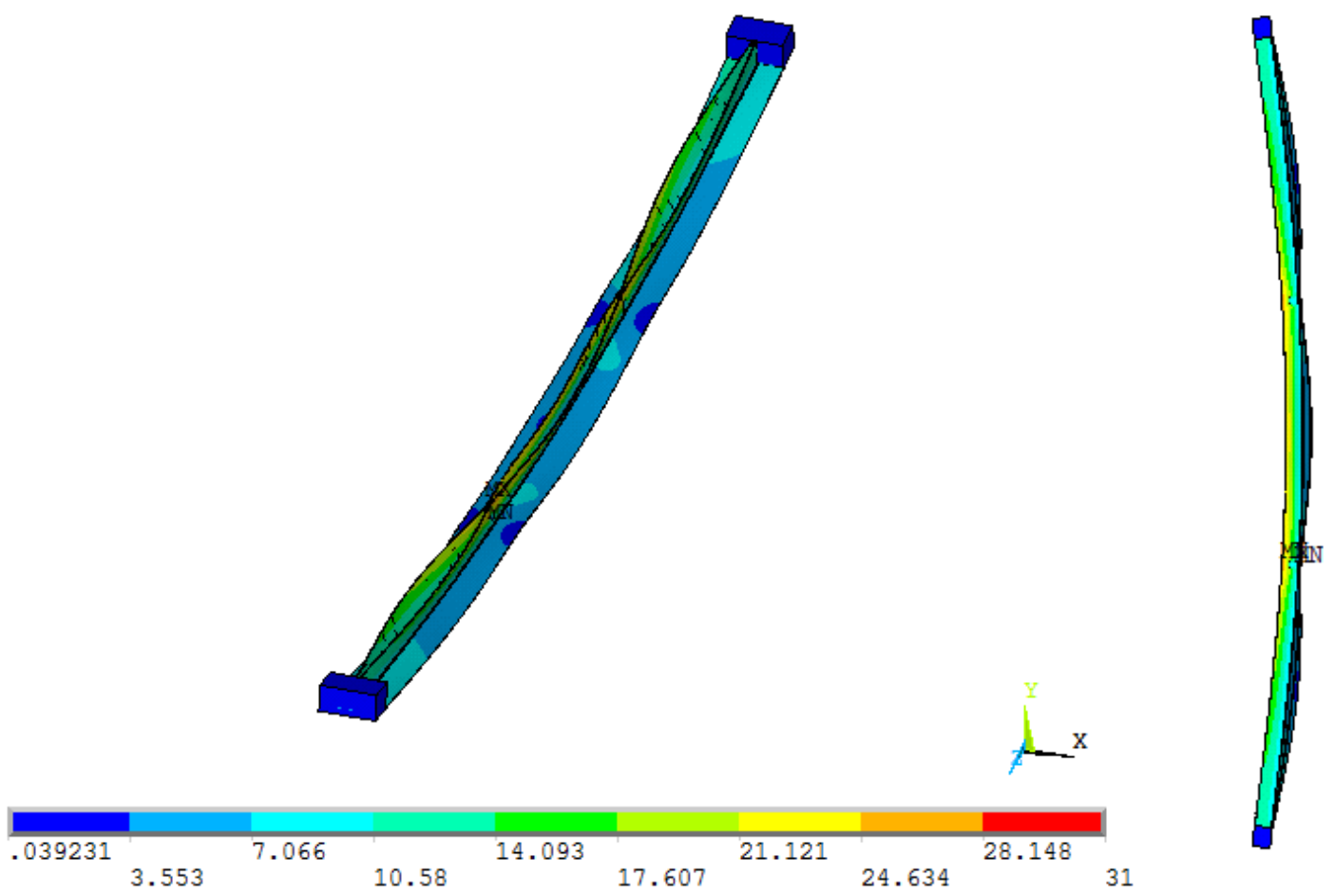

Figura 4.11 - Tensões de von Mises $\left(\mathrm{kN} / \mathrm{cm}^{2}\right)$ e deformadas (escala aumentada) no limite da capacidade resistente do perfil com $\mathbf{L}_{\text {perfil }}=\mathbf{2 6 3 0} \mathbf{m m}$ - Rótula no eixo-X. 


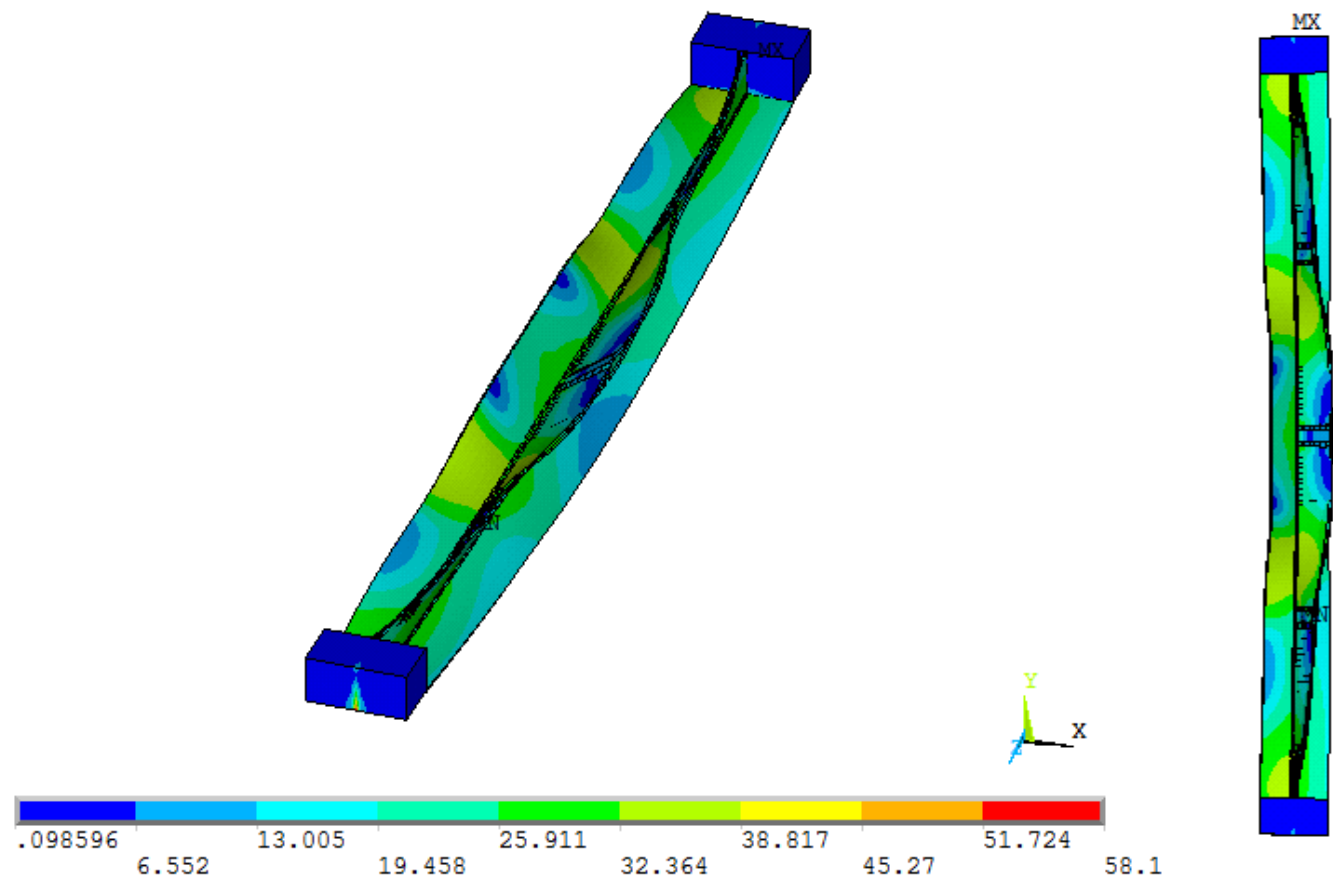

Figura 4.12 - Tensões de von Mises $\left(\mathrm{kN} / \mathrm{cm}^{2}\right.$ ) e deformadas (escala aumentada) no limite da capacidade resistente do perfil com $\mathbf{L}_{\text {perfil }}=\mathbf{1 3 5 5} \mathbf{m m}$ - Rótula no eixo-y.
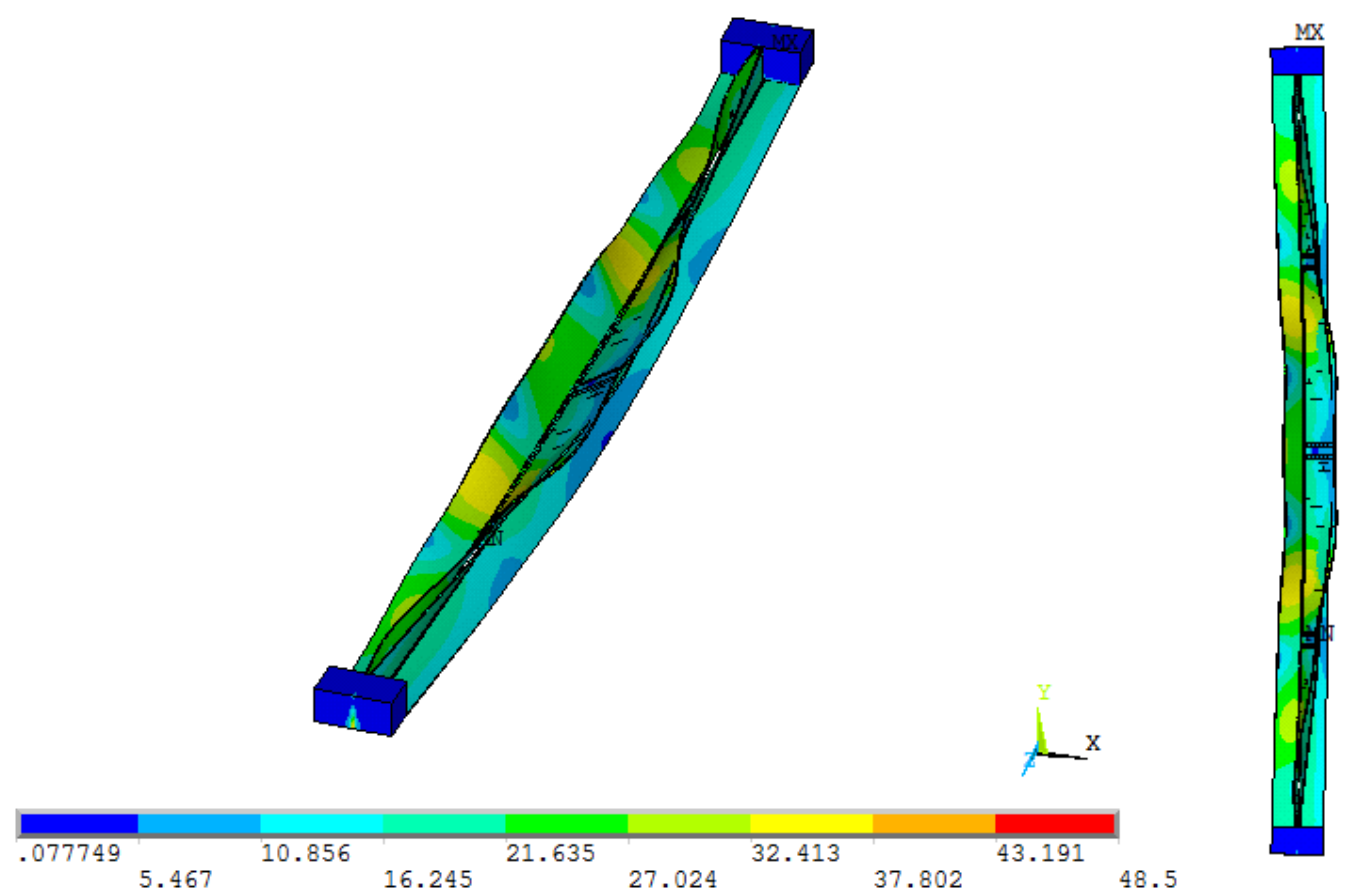

Figura 4.13 - Tensões de von Mises $\left(\mathrm{kN} / \mathrm{cm}^{2}\right)$ e deformadas (escala aumentada) no limite da capacidade resistente do perfil com $\mathbf{L}_{\text {perfil }}=\mathbf{1 8 8 5} \mathbf{m m}$ - Rótula no eixo-y. 


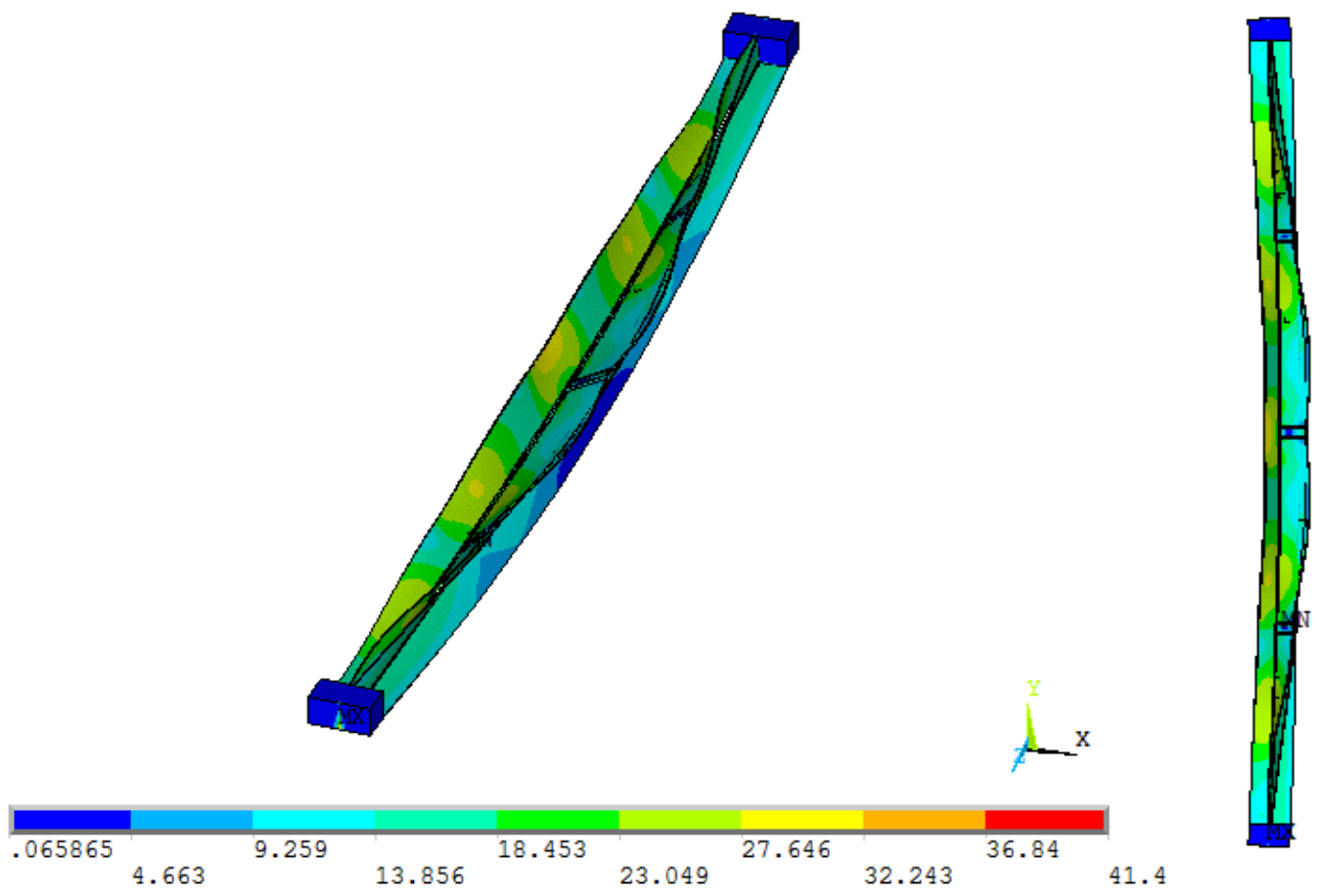

Figura 4.14 - Tensões de von Mises $\left(\mathrm{kN} / \mathrm{cm}^{2}\right)$ e deformadas (escala aumentada) no limite da capacidade resistente do perfil com $\mathbf{L}_{\text {perfil }}=\mathbf{2 4 1 5} \mathbf{m m}$ - Rótula no eixo-y.
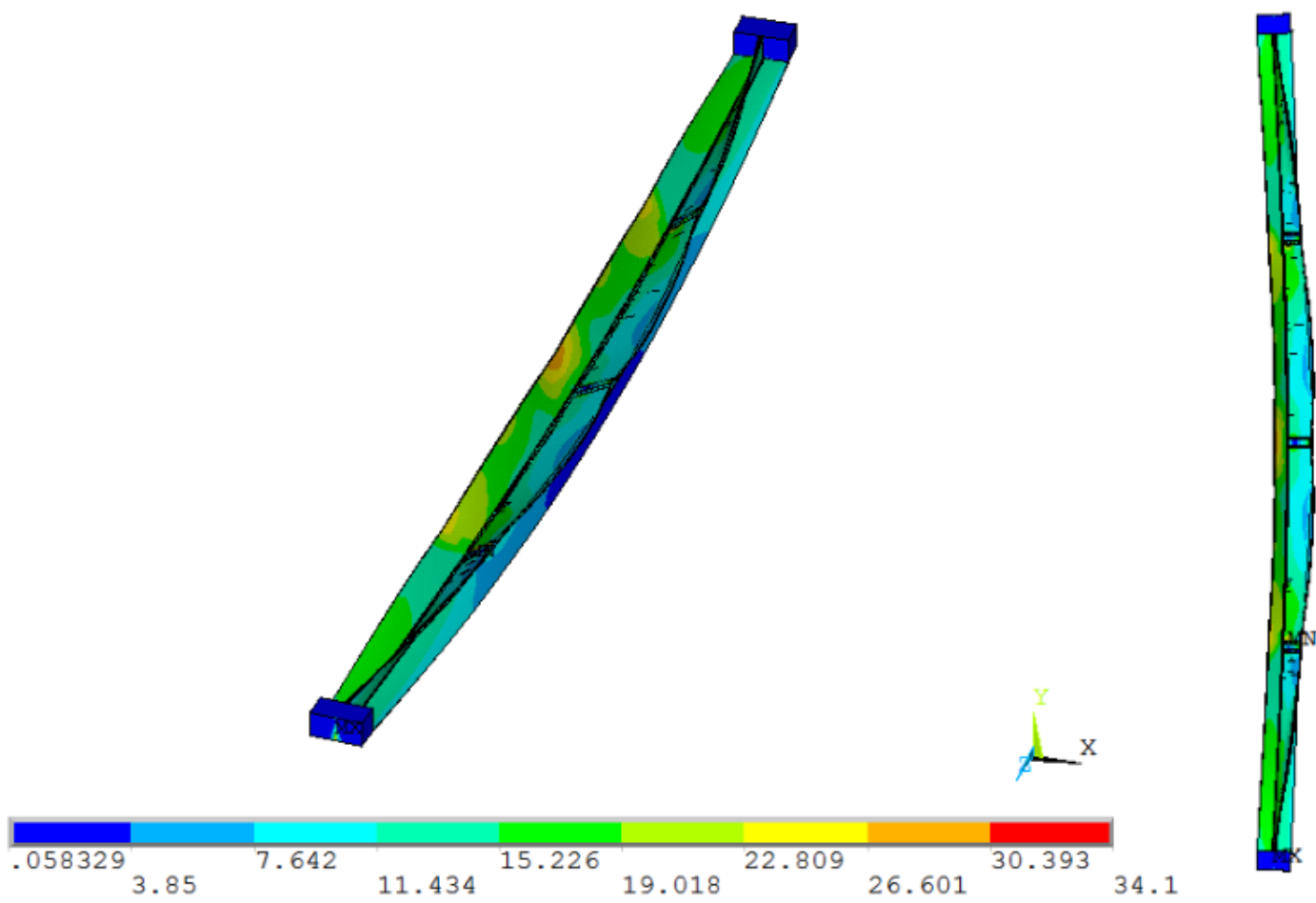

Figura 4.15 - Tensões de von Mises $\left(\mathrm{kN} / \mathrm{cm}^{2}\right)$ e deformadas (escala aumentada) no limite da capacidade resistente do perfil com $\mathbf{L}_{\text {perfil }}=\mathbf{2 9 2 5} \mathbf{m m}$ - Rótula no eixo-y. 
Mesmo não tendo uma ligação contínua entre as cantoneiras que compõem o perfil (a ligação entre as mesmas é feita por meio de presilhas, como dito), percebe-se certa aproximação do comportamento dos perfis analisados com o que prevê a teoria de instabilidade para os perfis “T”. Conforme enfatizado em TRAHAIR (1993), perfis monossimétricos com seção transversal aberta de paredes finas, tais como a maioria dos perfis formados a frio (PFF), possuem rigidez à torção muito pequena devido à reduzida espessura de suas chapas, fazendo com que predominem os modos de instabilidade torcionais no caso de perfis com menor esbeltez global. Além disso, a última referência cita ainda a grande interação entre os modos de flambagem por torção e por flexão (nesse caso, em torno do eixo de maior inércia), que faz com que as cargas críticas de flambagem por flexo-torção resultem mais baixas do que aquelas obtidas para os dois modos isoladamente.

Outra conseqüência importante da elevada esbeltez local dos PFF é o freqüente aparecimento de instabilidades locais simultaneamente às instabilidades globais citadas, conforme pode ser observado nos resultados das análises numéricas, o que tende a reduzir ainda mais a capacidade resistente do perfil.

Analisando comparativamente os resultados das análises numéricas considerando as diferentes condições de contorno empregadas (rótula cilíndrica no eixo-x ou no eixo-y), notase uma interessante diferença: enquanto os modelos com rótula no eixo-x apresentaram intensa participação das cantoneiras simples isoladas entre presilhas, aqueles com a rótula disposta no eixo-y proporcionaram deformações que se aproximam mais do comportamento de uma peça única (como um perfil “T”). Tal diferença pode ser uma das explicações para a maior sensibilidade dos perfis com rótula no eixo-x à forma das imperfeições locais, como visto anteriormente.

No que se refere à distribuição de tensões nas chapas, observa-se que nenhum dos perfis atingiu valores de tensão acima do valor referente à resistência ao escoamento do aço utilizado $\left(f_{y}=37,5 \mathrm{kN} / \mathrm{cm}^{2}\right)$ - vide Figura 4.8 à Figura 4.15 - o que confirma a tendência dos perfis formados a frio submetidos à compressão em alcançar o limite de sua capacidade resistente mesmo sem atingir a plastificação do aço, devido à elevada esbeltez local desses perfis. 


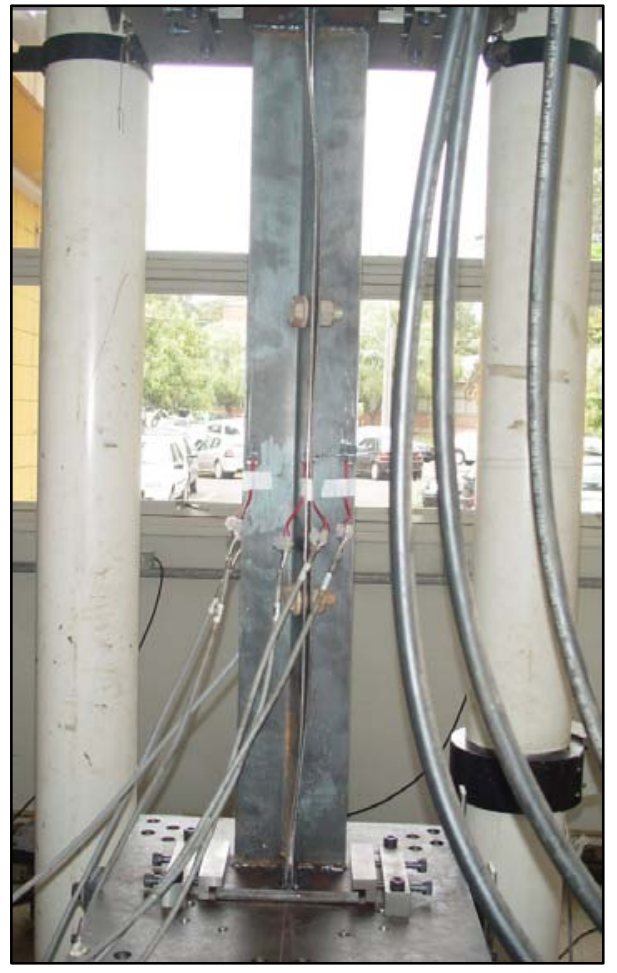

(a)

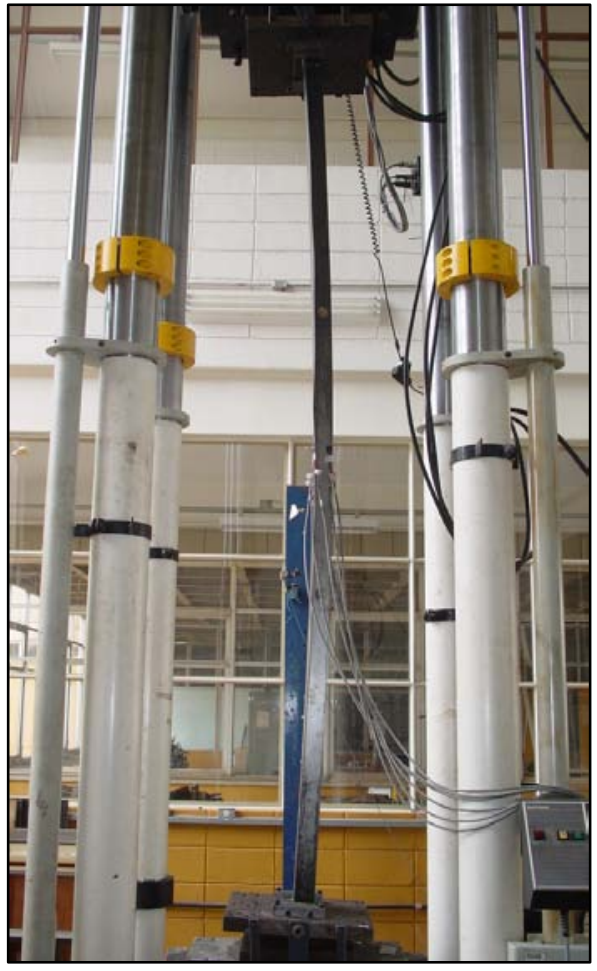

(b)

Figura 4.16 - Resultados experimentais de modelos com Rótula no eixo-x: (a) $\mathrm{L}_{\text {perfil }}=910 \mathrm{~mm}$ e (b) $\mathrm{L}_{\text {perfil }}=2630 \mathrm{~mm}$. Fonte: CHODRAUI (2006)

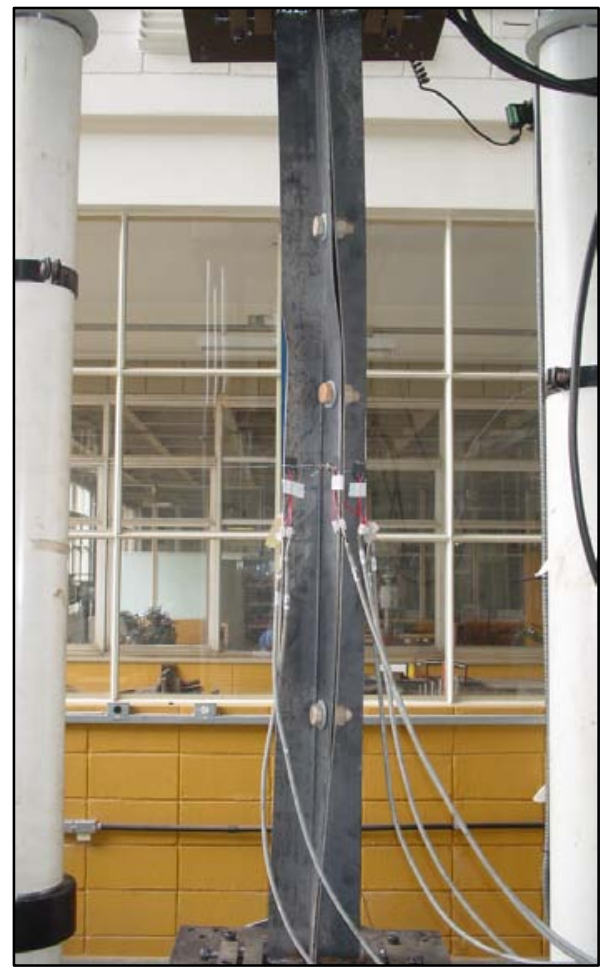

(a)

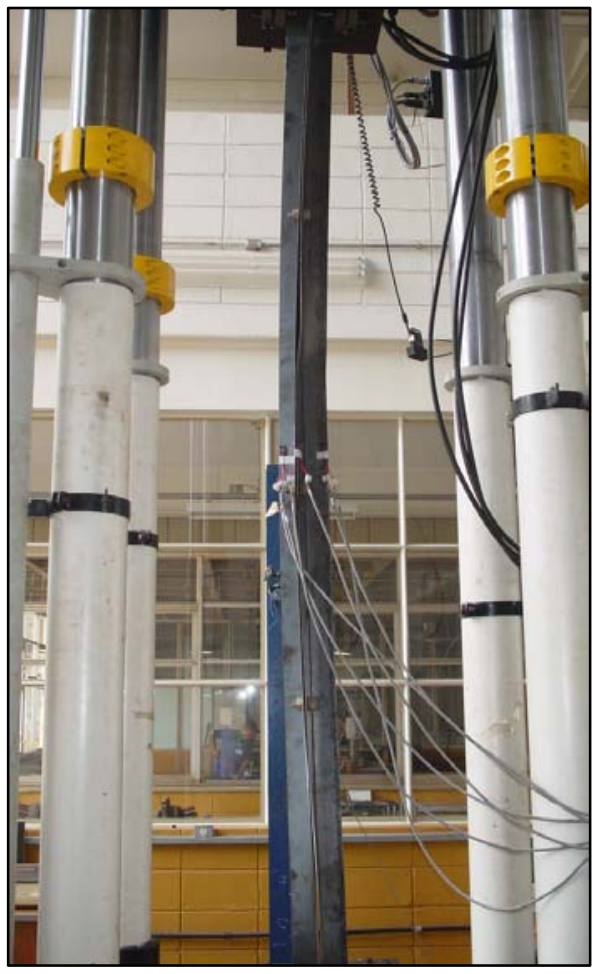

(b)

Figura 4.17 - Resultados experimentais de modelos com Rótula no eixo-y: (a) $\mathrm{L}_{\text {perfil }}=1355 \mathrm{~mm}$ e (b) $\mathrm{L}_{\text {perfil }}=2415 \mathrm{~mm}$. Fonte: CHODRAUI (2006) 
Passando agora à análise dos resultados de resistência à compressão dos perfis, são apresentados na Figura 4.18 e na Figura 4.19 os valores de força de compressão resistente $\left(\mathrm{N}_{\mathrm{c}, \mathrm{R}}\right)$ resultantes das análises numéricas (Tabela 4.6 e Tabela 4.7) e também aqueles obtidos nos ensaios experimentais apresentados em CHODRAUI (2006). Além disso, os gráficos ilustram, ainda, curvas referentes às previsões das normas ABNT NBR 14762:2010 e ANSI/AISI S100 (2007) para a resistência nominal à compressão dos perfis analisados em função do comprimento das peças, conforme a legenda a seguir:

- Experimental: resultados dos ensaios apresentados em CHODRAUI (2006);

- Modelos MEF: resultados das análises numéricas;

- NBR-FT: curva referente ao dimensionamento do perfil via ABNT NBR 14762:2010, considerando a flambagem por flexão e por flexo-torção;

- AISI-FT: curva referente ao dimensionamento do perfil via ANSI/AISI S100 (2007), considerando a flambagem por flexão e por flexo-torção;

- NBR-Fx: curva referente ao dimensionamento do perfil via ABNT NBR 14762:2010, considerando apenas flambagem por flexão em torno do eixo-x (situação hipotética);

- NBR-Fy: curva referente ao dimensionamento do perfil via ABNT NBR 14762:2010, considerando apenas flambagem por flexão em torno do eixo-y (situação hipotética);

- AISI-Fx: curva referente ao dimensionamento do perfil via ANSI/AISI S100 (2007), considerando apenas flambagem por flexão em torno do eixo-x (situação hipotética);

- AISI-Fy: curva referente ao dimensionamento do perfil via ANSI/AISI S100 (2007), considerando apenas flambagem por flexão em torno do eixo-y (situação hipotética).

Como as análises numéricas apresentaram resultados de resistência muito próximos mesmo variando as imperfeições geométricas iniciais, foram inseridos nos gráficos apenas os valores médios dos resultados de cada perfil buscando facilitar a visualização e interpretação dos mesmos.

É importante ressaltar que as metodologias de cálculo de ambas as normas (brasileira e norte-americana) especificam que tanto a flambagem por flexão como a flambagem por flexotorção devem ser consideradas nestes casos de perfis monossimétricos (curvas NBR-FT e AISI-FT), conforme exposto no item 2.5, sendo tomado como carga crítica de flambagem elástica do perfil o menor valor entre os dois modos. Portanto, as curvas apresentadas nos gráficos considerando somente a flambagem por flexão têm finalidade meramente comparativa, apenas para verificar possíveis tendências dos perfis em relação a essas curvas. 


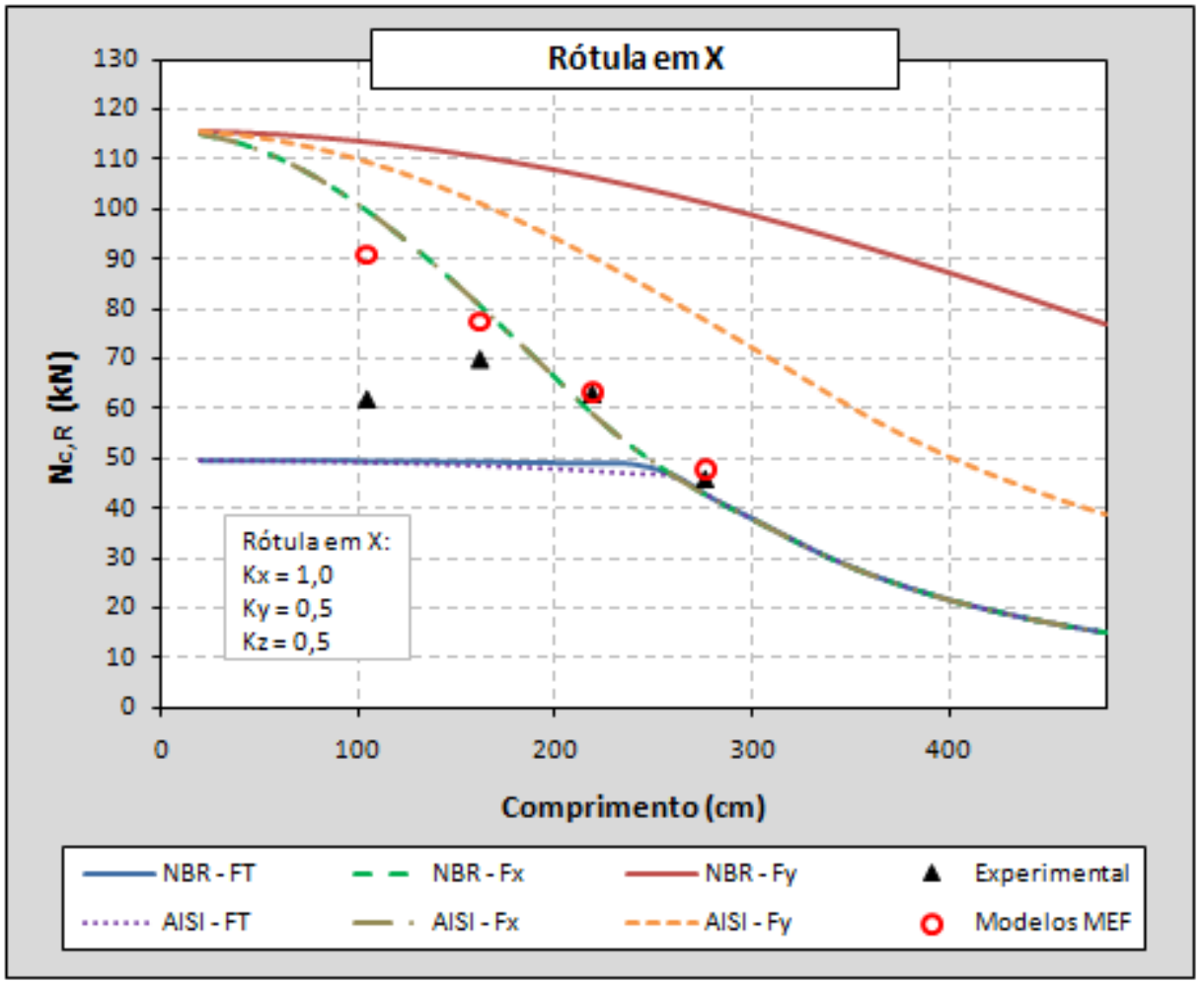

Figura 4.18 - Resistência à compressão: resultados numéricos, experimentais e previsões normativas - Rótula no eixo-X.

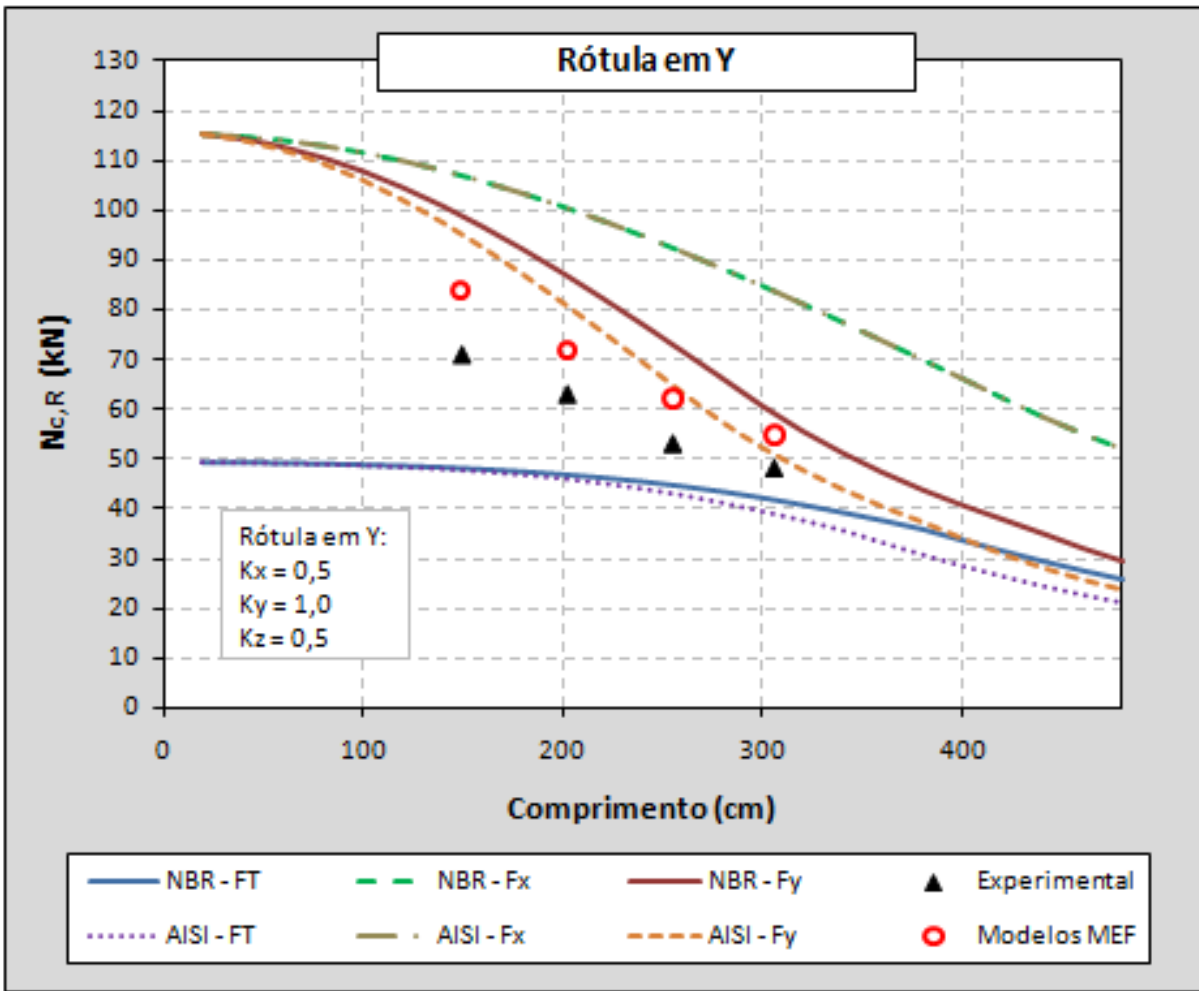

Figura 4.19 - Resistência à compressão: resultados numéricos, experimentais e previsões normativas - Rótula no eixo-y. 
Apesar de os resultados numéricos e experimentais apontarem o modo de instabilidade por flexo-torção (associado a instabilidades localizadas) como o principal responsável pela falha da maioria dos perfis analisados, nota-se que os valores de resistência alcançados apresentaram significativos desvios em relação às curvas de dimensionamento resultantes das prescrições das normas (curvas NBR-FT e AISI-FT), principalmente para os perfis com menor esbeltez global. Semelhantemente ao que ocorre com as cantoneiras simples (conforme discutido em MAIA, 2008), a resistência à compressão dos perfis dupla cantoneira tende a valores intermediários às curvas de flexão e de flexo-torção.

No caso dos perfis com rótula cilíndrica posicionada no eixo de menor inércia da seção (Figura 4.18), as curvas referentes à flambagem por flexão em torno desse mesmo eixo (curvas NBR-Fx e AISI-Fx) descrevem com boa aproximação os resultados das análises numéricas. Já os perfis modelados com rótula para flexão no eixo de maior inércia (Figura 4.19) apresentaram valores entre as curvas de flexão em torno do eixo que contém as rótulas (curvas NBR-Fy, AISI-Fy) e as de flexo-torção (NBR-FT e NBR-FT).

Portanto, comparando-se com os resultados numéricos e experimentais, percebe-se que os valores de resistência calculados com base nas prescrições normativas para os perfis dupla cantoneira com seção “T” resultam bastantes conservadores, principalmente no caso dos perfis com menor esbeltez global.

Como se sabe, modelos analisados com base em métodos numéricos nem sempre descrevem com perfeição o comportamento real de elementos ou sistemas estruturais, especialmente nesses casos em que envolvem problemas de instabilidade e imperfeições geométricas e de material. A impossibilidade de se quantificar e representar nos modelos todos os parâmetros que influenciam o comportamento estrutural acaba refletindo em divergências nos resultados, como aquelas observadas entre os resultados numéricos e os experimentais apresentados na Tabela 4.6 e na Tabela 4.7.

Essas divergências, embora não sejam tão significativas para a maioria dos casos analisados, reforçam a necessidade de mais pesquisas sobre os perfis dupla cantoneira em questão, principalmente no campo experimental, uma vez que a quantidade de resultados de ensaios laboratoriais com esses perfis ainda é muito pequena e insuficiente para conclusões definitivas sobre o seu comportamento estrutural. 


\subsubsection{COMPRESSÃO EXCÊNTRICA}

São apresentados no presente item os principais resultados, obtidos via análises numéricas, para os perfis dupla cantoneira com seção “T” submetidos à compressão excêntrica. Conforme exposto no Capítulo 3, esse carregamento excêntrico foi aplicado nos perfis por meio de chapas de ligação parafusadas em apenas uma das abas das cantoneiras que compõem o perfil (Figura 3.4), que é a situação mais comumente encontrada na prática devido a facilidades executivas das ligações.

Foram avaliados perfis com duas espessuras de chapa das cantoneiras, que, como já informado, correspondem aos valores de 1,5mm e 3,0mm. Além disso, foi verificado também o comportamento dos perfis mediante a variação do número de presilhas ao longo de seu comprimento, de forma a quantificar ganhos ou perdas de resistência devido a essa variação.

Primeiramente, seguindo o padrão dos modelos sob compressão centrada, foi feita uma análise de sensibilidade para a seleção das imperfeições geométricas iniciais e, em seguida, realizadas as análises numéricas não-lineares para a obtenção dos resultados de interesse, conforme explicado a seguir.

\subsubsection{Análise de sensibilidade às imperfeições geométricas}

Tomando como base os resultados alcançados com os modelos submetidos à compressão centrada, foram realizados testes com imperfeições geométricas iniciais semelhantes àquelas adotadas anteriormente. Por isso, a análise de sensibilidade realizada com os perfis sob compressão excêntrica limitou-se apenas a verificar se o número de presilhas e a mudança na forma de aplicação do carregamento tornam os perfis mais ou menos sensíveis às imperfeições, não sendo tão ampla quanto à análise descrita no item 4.1.1.1.

Os testes foram realizados nos perfis com dimensões da seção transversal de 60x60x3,0mm e número de presilhas igual a 1 (presilha posicionada no meio do comprimento do perfil) ou 2 (presilhas posicionadas nos terços do comprimento do perfil). O item 3.1.4 descreve com detalhes as imperfeições geométricas iniciais testadas, cujos resultados são apresentados na Tabela 4.8 e na Tabela 4.9 para os testes feitos com as imperfeições globais e locais, respectivamente. Os termos Forma1 e Forma2 presentes na Tabela 4.9 referem-se às imperfeições locais mostradas na Figura 3.18a e na Figura 3.18b. 
Tabela 4.8 - Compressão excêntrica: resultados da análise de sensibilidade às imperfeições geométricas iniciais do tipo global.

\begin{tabular}{|c|c|c|c|c|c|c|c|}
\hline \multicolumn{8}{|c|}{ Perfil 60x60x3,0mm - Compressão excêntrica } \\
\hline \multirow{2}{*}{$\begin{array}{c}\mathbf{L}_{\mathbf{r}} \\
(\mathbf{m m})\end{array}$} & \multirow{2}{*}{$\begin{array}{l}\text { Número } \\
\text { de } \\
\text { Presilhas }\end{array}$} & \multicolumn{5}{|c|}{ ANÁLISE NUMÉRICA } & \multirow{2}{*}{$\begin{array}{c}\mathbf{N}_{\text {FEM }} \\
/ \\
\mathbf{N}_{\mathbf{y}}\end{array}$} \\
\hline & & $\begin{array}{l}\text { Imperfeições } \\
\text { local e global }\end{array}$ & $\begin{array}{c}\mathbf{N}_{\text {FEM }} \\
(\mathbf{k N})\end{array}$ & $\begin{array}{l}\text { Modo } \\
\text { 2L }\end{array}$ & $\begin{array}{c}\text { Modo } \\
\text { L }\end{array}$ & Razão & \\
\hline \multirow{4}{*}{$\begin{array}{c}380 \\
\left(\lambda_{x}=20\right)\end{array}$} & \multirow{2}{*}{1} & 0t e -L/1500 & 146,2 & $\mathrm{~L}^{*}$ & $\mathrm{~T}$ & \multirow{2}{*}{0,99} & 0,61 \\
\hline & & $0 \mathrm{t} \mathrm{e}+\mathrm{L} / 1500$ & 147,7 & $\mathrm{~L}^{*}$ & $\mathrm{~T}$ & & 0,61 \\
\hline & \multirow{2}{*}{2} & 0t e -L/1500 & 148,7 & Inst.Lig. & - & \multirow{2}{*}{1,00} & 0,62 \\
\hline & & $0 \mathrm{t} \mathrm{e}+\mathrm{L} / 1500$ & 148,7 & Inst.Lig. & - & & 0,62 \\
\hline \multirow{4}{*}{$\begin{array}{c}755 \\
\left(\lambda_{x}=40\right)\end{array}$} & \multirow{2}{*}{1} & 0t e -L/1500 & 122,0 & $\mathrm{~F}+\mathrm{L}$ & FT & \multirow{2}{*}{1,00} & 0,50 \\
\hline & & $0 \mathrm{t}$ e $+\mathrm{L} / 1500$ & 122,2 & $\mathrm{~F}+\mathrm{L}$ & FT & & 0,51 \\
\hline & \multirow{2}{*}{2} & 0t e -L/1500 & 132,4 & $\mathrm{~F}+\mathrm{L}$ & FT & \multirow{2}{*}{1,00} & 0,55 \\
\hline & & $0 t \mathrm{e}+\mathrm{L} / 1500$ & 131,8 & $F+L$ & FT & & 0,55 \\
\hline \multirow{4}{*}{$\begin{array}{c}1325 \\
\left(\lambda_{x}=70\right)\end{array}$} & \multirow{2}{*}{1} & 0t e -L/1500 & 105,5 & $F+L$ & FT & \multirow{2}{*}{1,00} & 0,44 \\
\hline & & $0 t$ e $+\mathrm{L} / 1500$ & 105,7 & $F+L$ & FT & & 0,44 \\
\hline & \multirow{2}{*}{2} & 0t e -L/1500 & 105,6 & $\mathrm{~F}+\mathrm{L}$ & FT & \multirow{2}{*}{1,01} & 0,44 \\
\hline & & $0 \mathrm{t} \mathrm{e}+\mathrm{L} / 1500$ & 104,5 & $\mathrm{~F}+\mathrm{L}$ & FT & & 0,43 \\
\hline \multirow{4}{*}{$\begin{array}{c}1890 \\
\left(\lambda_{x}=100\right)\end{array}$} & \multirow{2}{*}{1} & 0t e -L/1500 & 93,6 & $F+L$ & FT & \multirow{2}{*}{0,99} & 0,39 \\
\hline & & $0 \mathrm{t} \mathrm{e}+\mathrm{L} / 1500$ & 94,1 & $F+L$ & FT & & 0,39 \\
\hline & \multirow{2}{*}{2} & 0t e -L/1500 & 95,1 & $F+L$ & FT & \multirow{2}{*}{1,00} & 0,39 \\
\hline & & $0 \mathrm{t} \mathrm{e}+\mathrm{L} / 1500$ & 94,9 & $\mathrm{~F}+\mathrm{L}$ & FT & & 0,39 \\
\hline \multirow{4}{*}{$\begin{array}{c}2460 \\
\left(\lambda_{x}=130\right)\end{array}$} & \multirow{2}{*}{1} & 0t e -L/1500 & 83,4 & $F+L$ & FT & \multirow{2}{*}{0,99} & 0,35 \\
\hline & & 0 t e $+\mathrm{L} / 1500$ & 84,2 & $F+L$ & $\mathrm{FT}$ & & 0,35 \\
\hline & \multirow{2}{*}{2} & 0t e -L/1500 & 85,2 & $\mathrm{~F}+\mathrm{T}^{*}+\mathrm{L}$ & $\mathrm{FT}$ & \multirow{2}{*}{0,99} & 0,35 \\
\hline & & 0 t e $+\mathrm{L} / 1500$ & 85,8 & $\mathrm{~F}+\mathrm{T}^{*}+\mathrm{L}$ & $\mathrm{FT}$ & & 0,36 \\
\hline \multirow{4}{*}{$\begin{array}{c}3030 \\
\left(\lambda_{x}=160\right)\end{array}$} & 1 & 0t e -L/1500 & 71,4 & $F+L$ & FT & 088 & 0,30 \\
\hline & 1 & $0 \mathrm{t} \mathrm{e}+\mathrm{L} / 1500$ & 73,0 & $F+L$ & FT & 0,98 & 0,30 \\
\hline & & 0t e -L/1500 & 73,5 & $\mathrm{~F}+\mathrm{T}^{*}+\mathrm{L}$ & FT & & 0,30 \\
\hline & 2 & 0 t e $+\mathrm{L} / 1500$ & 75,6 & $\mathrm{~F}+\mathrm{T}^{*}+\mathrm{L}$ & FT & 0,91 & 0,31 \\
\hline $\begin{array}{l}\mathrm{t}-\text { espessur } \\
\mathrm{L}-\text { comprir } \\
\mathrm{L}_{\mathrm{r}}-\text { compri } \\
\lambda_{\mathrm{x}}-\text { índice } \\
\mathrm{N}_{\mathrm{FEM}}-\text { for } \\
\text { Modo } 2 \mathrm{~L}- \\
\text { Modo } \mathrm{L}-\mathrm{n} \\
\mathrm{N}_{\mathrm{y}}=\mathrm{A}_{\text {ef. }} f_{y} \\
\\
\mathrm{~F}=\text { instabili } \\
\mathrm{T}=\text { instabil } \\
\mathrm{FT}=\text { instab } \\
\mathrm{L}=\text { instabil } \\
\text { * Modo de } \\
\text { Inst.Lig. }=\mathrm{i} \\
\end{array}$ & $\begin{array}{l}\text { ra das chapas c } \\
\text { mento do perf } \\
\text { imento do per } \\
\text { de esbeltez do } \\
\text { ça de compres } \\
\text { modo de inst } \\
\text { nodo de instal } \\
; \quad A_{\text {ef }} \text { : área } € \\
\text { idade global p } \\
\text { lidade global } \mathrm{p} \\
\text { ilidade global } \\
\text { lidade local (d } \\
\text { instabilidade } \\
\text { instabilidade c }\end{array}$ & $\begin{array}{l}\text { perfil; } \\
\text { tomado de centro a } \\
\text { erfil; } \\
\text { o resistente obtida n } \\
\text { lidade referente ao } \\
\text { dade das cantoneira } \\
\text { tiva da seção transv } \\
\text { flexão em torno do } \\
\text { torção; } \\
\text { or flexo-torção; } \\
\text { hapa); } \\
\text { dco pronunciado; } \\
\text { chapa de ligação. } \\
\end{array}$ & $\begin{array}{l}\text { ro de liga } \\
\text { álise num } \\
\text { l compos } \\
\text { ladas ent } \\
; \quad f_{y}=35 \\
\text {-x (de me }\end{array}$ & $\begin{array}{l}\text { ica (ANSYS); } \\
\text { presilhas; } \\
\text { MPa } \\
\text { or inércia); }\end{array}$ & & & \\
\hline
\end{tabular}


Tabela 4.9 - Compressão excêntrica: resultados da análise de sensibilidade às imperfeições geométricas iniciais do tipo local.

\begin{tabular}{|c|c|c|c|c|c|c|c|}
\hline \multicolumn{8}{|c|}{ Perfil 60x60x3,0mm - Compressão excêntrica } \\
\hline \multirow[b]{2}{*}{$\begin{array}{c}\mathbf{L}_{\mathbf{r}} \\
(\mathbf{m m})\end{array}$} & \multirow{2}{*}{$\begin{array}{c}\text { Número } \\
\text { de } \\
\text { ?resilha: }\end{array}$} & \multicolumn{5}{|c|}{ ANÁLISE NUMÉRICA } & \multirow{2}{*}{$\begin{array}{c}\mathbf{N}_{\text {FEM }} \\
/ \\
\mathbf{N}_{\mathbf{y}}\end{array}$} \\
\hline & & $\begin{array}{l}\text { Imperfeições } \\
\text { local e global }\end{array}$ & $\begin{array}{c}\mathbf{N}_{\text {FEM }} \\
(\mathbf{k N})\end{array}$ & $\begin{array}{l}\text { Modo } \\
\text { 2L }\end{array}$ & $\begin{array}{c}\text { Modo } \\
\text { L }\end{array}$ & Razão & \\
\hline \multirow{4}{*}{$\begin{array}{c}380 \\
\left(\lambda_{x}=20\right)\end{array}$} & \multirow[b]{2}{*}{1} & 0,64t (Forma1) e -L/1500 & 140,3 & $\mathrm{~F}^{*}+\mathrm{T}+\mathrm{L}$ & $\mathrm{T}$ & \multirow{2}{*}{1,05} & 0,58 \\
\hline & & 0,64t (Forma2) e -L/1500 & 133,7 & $\mathrm{~F}^{*}+\mathrm{T}+\mathrm{L}$ & $\mathrm{T}$ & & 0,55 \\
\hline & \multirow{2}{*}{2} & 0,64t (Forma1) e -L/1500 & 148,9 & Inst.Lig & - & \multirow{2}{*}{1,04} & 0,62 \\
\hline & & 0,64t (Forma2) e -L/1500 & 142,8 & $\mathrm{~F}^{*}+\mathrm{T}+\mathrm{L}$ & $\mathrm{T}$ & & 0,59 \\
\hline \multirow{4}{*}{$\begin{array}{c}755 \\
\left(\lambda_{x}=40\right)\end{array}$} & \multirow{2}{*}{1} & 0,64t (Forma1) e -L/1500 & 119,7 & $\overline{F+L}$ & FT & \multirow{2}{*}{1,05} & 0,50 \\
\hline & & 0,64t (Forma2) e -L/1500 & 113,7 & $\mathrm{~F}+\mathrm{T}^{*}+\mathrm{L}$ & FT & & 0,47 \\
\hline & \multirow{2}{*}{2} & 0,64t (Forma1) e -L/1500 & 123,4 & $\mathrm{~F}+\mathrm{T}+\mathrm{L}$ & FT & \multirow{2}{*}{0,99} & 0,51 \\
\hline & & 0,64t (Forma2) e -L/1500 & 124,5 & $F+T+L$ & FT & & 0,52 \\
\hline \multirow{4}{*}{$\begin{array}{c}1325 \\
\left(\lambda_{x}=70\right)\end{array}$} & \multirow{2}{*}{1} & 0,64t (Forma1) e -L/1500 & 999,2 & $\overline{\mathrm{F}+\mathrm{T}^{*}+\mathrm{L}}$ & $\begin{array}{l}\text { FT } \\
\end{array}$ & \multirow{2}{*}{0,97} & 0,41 \\
\hline & & 0,64t (Forma2) e -L/1500 & 102,1 & $\mathrm{~F}+\mathrm{T}^{*}+\mathrm{L}$ & FT & & 0,42 \\
\hline & \multirow{2}{*}{2} & 0,64t (Forma1) e -L/1500 & 103,4 & $\mathrm{~F}+\mathrm{T}^{*}+\mathrm{L}$ & FT & \multirow{2}{*}{0,98} & 0,43 \\
\hline & & 0,64t (Forma2) e -L/1500 & 105,4 & $\mathrm{~F}+\mathrm{T}^{*}+\mathrm{L}$ & FT & & 0,44 \\
\hline \multirow{4}{*}{$\left(\begin{array}{c}1890 \\
\left(\lambda_{x}=100\right)\end{array}\right.$} & \multirow{2}{*}{1} & 0,64t (Forma1) e -L/1500 & 90,5 & $\bar{F}+\mathrm{T}^{*}+\mathrm{L}$ & 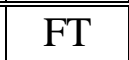 & \multirow{2}{*}{0,99} & 0,37 \\
\hline & & 0,64t (Forma2) e -L/1500 & 91,2 & $\mathrm{~F}+\mathrm{T}^{*}+\mathrm{L}$ & FT & & 0,38 \\
\hline & \multirow{2}{*}{2} & 0,64t (Forma1) e -L/1500 & 94,3 & $\mathrm{~F}+\mathrm{FT}^{*}+\mathrm{L}$ & FT & \multirow{2}{*}{0,99} & 0,39 \\
\hline & & 0,64t (Forma2) e -L/1500 & 95,7 & $\mathrm{~F}+\mathrm{FT}^{*}+\mathrm{L}$ & FT & & 0,40 \\
\hline \multirow{4}{*}{$\begin{array}{c}2460 \\
\left(\lambda_{x}=130\right)\end{array}$} & \multirow{2}{*}{1} & 0,64t (Forma1) e -L/1500 & 78,9 & $\mathrm{~F}+\mathrm{T}^{*}+\mathrm{L}$ & FT & \multirow{2}{*}{0,98} & 0,33 \\
\hline & & 0,64t (Forma2) e -L/1500 & 80,8 & $\mathrm{~F}+\mathrm{T}^{*}+\mathrm{L}$ & FT & & 0,33 \\
\hline & \multirow{2}{*}{2} & 0,64t (Forma1) e -L/1500 & 82,6 & $\mathrm{~F}+\mathrm{FT}^{*}+\mathrm{L}$ & FT & \multirow{2}{*}{0,99} & 0,34 \\
\hline & & 0,64t (Forma2) e -L/1500 & 83,5 & $\mathrm{~F}+\mathrm{FT}^{*}+\mathrm{L}$ & FT & & 0,35 \\
\hline \multirow{4}{*}{$\begin{array}{c}3030 \\
\left(\lambda_{x}=160\right)\end{array}$} & 1 & "0,64t (Forma1) e -L/1500 & 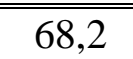 & $\overline{F+L}$ & $\begin{array}{c}\text { FT } \\
\end{array}$ & & 0,28 \\
\hline & 1 & 0,64t (Forma2) e -L/1500 & 69,9 & $F+L$ & FT & 0,98 & 0,29 \\
\hline & 2 & 0,64t (Forma1) e -L/1500 & 68,5 & $\mathrm{~F}+\mathrm{FT}+\mathrm{L}$ & FT & 004 & 0,28 \\
\hline & 2 & 0,64t (Forma2) e -L/1500 & 72,8 & $\mathrm{~F}+\mathrm{FT}+\mathrm{L}$ & FT & 0,94 & 0,30 \\
\hline $\begin{array}{l}\mathrm{t} \text { - espessu } \\
\mathrm{L}-\text { compr } \\
\mathrm{L}_{\mathrm{r}}-\text { comp } \\
\lambda_{\mathrm{x}}-\text { índice } \\
\mathrm{N}_{\mathrm{FEM}}-\text { fo } \\
\text { Modo } 2 \mathrm{~L}- \\
\text { Modo } \mathrm{L}- \\
\mathrm{N}_{\mathrm{y}}=\mathrm{A}_{\mathrm{ef}} \cdot f_{\mathrm{J}} \\
\mathrm{F}=\text { instabi } \\
\mathrm{T}=\text { instabi } \\
\mathrm{FT}=\text { insta } \\
\mathrm{L}=\text { instabi } \\
\text { * Modo de } \\
\text { Inst.Lig. }=\end{array}$ & $\begin{array}{l}\text { rça de com } \\
\text { - modo de } \\
\text { modo de ir } \\
\text {; } \quad A_{\text {ef }} \text { á a } \\
\text { lidade glot } \\
\text { ilidade glol } \\
\text { bilidade gl } \\
\text { ilidade loca } \\
\text { instabilid } \\
\text { instabilida }\end{array}$ & $\begin{array}{l}\text { do perfil; } \\
\text { fil; } \\
\text { rfil tomado de centro a centro de } \\
\text { do perfil; } \\
\text { essão resistente obtida na análise } \\
\text { tabilidade referente ao perfil con } \\
\text { abilidade das cantoneiras isolada } \\
\text { efetiva da seção transversal; } f_{y} \\
\text { por flexão em torno do eixo-x (c } \\
\text { por torção; } \\
\text { l por flexo-torção; } \\
\text { de chapa); } \\
\text { pouco pronunciado; } \\
\text { da chapa de ligação. }\end{array}$ & $\begin{array}{l}\text { ação; } \\
\text { nérica ( } A \\
\text { sto; } \\
\text { tre presi } \\
\text { 50MPa } \\
\text { enor iné }\end{array}$ & YS); & & & \\
\hline
\end{tabular}


Os resultados das análises numéricas revelam pouca influência das imperfeições geométricas iniciais testadas no comportamento dos perfis em questão quando submetidos à compressão excêntrica, independente do número de presilhas empregadas. Assim como os modos de instabilidade predominantes, os valores de resistência apresentados não sofreram alterações significativas nos testes, indicando que os esforços que surgem devido à excentricidade do carregamento resultam bem maiores do que aqueles oriundos das imperfeições geométricas iniciais.

Conforme se observa na Tabela 4.8, os resultados de resistência dos perfis se mantiveram praticamente uniformes com a variação da imperfeição global, sendo de 3\% a diferença máxima encontrada. No caso das imperfeições locais associadas à global, a oscilação foi um pouco maior; porém, não houve diferenças superiores a 6\% nos valores de resistência apresentados (vide Tabela 4.9).

Com isso, apesar de os perfis terem apresentado pouca sensibilidade nas análises numéricas, foram inseridas nos modelos finais as imperfeições geométricas iniciais que se mostraram mais desfavoráveis à resistência dos perfis (a favor da segurança), a saber: imperfeição global com sinal negativo (Figura 3.17b) associada a uma imperfeição local que contenha ondulações nas chapas das cantoneiras e uma torção global do perfil composto (semelhante à Figura 3.18a ou b, dependendo da esbeltez); no que se refere à magnitude, foi utilizado o valor de L/1500 para a imperfeição global e os valores de 0,64.t ou 0,94.t para a imperfeição local.

\subsubsection{Modelos finais: comparação com resultados teóricos}

Seguindo a seqüência de desenvolvimento da presente pesquisa, serão apresentados primeiro os resultados das análises dos perfis com espessura de chapa das cantoneiras de 3,0mm e, por fim, os resultados alcançados para os perfis com espessura de chapa de $1,5 \mathrm{~mm}$.

\section{- Perfis com espessura de chapa igual a $3,0 \mathrm{~mm}$}

A Tabela 4.10 mostra os principais resultados obtidos nas análises numéricas com o perfil 60x60x3,0mm. De acordo com as limitações prescritas na ABNT NBR 14762:2010 para o índice de esbeltez de perfis compostos, devem ser utilizadas no mínimo duas presilhas nos perfis analisados. No entanto, fez-se variar o número de presilhas nos modelos com o intuito de se investigar a sua real contribuição no comportamento estrutural dos perfis. 
Tabela 4.10 - Modelos finais: resultados das análises numéricas com o perfis 60x60x3,0mm - Compressão excêntrica.

\begin{tabular}{|c|c|c|c|c|c|c|c|}
\hline \multicolumn{8}{|c|}{ Perfil 60x60x3,0mm - Compressão excêntrica } \\
\hline \multirow[b]{2}{*}{$\begin{array}{c}\mathbf{L}_{\mathbf{r}} \\
(\mathbf{m m})\end{array}$} & \multirow{2}{*}{$\begin{array}{l}\text { Número } \\
\text { de } \\
\text { ?resilha: }\end{array}$} & \multicolumn{5}{|c|}{ ANÁLISE NUMÉRICA } & \multirow{2}{*}{$\begin{array}{c}\mathbf{N}_{\text {FEM }} \\
/ \\
\mathbf{N}_{\mathbf{y}}\end{array}$} \\
\hline & & $\begin{array}{l}\text { Imperfeições } \\
\text { local e global }\end{array}$ & $\begin{array}{c}\mathbf{N}_{\text {FEM }} \\
(\mathbf{k N})\end{array}$ & $\begin{array}{l}\text { Modo } \\
\text { 2L }\end{array}$ & $\begin{array}{c}\text { Modo } \\
\text { L }\end{array}$ & $\begin{array}{c}\mathbf{N}_{\text {FEM,m }} \\
(\mathbf{k N})\end{array}$ & \\
\hline \multirow{6}{*}{$\begin{array}{c}380 \\
\left(\lambda_{x}=20\right)\end{array}$} & \multirow{2}{*}{0} & $0,64 t$ e $-\mathrm{L} / 1500$ & 116,6 & $\mathrm{~L}$ & $\mathrm{FT}+\mathrm{L}$ & \multirow{2}{*}{116,4} & 0,53 \\
\hline & & $0,94 t$ e $-\mathrm{L} / 1500$ & 116,1 & $\mathrm{~L}$ & $\mathrm{FT}+\mathrm{L}$ & & 0,53 \\
\hline & \multirow{2}{*}{1} & $0,64 t \mathrm{e}-\mathrm{L} / 1500$ & 133,7 & $\mathrm{~F}^{*}+\mathrm{T}+\mathrm{L}$ & $\mathrm{T}$ & \multirow{2}{*}{133,0} & 0,61 \\
\hline & & $0,94 t$ e $-\mathrm{L} / 1500$ & 132,3 & $\mathrm{~F}^{*}+\mathrm{T}+\mathrm{L}$ & $\mathrm{T}$ & & 0,60 \\
\hline & \multirow{2}{*}{2} & $0,64 t$ e $-\mathrm{L} / 1500$ & 142,8 & $\mathrm{~F}^{*}+\mathrm{T}+\mathrm{L}$ & $\mathrm{T}$ & \multirow{2}{*}{141,8} & 0,65 \\
\hline & & $0,94 \mathrm{t}$ e $-\mathrm{L} / 1500$ & 140,8 & $\mathrm{~F}^{*}+\mathrm{T}+\mathrm{L}$ & $\mathrm{T}$ & & 0,64 \\
\hline \multirow{6}{*}{$\begin{array}{c}755 \\
\left(\lambda_{x}=40\right)\end{array}$} & \multirow{2}{*}{0} & $0,64 t$ e $-\mathrm{L} / 1500$ & 105,9 & L & $\overline{F T+L}$ & \multirow{2}{*}{105,6} & 0,48 \\
\hline & & $0,94 t$ e $-\mathrm{L} / 1500$ & 105,2 & $\mathrm{~L}$ & $\mathrm{FT}+\mathrm{L}$ & & 0,48 \\
\hline & \multirow{2}{*}{1} & $0,64 t$ e $-L / 1500$ & 113,7 & $\mathrm{~F}+\mathrm{T}^{*}+\mathrm{L}$ & $\mathrm{FT}+\mathrm{L}$ & \multirow{2}{*}{113,1} & 0,51 \\
\hline & & $0,94 t$ e $-\mathrm{L} / 1500$ & 112,5 & $\mathrm{~F}+\mathrm{T}^{*}+\mathrm{L}$ & $\mathrm{FT}+\mathrm{L}$ & & 0,51 \\
\hline & \multirow{2}{*}{2} & $0,64 t$ e $-L / 1500$ & 123,4 & $F+T+L$ & FT & \multirow{2}{*}{123,4} & 0,56 \\
\hline & & $0,94 \mathrm{t}$ e $-\mathrm{L} / 1500$ & 123,3 & $\mathrm{~F}+\mathrm{L}$ & $\mathrm{FT}$ & & 0,56 \\
\hline \multirow{8}{*}{$\begin{array}{c}1325 \\
\left(\lambda_{x}=70\right)\end{array}$} & \multirow{2}{*}{0} & 0,64t e -L/1500 & 80,0 & $\overline{\mathrm{L}}$ & 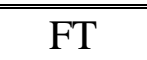 & \multirow{2}{*}{80,5} & 0,36 \\
\hline & & $0,94 \mathrm{t}$ e $-\mathrm{L} / 1500$ & 80,9 & $\mathrm{~L}$ & FT & & 0,36 \\
\hline & \multirow{2}{*}{1} & $0,64 t$ e $-\mathrm{L} / 1500$ & 99,2 & $\mathrm{~F}+\mathrm{T}^{*}+\mathrm{L}$ & FT & \multirow{2}{*}{98,3} & 0,45 \\
\hline & & $0,94 t$ e $-\mathrm{L} / 1500$ & 97,4 & $\mathrm{~F}+\mathrm{T}^{*}+\mathrm{L}$ & FT & & 0,44 \\
\hline & \multirow{2}{*}{2} & $0,64 t$ e $-L / 1500$ & 103,4 & $\mathrm{~F}+\mathrm{T}^{*}+\mathrm{L}$ & FT & \multirow{2}{*}{102,7} & 0,46 \\
\hline & & $0,94 \mathrm{t}$ e $-\mathrm{L} / 1500$ & 102,0 & $\mathrm{~F}+\mathrm{T}^{*}+\mathrm{L}$ & FT & & 0,46 \\
\hline & & $0,64 t$ e $-\mathrm{L} / 1500$ & 112,6 & $F+T+L$ & FT & & 0,51 \\
\hline & 3 & $0,94 t$ e $-\mathrm{L} / 1500$ & 110,7 & $F+T+L$ & FT & 111,7 & 0,50 \\
\hline & 0 & $0,64 t$ e -L/1500 & 59,0 & $\mathrm{~L}$ & FT & & 0,26 \\
\hline & 0 & $0,94 t$ e $-\mathrm{L} / 1500$ & 59,3 & $\mathrm{~L}$ & FT & 59,2 & 0,26 \\
\hline & & $0,64 t$ e $-\mathrm{L} / 1500$ & 90,5 & $\mathrm{~F}+\mathrm{L}$ & $\mathrm{FT}$ & & 0,40 \\
\hline & 1 & $0,94 t$ e $-\mathrm{L} / 1500$ & 87,9 & $F+L$ & FT & 89,2 & 0,39 \\
\hline 1890 & 2 & $0,64 t$ e -L/1500 & 94,3 & $\mathrm{~F}+\mathrm{FT}^{*}+\mathrm{L}$ & FT & & 0,42 \\
\hline$\left(\lambda_{x}=100\right)$ & 2 & $0,94 t$ e $-\mathrm{L} / 1500$ & 92,7 & $\mathrm{~F}+\mathrm{FT}^{*}+\mathrm{L}$ & FT & 93,5 & 0,41 \\
\hline & & $0,64 t$ e -L/1500 & 102,6 & $\mathrm{~F}+\mathrm{FT}+\mathrm{L}$ & FT & & 0,45 \\
\hline & 3 & $0,94 t$ e $-L / 1500$ & 100,6 & $\mathrm{~F}+\mathrm{FT}+\mathrm{L}$ & FT & 101,6 & 0,44 \\
\hline & 4 & $0,64 t$ e $-\mathrm{L} / 1500$ & 107,3 & $\mathrm{~F}+\mathrm{FT}+\mathrm{L}$ & FT & 1055 & 0,47 \\
\hline & 4 & $0,94 t$ e $-L / 1500$ & 103,7 & $\mathrm{~F}+\mathrm{FT}+\mathrm{L}$ & FT & 105,5 & 0,46 \\
\hline & & $0,64 t$ e $-L / 1500$ & 44,6 & $\overline{\mathrm{L}}$ & FT & & 0,18 \\
\hline & 0 & $0,94 \mathrm{t}$ e $-\mathrm{L} / 1500$ & 44,8 & $\mathrm{~L}$ & FT & 44,7 & 0,18 \\
\hline 2460 & 1 & $0,64 t$ e $-L / 1500$ & 78,9 & $\mathrm{~F}+\mathrm{FT}^{*}+\mathrm{L}$ & FT & 70 & 0,32 \\
\hline$\left(\lambda_{x}=130\right)$ & 1 & $0,94 \mathrm{t}$ e $-\mathrm{L} / 1500$ & 77,1 & $\mathrm{~F}+\mathrm{FT}^{*}+\mathrm{L}$ & $\mathrm{FT}$ & 10,0 & 0,31 \\
\hline & 2 & $0,64 t$ e $-L / 1500$ & 82,6 & $\mathrm{~F}+\mathrm{FT}^{*}+\mathrm{L}$ & FT & & 0,34 \\
\hline & 2 & $0,94 t$ e $-\mathrm{L} / 1500$ & 81,7 & $\mathrm{~F}+\mathrm{FT}^{*}+\mathrm{L}$ & FT & 82,2 & 0,33 \\
\hline
\end{tabular}


... continuação da Tabela 4.10

\begin{tabular}{|c|c|c|c|c|c|c|c|}
\hline $\begin{array}{c}\mathbf{L}_{\mathbf{r}} \\
(\mathbf{m m})\end{array}$ & $\begin{array}{c}\text { Número } \\
\text { de } \\
\text { ?resilha: }\end{array}$ & $\begin{array}{l}\text { Imperfeições } \\
\text { local e global }\end{array}$ & $\begin{array}{c}\mathbf{N}_{\text {FEM }} \\
(\mathbf{k N})\end{array}$ & $\begin{array}{l}\text { Modo } \\
\text { 2L }\end{array}$ & $\begin{array}{c}\text { Modo } \\
\text { L }\end{array}$ & $\begin{array}{c}\mathbf{N}_{\text {FEM,m }} \\
(\mathbf{k N})\end{array}$ & $\begin{array}{c}\mathbf{N}_{\exp } \\
/ \\
\mathbf{N}_{\mathbf{y}}\end{array}$ \\
\hline \multirow{4}{*}{$\begin{array}{c}2460 \\
\left(\lambda_{x}=130\right)\end{array}$} & \multirow{2}{*}{3} & $0,64 t$ e -L/1500 & 94,0 & $F+L$ & FT & \multirow{2}{*}{93,2} & 0,38 \\
\hline & & $0,94 \mathrm{t}$ e -L/1500 & 92,3 & $\mathrm{~F}+\mathrm{T}^{*}+\mathrm{L}$ & FT & & 0,38 \\
\hline & \multirow{2}{*}{4} & $0,64 t$ e $-\mathrm{L} / 1500$ & 98,1 & $F+L$ & FT & \multirow{2}{*}{97,4} & 0,40 \\
\hline & & $0,94 \mathrm{t}$ e $-\mathrm{L} / 1500$ & 96,7 & $\mathrm{~F}+\mathrm{L}$ & $\mathrm{FT}$ & & 0,39 \\
\hline \multirow{10}{*}{$\begin{array}{c}3030 \\
\left(\lambda_{x}=160\right)\end{array}$} & \multirow{2}{*}{0} & $0,64 t$ e $-L / 1500$ & 34,7 & $\mathrm{~L}$ & FT & \multirow{2}{*}{34,7} & 0,13 \\
\hline & & $0,94 \mathrm{t}$ e -L/1500 & 34,6 & $\mathrm{~L}$ & FT & & 0,13 \\
\hline & \multirow{2}{*}{1} & $0,64 t$ e $-L / 1500$ & 68,2 & $F+L$ & FT & \multirow{2}{*}{67,1} & 0,26 \\
\hline & & $0,94 \mathrm{t}$ e $-\mathrm{L} / 1500$ & 66,0 & $F+L$ & FT & & 0,25 \\
\hline & \multirow{2}{*}{2} & $0,64 t$ e $-\mathrm{L} / 1500$ & 68,5 & $\mathrm{~F}+\mathrm{FT}+\mathrm{L}$ & FT & \multirow{2}{*}{67,8} & 0,26 \\
\hline & & $0,94 \mathrm{t}$ e $-\mathrm{L} / 1500$ & 67,0 & $F+F T+L$ & FT & & 0,25 \\
\hline & \multirow{2}{*}{3} & $0,64 t$ e $-L / 1500$ & 80,1 & $F+F T+L$ & FT & \multirow{2}{*}{79,8} & 0,30 \\
\hline & & $0,94 t$ e $-L / 1500$ & 79,4 & $F+F T+L$ & FT & & 0,30 \\
\hline & \multirow{2}{*}{4} & $0,64 t$ e $-L / 1500$ & 84,7 & $\mathrm{~F}+\mathrm{FT}+\mathrm{L}^{*}$ & $\mathrm{FT}^{*}$ & \multirow{2}{*}{84,4} & 0,32 \\
\hline & & $0,94 \mathrm{t}$ e $-\mathrm{L} / 1500$ & 84,0 & $\mathrm{~F}+\mathrm{FT}+\mathrm{L}^{*}$ & FT* & & 0,32 \\
\hline \multicolumn{8}{|c|}{$\begin{array}{l}\text { t - espessura das chapas do perfil; } \\
\mathrm{L} \text { - comprimento do perfil; } \\
\mathrm{L}_{\mathrm{r}} \text { - comprimento do perfil tomado de centro a centro de ligação; } \\
\lambda_{\mathrm{x}} \text { - índice de esbeltez do perfil; } \\
\mathrm{N}_{\mathrm{FEM}} \text { - força de compressão resistente obtida na análise numérica (ANSYS); } \\
\mathrm{N}_{\mathrm{FEM}, \mathrm{m}} \text { - valor médio das forças de compressão resistentes obtidas nas análises numéricas (ANSYS); } \\
\text { Modo } 2 \mathrm{~L} \text { - modo de instabilidade referente ao perfil composto; } \\
\text { Modo L - modo de instabilidade das cantoneiras isoladas entre presilhas; } \\
\mathrm{N}_{\mathrm{y}}=\mathrm{A}_{\mathrm{ef}} \cdot f_{y} ; \quad \mathrm{A}_{\mathrm{ef}} \text { : área efetiva da seção transversal; } f_{y}=350 \mathrm{MPa} \\
\mathrm{F}=\text { instabilidade global por flexão em torno do eixo-x (de menor inércia); }\end{array}$} \\
\hline
\end{tabular}

São apresentadas, da Figura 4.20 à Figura 4.25, as configurações deformadas de alguns dos perfis analisados sob compressão excêntrica no instante em que ocorre a perda de sua capacidade resistente (escala aumentada). Por questões de espaço, apenas os perfis com duas presilhas estão apresentados neste texto - lembrando que os resultados dos demais perfis analisados se encontram no APÊNDICE E. Além das deformações, as referidas figuras mostram ainda a distribuição de tensões (von Mises) nas chapas dos perfis. 


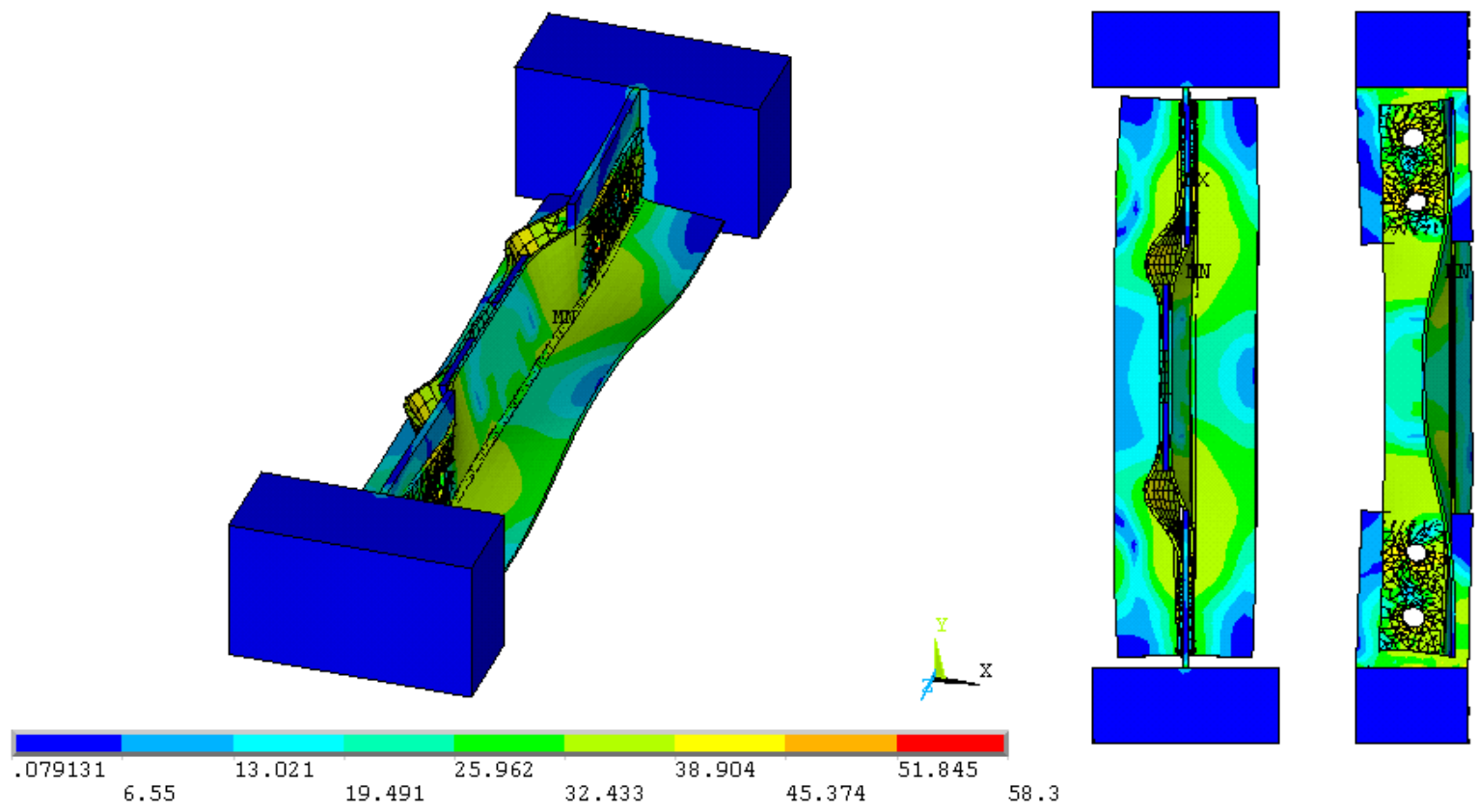

Figura 4.20 - Tensões de von Mises $\left(\mathrm{kN} / \mathrm{cm}^{2}\right)$ e deformadas (escala aumentada) no limite da capacidade resistente do perfil: $\mathbf{6 0 \times 6 0 \times 3 , 0 m m ~ - ~} \mathbf{L}_{\mathbf{r}}=\mathbf{3 8 0 m m}$ - Compressão Excêntrica.

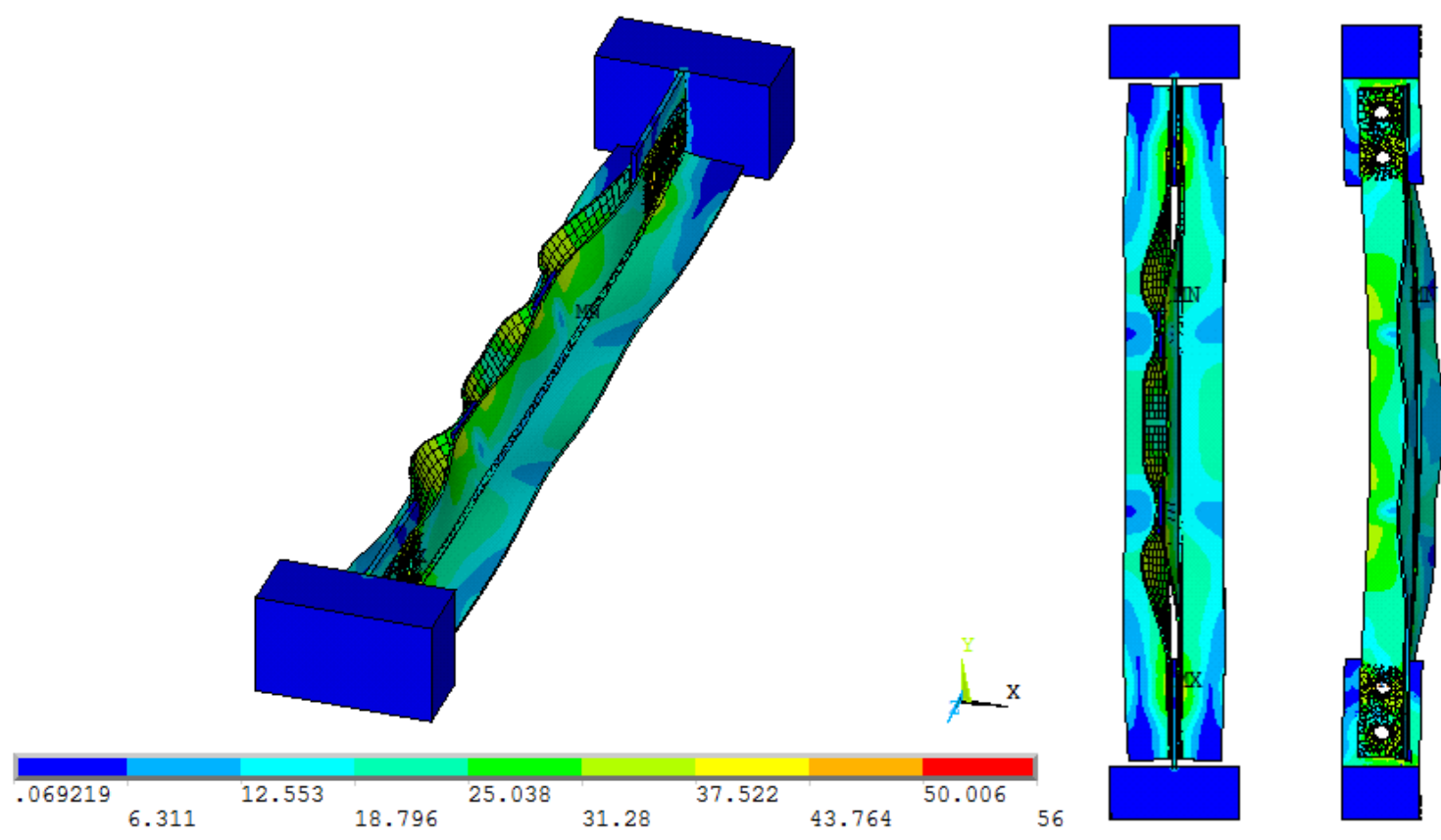

Figura 4.21 - Tensões de von Mises $\left(\mathrm{kN} / \mathrm{cm}^{2}\right)$ e deformadas (escala aumentada) no limite da capacidade resistente do perfil: 60x60x3,0mm - $\mathbf{L}_{\mathbf{r}}=\mathbf{7 5 5 m m}$ - Compressão Excêntrica. 


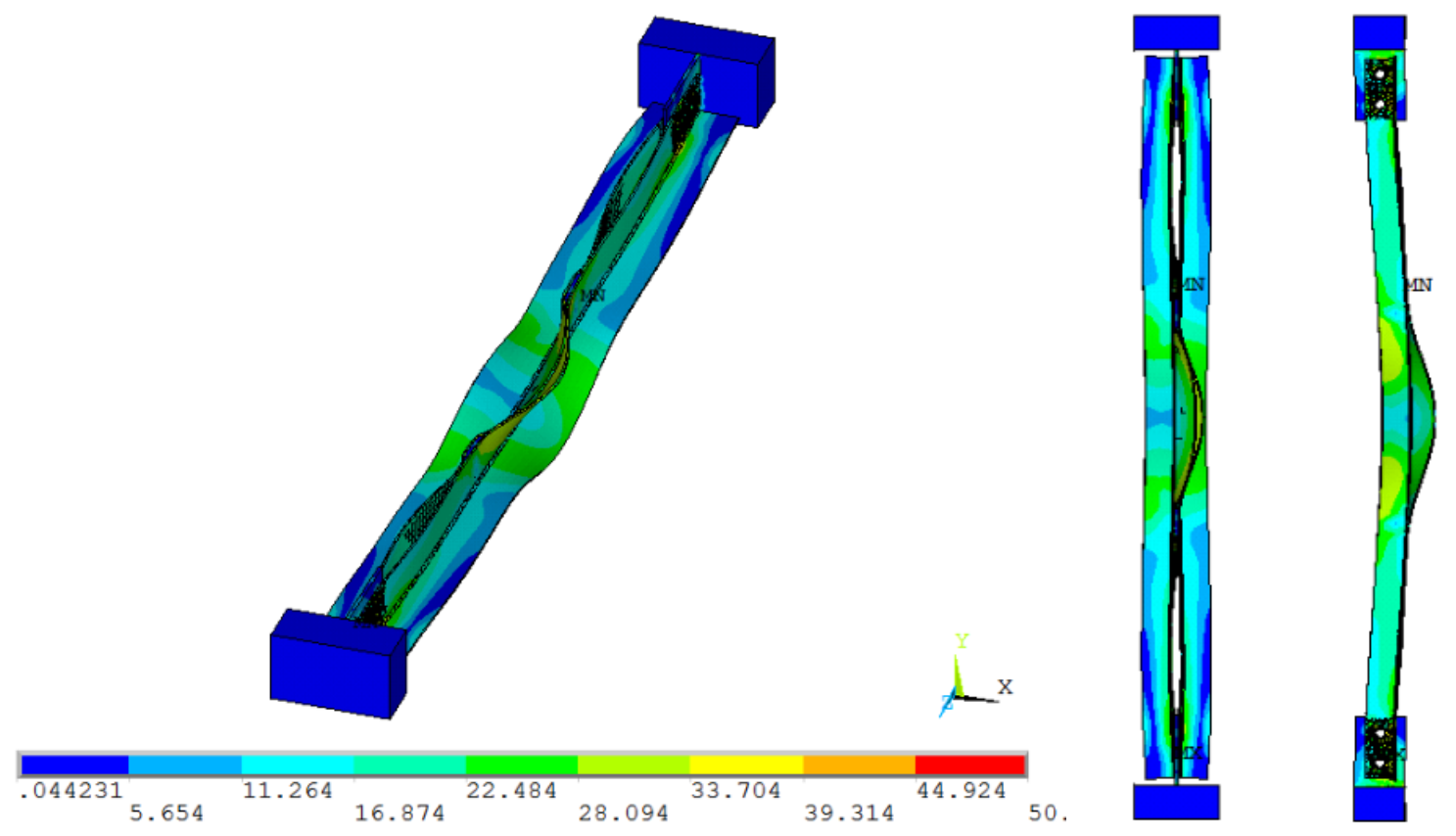

Figura 4.22 - Tensões de von Mises $\left(\mathrm{kN} / \mathrm{cm}^{2}\right)$ e deformadas (escala aumentada) no limite da capacidade resistente do perfil: $60 \times 60 \times 3,0 m m ~-~ \mathbf{L}_{\mathbf{r}}=\mathbf{1 3 2 5 m m}$ - Compressão Excêntrica.
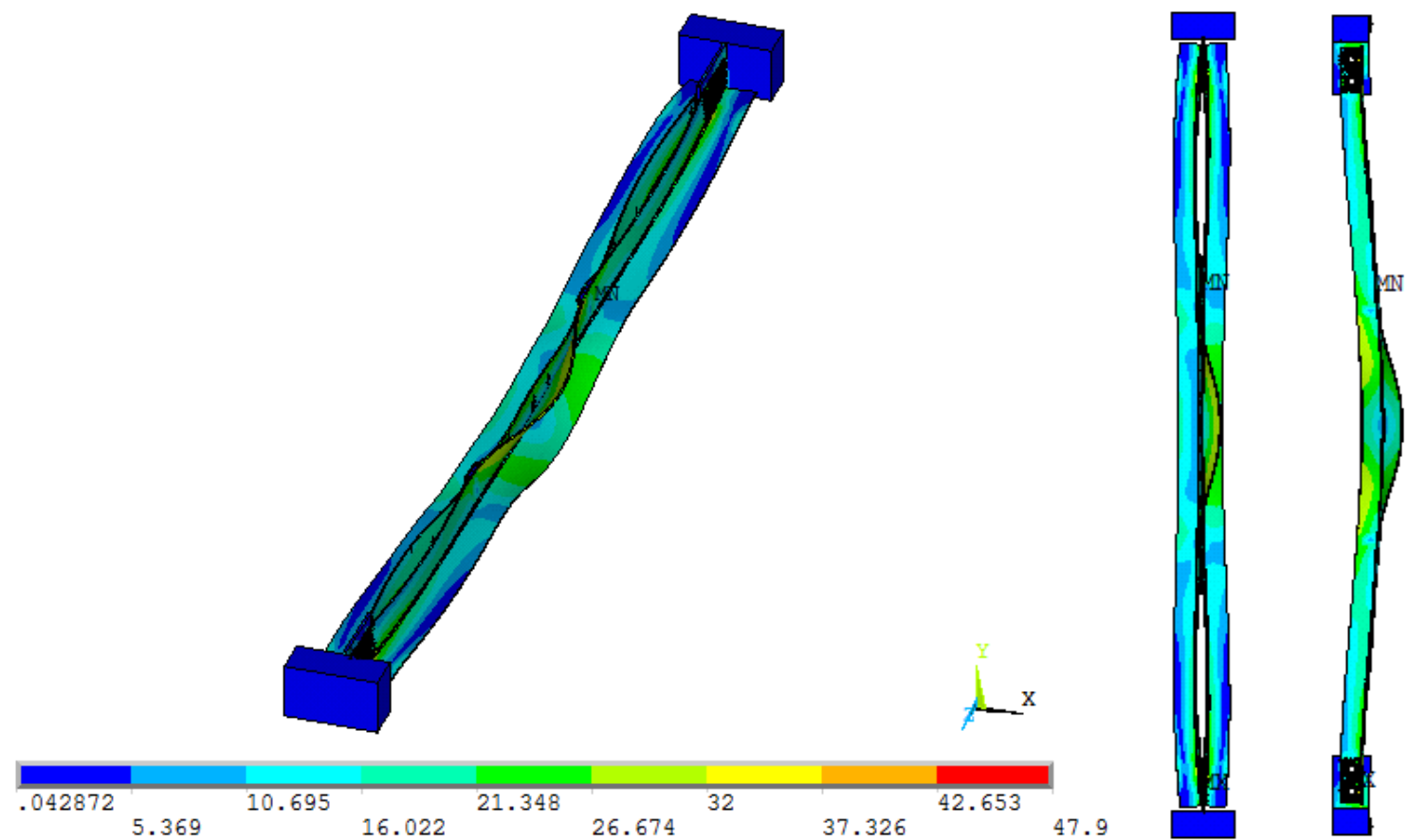

Figura 4.23 - Tensões de von Mises $\left(\mathrm{kN} / \mathrm{cm}^{2}\right)$ e deformadas (escala aumentada) no limite da capacidade resistente do perfil: $\mathbf{6 0 x 6 0 x 3 , 0 m m ~ - ~} \mathbf{L}_{\mathbf{r}}=\mathbf{1 8 9 0} \mathbf{m m}$ - Compressão Excêntrica. 


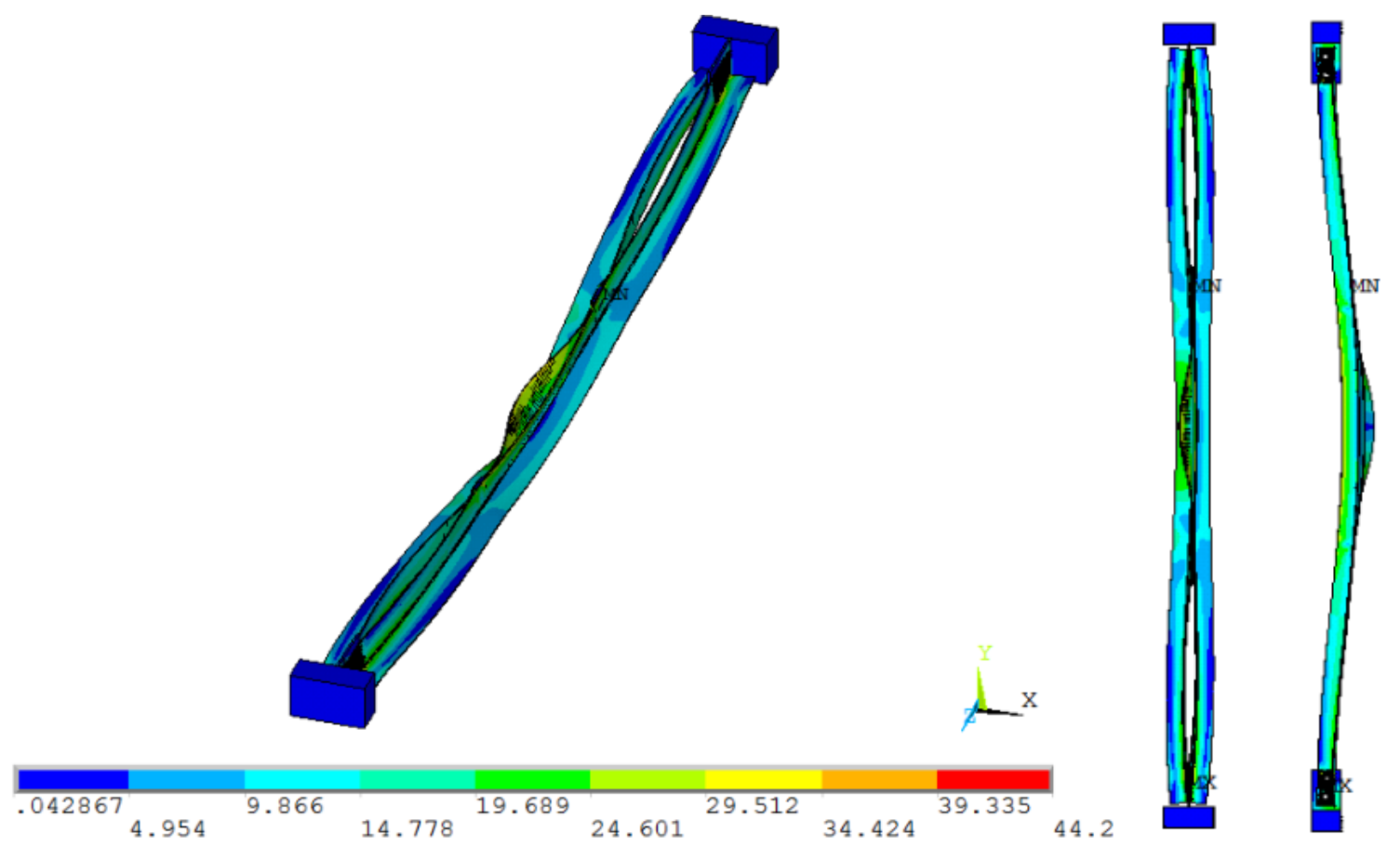

Figura 4.24 - Tensões de von Mises $\left(\mathrm{kN} / \mathrm{cm}^{2}\right)$ e deformadas (escala aumentada) no limite da capacidade resistente do perfil: $60 \times 60 \times 3,0 m m ~-~ \mathbf{L}_{\mathbf{r}}=\mathbf{2 4 6 0} \mathbf{m m}$ - Compressão Excêntrica.

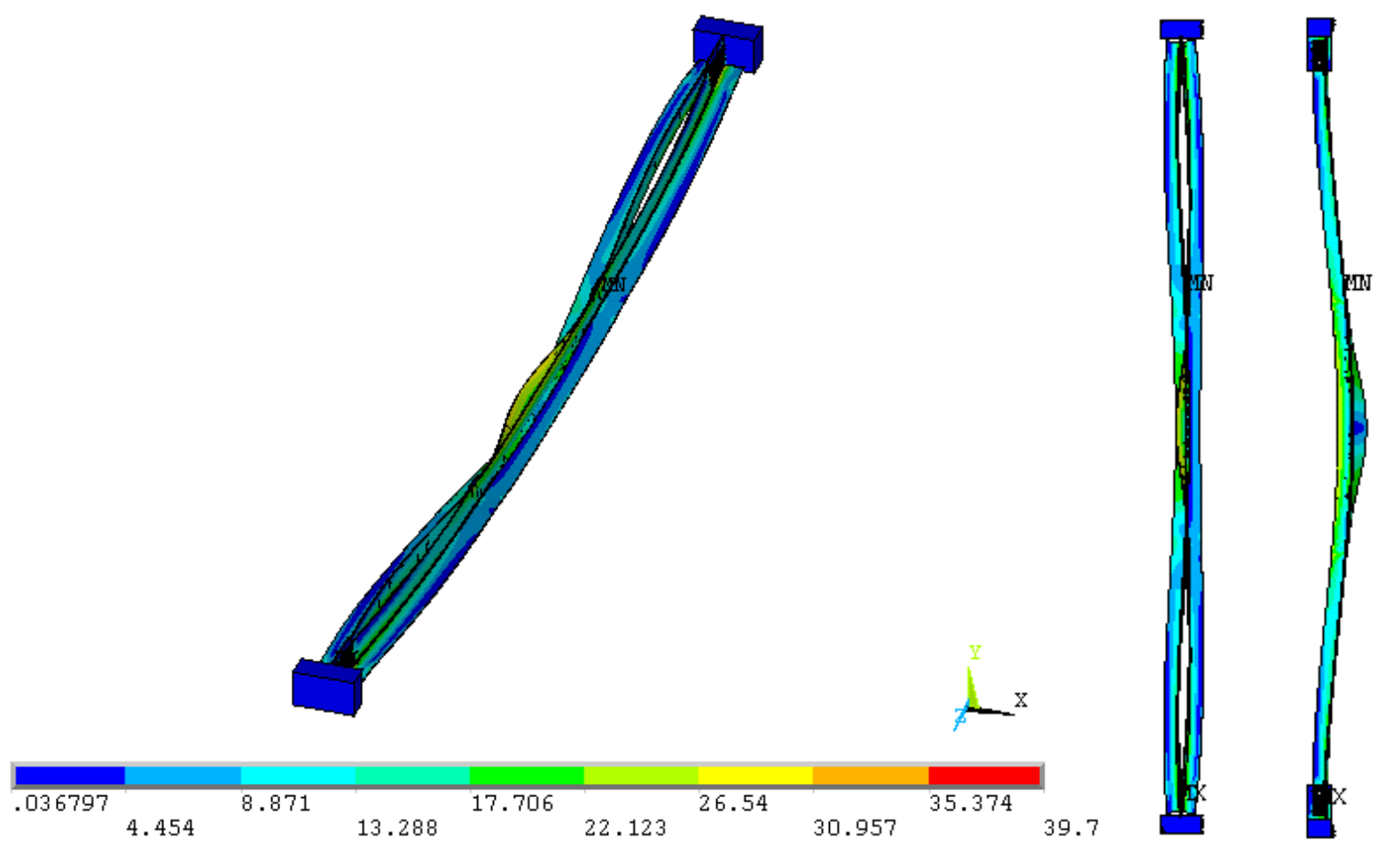

Figura 4.25 - Tensões de von Mises $\left(\mathrm{kN} / \mathrm{cm}^{2}\right)$ e deformadas (escala aumentada) no limite da capacidade resistente do perfil: $\mathbf{6 0 \times 6 0 x 3 , 0 m m ~ - ~} \mathbf{L}_{\mathbf{r}}=\mathbf{3 0 3 0} \mathbf{m m}$ - Compressão Excêntrica. 
Mais uma vez, os resultados das análises numéricas apontam grande interação dos modos de instabilidade no momento do colapso dos perfis. Porém, ao contrário dos modelos analisados sob compressão centrada, o modo global por flexo-torção da peça composta não foi predominante para os perfis com espessura igual a 3,0mm submetidos à compressão excêntrica. À exceção dos perfis menos esbeltos, onde os modos torcionais surgiram com mais clareza, o que se percebe é que o modo global de flexão em torno do eixo de menor inércia é, em conjunto com as instabilidades locais (flexo-torção das cantoneiras simples entre presilhas), o principal responsável pelo colapso do perfil.

Contudo, à medida que se aumenta a quantidade de presilhas ao longo do comprimento dos perfis, nota-se que o modo global por flexo-torção da seção composta passa a ter maior influência na estabilidade da barra, embora seu aparecimento não seja tão evidente quanto a flexão da peça (ver Figura 4.27). Com isso, fica clara a grande influência da excentricidade do carregamento na trajetória de deformações e, conseqüentemente, na resistência dos perfis analisados.

Os perfis modelados sem a inserção de presilhas são um caso à parte. Nessa situação, o comportamento dos perfis é equivalente ao comportamento de duas cantoneiras simples trabalhando individualmente, sem qualquer interação entre elas, resultando no modo global por flexo-torção característico das cantoneiras sob compressão (vide Figura 4.26).

Tal comportamento isolado reflete diretamente na resistência desses perfis, cujos valores de força de compressão resistente estão bem abaixo daqueles apresentados pelos perfis com uma ou mais presilhas, conforme Tabela 4.10. Estes resultados indicam a importância das presilhas no desempenho dos perfis dupla cantoneira em questão, não só no seu comportamento em serviço (limitação da esbeltez), mas também no referente aos Estados Limites Últimos desse elemento estrutural. 


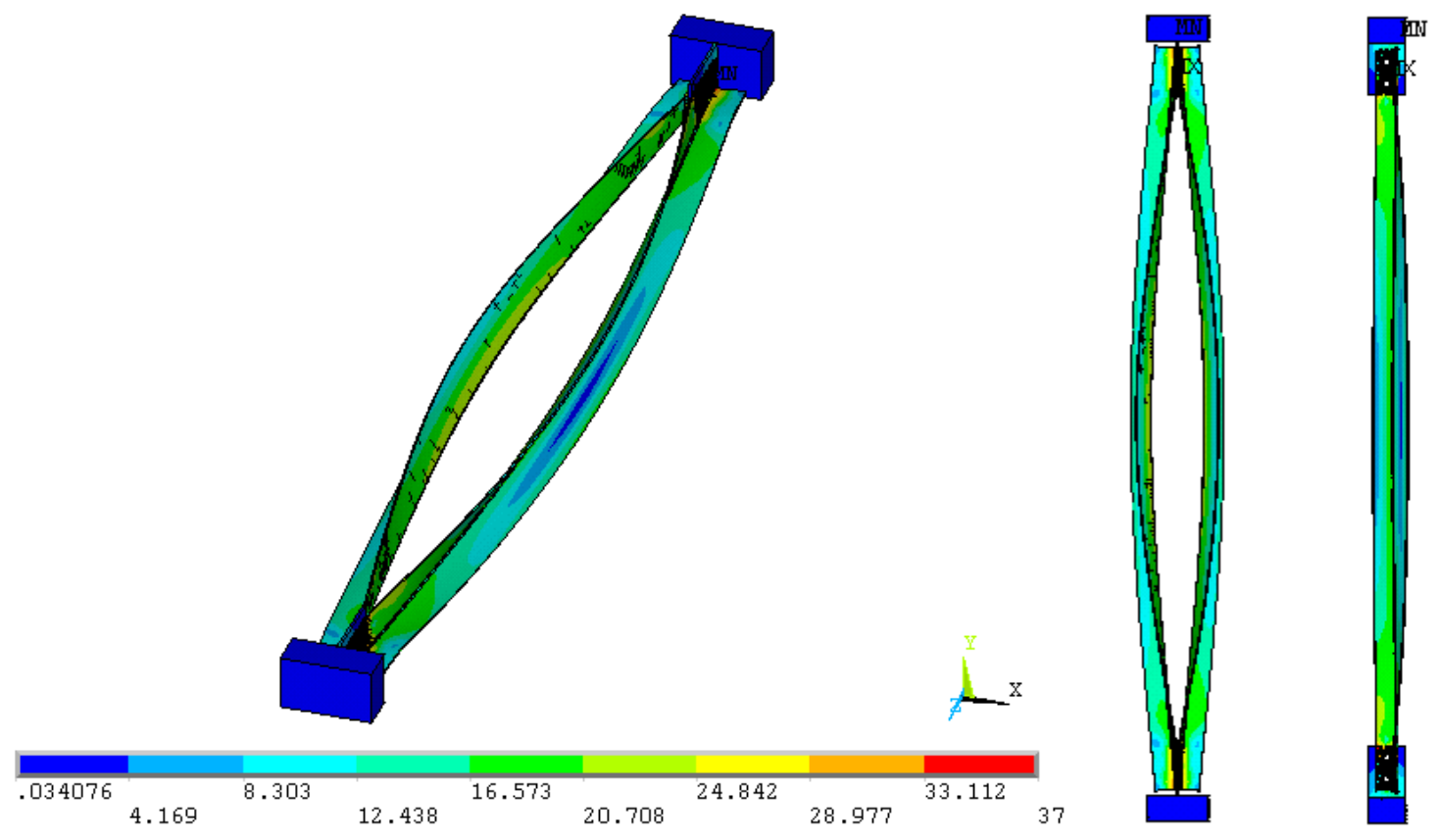

Figura 4.26 - Tensões de von Mises $\left(\mathrm{kN} / \mathrm{cm}^{2}\right)$ e deformadas (escala aumentada) no limite da capacidade resistente do perfil: $60 \times 60 \times 3,0 m m ~-~ \mathbf{L}_{\mathbf{r}}=\mathbf{1 8 9 0 m m}$ sem presilhas.
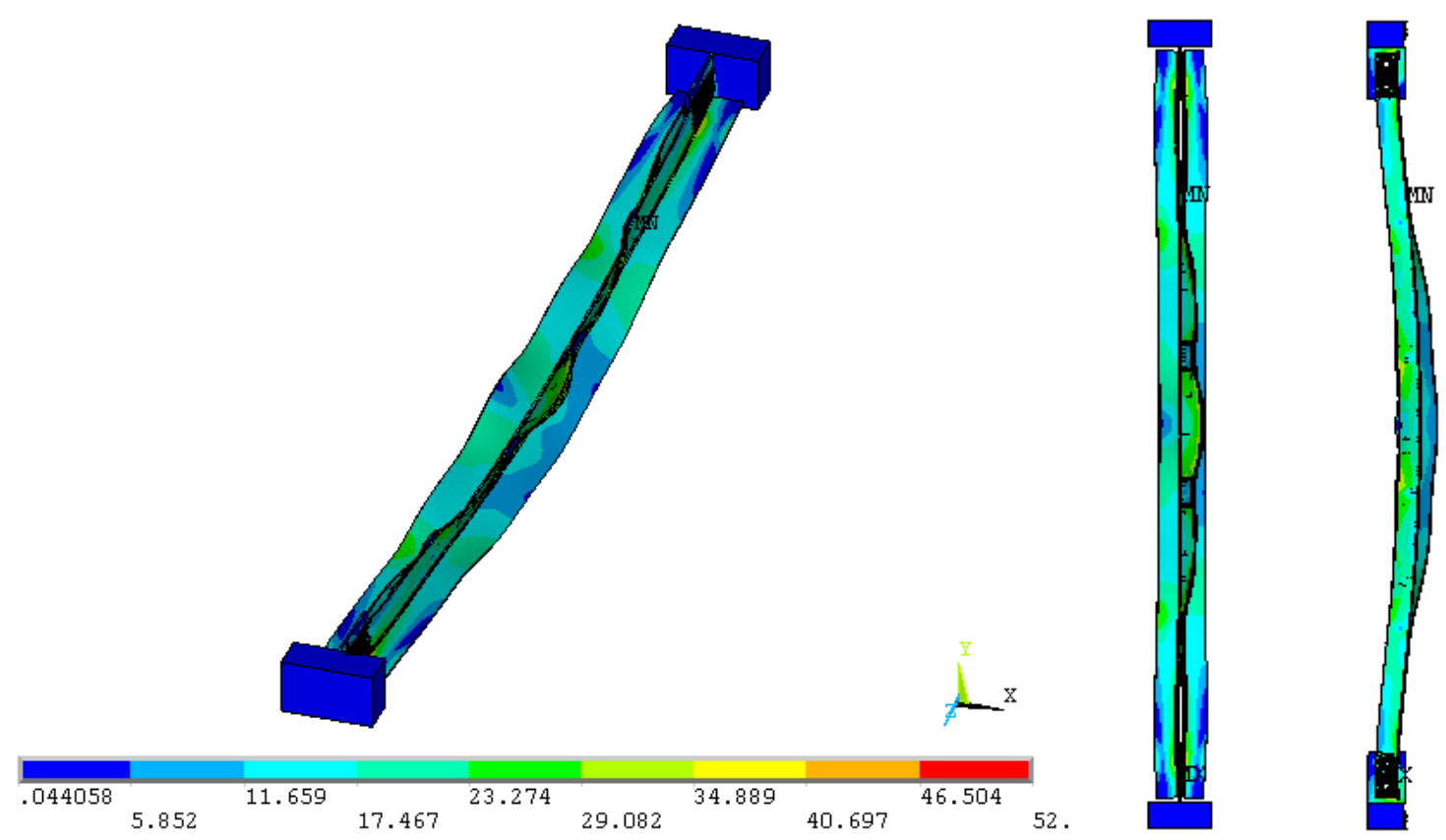

Figura 4.27 - Tensões de von Mises $\left(\mathrm{kN} / \mathrm{cm}^{2}\right.$ ) e deformadas (escala aumentada) no limite da capacidade resistente do perfil: $\mathbf{6 0 x 6 0 x 3 , 0 m m ~ - ~} \mathbf{L}_{\mathbf{r}}=\mathbf{1 8 9 0 m m}$ com 4 presilhas.

Para melhor visualização dos resultados, são mostrados nos gráficos a seguir os valores médios de resistência $\left(\mathrm{N}_{\mathrm{FEM}, \mathrm{m}}\right)$ obtidos por meio dos modelos numéricos juntamente 
com as previsões das normas ABNT NBR 14762:2010 e ANSI/AISI S100 (2007) para a força de compressão resistente destes perfis. Como a ligação parafusada não funciona como um vínculo perfeitamente engastado ou mesmo como uma rótula, o elemento estrutural foi considerado sob duas condições de vinculação distintas:

- Figura 4.28 - elemento bi-rotulado $\left(\mathrm{K}_{\mathrm{x}}=\mathrm{K}_{\mathrm{y}}=1,0\right)$, como é comum no dimensionamento de barras de treliças;

- Figura 4.29 - elemento semi-engastado em relação ao eixo de menor inércia $\left(K_{x}=0,8\right.$ e $\left.\mathrm{K}_{\mathrm{y}}=1,0\right)$, conforme sugere SCHULTE (1981).

A legenda presente nos gráficos tem o mesmo significado daquela apresentada para a compressão centrada (item 4.1.1.2), sendo considerada para a curva “NBR e AISI-F” apenas a flambagem global por flexão em torno do eixo de menor inércia. Os termos P0, P1, P2, P3 e P4 referem-se aos resultados numéricos dos perfis com 0, 1, 2, 3 e 4 presilhas, respectivamente.

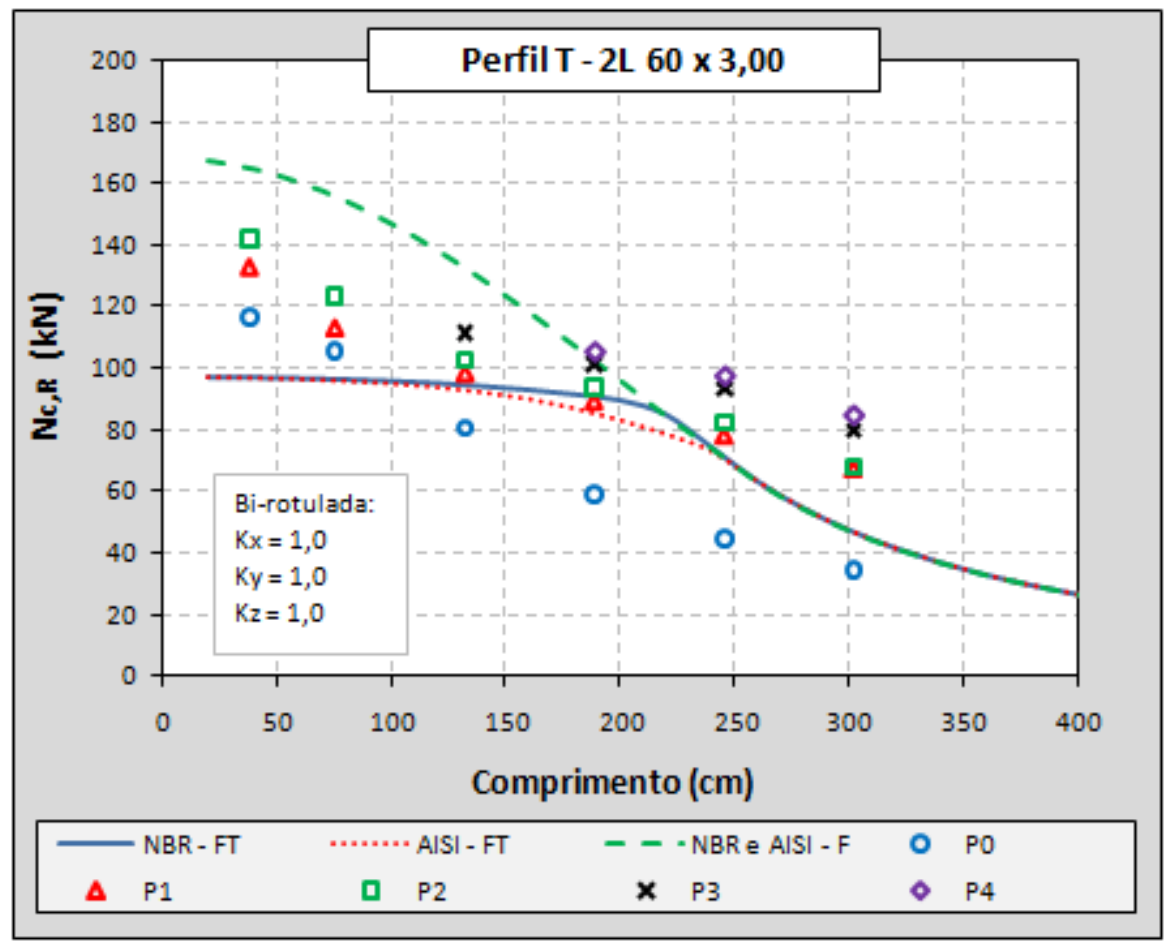

Figura 4.28 - Resistência à compressão: resultados numéricos e previsões normativas considerando $\mathrm{K}_{\mathrm{x}}=\mathrm{K}_{\mathrm{y}}=1,0$ - Compressão excêntrica. 


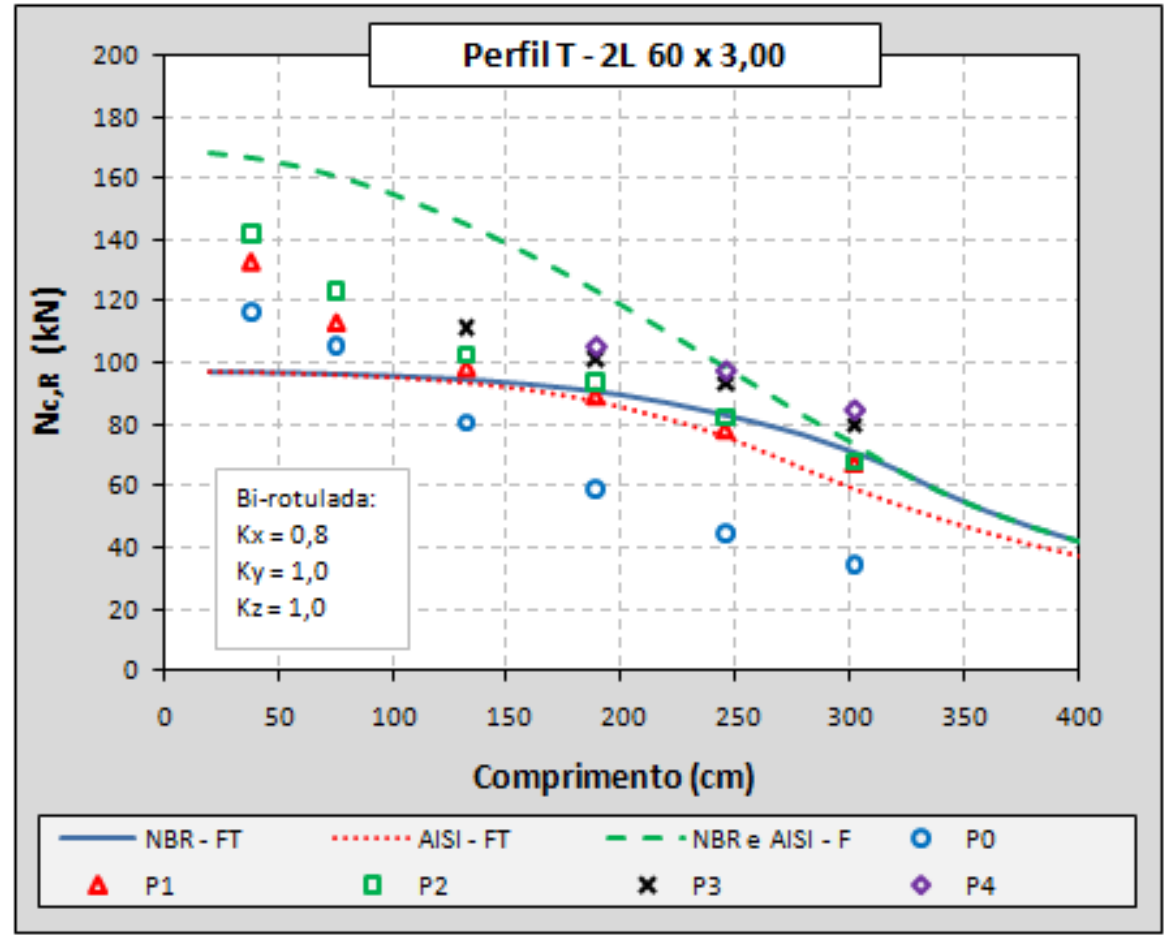

Figura 4.29 - Resistência à compressão: resultados numéricos e previsões normativas considerando $K_{x}=0,8$ e $K_{y}=1,0$ - Compressão excêntrica.

Comparando as duas opções de cálculo apresentadas nos gráficos, percebe-se que as curvas de flexo-torção resultantes das normas (curvas NBR-FT e AISI-FT) têm uma melhor aproximação com os resultados numéricos quando se consideram as ligações como sendo semi-engastada ( $\mathrm{K}_{\mathrm{x}}=0,8$ - Figura 4.29), exceto para os casos sem presilhas, que serão discutidos adiante. Outro fato importante observado é que, mais uma vez, os valores de força de compressão resistente previstos pelas prescrições normativas para os perfis com menor esbeltez global resultaram bem conservadores, embora as diferenças em relação aos resultados numéricos tenham sido bem menores do que na compressão centrada.

Como exposto anteriormente, os perfis modelados sem a inserção de presilhas ao longo do seu comprimento apresentaram comportamento bem diferente dos demais. Os gráficos da Figura 4.28 e da Figura 4.29 dão a noção da grande perda de capacidade resistente dos perfis quando da ausência dessas presilhas, o que pode ser explicado pelo fato de as cantoneiras que compõem o perfil trabalharem isoladamente nesta situação. Por esse motivo, os valores apresentados pelas análises numéricas foram também comparados com o que prevê a ABNT NBR 8800:2008, em seu Anexo E - item E.1.4, para a resistência de cantoneiras simples conectadas por uma das abas. Essa comparação pode ser visualizada por meio da 
Figura 4.30, onde se percebe boa aproximação das curvas obtidas conforme a referência com os resultados numéricos para a situação sem presilhas (pontos “P0”).

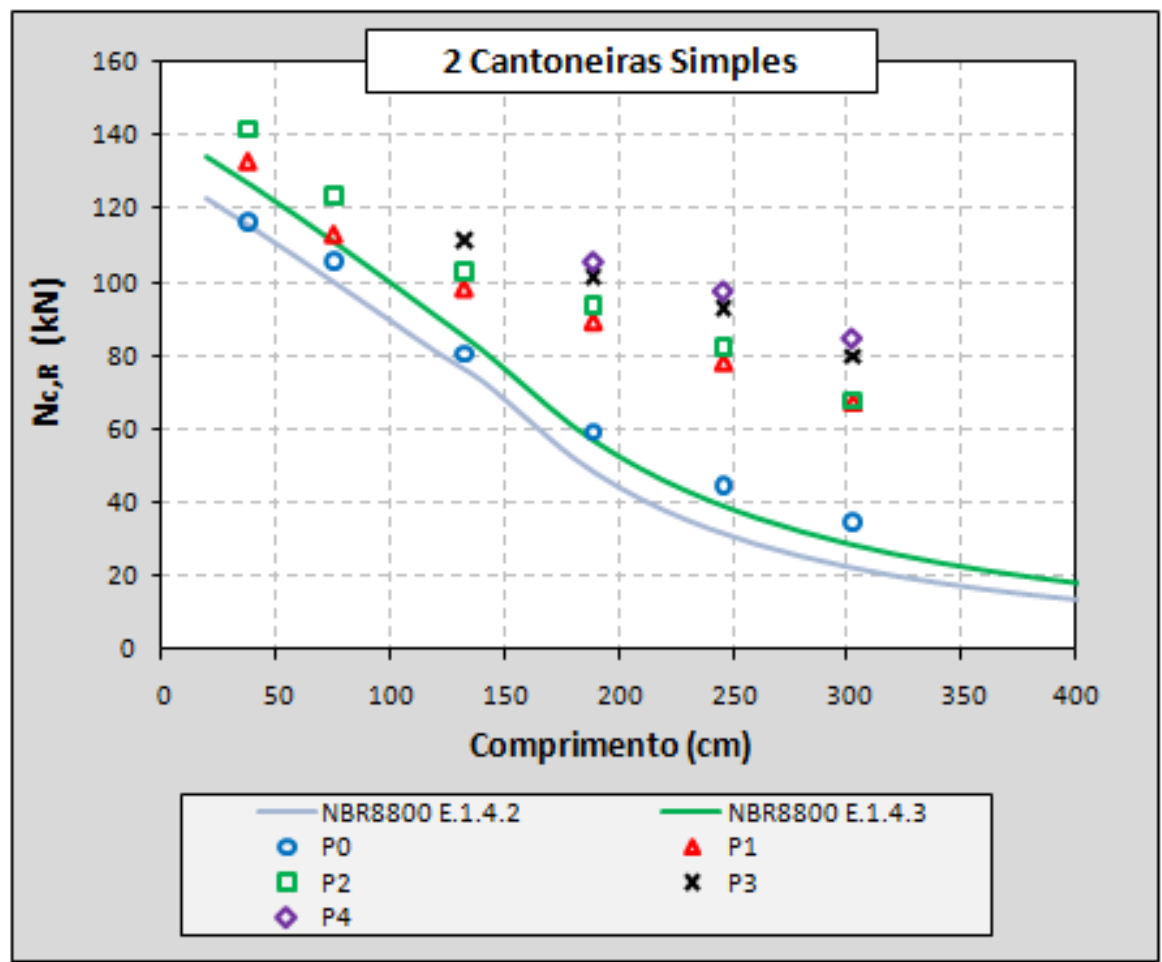

Figura 4.30 - Resistência à compressão: resultados numéricos e previsões da ABNT

NBR 8800:2008 para a resistência de duas cantoneiras simples conectadas por uma aba.

Em contrapartida, à medida que se aumenta o número de presilhas há um ganho considerável de resistência, principalmente quando se passa de um número par para um número ímpar de presilhas, conforme mostrado na Tabela 4.10 e nos gráficos anteriores. Ou seja, os resultados numéricos indicam que os perfis dupla cantoneira com seção "T" aumentam de forma significativa sua resistência à compressão quando há a inserção de uma presilha na metade do seu comprimento.

Na Figura 4.31 são ilustrados gráficos com os resultados das análises numéricas em função do número de presilhas utilizadas nos modelos. Nota-se que, exceto para os perfis menos esbeltos, há a tendência de formação de “degraus” nos gráficos que mostram de forma mais clara que o ganho de resistência é mais pronunciado nas situações com presilha posicionada na metade do vão da peça. Nesse caso, pode-se dizer que as duas presilhas especificadas pela norma brasileira ABNT NBR 14762:2010 (de acordo com os cálculos especificados) podem ser substituídas por apenas uma na metade do comprimento do perfil sem perdas significativas de resistência. 

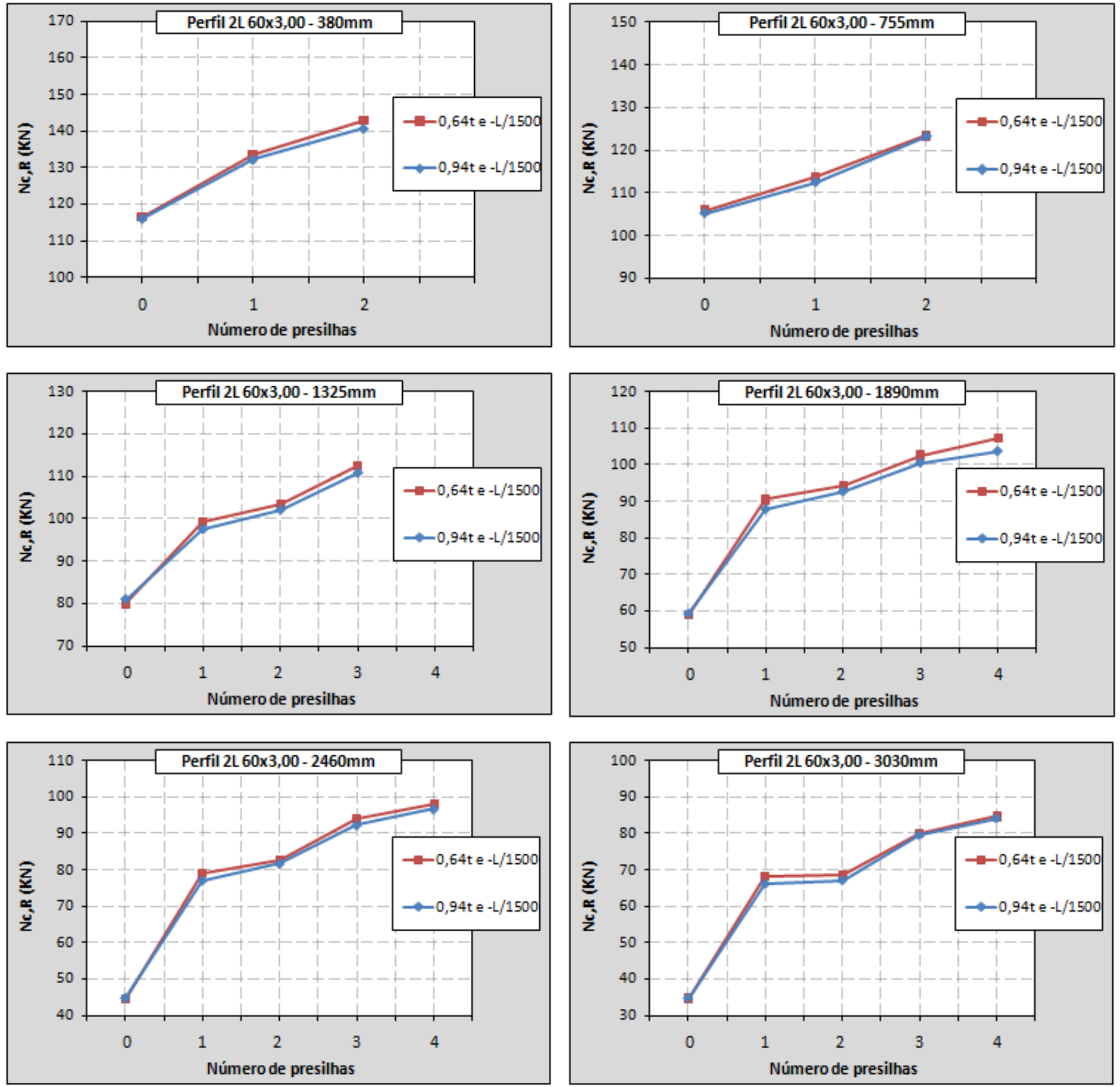

Figura 4.31 - Resistência à compressão: resultados das análises numéricas em função do número de presilhas utilizadas nos modelos - Perfil 60x60x3,0mm.

\section{- Perfis com espessura de chapa igual a $1,5 \mathrm{~mm}$}

Visando avaliar também a influência da esbeltez local, são apresentados na Tabela 4.11 os principais resultados obtidos dos perfis com seção de $60 \times 60 \times 1,5 m m$. A estratégia para a realização das análises numéricas foi a mesma adotada para os perfis com espessura de 3,0mm, incluindo as variações de esbeltez global e no número de presilhas. A única diferença foi na magnitude das imperfeições locais inseridas, sendo adotado o valor único de 0,64.t, já que as análises anteriores não apontaram grandes diferenças quando da variação dessas imperfeições. 
Tabela 4.11 - Modelos finais: resultados das análises numéricas com o perfis 60x60x1,5mm - Compressão excêntrica.

\begin{tabular}{|c|c|c|c|c|c|c|}
\hline \multicolumn{7}{|c|}{ Perfil 60x60x1,5mm - Compressão excêntrica } \\
\hline \multirow{2}{*}{$\begin{array}{c}\mathbf{L}_{\mathbf{r}} \\
(\mathbf{m m})\end{array}$} & \multirow{2}{*}{$\begin{array}{c}\text { Número } \\
\text { de } \\
\text { Presilhas }\end{array}$} & \multicolumn{4}{|c|}{ ANÁLISE NUMÉRICA } & \multirow{2}{*}{$\begin{array}{c}\mathbf{N}_{\mathrm{FEM}} \\
/ \\
\mathbf{N}_{\mathbf{y}}\end{array}$} \\
\hline & & $\begin{array}{l}\text { Imperfeições } \\
\text { local e global }\end{array}$ & $\begin{array}{c}\mathrm{N}_{\text {FEM }} \\
(\mathbf{k N})\end{array}$ & $\begin{array}{l}\text { Modo } \\
\text { 2L }\end{array}$ & $\begin{array}{c}\text { Modo } \\
\text { L }\end{array}$ & \\
\hline \multirow{3}{*}{$\begin{array}{c}575 \\
\left(\lambda_{x}=30\right)\end{array}$} & 0 & $0,64 t$ e $-\mathrm{L} / 1500$ & 41,2 & $\mathrm{~L}$ & $\mathrm{FT}+\mathrm{L}$ & 0,38 \\
\hline & 1 & $0,64 \mathrm{t}$ e $-\mathrm{L} / 1500$ & 48,0 & $\mathrm{~F}^{*}+\mathrm{L}$ & $\mathrm{L}$ & 0,45 \\
\hline & 2 & $0,64 t$ e $-\mathrm{L} / 1500$ & 49,4 & $\mathrm{~T}+\mathrm{L}$ & $\mathrm{T}+\mathrm{L}$ & 0,46 \\
\hline \multirow{4}{*}{$\begin{array}{c}1055 \\
\left(\lambda_{x}=55\right)\end{array}$} & 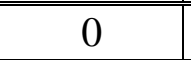 & $0,64 t$ e $-\mathrm{L} / 1500$ & 34,6 & $\overline{\mathrm{L}}$ & 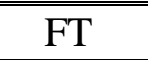 & 0,32 \\
\hline & 1 & $0,64 \mathrm{t}$ e $-\mathrm{L} / 1500$ & 40,1 & $\mathrm{~F}+\mathrm{T}^{*}+\mathrm{L}$ & FT & 0,37 \\
\hline & 2 & $0,64 t$ e $-\mathrm{L} / 1500$ & 39,5 & $\mathrm{~F}+\mathrm{T}^{*}+\mathrm{L}$ & FT & 0,37 \\
\hline & 3 & $0,64 t$ e $-\mathrm{L} / 1500$ & 39,4 & $\mathrm{~F}+\mathrm{L}$ & $\mathrm{L}$ & 0,37 \\
\hline \multirow{5}{*}{$\begin{array}{c}1625 \\
\left(\lambda_{x}=85\right)\end{array}$} & 0 & $0,64 t$ e $-\mathrm{L} / 1500$ & 24,2 & $\mathrm{~L}$ & FT & 0,22 \\
\hline & 1 & $0,64 t$ e $-\mathrm{L} / 1500$ & 31,1 & $\mathrm{~F}+\mathrm{FT}^{*}+\mathrm{L}$ & FT & 0,29 \\
\hline & 2 & $0,64 t$ e $-\mathrm{L} / 1500$ & 31,7 & $\mathrm{~F}+\mathrm{FT}^{*}+\mathrm{L}$ & FT & 0,29 \\
\hline & 3 & $0,64 t$ e $-\mathrm{L} / 1500$ & 38,2 & $\mathrm{~F}+\mathrm{FT}+\mathrm{L}$ & FT & 0,35 \\
\hline & 4 & $0,64 t$ e $-\mathrm{L} / 1500$ & 38,1 & $\mathrm{~F}+\mathrm{FT}+\mathrm{L}$ & FT & 0,35 \\
\hline \multirow{5}{*}{$\begin{array}{c}2200 \\
\left(\lambda_{x}=115\right)\end{array}$} & 0 & $0,64 \mathrm{t}$ e $-\mathrm{L} / 1500$ & 17,1 & $\mathrm{~L}$ & FT & 0,16 \\
\hline & 1 & $0,64 \mathrm{t}$ e $-\mathrm{L} / 1500$ & 24,1 & $\mathrm{~F}+\mathrm{FT}+\mathrm{L}$ & FT & 0,22 \\
\hline & 2 & $0,64 t$ e $-\mathrm{L} / 1500$ & 24,6 & $\mathrm{~F}+\mathrm{FT}+\mathrm{L}$ & FT & 0,23 \\
\hline & 3 & $0,64 t$ e -L/1500 & 29,3 & $F+F T+L$ & FT & 0,27 \\
\hline & 4 & $0,64 t$ e $-\mathrm{L} / 1500$ & 31,0 & $\mathrm{~F}+\mathrm{FT}+\mathrm{L}$ & FT & 0,28 \\
\hline \multirow{5}{*}{$\begin{array}{c}2775 \\
\left(\lambda_{x}=145\right)\end{array}$} & 0 & $0,64 t$ e $-\mathrm{L} / 1500$ & 12,6 & $\mathrm{~L}$ & FT & 0,12 \\
\hline & 1 & $0,64 t$ e $-\mathrm{L} / 1500$ & 19,4 & $\mathrm{~F}+\mathrm{FT}+\mathrm{L}$ & FT & 0,18 \\
\hline & 2 & $0,64 t$ e $-L / 1500$ & 20,3 & $\mathrm{~F}+\mathrm{FT}+\mathrm{L}$ & FT & 0,19 \\
\hline & 3 & $0,64 t$ e $-\mathrm{L} / 1500$ & 24,1 & $\mathrm{~F}+\mathrm{FT}+\mathrm{L}$ & FT & 0,22 \\
\hline & 4 & $0,64 t$ e $-\mathrm{L} / 1500$ & 24,2 & $\mathrm{~F}+\mathrm{FT}+\mathrm{L}$ & FT & 0,22 \\
\hline \multicolumn{7}{|c|}{$\begin{array}{l}\text { t - espessura das chapas do perfil; } \\
\mathrm{L} \text { - comprimento do perfil; } \\
\mathrm{L}_{\mathrm{r}} \text { - comprimento do perfil tomado de centro a centro de ligação; } \\
\lambda_{\mathrm{x}} \text { - índice de esbeltez do perfil; } \\
\mathrm{N}_{\mathrm{FEM}} \text { - força de compressão resistente obtida na análise numérica (ANSY } \\
\mathrm{N}_{\mathrm{FEM}, \mathrm{m}} \text { - valor médio das forças de compressão resistentes obtidas nas aná } \\
\text { Modo } 2 \mathrm{~L} \text { - modo de instabilidade referente ao perfil composto; } \\
\text { Modo } \mathrm{L} \text { - modo de instabilidade das cantoneiras isoladas entre presilhas; } \\
\mathrm{N}_{\mathrm{y}}=\mathrm{A}_{\mathrm{ef}} f_{y} ; \quad \mathrm{A}_{\mathrm{ef}} \text { : área efetiva da seção transversal; } f_{y}=350 \mathrm{MPa} \\
\mathrm{F}=\text { instabilidade global por flexão em torno do eixo-x (de menor inércia); } \\
\mathrm{T}=\text { instabilidade global por torção; } \\
\mathrm{FT}=\text { instabilidade global por flexo-torção; } \\
\mathrm{L}=\text { instabilidade local (de chapa); } \\
\text { * Modo de instabilidade pouco pronunciado; } \\
\text { Inst.Lig. = instabilidade da chapa de ligação. }\end{array}$} \\
\hline
\end{tabular}


Conforme comentários anteriores, o carregamento excêntrico acabou induzindo o aparecimento do modo de flexão nos perfis com espessura de chapa de 3,0mm, sendo esse, em associação com as instabilidades locais, o principal responsável pela falha da maioria dos perfis, embora os modos torcionais também tenham contribuído para a perda de sua capacidade resistente (principalmente dos menos esbeltos). No caso dos perfis compostos por cantoneiras com 1,5mm de espessura, as análises numéricas revelam um comportamento semelhante, porém, com maior interação entre os três modos de instabilidade característicos dos perfis monossimétricos (flexão, flexo-torção e local), conforme se observa da Figura 4.32 à Figura 4.36 (resultados com duas presilhas).

A maior participação dos modos torcionais nestes modelos pode ser explicada pelo fato de a inércia à torção ser diretamente proporcional ao cubo da espessura das chapas que compõem a seção do perfil, podendo qualquer variação nessa espessura ser determinante para a ocorrência mais ou menos pronunciada da flexo-torção. Além disso, a elevação da esbeltez local torna os perfis mais susceptíveis a instabilidades localizadas (que corresponde à flexotorção das cantoneiras entre presilhas), especialmente na região central da barra, que é o local onde surgem os maiores esforços de flexão devidos à imperfeição global e à excentricidade do carregamento.
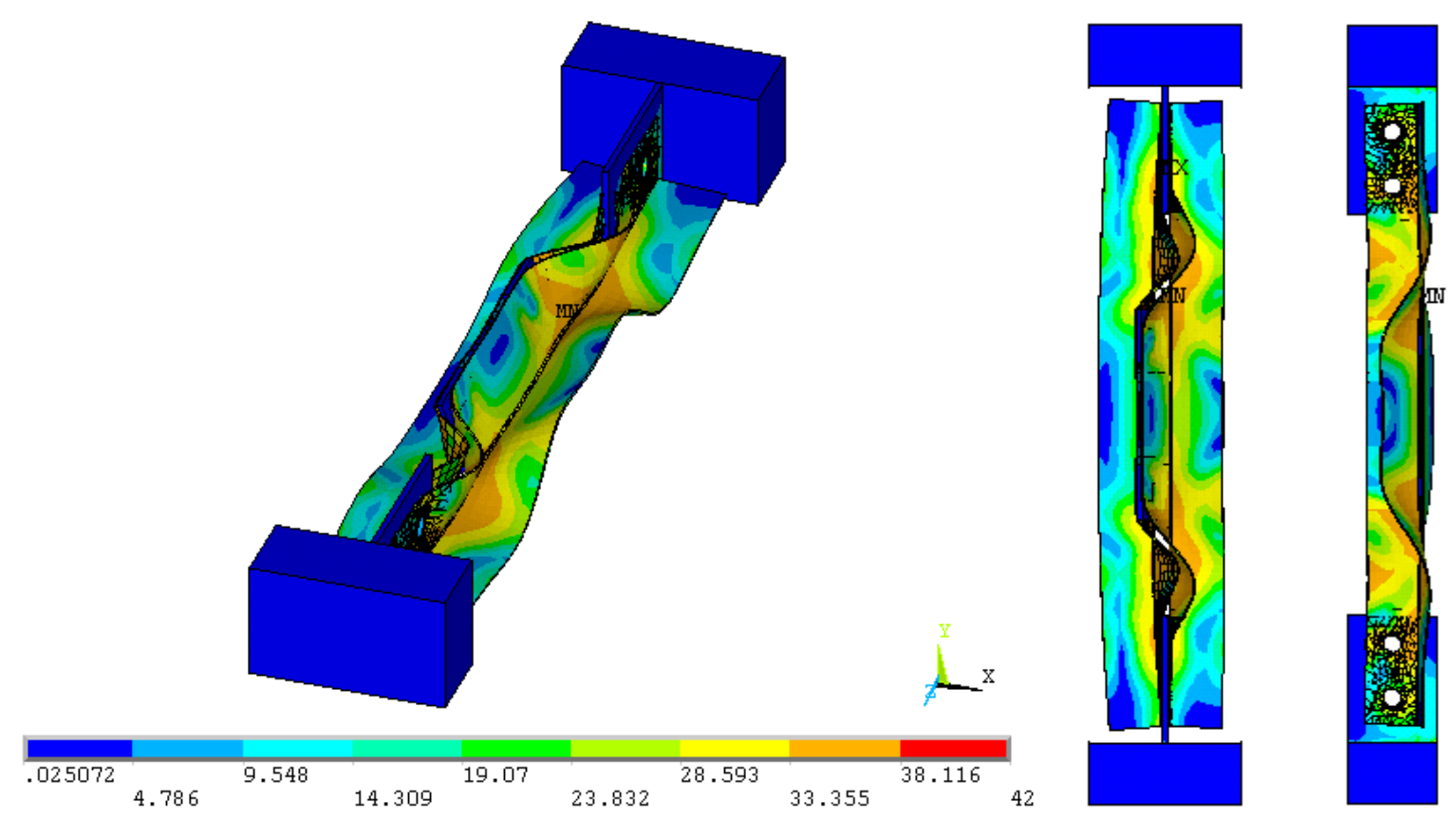

Figura 4.32 - Tensões de von Mises $\left(\mathrm{kN} / \mathrm{cm}^{2}\right)$ e deformadas (escala aumentada) no limite da capacidade resistente do perfil: $\mathbf{6 0 x 6 0 x 1 , 5 m m ~ - ~} \mathbf{L}_{\mathbf{r}}=\mathbf{5 7 5 m m}-$ Compressão Excêntrica. 


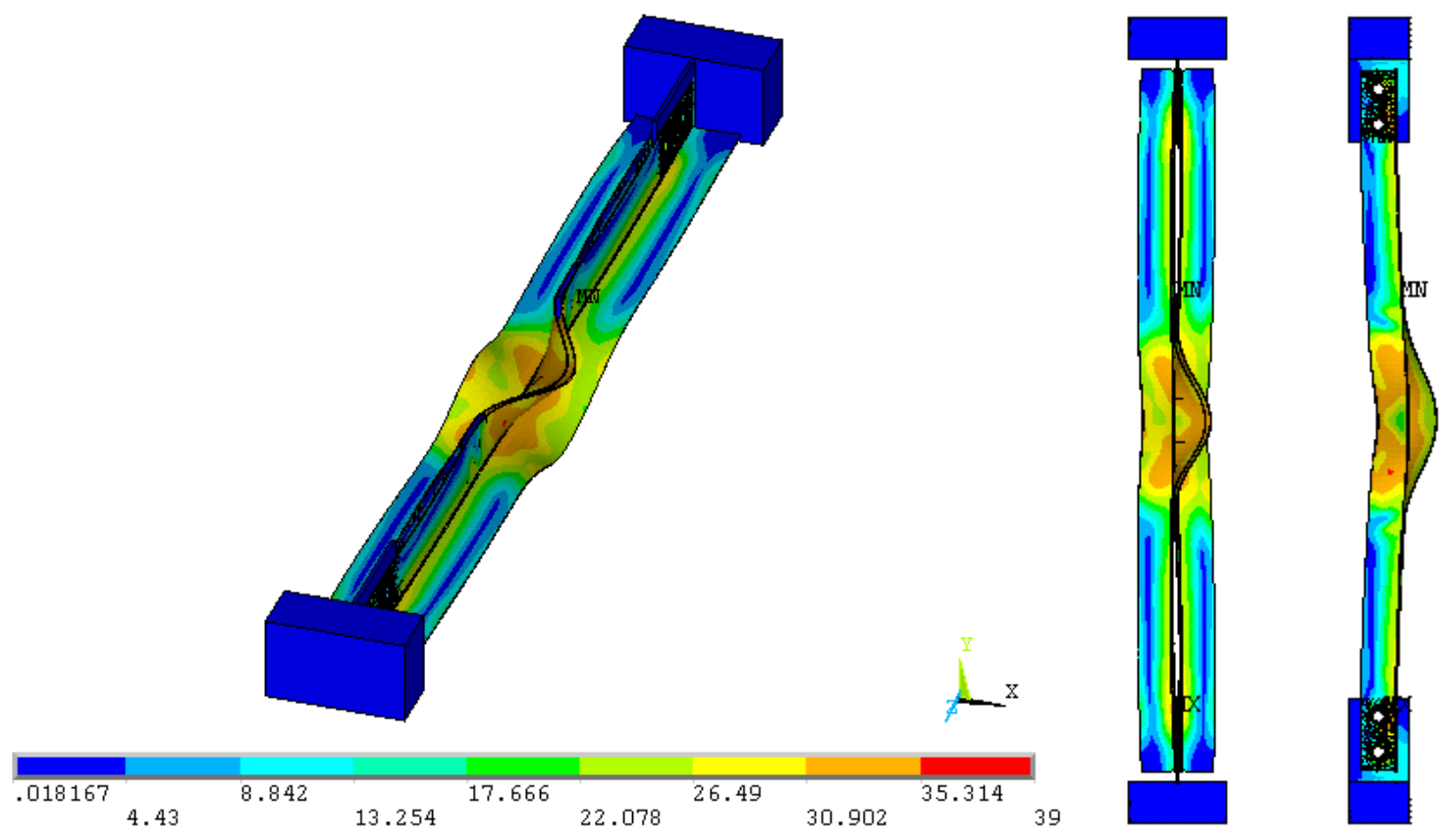

Figura 4.33 - Tensões de von Mises $\left(\mathrm{kN} / \mathrm{cm}^{2}\right)$ e deformadas (escala aumentada) no limite da capacidade resistente do perfil: $60 \times 60 \times 1,5 m m ~-~ \mathbf{L}_{\mathbf{r}}=\mathbf{1 0 5 5 m m}$ - Compressão Excêntrica.
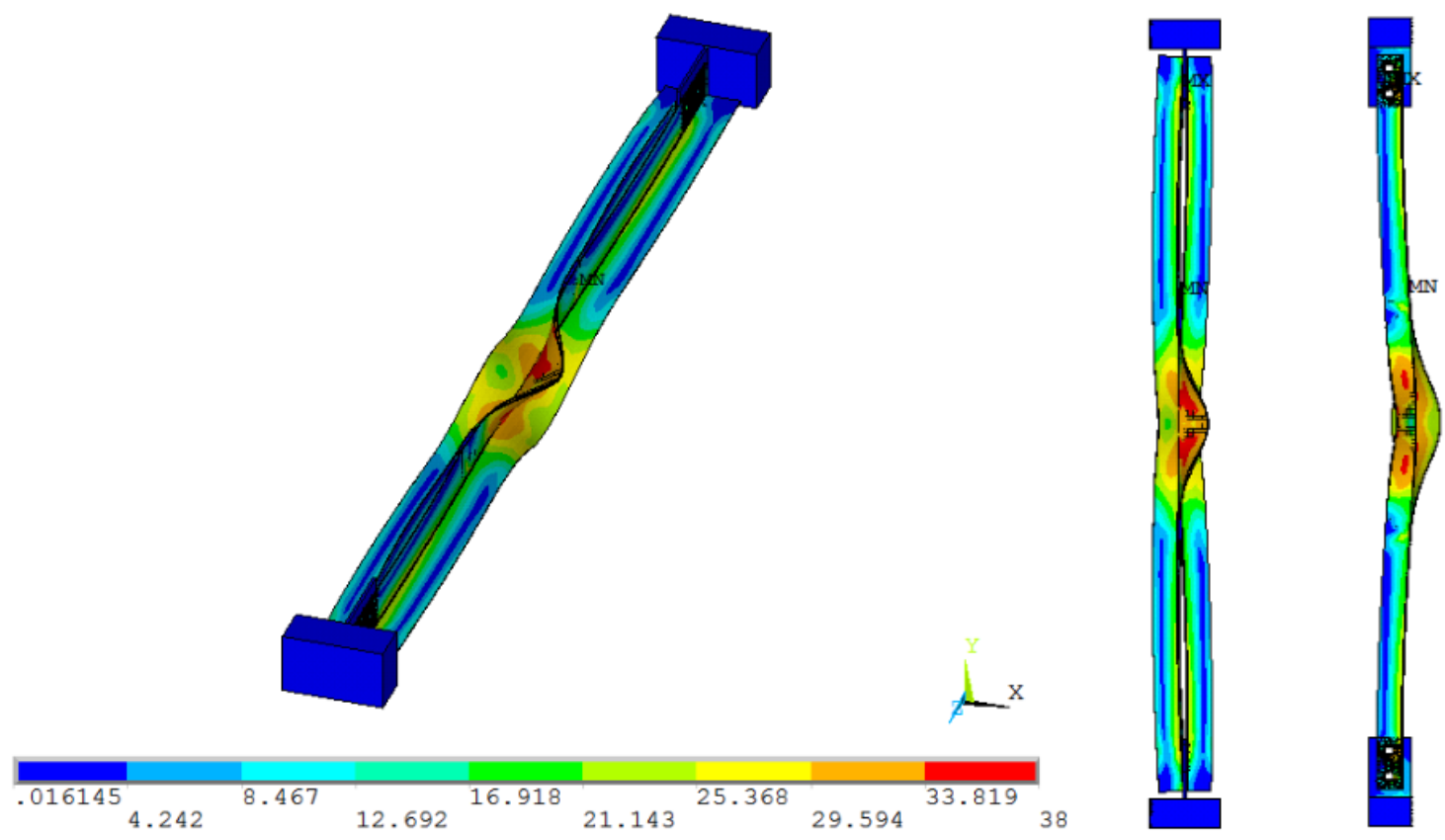

Figura 4.34 - Tensões de von Mises $\left(\mathrm{kN} / \mathrm{cm}^{2}\right)$ e deformadas (escala aumentada) no limite da capacidade resistente do perfil: $60 \times 60 \times 1,5 m m ~-~ \mathbf{L}_{\mathbf{r}}=\mathbf{1 6 2 5 m m}$ - Compressão Excêntrica. 


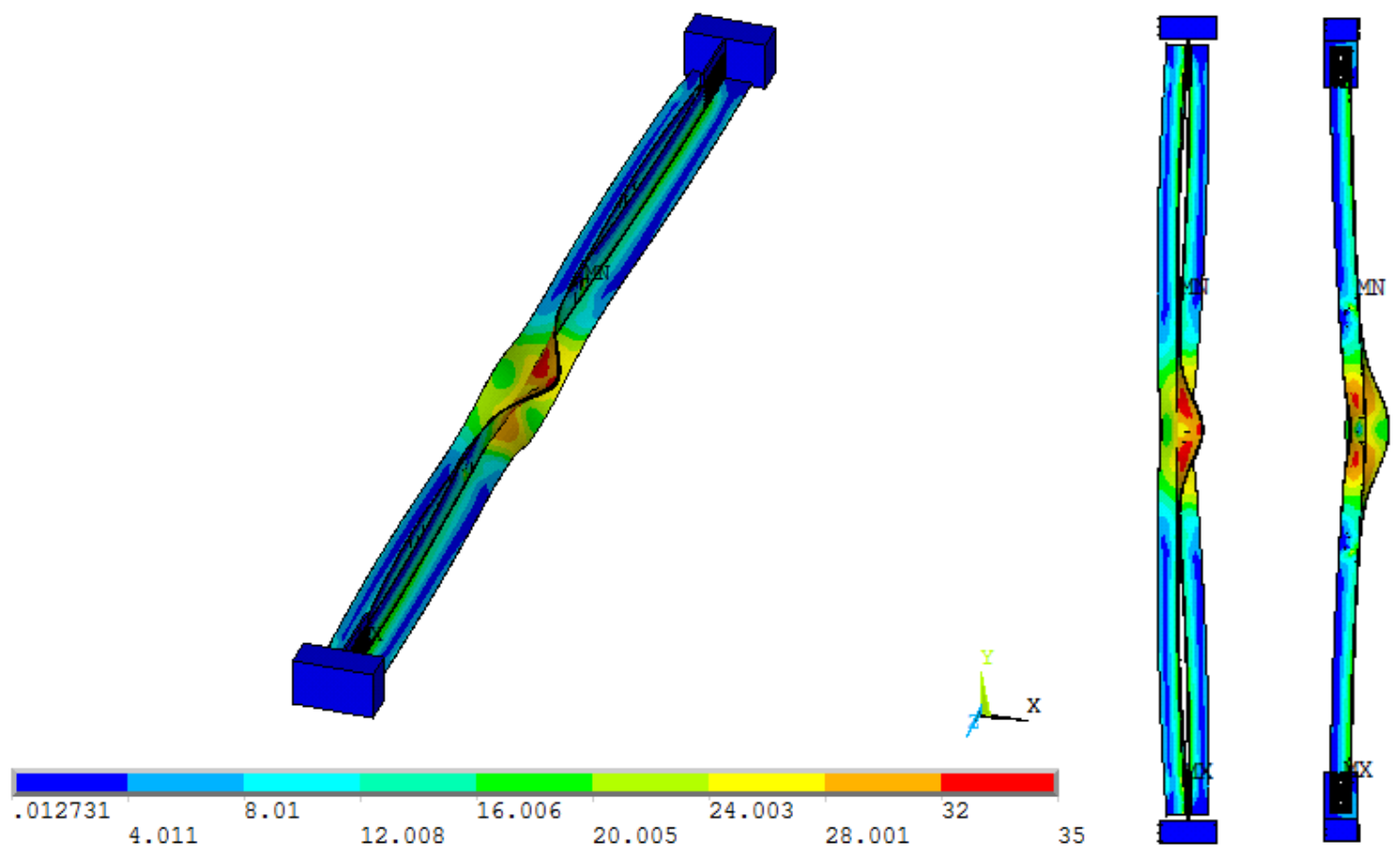

Figura 4.35 - Tensões de von Mises $\left(\mathrm{kN} / \mathrm{cm}^{2}\right)$ e deformadas (escala aumentada) no limite da capacidade resistente do perfil: $\mathbf{6 0 \times 6 0 x 1 , 5 m m ~ - ~} \mathbf{L}_{\mathbf{r}}=\mathbf{2 2 0 0 m m}$ - Compressão Excêntrica.

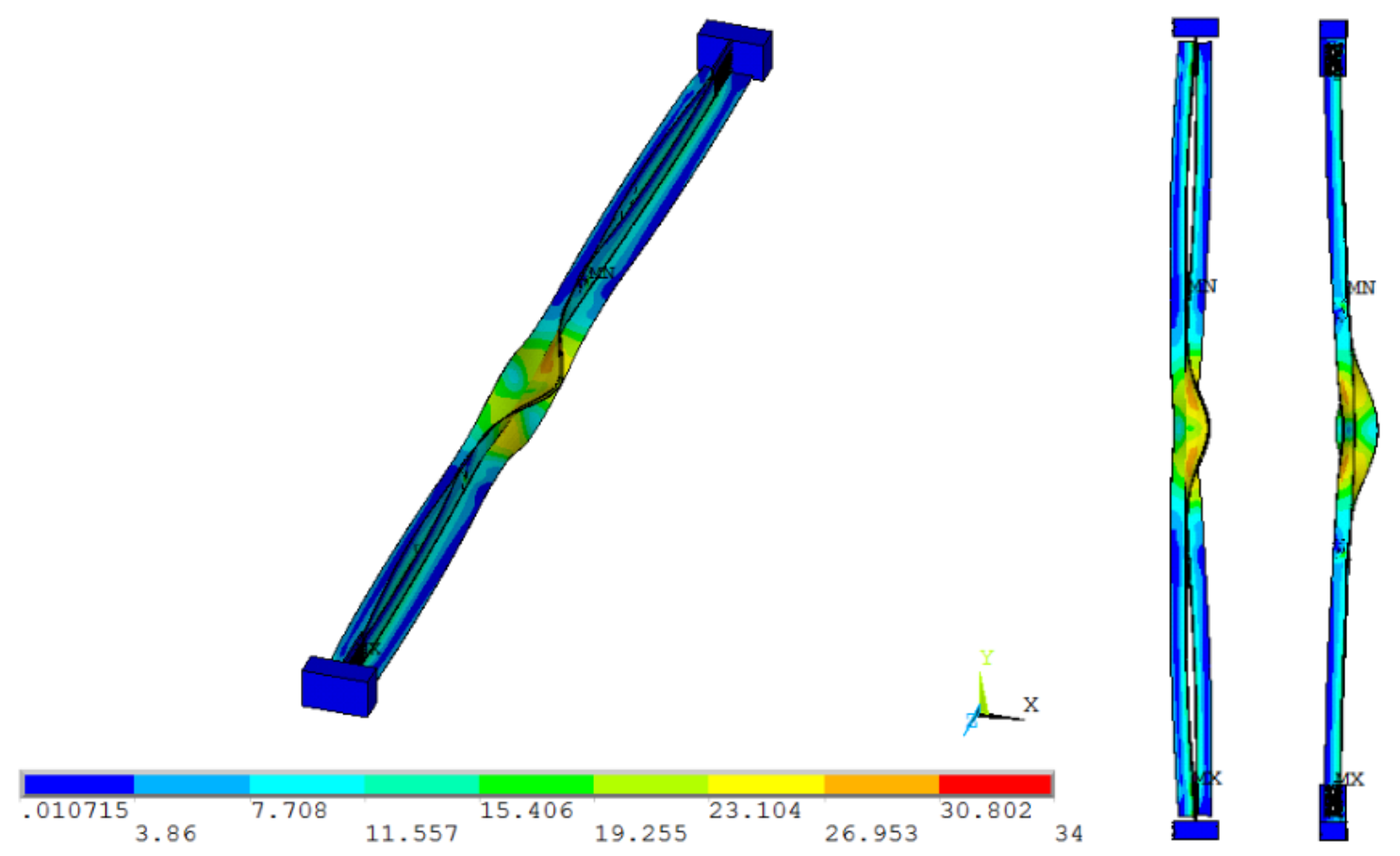

Figura 4.36 - Tensões de von Mises $\left(\mathrm{kN} / \mathrm{cm}^{2}\right)$ e deformadas (escala aumentada) no limite da capacidade resistente do perfil: 60x60x1,5mm - $\mathbf{L}_{\mathbf{r}}=\mathbf{2 7 7 5 m m}$ - Compressão Excêntrica.

Quanto à influência das presilhas nos modos de instabilidade, os resultados mostram o que já era esperado: o aumento do número de presilhas reduz o comportamento isolado das 
cantoneiras que compõem os perfis, que tendem a trabalhar como uma peça única (se aproximam do comportamento de um perfil “T”), conforme pode ser observado comparando a Figura 4.37 e a Figura 4.38.
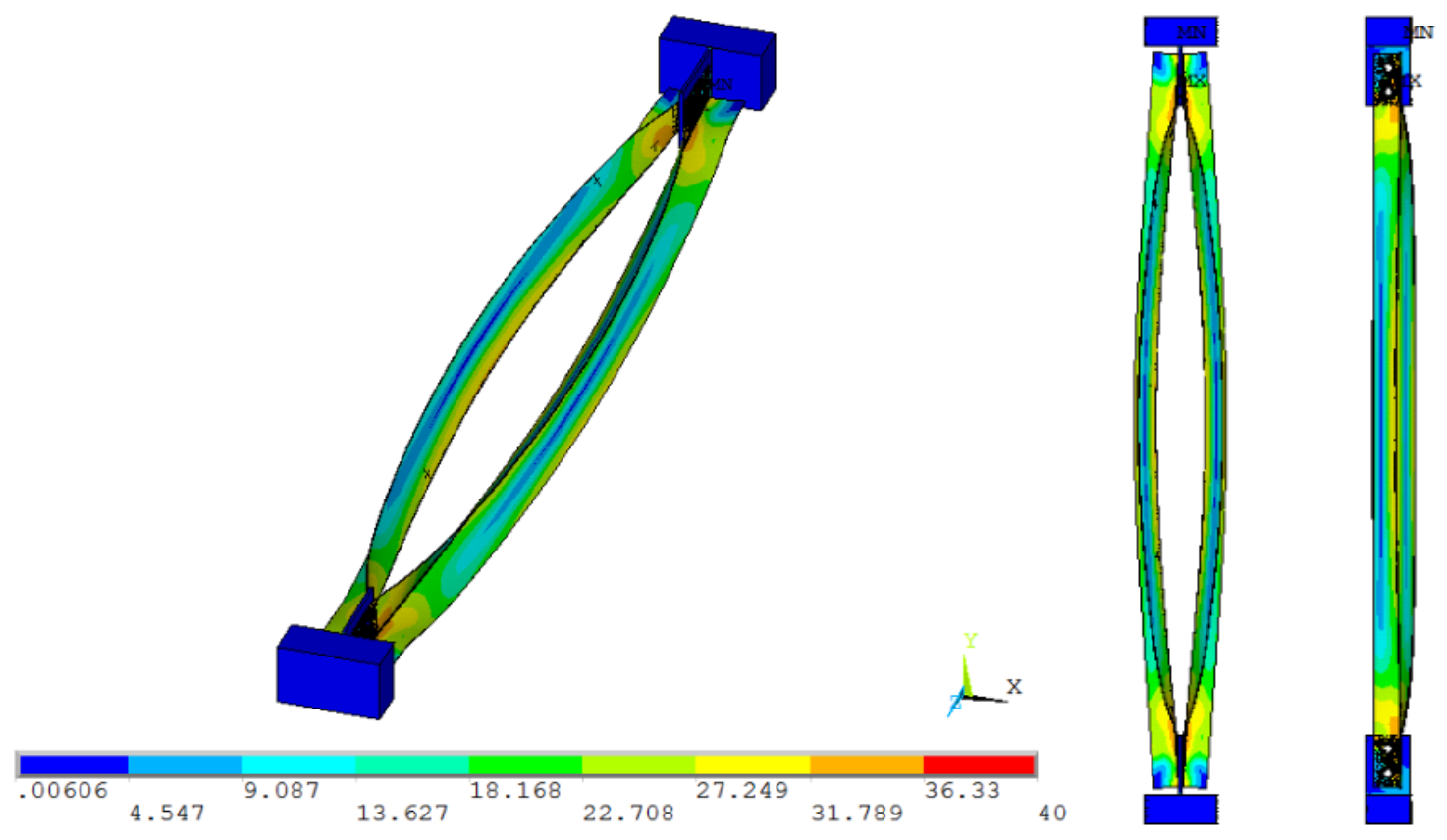

Figura 4.37 - Tensões de von Mises $\left(\mathrm{kN} / \mathrm{cm}^{2}\right)$ e deformadas (escala aumentada) no limite da capacidade resistente do perfil: $\mathbf{6 0 x 6 0 \times 1 , 5 m m ~ - ~} \mathbf{L}_{\mathbf{r}}=\mathbf{1 6 2 5 m m}$ sem presilhas.
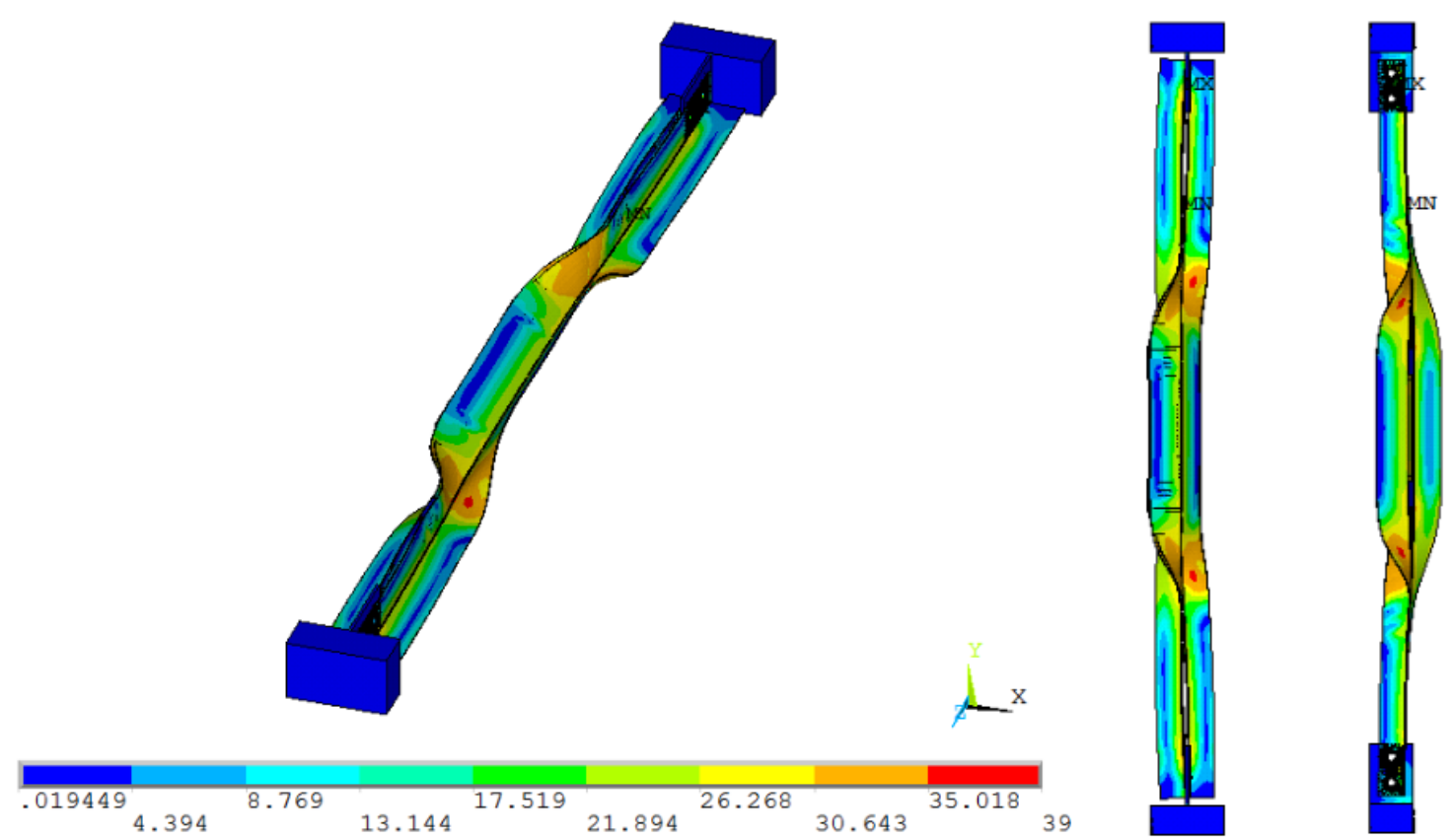

Figura 4.38 - Tensões de von Mises $\left(\mathrm{kN} / \mathrm{cm}^{2}\right)$ e deformadas (escala aumentada) no limite da capacidade resistente do perfil: $\mathbf{6 0 x 6 0 \times 3 , 0 m m ~ - ~} \mathbf{L}_{\mathbf{r}}=\mathbf{1 6 2 5 m m}$ com 4 presilhas. 
De forma semelhante ao que foi feito para os perfis com espessura de chapa igual a 3,0mm, são mostrados nos gráficos da Figura 4.39 e da Figura 4.40 os valores de resistência $\left(\mathrm{N}_{\mathrm{FEM}}\right)$ obtidos por meio dos modelos numéricos juntamente com as previsões das normas ABNT NBR 14762:2010 e ANSI/AISI S100 (2007) para a força de compressão resistente destes perfis. Os termos presentes nos gráficos têm o mesmo significado descrito anteriormente.

Como se pode observar, a redução da espessura das chapas faz com que os valores da força de compressão resistente calculados de acordo com as normas (curvas NBR-FT e AISIFT) resultem bem inferiores aos resultados alcançados por meio das análises numéricas, que tendem a valores intermediários às curvas de flexão e de flexo-torção. Neste caso, a utilização do coeficiente de flambagem $K_{x}=0,8$ (Figura 4.40) não reduz as diferenças encontradas entre os resultados teóricos e os numéricos em razão de os perfis analisados estarem dentro da faixa de esbeltez em que o dimensionamento feito com base nas prescrições normativas é comandado pela flexo-torção em vez da flexão.

Enfim, os resultados da modelagem numérica realizada no presente trabalho indicam que os valores de força de compressão resistente previstos pelas normas para os perfis dupla cantoneira com seção “T” podem resultar bastantes conservadores, principalmente no caso de perfis curtos e com elevada esbeltez local.

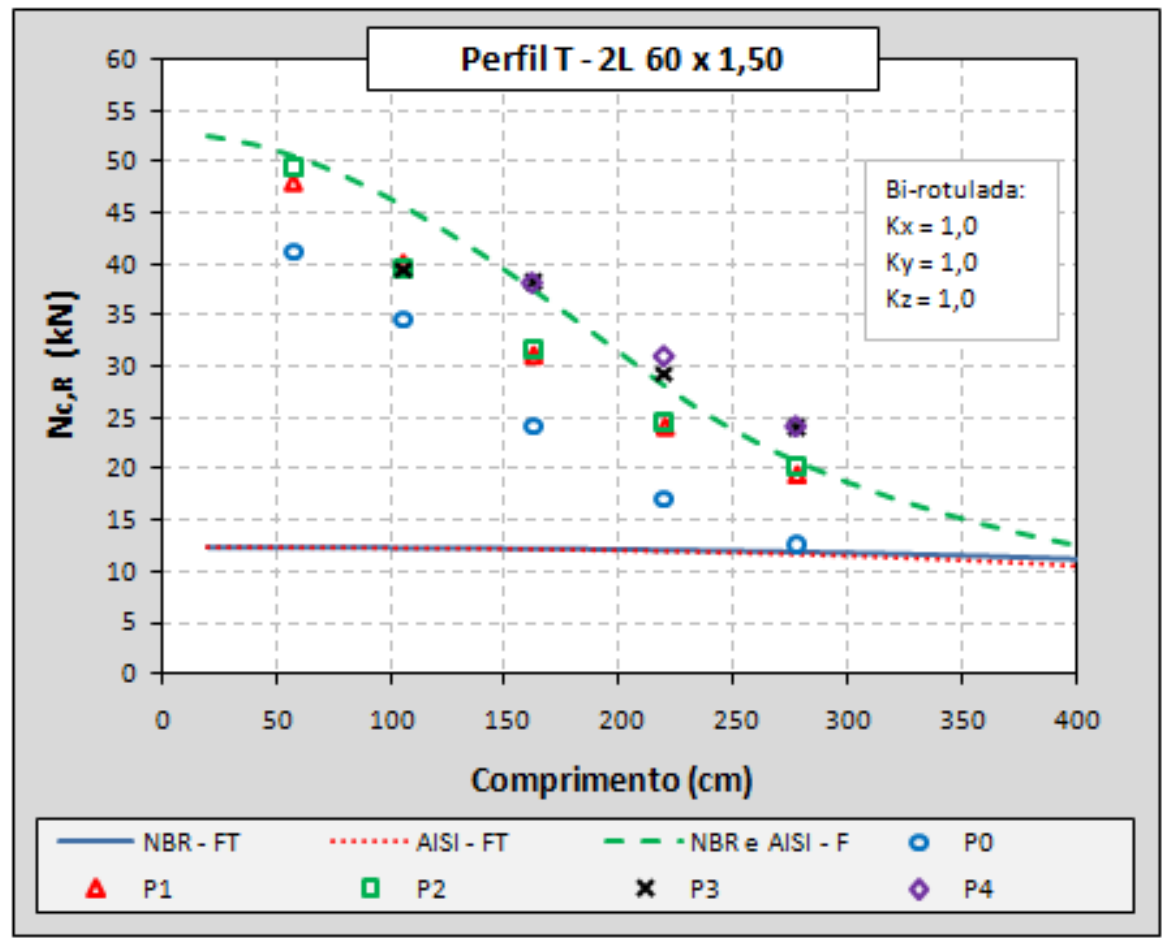

Figura 4.39 - Resistência à compressão: resultados numéricos e previsões normativas considerando $\mathrm{K}_{\mathrm{x}}=\mathrm{K}_{\mathrm{y}}=1,0$ - Compressão excêntrica. 


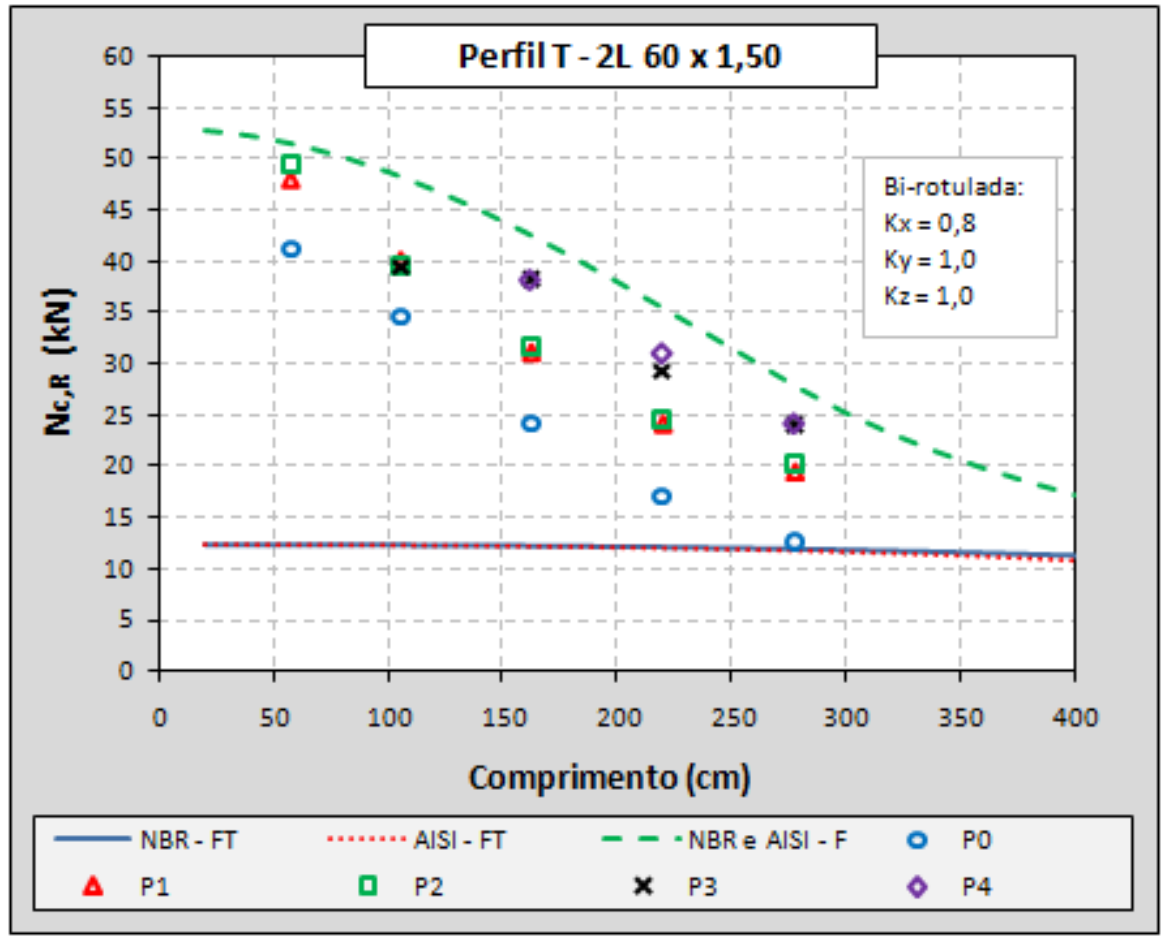

Figura 4.40 - Resistência à compressão: resultados numéricos e previsões normativas considerando $K_{x}=0,8$ e $K_{y}=1,0$ - Compressão excêntrica.

Assim como nos perfis com espessura de chapa igual a 3,0mm, a ausência de presilhas resultou numa queda brusca na resistência dos perfis com chapas iguais a 1,5mm. Novamente, observa-se que o comportamento dos perfis nessa situação corresponde exatamente ao de duas cantoneiras simples resistindo ao carregamento isoladamente, sem qualquer interação entre elas (Figura 4.37), diferentemente do que se espera numa composição de perfis.

A Figura 4.41 ilustra um gráfico com as curvas resultantes dos cálculos feitos conforme a ABNT NBR 8800:2008 (Anexo E) para a resistência de cantoneiras simples conectadas por uma das abas. Embora haja um desvio um pouco maior nos casos de menor esbeltez global, nota-se, mais uma vez, boa aproximação dos resultados dos perfis modelados sem presilhas (pontos "P0") com as referidas curvas, o que pode ser um indício de que tal metodologia também pode ser aplicada para cantoneiras de chapas finas conformadas a frio. 


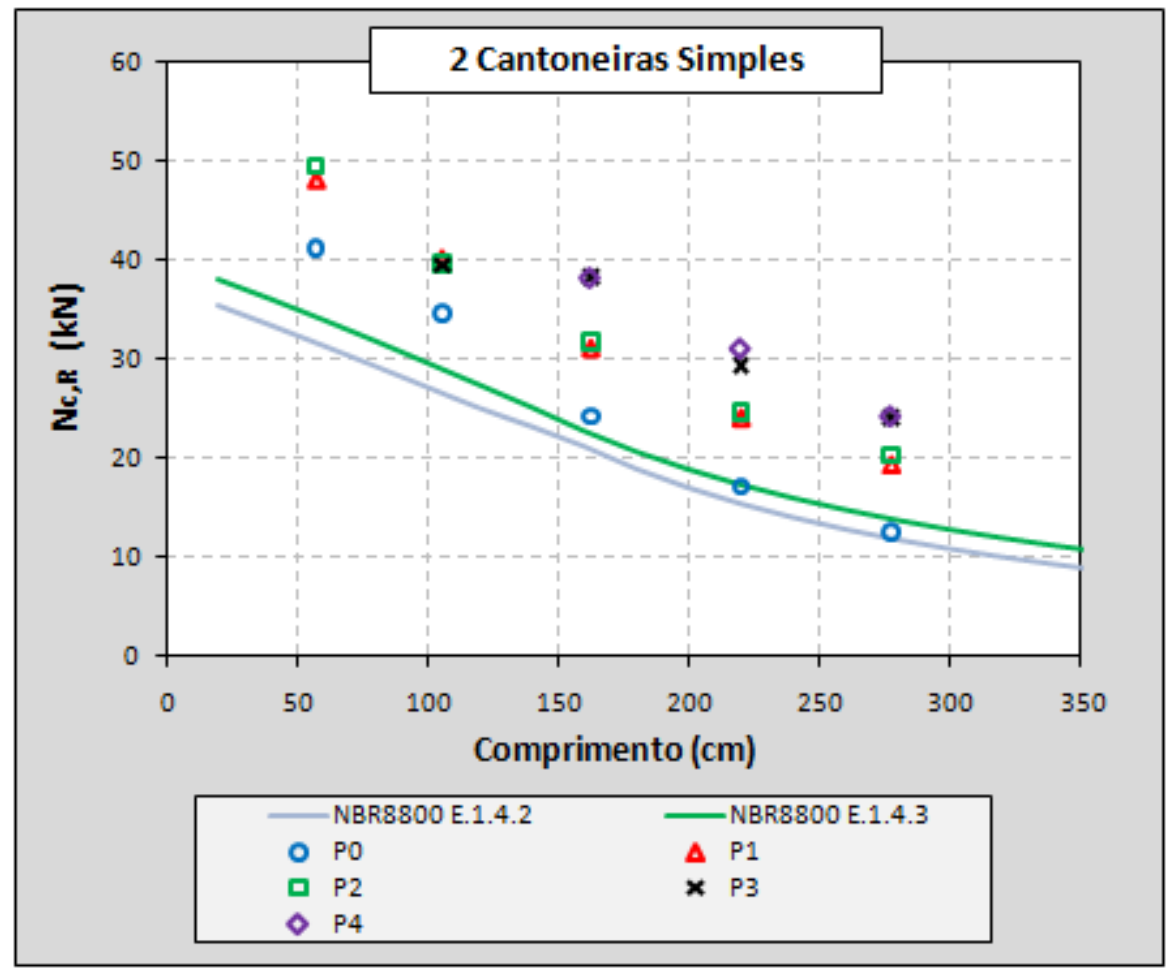

Figura 4.41 - Resistência à compressão: resultados numéricos e previsões da ABNT

NBR 8800:2008 para a resistência de duas cantoneiras simples conectadas por uma aba.

O ganho de resistência em função do aumento no número de presilhas ao longo do comprimento do perfil também seguiu a tendência mostrada para os perfis com 3,0mm de espessura. Conforme ilustrado na Figura 4.42, a inserção de uma presilha na metade do eixo longitudinal da barra aumenta de forma significativa a resistência à compressão dos perfis analisados, o que pode ser visualizado pela formação aproximada de “degraus” nos gráficos. Conclui-se, então, que a disposição ideal (em termos de resistência) das presilhas neste tipo de perfil está ligada a um número ímpar de chapas, considerando que as mesmas sejam inseridas igualmente espaçadas ao longo do comprimento do perfil. 

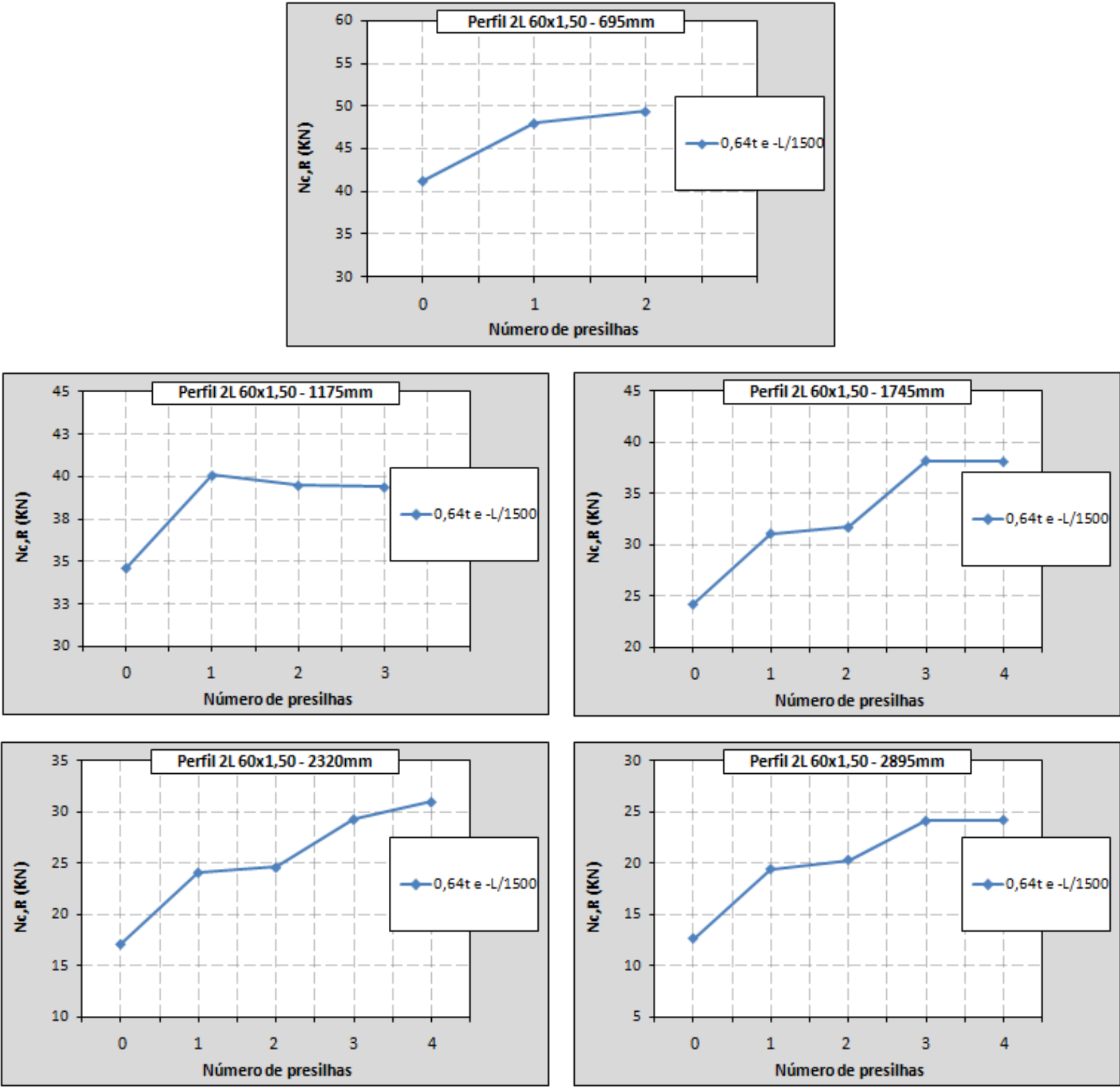

Figura 4.42 - Resistência à compressão: resultados das análises numéricas em função do número de presilhas utilizadas nos modelos - Perfil 60x60x1,5mm.

\subsection{ANÁLISES EM TEMPERATURAS ELEVADAS}

São apresentados, neste item, os principais resultados extraídos das análises termoestruturais realizadas no presente trabalho. Essas análises têm por objetivo retratar, ainda que em caráter apenas exploratório, o comportamento estrutural dos perfis dupla cantoneira aqui estudados mediante a ocorrência simultânea de solicitações mecânicas e térmicas, que, neste caso, resultam da atuação de uma força normal de compressão no perfil 
mediante exposição ao incêndio-padrão proposto na norma brasileira ABNT NBR 14432:2001, em concordância com a ISO 834-1:1999.

Para o carregamento mecânico, foram aplicadas forças de compressão correspondentes a 30\%, 50\% e 70\% da resistência à compressão dos perfis, obtidas à temperatura ambiente, cujos valores estão apresentados na Tabela 3.7. Já os efeitos da ação térmica nos perfis foram simulados por meio do acoplamento com os resultados das respectivas análises térmicas, atualizando os incrementos de temperatura a cada 6 segundos. Ressalta-se que os aspectos referentes à construção dos modelos são descritos detalhadamente no Capítulo 3 desta dissertação e podem ser conferidos, ainda, por meio dos scripts apresentados no APÊNDICE C.

A Tabela 4.12 resume os principais resultados alcançados nas análises realizadas em temperaturas elevadas, nas quais foram testados perfis com os quatro índices de esbeltez anteriormente informados $(\lambda=55,85,115$ e 145$)$.

Tabela 4.12 - Resultados das análises termoestruturais.

\begin{tabular}{|c|c|c|c|c|c|c|c|}
\hline PERFIL & $\begin{array}{l}\mathbf{L}_{\text {perfil }} \\
(\mathbf{m m})\end{array}$ & $\begin{array}{c}\mathbf{L}_{\mathbf{r}} \\
(\mathbf{m m})\end{array}$ & $\lambda$ & \multicolumn{2}{|c|}{$\begin{array}{c}F \\
(\mathbf{k N})\end{array}$} & $\begin{array}{c}\mathbf{t}_{\mathrm{cr}} \\
(\mathrm{min})\end{array}$ & $\begin{array}{c}\mathbf{T}_{\text {cr }} \\
\left({ }^{\circ} \mathbf{C}\right)\end{array}$ \\
\hline \multirow{12}{*}{$\begin{array}{c}\text { 2L 60x2,38mm } \\
\text { (rótula no eixo-x) } \\
K_{x}=1,0 \text { e } K_{y}=0,5\end{array}$} & \multirow{3}{*}{910} & \multirow{3}{*}{1045} & \multirow{3}{*}{55} & 27,5 & $30 \%$ & 6,3 & 597 \\
\hline & & & & 45,8 & $50 \%$ & 4,3 & 518 \\
\hline & & & & 64,1 & $70 \%$ & 2,5 & 349 \\
\hline & \multirow{3}{*}{1485} & \multirow{3}{*}{1620} & \multirow{3}{*}{85} & 23,3 & $30 \%$ & 6,7 & 599 \\
\hline & & & & 38,9 & $50 \%$ & 4,8 & 530 \\
\hline & & & & 54,4 & $70 \%$ & 2,6 & 362 \\
\hline & \multirow{3}{*}{2055} & \multirow{3}{*}{2190} & \multirow{3}{*}{115} & 19,3 & $30 \%$ & 7,4 & 617 \\
\hline & & & & 32,1 & $50 \%$ & 5,1 & 544 \\
\hline & & & & 44,9 & $70 \%$ & 3,4 & 441 \\
\hline & \multirow{3}{*}{2630} & \multirow{3}{*}{2765} & \multirow{3}{*}{145} & 14,6 & $30 \%$ & 7,3 & 614 \\
\hline & & & & 24,3 & $50 \%$ & 5,2 & 545 \\
\hline & & & & 34,0 & $70 \%$ & 3,5 & 448 \\
\hline \multicolumn{8}{|c|}{$\begin{array}{l}\mathrm{L}_{\text {perfil }} \text { - comprimento do perfil; } \\
\mathrm{L}_{\mathrm{r}} \text { - comprimento do perfil mais o dispositivo de apoio (6) } \\
\lambda \text { - índice de esbeltez do perfil (em relação ao eixo-x); } \\
\mathrm{F} \text { - força axial de compressão aplicada (ação mecânica); } \\
\mathrm{t}_{\mathrm{cr}} \text { - tempo de resistência ao fogo; } \\
\mathrm{T}_{\mathrm{cr}} \text { - temperatura em que ocorreu o colapso. }\end{array}$} \\
\hline
\end{tabular}

Os gráficos apresentados da Figura 4.43 à Figura 4.46 relacionam o deslocamento axial do topo do perfil em função do tempo de exposição ao incêndio simulado nas análises numéricas, que é referente à curva de incêndio-padrão mencionada anteriormente. Esses 
gráficos são interessantes pelo fato de permitirem visualizar um histórico dos efeitos das ações (mecânica e térmica) atuantes no elemento estrutural até o seu colapso.

Inicialmente, com a aplicação da força de compressão (F), ocorre um pequeno encurtamento das peças, o que explica as curvas tendo início em valores ligeiramente negativos. Em seguida, os efeitos do incêndio são considerados por meio do acoplamento com as análises térmicas e, à medida que se aumenta a temperatura das chapas, ocorre a livre dilatação do material (uma vez que não é aqui considerada a restrição axial nas extremidades dos perfis), resultando na curva ascendente mostrada nos gráficos. Como se sabe, esse aquecimento traz como conseqüência, ainda, a redução gradativa das propriedades mecânicas do aço, conduzindo o perfil ao fim de sua capacidade resistente devido a problemas de instabilidade (encurtamento brusco da barra), numericamente representado pela perda de convergência das análises.

As configurações deformadas e a distribuição de temperaturas nas chapas no instante em que ocorre a falha dos perfis (pontos de alongamento máximo dos perfis - pico das curvas “Deslocamento axial x Tempo”) são mostradas da Figura 4.47 à Figura 4.50. Podem ser visualizados, por meio dessas figuras, os valores apresentados na Tabela 4.12 para a temperatura máxima $\left(\mathrm{T}_{\mathrm{cr}}\right)$ atingida pelos perfis enquanto ainda resistiam às ações mecânicas e térmicas. Vale informar que essas figuras referem-se apenas aos resultados dos perfis com carregamento mecânico correspondente a 70\% de suas respectivas resistências à temperatura ambiente. Os resultados das demais análises termoestruturais são disponibilizados no APÊNDICE F dessa dissertação.

Nota-se que os perfis analisados em situação de incêndio não seguem exatamente o mesmo padrão de deformações observado nas análises à temperatura ambiente, mesmo sendo modelados com as mesmas imperfeições geométricas iniciais. Nota-se que a redução das propriedades mecânicas geradas pelo aquecimento do material torna os perfis mais sensíveis às instabilidades localizadas, que passaram a comandar a falha dos perfis na maioria dos casos. 


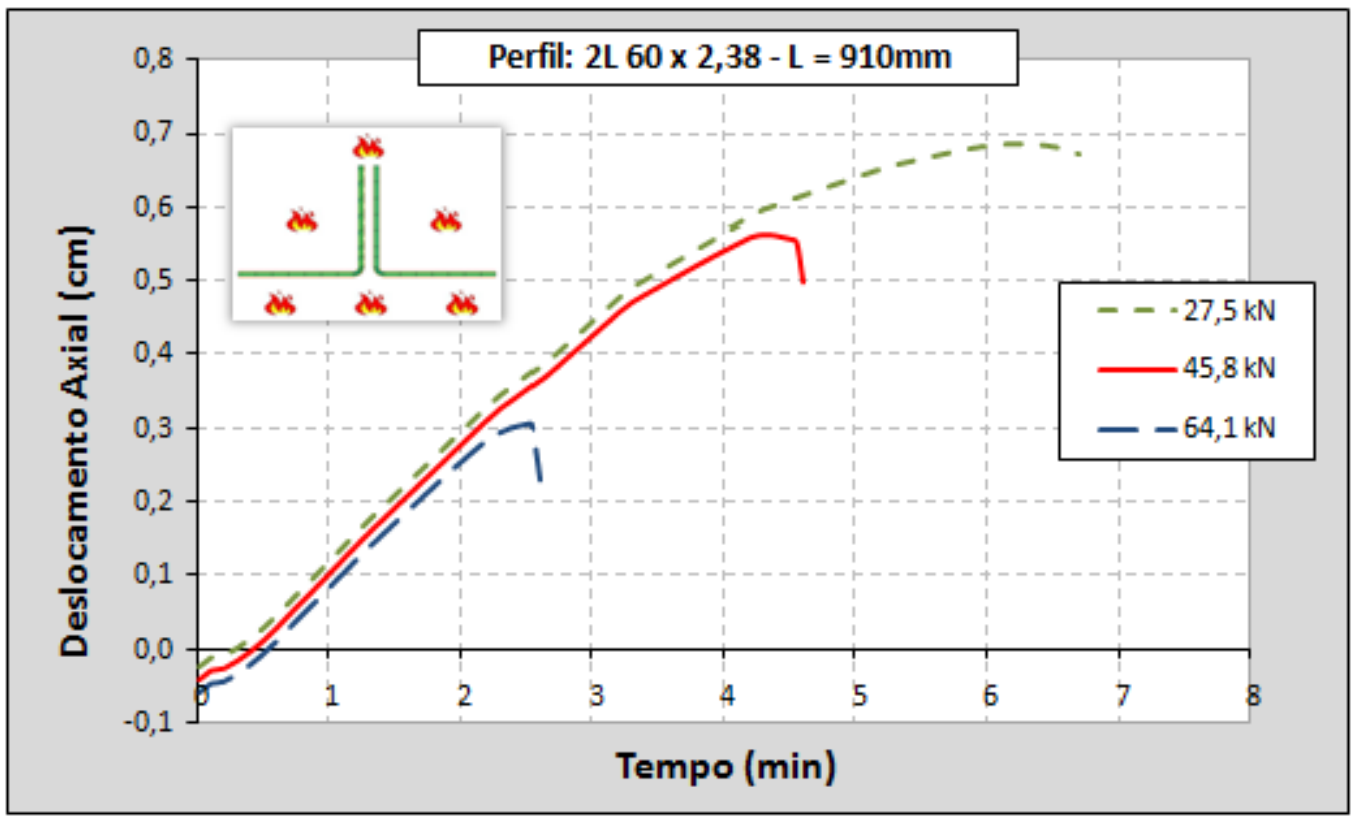

Figura 4.43 - Evolução do deslocamento axial do topo do perfil em função do tempo de exposição ao incêndio-padrão $-\lambda=55$.

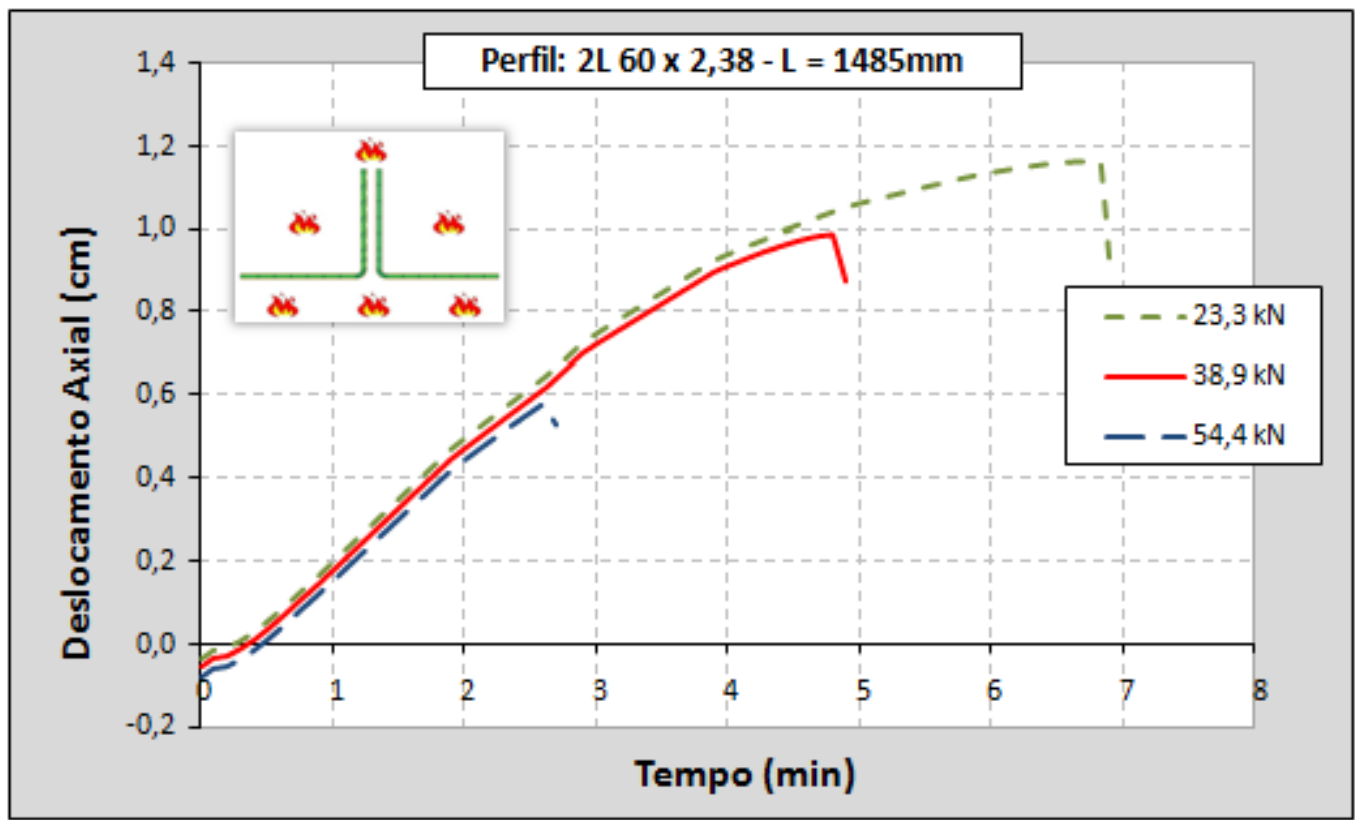

Figura 4.44 - Evolução do deslocamento axial do topo do perfil em função do tempo de exposição ao incêndio-padrão $-\lambda=85$. 


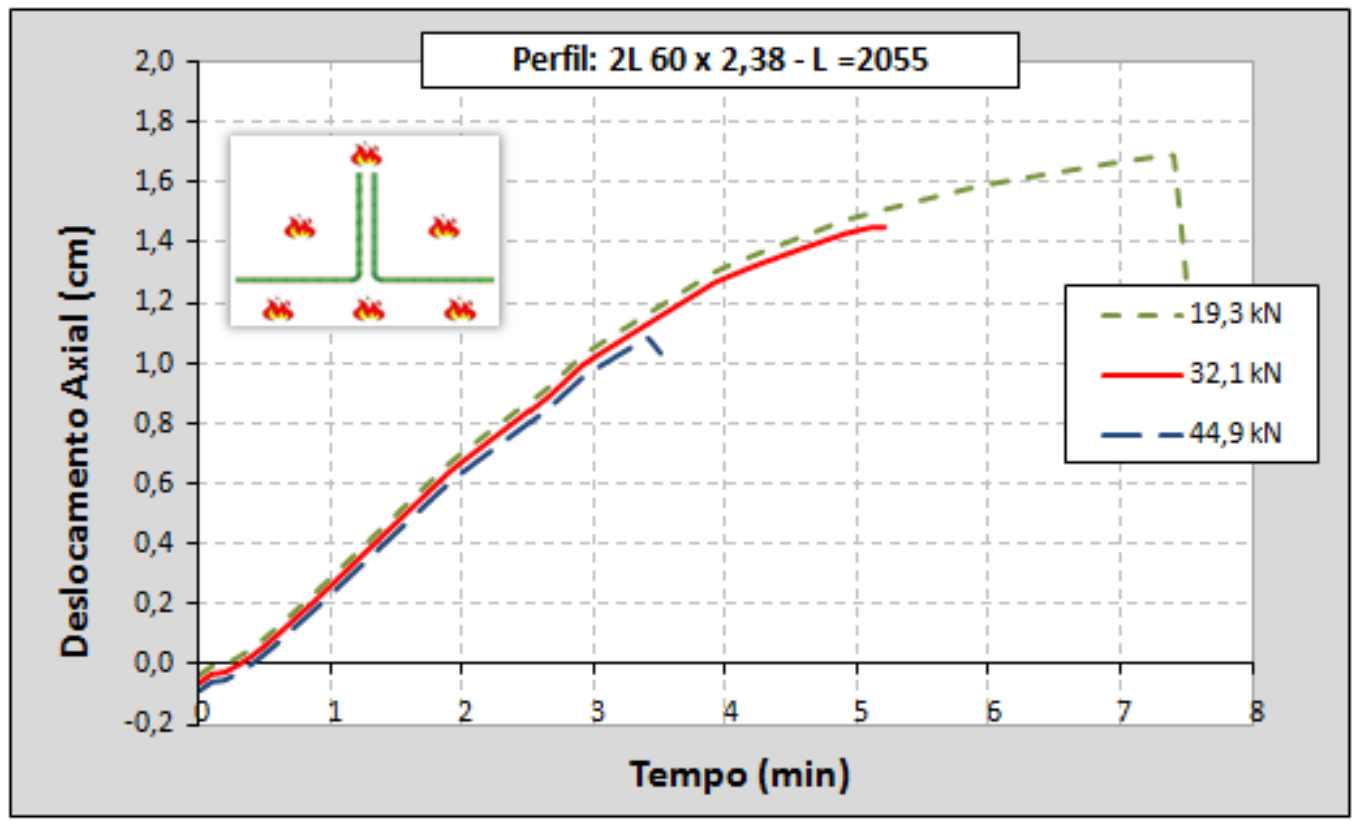

Figura 4.45 - Evolução do deslocamento axial do topo do perfil em função do tempo de exposição ao incêndio-padrão $-\lambda=115$.

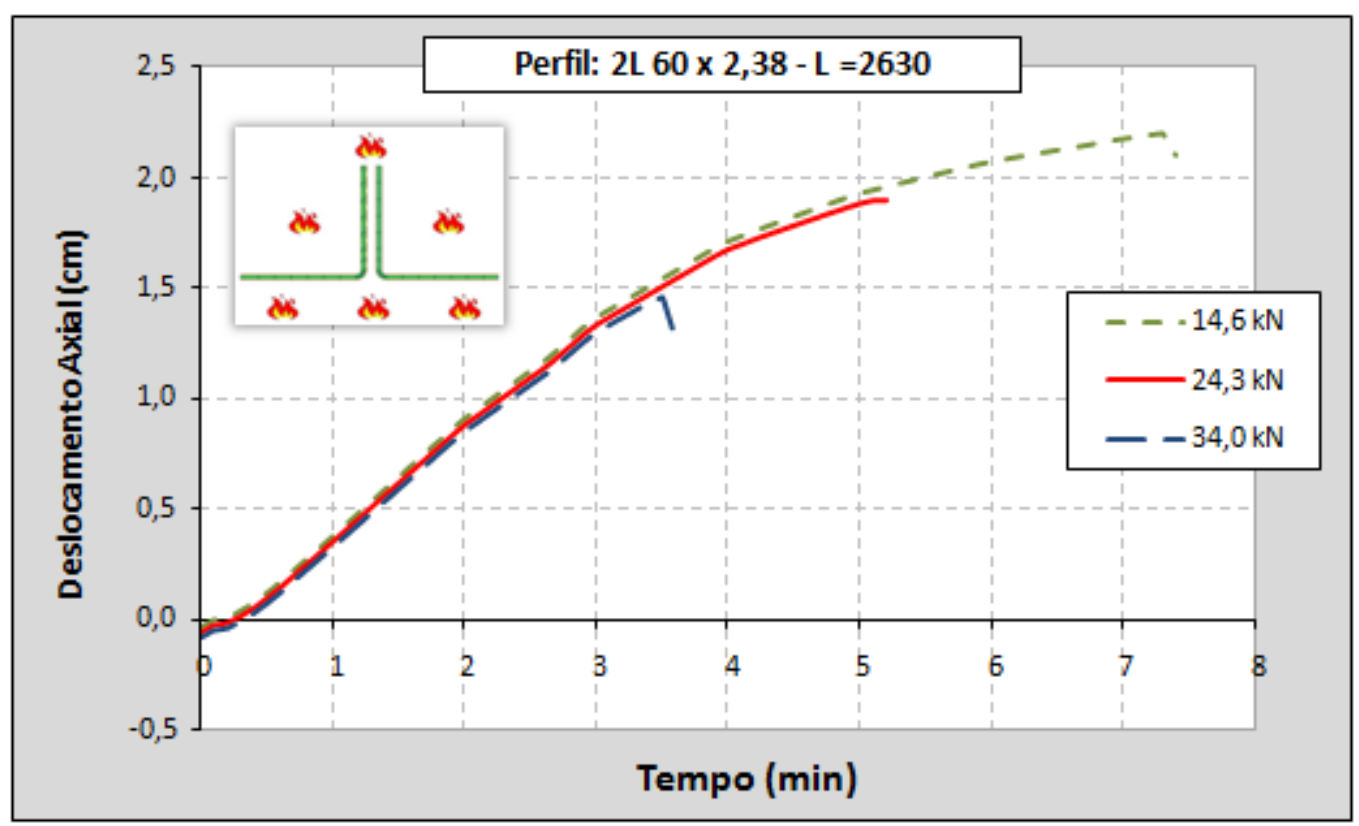

Figura 4.46 - Evolução do deslocamento axial do topo do perfil em função do tempo de exposição ao incêndio-padrão $-\lambda=145$. 


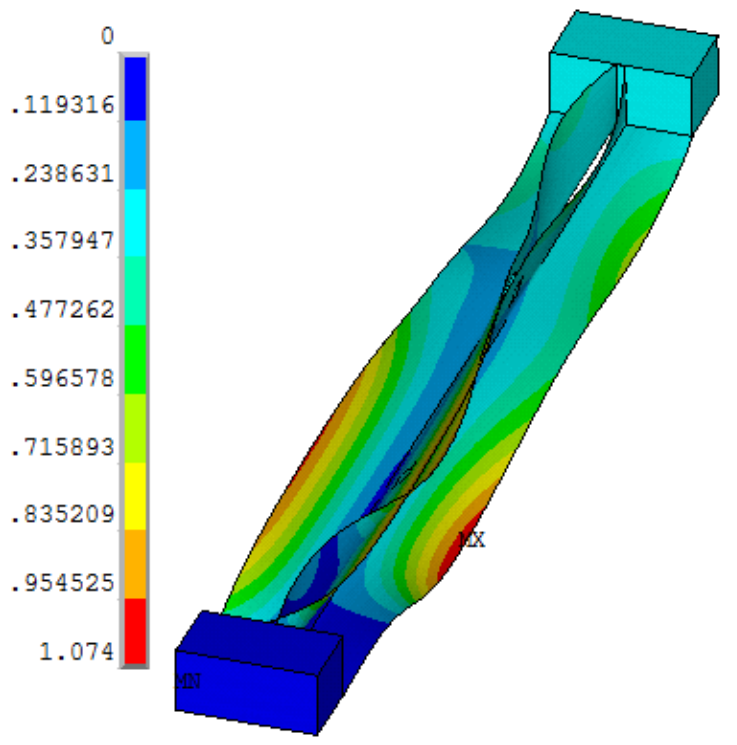

(a)

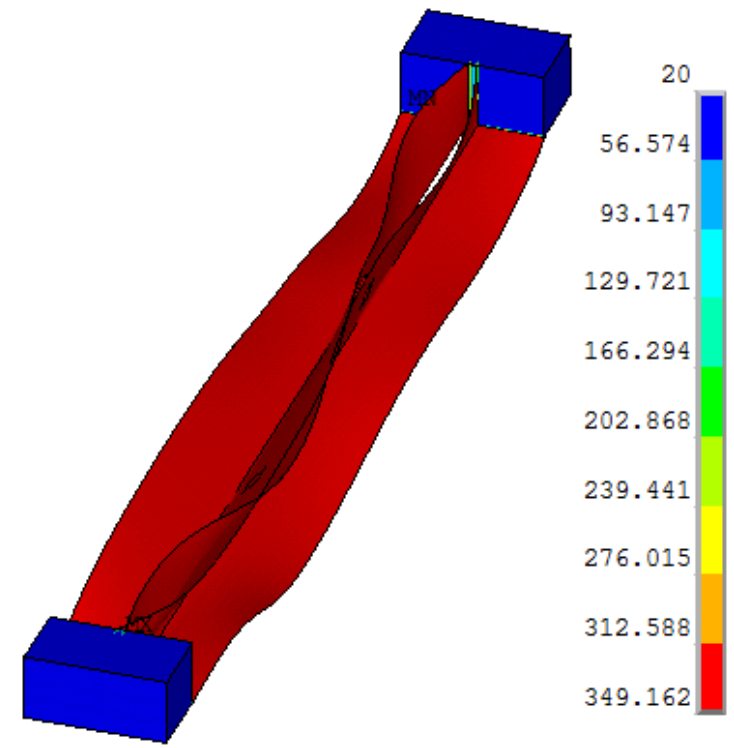

(b)

Figura 4.47 - Resultados das análises termoestruturais: (a) deslocamentos (cm) em escala ampliada e (b) máxima temperatura $\left({ }^{\circ} \mathrm{C}\right)$ atingida pelo perfil $-\lambda=55$.

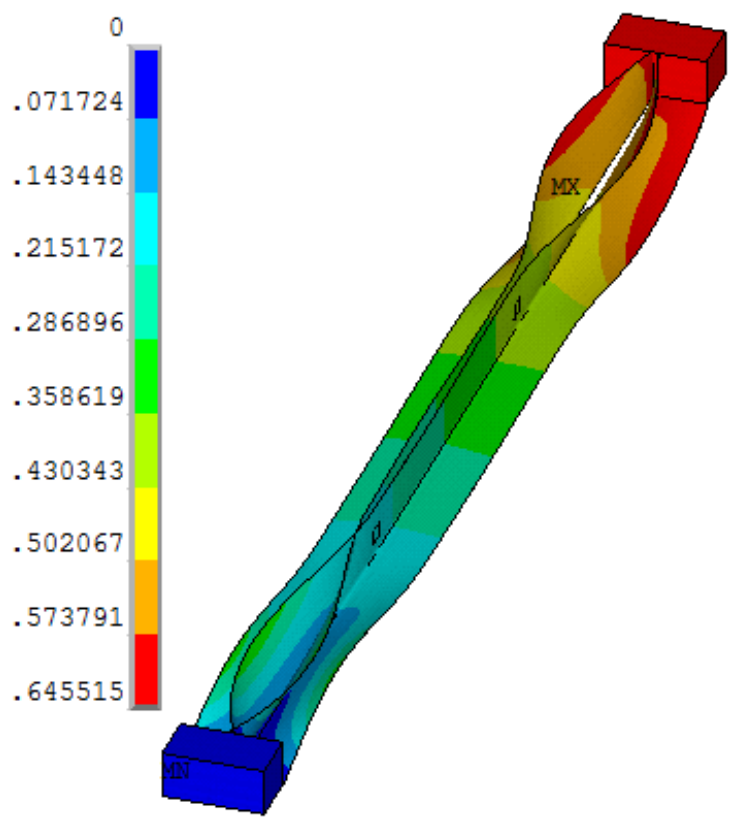

(a)

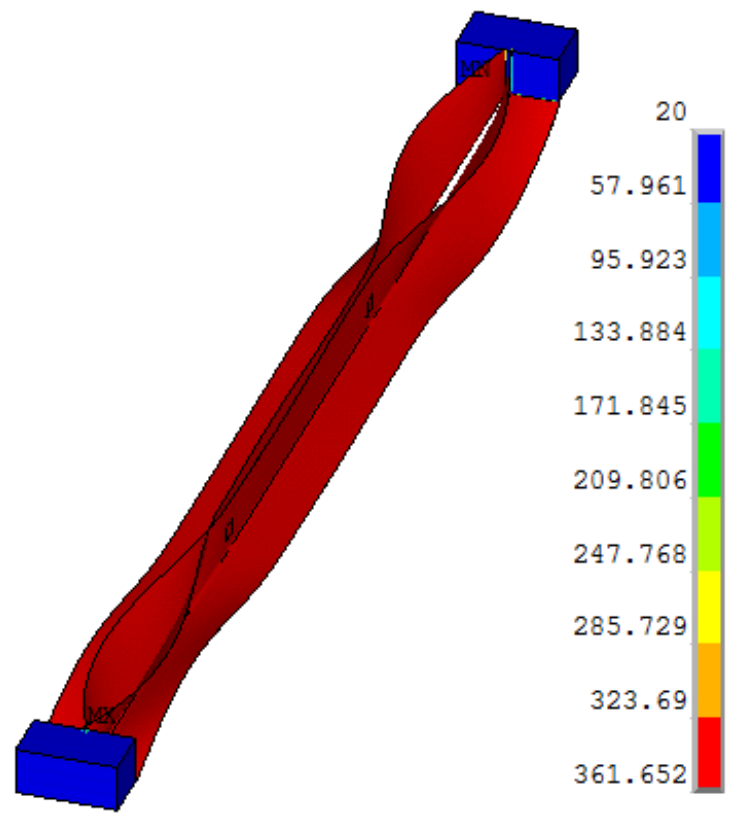

(b)

Figura 4.48 - Resultados das análises termoestruturais: (a) deslocamentos (cm) em escala ampliada e (b) máxima temperatura $\left({ }^{\circ} \mathrm{C}\right)$ atingida pelo perfil $-\lambda=85$. 


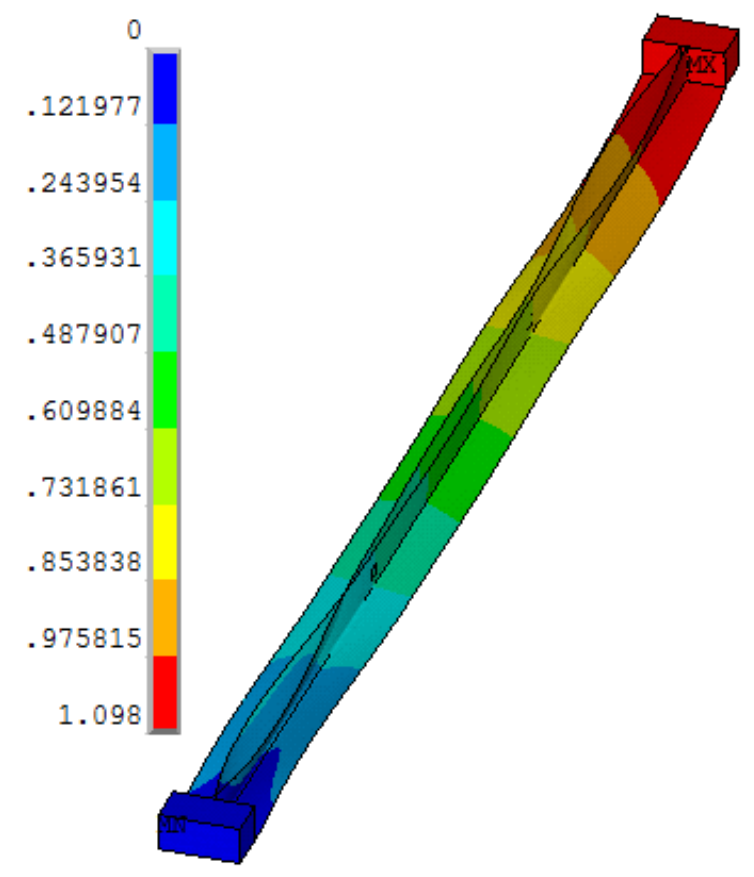

(a)

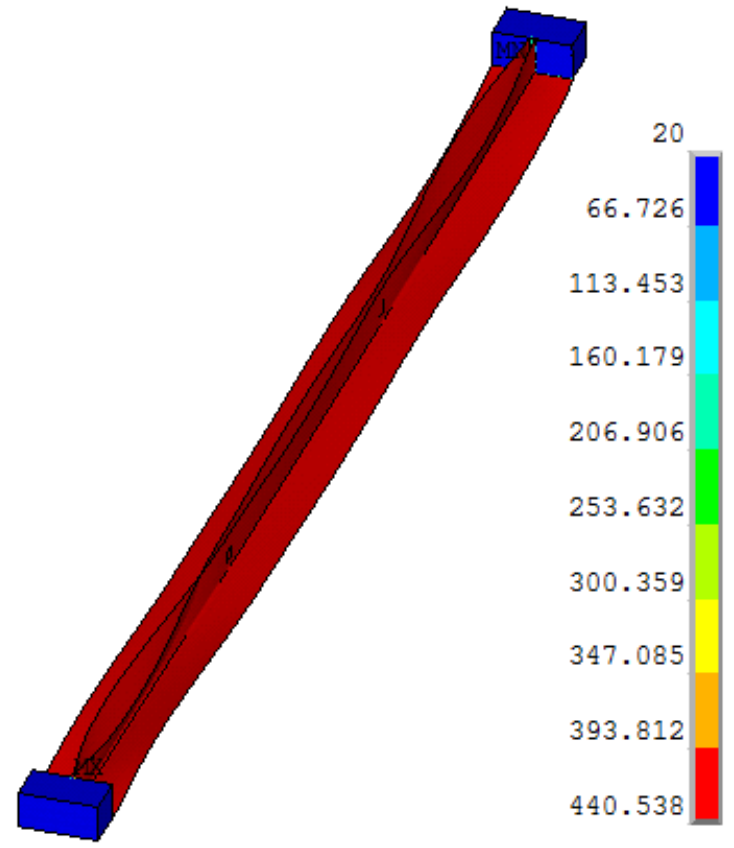

(b)

Figura 4.49 - Resultados das análises termoestruturais: (a) deslocamentos (cm) em escala ampliada e (b) máxima temperatura $\left({ }^{\circ} \mathrm{C}\right)$ atingida pelo perfil $-\lambda=115$.

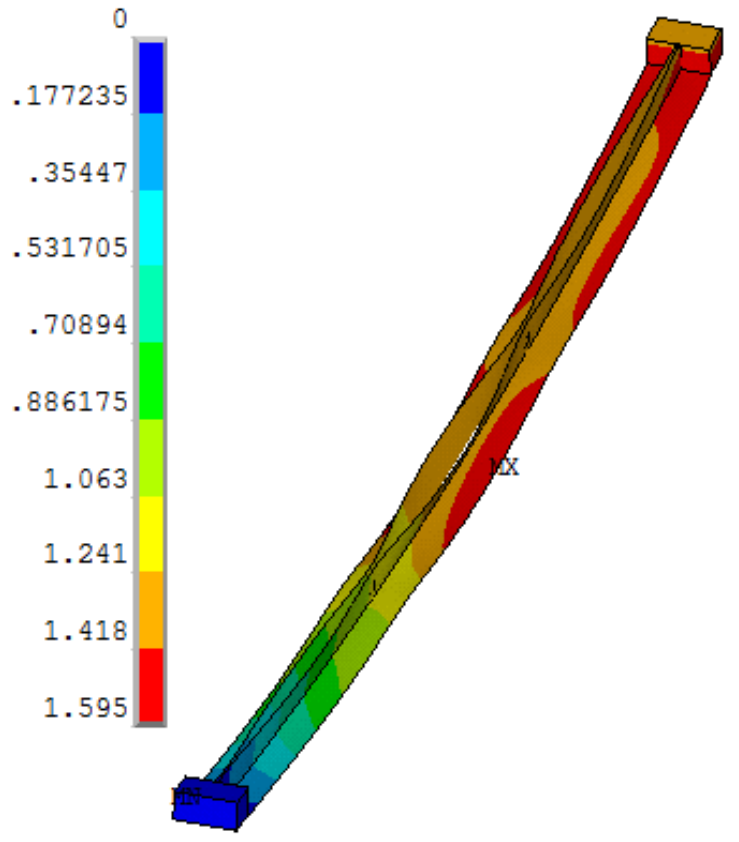

(a)

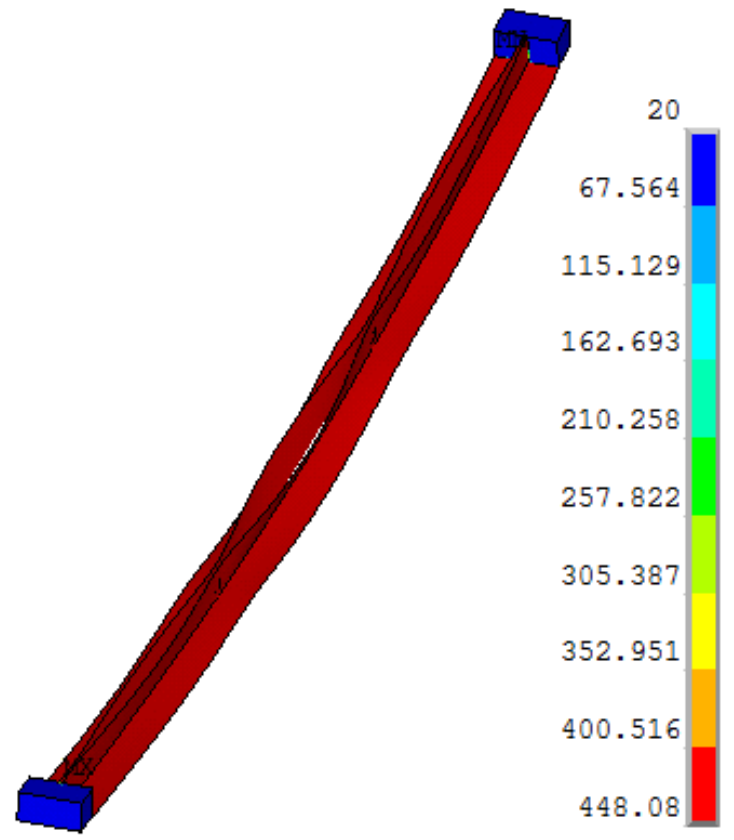

(b)

Figura 4.50 - Resultados das análises termoestruturais: (a) deslocamentos (cm) em escala ampliada e (b) máxima temperatura $\left({ }^{\circ} \mathrm{C}\right)$ atingida pelo perfil $-\lambda=145$. 
Conforme esperado, os resultados das análises numéricas apontam para tempos de resistência ao fogo bastante reduzidos e temperaturas de colapso relativamente baixas se comparados com aqueles normalmente resultantes de análises realizadas com perfis soldados ou laminados. Tais resultados são conseqüência do alto fator de massividade (ou fator de forma) dos perfis estudados, que, associado à elevada condutividade térmica do aço e à condição de incêndio sem compartimentação, acaba conduzindo a uma rápida degradação das propriedades mecânicas do material.

Isso pode trazer sérios problemas no que se refere à segurança de estruturas compostas por esses perfis, pois o que se observa são tempos de resistência ao fogo bem abaixo daqueles exigidos por normas específicas, tais como a ABNT NBR 14432:2001. Portanto, os resultados indicam a necessidade do uso de algum tipo de revestimento contra o fogo neste tipo de perfil, principalmente nesses casos de incêndio não compartimentado, para que sejam atendidas as prescrições normativas referentes à segurança estrutural em situações de incêndios.

Nesse contexto, é importante que sejam avaliados sistemas de proteção eficientes sem que tragam, contudo, impactos significativos nos custos da estrutura, já que uma das grandes vantagens competitivas dos perfis formados a frio é a economia proporcionada pelo baixo peso dos elementos estruturais. Fica aqui, como sugestão para trabalhos futuros, o estudo do comportamento dos perfis dupla cantoneira em análises termoestruturais considerando-se o uso de revestimento contra o fogo, o que pode ser feito por meio dos modelos numéricos desenvolvidos no presente trabalho, bastando, para isso, utilizar materiais com propriedades térmicas diferentes nas camadas externas do elemento finito utilizado no modelo térmico, conforme explicado no item 3.2.1.

São mostradas na Figura 4.51 as curvas resultantes da extrapolação dos resultados obtidos nas análises termoestruturais, de forma a se ter uma estimativa do tempo de resistência ao fogo dos perfis estudados a partir do carregamento axial de compressão aplicado (nesse gráfico, $\mathrm{N}_{\mathrm{ci}}$ corresponde à força axial de compressão atuante durante o incêndio e $\mathrm{N}_{\mathrm{ca}}$ é o esforço normal de compressão resistente do perfil à temperatura ambiente). Observa-se que tal extrapolação conduz a um decréscimo praticamente linear do carregamento máximo a ser aplicado no perfil em função do tempo de resistência ao fogo.

Por fim, ressalta-se, mais uma vez, que as análises numéricas à temperaturas elevadas realizadas no presente trabalho constituem apenas um estudo introdutório sobre o assunto, visando contribuir para a validação de estratégias numéricas já aplicadas com sucesso em outros casos (como em perfis pesados, por exemplo) e ainda incentivar pesquisas mais 
aprofundadas sobre o comportamento dos perfis formados a frio em geral em situação de incêndio, dada a importância do tema.

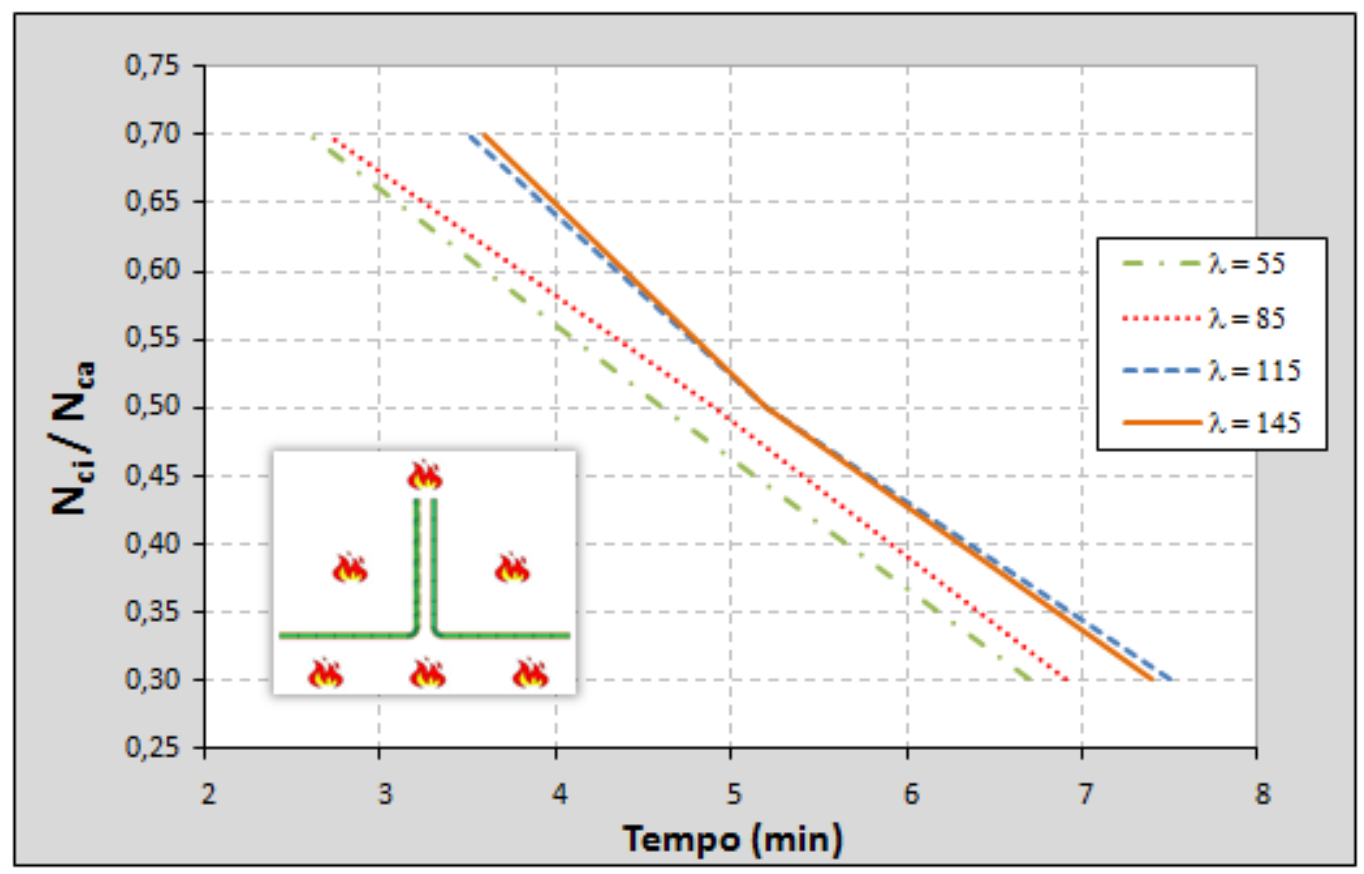

Figura 4.51 - Extrapolação dos resultados para a estimativa do tempo de resistência ao fogo em função do carregamento aplicado. 



\section{CAPÍTULO}

\section{CONCLUSÕES}

\subsection{QUANTO ÀS ANÁLISES À TEMPERATURA AMBIENTE}

Os resultados obtidos por meio das análises numéricas realizadas no presente trabalho indicam um complexo comportamento estrutural dos PFF compostos por dupla cantoneira com seção transversal na forma de "T" quando submetidos à compressão. A presença de presilhas intermitentes (em vez da ligação contínua entre as cantoneiras), associada à elevada esbeltez local dos perfis estudados, acabou conduzindo a situações intermediárias entre o comportamento do conjunto como um todo (como se fosse um perfil "T") e o de cantoneiras simples nos trechos entre presilhas.

Com isso, em vez dos clássicos fenômenos de instabilidade global ocorrendo isoladamente, o que se observou foi uma grande interação entre os modos de instabilidade globais (por flexão e/ou flexo-torção) e locais (que, a rigor, trata-se de uma instabilidade por flexo-torção das cantoneiras simples entre presilhas), sendo a predominância de um em relação ao outro dependente dos índices de esbeltez global e local do perfil e do número de presilhas inseridas ao longo do seu comprimento.

\section{- Compressão centrada}

Para os perfis submetidos à compressão centrada os resultados das análises numéricas, assim como os resultados experimentais presentes na literatura, indicam que os valores de força axial de compressão resistente obtidos conforme as prescrições da ABNT NBR 14762:2010 resultam bastantes conservadores, com a exceção dos perfis cuja esbeltez global em relação ao eixo de menor inércia de sua seção transversal é muito elevada, onde o predomínio da instabilidade global por flexão é bem representado pelas previsões normativas (Figura 4.18 e Figura 4.19).

Ao contrário do que se esperava, as resistências dos perfis modelados sob compressão centrada se aproximaram mais dos resultados teóricos que consideram apenas a flambagem por flexão do que daqueles que também levam em conta a flambagem global por flexo-torção, 
conforme especificam as normas para os casos de perfis monossimétricos. Nesse contexto, a utilização do índice de esbeltez modificado proposto na norma americana ANSI/AISI S100 (2007) para perfis compostos com presilhas intermitentes (item 2.5.2) aumentou ainda mais as diferenças entre as curvas referentes à flexo-torção e os resultados numéricos, já que a redução de resistência devido a essa ligação descontínua entre as cantoneiras que compõem os perfis são considerados nessa metodologia.

Em relação aos modos de instabilidade referentes ao colapso do perfil estudado, no geral, os modelos numéricos apresentaram resultados coerentes com as previsões teóricas para perfis monossimétricos. Apesar da grande interação entre os modos de instabilidade no momento em que ocorre a falha dos perfis, notou-se que o modo global por flexo-torção do perfil composto, juntamente com as instabilidades locais (flexo-torção das cantoneiras entre presilhas) foram predominantes na maioria dos perfis analisados (Figura 4.8 à Figura 4.15). No entanto, à medida que se aumenta a esbeltez do perfil o modo de instabilidade global por flexão em relação ao eixo de menor inércia da seção passa a exercer maior influência na estabilidade do elemento estrutural, exatamente como é previsto nas normas (Figura 4.11).

Outro fato interessante observado nas análises numéricas é que as condições de vinculação alteram de forma significativa o comportamento dos perfis. Para os modelos com dispositivos de apoio que permitem apenas a rotação em torno do eixo de maior inércia (Rótula no eixo-y) os perfis apresentaram trajetórias de deformações que se aproximam mais do comportamento de um perfil “T” (as duas cantoneiras tendem a trabalhar como uma peça única), tendo pouca alteração nos valores de resistência e nas configurações deformadas mesmo com a variação das imperfeições geométricas iniciais. Porém, nas situações em que os dispositivos de apoio permitem somente a rotação em torno do eixo de menor inércia (Rótula no eixo-x), notou-se grande participação das cantoneiras que compõem o perfil nos trechos entre presilhas, apresentando maior sensibilidade às imperfeições geométricas iniciais.

\section{- Compressão excêntrica}

No caso dos perfis submetidos à compressão excêntrica os valores de força normal de compressão resistente obtidos conforme as normas ABNT NBR 14762:2010 e ANSI/AISI S100 (2007) também se mostraram bem conservadores quando comparados com os resultados das análises numéricas. Verificou-se que a consideração da rigidez da ligação parafusada por meio da redução do coeficiente de flambagem $\left(\mathrm{K}_{\mathrm{x}}=0,8\right)$ contribui para uma melhor aproximação das curvas resultantes das prescrições normativas com os resultados numéricos 
nas situações em que predomina a instabilidade global por flexão, como nos perfis com maior esbeltez global. No entanto, para os perfis menos esbeltos tal consideração não gera qualquer influência nos resultados, uma vez que os feitos das instabilidades locais e torcionais predominam nos perfis mais curtos (Figura 4.28 e Figura 4.29).

A situação se torna mais crítica na medida em que se aumenta a esbeltez local dos perfis. As análises numéricas realizadas no presente trabalho para perfis com abas de $60 \mathrm{~mm}$ e espessura de 1,5mm (relação largura/espessura das abas das cantoneiras $b / t=40$ ) indicam que os valores de resistência dos perfis em questão podem resultar muito superiores àqueles obtidos por meio dos procedimentos normativos. Nesses casos, nem mesmo a redução do coeficiente de flambagem citada anteriormente $\left(K_{x}=0,8\right)$ é suficiente para aproximar as curvas de dimensionamento aos resultados numéricos, pois a reduzida espessura das chapas acaba conduzindo a uma baixa rigidez desses perfis aos modos torcionais, que passam a comandar o dimensionamento (Figura 4.39 e Figura 4.40).

Assim como a esbeltez local das chapas, o número e a disposição das presilhas que ligam as cantoneiras também mostraram grande influência no comportamento estrutural dos perfis analisados. Nota-se que a quantidade ideal de chapas separadoras está diretamente relacionada à inserção de uma presilha na metade do comprimento do perfil, situação em que se obtém maior resistência à compressão. Sendo assim, considerando presilhas igualmente espaçadas, percebem-se ganhos expressivos de resistência para os perfis em questão quando se altera um número par de presilhas para o numero ímpar imediatamente superior; ou, em outras palavras, não há perdas significativas de resistência quando da redução de um número par de presilhas para a quantidade ímpar imediatamente inferior (Figura 4.31 e Figura 4.42).

Conforme esperado, a não utilização de chapas separadoras conduz a significativos impactos na resistência e no comportamento estrutural desse tipo de perfil. Nessa situação, as cantoneiras que compõem o perfil passam a atuar isoladamente, sem qualquer interação entre elas, o que acaba resultando em valores de forças de compressão resistentes bem menores do que nos perfis que dispõem de uma ou mais presilhas. Dentro desse contexto, ressalta-se a boa aproximação das curvas resultantes dos procedimentos de cálculo da ABNT NBR 8800:2008 para cantoneiras simples sob compressão e conectadas por uma das abas, o que pode ser um indício de que tal procedimento também é aplicável para as cantoneiras de aço formadas a frio (Figura 4.30 e Figura 4.41).

Quanto aos modos de instabilidade predominantes, as análises numéricas confirmaram a expectativa de grande influência da excentricidade do carregamento e das condições de 
vinculação na configuração deformada resultante. Para os perfis com maior esbeltez local o modo global por flexão da barra é, juntamente com as instabilidades localizadas, o principal responsável pelo colapso do elemento estrutural. Porém, a redução da espessura das chapas e o aumento na quantidade de presilhas fazem com que os efeitos da instabilidade global por flexo-torção da peça composta também se tornem influentes na perda de estabilidade dos perfis, que passa a ser governada pela atuação simultânea dos três modos de instabilidade (local e global por flexão e por flexo-torção) característicos dos perfis monossimétricos (Figura 4.20 à Figura 4.27 e Figura 4.32 à Figura 4.38).

Portanto, conclui-se que a ocorrência de um ou outro modo de instabilidade nos perfis dupla cantoneira aqui estudados não é de fácil previsão, uma vez que depende de vários fatores, como: índices de esbeltez global e local dos perfis, forma de vinculação de suas extremidades, tipo de carregamento (se é centrado ou excêntrico), número de presilhas e imperfeições geométricas iniciais presentes. Além disso, as análises numéricas realizadas no presente trabalho apontam ainda para a necessidade de melhorias nos procedimentos de cálculo das normas no que diz respeito ao dimensionamento à compressão de perfis compostos, em especial dos perfis dupla cantoneira, embora os procedimentos atuais não tenham resultado contra a segurança em comparação com os valores de resistências obtidos na modelagem numérica.

\subsection{QUANTO ÀS ANÁLISES EM TEMPERATURAS ELEVADAS}

Embora os estudos realizados no presente trabalho para a avaliação do comportamento dos perfis dupla cantoneira submetidos a temperaturas elevadas tenham sido desenvolvidos apenas em caráter exploratório, podem ser retiradas conclusões importantes no que diz respeito ao desempenho desses perfis mediante situação de incêndio. As análises numéricas indicam que sistemas estruturais compostos pelos perfis em questão podem apresentar sérios problemas referentes à segurança estrutural caso não sejam previstos mecanismos de proteção dos elementos contra a ação do fogo, uma vez que tais análises resultaram em tempos de resistência ao fogo bem abaixo do valor mínimo exigido por normas específicas (Tabela 4.12), tais como a ABNT NBR 14432:2001, no caso, 30 minutos.

Mesmo nas situações em que o carregamento mecânico aplicado (força normal de compressão, neste caso) é bem inferior à capacidade resistente do perfil em temperatura ambiente (30\%) o seu desempenho não é satisfatório, sendo de, aproximadamente, 7 minutos 
e meio o tempo máximo de resistência ao fogo apresentado nas análises termoestruturais. Com isso, observam-se, no momento do colapso, temperaturas relativamente baixas nas chapas se comparadas com aquelas normalmente resultantes de análises realizadas com perfis soldados ou laminados.

Tais resultados são conseqüência do elevado fator de massividade (ou fator de forma) resultante da elevada esbeltez local dos perfis estudados, que, associado à alta condutividade térmica do aço e à condição de incêndio sem compartimentação a qual estes perfis geralmente são submetidos, acaba conduzindo a uma rápida degradação das propriedades mecânicas do material, o que precipita a ocorrência dos problemas de instabilidade no perfil.

Portanto, os resultados indicam a necessidade do uso de revestimento térmico nos PFF compostos por dupla cantoneira, principalmente nesses casos de incêndio não compartimentado, para que sejam atendidas as exigências normativas quanto ao tempo de resistência ao fogo. Contudo, é importante destacar que a escolha do sistema de proteção deve ser feita de forma racional, pois, além de ter que garantir a integridade estrutural durante o TRRF, esse sistema não pode acarretar impactos significativos nos custos da estrutura, já que uma das grandes vantagens competitivas dos perfis formados a frio é a economia proporcionada pelo baixo peso dos elementos estruturais.

\subsection{SUGESTÕES PARA TRABALHOS FUTUROS}

Conforme exposto nos capítulos anteriores, foram realizados no presente trabalho estudos aprofundados sobre os perfis dupla cantoneira por meio de modelos numéricos, cujos resultados podem ser de grande valia para futuras complementações das normas, em especial a ABNT NBR 14762:2010. No entanto, a redação de conclusões definitivas sobre o comportamento estrutural dos perfis em questão passa pela necessidade de novas pesquisas sobre o assunto, principalmente no campo experimental, uma vez que a quantidade de resultados presentes na literatura ainda resulta muito escassa e, conseqüentemente, aquém do necessário.

Sendo assim, fica como sugestão para trabalhos futuros a realização de estudos experimentais com esses perfis dupla cantoneira para a validação dos resultados numéricos alcançados e para que se chegue a um conhecimento mais completo do seu comportamento estrutural mediante esforços de compressão. Além disso, seria interessante a realização de novas análises numéricas considerando modelos com diferentes condições de vinculação e/ou 
atuação do carregamento, de forma a identificar possíveis diferenças no comportamento dos perfis.

Quanto às análises em temperaturas elevadas, apesar de os estudos realizados no presente trabalho terem sido apenas introdutórios, concluiu-se que os modelos numéricos desenvolvidos apresentaram resultados qualitativamente coerentes e que, portanto, podem ser utilizados em pesquisas futuras, com vistas a contribuir para futuras revisões da ABNT NBR 14323:1999. Como as análises numéricas resultaram em tempos de resistência ao incêndiopadrão bastante reduzidos, considera-se interessante a realização de novas análises com a inserção de materiais de revestimento contra a ação térmica nas faces dos perfis, situação que também é contemplada pelos modelos desenvolvidos.

Por fim, sugere-se que sejam implementadas rotinas capazes de simular os efeitos das restrições axiais as quais geralmente estão submetidos os perfis dentro do sistema estrutural, uma vez que essas restrições tendem a reduzir ainda mais o tempo de resistência ao fogo dos elementos estruturais. Dentro desse contexto, destaca-se a estratégia numérica apresentada em DORR (2010) para a consideração da restrição axial, que pode ser adaptada para fins de aplicação nos perfis compostos por dupla cantoneira analisados no presente trabalho. 


\section{REFERENCIAS}

ALMEIDA, S. J. C. (2007). Análise numérica de perfis de aço formados a frio comprimidos considerando imperfeições geométricas iniciais. 206p. Dissertação (Mestrado) - Escola de Engenharia de São Carlos, Universidade de São Paulo, São Carlos, 2007.

AMERICAN SOCIETY TESTING AND MATERIALS (2000). ASTM E119: Standard test methods for fire tests of building construction and materials. West Conshohohocken, 2000.

AMERICAN IRON AND STEEL INSTITUTE (2001). Commentary on North American specification for the design of cold-formed steel structural members. Washington: AISI.

AMERICAN IRON AND STEEL INSTITUTE (2007). North American specification for the design of cold-formed steel structural members. Washington: AISI.

ANGST, A. J. (2003). Estudo crítico das metodologias de cálculo para perfis dobrados a frio de vigas tipo canal sem enrijecedores de borda. Universidade Federal do Rio Grande do Sul, Porto Alegre, 2003.

ANSYS INC. Ansys Release v.13 - Documentation, 2011.

ALVES, M. C. (2006). Análise avançada sobre perfis formados a frio sob ação de incêndio. 301p. Dissertação (Mestrado) - COPPE, Universidade Federal do Rio de Janeiro, Rio de Janeiro, 2006.

ASSOCIAÇÃO BRASILEIRA DE NORMAS TÉCNICAS (1999). NBR 14323: Dimensionamento de estruturas de aço de edifícios em situação de incêndio Procedimento. Rio de Janeiro: ABNT, 1999.

ASSOCIAÇÃO BRASILEIRA DE NORMAS TÉCNICAS (2001). NBR 14432: Exigências de resistência ao fogo de elementos construtivos de edificações - Procedimento. Rio de Janeiro: ABNT, 2001. 
ASSOCIAÇÃO BRASILERA DE NORMAS TÉCNICAS (2001). NBR 5628: Componentes construtivos estruturais - Determinação da resistência ao fogo. Rio de Janeiro: ABNT, 2001.

ASSOCIAÇÃO BRASILEIRA DE NORMAS TÉCNICAS (2003). NBR 6355: Perfis estruturais de aço conformados a frio. Rio de Janeiro: ABNT, 2003.

ASSOCIAÇÃO BRASILEIRA DE NORMAS TÉCNICAS (2008). NBR 8800: Projeto de estruturas de aço e de estruturas mistas de aço e concreto de edifícios. Rio de Janeiro: ABNT, 2008.

ASSOCIAÇÃO BRASILEIRA DE NORMAS TÉCNICAS (2010). NBR 14762: Dimensionamento de estruturas de aço constituídas por perfis formados a frio. Rio de Janeiro: ABNT, 2010.

BLEICH, F. (1952). Buckling strength of metal structure. New York: McGraw-Hill Book, 1952. 508p.

BRYAN, G. H. (1891). On the stability of a plane plate under thursts in its own plane, with applications to the 'buckling' of the sides of a ship. Proc. London Math. Soc., Vol. 22, 1891.

CHAGES, A.; WINTER, G. (1965). Torsional-flexural buckling of thin-walled members. Journal of the Structural Division, ASCE, v.91.

CHODRAUI, G. M. B. (2003). Flambagem por distorção da seção transversal em perfis de aço formados a frio submetidos à compressão centrada e à flexão. 173p. Dissertação (Mestrado) - Escola de Engenharia de São Carlos, Universidade de São Paulo, São Carlos, 2003.

CHODRAUI, G. M. B. (2006). Análise teórica e experimental de perfis de aço formados a frio submetidos à compressão. 310p. Tese (Doutorado) - Escola de Engenharia de São Carlos, Universidade de São Paulo, São Carlos, 2006.

CHODRAUI, G. M. B.; SHIFFERAW, Y.; MALITE, M.; SCHAFER, B. W. (2006b). Coldformed steel angles under axial compression. In: LaBoube, R.A.; Yu, W.W. (Ed). Recent research and developments in cold-formed steel design and construction (18th International Specialty Conference on Cold-Formed Steel Structures, Orlando, USA, Oct. 26-27, 2006). Missouri University of Science \& Technology, Rolla, Missouri, USA, 2006. 
DORR, J. B. (2010). Modelos numéricos de pilares de aço em situação de incêndio considerando a influência da restrição axial. 210p. Dissertação (Mestrado) - Escola de Engenharia de São Carlos, Universidade de São Paulo, São Carlos, 2010.

EUROPEAN COMMITEE FOR STANDARDIZATION (1996). ENV 1993-1-3: EUROCODE 3: Design of steel structure. Part 1.3: General rules. Supplementary rules for cold-formed thin gauge members and sheeting. Brussels.

EUROPEAN COMMITEE FOR STANDARDIZATION (2010). NP EN 1993-1-2: EUROCODE 3: Design of steel structure. Part 1.2: General rules. Structural fire design. Brussels.

GALAMBOS, T. V. (1998). Guide to stability design criteria for metal structures. 5ed New York: John Wiley \& Sons, 1998. 911p.

GALAMBOS, T. V.; SUROVEK, A. E. (2008). Structural stability of steel: concepts and applications for structural engineers. New York: John Wiley \& Sons, 2008. 373p.

HANCOCK, G. J.; YANG, D. (2004). Numerical simulation of high strength steel lippedchannel Columns. Sydney, Australia. Department of Civil Engineering, University of Sydney, Research Report R843.

INTERNATIONAL ORGANIZATION FOR STANDARDIZATION (1999). Fire-resistance tests - Elements of building construction - Part 1: General requirements. ISO 834-1:1999, 1999.

KAITILA, O. (2002). Finite element modeling of cold-formed steel members at high temperatures. Thesis for the Degree of Licentiate of Science in Technology, Helsinki University of Technology, Department of Civil and Environmental Engineering, 2002.

KALYANARAMAN, V.; PEKÖZ, T.; WINTER, G. (1977). Unstiffened compression elements. Journal of the Structural Divison, ASCE, v.103, no.ST9, Proc. Paper 13197, p.1833-1848, 1977.

KIMURA, E. F. A. (2009). Análise termo-estrutural de pilares de aço em situação de incêndio. 225p. Dissertação (Mestrado) - Escola de Engenharia de São Carlos, Universidade de São Paulo, São Carlos, 2009. 
MAIA, W. F. (2008). Sobre a estabilidade de cantoneiras de aço formadas a frio submetidas à compressão. 196p. Dissertação (Mestrado) - Escola de Engenharia de São Carlos, Universidade de São Paulo, São Carlos, 2008.

MAIA, W. F.; MUNAIAR NETO, J.; MALITE, M. (2008). Stability of cold-formed steel simple and lipped angles under compression. In: LaBoube, R.A.; Yu, W.W. (Ed). Recent research and developments in cold-formed steel design and construction (19th International Specialty Conference on Cold-Formed Steel Structures, St. Louis, USA, Oct. 14-15, 2008). Missouri University of Science \& Technology, Rolla, Missouri, USA, 2008.

MAIA, W. F.; MUNAIAR NETO, J.; MALITE, M. (2009). Estabilidade de cantoneiras simples e enrijecidas de aço formadas a frio submetidas à compressão centrada e excêntrica. Revista Minerva, v. 6, p. 139-149, 2009.

MENDES, C. L. (2004). Estudo teórico sobre perfis formados a frio em situação de incêndio. 160p. Dissertação (Mestrado) - Escola de Engenharia de São Carlos, Universidade de São Paulo, São Carlos, 2004.

RASMUSSEN, K. J. R. (2003). Design of angles columns with locally unstable legs. Department of Civil Engineering, Research Report n. R830, University of Sydney, Australia, June, 2003.

REGOBELlO, R. (2007). Análise numérica de seções transversais e de elementos estruturais de aço e mistos de aço e concreto em situação de incêndio. 269p. Dissertação (Mestrado) - Escola de Engenharia de São Carlos, Universidade de São Paulo, São Carlos, 2007.

SALMON, C. G.; JOHNSON, J. E. (1996). Steel structures: design and behavior. 4ed. New York: Harper Collins College Publishers, 1996. 1044p.

SANTOS, R. T. (2009). Modelos Numéricos de Pilares Mistos Curtos de Seções Circulares de Aço Preenchidos com Concreto em Situação de Incêndio. 177p. Dissertação (Mestrado) - Escola de Engenharia de São Carlos, Universidade de São Paulo, São Carlos, 2009.

SCHAFER, B. W.; PEKÖZ, T. (1998). Computational modeling of cold-formed steel: characterizing geometric imperfections and residual stresses. Journal of Constructional Steel Research, v.47, p.193-210, January, 1998. 
SCHAFER, B. W. (1997). Cold-formed steel behavior and design: analytical and numerical modeling of elements and members with longitudinal stiffeners. $\mathrm{PhD}$ Dissertation - Cornell University, Ithaca, 1997.

SCHAFER, B. W. (2001). Finite strip analysis of thin-walled members. In: CUFSM: Cornell University - Finite Strip Method.

SILVA, V. P. (2004). Estruturas de aço em situação de incêndio. São Paulo: Editora Zigurate, 2004. 254p.

SCHULTE, H. (1981). Estruturas de aço - elementos básicos. São Carlos: Editora USP, 1981. 347p.

TEMPLE, M. C.; MCCLOSKEY, D. C.; KENNEDY, D. J. L. (1986). Interconnection of Starred Angle Compression Members. Can. J. Civ. Eng., v.13, № 6, p.606-619, 1986.

TEMPLE, M. C.; SCHEPERS, J. A.; CALABRESSE, J. M. (1987). The Interconnection of Boxed Angle Compression Members. Can. J. Civ. Eng., v.14, № 4, p.534-541, 1987.

TEMPLE, M. C.; TAN, J. C. (1988). Interconnection of Widely Spaced Angles. Can. J. Civ. Eng., v.15, № 4, p.732-741, 1988.

TIMOSHENKO, S. P.; GERE, J. M. (1961). Theory of elastic stability. 2ed. New York: McGraw-Hill Book, 1961. 541p.

TRAHAIR, N. S., (1993). Flexural-Torsional Buckling of Structures. 1ed. London: E \& FN Spon, 1993. 363p.

VISHNUVARDHAN, S.; SAMUEL KNIGHT, G. M. (2008). Behavior of cold-formed steel angle and compound plain angles in compression. Advanced Steel Construction, v.4, n.1, p.46-58, 2008.

VON KARMAN, T.; SECHLER, E. E.; DONNEL, L. H. (1932). The strength of thin plates in compression. Transactions, American Society of Mechanical Engineers (ASME), v.54, p.53-57, 1932. 
WANG, Y. C. (2002). Steel and Composite Structures - Behavior and Design for Fire Safety. Spon Press, London, 2002.

WENG, C. C.; PEKÖZ, T. (1990). Residual stresses in cold-formed steel members. Journal of Structural Engineering, ASCE, v.116, n.6, p.1230-1246, 1990.

WINTER, G. (1947). Strength of thin steel compression flanges. Transactions, American Society of Mechanical Engineers, ASME, v.112, p.527-554, 1947.

YOUNG, B.; ELLOBODY, E. (2005). Buckling analysis of cold-formed steel lipped angles columns. Journal of Structural Engineering, ASCE, v.131, n.10, p.1570-1579, 1990

YU, W. W. (2000). Cold-formed steel design. 3ed. New York: John Wiley \& Sons, 2000. 750p. 


\section{APÊNDICE A - Scripts para as análises à temperatura ambiente: compressão centrada}

Neste apêndice, são disponibilizados os scripts desenvolvidos no presente trabalho para os perfis estudados sob compressão centrada. Conforme explicado no Capítulo 3, os resultados foram obtidos a partir de três análises numéricas, a saber:

1) Script 1: Análise elástica de autovalor para a obtenção das imperfeições geométricas iniciais locais;

2) Script 2: Análise elástica para a obtenção das imperfeição geométrica inicial global;

3) Script 3: Análise final considerando as não-linearidades geométricas e de material.

A seguir, são apresentados os scripts dos perfis modelados com a rótula cilíndrica no eixo-x. No caso dos perfis com a rótula no eixo-y o código é semelhante, sendo necessárias apenas as adequações referentes às restrições nodais aplicadas no dispositivo de apoio e à direção do carregamento do Script 2 (ver Capítulos 3).

\section{1) Script 1:}

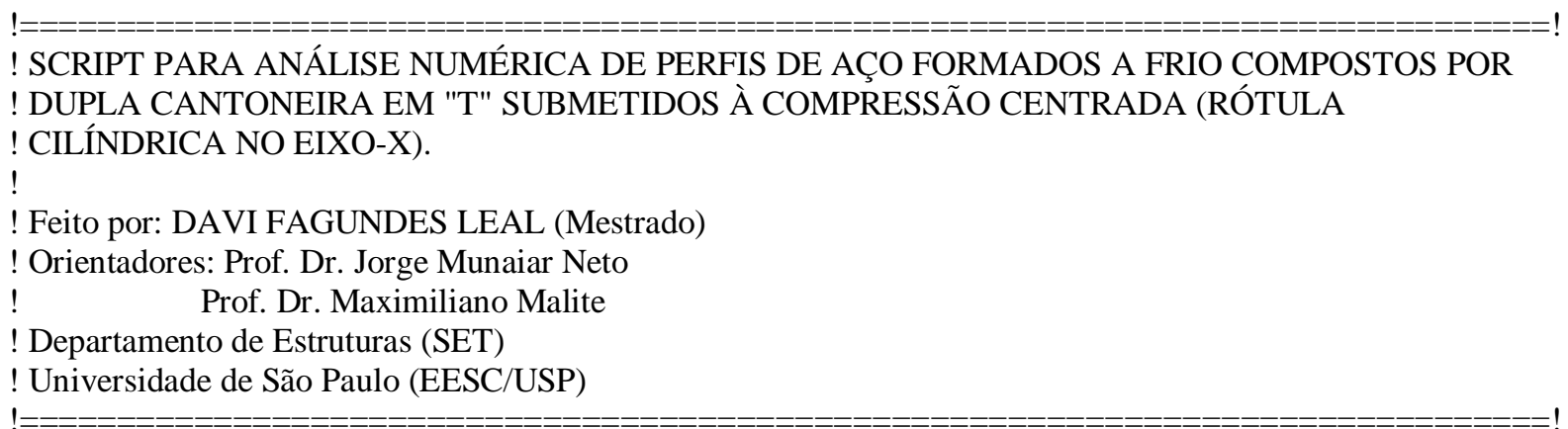

FINISH

/CLEAR

*GET,NProcessadores,ACTIVE, ,NPROC ! Obtém o número de processadores disponíveis no computador. /CONFIG,NPROC,NProcessadores ! Indica o número de processadores a serem usados.

/PREP7 


$\begin{array}{ll}\text { bf=6 } & \text { ! Largura da mesa do perfil, cm } \\ \text { t=0.238 } & \text { ! Espessura do perfil, cm } \\ \text { ri=0.238 } & \text { ! Raio interno de dobramento, cm } \\ \text { comp }=148.5 & \text { ! Comprimento efetivo do perfil, cm } \\ \text { DeslocP=0.2 } & \text { ! Deslocamento prescrito - medido em ensaio, cm } \\ \text { E=20536.8425 } & \text { ! Módulo de elasticidade do aço utilizado, KN/cm2 } \\ \text { v=0.3 } & \text { ! Coeficiente de Poisson do aço utilizado. } \\ \text { dep=0.5 } & \text { ! Distância entre perfis (espessura da chapa de ligação), cm } \\ \text { Lpres=2 } & \text { ! Comprimento da presilha (chapa separadora), cm } \\ \text { Lap=6.75 } & \text { ! Tamanho do dispositivo de apoio (chapa de topo + rótula "faca"), cm } \\ \text { Npres }=2 & \text { ! Número de presilhas (chapas separadoras) utilizadas. } \\ \text { dx=0 } & \text { ! Translação em x do perfil em relação ao (0,0) global. } \\ \text { dy=0 } & \text { ! Translação em y do perfil em relação ao (0,0) global. } \\ \text { ndc=2 } & \text { ! Número de divisões das linhas do canto. } \\ \text { nd1m=5 } & \text { ! Número de divisões das linhas do primeiro trecho da aba com presilhas. } \\ \text { nd2m=2 } & \text { ! Número de divisões das linhas do segundo trecho da aba com presilhas. } \\ \text { nd3m=7 } & \text { ! Número de divisões das linhas da aba livre. } \\ \text { ndCG=20 } & \text { ! Número de divisões da linha que passa pelo CG. } \\ \text { ndT1=4 } & \text { ! Número de divisões da linha auxiliar que liga as abas travejadas. } \\ \text { ndL=comp } & \text { ! Número de divisões das linhas do comprimento do perfil. }\end{array}$

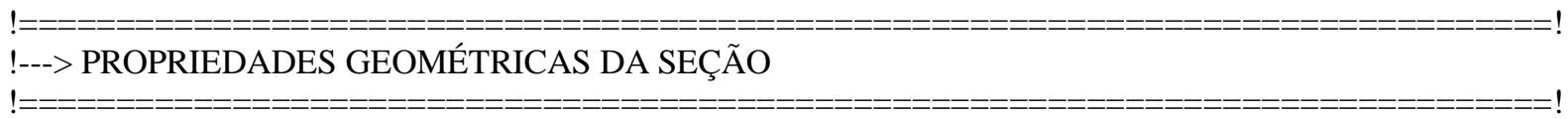

$\begin{array}{ll}\mathrm{rm}=\mathrm{ri}+0.5^{*} \mathrm{t} & \text { ! Raio de dobramento referente a linha média da seção, } \mathrm{cm} \\ \mathrm{b}=\mathrm{bf}-\left(\mathrm{rm}+0.5^{*} \mathrm{t}\right) & \text { ! Largura da parte plana da mesa do perfil, } \mathrm{cm} \\ \mathrm{bm}=\mathrm{bf}-\mathrm{t} / 2 & \text { ! Largura da mesa referente à linha média da seção, cm } \\ \mathrm{u} 1=1.571^{*} \mathrm{rm} & \text { ! Desenvolvimento da parte curva da seção referente à dobra em } 90, \mathrm{~cm} \\ \mathrm{As}=\mathrm{t} *(2 * \mathrm{~b}+\mathrm{u} 1) & \text { ! Área da seção tranversal de uma cantoneira simples, cm2 } \\ \mathrm{Yg}=(\mathrm{t} / \mathrm{As}) *\left(\mathrm{~b}^{*}\left(0.5^{*} \mathrm{~b}+\mathrm{rm}\right)+\mathrm{u} 1 *\left(0.363^{*} \mathrm{rm}\right)\right)+0.5^{*} \mathrm{t} \text { ! Distância do CG à face externa do perfil (direção y) } \\ \text { Ygm=Yg-t/2 }\end{array}$

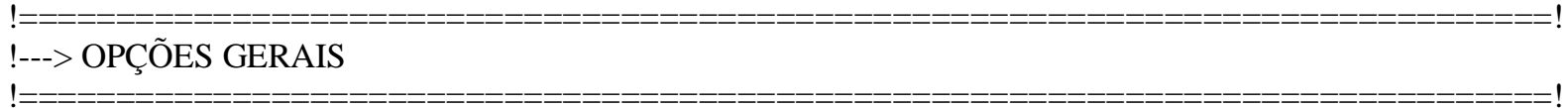

/VIEW,1,1,1,1 ! Vista da tela 1 com diretriz que passa pelo ponto $(1,1,1)$.

/ANGLE, 1

/ESHAPE,1.0

/UIS,MSGPOP,3

/PBC,ALL, ,1

/REP,FAST

! Visualização da geometria do elemento.ex: espessura de elementos de casca.

! Mostra somente as mensagens de erros.

! Plot Boundary Conditions=1, mostra somente o símbolo da restrição.

! Redesenha o modelo.

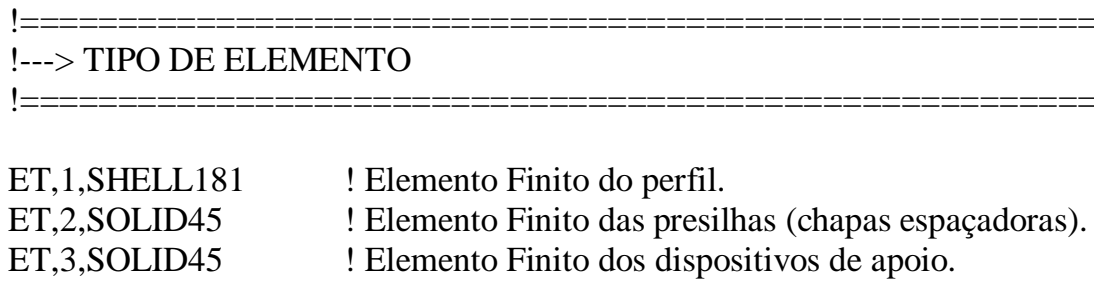




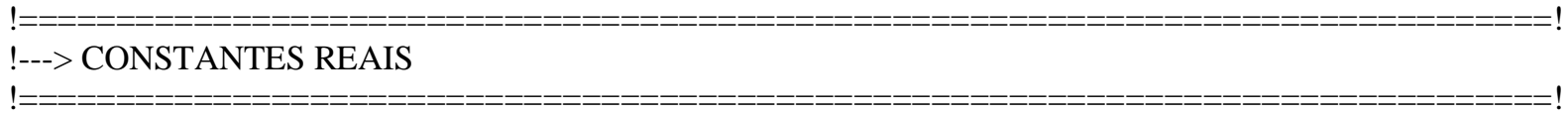

R,1,t ! Espessura do elemento finito (SHELL181).

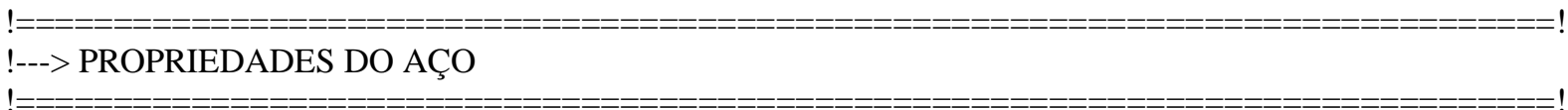

MP,EX,1,E

MP,PRXY,1,v

$\mathrm{MP}, \mathrm{EX}, 2, \mathrm{E}$

MP,PRXY,2,v

$\mathrm{MP}, \mathrm{EX}, 3, \mathrm{E}$

MP,PRXY,3,v
! Atribuição do módulo de elasticidade do perfil.

! Atribuição do coeficiente de Poisson do perfil.

! Atribuição do módulo de elasticidade das presilhas.

! Atribuição do coeficiente de Poisson das presilhas.

! Atribuição do módulo de elasticidade do dispositivo de apoio.

! Atribuição do coeficiente de Poisson do dispositivo de apoio.

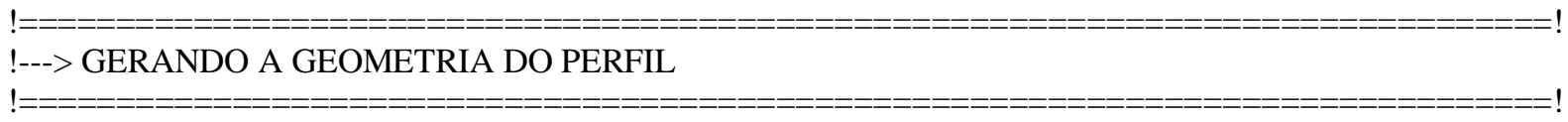

$\mathrm{K}, 1, \mathrm{dx}+\mathrm{dep} / 2+\mathrm{t} / 2, \mathrm{dy}+\mathrm{bm}, 0$

$\mathrm{K}, 2, \mathrm{dx}+\mathrm{dep} / 2+\mathrm{t} / 2, \mathrm{dy}+\mathrm{Ygm}, 0$

$\mathrm{K}, 3, \mathrm{dx}+\mathrm{dep} / 2+\mathrm{t} / 2, \mathrm{dy}, 0$

$\mathrm{K}, 4, \mathrm{dx}+\mathrm{dep} / 2+\mathrm{t} / 2+\mathrm{bm}, \mathrm{dy}, 0$

\section{$\mathrm{L}, 1,2$}

$\mathrm{L}, 2,3$

$\mathrm{L}, 3,4$

LFILLT,2,3,rm, ,

$\mathrm{K}, 7, \mathrm{dx}-(\mathrm{dep} / 2+\mathrm{t} / 2+\mathrm{bm}), \mathrm{dy}, 0$

$\mathrm{K}, 8, \mathrm{dx}-(\mathrm{dep} / 2+\mathrm{t} / 2)$,dy,0

$\mathrm{K}, 9, \mathrm{dx}-(\mathrm{dep} / 2+\mathrm{t} / 2), \mathrm{dy}+\mathrm{Ygm}, 0$

$\mathrm{K}, 10$,dx-(dep/2+t/2),dy+bm,0

$\mathrm{L}, 7,8$

L, 8,9

$\mathrm{L}, 9,10$

LFILLT,5,6,rm, ,

$\mathrm{K}, 13, \mathrm{dx}+\mathrm{dep} / 2+\mathrm{t} / 2, \mathrm{dy}+\mathrm{bm}, \mathrm{comp}$

$\mathrm{L}, 1,13$

ADRAG,1,2,3,4, , ,9

LDELE,9

KDELE, 13

NUMCMP,ALL

K,18,dx-(dep/2+t/2+bm),dy,comp $\mathrm{L}, 7,18$

ADRAG,5,6,7,8, , ,18

LDELE, 18

KDELE,18

NUMCMP,ALL
! Gera pontos chaves da seção do perfil 1.

! Gera linhas que compõem o perfil 1.

! Faz o arredondamento do canto do perfil 1.

! Gera pontos chaves da seção do perfil 2.

! Gera linhas que compõem o perfil 2.

! Faz o arredondamento do canto do perfil 2.

! Cria um ponto chave auxiliar para o perfil 1.

! Cria uma linha auxiliar.

! Gera áreas arrastando um conjunto de linhas ao longo de um caminho.

! Deleta a linha que foi duplicada.

! Deleta o ponto chave auxiliar que foi criado.

! Renumera itens reutilizando os números já deletados ou não utilizados.

! Cria um ponto chave auxiliar para o perfil 2

! Cria uma linha auxiliar.

! Gera áreas arrastando um conjunto de linhas ao longo de um caminho.

! Deleta a linha que foi duplicada.

! Deleta o ponto chave auxiliar que foi criado.

! Renumera itens reutilizando os números já deletados ou não utilizados. 
$\mathrm{L}, 2,9$

$\mathrm{L}, 14,21$
! Cria uma linha que passa pelo centróide em 0.

! Cria uma linha que passa pelo centróide em comp.

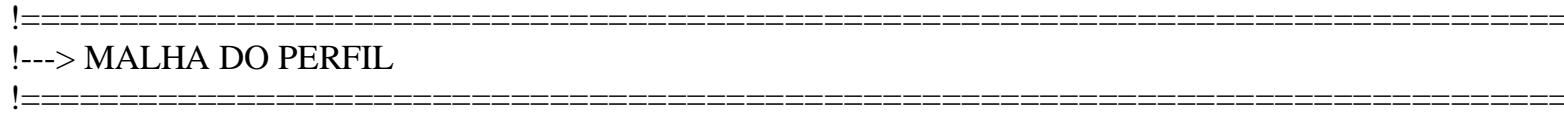

!--- COMPRIMENTO DO PERFIL:

Dpres $=$ comp/(Npres+1) ! Distância entre centros de presilhas.

LocWP=Dpres

Nloop1=Npres

! Variável de loop.

*DOWHILE,Nloop1

ASEL,S,LOC,Z,0.001,comp-0.001 ! Divisão das linhas para alocar as presilhas.

WPAVE,0,0,LocWP-Lpres/2

ASBW,ALL

WPAVE,0,0,LocWP+Lpres/2

ASBW,ALL

LSEL,S,LOC,Z,LocWP-Lpres/2+0.001,LocWP+Lpres/2-0.001 ! Malha nas regiões das presilhas.

LESIZE,ALL, , ,Lpres, , , , ,1

LocWP=LocWP+Dpres

Nloop1=Nloop1-1

*ENDDO

WPAVE, 0,0,0

PtLoc $=$ Dpres

Nloop2=Npres+1 ？ Variável de loop.

*DOWHILE,Nloop2 ～～～Malha fora das regiões das presilhas.

*IF,(Nloop2),EQ,(Npres+1),THEN

LSEL,S,LOC,Z,PtLoc-Lpres/2-0.001,PtLoc-Dpres+0.001

LESIZE,ALL, , ,Dpres-Lpres/2, , , , ,1

*ELSEIF,(Nloop2),EQ,(1),THEN

LSEL,S,LOC,Z,PtLoc-0.001,PtLoc-Dpres+Lpres/2+0.001

LESIZE,ALL, , ,Dpres-Lpres/2, , , , ,1

*ELSE

LSEL,S,LOC,Z,PtLoc-Lpres/2-0.001,PtLoc-Dpres+Lpres/2+0.001

*ENDIF

LESIZE,ALL, , ,Dpres-Lpres, , , , ,1

PtLoc $=$ PtLoc + Dpres

Nloop2=Nloop2-1

*ENDDO

ASEL,ALL

AGLUE,ALL ! ! Une ("cola") as áreas selecionadas. 
!--- Primeira parte da aba:

LSEL,S,LOC,Z,-0.001,comp+0.001

LSEL,R,LOC,Y,dy+Ygm+0.001,dy+bm+0.001 centróide (Ygm).

LESIZE,ALL, , ,nd1m, , , , ,1

ASEL,S,LOC,Y,dy+Ygm+0.001,dy+bm+0.001

MSHKEY,1

MAT,1

TYPE,1

REAL, 1

MSHAPE,0,2D

AMESH,ALL

ASEL,ALL

!--- Segunda parte da aba:

LSEL,S,LOC,Z,-0.001,comp+0.001

LSEL,R,LOC,Y,dy+rm,dy+Ygm-0.001

LESIZE,ALL, , ,nd2m, , , , ,1

ASEL,S,LOC,Y,dy+rm,dy+Ygm-0.001

\section{MSHKEY,1}

MAT,1

TYPE, 1

REAL, 1

MSHAPE,0,2D

AMESH,ALL

ASEL,ALL

!--- Parte curva:

LSEL,S,LOC,Z,-0.001,comp+0.001

LSEL,R,LOC,Y,dy+0.001,dy+rm-0.001

LESIZE,ALL, , ,ndc, , , , ,1

ASEL,R,LOC,Y,dy+0.001,dy+rm-0.001

\section{MSHKEY,1}

MAT,1

TYPE,1

REAL,1

MSHAPE, 0,2D

AMESH,ALL

ASEL,ALL
! Seleciona as linhas das seções acima da coordenada Y do

! Seleciona todas as linhas do perfil.

! Divide as linhas da primeira parte da aba.

! Tipo da malha: Mapeada

! Material da aba

! Tipo do elemento da aba

! Constante real do elemento da aba

! Malha realizada com elemento 2D

! Gerando a malha

! Seleciona todas as linhas do perfil.

! Seleciona as linhas entre o fim da dobra e Ygm.

! Divide as linhas da segunda parte da aba.

! Tipo da malha: Mapeada

! Material da aba

! Tipo do elemento da aba

! Constante real do elemento da aba

! Malha realizada com elemento 2D

! Gerando a malha

! Seleciona todas as linhas do perfil.

! Seleciona a linha curva das dobras das seções.

! Divide a linhas da dobras.

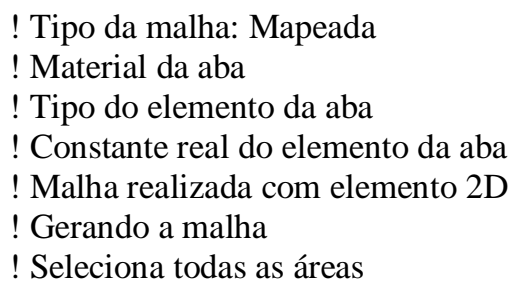

! Tipo da malha: Mapeada

! Material da aba

! Tipo do elemento da aba

! Constante real do elemento da aba

! Gerando a malha

! Seleciona todas as áreas

!--- ABAS LIVRES (SEM PRESILHAS):

LSEL,S,LOC,Z,-0.001,comp+0.001

LSEL,R,LOC,X,dx+dep/2+t/2+rm+0.001,dx+dep/2+t/2+bm-0.001

LESIZE,ALL, , ,nd3m, , , , ,1
! Seleciona todas as linhas do perfil.

! Seleciona a linha da aba livre do perfil 1.

! Divide a linha da aba livre do perfil 1. 
MSHKEY,1

MAT,1

TYPE, 1

REAL, 1

MSHAPE,0,2D

AMESH,ALL

ASEL,ALL
! Tipo da malha: Mapeada

! Material da aba

! Tipo do elemento da aba

! Constante real do elemento da aba

! Malha realizada com elemento 2D

! Gerando a malha

LSEL,S,LOC,Z,-0.001,comp+0.001

! Seleciona todas as linhas do perfil.

LSEL,R,LOC,X,dx-(dep/2+t/2+rm-0.001),dx-(dep/2+t/2+bm+0.001) ! Seleciona a linha da aba livre do perfil 2.

LESIZE,ALL, , ,nd3m, , , , ,1

! Divide a linha da aba livre do perfil 2.

ASEL,S,LOC,X,dx-(dep/2+t/2+rm-0.001),dx-(dep/2+t/2+bm+0.001)

MSHKEY,1

MAT,1

TYPE,1

REAL, 1

MSHAPE,0,2D

AMESH,ALL

ASEL,ALL
! Tipo da malha: Mapeada

! Material da aba

! Tipo do elemento da aba

! Constante real do elemento da aba

! Malha realizada com elemento 2D

! Gerando a malha

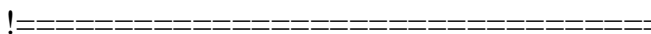

LSEL,ALL

NSEL,ALL

KSEL,ALL

*GET,Nkp,KP,0,COUNT, ,

!--- DISPOSITIVOS DE APOIO:

! Cria keypoints auxiliares na seção Z=0:

$\mathrm{K}, 0, \mathrm{dx}+\mathrm{dep} / 2+\mathrm{t} / 2+\mathrm{bm}, \mathrm{dy}+\mathrm{bm}, 0$

$\mathrm{K}, 0, \mathrm{dx}-\mathrm{dep} / 2-\mathrm{t} / 2-\mathrm{bm}, \mathrm{dy}+\mathrm{bm}, 0$

$\mathrm{K}, 0, \mathrm{dx}+\mathrm{dep} / 2+\mathrm{t} / 2+\mathrm{rm}, \mathrm{dy}+\mathrm{bm}, 0$

$\mathrm{K}, 0, \mathrm{dx}-\mathrm{dep} / 2 \mathrm{t} / 2-\mathrm{rm}, \mathrm{dy}+\mathrm{bm}, 0$

$\mathrm{K}, 0, \mathrm{dx}+\mathrm{dep} / 2+\mathrm{t} / 2+\mathrm{bm}, \mathrm{dy}+\mathrm{rm}, 0$

$\mathrm{K}, 0, \mathrm{dx}-\mathrm{dep} / 2 \mathrm{t} / 2-\mathrm{bm}, \mathrm{dy}+\mathrm{rm}, 0$

$\mathrm{K}, 0, \mathrm{dx}+\mathrm{dep} / 2+\mathrm{t} / 2+\mathrm{bm}, \mathrm{dy}+\mathrm{ygm}, 0$

$\mathrm{K}, 0$,dx-dep/2-t/2-bm,dy+ygm,0

$\mathrm{K}, 0, \mathrm{dx}+\mathrm{dep} / 2+\mathrm{t} / 2+\mathrm{rm}, \mathrm{dy}+\mathrm{rm}, 0$

$\mathrm{K}, 0, \mathrm{dx}-\mathrm{dep} / 2-\mathrm{t} / 2-\mathrm{rm}, \mathrm{dy}+\mathrm{rm}, 0$

$\mathrm{K}, 0, \mathrm{dx}+\mathrm{dep} / 2+\mathrm{t} / 2+\mathrm{rm}, \mathrm{dy}+\mathrm{ygm}, 0$

$\mathrm{K}, 0$,dx-dep/2-t/2-rm,dy+ygm,0

$\mathrm{K}, 0, \mathrm{dx}+\mathrm{dep} / 2+\mathrm{t} / 2, \mathrm{dy}+\mathrm{bm}, 0$

$\mathrm{K}, 0, \mathrm{dx}-(\mathrm{dep} / 2+\mathrm{t} / 2), \mathrm{dy}+\mathrm{bm}, 0$

$\mathrm{K}, 0, \mathrm{dx}+\mathrm{dep} / 2+\mathrm{t} / 2, \mathrm{dy}+\mathrm{Ygm}, 0$

$\mathrm{K}, 0, \mathrm{dx}-(\mathrm{dep} / 2+\mathrm{t} / 2), \mathrm{dy}+\mathrm{Ygm}, 0$

$\mathrm{K}, 0, \mathrm{dx}+\mathrm{dep} / 2+\mathrm{t} / 2, \mathrm{dy}+\mathrm{rm}, 0$

$\mathrm{K}, 0, \mathrm{dx}-(\mathrm{dep} / 2+\mathrm{t} / 2), \mathrm{dy}+\mathrm{rm}, 0$
! Seleciona todas as linhas do modelo.

! Seleciona todos os nós do modelo.

! Seleciona todos os keypoints do modelo.

! Obtém o número de Keypoints. 
$\mathrm{K}, 0, \mathrm{dx}+\mathrm{dep} / 2+\mathrm{t} / 2, \mathrm{dy}, 0$

$\mathrm{K}, 0, \mathrm{dx}-(\mathrm{dep} / 2+\mathrm{t} / 2), \mathrm{dy}, 0$

$\mathrm{K}, 0, \mathrm{dx}+\mathrm{dep} / 2+\mathrm{t} / 2+\mathrm{rm}, \mathrm{dy}, 0$

$\mathrm{K}, 0, \mathrm{dx}-(\mathrm{dep} / 2+\mathrm{t} / 2+\mathrm{rm}), \mathrm{dy}, 0$

$\mathrm{K}, 0, \mathrm{dx}+\mathrm{dep} / 2+\mathrm{t} / 2+\mathrm{bm}, \mathrm{dy}, 0$

$\mathrm{K}, 0, \mathrm{dx}-(\mathrm{dep} / 2+\mathrm{t} / 2+\mathrm{bm}), \mathrm{dy}, 0$

A,(Nkp+24),(Nkp+22),(Nkp+10),(Nkp+6)

$\mathrm{A},(\mathrm{Nkp}+6),(\mathrm{Nkp}+10),(\mathrm{Nkp}+12),(\mathrm{Nkp}+8)$

$\mathrm{A},(\mathrm{Nkp}+8),(\mathrm{Nkp}+12),(\mathrm{Nkp}+4),(\mathrm{Nkp}+2)$

$\mathrm{A},(\mathrm{Nkp}+22),(\mathrm{Nkp}+20),(\mathrm{Nkp}+18),(\mathrm{Nkp}+10)$

$\mathrm{A},(\mathrm{Nkp}+10),(\mathrm{Nkp}+18),(\mathrm{Nkp}+16),(\mathrm{Nkp}+12)$

$\mathrm{A},(\mathrm{Nkp}+12),(\mathrm{Nkp}+16),(\mathrm{Nkp}+14),(\mathrm{Nkp}+4)$

$\mathrm{A},(\mathrm{Nkp}+20),(\mathrm{Nkp}+19),(\mathrm{Nkp}+17),(\mathrm{Nkp}+18)$

$\mathrm{A},(\mathrm{Nkp}+18),(\mathrm{Nkp}+17),(\mathrm{Nkp}+15),(\mathrm{Nkp}+16)$

$\mathrm{A},(\mathrm{Nkp}+16),(\mathrm{Nkp}+15),(\mathrm{Nkp}+13),(\mathrm{Nkp}+14)$

$\mathrm{A},(\mathrm{Nkp}+19),(\mathrm{Nkp}+21),(\mathrm{Nkp}+9),(\mathrm{Nkp}+17)$

$\mathrm{A},(\mathrm{Nkp}+17),(\mathrm{Nkp}+9),(\mathrm{Nkp}+11),(\mathrm{Nkp}+15)$

$\mathrm{A},(\mathrm{Nkp}+15),(\mathrm{Nkp}+11),(\mathrm{Nkp}+3),(\mathrm{Nkp}+13)$

$\mathrm{A},(\mathrm{Nkp}+21),(\mathrm{Nkp}+23),(\mathrm{Nkp}+5),(\mathrm{Nkp}+9)$

$\mathrm{A},(\mathrm{Nkp}+9),(\mathrm{Nkp}+5),\left(\mathrm{Nkp}^{+7}\right),(\mathrm{Nkp}+11)$

$\mathrm{A},(\mathrm{Nkp}+11),(\mathrm{Nkp}+7),(\mathrm{Nkp}+1),(\mathrm{Nkp}+3)$

ASEL,S,LOC,Z,0.001,-0.001

AGEN,2,ALL, , ,0,0,comp,0,1,0

ASEL,S,LOC,Z,0.001,-0.001

VEXT,ALL, , ,0,0,-Lap,1,1,1

VSEL,S,LOC,Z,-0.001,-Lap+0.001

VGLUE,ALL

! Cria um volume: apoio do tipo "faca" em Z=0.

! Seleciona o volume do apoio em Z $=0$.

! Une ("cola") os volumes selecionados.

ASEL,S,LOC,Z,comp+0.001,comp-0.001

VEXT,ALL, , ,0,0,Lap,1,1,1

VSEL,S,LOC,Z,comp+Lap+0.001,comp-0.001

! Cria um volume: apoio do tipo "faca" em Z=comp.

VGLUE,ALL

! Seleciona o volume do apoio em $\mathrm{Z}=$ comp.

! Une ("cola") os volumes selecionados.

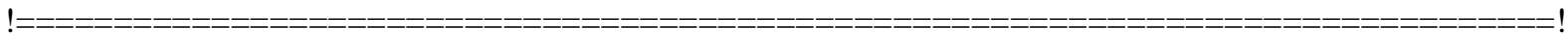

!---> MALHA DOS DISPOSITIVOS DE APOIO

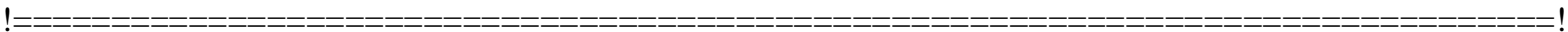

!--- Malha em z=0:

NSEL,NONE

LSEL,S,LOC,Z,-0.001,-Lap+0.001

LESIZE,ALL, , ,Lap, , , , ,1

! Seleciona as linhas do apoio na direção longitudinal.

LSEL,S,LOC,Z,0.001,-Lap-0.001

LSEL,R,LOC,Y,dy+Ygm+0.001,dy+bm-0.001

! Seleciona as linhas do apoio em $\mathrm{z}=0$.

LESIZE,ALL, , ,nd1m, , , , ,1

LSEL,S,LOC,Z,0.001,-Lap-0.001

LSEL,R,LOC,Y,dy+rm+0.001,dy+Ygm-0.001

! Seleciona as linhas do apoio em z=0.

LESIZE,ALL, , ,nd2m, , , , ,1

LSEL,S,LOC,Z,0.001,-Lap-0.001

! Seleciona as linhas do apoio em z=0.

LSEL,R,LOC,Y,dy+0.001,dy+rm-0.001

LESIZE,ALL, , ,ndc, , , , ,1
} 
LSEL,S,LOC,Z,0.001,-Lap-0.001

! Seleciona as linhas do apoio em $\mathrm{z}=0$.

LSEL,R,LOC,X,dx+dep/2+t/2+rm+0.001,dx+dep/2+t/2+bm-0.001

LESIZE,ALL, , ,nd3m, , , , , 1

LSEL,S,LOC,Z,0.001,-Lap-0.001

! Seleciona as linhas do apoio em $\mathrm{z}=0$.

LSEL,R,LOC,X,dx-dep/2-t/2-rm-0.001,dx-dep/2-t/2-bm+0.001

LESIZE,ALL, , ,nd3m, , , , , 1

LSEL,S,LOC,Z,0.001,-Lap-0.001

! Seleciona as linhas do apoio em $\mathrm{z}=0$.

LSEL,R,LOC,X,dx+dep/2+t/2+0.001,dx+dep/2+t/2+rm-0.001

LESIZE,ALL, , ,ndc, , , , , 1

LSEL,S,LOC,Z,0.001,-Lap-0.001

! Seleciona as linhas do apoio em $\mathrm{z}=0$.

LSEL,R,LOC,X,dx-dep/2-t/2+0.001,dx-dep/2-t/2-rm+0.001

LESIZE,ALL, , ,ndc, , , , , 1

LSEL,S,LOC,Z,0.001,-Lap-0.001

! Seleciona as linhas do apoio em $\mathrm{z}=0$.

LSEL,R,LOC,X,dx-dep/2-t/2+0.001,dx+dep/2+t/2-0.001

LESIZE,ALL, , , 2, , , , , 1

VSEL,S,LOC,Z,0.001,-Lap-0.001

MSHKEY,1

MAT,3

TYPE, 3

MSHAPE, 0,3D

VMESH,ALL

VSEL,ALL

NSEL,S,LOC,Z,0.001,-0.001

NUMMRG,NODE,0.05, , ,LOW

NUMCMP,ALL

! Seleciona os nós em Z $\mathrm{Z}=0$.

! Junta os nós muito próximos.

! Renumera itens reutilizando os números já deletados.

!--- Malha em z=comp:

LSEL,S,LOC,Z,comp+Lap-0.001,comp+0.001

LESIZE,ALL, , ,Lap, , , , , 1

LSEL,S,LOC,Z,comp+Lap+0.001,comp-0.001

! Tipo da malha: Mapeada

! Material da chapa de topo

! Tipo do elemento da chapa de topo

! Malha realizada com elemento 3D

! Gerando a malha

LSEL,R,LOC,Y,dy+Ygm+0.001,dy+bm-0.001

LESIZE,ALL, , ,nd1m, , , , ,1

LSEL,S,LOC,Z,comp+Lap+0.001,comp-0.001

LSEL,R,LOC,Y,dy+rm+0.001,dy+Ygm-0.001

! Seleciona as linhas do apoio na direção longitudinal.

LESIZE,ALL, , ,nd2m, , , , ,1

LSEL,S,LOC,Z,comp+Lap+0.001,comp-0.001

LSEL,R,LOC,Y,dy+0.001,dy+rm-0.001

LESIZE,ALL, , ,ndc, , , , ,1

LSEL,S,LOC,Z,comp+Lap+0.001,comp-0.001 ! Seleciona as linhas do apoio em z=comp.

LSEL,R,LOC,X,dx+dep/2+t/2+rm+0.001,dx+dep/2+t/2+bm-0.001

LESIZE,ALL, , ,nd3m, , , , ,1

LSEL,S,LOC,Z,comp+Lap+0.001,comp-0.001 ! Seleciona as linhas do apoio em z=comp.

LSEL,R,LOC,X,dx-dep/2-t/2-rm-0.001,dx-dep/2-t/2-bm+0.001

LESIZE,ALL, , ,nd3m, , , , ,1

LSEL,S,LOC,Z,comp+Lap+0.001,comp-0.001 I Seleciona as linhas do apoio em z=comp. 
LSEL,R,LOC,X,dx+dep/2+t/2+0.001,dx+dep/2+t/2+rm-0.001

LESIZE,ALL, , ,ndc, , , , ,1

LSEL,S,LOC,Z,comp+Lap+0.001,comp-0.001 ! Seleciona as linhas do apoio em z=comp.

LSEL,R,LOC,X,dx-dep/2-t/2+0.001,dx-dep/2-t/2-rm+0.001

LESIZE,ALL, , ,ndc, , , , ,1

LSEL,S,LOC,Z,comp+Lap+0.001,comp-0.001 ! Seleciona as linhas do apoio em z=comp.

LSEL,R,LOC,X,dx-dep/2-t/2+0.001,dx+dep/2+t/2-0.001

LESIZE,ALL, , ,2, , , , ,1

VSEL,S,LOC,Z,comp+Lap+0.001,comp-0.001

MSHKEY,1

MAT,3

TYPE,3

MSHAPE,0,3D

VMESH,ALL

VSEL,ALL

NSEL,S,LOC,Z,comp-0.001,comp+0.001

NUMMRG,NODE,0.05, , ,LOW

! Tipo da malha: Mapeada

! Material da chapa de topo

! Tipo do elemento da chapa de topo

! Malha realizada com elemento 3D

! Gerando a malha

NUMCMP,ALL

! Seleciona os nós em Z=comp.

! Junta os nós muito próximos.

! Renumera itens reutilizando os números já deletados.

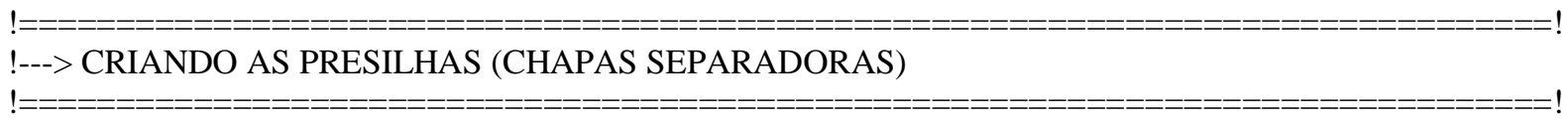

elm1 $=(b f-Y g) / n d 1 m$

Dpres $=$ comp $/($ Npres +1$)$

LocPres $=$ Dpres

Nloop3=Npres
! Tamanho dos elementos do primeiro trecho da aba com presilhas.

! Distância entre centros de presilhas.

! Variável de localização das presilhas.

! Variável de loop.

*DOWHILE,Nloop3

KSEL,ALL

*GET,Nkp,KP,0,COUNT, , Obtém o número de Keypoints.

$\mathrm{K}, 0, \mathrm{dx}+\mathrm{dep} / 2, \mathrm{dy}+$ Ygm,LocPres-Lpres/2

$\mathrm{K}, 0, \mathrm{dx}-\mathrm{dep} / 2, \mathrm{dy}+$ Ygm,LocPres-Lpres/2

! Criando os pontos da presilha.

$\mathrm{K}, 0, \mathrm{dx}+\mathrm{dep} / 2, \mathrm{dy}+\mathrm{Ygm}+2 * \mathrm{elm} 1$, LocPres-Lpres/2

! Criando os pontos da presilha.

K,0,dx-dep/2,dy+Ygm+2*elm1,LocPres-Lpres/2

! Criando os pontos da presilha.

! Criando os pontos da presilha.

$\mathrm{A},(\mathrm{Nkp}+1),(\mathrm{Nkp}+2),(\mathrm{Nkp}+4),(\mathrm{Nkp}+3)$

ASEL,S,LOC,X,dx-dep/2-0.001,dx+dep/2+0.001

ASEL,R,LOC,Z,LocPres-Lpres/2-0.001,LocPres-Lpres/2+0.001

VEXT,ALL, , ,0,0,Lpres,1,1,1

! Cria a geometria da presilha (volume).

LSEL,S,LOC,Z,LocPres-Lpres/2+0.001,LocPres+Lpres/2-0.001 ! Divisão das linhas longitudinais da

LSEL,R,LOC,X,dx-dep/2-0.001,dx+dep/2+0.001 presilha.

LESIZE,ALL, , ,Lpres, , , , ,1

LocPres $=$ LocPres + Dpres

Nloop3=Nloop3-1

*ENDDO

ASEL,ALL 


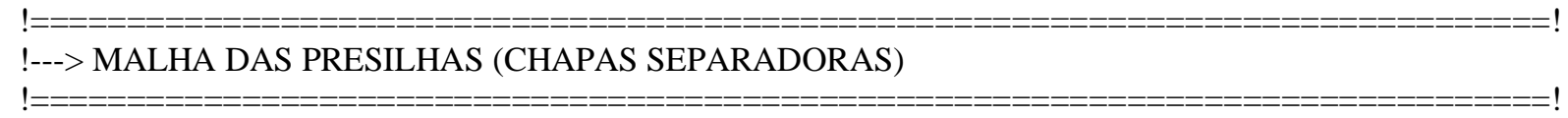

!--- Gerando a malha das presilhas:

LSEL,S,LOC,X,dx-dep/2+0.001,dx+dep/2-0.001

! Seleciona as linhas da espessura das presilhas.

LSEL,R,LOC,Z,0.001,comp-0.001

LESIZE,ALL, , ,1, , , , ,1

LSEL,S,LOC,X,dx-dep/2-0.001,dx+dep/2+0.001

! Seleciona as linhas das presilhas.

LSEL,R,LOC,Z,0.001,comp-0.001

LSEL,R,LOC,Y,dy+Ygm+0.001,dy+Ygm+2*elm1-0.001

! Seleciona as linhas da altura das presilhas.

LESIZE,ALL, , ,2, , , , ,1

VSEL,S,LOC,Z,0.001,comp-0.001

VSEL,R,LOC,X,dx-dep/2+0.001,dx+dep/2-0.001

MSHKEY,1

MAT,2

TYPE,2

MSHAPE,0,3D

VMESH,ALL

VSEL,ALL

! Seleciona todas as presilhas.

! Tipo da malha: Mapeada

! Material da chapa de topo

! Tipo do elemento da chapa de topo

! Malha realizada com elemento 3D

! Gerando a malha

!--- Juntando os nós da região parafusada:

elm1=(bf-Yg)/nd1m

Dpres $=$ comp/(Npres +1$)$

LocPres $=$ Dpres

Nloop4=Npres

*DOWHILE,Nloop4

NSEL,S,LOC,Z,LocPres-1-0.001,LocPres+1+0.001

NSEL,R,LOC,Y,dy+Ygm-0.001,dy+Ygm+2*elm1+0.001

NSEL,R,LOC,X,dx-0.001,dx-dep/2-t/2-0.001

NUMMRG,NODE,t/2+0.001, , ,LOW

NSEL,S,LOC,Z,LocPres-1-0.001,LocPres+1+0.001

NSEL,R,LOC,Y,dy+Ygm-0.001,dy+Ygm+2*elm1+0.001

NSEL,R,LOC,X, dx+0.001,dx+dep/2+t/2+0.001

NUMMRG,NODE,t/2+0.001, , ,LOW

LocPres $=$ LocPres + Dpres

Nloop4=Nloop4-1

*ENDDO

/NUMBER,1

/PNUM,MAT,1

/REPLOT
! Tamanho dos elementos do primeiro trecho da aba com presilhas.

! Distância entre centros de presilhas.

! Variável de localização das presilhas.

! Variável de loop.
! Presilha parafusada aos perfis - $2 \mathrm{~cm} \times 2 \mathrm{~cm}$, aprox. ! Presilha parafusada aos perfis $-2 \mathrm{~cm} \times 2 \mathrm{~cm}$, aprox. ! Seleciona os nós do lado esquerdo da presilha. ! Junta os nós muito próximos.

! Presilha parafusada aos perfis - $2 \mathrm{~cm} \times 2 \mathrm{~cm}$, aprox. ! Presilha parafusada aos perfis $-2 \mathrm{~cm} \times 2 \mathrm{~cm}$, aprox. ! Seleciona os nós do lado direito da presilha.

! Junta os nós muito próximos. 
FINISH

/SOLU

!--- ACOPLAMENTO DOS NÓS DOS APOIOS:

! Apoio em $\mathrm{z}=0$ :

NSEL,S,LOC,Z,-Lap+0.001,-Lap-0.001

NPLOT,ALL

CP,10,UZ,ALL

! Seleção dos nós do apoio em Z=0.

NSEL,ALL

ostra os nós selecionados e seus respectivos números.

! Acoplamento dos nós.

! Apoio em $\mathrm{z}=$ comp:

NSEL,S,LOC,Z,comp+Lap+0.001,comp+Lap-0.001 ! Seleção dos nós do apoio em Z=comp.

NPLOT,ALL

! Mostra os nós selecionados e seus respectivos números.

CP,20,UZ,ALL

! Acoplamento dos nós.

NSEL,ALL

!--- CONDIÇÕES DE CONTORNO DOS NÓS DAS CHAPAS DE TOPO:

! Restrições em Z=0:

NSEL,S,LOC,Z,-Lap+0.001,-Lap-0.001

! Seleciona os nós do apoio em $\mathrm{Z}=0$.

NPLOT,ALL

D,ALL,UX,0, , , ,UY,ROTX,ROTY,ROTZ ! Restrições ao deslocamento dos nós selecionados.

NSEL,ALL

! Restrições em Z=comp:

NSEL,S,LOC,Z,comp+Lap+0.001,comp+Lap-0.001 ! Seleciona os nós do apoio em z=comp. NPLOT,ALL

D,ALL,UX,0, , , ,UY,UZ,ROTX,ROTY,ROTZ ! Restrições ao deslocamento dos nós selecionados.

NSEL,ALL

FINISH

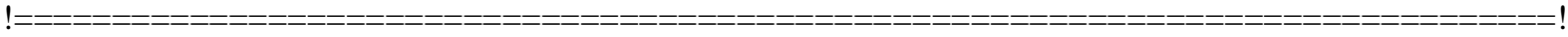

!---> OPÇÕES DE PROCESSAMENTO

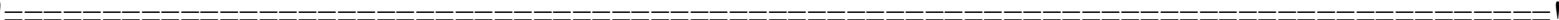

/SOLU

ANTYPE,0

! Análise estática.

NLGEOM,OFF

! Desativa a não linearidade geométrica.

EQSLV,SPAR, ,0

! Solver escolhido (DEFAULT).

PSTRES,ON

FINISH

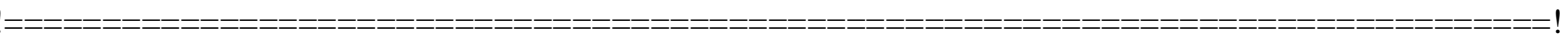

!---> CARREGAMENTO

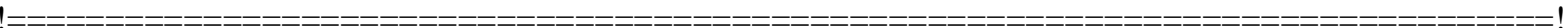


/SOLU

NSEL,S,LOC,Z,-Lap+0.001,-Lap-0.001

NSEL,R,LOC,Y,dy+Ygm-0.001,dy+Ygm+0.001 ! Seleção dos nós que passam pela "faca" no apoio em Z=0.

NPLOT,ALL

*GET,nmestre,NODE,0,NUM,MIN

NPLOT,ALL

F,nmestre,FZ,1

! Pega o nó mestre (menor numeração de nó da linha).

GPLOT

! Aplica uma força unitária no nó mestre na direção Z.

ALLSEL,ALL

CSDELE, 11

/REPLOT

! Deleta sistemas de coordenadas locais.

FINISH

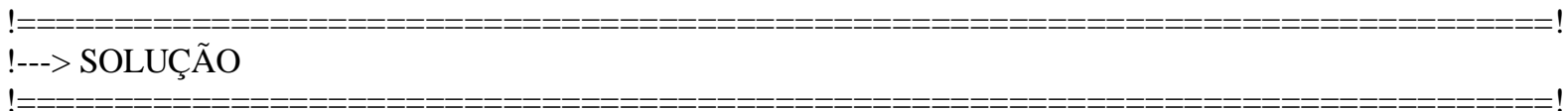

/SOLU

/STATUS,SOLU

SOLVE

FINISH

!--- BUCKLING ANÁLISE

/SOLU

ANTYPE, 1

BUCOPT,LANB,50

SOLVE

FINISH

/SOLU

EXPASS,ON

MXPAND,50

SOLVE

FINISH

SAVE

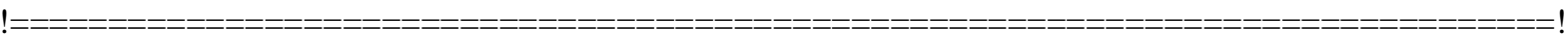

\section{2) Script 2:}

Para a obtenção da imperfeição geométrica inicial global, a construção do modelo é semelhante ao que é apresentado no Script 1, sendo as únicas diferenças referentes aos itens Condições de Contorno, Carregamento e Solução, cujo código foi reescrito da seguinte forma: 
FINISH

/SOLU

\section{!--- ACOPLAMENTO DOS NÓS DA LINHA QUE PASSA PELA RÓTULA:}

! Apoio em $\mathrm{z}=0$ :

NSEL,S,LOC,Z,-Lap+0.001,-Lap-0.001

NSEL,R,LOC,Y,dy+Ygm-0.001,dy+Ygm+0.001

! Seleção dos nós da rótula no apoio em Z=0.

NPLOT,ALL

CP,10,UZ,ALL

! Mostra os nós selecionados e seus respectivos números.

NSEL,ALL

! Acoplamento dos nós.

! Apoio em $\mathrm{z}=\mathrm{comp}$ :

NSEL,S,LOC,Z,comp+Lap+0.001,comp+Lap-0.001

NSEL,R,LOC,Y,dy+Ygm-0.001,dy+Ygm+0.001

NPLOT,ALL

CP,20,UZ,ALL

! Seleção dos nós da rótula no apoio em Z=comp.

NSEL,ALL

! Mostra os nós selecionados e seus respectivos números.

! Acoplamento dos nós.

!--- CONDIÇÕES DE CONTORNO DOS NÓS DAS CHAPAS DE TOPO:

! Restrições em Z=0:

NSEL,S,LOC,Z,-Lap+0.001,-Lap-0.001 ! Seleciona os nós do apoio em Z=0.

NPLOT,ALL

D,ALL,UX,0, , , ,ROTY,ROTZ ! Restrições ao deslocamento dos nós selecionados.

NSEL,ALL

! Restrições em Z=comp:

NSEL,S,LOC,Z,comp+Lap+0.001,comp+Lap-0.001 ! Seleciona os nós do apoio em z=comp.

NPLOT,ALL

D,ALL,UX,0, , , ,ROTY,ROTZ ! Restrições ao deslocamento dos nós selecionados.

NSEL,ALL

!--- CONDIÇÕES DE CONTORNO DOS NÓS DO CENTRÓIDE:

! Restrições em Z=0:

NSEL,S,LOC,Z,-Lap+0.001,-Lap-0.001

NSEL,R,LOC,Y,dy+Ygm-0.001,dy+Ygm+0.001 ! Seleção dos nós da rótula no apoio no apoio em Z=0.

NPLOT,ALL

D,ALL,UX,0, , , ,UY,ROTY,ROTZ

! Restrições ao deslocamento dos nós selecionados.

NSEL,ALL

! Restrições em Z=comp:

NSEL,S,LOC,Z,comp+Lap+0.001,comp+Lap-0.001

NSEL,R,LOC,Y,dy+Ygm-0.001,dy+Ygm+0.001 ! Seleção dos nós da rótula no apoio no apoio em Z=comp. NPLOT,ALL

D,ALL,UX,0, , , ,UY,UZ,ROTY,ROTZ

! Restrições ao deslocamento dos nós selecionados. 
FINISH

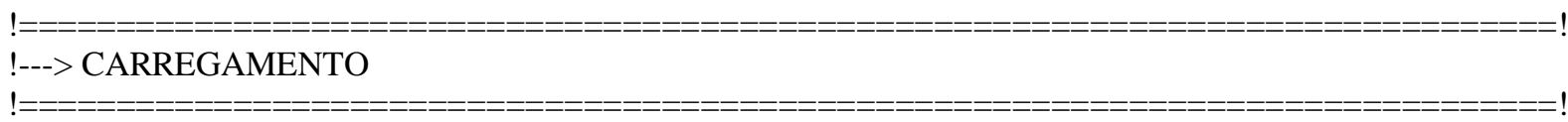

ISOLU

espmed $=$ comp/(Npres +1$)$-Lpres

nelmed $=$ NINT(espmed)

lelmed=espmed/nelmed

resto=MOD(Npres,2)

*IF,(resto),EQ,(0),THEN

! Número par de presilhas.

NSEL,ALL

NSEL,S,LOC,Z,Comp/2+lelmed/2,Comp/2-lelmed/2 ! Seleção dos nós situados no meio do perfil.

*ELSE

NSEL,ALL

! Número ímpar de presilhas.

NSEL,S,LOC,Z,Comp/2+0.501,Comp/2-0.501

! Seleção dos nós situados no meio do perfil.

*ENDIF

NPLOT,ALL

! Plotando os nós situados no meio do perfil.

D,ALL,UY,-1

! Aplica um deslocamento unitário na direção perpendicular à rótula.

GPLOT

! Deleta sistemas de coordenadas locais.

SEL,ALL

CSDELE, 11

/REPLOT

FINISH

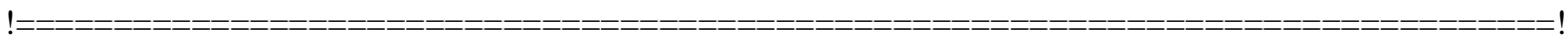

!---> SOLUÇÃO

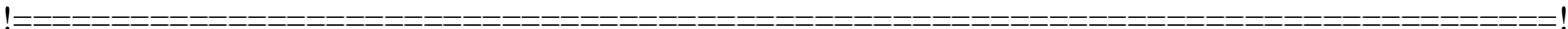

/SOLU

/STATUS,SOLU

SOLVE

FINISH

\section{3) Script 3:}

Para as análises não-lineares, a construção dos modelos é feita de forma semelhante ao procedimento do Script 1. As diferenças ficam por conta apenas dos itens Propriedades do Aço, Criando Elementos de Contato, Condições de Contorno, Opções de Processamento, Carregamento e Solução. Além disso, as imperfeições geométricas são importadas para estes modelos por meio do item Atualizando a Geometria. A seguir, são mostrados os trechos do Script 3 referentes aos itens citados. 


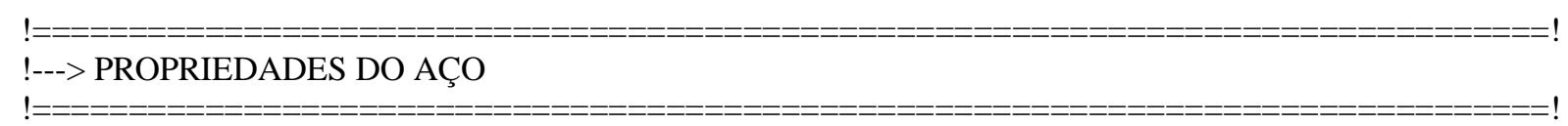

MP,EX,1,E

MP,PRXY,1,V

TB,MISO,1,1,12

TBPT, 0,0

TBPT,,0.001248001,25.63

TВPT,,0.001774025,31.58

TВPT,,0.002212650,34.15

TBPT,,0.003063064,36.67

TBPT,,0.004857802,38.26

TBPT,,0.015629028,42.50

TBPT,,0.027654466,46.25

TBPT,,0.039714630,49.07

TBPT,,0.051688816,51.18

TBPT,,0.074426350,54.41

TBPT,,0.107727313,57.27

MP,EX,2,E

MP,PRXY,2,v

MP,EX,3,E

MP,PRXY,3,v
! Atribuição do módulo de elasticidade do perfil.

! Atribuição do coeficiente de Poisson do perfil.

! Não linearidade física, tensão X deformação.

! Pontos da curva tensão X deformação.

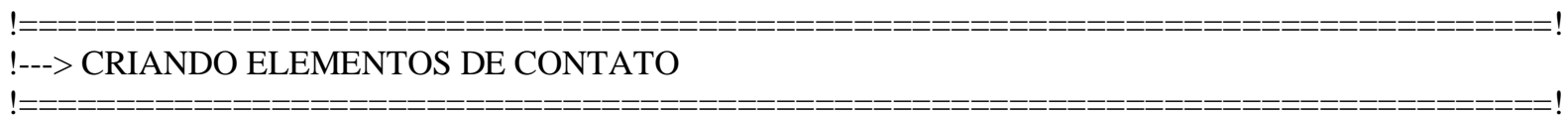

ET,5,CONTA173

KEYOPT,5,1,0

KEYOPT,5,5,0

KEYOPT,5,6,0

KEYOPT,5,7,2

KEYOPT,5,9,3

KEYOPT,5,10,2

KEYOPT,5,11,1

KEYOPT,5,12,0

ET,7,TARGE170

KEYOPT,7,4,0

$\mathrm{R}, 5$, , ,0.1,-0.01,0, ,

RMORE, , , ,0, , ,

!--- CONTATO PERFIL/PERFIL:

! Contact:

! Atribuição do módulo de elasticidade das presilhas.

! Atribuição do coeficiente de Poisson das presilhas.

! Atribuição do módulo de elasticidade do dispositivo de apoio.

! Atribuição do coeficiente de Poisson do dispositivo de apoio.

NSEL,S,LOC,Z,-0.001,comp+0.001

NSEL,R,LOC,X,dx+dep/2+t/2-0.001,dx+dep/2+t/2+0.001

LocPres $=$ Dpres

PtLoc $=$ Dpres 

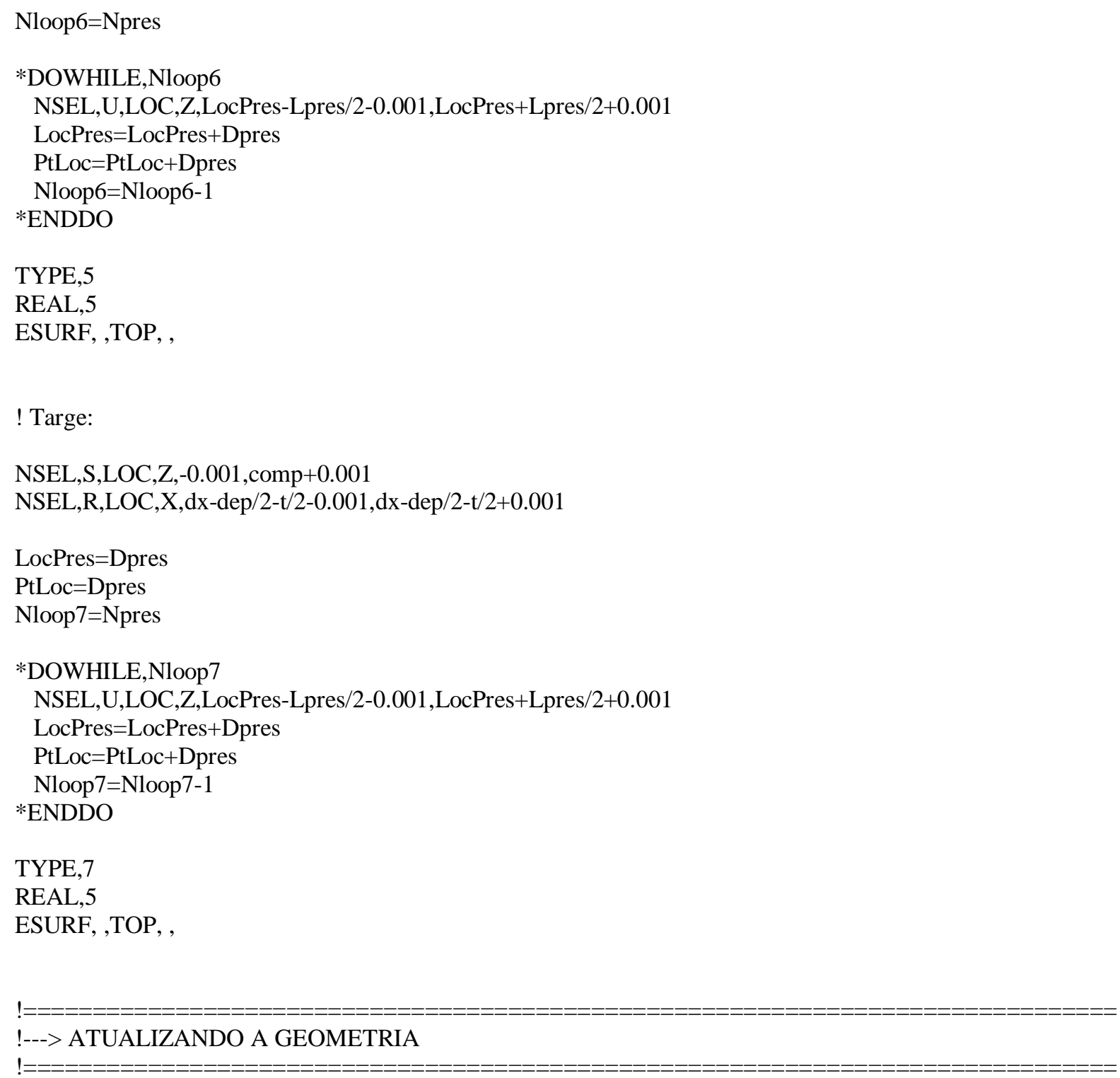

!--- MODO LOCAL:

$\mathrm{DMX}=1.002 \quad$ ! Deslocamento máximo local do ansys.

$\mathrm{d} 1=0.64 * \mathrm{t} \quad$ ! Amplitude requerida no perfil.

FATloc=d1/DMX ! Fator de amplificação da amplitude local requerida.

UPGEOM,FATloc,1,1, 'Endereço onde se localiza o Script 1 mais o nome do arquivo','rst'

!--- MODO GLOBAL DE FLEXÃO:

$\mathrm{DMX}=1.000$

FATglob_F_aplicado=comp/1500

FATglob_F=FATglob_F_aplicado/DMX ! Amplitude da imperfeição global.

UPGEOM,FATglob_F,LAST,LAST, 'Endereço onde se localiza o Script 2 mais o nome do arquivo','rst'

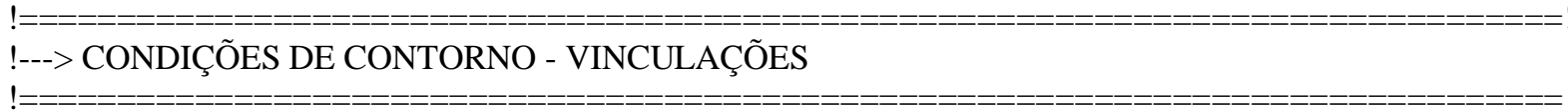

FINISH 
/SOLU

!--- ACOPLAMENTO DOS NÓS DA LINHA QUE PASSA PELA RÓTULA:

! Apoio em $\mathrm{z}=0$ :

NSEL,S,LOC,Z,-Lap+0.001,-Lap-0.001

NSEL,R,LOC,Y,dy+Ygm-0.001,dy+Ygm+0.001 ! Seleção dos nós da rótula no apoio em Z=0.

NPLOT,ALL

! Mostra os nós selecionados e seus respectivos números.

CP,10,UZ,ALL

! Acoplamento dos nós.

NSEL,ALL

! Apoio em z=comp:

NSEL,S,LOC,Z,comp+Lap+0.001,comp+Lap-0.001

NSEL,R,LOC,Y,dy+Ygm-0.001,dy+Ygm+0.001 ! Seleção dos nós da rótula no apoio em Z=comp.

NPLOT,ALL

! Mostra os nós selecionados e seus respectivos números.

CP,20,UZ,ALL

! Acoplamento dos nós.

NSEL,ALL

!--- CONDIÇÕES DE CONTORNO DOS NÓS DAS CHAPAS DE TOPO:

! Restrições em Z=0:

NSEL,S,LOC,Z,-Lap+0.001,-Lap-0.001

! Seleciona os nós do apoio em $\mathrm{Z}=0$.

NPLOT,ALL

D,ALL,UX,0, , , ,ROTY,ROTZ

! Restrições ao deslocamento dos nós selecionados.

NSEL,ALL

! Restrições em Z=comp:

NSEL,S,LOC,Z,comp+Lap+0.001,comp+Lap-0.001 ! Seleciona os nós do apoio em z=comp.

NPLOT,ALL

D,ALL,UX,0, , , ,ROTY,ROTZ ! ! Restrições ao deslocamento dos nós selecionados.

NSEL,ALL

!--- CONDIÇÕES DE CONTORNO DOS NÓS DO CENTRÓIDE:

! Restrições em $\mathrm{Z}=0$ :

NSEL,S,LOC,Z,-Lap+0.001,-Lap-0.001

NSEL,R,LOC,Y,dy+Ygm-0.001,dy+Ygm+0.001 ! Seleção dos nós da rótula no apoio no apoio em Z=0.

NPLOT,ALL

D,ALL,UX,0, , , ,UY,ROTY,ROTZ ! ! Restrições ao deslocamento dos nós selecionados.

NSEL,ALL

! Restrições em Z=comp:

NSEL,S,LOC,Z,comp+Lap+0.001,comp+Lap-0.001

NSEL,R,LOC,Y,dy+Ygm-0.001,dy+Ygm+0.001 ! Seleção dos nós da rótula no apoio no apoio em Z=comp. NPLOT,ALL

D,ALL,UX,0, , , ,UY,UZ,ROTY,ROTZ

! Restrições ao deslocamento dos nós selecionados.

NSEL,ALL

FINISH 


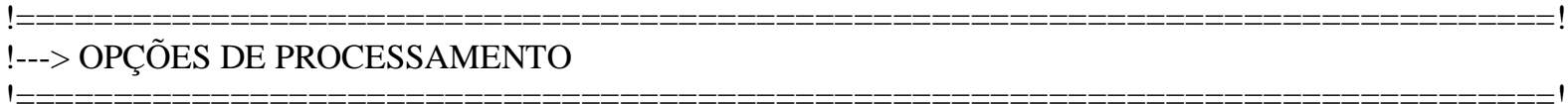

/SOLU

ANTYPE,0

! Análise estática.

NLGEOM,1

! Ativa a não linearidade geométrica.

NROPT,FULL, ,OFF

! Newton-Raphson completo.

LNSRCH,ON

EQSLV,SPAR, ,0

! Solver escolhido (DEFAULT).

PIVCHECK,ON

SSTIF,ON

! Atualiza a matriz de rigidez a cada iteração.

NEQIT,20

! Número máximo de equações de equilíbrio.

CNVTOL,U,1,0.001,2, ,

STABILIZE,CONSTANT,ENERGY,0.0001,NO

! ATENÇÃO: comando usado somente para modelos com problemas de convergência.

FINISH

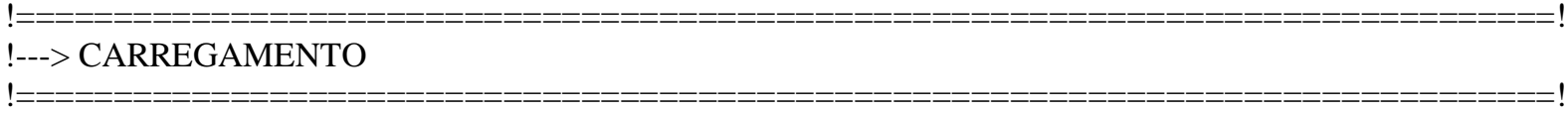

/SOLU

NSEL,S,LOC,Z,-Lap+0.001,-Lap-0.001

NSEL,R,LOC,Y,dy+Ygm-0.001,dy+Ygm+0.001 ! Seleção dos nós da rótula no apoio em Z=0.

NPLOT,ALL

*GET,nmestre,NODE,0,NUM,MIN

NPLOT,ALL

D,nmestre,UZ,DeslocP, , , , , ,

! Pega o nó mestre (menor numeração de nó da linha).

AUTOTS,ON

TIME,DeslocP

DELTIM,DeslocP/100,DeslocP/1000000,DeslocP/100

! Aplica um deslocamento prescrito no nó mestre na direção Z.

OUTRES,ERASE

OUTRES,ALL,ALL

GPLOT

ALLSEL,ALL

/REPLOT

FINISH

SAVE

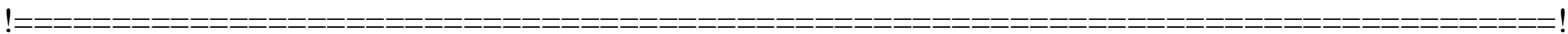

!---> SOLUÇÃO

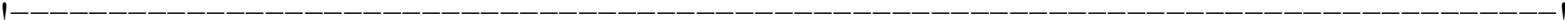


/SOLU

/STATUS,SOLU

SOLVE

FINISH

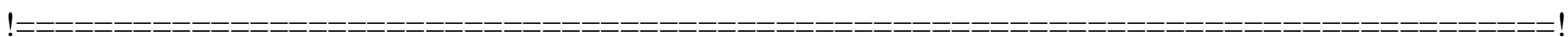




\section{APENDICE B - Scripts para as análises à}

\section{temperatura ambiente: compressão excêntrica}

Neste apêndice, são disponibilizados os scripts desenvolvidos no presente trabalho para os perfis estudados sob compressão excêntrica. A seguir, são apresentadas as linhas de comando programadas para a realização das análises numéricas (via ANSYS), sendo essas análises divididas em três etapas:

1) Script 1: Análise elástica de autovalor para a obtenção das imperfeições geométricas iniciais locais;

2) Script 2: Análise elástica para a obtenção das imperfeição geométrica inicial global;

3) Script 3: Análise final considerando as não-linearidades geométricas e de material.

\section{1) Script 1:}

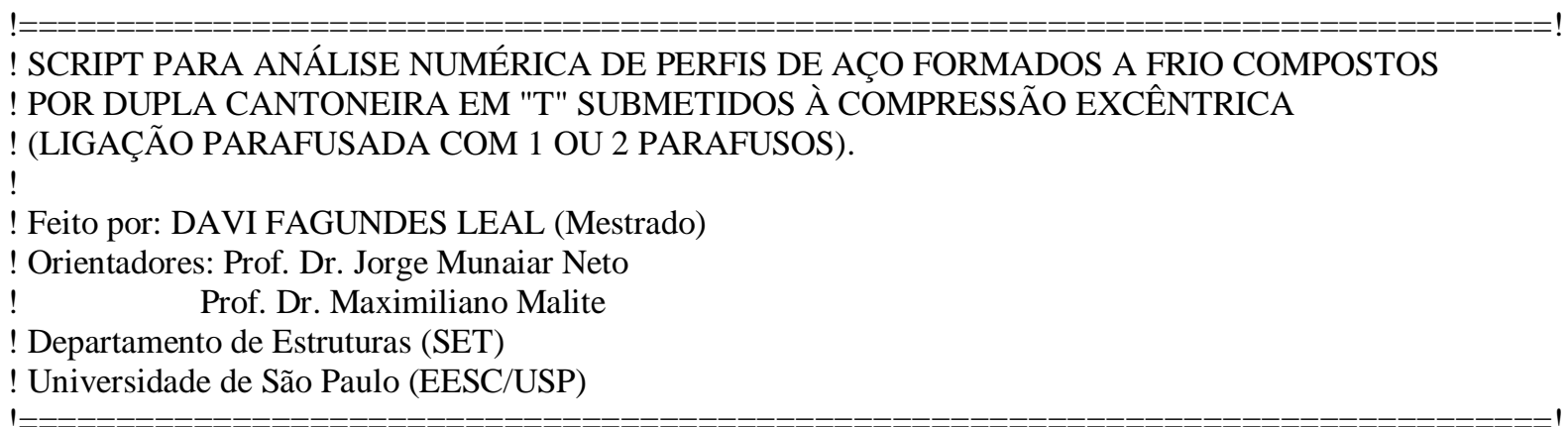

FINISH

/CLEAR

*GET,NProcessadores,ACTIVE, ,NPROC /CONFIG,NPROC,NProcessadores

! Obtém o número de processadores disponíveis no computador. ! Indica o número de processadores a serem usados.

/PREP7

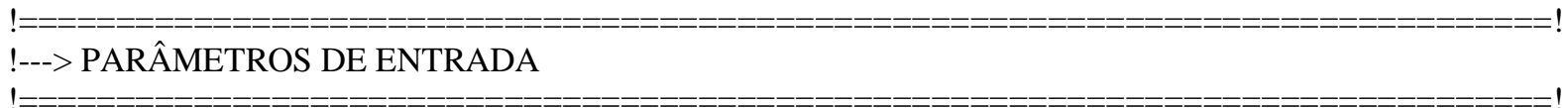

$\mathrm{bf}=6 \quad$ ! Largura da mesa do perfil, $\mathrm{cm}$

$\mathrm{t}=0.300 \quad$ ! Espessura da chapa do perfil, $\mathrm{cm}$

$\mathrm{ri}=0.300 \quad$ ! Raio interno de dobramento, $\mathrm{cm}$

comp $=201.0 \quad$ ! Comprimento efetivo do perfil, $\mathrm{cm}$

DeslocP $=0.4$ ! Deslocamento prescrito, $\mathrm{cm}$

E=17975.7871 ! Módulo de elasticidade do aço utilizado, KN/cm2

$\mathrm{v}=0.3$

! Coeficiente de Poisson do aço utilizado.

Nparf=2 ! Ligação: número de parafusos (1 ou 2). 


$\begin{array}{ll}\begin{array}{l}\text { Dparf=2.1 } \\ \text { dff=6 }\end{array} & \text { ! Ligação: diâmetro dos furos, cm. } \\ \text { !fb=3 } & \text { ! Ligação: distância entre centros de furos, cm. } \\ \text { sch=2.0 } & \text { ! Ligação: distância centro de furo e borda, cm. } \\ & \text { ! Ligação: "sobra" da chapa de ligação, cm. } \\ \text { Lpres=2*dfb } & \text { ! Comprimento da presilha (chapa separadora), cm } \\ \text { dep=0.5 } & \text { ! Distância entre perfis (espessura da chapa de ligação e da presilha), cm } \\ \text { Lap=6.75 } & \text { ! Tamanho do dispositivo de apoio (ou chapa de topo), cm } \\ \text { Npres=2 } & \text { ! Número de presilhas (chapas separadoras) utilizadas. } \\ \text { dx=0 } & \text { ! Translação em x do perfil em relação ao (0,0) global. } \\ \text { dy=0 } & \text { ! Translação em y do perfil em relação ao (0,0) global. } \\ \text { ndf }=16 & \text { ! Número de divisões das linhas dos furos das ligações. } \\ \text { ndc=2 } & \text { ! Número de divisões das linhas do canto. } \\ \text { nd1m=6 } & \text { ! Número de divisões das linhas das abas. }\end{array}$

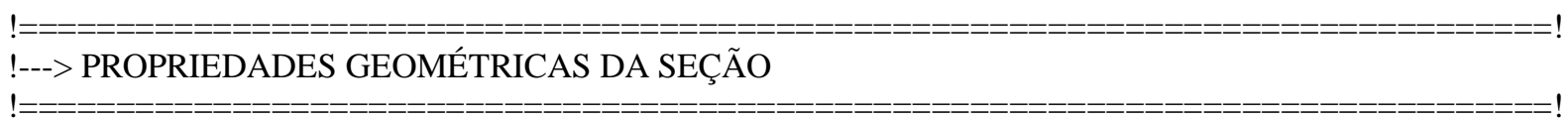

$\begin{array}{ll} & \text { ! NBR 6355: } \\ \mathrm{rm}=\mathrm{ri}+0.5^{*} \mathrm{t} & \text { ! Raio de dobramento referente a linha média da seção, } \mathrm{cm} \\ \mathrm{b}=\mathrm{bf}-(\mathrm{rm}+0.5 * \mathrm{t}) & \text { ! Largura da parte plana da mesa do perfil, cm } \\ \mathrm{bm}=\mathrm{bf}-\mathrm{t} / 2 & \text { ! Largura da mesa referente à linha média da seção, cm } \\ \mathrm{u} 1=1.571^{*} \mathrm{rm} & \text { ! Desenvolvimento da parte curva da seção referente à dobra em } 90, \mathrm{~cm} \\ \mathrm{As}=\mathrm{t} *(2 * \mathrm{~b}+\mathrm{u} 1) & \text { ! Área da seção tranversal de uma cantoneira simples, cm2 } \\ \mathrm{Yg}=(\mathrm{t} / \mathrm{As})^{*}\left(\mathrm{~b} *(0.5 * \mathrm{~b}+\mathrm{rm})+\mathrm{u} 1 *\left(0.363^{*} \mathrm{rm}\right)\right)+0.5 * \mathrm{t} \text { ! Distância do CG à face externa do perfil (direção y). } \\ \text { Ygm=Yg-t/2 } \\ \text { ! Distância do centróide à linha de esqueleto do perfil, eixo-y }\end{array}$

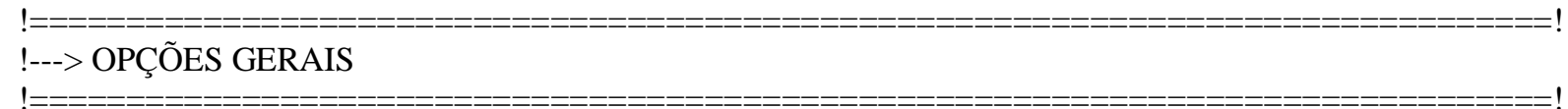

/VIEW,1,1,1,1 ! ! Vista da tela 1 com diretriz que passa pelo ponto $(1,1,1)$.

/ANGLE, 1

/ESHAPE,1.0

! Visualização da geometria do elemento.ex: espessura de elementos de casca.

/UIS,MSGPOP,3 ! ! Mostra somente as mensagens de erros.

/PBC,ALL, ,1 ! Plot Boundary Conditions=1, mostra somente o símbolo da restrição.

/REP,FAST ! Redesenha o modelo.

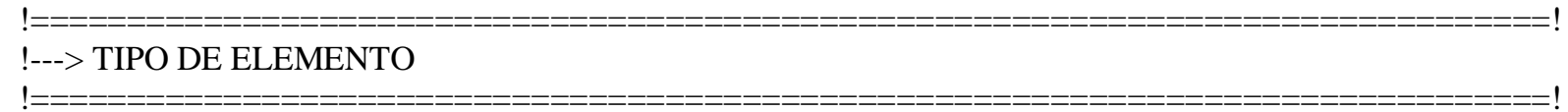
ET,1,SHELL181 ! Elemento Finito do perfil.
ET,2,SOLID45 ! Elemento Finito das presilhas (chapas espaçadoras).
ET,3,SOLID45 ! Elemento Finito dos dispositivos de apoio.
ET,4,SOLID95 ! Elemento Finito da chapa da ligação.

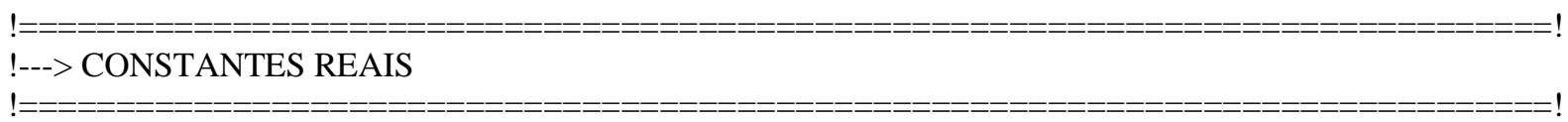

R,1,t ! Espessura do elemento finito 1 (SHELL181). 


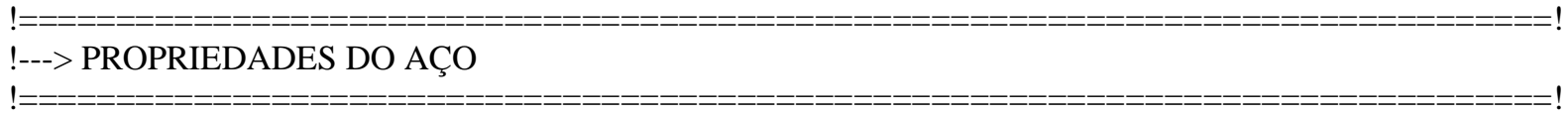

MP,EX,1,E ! ! Atribuição do módulo de elasticidade do perfil.

MP,PRXY,1,v ! ! Atribuição do coeficiente de Poisson do perfil.

MP,EX,2,E

MP,PRXY,2,v

! Atribuição do módulo de elasticidade das presilhas.

! Atribuição do coeficiente de Poisson das presilhas.

MP,EX,3,E

MP,PRXY,3,v

! Atribuição do módulo de elasticidade do dispositivo de apoio.

! Atribuição do coeficiente de Poisson do dispositivo de apoio.

MP,EX,4,E

! Atribuição do módulo de elasticidade da chapa de ligação.

$\mathrm{MP}, \mathrm{PRXY}, 4, \mathrm{v}$

! Atribuição do coeficiente de Poisson da chapa de ligação.

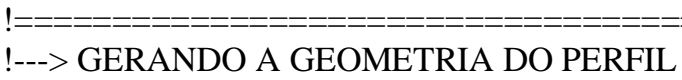

!--- PERFIL 1:

$\mathrm{K}, 1, \mathrm{dx}+\mathrm{dep} / 2+\mathrm{t} / 2, \mathrm{dy}+\mathrm{bm}, 0$

! Gera pontos chaves da seção do perfil 1.

$\mathrm{K}, 2, \mathrm{dx}+\mathrm{dep} / 2+\mathrm{t} / 2, \mathrm{dy}, 0$

$\mathrm{K}, 3, \mathrm{dx}+\mathrm{dep} / 2+\mathrm{t} / 2+\mathrm{bm}, \mathrm{dy}, 0$

$\mathrm{L}, 1,2$

$\mathrm{L}, 2,3$

! Gera linhas que compõem o perfil 1.

LFILLT,1,2,rm, ,

! Faz o arredondamento do canto do perfil 1.

$\mathrm{K}, 6, \mathrm{dx}+\mathrm{dep} / 2+\mathrm{t} / 2, \mathrm{dy}+\mathrm{bm}, \mathrm{comp}$

$\mathrm{L}, 1,6$

ADRAG,1,2,3, , , ,4

! Cria um ponto chave auxiliar para o perfil 1.

! Cria uma linha auxiliar.

! Gera áreas arrastando um conjunto de linhas ao longo de um caminho.

LDELE, 4

KDELE, 6

NUMCMP,ALL

! Deleta a linha que foi duplicada.

! Deleta o ponto chave auxiliar que foi criado.

! Renumera itens reutilizando os números já deletados ou não utilizados.

!--- FUROS DAS LIGAÇÕES:

ASEL,ALL

APLOT,ALL

*IF,(Nparf),EQ,(1),THEN

! Ligação com 1 parafuso.

WPLANE,1,(dep+t)/2,bm/2,dfb,(dep+t)/2,bm/2,0,(dep+t)/2,1000,dfb ! Working Plane no centro do parafuso.

CYL4,0,0,Dparf/2

*GET,Nar,AREA,0,COUNT, ,

ASEL,ALL

ASBA,ALL,Nar

NUMCMP,ALL
! Desenha um círculo.

! Obtém o número de áreas no modelo.

! Seleciona todas as áreas do modelo.

! Deleta área do círculo (cria o furo).

! Renumera itens desenhados.

WPLANE,1,(dep+t)/2,bm/2,comp-dfb,(dep+t)/2,bm/2,0,(dep+t)/2,1000,comp-dfb ! Working Plane no centro

CYL4,0,0,Dparf/2

*GET,Nar,AREA,0,COUNT, ,

ASEL,ALL

ASBA,ALL,Nar

NUMCMP,ALL
! Desenha um círculo. do parafuso.
! Obtém o número de áreas no modelo.

! Seleciona todas as áreas do modelo.

! Deleta área do círculo (cria o furo).

! Renumera itens desenhados. 
WPLANE, 1,0,0,0,1,0,0,0,1,0 ! Working plane com origem em $(0,0,0)$.

*ELSEIF,(Nparf),EQ,(2),THEN ! Ligação com 2 parafusos.

WPLANE,1,(dep+t)/2,bm/2,dfb,(dep+t)/2,bm/2,0,(dep+t)/2,1000,dfb ! Working Plane (z=0).

CYL4,0,0,Dparf/2 ! Desenha um círculo (parafuso 1).

CYL4,-dff,0,Dparf/2 ! Desenha um círculo (parafuso 2).

*GET,Nar,AREA,0,COUNT, , ! Obtém o número de áreas no modelo.

ASEL,ALL

ASBA,ALL,Nar ! Deleta área do círculo (cria o furo 1).

ASEL,ALL ! Seleciona todas as áreas do modelo.

ASBA,ALL,Nar-1 ! Deleta área do círculo (cria o furo 2).

NUMCMP,ALL ! Renumera itens desenhados.

WPLANE,1,(dep+t)/2,bm/2,comp-dfb,(dep+t)/2,bm/2,0,(dep+t)/2,1000,comp-dfb ～! Working Plane em

CYL4,0,0,Dparf/2

CYL4,dff,0,Dparf/2

*GET,Nar,AREA,0,COUNT, ,

ASEL,ALL

ASBA,ALL,Nar

ASEL,ALL

ASBA,ALL,Nar-1

NUMCMP,ALL

WPLANE,1,0,0,0,1,0,0,0,1,0

*ENDIF

!--- PERFIL 2:

/VIEW,1,1,1,1

/AUTO,1

/REP,FAST

ASEL,ALL

APLOT,ALL

ARSYM,X,ALL, , , ,0,0
! Desenha um círculo (parafuso 1).

( $\mathrm{z}=\mathrm{comp}$ ).

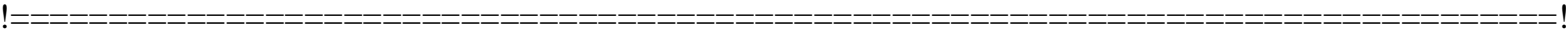

!---> MALHA DO PERFIL

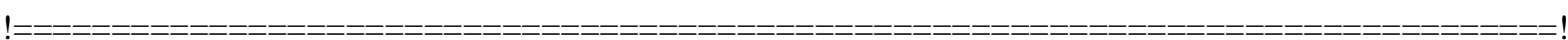

!--- COMPRIMENTO DO PERFIL:

! Divisão das linhas para alocar as ligações:

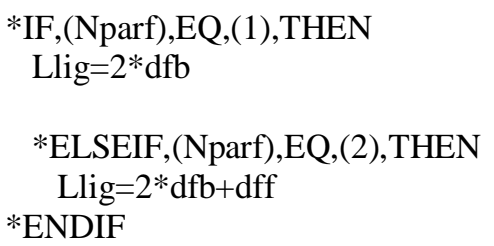

! Ligação com um parafuso.

! Comprimento da ligação.

! Ligação com dois parafusos.

! Comprimento da ligação. 
WPAVE,0,0,Llig

ASBW,ALL

LSEL,S,LOC,Z,0.001,Llig-0.001

LSEL,U,LOC,Y,rm+0.001,bm-0.001

LESIZE,ALL, , ,Llig, , , , ,1

WPAVE,0,0,comp-Llig

ASBW,ALL

LSEL,S,LOC,Z,comp-0.001,comp-Llig+0.001

LSEL,U,LOC,Y,rm+0.001,bm-0.001

LESIZE,ALL, , ,Llig, , , , ,1

WPAVE,0,0,0

! Divisão das linhas para alocar as presilhas:

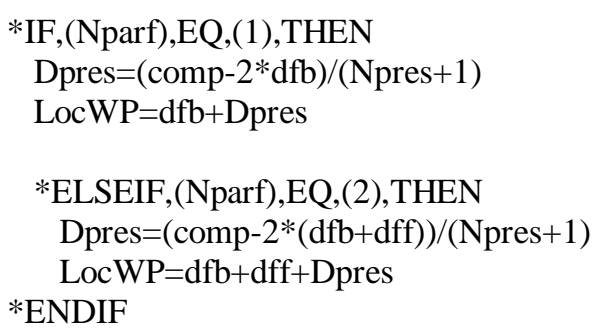

Nloop1=Npres

*DOWHILE,Nloop1

ASEL,S,LOC,Z,0.001,comp-0.001

WPAVE,0,0,LocWP-Lpres/2

ASBW,ALL

WPAVE,0,0,LocWP+Lpres/2

ASBW,ALL

LSEL,S,LOC,Z,LocWP-Lpres/2+0.001,LocWP+Lpres/2-0.001

LESIZE,ALL, , ,Lpres, , , , ,1

LocWP=LocWP+Dpres

Nloop1=Nloop1-1

*ENDDO

WPAVE,0,0,0

! Divisão das linhas fora das regiões das presilhas:

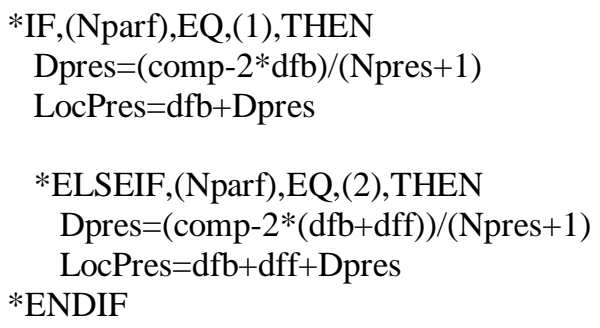

Nloop2=Npres +1
! Malha na região da ligação em z=0.

! Retira as linhas dos furos do conjunto-seleção.

! Malha na região da ligação em $\mathrm{z}=$ comp.

! Retira as linhas dos furos do conjunto-seleção.
! Ligação com um parafuso.

! Distância entre centros de presilhas.

! Variável para localização de cada presilha.

! Ligação com dois parafusos.

! Distância entre centros de presilhas.

! Variável para localização de cada presilha.

! Variável de loop.

! Malha nas regiões das presilhas.

*DOWHILE,Nloop2

! Ligação com um parafuso.

! Distância entre centros de presilhas.

! Variável para localização de cada presilha.

! Ligação com dois parafusos.

! Distância entre centros de presilhas.

! Variável para localização de cada presilha.

! Variável de loop. 


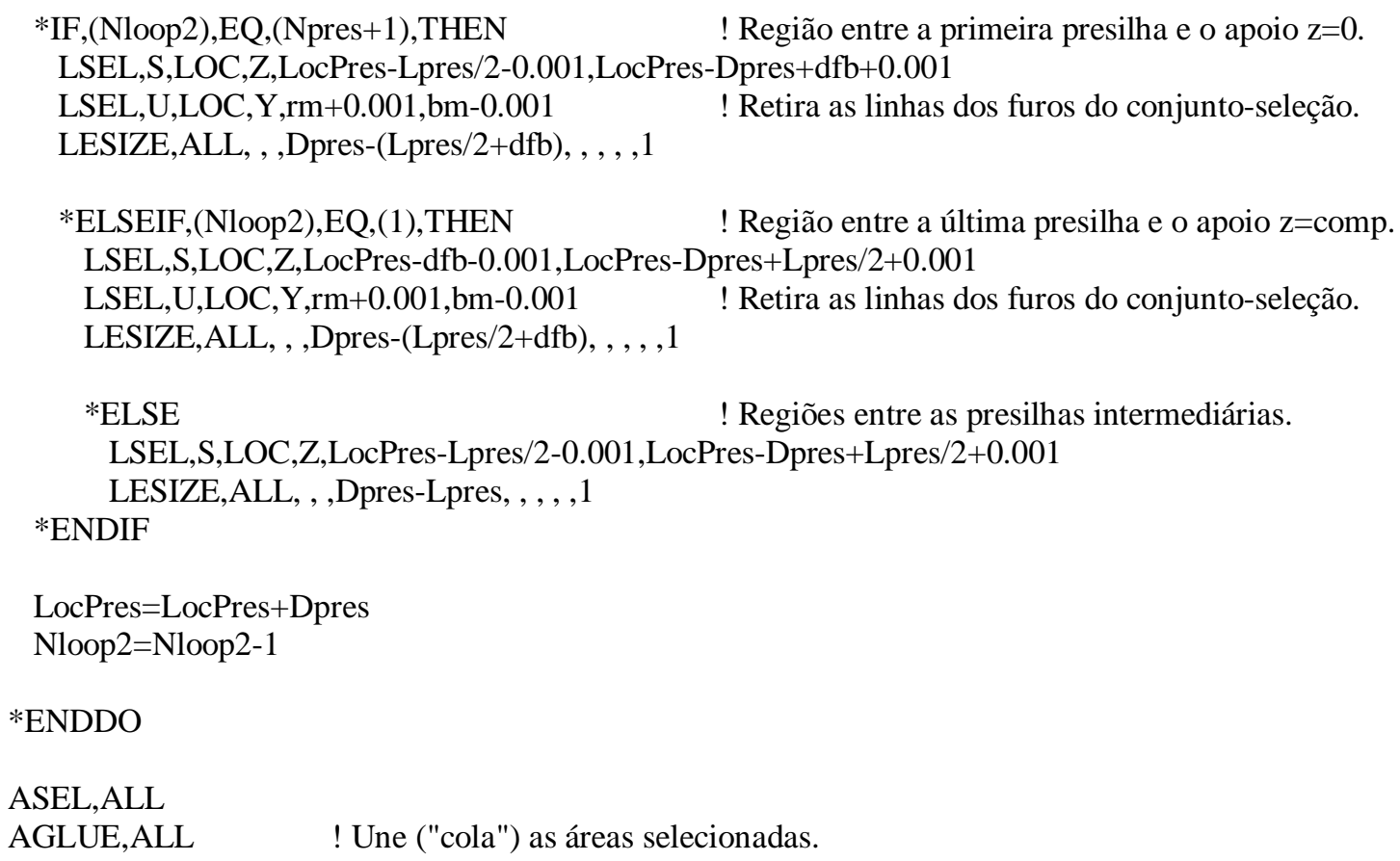

!--- ABAS COM PRESILHAS (CHAPAS ESPAÇADORAS):

LSEL,S,LOC,Z,-0.001,comp+0.001

LSEL,R,LOC,Y,dy+rm+0.001,dy+bm-0.001

LSEL,U,LOC,Z,0.001,Llig-0.001

LSEL,U,LOC,Z,comp-0.001,comp-Llig+0.001

LESIZE,ALL, , ,nd1m, , , , ,1

LSEL,S,LOC,Z,0.001,Llig-0.001

LSEL,R,LOC,Y,dy+rm+0.001,dy+bm-0.001

LESIZE,ALL, , ,ndf/4, , , , , 1

LSEL,S,LOC,Z,comp-0.001,comp-Llig+0.001

LSEL,R,LOC,Y,dy+rm+0.001,dy+bm-0.001

LESIZE,ALL, , ,ndf/4, , , , ,1

ASEL,S,LOC,Y,dy+rm+0.001,dy+bm-0.001

ASEL,U,LOC,Z,Llig+0.001,comp-Llig-0.001

MSHKEY,0

MAT, 1

TYPE, 1

REAL, 1

MSHAPE,1,2D

AMESH,ALL

ASEL,ALL

ASEL,S,LOC,Z,Llig+0.001,comp-Llig-0.001

ASEL,R,LOC,Y,dy+rm+0.001,dy+bm-0.001

MSHKEY,1

MAT,1
! Seleciona todas as linhas do perfil.

! Seleciona as linhas das seções das abas com presilhas.

! Retira as linhas dos furos do conjunto-seleção.

! Retira as linhas dos furos do conjunto-seleção.

! Divide as linhas das seções das abas com presilhas.

! Seleciona as linhas dos furos em $\mathrm{z}=0$.

! Divide as linhas dos furos da ligação.

! Seleciona as linhas dos furos em $\mathrm{z}=$ comp.

! Divide as linhas dos furos da ligação.

! Tipo da malha: Free

! Material da aba

! Tipo do elemento a ser utilizado

! Constante real do elemento

! Malha realizada com elemento 2D

! Gerando a malha

! Tipo da malha: Mapeada

! Material da aba 
TYPE,1

REAL, 1

MSHAPE,0,2D

AMESH,ALL

ASEL,ALL

!--- PARTE CURVA:

LSEL,S,LOC,Z,-0.001,comp+0.001

LSEL,R,LOC,Y,dy+0.001, dy+rm-0.001

LESIZE,ALL, , ,ndc, , , , ,1

ASEL,R,LOC,Y,dy+0.001,dy+rm-0.001

\section{MSHKEY,1}

MAT, 1

TYPE, 1

REAL, 1

MSHAPE,0,2D

AMESH,ALL

ASEL,ALL
! Tipo do elemento a ser utilizado

! Constante real do elemento

! Malha realizada com elemento 2D

! Gerando a malha
! Seleciona todas as linhas do perfil.

! Seleciona a linha curva das dobras das seções.

! Divide a linhas da dobras.

\section{!--- ABAS LIVRES (SEM PRESILHAS):}

LSEL,S,LOC,Z,-0.001,comp+0.001

! Seleciona todas as linhas do perfil.

LSEL,R,LOC,X,dx+dep/2+t/2+rm+0.001,dx+dep/2+t/2+bm-0.001 ! Seleciona a linha da aba livre do perfil 1.

LESIZE,ALL, , ,nd1m, , , , ,1

! Divide a linha da aba livre do perfil 1.

ASEL,S,LOC,X,dx+dep/2+t/2+rm+0.001,dx+dep/2+t/2+bm-0.001

$\begin{array}{ll}\text { MSHKEY,1 } & \text { ! Tipo da malha: Mapeada } \\ \text { MAT,1 } & \text { ! Material da aba } \\ \text { TYPE,1 } & \text { ! Tipo do elemento a ser utilizado } \\ \text { REAL,1 } & \text { ! Constante real do elemento } \\ \text { MSHAPE,0,2D } & \text { ! Malha realizada com elemento 2D } \\ \text { AMESH,ALL } & \text { ! Gerando a malha }\end{array}$

ASEL,ALL

LSEL,S,LOC,Z,-0.001,comp+0.001 ! Seleciona todas as linhas do perfil.

LSEL,R,LOC,X,dx-(dep/2+t/2+rm-0.001),dx-(dep/2+t/2+bm+0.001) ! Seleciona a linha da aba livre do perfil 2.

LESIZE,ALL, , ,nd1m, , , , ,1 ! Divide a linha da aba livre do perfil 2.

ASEL,S,LOC,X,dx-(dep/2+t/2+rm-0.001),dx-(dep/2+t/2+bm+0.001)

\section{MSHKEY,1}

MAT, 1

TYPE,1

REAL,1

MSHAPE,0,2D

AMESH,ALL

ASEL,ALL
! Tipo da malha: Mapeada

! Material da aba

! Tipo do elemento a ser utilizado

! Constante real do elemento

! Malha realizada com elemento 2D

! Gerando a malha 
LSEL,ALL

NSEL,ALL

*IF,(Nparf),EQ,(1),THEN

Llig $=2 * \mathrm{dfb}$

*ELSEIF,(Nparf),EQ,(2),THEN

Llig $=2 * \mathrm{dfb}+\mathrm{dff}$

*ENDIF

Lch=Llig + sch

!--- SÓLIDO DE TOPO EQUIVALENTE:

KSEL,ALL

*GET,Nkp,KP,0,COUNT, ,

$\mathrm{K}, 0, \mathrm{dx}+\mathrm{dep} / 2+\mathrm{t} / 2+\mathrm{bm}+\mathrm{sch}, \mathrm{dy}+\mathrm{bm}+\mathrm{sch},-\mathrm{sch}$

$\mathrm{K}, 0, \mathrm{dx}-(\mathrm{dep} / 2+\mathrm{t} / 2+\mathrm{bm}+\mathrm{sch}), \mathrm{dy}+\mathrm{bm}+\mathrm{sch},-\mathrm{sch}$

$\mathrm{K}, 0, \mathrm{dx}+\mathrm{dep} / 2+\mathrm{t} / 2+\mathrm{bm}+\mathrm{sch}, \mathrm{dy}-\mathrm{sch},-\mathrm{sch}$

$\mathrm{K}, 0, \mathrm{dx}-(\mathrm{dep} / 2+\mathrm{t} / 2+\mathrm{bm}+\mathrm{sch}), \mathrm{dy}-\mathrm{sch},-\mathrm{sch}$

$\mathrm{K}, 0, \mathrm{dx}+\mathrm{dep} / 2, \mathrm{dy}+\mathrm{bm}+\mathrm{sch},-\mathrm{sch}$

$\mathrm{K}, 0, \mathrm{dx}-\mathrm{dep} / 2, \mathrm{dy}+\mathrm{bm}+\mathrm{sch},-\mathrm{sch}$

$\mathrm{K}, 0, \mathrm{dx}+\mathrm{dep} / 2$,dy-sch,-sch

K,0,dx-dep/2,dy-sch,-sch

$\mathrm{K}, 0, \mathrm{dx}+\mathrm{dep} / 2+\mathrm{t} / 2+\mathrm{bm}+\mathrm{sch}, \mathrm{dy}+\mathrm{bm},-\mathrm{sch}$

$\mathrm{K}, 0, \mathrm{dx}-(\mathrm{dep} / 2+\mathrm{t} / 2+\mathrm{bm}+\mathrm{sch}), \mathrm{dy}+\mathrm{bm},-\mathrm{sch}$

$\mathrm{K}, 0, \mathrm{dx}+\mathrm{dep} / 2, \mathrm{dy}+\mathrm{bm},-\mathrm{sch}$

$\mathrm{K}, 0, \mathrm{dx}$-dep/2,dy+bm,-sch

$\mathrm{K}, 0, \mathrm{dx}+\mathrm{dep} / 2+\mathrm{t} / 2+\mathrm{bm}+\mathrm{sch}, \mathrm{dy}+\mathrm{rm},-\mathrm{sch}$

$\mathrm{K}, 0, \mathrm{dx}-(\mathrm{dep} / 2+\mathrm{t} / 2+\mathrm{bm}+\mathrm{sch}), \mathrm{dy}+\mathrm{rm},-\mathrm{sch}$

$\mathrm{K}, 0, \mathrm{dx}+\mathrm{dep} / 2, \mathrm{dy}+\mathrm{rm},-\mathrm{sch}$

$\mathrm{K}, 0, \mathrm{dx}$-dep/2,dy+rm,-sch

$\mathrm{K}, 0, \mathrm{dx}+\mathrm{dep} / 2+\mathrm{t} / 2+\mathrm{bm}+\mathrm{sch}, \mathrm{dy},-\mathrm{sch}$

$\mathrm{K}, 0$,dx-(dep/2+t/2+bm+sch),dy,-sch

$\mathrm{K}, 0, \mathrm{dx}+\mathrm{dep} / 2$,dy,-sch

$\mathrm{K}, 0$,dx-dep/2,dy,-sch

A,(Nkp+4),(Nkp+8),(Nkp+20),(Nkp+18)

$\mathrm{A},(\mathrm{Nkp}+18),(\mathrm{Nkp}+20),(\mathrm{Nkp}+16),(\mathrm{Nkp}+14)$

$\mathrm{A},(\mathrm{Nkp}+14),(\mathrm{Nkp}+16),(\mathrm{Nkp}+12),(\mathrm{Nkp}+10)$

$\mathrm{A},(\mathrm{Nkp}+10),(\mathrm{Nkp}+12),(\mathrm{Nkp}+6),(\mathrm{Nkp}+2)$

$\mathrm{A},(\mathrm{Nkp}+8),(\mathrm{Nkp}+7),(\mathrm{Nkp}+19),(\mathrm{Nkp}+20)$

$\mathrm{A},(\mathrm{Nkp}+20),(\mathrm{Nkp}+19),(\mathrm{Nkp}+15),(\mathrm{Nkp}+16)$

$\mathrm{A},(\mathrm{Nkp}+16),(\mathrm{Nkp}+15),(\mathrm{Nkp}+11),(\mathrm{Nkp}+12)$

$\mathrm{A},(\mathrm{Nkp}+12),(\mathrm{Nkp}+11),(\mathrm{Nkp}+5),(\mathrm{Nkp}+6)$

$\mathrm{A},(\mathrm{Nkp}+7),(\mathrm{Nkp}+3),(\mathrm{Nkp}+17),(\mathrm{Nkp}+19)$

A,(Nkp+19),(Nkp+17),(Nkp+13),(Nkp+15)

$\mathrm{A},(\mathrm{Nkp}+15),(\mathrm{Nkp}+13),(\mathrm{Nkp}+9),(\mathrm{Nkp}+11)$

A,(Nkp+11),(Nkp+9),(Nkp+1),(Nkp+5)

ASEL,S,LOC,Z,-sch+0.001,-sch-0.001

AGEN,2,ALL, , ,0,0,comp+2*sch,0,1,0

ASEL,S,LOC,Z,-sch+0.001,-sch-0.001

VEXT,ALL, , ,0,0,-Lap,1,1,1

VSEL,S,LOC,Z,-sch+0.001,-sch-Lap-0.001

VGLUE,ALL
! Seleciona todas as linhas do modelo.

! Seleciona todos os nós do modelo.

! Ligação com um parafuso.

! Comprimento da ligação.

! Ligação com dois parafusos.

! Comprimento da ligação.

! Tamanho da chapa de ligação.

! Seleciona todos os keypoints do modelo.

! Obtém o número de Keypoints.
! Cria um volume para simular o apoio $\mathrm{Z}=0$.

! Seleciona o volume do apoio em $\mathrm{Z}=0$.

! Une ("cola") os volumes selecionados. 
ASEL,S,LOC,Z,comp+sch+0.001,comp+sch-0.001

VEXT,ALL, , ,0,0,Lap,1,1,1

VSEL,S,LOC,Z,comp+sch+Lap+0.001,comp+sch-0.001

VGLUE,ALL

\section{!--- CHAPA DE LIGAÇÃO:}

KSEL,ALL

*GET,Nkp,KP,0,COUNT, ,

$\mathrm{K}, 0, \mathrm{dx}+\mathrm{dep} / 2$,dy-sch,Llig

K,0,dx-dep/2,dy-sch,Llig

$\mathrm{K}, 0, \mathrm{dx}+\mathrm{dep} / 2$,dy,Llig

K,0,dx-dep/2,dy,Llig

$\mathrm{K}, 0, \mathrm{dx}+\mathrm{dep} / 2, \mathrm{dy}+\mathrm{rm}$,Llig

$\mathrm{K}, 0$,dx-dep/2,dy+rm,Llig

$\mathrm{K}, 0, \mathrm{dx}+\mathrm{dep} / 2, \mathrm{dy}+\mathrm{bm}$,Llig

$\mathrm{K}, 0$,dx-dep/2,dy+bm,Llig

$\mathrm{K}, 0, \mathrm{dx}+\mathrm{dep} / 2, \mathrm{dy}+\mathrm{bm}+\mathrm{sch}, \mathrm{Llig}$

$\mathrm{K}, 0, \mathrm{dx}-\mathrm{dep} / 2, \mathrm{dy}+\mathrm{bm}+\mathrm{sch}, \mathrm{Llig}$
! Cria um volume para simular o apoio $\mathrm{Z}=$ comp. ! Seleciona o volume do apoio em $\mathrm{Z}=$ comp.

! Une ("cola") os volumes selecionados.

A, $(\mathrm{Nkp}+1),(\mathrm{Nkp}+2),(\mathrm{Nkp}+4),(\mathrm{Nkp}+3)$

A, $(\mathrm{Nkp}+3),(\mathrm{Nkp}+4),(\mathrm{Nkp}+6),(\mathrm{Nkp}+5)$

$\mathrm{A},(\mathrm{Nkp}+5),(\mathrm{Nkp}+6),(\mathrm{Nkp}+8),(\mathrm{Nkp}+7)$

$\mathrm{A},(\mathrm{Nkp}+7),(\mathrm{Nkp}+8),(\mathrm{Nkp}+10),(\mathrm{Nkp}+9)$

ASEL,S,LOC,Z,Llig+0.001,Llig-0.001

AGEN,2,ALL, , ,0,0,comp-2*Llig,0,1,0

! Seleciona a área criada.

! Copia a área selecionada para a outra extremidade.

ASEL,S,LOC,X,dx-dep/2-0.001,dx+dep/2+0.001

ASEL,S,LOC,Z,Llig+0.001,Llig-0.001

VEXT,ALL, , ,0,0,-Lch,1,1,1

! Cria a geometria de uma das chapas de ligação (volume).

ASEL,S,LOC,X,dx-dep/2-0.001,dx+dep/2+0.001

ASEL,S,LOC,Z,comp-Llig-0.001,comp-Llig+0.001

VEXT,ALL, , ,0,0,Lch,1,1,1

! Cria a geometria de uma das chapas de ligação (volume).

!--- FUROS DAS LIGAÇÕES:

ASEL,ALL

APLOT,ALL

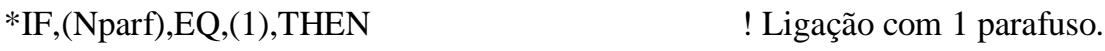

WPLANE,1,dep/2,bm/2,dfb,dep/2,bm/2,0,dep/2,1000,dfb ! ! Working Plane no centro do parafuso.

CYLIND,0,Dparf/2,0,-dep, ,

VSEL,ALL

VPLOT,ALL

*GET,Nvl,VOLU,0,COUNT, ,

VSEL,S,LOC,Z,-sch-0.001,Llig+0.001

VSBV,ALL,Nvl

NUMCMP,ALL
! Desenha um cilindro.

! Seleciona todos os volumes do modelo.

! Plota todos os volumes do modelo.

! Obtém o número de volumes no modelo.

! Seleciona a chapa de ligação.

! Deleta o volume do cilindro da chapa de ligação (furo).

! Renumera itens desenhados.
WPLANE,1,dep/2,bm/2,comp-dfb,dep/2,bm/2,0,dep/2,1000,comp-dfb

CYLIND,0,Dparf/2,0,-dep, , VSEL,ALL

VPLOT,ALL
! Desenha um cilindro.

! Working Plane no centro do parafuso.

! Seleciona todos os volumes do modelo.

! Plota todos os volumes do modelo. 


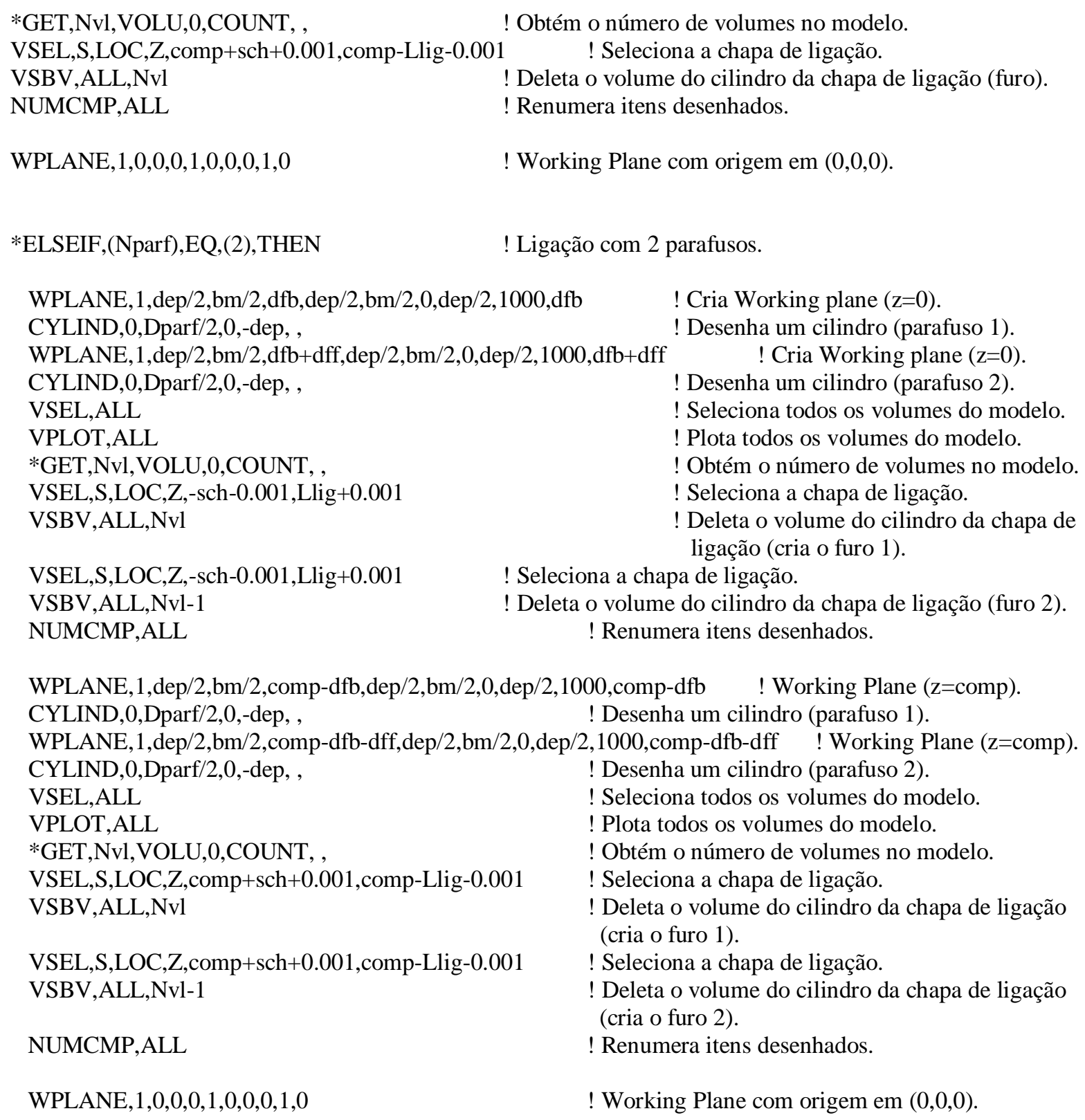

*ENDIF

ASEL,ALL

APLOT,ALL

/VIEW,1,1,1,1 ! ! Vista da tela 1 com diretriz que passa pelo ponto $(1,1,1)$.

IAUTO,1 ! Zoom (Fit view) para enquadramento na tela.

/REP,FAST

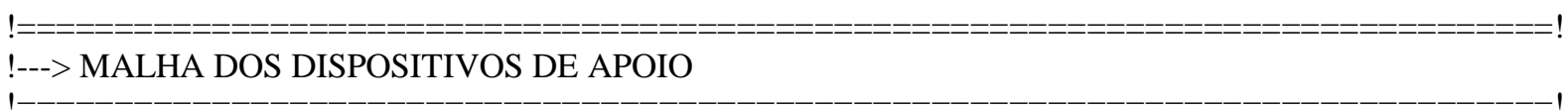

!--- APOIO EM z=0:

! Malha do sólido de topo equivalente:

NSEL,NONE 
LSEL,S,LOC,Z,-sch-0.001,-sch-Lap+0.001

LESIZE,ALL, , ,Lap, , , , ,1

LSEL,S,LOC,Z,-sch+0.001,-sch-Lap-0.001

LSEL,A,LOC,Z,Llig+0.001,Llig-0.001

LSEL,R,LOC,Y,dy+rm+0.001,dy+bm-0.001

LESIZE,ALL, , ,nd1m, , , , ,1

LSEL,S,LOC,Z,-sch+0.001,-sch-Lap-0.001

LSEL,A,LOC,Z,Llig+0.001,Llig-0.001

LSEL,R,LOC,Y,dy-0.001,dy-sch+0.001

LESIZE,ALL, , ,sch, , , , ,1

LSEL,S,LOC,Z,-sch+0.001,-sch-Lap-0.001

LSEL,A,LOC,Z,Llig+0.001,Llig-0.001

LSEL,R,LOC,Y,dy+bm+0.001,dy+bm+sch-0.001

LESIZE,ALL, , ,sch, , , , ,1

LSEL,S,LOC,Z,-sch+0.001,-sch-Lap-0.001

LSEL,A,LOC,Z,Llig+0.001,Llig-0.001

LSEL,R,LOC,Y,dy+0.001,dy+rm-0.001

LESIZE,ALL, , ,1, , , , ,1

LSEL,S,LOC,Z,-sch+0.001,-sch-Lap-0.001

LSEL,A,LOC,Z,Llig+0.001,Llig-0.001

LSEL,R,LOC,X,dx-dep/2+0.001,dx+dep/2-0.001

LESIZE,ALL, , ,1, , , , ,1

LSEL,S,LOC,Z,-sch+0.001,-sch-Lap-0.001

LSEL,R,LOC,X,dx+dep/2+0.001,dx+dep/2+bm-0.001

LESIZE,ALL, , ,nd1m, , , , ,1

LSEL,S,LOC,Z,-sch+0.001,-sch-Lap-0.001

LSEL,R,LOC,X,dx-dep/2-0.001,dx-dep/2-bm+0.001

LESIZE,ALL, , ,nd1m, , , , ,1

VSEL,S,LOC,Z,-sch+0.001,-sch-Lap-0.001

\section{MSHKEY,1}

MAT,3

TYPE,3

MSHAPE,0,3D

VMESH,ALL

VSEL,ALL

! Malha da chapa de ligação:

NSEL,NONE

LSEL,S,LOC,Z,-sch+0.001,Llig-0.001

LSEL,U,LOC,Y,rm+0.001,bm-0.001

LESIZE,ALL, , ,Llig+sch, , , , ,1

LSEL,S,LOC,Z,0.001,Llig-0.001

LSEL,R,LOC, Y,dy+rm+0.001,dy+bm-0.001

LSEL,R,LOC,X,dx+dep/2+0.001,dx-dep/2-0.001

LSEL,U,LOC,X,dx+dep/2-0.001,dx-dep/2+0.001

LESIZE,ALL, , ,ndf/4, , , , ,1

LSEL,S,LOC,Z,0.001,Llig-0.001
! Seleciona as linhas do apoio na direção longitudinal.

! Seleciona as linhas do apoio em z=0.

! Seleciona as linhas do apoio em z=0.

! Seleciona as linhas do apoio em $\mathrm{z}=0$.

! Seleciona as linhas do apoio em z=0.

! Seleciona as linhas do apoio em z=0.

! Seleciona as linhas do apoio em $\mathrm{z}=0$.

! Seleciona as linhas do apoio em z=0.

! Tipo da malha: Mapeada

! Material da chapa de topo

! Tipo do elemento a ser utilizado

! Malha realizada com elemento 3D

! Gerando a malha

! Seleciona as linhas longitudinais da chapa de ligação. ! Retira as linhas dos furos do conjunto-seleção.

! Seleciona as linhas dos furos em $\mathrm{z}=0$.

! Divide as linhas dos furos da ligação.

! Seleciona as linhas que ligam os círculos dos furos. 
LSEL,R,LOC,Y,dy+rm+0.001,dy+bm-0.001

LSEL,R,LOC,X,dx+dep/2-0.001,dx-dep/2+0.001

LESIZE,ALL, , ,1, , , , ,1

VSEL,S,LOC,Z,-sch+0.001,Llig-0.001

MSHKEY,0

! Tipo da malha: Free

MAT,4

TYPE,4

MSHAPE,1,3D

VMESH,ALL

VSEL,ALL

! Material da chapa de ligação

! Tipo do elemento a ser utilizado

! Malha realizada com elemento 3D

! Gerando a malha

NSEL,S,LOC,Z,-sch+0.001,-sch-0.001

NUMMRG,NODE,0.05, , ,LOW

NUMCMP,ALL

! Seleciona os nós do apoio em $\mathrm{Z}=0$.

! Junta os nós muito próximos.

! Renumera itens reutilizando os números dos itens já deletados.

!--- APOIO EM z=comp:

! Malha do sólido de topo equivalente:

NSEL,NONE

LSEL,S,LOC,Z,comp+sch+0.001,comp+sch+Lap-0.001 longitudinal.

LESIZE,ALL, , ,Lap, , , , ,1

LSEL,S,LOC,Z,comp+sch-0.001,comp+sch+Lap+0.001

LSEL,A,LOC,Z,comp-Llig+0.001,comp-Llig-0.001

LSEL,R,LOC,Y,dy+rm+0.001,dy+bm-0.001

LESIZE,ALL, , ,nd1m, , , , ,1

LSEL,S,LOC,Z,comp+sch-0.001,comp+sch+Lap+0.001

LSEL,A,LOC,Z,comp-Llig+0.001,comp-Llig-0.001

LSEL,R,LOC,Y,dy-0.001,dy-sch+0.001

LESIZE,ALL, , ,sch, , , , ,1

LSEL,S,LOC,Z,comp+sch-0.001,comp+sch+Lap+0.001

LSEL,A,LOC,Z,comp-Llig+0.001,comp-Llig-0.001

LSEL,R,LOC,Y,dy+bm+0.001,dy+bm+sch-0.001

LESIZE,ALL, , ,sch, , , , ,1

LSEL,S,LOC,Z,comp+sch-0.001,comp+sch+Lap+0.001

! Seleciona as linhas do apoio na direção

LSEL,A,LOC,Z,comp-Llig+0.001,comp-Llig-0.001

LSEL,R,LOC,Y,dy+0.001,dy+rm-0.001

LESIZE,ALL, , ,1, , , , ,1

LSEL,S,LOC,Z,comp+sch-0.001,comp+sch+Lap+0.001

LSEL,A,LOC,Z,comp-Llig+0.001,comp-Llig-0.001

LSEL,R,LOC,X,dx-dep/2+0.001,dx+dep/2-0.001

LESIZE,ALL, , ,1, , , , ,1

LSEL,S,LOC,Z,comp+sch-0.001,comp+sch+Lap+0.001

LSEL,R,LOC,X,dx+dep/2+0.001,dx+dep/2+bm-0.001

LESIZE,ALL, , ,nd1m, , , , ,1

LSEL,S,LOC,Z,comp+sch-0.001,comp+sch+Lap+0.001

LSEL,R,LOC,X,dx-dep/2-0.001,dx-dep/2-bm+0.001

LESIZE,ALL, , ,nd1m, , , , ,1

! Seleciona as linhas do apoio em z=comp.

! Seleciona as linhas do apoio em z=comp.

! Seleciona as linhas do apoio em z=comp.

! Seleciona as linhas do apoio em z=comp.

! Seleciona as linhas do apoio em z=comp.

! Seleciona as linhas do apoio em z=comp.

! Seleciona as linhas do apoio em z=comp. 
VSEL,S,LOC,Z,comp+sch-0.001,comp+sch+Lap+0.001 MSHKEY,1

MAT,3

TYPE,3

MSHAPE,0,3D

VMESH,ALL

VSEL,ALL
! Tipo da malha: Mapeada

! Material da chapa de topo

! Tipo do elemento a ser utilizado

! Malha realizada com elemento 3D

! Gerando a malha

! Malha da chapa de ligação:

NSEL,NONE

LSEL,S,LOC,Z,comp+sch-0.001,comp-Llig+0.001 ! Seleciona as linhas longitudinais da chapa de ligação.

LSEL,U,LOC,Y,rm+0.001,bm-0.001

! Retira as linhas dos furos do conjunto-seleção.

LESIZE,ALL, , ,Llig+sch, , , , , 1

LSEL,S,LOC,Z,comp-0.001,comp-Llig+0.001

! Seleciona as linhas dos furos em $\mathrm{z}=$ comp.

LSEL,R,LOC,Y,dy+rm+0.001,dy+bm-0.001

LSEL,R,LOC,X,dx+dep/2+0.001,dx-dep/2-0.001

LSEL,U,LOC,X,dx+dep/2-0.001,dx-dep/2+0.001

LESIZE,ALL, , ,ndf/4, , , , , 1

! Divide as linhas dos furos da ligação.

LSEL,S,LOC,Z,comp-0.001,comp-Llig+0.001

LSEL,R,LOC, Y,dy+rm+0.001,dy+bm-0.001

! Seleciona as linhas que ligam os círculos dos furos.

LSEL,R,LOC,X,dx+dep/2-0.001,dx-dep/2+0.001

LESIZE,ALL, , , 1, , , , , 1

VSEL,S,LOC,Z,comp+sch-0.001,comp-Llig+0.001

MSHKEY,0

! Tipo da malha: Free

MAT,4

TYPE, 4

! Material da chapa de ligação

! Tipo do elemento a ser utilizado

MSHAPE,1,3D

VMESH,ALL

! Malha realizada com elemento 3D

VSEL,ALL

! Gerando a malha

NSEL,S,LOC,Z,comp+sch-0.001,comp+sch+0.001 ! Seleciona os nós do apoio em Z=0.

NUMMRG,NODE,0.05, , ,LOW

! Junta os nós muito próximos.

NUMCMP,ALL

! Renumera itens reutilizando os números dos itens já deletados.

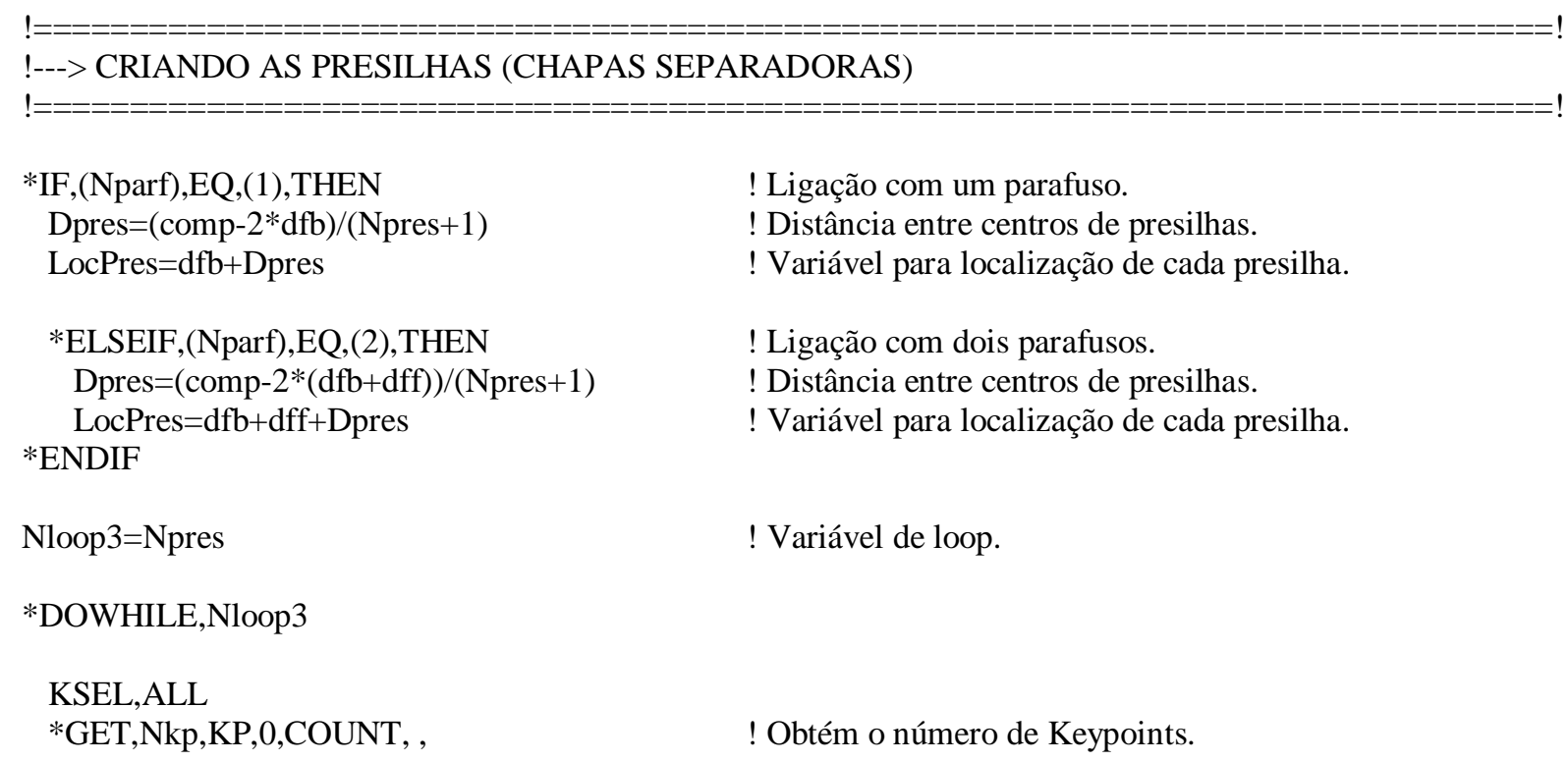


$\mathrm{K}, 0, \mathrm{dx}+\mathrm{dep} / 2, \mathrm{dy}-\mathrm{t} / 2$, LocPres-Lpres/2 $\mathrm{K}, 0, \mathrm{dx}$-dep/2,dy-t/2,LocPres-Lpres/2 $\mathrm{K}, 0, \mathrm{dx}+\mathrm{dep} / 2, \mathrm{dy}+\mathrm{rm}$, LocPres-Lpres/2 K,0,dx-dep/2,dy+rm,LocPres-Lpres/2 $\mathrm{K}, 0, \mathrm{dx}+\mathrm{dep} / 2, \mathrm{dy}+\mathrm{bm}$, LocPres-Lpres/2 $\mathrm{K}, 0, \mathrm{dx}$-dep/2,dy+bm,LocPres-Lpres/2

$\mathrm{A},(\mathrm{Nkp}+1),(\mathrm{Nkp}+2),(\mathrm{Nkp}+4),(\mathrm{Nkp}+3)$

$\mathrm{A},(\mathrm{Nkp}+3),(\mathrm{Nkp}+4),(\mathrm{Nkp}+6),(\mathrm{Nkp}+5)$

ASEL,S,LOC,X,dx-dep/2-0.001,dx+dep/2+0.001

ASEL,R,LOC,Z,LocPres-Lpres/2-0.001,LocPres-Lpres/2+0.001

VEXT,ALL, , ,0,0,Lpres,1,1,1

VSEL,S,LOC,Z,LocPres-Lpres/2-0.001,LocPres+Lpres/2+0.001

VGLUE,ALL

Cria a geometria da presilha (volume)

! Seleciona o volume da presilha criada.

! Une ("cola") os volumes selecionados.

LSEL,S,LOC,Z,LocPres-Lpres/2+0.001,LocPres+Lpres/2-0.001 Divisão das linhas longitudinais da presilha. LSEL,R,LOC,X,dx-dep/2-0.001,dx+dep/2+0.001

LESIZE,ALL, , ,Lpres, , , , ,1

LocPres $=$ LocPres + Dpres

Nloop3=Nloop3-1

*ENDDO

ASEL,ALL

\section{!---> MALHA DAS PRESILHAS (CHAPAS SEPARADORAS)}

!--- Gerando a malha das presilhas:

*IF,(Npres),NE,(0),THEN

LSEL,S,LOC,X,dx-dep/2+0.001,dx+dep/2-0.001 LSEL,R,LOC,Z,Llig+0.001,comp-Llig-0.001

LESIZE,ALL, , ,1, , , , ,1

LSEL,S,LOC,X,dx-dep/2-0.001,dx+dep/2+0.001 ! Seleciona as linhas das presilhas. LSEL,R,LOC,Z,Llig+0.001,comp-Llig-0.001

LSEL,R,LOC,Y,dy-t/2+0.001,dy+rm-0.001

LESIZE,ALL, , ,1, , , , ,1

LSEL,S,LOC,X,dx-dep/2-0.001,dx+dep/2+0.001 ! Seleciona as linhas das presilhas. LSEL,R,LOC,Z,Llig+0.001,comp-Llig-0.001 ! Seleciona todas as presilhas.

LSEL,R,LOC,Y,dy+rm+0.001,dy+bm-0.001 ! Seleciona linhas entre o fim da região curva e o fim da aba.
! Verifica se o número de presilhas é diferente de zero.

! Seleciona as linhas da espessura das presilhas.

! Seleciona todas as presilhas.

! Seleciona todas as presilhas.

! Seleciona as linhas entre a extremidade inferior e o fim da região curva.
VSEL,S,LOC,Z,Llig+0.001,comp-Llig-0.001 VSEL,R,LOC,X,dx-dep/2+0.001,dx+dep/2-0.001 MSHKEY,1

MAT,2

TYPE, 2

MSHAPE,0,3D

VMESH,ALL
! Seleciona todas as presilhas.

! Tipo da malha: Mapeada

! Material da presilha

! Tipo do elemento a ser utilizado

! Malha realizada com elemento 3D

! Gerando a malha 
VSEL,ALL

*ENDIF

!--- Juntando os nós da região parafusada:

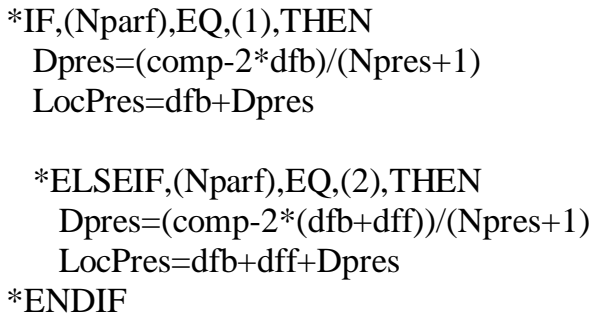

NSEL,S,LOC,Z,LocPres-1-0.001,LocPres+1+0.001 NSEL,R,LOC,Y,dy+(bm-rm)/3-0.5,dy+2*(bm-rm)/3+0.5 NSEL,R,LOC,X,dx-0.001,dx-dep/2-t/2-0.001 NUMMRG,NODE, $\mathrm{t} / 2+0.001$, , ,LOW

NSEL,S,LOC,Z,LocPres-1-0.001,LocPres+1+0.001 NSEL,R,LOC,Y,dy+(bm-rm)/3-0.5,dy+2*(bm-rm)/3+0.5 NSEL,R,LOC,X, dx+0.001, dx+dep/2+t/2+0.001 NUMMRG,NODE, $\mathrm{t} / 2+0.001$, , ,LOW

! Ligação com um parafuso.

! Distância entre centros de presilhas.

! Variável para localização de cada presilha.

! Ligação com dois parafusos.

! Distância entre centros de presilhas.

! Variável para localização de cada presilha.

LocPres $=$ LocPres + Dpres

Nloop4=Nloop4-1

*ENDDO

/NUMBER,1

! Distingue, por cores, os diferentes elementos finitos

/PNUM,MAT,1

! de acordo com seus respectivos materiais.

/REPLOT

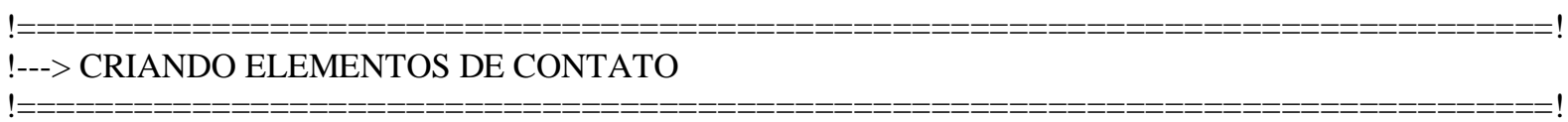

ET,5,CONTA173

KEYOPT,5,1,0

KEYOPT,5,7,2

ET,6,TARGE170

KEYOPT,6,4,0

R,5, , ,0.1,0, , ,

RMORE, , , t/2, , , 


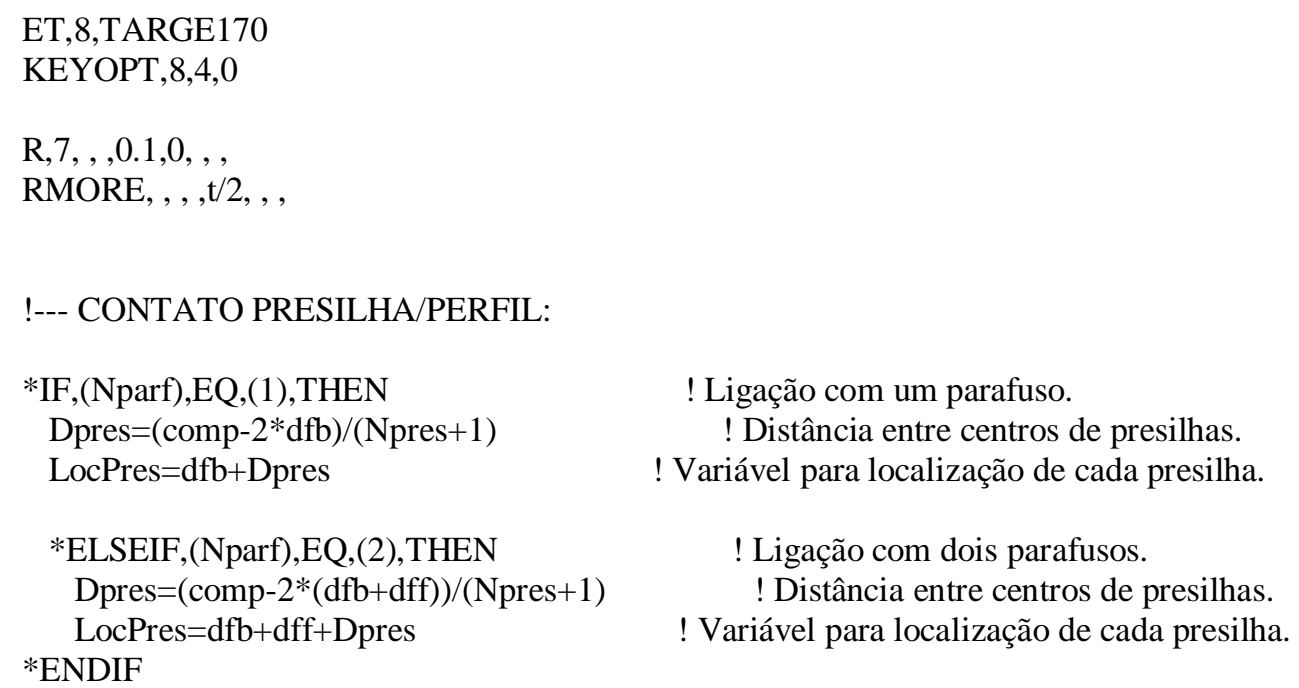

Nloop5=Npres ! Variável de loop.

*DOWHILE,Nloop5

NSEL,S,LOC,Z,LocPres-Lpres/2-0.001,LocPres+Lpres/2+0.001

NSEL,R,LOC,X,dx-dep/2-0.001,dx+dep/2+0.001

TYPE, 5

REAL,5

ESURF

NSEL,S,LOC,Z,LocPres-Lpres/2-0.001,LocPres+Lpres/2+0.001

NSEL,R,LOC,X,dx-dep/2-t/2-0.001,dx+dep/2+t/2+0.001

NSEL,U,LOC,X,dx-dep/2-0.001,dx+dep/2+0.001

TYPE,6

REAL,5

ESURF, ,TOP, ,

LocPres $=$ LocPres + Dpres

Nloop5=Nloop5-1

*ENDDO

!--- CONTATO CHAPA DE LIGAÇÃO/PERFIL:

*IF,(Nparf),EQ,(1),THEN

Llig $=2 *$ dfb

! Ligação com um parafuso.

*ELSEIF,(Nparf),EQ,(2),THEN

Llig $=2 * \mathrm{dfb}+\mathrm{dff}$

! Comprimento da ligação.

*ENDIF

! Ligação com dois parafusos.

! Comprimento da ligação.

! Chapa de ligação em z=0:

NSEL,S,LOC,Z,-sch-0.001,Llig+0.001

NSEL,R,LOC,X,dx-dep/2-0.001,dx+dep/2+0.001

TYPE,7

REAL,7

ESURF

NSEL,S,LOC,Z,-0.001,Llig+0.001 
NSEL,R,LOC,X,dx-dep/2-t/2-0.001,dx+dep/2+t/2+0.001

NSEL,U,LOC,X,dx-dep/2-0.001,dx+dep/2+0.001

TYPE, 8

REAL, 7

ESURF, ,TOP, ,

! Chapa de ligação em z=comp:

NSEL,S,LOC,Z,comp+sch+0.001,comp-Llig-0.001

NSEL,R,LOC,X,dx-dep/2-0.001,dx+dep/2+0.001

TYPE, 7

REAL,7

ESURF

NSEL,S,LOC,Z,comp+0.001,comp-Llig-0.001

NSEL,R,LOC,X,dx-dep/2-t/2-0.001,dx+dep/2+t/2+0.001

NSEL,U,LOC,X,dx-dep/2-0.001,dx+dep/2+0.001

TYPE, 8

REAL,7

ESURF, ,TOP, ,

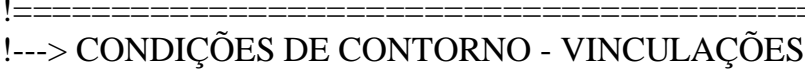

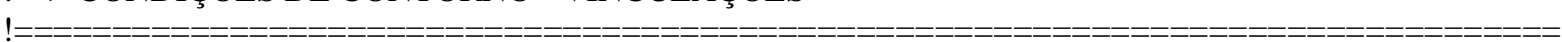

FINISH

/SOLU

!--- ACOPLAMENTO DOS NÓS DOS APOIOS:

! Apoio em $\mathrm{z}=0$ :

NSEL,S,LOC,Z,-sch-Lap+0.001,-sch-Lap-0.001

NPLOT,ALL

! Seleção dos nós do apoio em Z=0.

CP,NEXT,UZ,ALL

! Mostra os nós selecionados e seus respectivos números.

NSEL,ALL

! Acoplamento dos nós.

! Apoio em z=comp:

NSEL,S,LOC,Z,comp+sch+Lap+0.001,comp+sch+Lap-0.001 ! Seleção dos nós do apoio em Z=comp.

NPLOT,ALL

CP,NEXT,UZ,ALL

! Mostra os nós selecionados e seus respectivos números.

NSEL,ALL

! Acoplamento dos nós.

!--- CONDIÇÕES DE CONTORNO DOS NÓS DAS CHAPAS DE TOPO:

! Restrições em Z=0:

NSEL,S,LOC,Z,-sch-Lap+0.001,-sch-Lap-0.001

! Seleção dos nós do apoio em Z=0.

NPLOT,ALL

D,ALL,UX,0, , , ,UY,ROTX,ROTY,ROTZ

! Restrições ao deslocamento dos nós selecionados. NSEL,ALL

! Restrições em Z=comp: 
NSEL,S,LOC,Z,comp+sch+Lap+0.001,comp+sch+Lap-0.001 ! Seleção dos nós do apoio em Z=comp. NPLOT,ALL

D,ALL,UX,0, , , ,UY,UZ,ROTX,ROTY,ROTZ

! Restrições ao deslocamento dos nós selecionados. NSEL,ALL

\section{!--- ACOPLAMENTO DOS NÓS DA LIGAÇÃO PARAFUSADA:}

LSEL,ALL

NSEL,ALL

NPLOT,ALL

*IF,(Nparf),EQ,(1),THEN

! Ligação com 1 parafuso.

! Ligação em z=0:

LSEL,S,LOC,Z,dfb+Dparf/2+0.001,dfb-Dparf/2-0.001

LSEL,R,LOC,Y,dy+rm+0.001,dy+bm-0.001

NSLL,S, 1

CP,NEXT,UX,ALL

CP,NEXT,UY,ALL

LSEL,S,LOC,Z,dfb+0.001,dfb-Dparf/2-0.001

LSEL,R,LOC,Y,dy+rm+0.001,dy+bm-0.001

NSLL,S,1

NSEL,R,LOC,Z,dfb-(0.707107*Dparf/2)+0.001,dfb-Dparf/2-0.001

NPLOT,ALL

CP,NEXT,UZ,ALL

LSEL,ALL

NSEL,ALL

! Ligação em z=comp:
! Seleção das linhas do furo.

! Seleção das linhas do furo.

! Seleção dos nós das linhas selecionadas.

! Acoplamento UX dos nós.

! Acoplamento UY dos nós.

! Seleção das linhas do furo.

! Seleção das linhas do furo.

! Seleção dos nós das linhas selecionadas.

! Seleção dos nós de $1 / 4$ do furo.

! Acoplamento UZ dos nós.

LSEL,S,LOC,Z,comp-dfb-Dparf/2-0.001,comp-dfb+Dparf/2+0.001 ! Seleção das linhas do furo.

LSEL,R,LOC,Y,dy+rm+0.001,dy+bm-0.001

! Seleção das linhas do furo.

NSLL,S, 1

CP,NEXT,UX,ALL

! Seleção dos nós das linhas selecionadas.

CP,NEXT,UY,ALL

LSEL,S,LOC,Z,comp-dfb-0.001,comp-dfb+Dparf/2+0.001

LSEL,R,LOC,Y,dy+rm+0.001,dy+bm-0.001

NSLL,S,1

! Acoplamento UX dos nós.

! Acoplamento UY dos nós.

! Seleção das linhas do furo.

! Seleção das linhas do furo.

NSEL,R,LOC,Z,comp-dfb+(0.707107*Dparf/2)-0.001,comp-dfb+D

! Seleção dos nós das linhas selecionadas.

NPLOT,ALL

CP,NEXT,UZ,ALL

LSEL,ALL

NSEL,ALL

*ELSEIF,(Nparf),EQ,(2),THEN

! Ligação com 2 parafusos.

! Ligação em z=0:

LSEL,S,LOC,Z,dfb+Dparf/2+0.001,dfb-Dparf/2-0.001

LSEL,R,LOC,Y,dy+rm+0.001,dy+bm-0.001

NSLL,S, 1

CP,NEXT,UX,ALL

CP,NEXT,UY,ALL

LSEL,S,LOC,Z,dfb+0.001,dfb-Dparf/2-0.001

LSEL,R,LOC,Y,dy+rm+0.001,dy+bm-0.001

Seleção dos nós de $1 / 4$ do furo.

NSLL,S, 1

! Acoplamento UZ dos nós.

NSEL,R,LOC,Z,dfb-(0.707107*Dparf/2)+0.001,dfb-Dparf/2-0.001

! Seleção das linhas do furo 1.

! Seleção das linhas do furo 1.

! Seleção dos nós das linhas selecionadas.

! Acoplamento UX dos nós do furo 1.

! Acoplamento UY dos nós do furo 1.

! Seleção das linhas do furo 1.

! Seleção das linhas do furo 1.

! Seleção dos nós das linhas selecionadas. ! Seleção dos nós de 
NPLOT,ALL

CP,NEXT,UZ,ALL

LSEL,ALL

NSEL,ALL

LSEL,S,LOC,Z,dfb+dff+Dparf/2+0.001,dfb+dff-Dparf/2-0.001

LSEL,R,LOC,Y,dy+rm+0.001,dy+bm-0.001

NSLL,S, 1

CP,NEXT,UX,ALL

CP,NEXT,UY,ALL

LSEL,S,LOC,Z,dfb+dff+0.001,dfb+dff-Dparf/2-0.001

LSEL,R,LOC,Y,dy+rm+0.001,dy+bm-0.001

NSLL,S, 1

NSEL,R,LOC,Z,dfb+dff-(0.707107*Dparf/2)+0.001,dfb+dff-Dparf/2-0.001

NPLOT,ALL

CP,NEXT,UZ,ALL

LSEL,ALL

NSEL,ALL

! Ligação em z=comp:

LSEL,S,LOC,Z,comp-dfb-Dparf/2-0.001,comp-dfb+Dparf/2+0.001

LSEL,R,LOC,Y,dy+rm+0.001,dy+bm-0.001

NSLL,S, 1

CP,NEXT,UX,ALL

CP,NEXT,UY,ALL

LSEL,S,LOC,Z,comp-dfb-0.001,comp-dfb+Dparf/2+0.001

LSEL,R,LOC,Y,dy+rm+0.001,dy+bm-0.001

NSLL, S, 1

NSEL,R,LOC,Z,comp-dfb+(0.707107*Dparf/2)-0.001,comp-dfb+Dparf/2+0.001

NPLOT,ALL

CP,NEXT,UZ,ALL

LSEL,ALL

NSEL,ALL

LSEL,S,LOC,Z,comp-dfb-dff-Dparf/2-0.001,comp-dfb-dff+Dparf/2+0.001 ! Seleção das linhas do furo 2.

LSEL,R,LOC,Y,dy+rm+0.001,dy+bm-0.001

NSLL, S, 1

CP,NEXT,UX,ALL

CP,NEXT,UY,ALL

LSEL,S,LOC,Z,comp-dfb-dff-0.001,comp-dfb-dff+Dparf/2+0.001

LSEL,R,LOC,Y,dy+rm+0.001,dy+bm-0.001

NSLL,S, 1

NSEL,R,LOC,Z,comp-dfb-dff+(0.707107*Dparf/2)-0.001,comp-dfb-dff+Dparf/2+0.001

! Seleção dos nós das linhas selecionadas.

! Acoplamento UX dos nós do furo 2.

! Seleção dos nós das linhas selecionadas.

NPLOT,ALL

CP,NEXT,UZ,ALL

LSEL,ALL

NSEL,ALL

*ENDIF

FINISH
! Seleção das linhas do furo 2

! Acoplamento UY dos nós do furo 2.

! Seleção das linhas do furo 2. ! Seleção das linhas do furo 2.

! Seleção das linhas do furo 1.

! Seleção dos nós das linhas selecionadas.

! Seleção das linhas do furo 1.

! Seleção das linhas do furo 1.

Seleção dos nós de $1 / 4$ do furo.

Seleção dos

nós de $1 / 4$ do furo.
! Acoplamento UZ de 1/4 dos nós do furo 2. 
/SOLU

ANTYPE,0

NLGEOM,OFF

EQSLV,SPAR, ,0

PSTRES,ON

! Contato:

AUTOTS,ON

NSUBST,100,1000,20

NROPT,FULL, ,OFF

NEQIT,50

LNSRCH,ON

FINISH
! Análise estática.

! Desativa a não linearidade geométrica.

! Solver escolhido (DEFAULT).

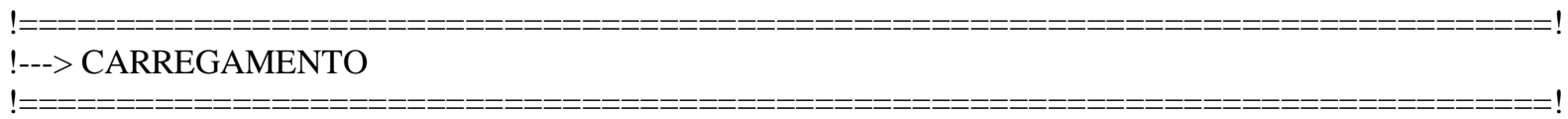

/SOLU

NSEL,S,LOC,Z,-sch-Lap+0.001,-sch-Lap-0.001

NSEL,R,LOC,X,dx-dep/2-0.001,dx+dep/2+0.001 ! Seleção dos nós que passam pela região central do apoio em Z $=0$.

NPLOT,ALL

*GET,nmestre,NODE,0,NUM,MIN

! Pega o nó mestre (menor numeração de nó da linha).

NPLOT,ALL

F,nmestre,FZ,1

! Aplica uma força unitária no nó mestre na direção Z.

GPLOT

ALLSEL,ALL

/REPLOT

FINISH

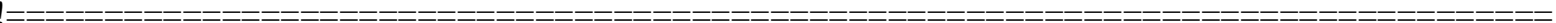

!---> SOLUÇÃO

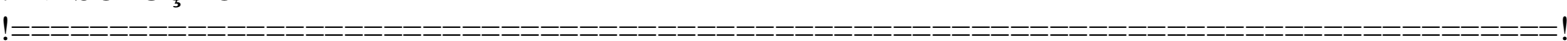

/SOLU

ISTATUS,SOLU

SOLVE

FINISH

SAVE

!--- BUCKLING ANALISE:

ISOLU

ANTYPE, 1

BUCOPT,LANB,50

SOLVE

FINISH 
ISOLU

EXPASS,ON

MXPAND,50

SOLVE

FINISH

SAVE

\section{2) Script 2:}

Para a obtenção da imperfeição geométrica inicial global, a construção do modelo é semelhante ao que é apresentado no Script 1, sendo as únicas diferenças referentes aos itens Carregamento e Solução, cujo código foi reescrito da seguinte forma:

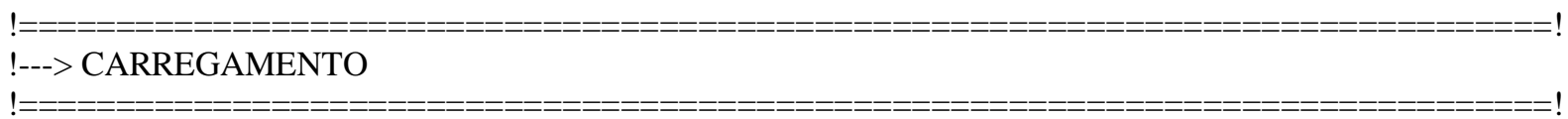

/SOLU

espmed=Dpres-Lpres nelmed=NINT(espmed) lelmed=espmed/nelmed resto $=\mathrm{MOD}(\mathrm{Npres}, 2)$

*IF,(resto),EQ,(0),THEN

NSEL,ALL

NSEL,S,LOC,Z,Comp/2+lelmed/2,Comp/2-lelmed/2

*ELSE

NSEL,ALL

NSEL,S,LOC,Z,Comp/2+0.501,Comp/2-0.501

*ENDIF

NPLOT,ALL

D,ALL,UY,-1

GPLOT

ALLSEL,ALL

/REPLOT

FINISH
! Número par de presilhas.

! Seleção dos nós situados no meio do perfil.

! Número ímpar de presilhas.

! Seleção dos nós situados no meio do perfil.

! Plotando os nós situados no meio do perfil. ! Aplica um deslocamento unitário na direção perpendicular ao eixo da barra.

!============
!--> SOLUÇÃO

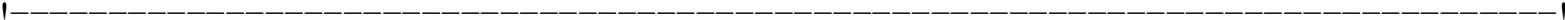


SAVE

\section{3) Script 3:}

Para as análises não-lineares, a construção dos modelos é feita de forma semelhante ao procedimento do Script 1. As diferenças ficam por conta apenas dos itens Propriedades do Aço, Criando Elementos de Contato, Opções de Processamento, Carregamento e Solução. Além disso, as imperfeições geométricas são importadas para estes modelos por meio do item Atualizando a Geometria. A seguir, são mostrados os trechos do Script 3 referentes aos itens citados.

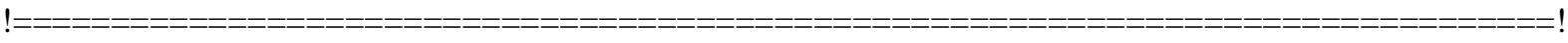

!---> PROPRIEDADES DO AÇO
}

$\mathrm{MP}, \mathrm{EX}, 1, \mathrm{E}$

MP,PRXY,1,v

TB,MISO,1,1,20

TBPT, 0,0

TBPT,,0.000560198,10.07

TВPT,,0.001168127,20.06

TBPT,,0.002134513,30.01

TBPT,,0.003035289,34.17

TBPT,,0.003687244,35.05

TBPT,,0.003880113,35.14

TBPT,,0.004305244,35.25

TBPT,,0.005041296,35.37

TBPT,,0.005783990,35.50

TBPT,,0.006239394,35.62

TВPT,,0.006901256,35.84

TBPT,,0.008079200,36.32

TBPT,,0.013082401,38.52

TBPT,,0.018976772,40.84

TВРТ,,0.028012705,43.74

TВPT,,0.040191636,46.86

TBPT,,0.063349846,50.70

TBPT,,0.116830360,55.81

TBPT,,0.163332611,58.64

MP,EX,2,E

MP,PRXY,2,v

TB,MISO,2,1,20

TBPT, $, 0,0$

TBPT,,0.000560198,10.07

TBPT,,0.001168127,20.06

TBPT,,0.002134513,30.01

TBPT,,0.003035289,34.17

TBPT,,0.003687244,35.05
! Atribuição do módulo de elasticidade do perfil.

! Atribuição do coeficiente de Poisson do perfil.

! Não linearidade física, tensão X deformação.

! Pontos da curva tensão X deformação.

! Atribuição do módulo de elasticidade das presilhas.

! Atribuição do coeficiente de Poisson das presilhas.

! Não linearidade física, tensão X deformação.

! Pontos da curva tensão X deformação. 
TBPT,,0.003880113,35.14 TBPT,,0.004305244,35.25 TBPT,,0.005041296,35.37 TBPT,,0.005783990,35.50 TBPT,,0.006239394,35.62 TBPT,,0.006901256,35.84 TBPT,,0.008079200,36.32 TBPT,,0.013082401,38.52 TBPT,,0.018976772,40.84 TBPT,,0.028012705,43.74 TBPT,,0.040191636,46.86 TBPT,,0.063349846,50.70 TBPT,,0.116830360,55.81 TBPT,,0.163332611,58.64

MP,EX,3,20000 MP,PRXY,3,v

MP,EX,4,E MP,PRXY,4,v

TB,MISO,4,1,20

TBPT,,0,0

TBPT,,0.000560198,10.07

TBPT,,0.001168127,20.06 TBPT,,0.002134513,30.01 TBPT,,0.003035289,34.17 ТВРТ,,0.003687244,35.05 ТВРТ,,0.003880113,35.14 TBPT,,0.004305244,35.25 ТВРТ,,0.005041296,35.37 ТВРТ,,0.005783990,35.50 ТВРТ,,0.006239394,35.62 TВРT,,0.006901256,35.84 TВPT,,0.008079200,36.32 ТВРТ,,0.013082401,38.52 TBPT,,0.018976772,40.84 TBPT,,0.028012705,43.74 TBPT,,0.040191636,46.86 TBPT,,0.063349846,50.70 TBPT,,0.116830360,55.81 TBPT,,0.163332611,58.64
! Atribuição do módulo de elasticidade do dispositivo de apoio. ! Atribuição do coeficiente de Poisson do dispositivo de apoio.

! Atribuição do módulo de elasticidade da chapa de ligação.

! Atribuição do coeficiente de Poisson da chapa de ligação.

! Não linearidade física, tensão X deformação.

! Pontos da curva tensão X deformação.

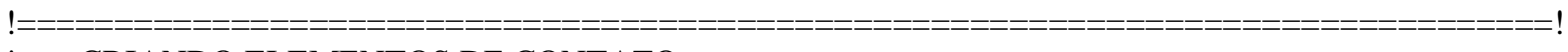

!---> CRIANDO ELEMENTOS DE CONTATO

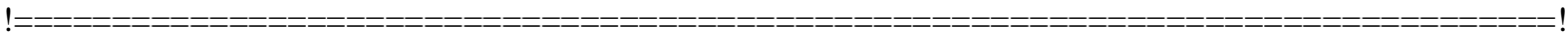

ET,5,CONTA173

KEYOPT,5,1,0

KEYOPT,5,7,2

ET,6,TARGE170

KEYOPT,6,4,0

$\mathrm{R}, 5$, , , 0.1,0, , ,

RMORE, , , ,t/2, , , 


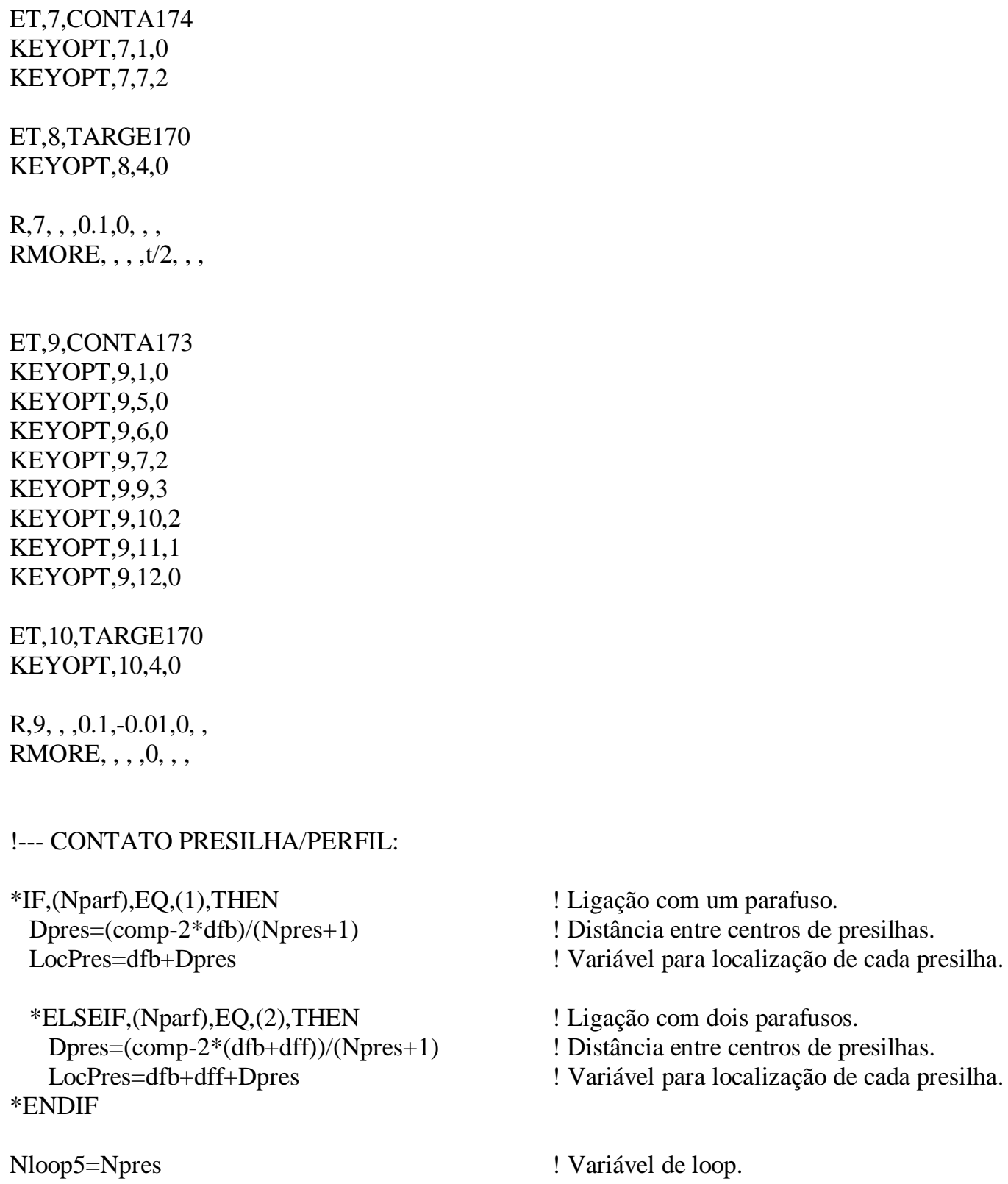

*DOWHILE,Nloop5

NSEL,S,LOC,Z,LocPres-Lpres/2-0.001,LocPres+Lpres/2+0.001

NSEL,R,LOC,X,dx-dep/2-0.001,dx+dep/2+0.001

TYPE, 5

REAL,5

ESURF

NSEL,S,LOC,Z,LocPres-Lpres/2-0.001,LocPres+Lpres/2+0.001

NSEL,R,LOC,X,dx-dep/2-t/2-0.001,dx+dep/2+t/2+0.001

NSEL,U,LOC,X,dx-dep/2-0.001,dx+dep/2+0.001

TYPE, 6

REAL,5

ESURF, ,TOP, ,

LocPres $=$ LocPres + Dpres

Nloop5=Nloop5-1 
*ENDDO

!--- CONTATO CHAPA DE LIGAÇÃO/PERFIL:

$\begin{array}{ll}\text { *IF,(Nparf),EQ,(1),THEN } & \text { ! Ligação com um parafuso. } \\ \text { Llig=2*dfb } & \text { ! Comprimento da ligação. } \\ \text { *ELSEIF,(Nparf),EQ,(2),THEN } & \text { ! Ligação com dois parafusos. } \\ \text { Llig=2*dfb+dff } & \text { ! Comprimento da ligação. }\end{array}$

! Chapa de ligação em z=0:

NSEL,S,LOC,Z,-sch-0.001,Llig+0.001

NSEL,R,LOC,X,dx-dep/2-0.001,dx+dep/2+0.001

TYPE, 7

REAL,7

ESURF

NSEL,S,LOC,Z,-0.001,Llig+0.001

NSEL,R,LOC,X,dx-dep/2-t/2-0.001,dx+dep/2+t/2+0.001

NSEL,U,LOC,X,dx-dep/2-0.001,dx+dep/2+0.001

TYPE, 8

REAL,7

ESURF, ,TOP, ,

! Chapa de ligação em z=comp:

NSEL,S,LOC,Z,comp+sch+0.001,comp-Llig-0.001

NSEL,R,LOC,X,dx-dep/2-0.001,dx+dep/2+0.001

TYPE,7

REAL,7

ESURF

NSEL,S,LOC,Z,comp+0.001,comp-Llig-0.001

NSEL,R,LOC,X,dx-dep/2-t/2-0.001,dx+dep/2+t/2+0.001

NSEL,U,LOC,X,dx-dep/2-0.001,dx+dep/2+0.001

TYPE, 8

REAL,7

ESURF, ,TOP, ,

!--- CONTATO PERFIL/PERFIL:

! Contact:

NSEL,S,LOC,Z,Llig+0.001,comp-Llig-0.001

NSEL,R,LOC,X,dx+dep/2+t/2-0.001,dx+dep/2+t/2+0.001

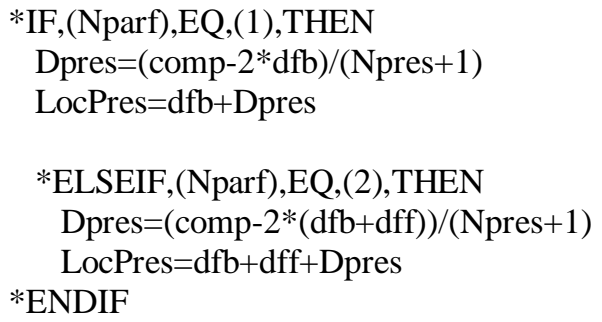

! Ligação com um parafuso.

! Distância entre centros de presilhas.

! Variável para localização de cada presilha.

! Ligação com dois parafusos.

! Distância entre centros de presilhas.

! Variável para localização de cada presilha. 


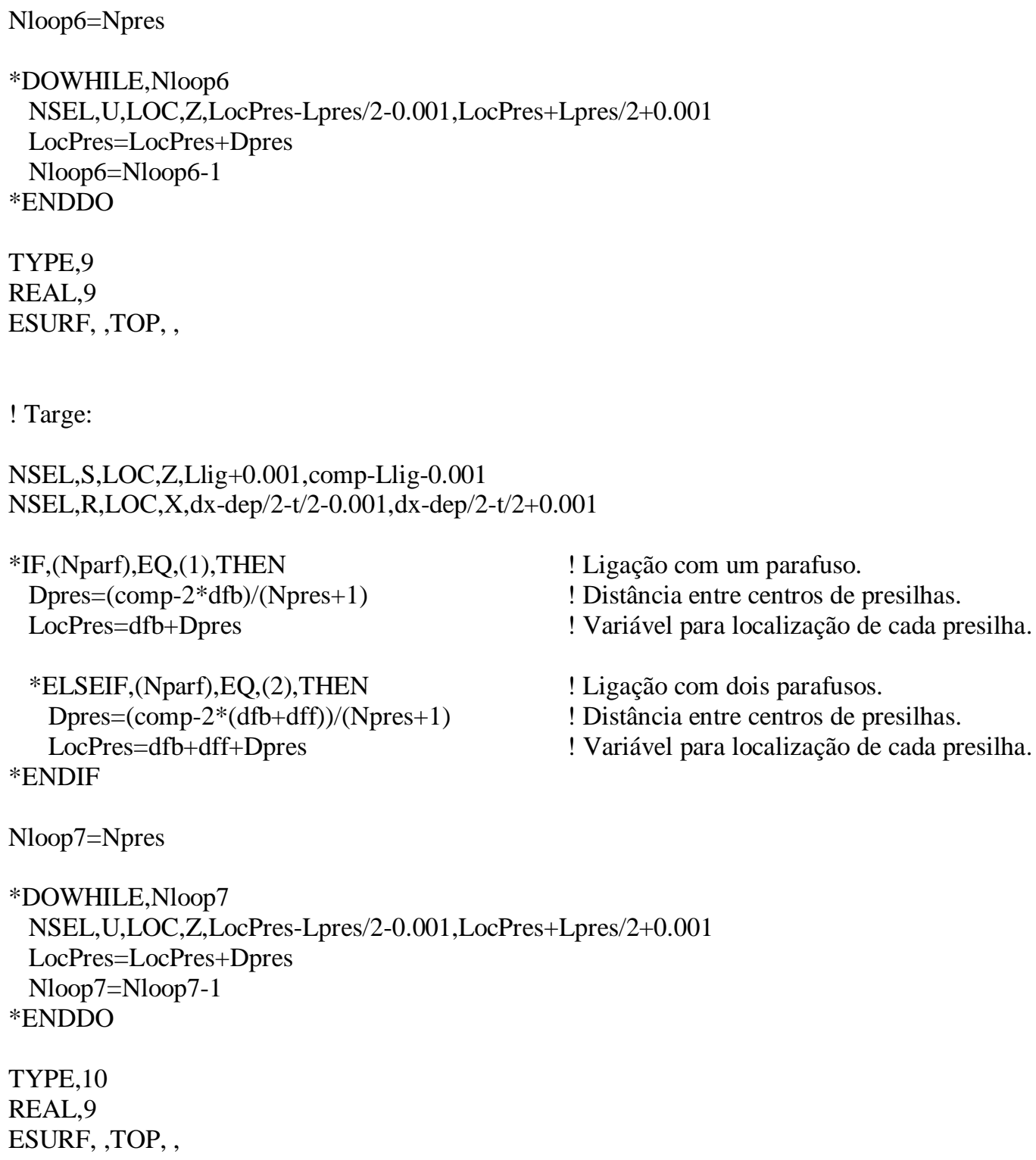

Nloop7=Npres

*DOWHILE,Nloop7

NSEL,U,LOC,Z,LocPres-Lpres/2-0.001,LocPres+Lpres/2+0.001

LocPres=LocPres+Dpres

Nloop7=Nloop7-1

*ENDDO

TYPE,10

REAL,9

ESURF, ,TOP, ,

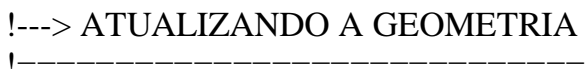

$\mathrm{DMX}=1.005$

$\mathrm{d} 1=0.64 * \mathrm{t}$

FATloc $=\mathrm{d} 1 / \mathrm{DMX}$

! Atualização da geometria:

UPGEOM,FATloc,1,4,'Endereço onde se localiza o Script 1 mais o nome do arquivo','rst',

!--- MODO GLOBAL DE FLEXÃO:

$\mathrm{DMX}=1.002$

FATglob_F_aplicado $=$ comp $/ 1500$

FATglob_F=FATglob_F_aplicado/DMX

! Atualização da geometria:

! Deslocamento máximo local do ansys.

! Amplitude requerida no perfil.

! Fator de amplificação da amplitude local requerida. 
UPGEOM,FATglob_F,LAST,LAST,'Endereço onde se localiza o Script 2 mais o nome do arquivo','rst',

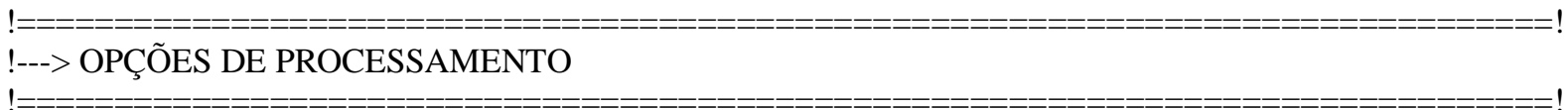

/SOLU

ANTYPE,0

! Análise estática.

NLGEOM,1

NROPT,FULL, ,OFF

! Ativa a não linearidade geométrica.

LNSRCH,ON

! Newton-Raphson completo.

EQSLV,SPAR, ,0

PIVCHECK,ON

SSTIF,ON

NEQIT,20

! Solver escolhido (DEFAULT).

! Atualiza a matriz de rigidez a cada iteração.

! Número máximo de equações de equilíbrio.

CNVTOL,U,1,0.001,2, ,

STABILIZE,CONSTANT,ENERGY,0.0001,NO ～! ATENÇÃO: comando usado somente para modelos com problemas de convergência.

FINISH

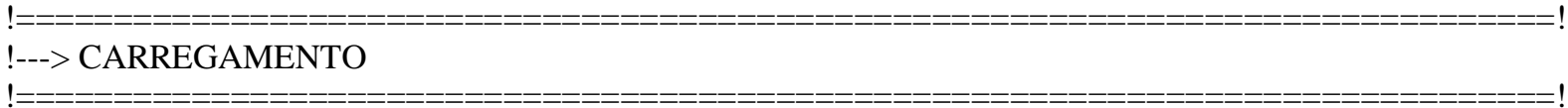

/SOLU

NSEL,S,LOC,Z,-sch-Lap+0.001,-sch-Lap-0.001

! Seleção dos nós da "chapa de topo" do apoio em z=0.

NPLOT,ALL

*GET,nmestre,NODE,0,NUM,MIN

! Pega o nó mestre (menor numeração de nó da linha).

NPLOT,ALL

D,nmestre,UZ,DeslocP, , , , , ,

! Deslocamento prescrito no nó mestre na direção Z.

AUTOTS,ON

TIME,DeslocP

DELTIM,DeslocP/100,DeslocP/1000000,DeslocP/100

OUTRES,ERASE

OUTRES,ALL,ALL

GPLOT

ALLSEL,ALL

/REPLOT

FINISH

SAVE
! Automático time step ativado.

! Time=deslocamento prescrito.

! Chute inicial, mínimo time,máximo time.

$!============$
$!--->$ SOLUÇÃO

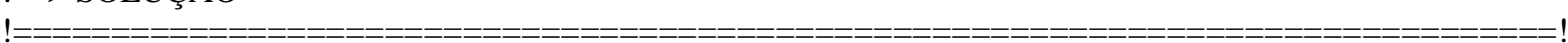


ISTATUS,SOLU

SOLVE

FINISH

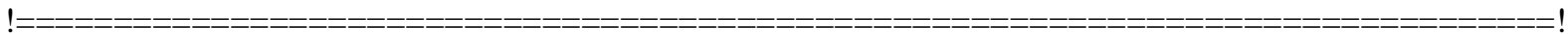




\section{APÊNDICE C - Scripts para as análises em temperaturas elevadas}

Neste apêndice, são disponibilizados os scripts desenvolvidos no presente trabalho para o estudo dos perfis dupla cantoneira sob temperaturas elevadas, cujas análises foram divididas da seguinte maneira:

1) Script 1: Análise térmica;

2) Script 2: Análise termoestrutural.

\section{1) Script 1:}

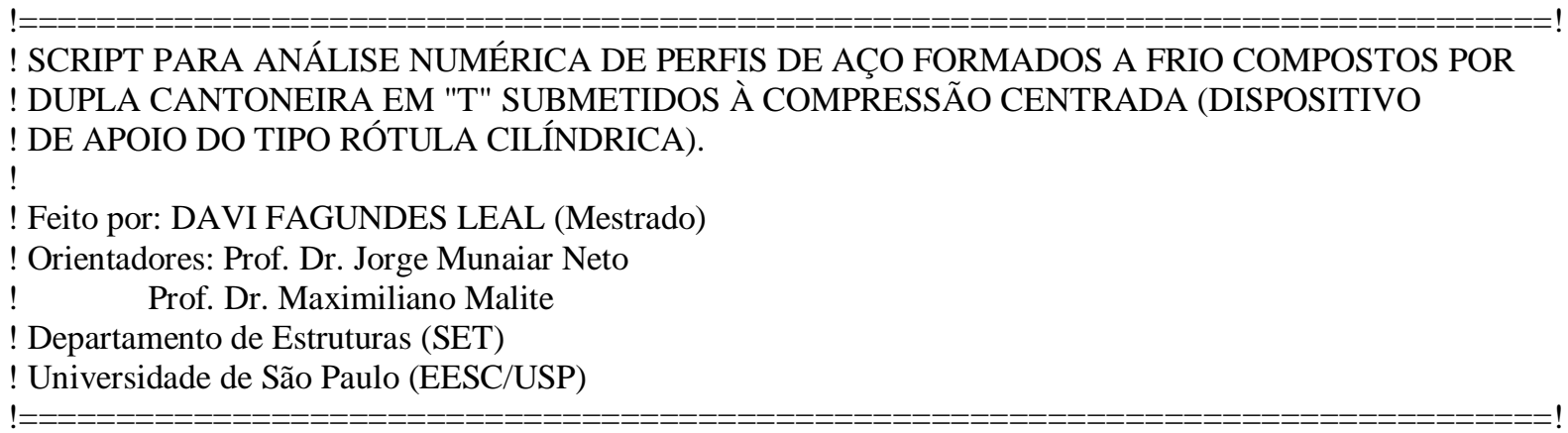

! ESTE SCRIPT FOI DESENVOLVIDO PARA SER UTILIZADO NO ANSYS 11.

! VERSÕES ANTERIORES NÃO POSSUEM CERTAS PARTICULARIDADES NECESSÁRIAS PARA ! O MODELO.

FINISH

/CLEAR

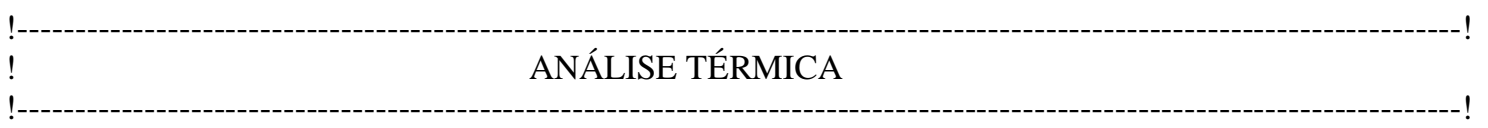

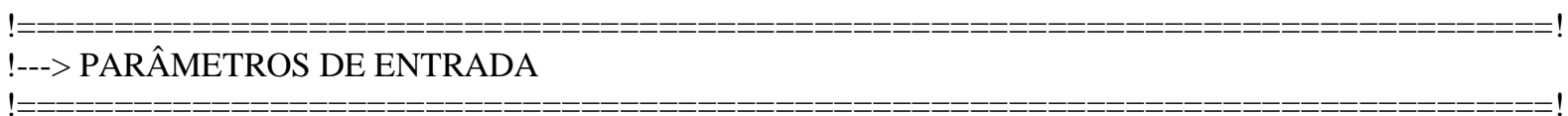

$\mathrm{bf}=6$

$\mathrm{t}=0.238$

$\mathrm{ri}=0.238$

comp $=148.5$

dep $=0.5$

Lpres $=2$

Lap $=6.75$

Npres $=2$

$\mathrm{dx}=0$

$\mathrm{dy}=0$

ndc $=2$
! Largura da mesa do perfil, cm

! Espessura do perfil, cm

! Raio interno de dobramento, cm

! Comprimento efetivo do perfil, $\mathrm{cm}$

! Distância entre perfis (espessura da chapa de ligação), cm

! Comprimento da presilha (chapa separadora), cm

! Tamanho do dispositivo de apoio (chapa de topo + rótula "faca"), cm

! Número de presilhas (chapas separadoras) utilizadas.

! Translação em x do perfil em relação ao $(0,0)$ global.

! Translação em y do perfil em relação ao $(0,0)$ global.

! Número de divisões das linhas do canto. 
$\mathrm{nd} 1 \mathrm{~m}=5$

$\mathrm{nd} 2 \mathrm{~m}=2$

$\mathrm{nd} 3 \mathrm{~m}=7$

DeslocP $=0.2$

$\mathrm{E}=20536.8425$

$\mathrm{v}=0.3$

ncamadas $=2$

emissividade $=0.7$

horas $=1.0$
! Número de divisões das linhas do primeiro trecho da aba com presilhas.

! Número de divisões das linhas do segundo trecho da aba com presilhas.

! Número de divisões das linhas da aba livre.

! Deslocamento prescrito - medido em ensaio, $\mathrm{cm}$

! Módulo de elasticidade do aço utilizado, KN/cm2

! Coeficiente de Poisson do aço utilizado.

! Número de camadas na espessura da SHELL.

! Numeração do nó extra (se a malha tiver mais de 1000000 de nós, aumentar)

! Emissividade do incêndio no aço (ENTRADA E SAÍDA).

! Tempo em horas até quando obter os resultados.

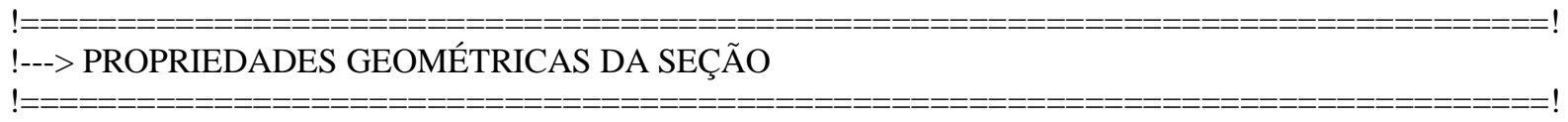

! NBR 6355:

$\mathrm{rm}=\mathrm{ri}+0.5 * \mathrm{t} \quad$ ! Raio de dobramento referente a linha média da seção, $\mathrm{cm}$

$\mathrm{b}=\mathrm{bf}-(\mathrm{rm}+0.5 * \mathrm{t}) \quad$ ! Largura da parte plana da mesa do perfil, cm

bm=bf-t/2 ! Largura da mesa referente à linha média da seção, cm

u1=1.571*rm ! Desenvolvimento da parte curva da seção referente à dobra em 90, cm

As $=\mathrm{t} *(2 * \mathrm{~b}+\mathrm{u} 1) \quad$ ! Área da seção tranversal de uma cantoneira simples, $\mathrm{cm} 2$

$\mathrm{Yg}=(\mathrm{t} / \mathrm{As}) *\left(\mathrm{~b} *\left(0.5^{*} \mathrm{~b}+\mathrm{rm}\right)+\mathrm{u} 1 *\left(0.363^{*} \mathrm{rm}\right)\right)+0.5 * \mathrm{t} \quad$ ! Distância do CG à face externa do perfil, na direção y

Ygm=Yg-t/2 ! Distância do centróide à linha de esqueleto do perfil, eixo-y

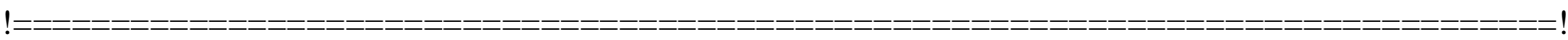

!---> OPÇÕES GERAIS

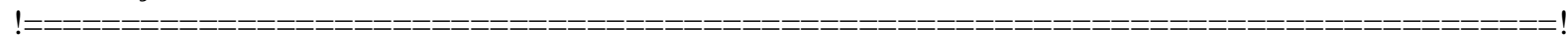

*GET,NProcessadores,ACTIVE, ,NPROC ! Obtém o número de processadores disponíveis no computador. /CONFIG,NPROC,NProcessadores ! Indica o número de processadores a serem usados.

/VIEW,1,1,1,1 ! Vista da tela 1 com diretriz que passa pelo ponto $(1,1,1)$.

/ANGLE, 1

/ESHAPE,1.0

/UIS,MSGPOP,3

/PBC,ALL, ,1

/REP,FAST

/PREP7

/NUMBER,1

/PNUM,MAT,1

/REPLOT
! Visualização da geometria do elemento.ex: espessura de elementos de casca.

! Mostra somente as mensagens de erros.

! Plot Boundary Conditions=1, mostra somente o símbolo da restrição.

! Redesenha o modelo.

! Distingue, por cores, os diferentes elementos finitos

! de acordo com seus respectivos materiais. 
KEYOPT ,1,4, ncamadas , KEYOPT ,1,6,1

ET,2,SOLID70

KEYOPT ,2,2,0

KEYOPT ,2,4,0

KEYOPT ,2,7,0

KEYOPT ,2,8,0

ET,3,SURF152

KEYOPT ,3,1,0

KEYOPT ,3,2,0

KEYOPT ,3,3,1

KEYOPT ,3,4,1

KEYOPT ,3,5,1

KEYOPT ,3,6,0

KEYOPT ,3,7,0

KEYOPT ,3,8,0

KEYOPT ,3,9,1

KEYOPT ,3,11,1

ET,4,SURF152

KEYOPT ,4,1,0

KEYOPT ,4,2,0

KEYOPT ,4,3,1

KEYOPT ,4,4,1

KEYOPT ,4,5,1

KEYOPT ,4,6,0

KEYOPT ,4,7,0

KEYOPT ,4,8,0

KEYOPT ,4,9,1

KEYOPT ,4,11,0

ET,5,SURF152

KEYOPT ,5,1,0

KEYOPT ,5,2,0

KEYOPT ,5,3,1

KEYOPT ,5,4,1

KEYOPT ,5,5,1

KEYOPT ,5,6,0

KEYOPT ,5,7,0

KEYOPT ,5,8,5

KEYOPT ,5,9,0

KEYOPT ,5,11,1

ET,6,SURF152

KEYOPT ,6,1,0

KEYOPT ,6,2,0
! Número de camadas

! 1-Paint Application (TBOT -> TEMP).

! Elemento Finito das presilhas (chapas espaçadoras).

! 0 - Evaluate at an average film temperature, (TS+TB)/2

! 0 - Element coordinate system is parallel to the global coordinate system.

! Standard heat transfer element.

! No mass transport effects.

! Elemento de Superfície para RADIAÇÃO TTOP

! Adiabatic wall temperature option:

! Recovery factor (FR) option:

! Axis of symmetry: 0 -- OMEG used about global Cartesian X-axis

! Midside nodes: 1 -- Does not have midside nodes

! Extra node for radiation and/or convection calculations: 1 -- Has extra node (optional if KEYOPT (8) > 1; required if KEYOPT (9) > 0)

! Use of bulk temperature: 0 -- Extra node temperature used as bulk temperature

! Empirical term: 0 -- Do not multiply film coefficient by empirical term.

! Heat flux and convection loads: 0 -- Ignore heat flux and convection surface loads (if any)

! Radiation form factor calculation: 1 -- Use radiation with the form factor real constant

! DOF dos nós (exceto nó-extra): 1-TTOP

! Elemento de Superfície para RADIAÇÃO TEMP

! Heat flux and convection loads: ! 0 -- Ignore heat flux and convection surface loads (if any)

! Radiation form factor calculation: 1 -- Use radiation with the form factor real constant

! DOF dos nós (exceto nó-extra): 0-TEMP

! Superfície para CONVECÇÃO TTOP

! Heat flux and convection loads: 5 -- Evaluate hf at differential temperature, |TS-TB|

! Radiation form factor calculation: 0 -- Do not include radiation

! DOF dos nós (exceto nó-extra): 1-TTOP

! Superfície para CONVECÇÃO TEMP 
KEYOPT ,6,3,1

KEYOPT ,6,4,1

KEYOPT ,6,5,1

KEYOPT ,6,6,0

KEYOPT ,6,7,0

KEYOPT ,6,8,5

! Heat flux and convection loads: 5 -- Evaluate hf at differential temperature, |TS-TB|

KEYOPT ,6,9,0

! Radiation form factor calculation: 0 -- Do not include radiation

KEYOPT ,6,11,0

! DOF dos nós (exceto nó-extra): 0-TEMP

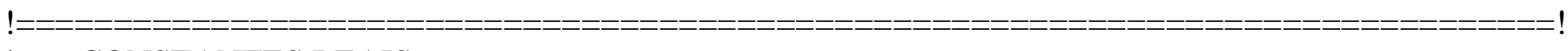

!---> CONSTANTES REAIS

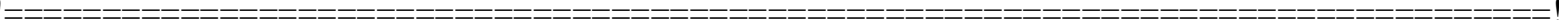

$\mathrm{R}, 1$,

! SHELL para análise térmica (SHELL131)

!--- PARA SUPERFÍCIES DE GANHO DE CALOR:

! R ,nset,fatordeforma,stefan-boltzmann W/(cm2.K4)

R,2,1,5.67E-12 ! Superfície para RADIAÇÃO - DOF=TTOP/TBOT

RMORE ,0.005,,, "Espessura" do surf - só para melhorar visualização.

R,3, $\quad$ ! Superfície para CONVECÇÃO - DOF=TTOP/TBOT

RMORE ,0.005,,, "Espessura" do surf - só para melhorar visualização.

! A ESPESSURA (0.005) DO ELEMENTO SURF É UTILIZADA PARA O CÁLCULO DA MASSA,

! DO VOLUME E DA GERAÇÃO DE CALOR, COMO NENHUM DESSES EFEITOS É

! NECESSÁRIO NESTE MODELO, O VALOR É UTILIZADO INFERIOR A UNIDADE APENAS

! PARA EFEITO DE VISUALIZAÇÃO (/ESHAPE).

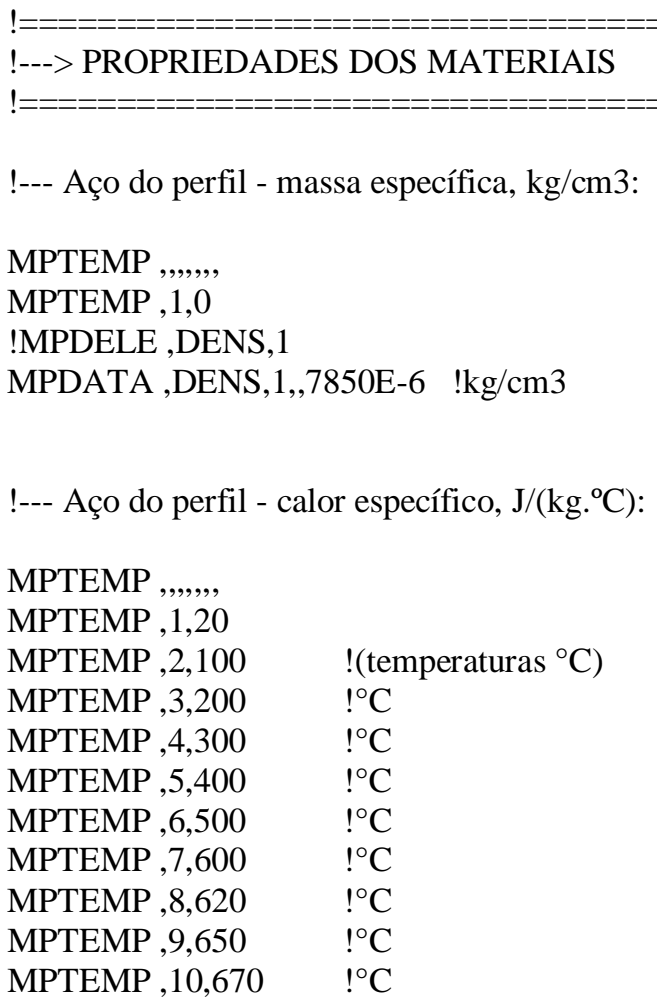




\begin{tabular}{|c|c|}
\hline РТЕMP ,11,700 & $!^{0^{\circ}}$ \\
\hline МРТЕМР ,12,710 & \\
\hline МРТЕМР ,13,720 & \\
\hline МРТЕМР ,14,730 & \\
\hline МРТЕМР ,15,731 & \\
\hline МРТЕМР ,16,732 & \\
\hline МРТЕМР ,17,733 & \\
\hline МРТЕМР ,18,734 & \\
\hline МРТЕМР ,19,735 & \\
\hline MPTEMP ,20,736 & \\
\hline MPTEMP ,21,737 & \\
\hline МРТЕМР ,22,738 & \\
\hline МРТЕМР ,23,739 & \\
\hline MPTEMP ,24,740 & \\
\hline MPTEMP ,25,741 & \\
\hline MPTEMP ,26,742 & \\
\hline MPTEMP ,27,743 & \\
\hline MPTEMP ,28,744 & \\
\hline MPTEMP ,29,745 & \\
\hline MPTEMP ,30,746 & \\
\hline MPTEMP ,31,747 & \\
\hline MPTEMP ,32,748 & \\
\hline МРТЕМР ,33,749 & \\
\hline MPTEMP ,34,750 & \\
\hline MPTEMP ,35,751 & \\
\hline MPTEMP ,36,752 & \\
\hline MPTEMP ,37,753 & \\
\hline MPTEMP ,38,754 & \\
\hline MPTEMP ,39,755 & \\
\hline MPTEMP ,40,758 & \\
\hline MPTEMP ,41,760 & \\
\hline MPTEMP ,42,765 & \\
\hline MPTEMP ,43,770 & \\
\hline MPTEMP ,44,775 & \\
\hline MPTEMP ,45,780 & \\
\hline MPTEMP ,46,785 & \\
\hline MPTEMP ,47,790 & \\
\hline MPTEMP ,48,795 & \\
\hline MPTEMP ,49,800 & \\
\hline MPTEMP ,50,810 & \\
\hline MPTEMP ,51,820 & \\
\hline MPTEMP ,52,830 & \\
\hline МРTEMP ,53,840 & \\
\hline MPTEMP ,54,850 & \\
\hline MPTEMP ,55,860 & \\
\hline MPTEMP ,56,880 & \\
\hline MPTEMP ,57,900 & \\
\hline MPTEMP ,58,1000 & \\
\hline MPTEMP ,59,1100 & \\
\hline MPTEMP ,60,1200 & \\
\hline
\end{tabular}

!MPDELE ,C,1

MPDATA ,C, $1,, 439.80 \quad ! 20^{\circ} \mathrm{C}$

MPDATA ,C, $1,487.62 \quad ! 100^{\circ} \mathrm{C}$

MPDATA ,C, $1,, 529.76 \quad ! 200^{\circ} \mathrm{C}$

MPDATA ,C, $1,, 564.74 \quad ! 300^{\circ} \mathrm{C}$

MPDATA ,C, $1,, 605.88 \quad ! 400^{\circ} \mathrm{C}$

MPDATA ,C, $1,, 666.5 \quad ! 500^{\circ} \mathrm{C}$

MPDATA ,C, $1,, 760.22 \quad ! 600^{\circ} \mathrm{C}$

MPDATA ,C, $1,, 776.19 \quad ! 620^{\circ} \mathrm{C}$ 


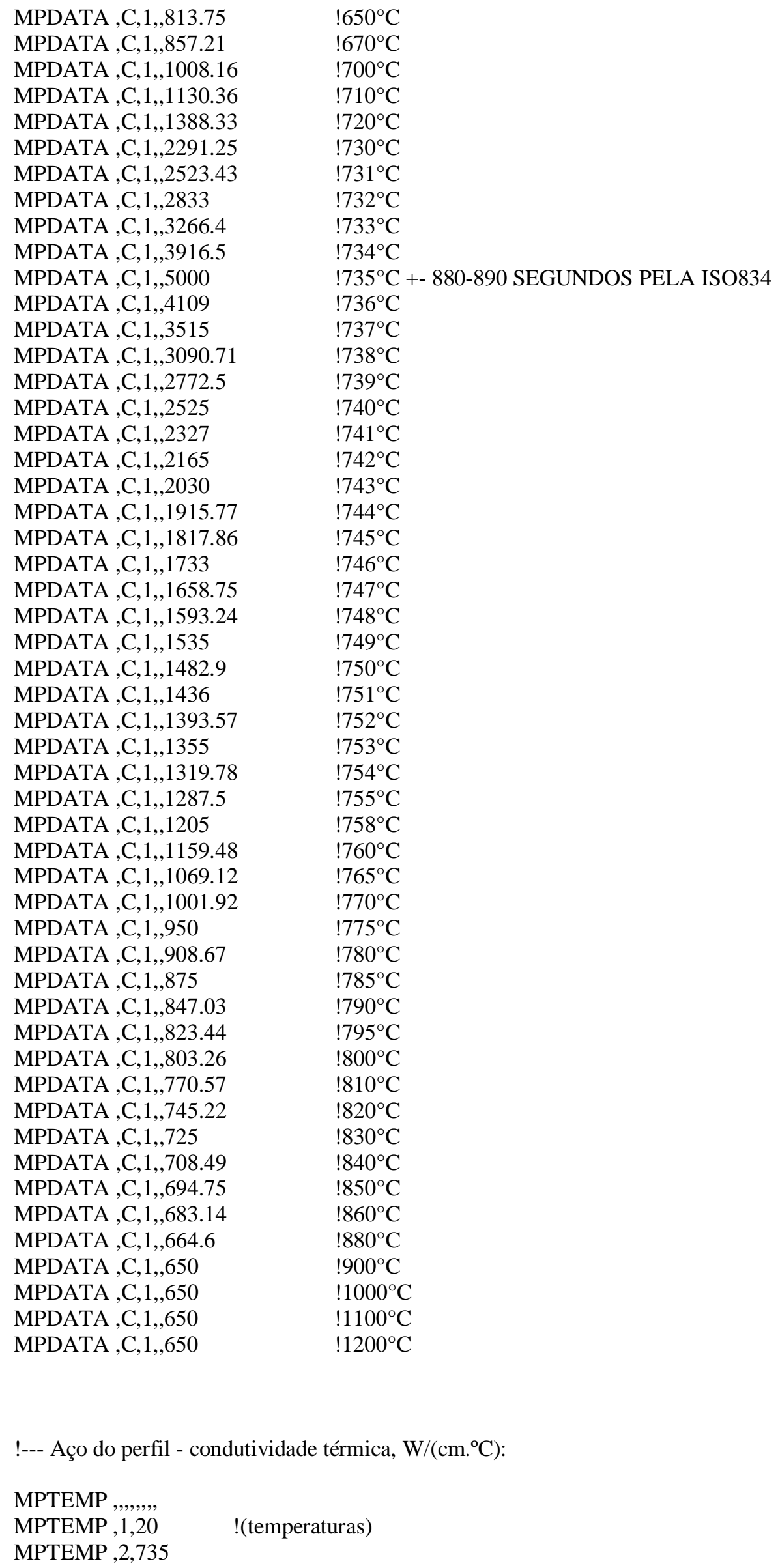


MPTEMP ,3,800

MPTEMP ,4,1200

!MPDELE ,KXX,1

MPDATA ,KXX,1,53.334E-2

! Condutividade térmica, $\mathrm{W} /\left(\mathrm{cm} .{ }^{\circ} \mathrm{C}\right)$

MPDATA ,KXX,1,,29.5245E-2

!20 ${ }^{\circ} \mathrm{C} \quad$ !reta decrescente

!735 ${ }^{\circ} \mathrm{C}$ !reta decrescente

!800 ${ }^{\circ} \mathrm{C}$ !constante

MPDATA ,KXX,1,,27.3E-2

MPDATA ,KXX,1,27.3E-2

!1200 ${ }^{\circ} \mathrm{C}$ !constante

!--- Filme - superfície convecção perfil:

MPTEMP,,,,,,,

MPTEMP, 1,0

MPDATA,HF,4,

!--- Aço do perfil - Emissividade:

MP,EMISS,3,emissividade ! ! Emissividade resultante - superfície radiação perfil.

TOFFST,273.15 ! Correção unidade temperatura ${ }^{\circ} \mathrm{C} \mathrm{-->} \mathrm{K}$

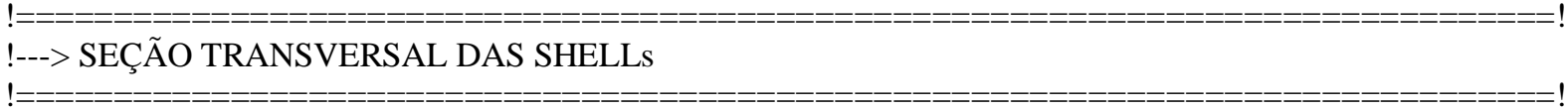

!--- Chapas do perfil:

SECTYPE,1,SHELL, ,Chperf

*DO,k,1,ncamadas, 1

SECDATA,t/ncamadas, $1,0.0,3$

! Espessura, material, orientação, pontos de integração.

*ENDDO

SECOFFSET,MID

!================================
!--> GERANDO A GEOMETRIA DO PERFIL

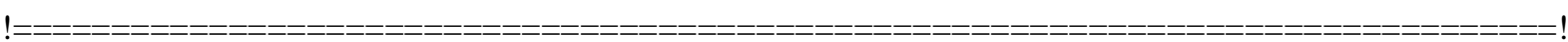

$\mathrm{K}, 1, \mathrm{dx}+\mathrm{dep} / 2+\mathrm{t} / 2, \mathrm{dy}+\mathrm{bm}, 0 \quad$ ! Gera pontos chaves da seção do perfil 1.

$\mathrm{K}, 2, \mathrm{dx}+\mathrm{dep} / 2+\mathrm{t} / 2, \mathrm{dy}+\mathrm{Ygm}, 0$

$\mathrm{K}, 3, \mathrm{dx}+\mathrm{dep} / 2+\mathrm{t} / 2, \mathrm{dy}, 0$

$\mathrm{K}, 4, \mathrm{dx}+\mathrm{dep} / 2+\mathrm{t} / 2+\mathrm{bm}, \mathrm{dy}, 0$

$\mathrm{L}, 1,2$

$\mathrm{L}, 2,3$

$\mathrm{L}, 3,4$

LFILLT,2,3,rm, ,

! Faz o arredondamento do canto do perfil 1.

$\mathrm{K}, 7, \mathrm{dx}-(\mathrm{dep} / 2+\mathrm{t} / 2+\mathrm{bm}), \mathrm{dy}, 0$

! Gera pontos chaves da seção do perfil 2.

$\mathrm{K}, 8, \mathrm{dx}-(\mathrm{dep} / 2+\mathrm{t} / 2), \mathrm{dy}, 0$

$\mathrm{K}, 9, \mathrm{dx}-(\mathrm{dep} / 2+\mathrm{t} / 2), \mathrm{dy}+\mathrm{Ygm}, 0$

$\mathrm{K}, 10, \mathrm{dx}-(\mathrm{dep} / 2+\mathrm{t} / 2), \mathrm{dy}+\mathrm{bm}, 0$

L,7,8 ! Gera linhas que compõem o perfil 2. 
$\mathrm{L}, 8,9$

$\mathrm{L}, 9,10$

LFILLT,5,6,rm, ,

! Faz o arredondamento do canto do perfil 2.

$\mathrm{K}, 13, \mathrm{dx}+\mathrm{dep} / 2+\mathrm{t} / 2, \mathrm{dy}+\mathrm{bm}$,comp $\quad$ ! Cria um ponto chave auxiliar para o perfil 1.

$\mathrm{L}, 1,13$

! Cria uma linha auxiliar.

ADRAG,1,2,3,4, , ,9 ! ! Gera áreas arrastando um conjunto de linhas ao longo de um caminho.

LDELE,9

! Deleta a linha que foi duplicada.

KDELE,13

! Deleta o ponto chave auxiliar que foi criado.

NUMCMP,ALL

! Renumera itens reutilizando os números já deletados ou não utilizados.

$\mathrm{K}, 18$,dx-(dep/2+t/2+bm),dy,comp $\mathrm{L}, 7,18$

! Cria um ponto chave auxiliar para o perfil 2

ADRAG,5,6,7,8, , , 18

! Cria uma linha auxiliar.

LDELE,18

! Gera áreas arrastando um conjunto de linhas ao longo de um caminho.

KDELE,18

! Deleta a linha que foi duplicada.

NUMCMP,ALL

! Deleta o ponto chave auxiliar que foi criado.

! Renumera itens reutilizando os números já deletados ou não utilizados.

$\mathrm{L}, 2,9$

$\mathrm{L}, 14,21$

! Cria uma linha que passa pelo centróide em 0.

! Cria uma linha que passa pelo centróide em comp.

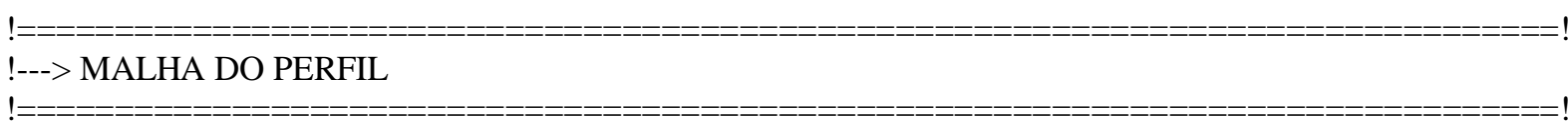

!--- COMPRIMENTO DO PERFIL:

Dpres $=$ comp $/($ Npres +1$)$

! Distância entre centros de presilhas.

LocWP=Dpres

Nloop1=Npres

! Variável de loop.

*DOWHILE,Nloop1

ASEL,S,LOC,Z,0.001,comp-0.001 ! Divisão das linhas para alocar as presilhas.

WPAVE,0,0,LocWP-Lpres/2

ASBW,ALL

WPAVE,0,0,LocWP+Lpres/2

ASBW,ALL

LSEL,S,LOC,Z,LocWP-Lpres/2+0.001,LocWP+Lpres/2-0.001

! Malha nas regiões das presilhas.

LESIZE,ALL, , ,Lpres, , , , ,1

LocWP=LocWP+Dpres

Nloop1=Nloop1-1

*ENDDO

WPAVE,0,0,0

PtLoc $=$ Dpres

Nloop2=Npres +1

! Variável de loop.

*DOWHILE,Nloop2

! Malha fora das regiões das presilhas.

*IF,(Nloop2),EQ,(Npres+1),THEN

LSEL,S,LOC,Z,PtLoc-Lpres/2-0.001,PtLoc-Dpres+0.001

LESIZE,ALL, , ,Dpres-Lpres/2, , , , ,1 


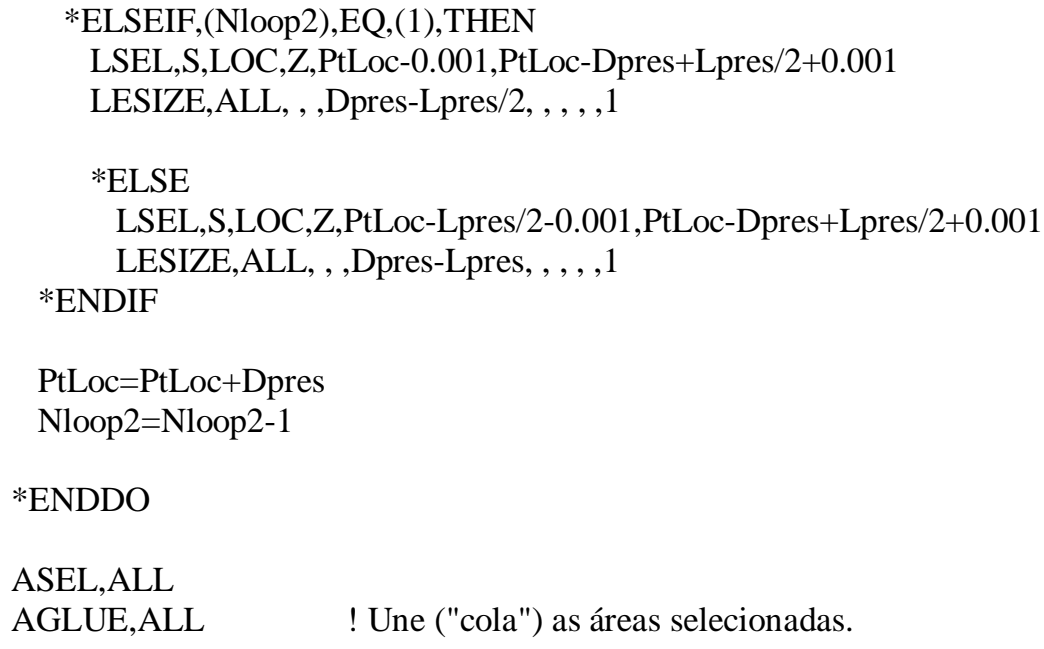

ASEL,ALL

AGLUE,ALL ! ! Une ("cola") as áreas selecionadas.

\section{!--- ABAS COM PRESILHAS (CHAPAS ESPAÇADORAS):}

!--- Primeira parte da aba:

LSEL,S,LOC,Z,-0.001,comp+0.001

LSEL,R,LOC,Y,dy+Ygm+0.001,dy+bm+0.001 centróide (Ygm).

LESIZE,ALL, , ,nd1m, , , , ,1

ASEL,S,LOC,Y,dy+Ygm+0.001,dy+bm+0.001
! Seleciona todas as linhas do perfil.

! Seleciona as linhas das seções acima da coordenada Y do

! Divide as linhas da primeira parte da aba.
AATT,1,1,1,0,1

MSHKEY,1

MSHAPE,0,2D

AMESH,ALL

ASEL,ALL

!--- Segunda parte da aba:

LSEL,S,LOC,Z,-0.001,comp+0.001 LSEL,R,LOC,Y,dy+rm,dy+Ygm-0.001 LESIZE,ALL, , ,nd2m, , , , ,1

ASEL,S,LOC,Y,dy+rm,dy+Ygm-0.001

AATT,1,1,1,0,1

MSHKEY,1

MSHAPE,0,2D

AMESH,ALL

ASEL,ALL

!--- Parte curva:

LSEL,S,LOC,Z,-0.001,comp+0.001 LSEL,R,LOC,Y,dy+0.001,dy+rm-0.001 LESIZE,ALL, , ,ndc, , , , ,1

ASEL,R,LOC,Y,dy+0.001,dy+rm-0.001

\author{
! AATT,MAT,REAL,TYPE,ESYS,SECN \\ ! Tipo da malha: Mapeada \\ ! Malha realizada com elemento 2D \\ ! Gerando a malha \\ ! Seleciona todas as áreas
}

! Seleciona todas as linhas do perfil.

! Seleciona as linhas das seções entre o fim da dobra e Ygm.

! Divide as linhas da segunda parte da aba. 
MSHKEY,1

MSHAPE,0,2D

AMESH,ALL

ASEL,ALL
! Tipo da malha: Mapeada

! Malha realizada com elemento 2D

! Gerando a malha

! Seleciona todas as áreas

!--- ABAS LIVRES (SEM PRESILHAS):

LSEL,S,LOC,Z,-0.001,comp+0.001 ! Seleciona todas as linhas do perfil.

LSEL,R,LOC,X,dx+dep/2+t/2+rm+0.001,dx+dep/2+t/2+bm-0.001 ! Seleciona a linha da aba livre do perfil 1. LESIZE,ALL, , ,nd3m, , , , ,1 ! Divide a linha da aba livre do perfil 1.

ASEL,S,LOC,X,dx+dep/2+t/2+rm+0.001,dx+dep/2+t/2+bm-0.001

AATT,1,1,1,0,1

MSHKEY,1

MSHAPE,0,2D

AMESH,ALL

ASEL,ALL
! AATT,MAT,REAL,TYPE,ESYS,SECN

! Tipo da malha: Mapeada

! Malha realizada com elemento 2D

! Gerando a malha

! Seleciona todas as áreas

LSEL,S,LOC,Z,-0.001,comp+0.001

! Seleciona todas as linhas do perfil.

LSEL,R,LOC,X,dx-(dep/2+t/2+rm-0.001),dx-(dep/2+t/2+bm+0.001) ! Seleciona a linha da aba livre do perfil 2.

LESIZE,ALL, , , nd3m, , , , ,1

! Divide a linha da aba livre do perfil 2.

ASEL,S,LOC,X,dx-(dep/2+t/2+rm-0.001),dx-(dep/2+t/2+bm+0.001)

AATT,1,1,1,0,1

MSHKEY,1

MSHAPE,0,2D

AMESH,ALL

ASEL,ALL
! AATT,MAT,REAL,TYPE,ESYS,SECN

! Tipo da malha: Mapeada

! Malha realizada com elemento 2D

! Gerando a malha

! Seleciona todas as áreas

\section{!---> CRIANDO AS PRESILHAS (CHAPAS SEPARADORAS)}

elm1 $=(\mathrm{bf}-\mathrm{Yg}) / \mathrm{nd} 1 \mathrm{~m}$

Dpres=comp/(Npres+1)

LocPres $=$ Dpres

Nloop3=Npres
! Tamanho dos elementos do primeiro trecho da aba com presilhas.

! Distância entre centros de presilhas.

! Variável de localização das presilhas.

! Variável de loop.

*DOWHILE,Nloop3

KSEL,ALL

*GET,Nkp,KP,0,COUNT, , ! Obtém o número de Keypoints.

$\mathrm{K}, 0, \mathrm{dx}+\mathrm{dep} / 2, \mathrm{dy}+$ Ygm,LocPres-Lpres/2 ! Criando os pontos da presilha.

$\mathrm{K}, 0$,dx-dep/2,dy+Ygm,LocPres-Lpres/2 ! Criando os pontos da presilha.

$\mathrm{K}, 0, \mathrm{dx}+\mathrm{dep} / 2, \mathrm{dy}+\mathrm{Ygm}+2 * \mathrm{elm} 1$,LocPres-Lpres/2 ! Criando os pontos da presilha.

K,0,dx-dep/2,dy+Ygm+2*elm1,LocPres-Lpres/2 ! Criando os pontos da presilha.

$\mathrm{A},(\mathrm{Nkp}+1),(\mathrm{Nkp}+2),(\mathrm{Nkp}+4),(\mathrm{Nkp}+3)$

ASEL,S,LOC,X,dx-dep/2-0.001,dx+dep/2+0.001

ASEL,R,LOC,Z,LocPres-Lpres/2-0.001,LocPres-Lpres/2+0.001

VEXT,ALL, , ,0,0,Lpres,1,1,1 ! Cria a geometria da presilha (volume).

LSEL,S,LOC,Z,LocPres-Lpres/2+0.001,LocPres+Lpres/2-0.001 ! Divisão das linhas longitudinais da presilha. 
LSEL,R,LOC,X,dx-dep/2-0.001,dx+dep/2+0.001

LESIZE,ALL, , ,Lpres, , , , ,1

LocPres $=$ LocPres + Dpres

Nloop3=Nloop3-1

*ENDDO

ASEL,ALL

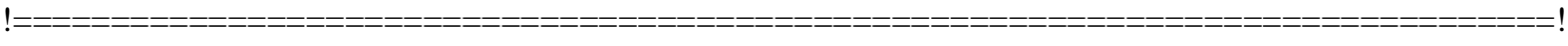

!---> MALHA DAS PRESILHAS (CHAPAS SEPARADORAS)

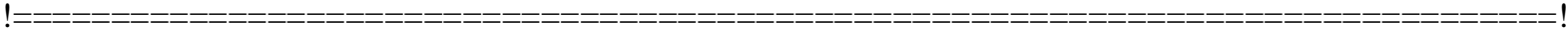

!--- Gerando a malha das presilhas:

LSEL,S,LOC,X,dx-dep/2+0.001,dx+dep/2-0.001

LSEL,R,LOC,Z,0.001,comp-0.001

! Seleciona as linhas da espessura das presilhas.

LESIZE,ALL, , , 1, , , , , 1

LSEL,S,LOC,X,dx-dep/2-0.001,dx+dep/2+0.001

LSEL,R,LOC,Z,0.001,comp-0.001

LSEL,R,LOC,Y,dy+Ygm+0.001,dy+Ygm+2*elm1-0.001

! Seleciona as linhas das presilhas.

LESIZE,ALL, , ,2, , , , ,1

! Seleciona as linhas da altura das presilhas.

VSEL,S,LOC,Z,0.001,comp-0.001

VSEL,R,LOC,X,dx-dep/2+0.001,dx+dep/2-0.001

! Seleciona todas as presilhas.

VATT, 1, ,2,0

! VATT,MAT,REAL,TYPE,ESYS

MSHKEY,1

! Tipo da malha: Mapeada

MSHAPE,0,3D

! Malha realizada com elemento 3D

VMESH,ALL

! Gerando a malha

VSEL,ALL

/NUMBER,1

/PNUM,MAT,1

! Distingue, por cores, os diferentes elementos finitos

/REPLOT

! de acordo com seus respectivos materiais.

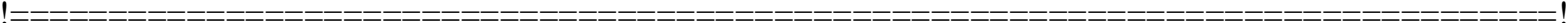

!---> APLICAÇÃO DO CARREGAMENTO DE RADIAÇÃO E CONVECÇÃO (COM SURF152) - GANHO

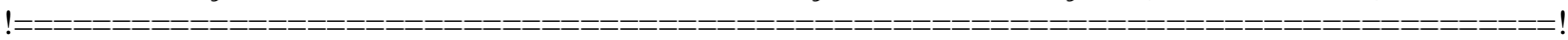

!--- DEFINE UM NÓ (NOEXTRA - PARA GANHO DE CALOR):

N,NOEXTRA,dx+dep/2+bf/2,dy+bf/2,comp/2 ! Nó de controle - convecção e radiação.

NPLOT

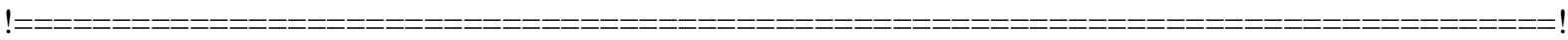

!---> SUPERFÍCIE DE GANHO DE CALOR

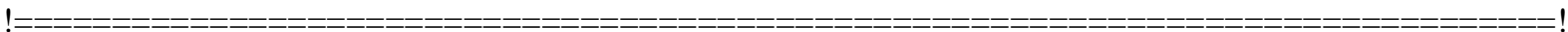

!--- SELEÇÃO DAS PARTES QUE RECEBERÃO AÇÃO TÉRMICA:

ASEL,S,SEC, ,1

! 1 - chapas do perfil.

APLOT 
NSLA,S,1

NPLOT

!--- RADIAÇÃO com DOF=TTOP:

TYPE,3

! SURF152 RADIAÇÃO TTOP

REAL,2

! REAL CONSTANTE COM FATOR DE FORMA=1 E STEFAN-

BOLTZMANN=5.67E-8

MAT,3

! Emissividade

ESURF , NOEXTRA

!--- CONVECÇÃO com DOF=TTOP:

TYPE, 5

! SURF152 CONVECÇÃO TTOP

REAL,3

! Filme de CONVECÇÃO HF,,

ESURF , NOEXTRA

!--- RADIAÇÃO com DOF=TEMP:

TYPE, 4

! SURF152 RADIAÇÃO TEMP

REAL,2

! REAL CONSTANTE COM FATOR DE FORMA=1 E STEFAN-

BOLTZMANN=5.67E-8

MAT,3

! Emissividade

ESURF , NOEXTRA

!--- CONVECÇÃO com DOF=TEMP:

TYPE,6

REAL,3

! SURF152 CONVECÇÃO TEMP

MAT,4

! Filme de CONVECÇÃO HF,,

ESURF , NOEXTRA

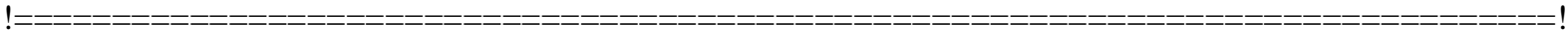

!---> APLICAÇÃO DE FILME DE CONVECÇÃO DO GANHO

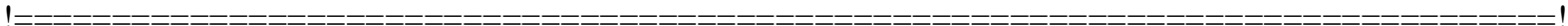

ALLSEL,ALL

EPLOT

ESEL,S,REAL, ,3

! REAL 3 = convecção

SFE,ALL,1,CONV,0,25E-4, ! W/cm2 ${ }^{\circ} \mathrm{C}$

ALLSEL,ALL

EPLOT

!---> CONSTRÓI A TABELA COM AS TEMPERATURAS DO INCÊNDIO ISO834-1:1999 


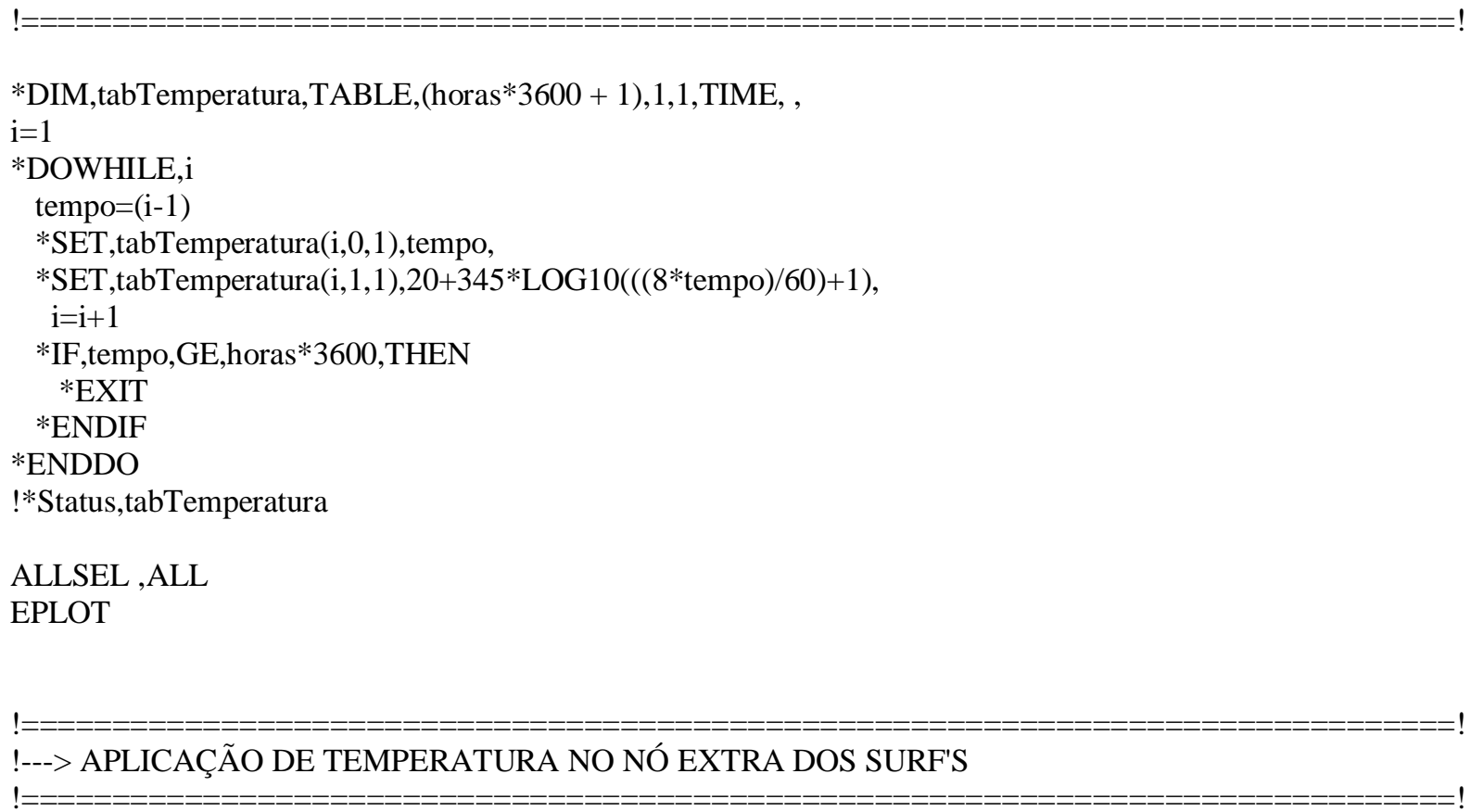

D,NOEXTRA,TEMP,\%tabTemperatura\%

ALLSEL ,ALL

EPLOT

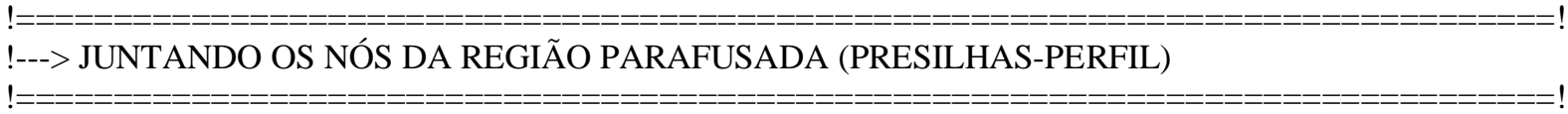

elm1=(bf-Yg)/nd1m

Dpres $=$ comp $/($ Npres +1$)$

LocPres $=$ Dpres

Nloop4=Npres
! Tamanho dos elementos do primeiro trecho da aba com presilhas.

! Distância entre centros de presilhas.

! Variável de localização das presilhas.

! Variável de loop.

*DOWHILE,Nloop4

NSEL,S,LOC,Z,LocPres-1-0.001,LocPres+1+0.001

NSEL,R,LOC,Y,dy+Ygm-0.001,dy+Ygm+2*elm1+0.001

NSEL,R,LOC,X,dx-0.001,dx-dep/2-t/2-0.001

NUMMRG,NODE,t/2+0.001, , ,LOW

NSEL,S,LOC,Z,LocPres-1-0.001,LocPres+1+0.001

NSEL,R,LOC,Y,dy+Ygm-0.001,dy+Ygm+2*elm1+0.001 NSEL,R,LOC,X, dx+0.001,dx+dep/2+t/2+0.001

NUMMRG,NODE,t/2+0.001, , ,LOW

LocPres $=$ LocPres + Dpres

Nloop4=Nloop4-1

*ENDDO
! Presilha parafusada aos perfis - 2cmx2cm, aprox. ! Presilha parafusada aos perfis - $2 \mathrm{~cm} \times 2 \mathrm{~cm}$, aprox. ! Seleciona os nós do lado esquerdo da presilha. ! Junta os nós muito próximos.

! Presilha parafusada aos perfis - 2cmx2cm, aprox. ! Presilha parafusada aos perfis - 2cmx2cm, aprox. ! Seleciona os nós do lado direito da presilha. ! Junta os nós muito próximos. 
!--- ESPECIFICAÇÃO DA TEMPERATURA INICIAL UNIFORME:

ALLSEL,ALL

TUNIF,20 ! Determina uma temperatura uniforme para todos os nós.

TREF,20

! Temperatura de referência para expansão térmica.

!IC,ALL,TEMP,20

! Definição das condições iniciais - temperatura de $20^{\circ} \mathrm{C}$.

!--- OPÇÕES DE PROCESSAMENTO:

ANTYPE,4 ! Definição do tipo de análise - Transiente.

KBC,1 ! Specifies stepped or ramped loading within a load step.

AUTOTS,1 ! Automatic Time Stepping.

TIME,horas*3600 ! Em segundos.

DELTIM,10,.001,60, ! Inicial,mínimo,máximo.

OUTRES,ERASE

OUTRES,NSOL,ALL

SAVE

FINISH

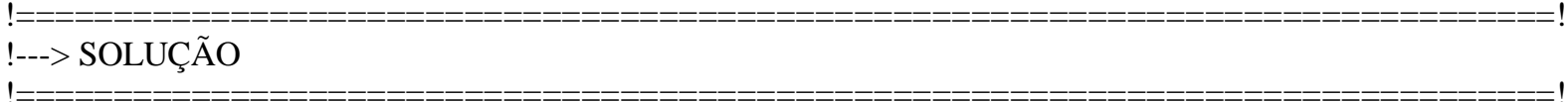

/SOL

ISTATUS,SOLU

SOLVE

FINISH

SAVE

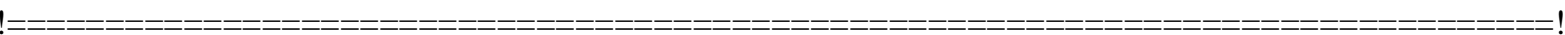

\section{2) Script 2:}

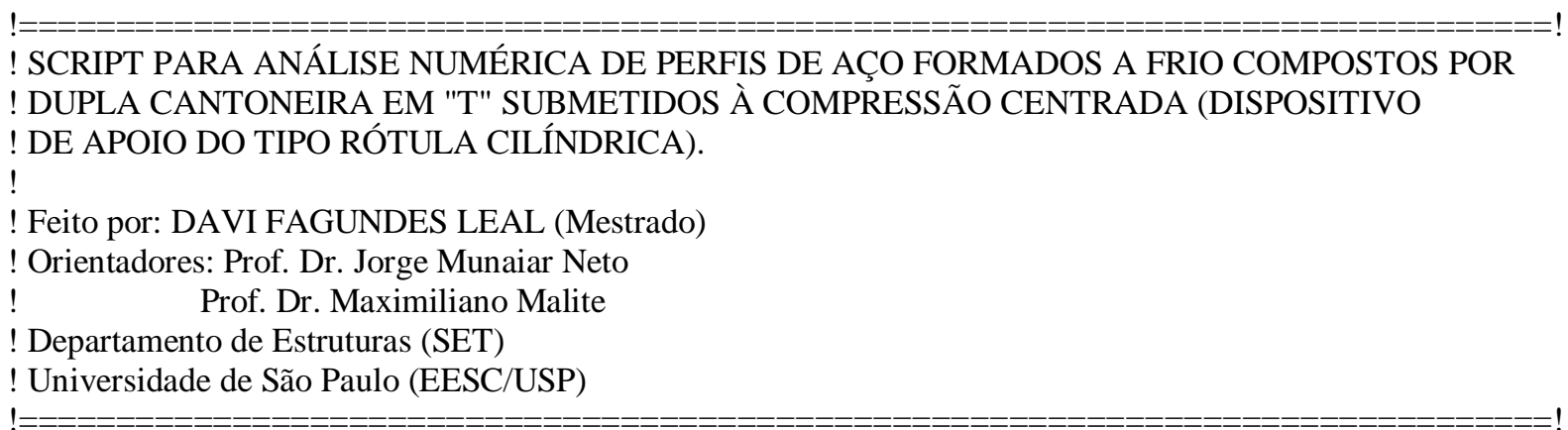

! ESTE SCRIPT FOI DESENVOLVIDO PARA SER UTILIZADO NO ANSYS 11.

! VERSÕES ANTERIORES NÃO POSSUEM CERTAS PARTICULARIDADES NECESSÁRIAS PARA

! O MODELO.

FINISH

/CLEAR 


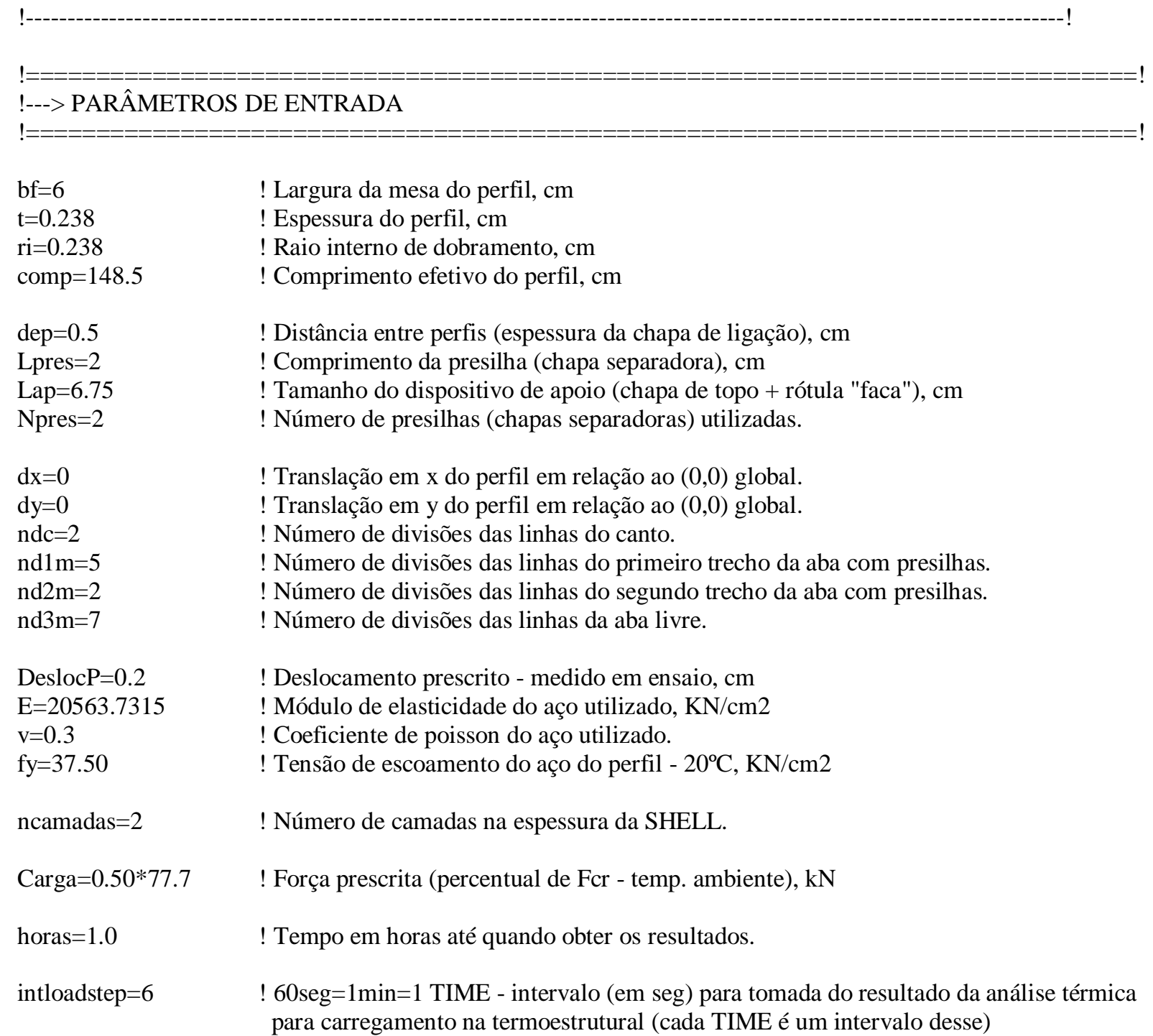

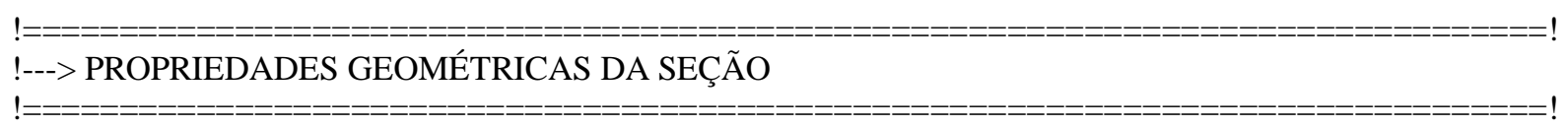

\section{! NBR 6355:}

$\mathrm{rm}=\mathrm{ri}+0.5 * \mathrm{t}$

$\mathrm{b}=\mathrm{bf}-(\mathrm{rm}+0.5 * \mathrm{t})$

$\mathrm{bm}=\mathrm{bf}-\mathrm{t} / 2$

$\mathrm{u} 1=1.571 * \mathrm{rm}$

$\mathrm{As}=\mathrm{t} *(2 * \mathrm{~b}+\mathrm{u} 1)$

! Raio de dobramento referente a linha média da seção, cm

! Largura da parte plana da mesa do perfil, cm

! Largura da mesa referente à linha média da seção, cm

! Desenvolvimento da parte curva da seção (dobra em 90), cm

! Área da seção tranversal de uma cantoneira simples, $\mathrm{cm} 2$

$\mathrm{Yg}=(\mathrm{t} / \mathrm{As}) *(\mathrm{~b} *(0.5 * \mathrm{~b}+\mathrm{rm})+\mathrm{u} 1 *(0.363 * \mathrm{rm}))+0.5 * \mathrm{t} \quad$ ! Distância do CG à face externa do perfil, na direção y Ygm $=$ Yg-t/2
! Distância do centróide à linha de esqueleto do perfil, eixo-y

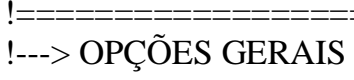

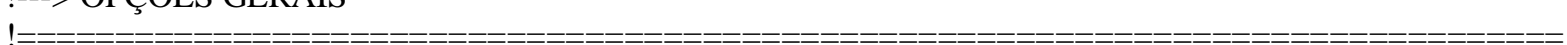

*GET,NProcessadores,ACTIVE, ,NPROC ! Obtém o número de processadores disponíveis no computador. /CONFIG,NPROC,NProcessadores ! Indica o número de processadores a serem usados. /CONFIG, NRES ,5000

! Número máximo de resultados (sets) permitidos (Default=1000).
} 
/VIEW,1,1,1,1

/ANGLE,1

/ESHAPE, 1.0

/UIS,MSGPOP,3

/PBC,ALL, , 1

/REP,FAST

/PREP7

/NUMBER,1

/PNUM,MAT,1

/REPLOT
! Vista da tela 1 com diretriz que passa pelo ponto $(1,1,1)$.

! Visualização da geometria do elemento.ex: espessura de elementos de casca.

! Mostra somente as mensagens de erros.

! Plot Boundary Conditions=1, mostra somente o símbolo da restrição.

! Redesenha o modelo.

!====================
!---> TIPO DE ELEMENTO

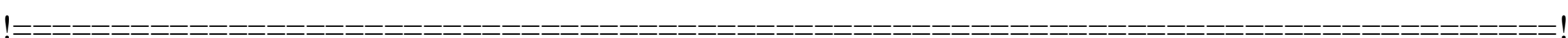

ET,1,SHELL181 ! Elemento da casca do perfil

KEYOPT,1,1,0 ! Bending and membrane stiffness (default)

!KEYOPT,1,3,0

KEYOPT,1,3,2

! Reduced integration with hourglass control (default) - FLEXÃO OUT-OF-PLANE

KEYOPT,1,8,0

! Full integration with incompatible modes - FLEXÃO NO PLANO

!KEYOPT,1,8,1

! Store data for bottom of bottom layer and top of top layer (multi-layer elements)

! Store data for TOP and BOTTOM, for all layers (multi-layer elements) - VOLUME OF DATA MAY BE EXCESSIVE.

!KEYOPT,1,8,2 ! Store data for TOP, BOTTOM, and MID for all layers; applies to single- and multilayer elements

KEYOPT,1,9,0 ! No user subroutine to provide initial thickness (default)

KEYOPT,1,10,0 ! No user subroutine to provide initial stress (default)

ET,2,SOLID45 ! Elemento Finito das presilhas (chapas espaçadoras).

KEYOPT,2,1,0 ! Suppress extra displacement shapes

KEYOPT,2,2,0 ! Uniform reduced integration with hourglass control

ET,3,SOLID45 ! Elemento Finito dos dispositivos de apoio.

KEYOPT,3,1,1 ! Suppress extra displacement shapes

KEYOPT,3,2,1 ! Uniform reduced integration with hourglass control

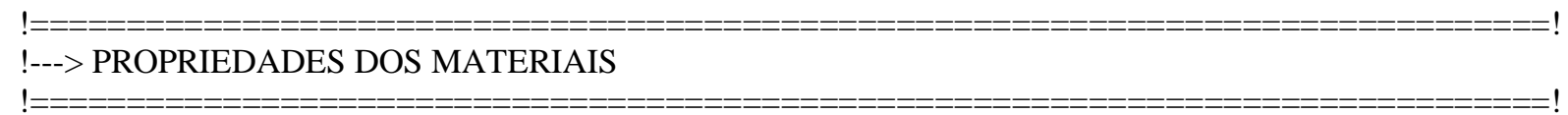

! PERFIL DE AÇO

!MPTEMP ,,,,,,

MPTEMP ,1,20

MPTEMP ,2,100

MPTEMP ,3,200

MPTEMP , 4,300

MPTEMP ,5,400

MPTEMP ,6,500

MPTEMP ,7,600

MPTEMP ,8,700

MPTEMP ,9,800

MPTEMP ,10,900

! Aço do perfil - propriedades elásticas 


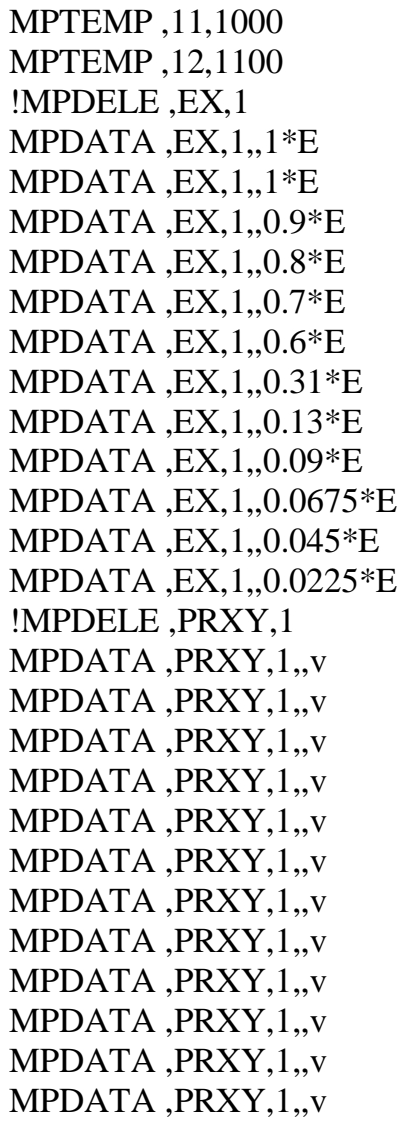

TBDE ,MISO,1,,

TB ,MISO,1,12,8,

TBTEMP ,20

fy_theta $=1.0 *$ fy

ME_theta $=1.0 * \mathrm{E}$

fp_theta $=0.85 *$ fy

epsilo_fp $=$ fp_theta/ME_theta

epsilo_fy $=0.02$

epsilo_l $=0.15$

epsilo_u $=0.2$

cc $=($ fy_theta-fp_theta $) * * 2 /\left((\right.$ epsilo_fy-epsilo_fp $\left.) * M E \_t h e t a-2 *\left(f y \_t h e t a-f p \_t h e t a\right)\right)$

aa $=(($ epsilo_fy-epsilo_fp $) *($ epsilo_fy-epsilo_fp+cc/ME_theta $) * * 0.5$

bb $=\left(c c *\left(e p s i l o \_f y-e p s i l o \_f p\right) * M E \_t h e t a+c c * * 2\right) * * 0.5$

TBPT ,fp_theta/ME_theta,fp_theta

TBPT ,0.0015,fp_theta-cc+(bb/aa)*(aa**2-(epsilo_fy-0.0013)**2)**0.5

TBPT „0.00175,fp_theta-cc+(bb/aa)*(aa**2-(epsilo_fy-0.0015)**2)**0.5

TBPT „0.002,fp_theta-cc+(bb/aa)*(aa**2-(epsilo_fy-0.0017)**2)**0.5

TBPT ,0.0025,fy_theta

TBPT ,epsilo_fy,fy_theta

TBPT ,epsilo_l,fy_theta+(0.15-.02)*0.001

TBPT ,epsilo_u,0

TBTEMP , 100

! Define a temperatura para os dados da tabela.

fy_theta $=1.0 * \mathrm{fy}$

ME_theta $=1.0 * \mathrm{E}$

fp_theta $=0.85 *$ fy

epsilo_fp $=\mathrm{fp}$ _theta/ME_theta

epsilo_fy $=0.02$

epsilo_l $=0.15$ 
epsilo_u $=0.2$

cc $=\left({ }_{f y}\right.$ theta-fp_theta) $) * 2 /\left((\right.$ epsilo_fy-epsilo_fp $\left.) * M E \_t h e t a-2 *\left(f y \_t h e t a-f p \_t h e t a\right)\right)$

aa $=\left((\right.$ epsilo_fy-epsilo_fp $) *($ epsilo_fy-epsilo_fp+cc/ME_theta) $){ }^{* *} 0.5$

$\mathrm{bb}=\left(\mathrm{cc} *(\right.$ epsilo_fy-epsilo_fp $\left.) * M E \_t h e t a+c c^{* *} 2\right) * * 0.5$

TBPT ,fp_theta/ME_theta,fp_theta

TBPT „0.0015,fp_theta-cc+(bb/aa)*(aa**2-(epsilo_fy-0.0013)**2)**0.5

TBPT ,0.00175,fp_theta-cc+(bb/aa)*(aa**2-(epsilo_fy-0.0015)**2)**0.5

TBPT „0.002,fp_theta-cc+(bb/aa)*(aa**2-(epsilo_fy-0.0017)**2)**0.5

TBPT „0.0025,fy_theta

TBPT ,epsilo_fy,fy_theta

TBPT ,,epsilo_l,fy_theta+(0.15-.02)*0.001

TBPT „epsilo_u,0

TBTEMP ,200

! Define a temperatura para os dados da tabela.

fy_theta $=1.0 *$ fy

ME_theta $=0.9 * E$

fp_theta $=0.807 * f y$

epsilo_fp $=\mathrm{fp} \_$theta/ME_theta

epsilo_fy $=0.02$

epsilo_l $=0.15$

epsilo_u $=0.2$

cc $=\left(\right.$ fy_theta-fp_theta) $* * 2 /\left((\right.$ epsilo_fy-epsilo_fp $\left.) * M E \_t h e t a-2 *\left(f y \_t h e t a-f p \_t h e t a\right)\right)$

aa $=(($ epsilo_fy-epsilo_fp $) *($ epsilo_fy-epsilo_fp+cc/ME_theta) $) * * 0.5$

bb $=(c c *($ epsilo_fy-epsilo_fp)*ME_theta+cc**2)**0.5

TBPT ,fp_theta/ME_theta,fp_theta

TBPT ,0.002,fp_theta-cc+(bb/aa)*(aa**2-(epsilo_fy-0.002)**2)**0.5

TBPT „,0.005,fp_theta-cc+(bb/aa)*(aa**2-(epsilo_fy-0.005)**2)**0.5

TBPT „,0.010,fp_theta-cc+(bb/aa)*(aa**2-(epsilo_fy-0.010)**2)**0.5

TBPT „,0.015,fp_theta-cc+(bb/aa)*(aa**2-(epsilo_fy-0.015)**2)**0.5

TBPT ,epsilo_fy,fy_theta

TBPT ,epsilo_l,fy_theta+(0.15-.02)*0.001

TBPT ,epsilo_u,0

TBTEMP ,300

! Define a temperatura para os dados da tabela.

fy_theta $=1.0 *$ fy

ME_theta $=0.8 * E$

fp_theta $=0.613 *$ fy

epsilo_fp $=$ fp_theta/ME_theta

epsilo_fy $=0.02$

epsilo_l $=0.15$

epsilo_u $=0.2$

cc $=($ fy_theta-fp_theta $) * * 2 /\left((\right.$ epsilo_fy-epsilo_fp $\left.) * M E \_t h e t a-2 *\left(f y \_t h e t a-f p \_t h e t a\right)\right)$

aa $=((\text { epsilo_fy-epsilo_fp }) *(\text { epsilo_fy-epsilo_fp+cc/ME_theta }))^{* *} 0.5$

$\mathrm{bb}=(\mathrm{cc} *($ epsilo_fy-epsilo_fp)*ME_theta+cc**2)**0.5

TBPT ,fp_theta/ME_theta,fp_theta

TBPT „0.002,fp_theta-cc+(bb/aa)*(aa**2-(epsilo_fy-0.002)**2)**0.5

TBPT ,0.005,fp_theta-cc+(bb/aa)*(aa**2-(epsilo_fy-0.005)**2)**0.5

TBPT „,0.010,fp_theta-cc+(bb/aa)*(aa**2-(epsilo_fy-0.010)**2)**0.5

TBPT ,0.015,fp_theta-cc+(bb/aa)*(aa**2-(epsilo_fy-0.015)**2)**0.5

TBPT ,epsilo_fy,fy_theta

TBPT ,epsilo_l,fy_theta+(0.15-.02)*0.001

TBPT ,epsilo_u,0

TBTEMP, 400

! Define a temperatura para os dados da tabela.

fy_theta $=1.0 *$ fy

ME_theta $=0.70 * \mathrm{E}$

fp_theta $=0.420 *$ fy

epsilo_fp $=\mathrm{fp} \_$theta/ME_theta

epsilo_fy $=0.02$

epsilo_l $=0.15$ 
epsilo_u $=0.2$

$\mathrm{CC}=\left(\mathrm{fy} \_\right.$theta-fp_theta $) * * 2 /\left((\right.$ epsilo_fy-epsilo_fp $) * \mathrm{ME} \_$theta- $2 *\left(\mathrm{fy} \_\right.$theta-fp_theta $\left.)\right)$

aa $=\left((\right.$ epsilo_fy-epsilo_fp $) *($ epsilo_fy-epsilo_fp + cc/ME_theta $){ }^{* *} 0.5$

$\mathrm{bb}=(\mathrm{cc} *($ epsilo_fy-epsilo_fp $) *$ ME_theta+cc**2$) * * 0.5$

TBPT ,fp_theta/ME_theta,fp_theta

TBPT ,0.002,fp_theta-cc+(bb/aa)*(aa**2-(epsilo_fy-0.002)**2)**0.5

TBPT ,0.005,fp_theta-cc+(bb/aa)*(aa**2-(epsilo_fy-0.005)**2)**0.5

TBPT , 0.010 ,fp_theta-cc+(bb/aa)*(aa**2-(epsilo_fy-0.010)**2)**0.5

TBPT ,0.015,fp_theta-cc+(bb/aa)*(aa**2-(epsilo_fy-0.015)**2) ${ }^{* *} 0.5$

TBPT ,epsilo_fy,fy_theta

TBPT ,epsilo_l,fy_theta+(0.15-.02)*0.001

TBPT „epsilo_u,0

TBTEMP ,500

! Define a temperatura para os dados da tabela.

fy_theta $=0.78 * \mathrm{fy}$

ME_theta $=0.60 * \mathrm{E}$

fp_theta $=0.360 * \mathrm{fy}$

epsilo_fp $=$ fp_theta/ME_theta

epsilo_fy $=0.02$

epsilo_l $=0.15$

epsilo_u $=0.2$

cC $=($ fy_theta-fp_theta $) * * 2 /\left((\right.$ epsilo_fy-epsilo_fp $\left.) * M E \_t h e t a-2 *\left(f y \_t h e t a-f p \_t h e t a\right)\right)$

aa $=\left((\text { epsilo_fy-epsilo_fp }) *\left(\text { epsilo_fy-epsilo_fp }+c c / M E \_t h e t a\right)\right)^{* *} 0.5$

$\mathrm{bb}=\left(\mathrm{cc} *(\right.$ epsilo_fy-epsilo_fp $) * M E_{-}$theta $\left.+\mathrm{cc} * * 2\right) * * 0.5$

TBPT ,fp_theta/ME_theta,fp_theta

TBPT „0.002,fp_theta-cc+(bb/aa)*(aa**2-(epsilo_fy-0.002)**2)**0.5

TBPT „0.005,fp_theta-cc+(bb/aa)*(aa**2-(epsilo_fy-0.005)**2)**0.5

TBPT ,0.010,fp_theta-cc+(bb/aa)*(aa**2-(epsilo_fy-0.010)**2)**0.5

TBPT „0.015,fp_theta-cc+(bb/aa)*(aa**2-(epsilo_fy-0.015)**2) ${ }^{* *} 0.5$

TBPT „epsilo_fy,fy_theta

TBPT ,,epsilo_l,fy_theta+(0.15-.02)*0.001

TBPT ,epsilo_u,0

TBTEMP ,600

! Define a temperatura para os dados da tabela.

fy_theta $=0.47 * \mathrm{fy}$

ME_theta $=0.31 * \mathrm{E}$

fp_theta $=0.180 * \mathrm{fy}$

epsilo_fp $=$ fp_theta/ME_theta

epsilo_fy $=0.02$

epsilo_l $=0.15$

epsilo_u $=0.2$

cC $=($ fy_theta-fp_theta $) * * 2 /\left((\right.$ epsilo_fy-epsilo_fp $\left.) * M E \_t h e t a-2 *\left(f y \_t h e t a-f p \_t h e t a\right)\right)$

aa $=\left((\text { epsilo_fy-epsilo_fp }) *\left(\text { epsilo_fy-epsilo_fp }+c c / M E \_t h e t a\right)\right)^{* *} 0.5$

$\mathrm{bb}=\left(\mathrm{cc} *(\right.$ epsilo_fy-epsilo_fp $\left.) * M E \_t h e t a+c c^{* *} 2\right) * * 0.5$

TBPT ,fp_theta/ME_theta,fp_theta

TBPT ,0.002,fp_theta-cc+(bb/aa)*(aa**2-(epsilo_fy-0.002)**2)**0.5

TBPT „,0.005,fp_theta-cc+(bb/aa)*(aa**2-(epsilo_fy-0.005)**2)**0.5

TBPT „,0.010,fp_theta-cc+(bb/aa)*(aa**2-(epsilo_fy-0.010)**2)**0.5

TBPT ,0.015,fp_theta-cc+(bb/aa)*(aa**2-(epsilo_fy-0.015)**2) ${ }^{* *} 0.5$

TBPT ,epsilo_fy,fy_theta

TBPT „,epsilo_l,fy_theta+(0.15-.02)*0.001

TBPT ,epsilo_u,0

TBTEMP ,700

! Define a temperatura para os dados da tabela.

fy_theta $=0.23 * \mathrm{fy}$

ME_theta $=0.13 * \mathrm{E}$

fp_theta $=0.075 * \mathrm{fy}$

epsilo_fp $=$ fp_theta/ME_theta

epsilo_fy $=0.02$

epsilo_l $=0.15$ 
epsilo_u $=0.2$

cc $=\left({ }_{f y}\right.$ theta-fp_theta) $) * 2 /\left((\right.$ epsilo_fy-epsilo_fp $\left.) * M E \_t h e t a-2 *\left(f y \_t h e t a-f p \_t h e t a\right)\right)$

aa $=(($ epsilo_fy-epsilo_fp $) *($ epsilo_fy-epsilo_fp+cc/ME_theta) $) * * 0.5$

$\mathrm{bb}=\left(\mathrm{cc} *(\text { epsilo_fy-epsilo_fp })^{*} \mathrm{ME} \_\right.$theta $\left.+\mathrm{cc} * * 2\right) * * 0.5$

TBPT ,fp_theta/ME_theta,fp_theta

TBPT ,0.002,fp_theta-cc+(bb/aa)*(aa**2-(epsilo_fy-0.002)**2)**0.5

TBPT ,0.005,fp_theta-cc+(bb/aa)*(aa**2-(epsilo_fy-0.005)**2)**0.5

TBPT „0.010,fp_theta-cc+(bb/aa)*(aa**2-(epsilo_fy-0.010)**2)**0.5

TBPT ,0.015,fp_theta-cc+(bb/aa)*(aa**2-(epsilo_fy-0.015)**2)**0.5

TBPT ,epsilo_fy,fy_theta

TBPT ,epsilo_l,fy_theta+(0.15-.02)*0.001

TBPT „epsilo_u,0

TBTEMP ,800

! Define a temperatura para os dados da tabela.

fy_theta $=0.11 * \mathrm{fy}$

ME_theta $=0.09 * \mathrm{E}$

fp_theta $=0.050 *$ fy

epsilo_fp $=\mathrm{fp} \_$theta/ME_theta

epsilo_fy $=0.02$

epsilo_l $=0.15$

epsilo_u $=0.2$

cc $=\left(\right.$ fy_theta-fp_theta) $* * 2 /\left((\right.$ epsilo_fy-epsilo_fp $\left.) * M E \_t h e t a-2 *\left(f y \_t h e t a-f p \_t h e t a\right)\right)$

aa $=(($ epsilo_fy-epsilo_fp $) *($ epsilo_fy-epsilo_fp+cc/ME_theta) $) * * 0.5$

bb $=(c c *($ epsilo_fy-epsilo_fp)*ME_theta+cc**2)**0.5

TBPT „,fp_theta/ME_theta,fp_theta

TBPT „,0.002,fp_theta-cc+(bb/aa)*(aa**2-(epsilo_fy-0.002)**2)**0.5

TBPT „0.005,fp_theta-cc+(bb/aa)*(aa**2-(epsilo_fy-0.005)**2)**0.5

TBPT „,0.010,fp_theta-cc+(bb/aa)*(aa**2-(epsilo_fy-0.010)**2)**0.5

TBPT „,0.015,fp_theta-cc+(bb/aa)*(aa**2-(epsilo_fy-0.015)**2)**0.5

TBPT ,epsilo_fy,fy_theta

TBPT ,epsilo_l,fy_theta+(0.15-.02)*0.001

TBPT ,epsilo_u,0

TBTEMP ,900

! Define a temperatura para os dados da tabela.

fy_theta $=0.06 *$ fy

ME_theta $=0.0675 * \mathrm{E}$

fp_theta $=0.0375 *$ fy

epsilo_fp $=$ fp_theta/ME_theta

epsilo_fy $=0.02$

epsilo_l $=0.15$

epsilo_u $=0.2$

cc $=($ fy_theta-fp_theta $) * * 2 /\left((\right.$ epsilo_fy-epsilo_fp $\left.) * M E \_t h e t a-2 *\left(f y \_t h e t a-f p \_t h e t a\right)\right)$

aa $=(($ epsilo_fy-epsilo_fp $) *($ epsilo_fy-epsilo_fp+cc/ME_theta $) * * 0.5$

$\mathrm{bb}=(\mathrm{cc} *($ epsilo_fy-epsilo_fp)*ME_theta+cc**2)**0.5

TBPT ,fp_theta/ME_theta,fp_theta

TBPT „,0.002,fp_theta-cc+(bb/aa)*(aa**2-(epsilo_fy-0.002)**2)**0.5

TBPT ,0.005,fp_theta-cc+(bb/aa)*(aa**2-(epsilo_fy-0.005)**2)**0.5

TBPT ,0.010,fp_theta-cc+(bb/aa)*(aa**2-(epsilo_fy-0.010)**2)**0.5

TBPT ,0.015,fp_theta-cc+(bb/aa)*(aa**2-(epsilo_fy-0.015)**2)**0.5

TBPT ,epsilo_fy,fy_theta

TBPT ,epsilo_l,fy_theta+(0.15-.02)*0.001

TBPT ,epsilo_u,0

TBTEMP ,1000

! Define a temperatura para os dados da tabela.

fy_theta $=0.04 *$ fy

ME_theta $=0.045 * \mathrm{E}$

fp_theta $=0.025 *$ fy

epsilo_fp $=$ fp_theta/ME_theta

epsilo_fy $=0.02$

epsilo_l $=0.15$ 
epsilo_u $=0.2$

cc $=($ fy_theta-fp_theta $) * * 2 /\left((\right.$ epsilo_fy-epsilo_fp $\left.) * M E \_t h e t a-2 *\left(f y \_t h e t a-f p \_t h e t a\right)\right)$

aa $=(($ epsilo_fy-epsilo_fp $) *($ epsilo_fy-epsilo_fp+cc/ME_theta $) * * 0.5$

$\mathrm{bb}=(\mathrm{cc} *($ epsilo_fy-epsilo_fp $) *$ ME_theta+cc**2)**0.5

TBPT ,fp_theta/ME_theta,fp_theta

TBPT ,0.002,fp_theta-cc+(bb/aa)*(aa**2-(epsilo_fy-0.002)**2)**0.5

TBPT ,0.005,fp_theta-cc+(bb/aa)*(aa**2-(epsilo_fy-0.005)**2)**0.5

TBPT ,0.010,fp_theta-cc+(bb/aa)*(aa**2-(epsilo_fy-0.010)**2)**0.5

TBPT ,0.015,fp_theta-cc+(bb/aa)*(aa**2-(epsilo_fy-0.015)**2)**0.5

TBPT ,epsilo_fy,fy_theta

TBPT ,,epsilo_l,fy_theta+(0.15-.02)*0.001

TBPT ,epsilo_u,0

TBTEMP ,1100

! Define a temperatura para os dados da tabela.

fy_theta $=0.02 * \mathrm{fy}$

ME_theta $=0.0225 * \mathrm{E}$

fp_theta $=0.0125 * \mathrm{fy}$

epsilo_fp $=\mathrm{fp}$ _theta/ME_theta

epsilo_fy $=0.02$

epsilo_l $=0.15$

epsilo_u $=0.2$

cc $=\left(\right.$ fy_theta-fp_theta) $* * 2 /\left((\right.$ epsilo_fy-epsilo_fp $\left.) * M E \_t h e t a-2 *\left(f y \_t h e t a-f p \_t h e t a\right)\right)$

aa $=(($ epsilo_fy-epsilo_fp $) *($ epsilo_fy-epsilo_fp+cc/ME_theta $) * * 0.5$

$\mathrm{bb}=(\mathrm{cc} *($ epsilo_fy-epsilo_fp)*ME_theta+cc**2)**0.5

TBPT ,fp_theta/ME_theta,fp_theta

TBPT „,0.002,fp_theta-cc+(bb/aa)*(aa**2-(epsilo_fy-0.002)**2)**0.5

TBPT ,,0.005,fp_theta-cc+(bb/aa)*(aa**2-(epsilo_fy-0.005)**2)**0.5

TBPT ,0.010,fp_theta-cc+(bb/aa)*(aa**2-(epsilo_fy-0.010)**2)**0.5

TBPT „,0.015,fp_theta-cc+(bb/aa)*(aa**2-(epsilo_fy-0.015)**2)**0.5

TBPT ,epsilo_fy,fy_theta

TBPT ,epsilo_l,fy_theta+(0.15-.02)*0.001

TBPT „epsilo_u,0

\author{
MPDE ,THSX,1 \\ MPTEMP ,,,,,,, \\ MPTEMP ,1,20 \\ MPTEMP ,2,365 \\ MPTEMP ,3,750 \\ MPTEMP ,4,860 \\ MPTEMP ,5,1200 \\ UIMP ,1,REFT,,,20 \\ MPDATA ,THSX,1,0 \\ MPDATA ,THSX,1,,0.004671 \\ MPDATA ,THSX,1,,0.011 \\ MPDATA ,THSX,1,,0.011 \\ MPDATA ,THSX,1,,0.0178
}

! Expansão térmica

!CHAPA DE TOPO

$\mathrm{MP}, \mathrm{EX}, 2, \mathrm{E}$

MP,PRXY,2,v

! Atribuição do módulo de elasticidade do dispositivo de apoio.

! Atribuição do coeficiente de Poisson do dispositivo de apoio.

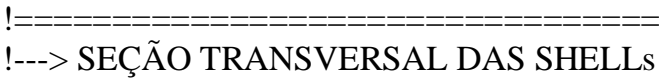

!--- Chapas do perfil: 
SECTYPE,1,SHELL, ,Chperf

*DO,k,1,ncamadas, 1

SECDATA,t/ncamadas,1,0.0,3 ! Espessura, material, orientação, pontos de integração. *ENDDO

SECOFFSET,MID

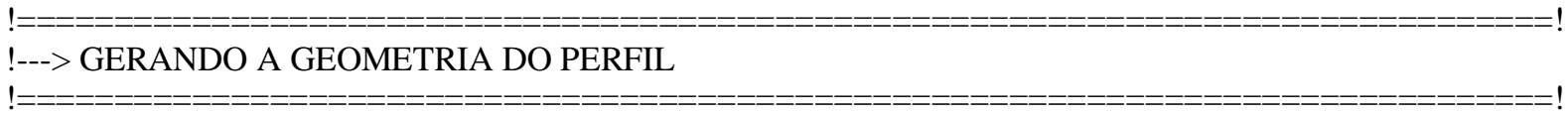

$\mathrm{K}, 1, \mathrm{dx}+\mathrm{dep} / 2+\mathrm{t} / 2, \mathrm{dy}+\mathrm{bm}, 0 \quad$ ! Gera pontos chaves da seção do perfil 1.

$\mathrm{K}, 2, \mathrm{dx}+\mathrm{dep} / 2+\mathrm{t} / 2, \mathrm{dy}+\mathrm{Ygm}, 0$

$\mathrm{K}, 3, \mathrm{dx}+\mathrm{dep} / 2+\mathrm{t} / 2, \mathrm{dy}, 0$

$\mathrm{K}, 4, \mathrm{dx}+\mathrm{dep} / 2+\mathrm{t} / 2+\mathrm{bm}, \mathrm{dy}, 0$

$\mathrm{L}, 1,2$

$\mathrm{L}, 2,3$

! Gera linhas que compõem o perfil 1.

$\mathrm{L}, 3,4$

LFILLT,2,3,rm, ,

! Faz o arredondamento do canto do perfil 1.

$\mathrm{K}, 7, \mathrm{dx}-(\mathrm{dep} / 2+\mathrm{t} / 2+\mathrm{bm}), \mathrm{dy}, 0$

! Gera pontos chaves da seção do perfil 2.

$\mathrm{K}, 8, \mathrm{dx}-(\mathrm{dep} / 2+\mathrm{t} / 2)$,dy,0

$\mathrm{K}, 9$,dx-(dep/2+t/2),dy+Ygm,0

$\mathrm{K}, 10, \mathrm{dx}-(\mathrm{dep} / 2+\mathrm{t} / 2), \mathrm{dy}+\mathrm{bm}, 0$
$\mathrm{L}, 7,8$
! Gera linhas que compõem o perfil 2.
$\mathrm{L}, 8,9$
$\mathrm{L}, 9,10$
LFILLT,5,6,rm, ,
! Faz o arredondamento do canto do perfil 2.

$\mathrm{K}, 13, \mathrm{dx}+\mathrm{dep} / 2+\mathrm{t} / 2, \mathrm{dy}+\mathrm{bm}$,comp $\quad$ ! Cria um ponto chave auxiliar para o perfil 1.

$\mathrm{L}, 1,13$

ADRAG,1,2,3,4, , ,9

LDELE,9

! Cria uma linha auxiliar.

KDELE,13

! Gera áreas arrastando um conjunto de linhas ao longo de um caminho.

! Deleta a linha que foi duplicada.

NUMCMP,ALL

! Deleta o ponto chave auxiliar que foi criado.

! Renumera itens reutilizando os números já deletados ou não utilizados.

$\mathrm{K}, 18, \mathrm{dx}-(\mathrm{dep} / 2+\mathrm{t} / 2+\mathrm{bm}), \mathrm{dy}, \mathrm{comp}$ ! Cria um ponto chave auxiliar para o perfil 2

$\mathrm{L}, 7,18$

! Cria uma linha auxiliar.

ADRAG,5,6,7,8, , ,18

! Gera áreas arrastando um conjunto de linhas ao longo de um caminho.

LDELE,18

! Deleta a linha que foi duplicada.

KDELE, 18

! Deleta o ponto chave auxiliar que foi criado.

NUMCMP,ALL

! Renumera itens reutilizando os números já deletados ou não utilizados.

$\mathrm{L}, 2,9$

$\mathrm{L}, 14,21$

! Cria uma linha que passa pelo centróide em 0.

! Cria uma linha que passa pelo centróide em comp.

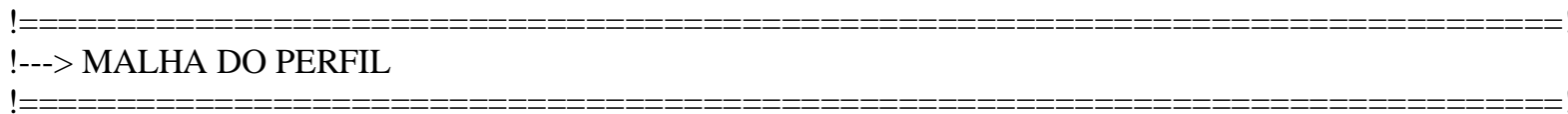

!--- COMPRIMENTO DO PERFIL:

Dpres $=$ comp $/($ Npres +1$)$

! Distância entre centros de presilhas.

LocWP=Dpres 


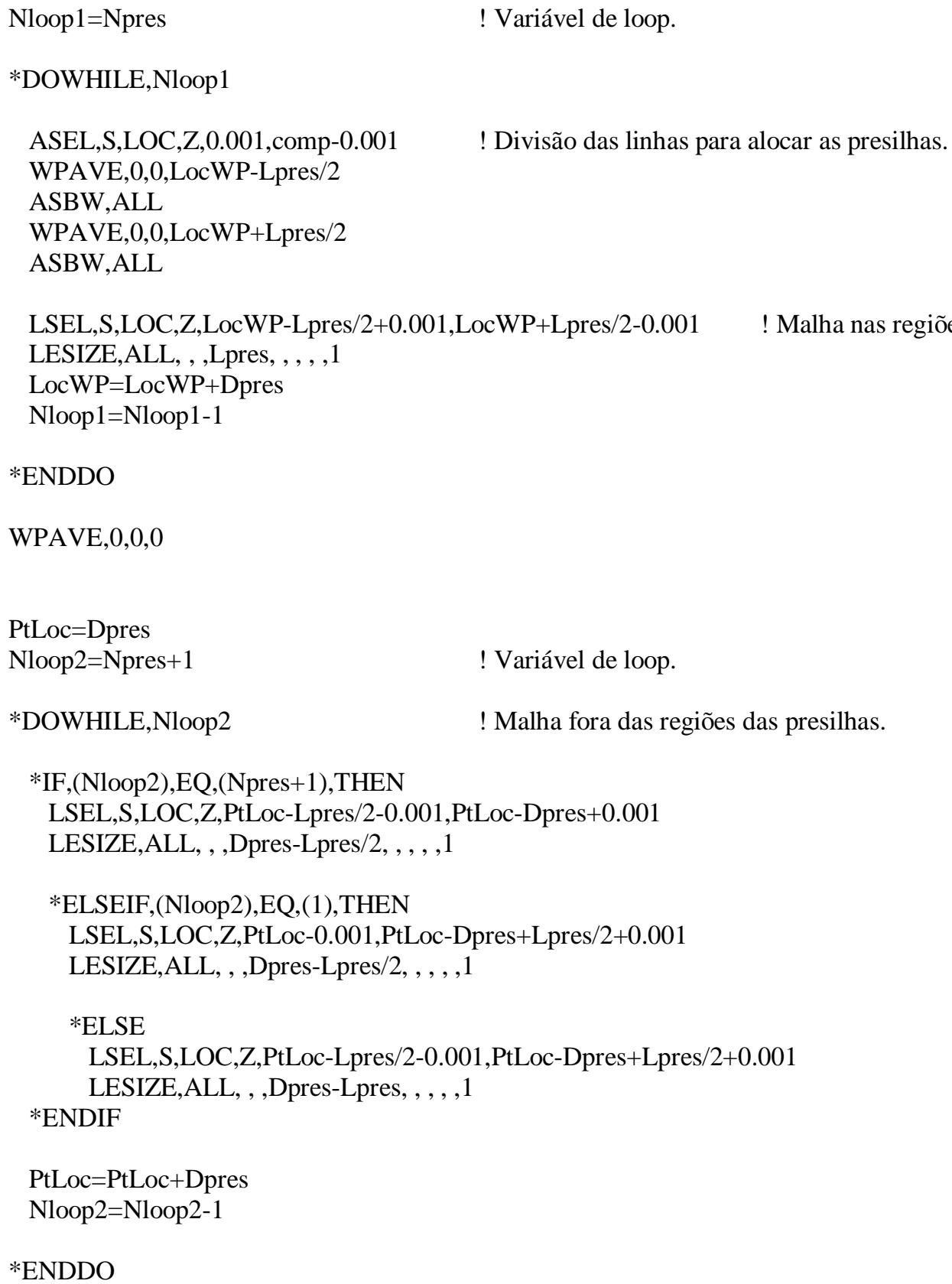

ASEL,ALL

AGLUE,ALL ! ! Une ("cola") as áreas selecionadas.

\section{!--- ABAS COM PRESILHAS (CHAPAS ESPAÇADORAS):}

!--- Primeira parte da aba:

LSEL,S,LOC,Z,-0.001,comp+0.001

LSEL,R,LOC,Y,dy+Ygm+0.001,dy+bm+0.001

LESIZE,ALL, , ,nd1m, , , , ,1

ASEL,S,LOC,Y,dy+Ygm+0.001,dy+bm+0.001
AATT, $1,1,1,0,1$ MSHKEY,1

MSHAPE,0,2D
! Seleciona todas as linhas do perfil.

! Seleciona as linhas acima da coordenada Y do CG (Ygm).

! Divide as linhas da primeira parte da aba.
! AATT,MAT,REAL,TYPE,ESYS,SECN

! Tipo da malha: Mapeada

! Malha realizada com elemento 2D 
AMESH,ALL

ASEL,ALL

!--- Segunda parte da aba:

LSEL,S,LOC,Z,-0.001,comp+0.001

LSEL,R,LOC,Y,dy+rm,dy+Ygm-0.001

LESIZE,ALL, , ,nd2m, , , , ,1

ASEL,S,LOC,Y,dy+rm,dy+Ygm-0.001

AATT,1,1,1,0,1

MSHKEY,1

MSHAPE,0,2D

AMESH,ALL

ASEL,ALL

!--- Parte curva:

LSEL,S,LOC,Z,-0.001,comp+0.001

LSEL,R,LOC,Y,dy+0.001,dy+rm-0.001

LESIZE,ALL, , ,ndc, , , , ,1

ASEL,R,LOC,Y,dy+0.001,dy+rm-0.001

AATT,1,1,1,0,1

MSHKEY,1

MSHAPE,0,2D

AMESH,ALL

ASEL,ALL
! Gerando a malha

! Seleciona todas as áreas

! Seleciona todas as linhas do perfil.

! Seleciona as linhas das seções entre o fim da dobra e Ygm.

! Divide as linhas da segunda parte da aba.

! Seleciona todas as linhas do perfil.

! Seleciona a linha curva das dobras das seções.

! Divide a linhas da dobras.

\author{
! AATT,MAT,REAL,TYPE,ESYS,SECN \\ ! Tipo da malha: Mapeada \\ ! Malha realizada com elemento 2D \\ ! Gerando a malha \\ ! Seleciona todas as áreas
}

\title{
!--- ABAS LIVRES (SEM PRESILHAS):
}

LSEL,S,LOC,Z,-0.001,comp+0.001

LSEL,R,LOC,X,dx+dep/2+t/2+rm+0.001,dx+dep/2+t/2+bm-0.001

LESIZE,ALL, , ,nd3m, , , , ,1

ASEL,S,LOC,X,dx+dep/2+t/2+rm+0.001,dx+dep/2+t/2+bm-0.001

AATT,1,1,1,0,1

MSHKEY,1

MSHAPE,0,2D

AMESH,ALL

ASEL,ALL
! Seleciona todas as linhas do perfil.

! Seleciona a linha da aba livre do perfil 1.

! Divide a linha da aba livre do perfil 1.
LSEL,S,LOC,Z,-0.001,comp+0.001

LSEL,R,LOC,X,dx-(dep/2+t/2+rm-0.001),dx-(dep/2+t/2+bm+0.001)

LESIZE,ALL, , ,nd3m, , , , ,1

\section{! AATT,MAT,REAL,TYPE,ESYS,SECN}

! Tipo da malha: Mapeada

! Malha realizada com elemento 2D

! Gerando a malha

! Seleciona todas as áreas

ASEL,S,LOC,X,dx-(dep/2+t/2+rm-0.001),dx-(dep/2+t/2+bm+0.001)

AATT,1,1,1,0,1

MSHKEY,1

MSHAPE,0,2D

AMESH,ALL

ASEL,ALL
! Seleciona todas as linhas do perfil.

! Seleciona a linha da aba livre do perfil 2.

! Divide a linha da aba livre do perfil 2. 


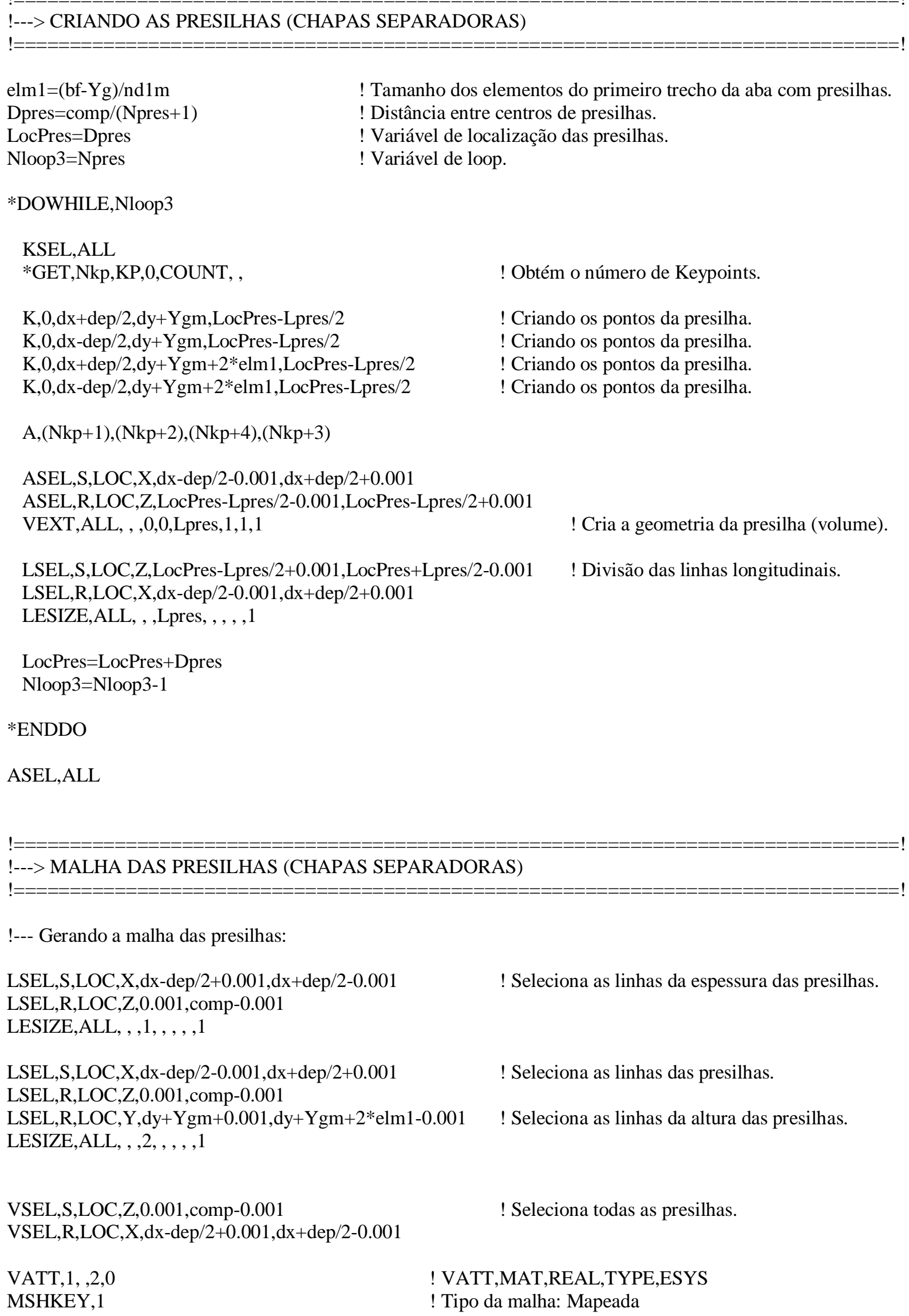


MSHAPE,0,3D

VMESH,ALL

VSEL,ALL

!--- Juntando os nós da região parafusada:

elm1=(bf-Yg)/nd1m

Dpres $=$ comp/(Npres +1$)$

LocPres=Dpres

Nloop4=Npres
! Malha realizada com elemento 3D

! Gerando a malha

*DOWHILE,Nloop4

NSEL,S,LOC,Z,LocPres-1-0.001,LocPres+1+0.001 NSEL,R,LOC,Y,dy+Ygm-0.001,dy+Ygm+2*elm1+0.001 NSEL,R,LOC,X,dx-0.001,dx-dep/2-t/2-0.001

NUMMRG,NODE,t/2+0.001, , ,LOW

NSEL,S,LOC,Z,LocPres-1-0.001,LocPres+1+0.001

NSEL,R,LOC,Y,dy+Ygm-0.001,dy+Ygm+2*elm1+0.001

NSEL,R,LOC,X,dx+0.001,dx+dep/2+t/2+0.001

NUMMRG,NODE,t/2+0.001, , ,LOW

LocPres=LocPres + Dpres

Nloop4=Nloop4-1

*ENDDO

/NUMBER, 1

/PNUM,MAT,1

/REPLOT
! Presilha parafusada aos perfis - $2 \mathrm{cmx} 2 \mathrm{~cm}$, aprox. ! Presilha parafusada aos perfis - 2cmx2cm, aprox. ! Seleciona os nós do lado esquerdo da presilha. ! Junta os nós muito próximos.

! Presilha parafusada aos perfis - 2cmx2cm, aprox. ! Presilha parafusada aos perfis - 2cmx2cm, aprox. ! Seleciona os nós do lado direito da presilha. ! Junta os nós muito próximos.

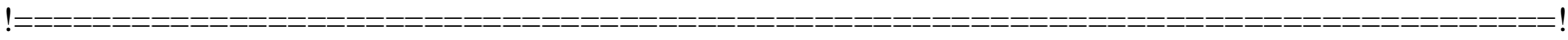

!---> CRIANDO DISPOSITIVOS DE APOIO

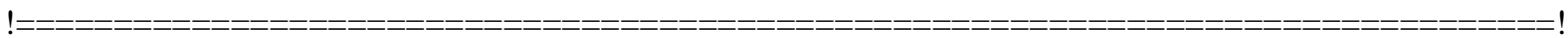

LSEL,ALL

NSEL,ALL

KSEL,ALL

*GET,Nkp,KP,0,COUNT, ,

\section{!--- DISPOSITIVOS DE APOIO:}

! Cria keypoints auxiliares na seção Z=0:

$\mathrm{K}, 0, \mathrm{dx}+\mathrm{dep} / 2+\mathrm{t} / 2+\mathrm{bm}, \mathrm{dy}+\mathrm{bm}, 0$

$\mathrm{K}, 0, \mathrm{dx}-\mathrm{dep} / 2-\mathrm{t} / 2-\mathrm{bm}, \mathrm{dy}+\mathrm{bm}, 0$

$\mathrm{K}, 0, \mathrm{dx}+\mathrm{dep} / 2+\mathrm{t} / 2+\mathrm{rm}, \mathrm{dy}+\mathrm{bm}, 0$

$\mathrm{K}, 0, \mathrm{dx}-\mathrm{dep} / 2-\mathrm{t} / 2-\mathrm{rm}, \mathrm{dy}+\mathrm{bm}, 0$

$\mathrm{K}, 0, \mathrm{dx}+\mathrm{dep} / 2+\mathrm{t} / 2+\mathrm{bm}, \mathrm{dy}+\mathrm{rm}, 0$

$\mathrm{K}, 0, \mathrm{dx}-\mathrm{dep} / 2-\mathrm{t} / 2-\mathrm{bm}, \mathrm{dy}+\mathrm{rm}, 0$

$\mathrm{K}, 0, \mathrm{dx}+\mathrm{dep} / 2+\mathrm{t} / 2+\mathrm{bm}, \mathrm{dy}+\mathrm{ygm}, 0$

$\mathrm{K}, 0, \mathrm{dx}-\mathrm{dep} / 2-\mathrm{t} / 2-\mathrm{bm}, \mathrm{dy}+\mathrm{ygm}, 0$

$\mathrm{K}, 0, \mathrm{dx}+\mathrm{dep} / 2+\mathrm{t} / 2+\mathrm{rm}, \mathrm{dy}+\mathrm{rm}, 0$

$\mathrm{K}, 0, \mathrm{dx}-\mathrm{dep} / 2-\mathrm{t} / 2-\mathrm{rm}, \mathrm{dy}+\mathrm{rm}, 0$
! Seleciona todas as linhas do modelo.

! Seleciona todos os nós do modelo.

! Seleciona todos os keypoints do modelo.

! Obtém o número de Keypoints. 
$\mathrm{K}, 0, \mathrm{dx}+\mathrm{dep} / 2+\mathrm{t} / 2+\mathrm{rm}, \mathrm{dy}+\mathrm{ygm}, 0$

$\mathrm{K}, 0$,dx-dep/2-t/2-rm,dy+ygm,0

$\mathrm{K}, 0, \mathrm{dx}+\mathrm{dep} / 2+\mathrm{t} / 2, \mathrm{dy}+\mathrm{bm}, 0$

$\mathrm{K}, 0, \mathrm{dx}-(\mathrm{dep} / 2+\mathrm{t} / 2), \mathrm{dy}+\mathrm{bm}, 0$

$\mathrm{K}, 0, \mathrm{dx}+\mathrm{dep} / 2+\mathrm{t} / 2, \mathrm{dy}+\mathrm{Ygm}, 0$

$\mathrm{K}, 0, \mathrm{dx}-(\mathrm{dep} / 2+\mathrm{t} / 2), \mathrm{dy}+\mathrm{Ygm}, 0$

$\mathrm{K}, 0, \mathrm{dx}+\mathrm{dep} / 2+\mathrm{t} / 2, \mathrm{dy}+\mathrm{rm}, 0$

$\mathrm{K}, 0, \mathrm{dx}-(\mathrm{dep} / 2+\mathrm{t} / 2), \mathrm{dy}+\mathrm{rm}, 0$

$\mathrm{K}, 0, \mathrm{dx}+\mathrm{dep} / 2+\mathrm{t} / 2$,dy, 0

$\mathrm{K}, 0, \mathrm{dx}-(\mathrm{dep} / 2+\mathrm{t} / 2)$,dy,0

$\mathrm{K}, 0, \mathrm{dx}+\mathrm{dep} / 2+\mathrm{t} / 2+\mathrm{rm}, \mathrm{dy}, 0$

$\mathrm{K}, 0, \mathrm{dx}-(\mathrm{dep} / 2+\mathrm{t} / 2+\mathrm{rm}), \mathrm{dy}, 0$

$\mathrm{K}, 0, \mathrm{dx}+\mathrm{dep} / 2+\mathrm{t} / 2+\mathrm{bm}, \mathrm{dy}, 0$

$\mathrm{K}, 0, \mathrm{dx}-(\mathrm{dep} / 2+\mathrm{t} / 2+\mathrm{bm}), \mathrm{dy}, 0$

A,(Nkp+24),(Nkp+22),(Nkp+10), $(\mathrm{Nkp}+6)$

$\mathrm{A},(\mathrm{Nkp}+6),(\mathrm{Nkp}+10),(\mathrm{Nkp}+12),(\mathrm{Nkp}+8)$

$\mathrm{A},(\mathrm{Nkp}+8),(\mathrm{Nkp}+12),(\mathrm{Nkp}+4),(\mathrm{Nkp}+2)$

$\mathrm{A},(\mathrm{Nkp}+22),(\mathrm{Nkp}+20),(\mathrm{Nkp}+18),(\mathrm{Nkp}+10)$

$\mathrm{A},(\mathrm{Nkp}+10),(\mathrm{Nkp}+18),(\mathrm{Nkp}+16),(\mathrm{Nkp}+12)$

$\mathrm{A},(\mathrm{Nkp}+12),(\mathrm{Nkp}+16),(\mathrm{Nkp}+14),(\mathrm{Nkp}+4)$

$\mathrm{A},(\mathrm{Nkp}+20),(\mathrm{Nkp}+19),(\mathrm{Nkp}+17),(\mathrm{Nkp}+18)$

$\mathrm{A},(\mathrm{Nkp}+18),(\mathrm{Nkp}+17),(\mathrm{Nkp}+15),(\mathrm{Nkp}+16)$

$\mathrm{A},(\mathrm{Nkp}+16),(\mathrm{Nkp}+15),(\mathrm{Nkp}+13),(\mathrm{Nkp}+14)$

$\mathrm{A},(\mathrm{Nkp}+19),(\mathrm{Nkp}+21),(\mathrm{Nkp}+9),(\mathrm{Nkp}+17)$

A,(Nkp+17),(Nkp+9),(Nkp+11),(Nkp+15)

$\mathrm{A},(\mathrm{Nkp}+15),(\mathrm{Nkp}+11),(\mathrm{Nkp}+3),(\mathrm{Nkp}+13)$

$\mathrm{A},(\mathrm{Nkp}+21),(\mathrm{Nkp}+23),(\mathrm{Nkp}+5),(\mathrm{Nkp}+9)$

$\mathrm{A},(\mathrm{Nkp}+9),(\mathrm{Nkp}+5),(\mathrm{Nkp}+7),(\mathrm{Nkp}+11)$

$\mathrm{A},(\mathrm{Nkp}+11),(\mathrm{Nkp}+7),(\mathrm{Nkp}+1),(\mathrm{Nkp}+3)$

ASEL,S,LOC,Z,0.001,-0.001

AGEN,2,ALL, , ,0,0,comp,0,1,0

ASEL,S,LOC,Z,0.001,-0.001

VEXT,ALL, , ,0,0,-Lap,1,1,1

VSEL,S,LOC,Z,-0.001,-Lap+0.001

VGLUE,ALL

ASEL,S,LOC,Z,comp+0.001,comp-0.001

VEXT,ALL, , ,0,0,Lap,1,1,1

VSEL,S,LOC,Z,comp+Lap+0.001,comp-0.001

VGLUE,ALL
! Cria um volume: apoio do tipo "faca" em Z=0.

! Seleciona o volume do apoio em $\mathrm{Z}=0$.

! Une ("cola") os volumes selecionados.

! Cria um volume: apoio do tipo "faca" em Z=comp. ! Seleciona o volume do apoio em $\mathrm{Z}=$ comp.

! Une ("cola") os volumes selecionados.

!===================================
!--> MALHA DOS DISPOSITIVOS DE APOIO

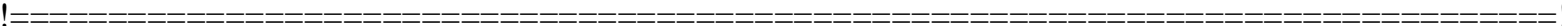

!--- Malha em z=0:

NSEL,NONE

LSEL,S,LOC,Z,-0.001,-Lap+0.001

LESIZE,ALL, , ,Lap, , , , ,1

! Seleciona as linhas do apoio na direção longitudinal. 


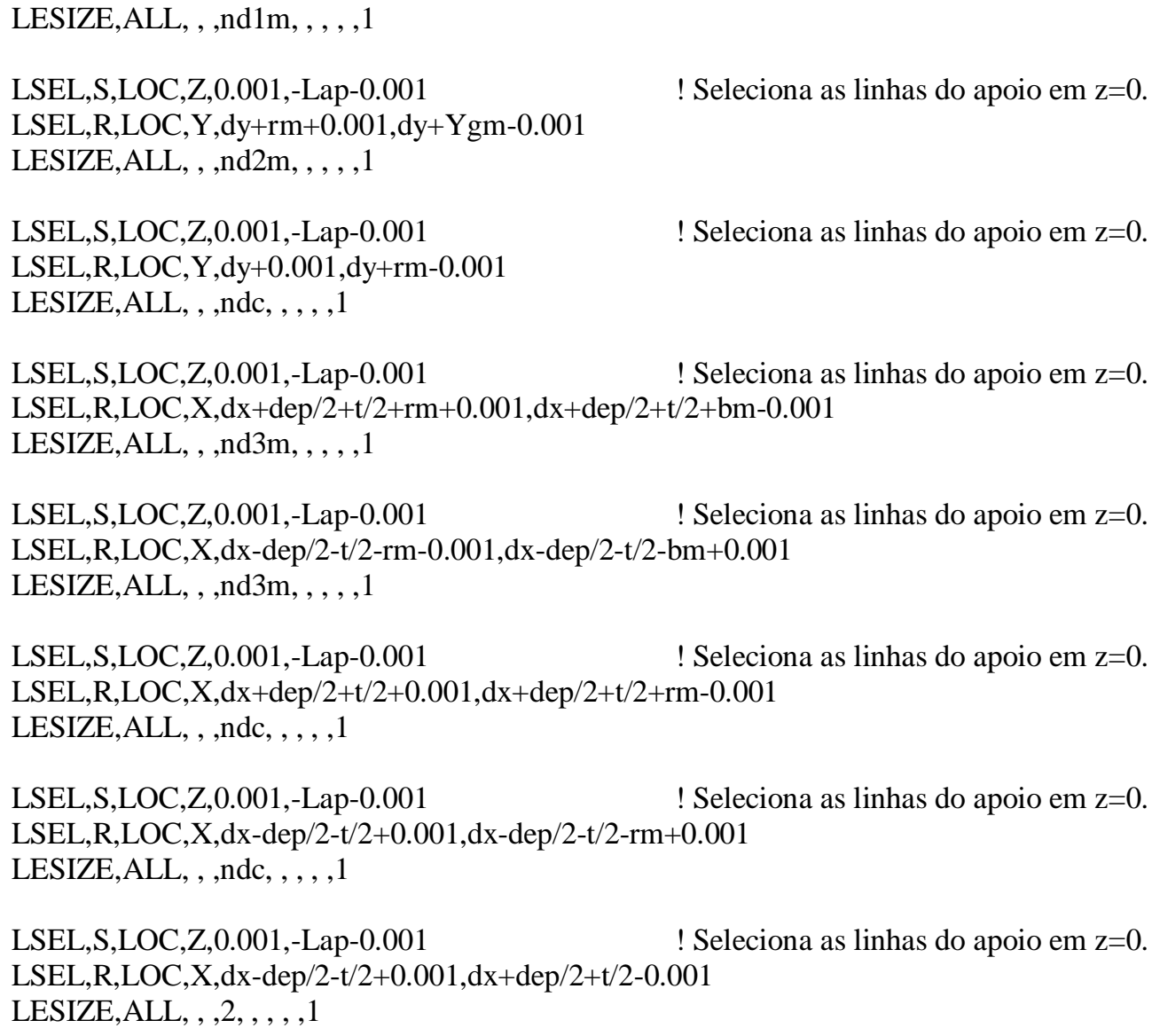

\section{! VATT,MAT,REAL,TYPE,ESYS \\ ! Tipo da malha: Mapeada \\ ! Malha realizada com elemento 3D \\ ! Gerando a malha}

! Seleciona os nós em $\mathrm{Z}=0$.

! Junta os nós muito próximos.

! Renumera itens reutilizando os números já deletados.

! Seleciona as linhas do apoio na direção longitudinal.

! Seleciona as linhas do apoio em $\mathrm{z}=$ comp.

! Seleciona as linhas do apoio em $\mathrm{z}=$ comp.

! Seleciona as linhas do apoio em $\mathrm{z}=$ comp. 
LSEL,S,LOC,Z,comp+Lap+0.001,comp-0.001

! Seleciona as linhas do apoio em $\mathrm{z}=$ comp.

LSEL,R,LOC,X,dx+dep/2+t/2+rm+0.001,dx+dep/2+t/2+bm-0.001

LESIZE,ALL, , ,nd3m, , , , ,1

LSEL,S,LOC,Z,comp+Lap+0.001,comp-0.001

LSEL,R,LOC,X,dx-dep/2-t/2-rm-0.001,dx-dep/2-t/2-bm+0.001

LESIZE,ALL, , ,nd3m, , , , ,1

LSEL,S,LOC,Z,comp+Lap+0.001,comp-0.001

LSEL,R,LOC,X,dx+dep/2+t/2+0.001,dx+dep/2+t/2+rm-0.001

LESIZE,ALL, , ,ndc, , , , ,1

LSEL,S,LOC,Z,comp+Lap+0.001,comp-0.001

LSEL,R,LOC,X,dx-dep/2-t/2+0.001,dx-dep/2-t/2-rm+0.001

LESIZE,ALL, , ,ndc, , , , ,1

LSEL,S,LOC,Z,comp+Lap+0.001,comp-0.001

Seleciona as linhas do apoio em z=comp.

LSEL,R,LOC,X,dx-dep/2-t/2+0.001,dx+dep/2+t/2-0.001

LESIZE,ALL, , ,2, , , , ,1

VSEL,S,LOC,Z,comp+Lap+0.001,comp-0.001

VATT,2, ,3,0

MSHKEY,1

MSHAPE,0,3D

VMESH,ALL

VSEL,ALL

! Seleciona as linhas do apoio em $\mathrm{z}=$ comp.

NSEL,S,LOC,Z,comp-0.001,comp+0.00

NUMMRG,NODE,0.05, , ,LOW

NUMCMP,ALL

! Seleciona as linhas do apoio em z=comp.

! Seleciona as linhas do apoio em z=comp.

! VATT,MAT,REAL,TYPE,ESYS

! Tipo da malha: Mapeada

! Malha realizada com elemento 3D

! Gerando a malha

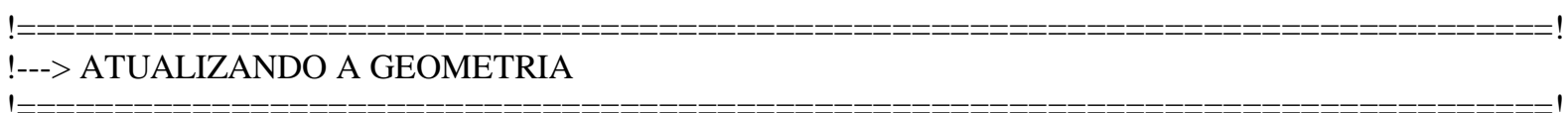

!--- MODO LOCAL:

$\mathrm{DMX}=1.002$

$\mathrm{d} 1=0.64 * \mathrm{t}$

! Deslocamento máximo local do ansys.

FATloc $=\mathrm{d} 1 / \mathrm{DMX}$

! Amplitude requerida no perfil.

! Seleciona os nós em Z=comp.

! Junta os nós muito próximos.

! Renumera itens reutilizando os números já deletados.

!--- MODO GLOBAL DE FLEXÃO:

$\mathrm{DMX}=1.000$

FATglob_F_aplicado $=$ comp $/ 1500$

FATglob_F=FATglob_F_aplicado/DMX

! Amplitude da imperfeição global.

UPGEOM,FATglob_F,LAST,LAST, 'Endereço onde se localiza a imperfeição global mais o nome do arquivo','rst', 
FINISH

ISOLU

!--- ACOPLAMENTO DOS NÓS DA LINHA QUE PASSA PELA RÓTULA:

! Apoio em z=0:

NSEL,S,LOC,Z,-Lap+0.001,-Lap-0.001

NSEL,R,LOC,Y,dy+Ygm-0.001,dy+Ygm+0.001 ! Seleção dos nós que passam pela rótula em Z=0 .

NPLOT,ALL

CP,10,UZ,ALL

! Mostra os nós selecionados e seus respectivos números.

NSEL,ALL

! Acoplamento dos nós.

! Apoio em $\mathrm{z}=$ comp:

NSEL,S,LOC,Z,comp+Lap+0.001,comp+Lap-0.001

NSEL,R,LOC,Y,dy+Ygm-0.001,dy+Ygm+0.001 ! Seleção dos nós que passam pela rótula em Z=comp. NPLOT,ALL

CP,20,UZ,ALL

! Mostra os nós selecionados e seus respectivos números.

NSEL,ALL

! Acoplamento dos nós.

!--- CONDIÇÕES DE CONTORNO DOS NÓS DAS CHAPAS DE TOPO:

! Restrições em Z=0:

NSEL,S,LOC,Z,-Lap+0.001,-Lap-0.001 ! Seleciona os nós do apoio em Z=0.

NPLOT,ALL

D,ALL,UX,0, , , ,ROTY,ROTZ

NSEL,ALL

! Restrições ao deslocamento dos nós selecionados.

! Restrições em Z=comp:

NSEL,S,LOC,Z,comp+Lap+0.001,comp+Lap-0.001

! Seleciona os nós do apoio em z=comp.

NPLOT,ALL

D,ALL,UX,0, , , ,ROTY,ROTZ ! Restrições ao deslocamento dos nós selecionados.

NSEL,ALL

!--- CONDIÇÕES DE CONTORNO DOS NÓS DO CENTRÓIDE:

! Restrições em Z=0:

NSEL,S,LOC,Z,-Lap+0.001,-Lap-0.001

NSEL,R,LOC,Y,dy+Ygm-0.001,dy+Ygm+0.001 ! Seleção dos nós que passam pela rótula em Z $\mathrm{Z}=0$.

NPLOT,ALL

D,ALL,UX,0, , , ,UY,ROTY,ROTZ ! Restrições ao deslocamento dos nós selecionados.

NSEL,ALL

! Restrições em Z=comp:

NSEL,S,LOC,Z,comp+Lap+0.001,comp+Lap-0.001

NSEL,R,LOC,Y,dy+Ygm-0.001,dy+Ygm+0.001 ! Seleção dos nós que passam pela rótula em Z=comp. NPLOT,ALL

D,ALL,UX,0, , , ,UY,UZ,ROTY,ROTZ

! Restrições ao deslocamento dos nós selecionados.

NSEL,ALL 
/SOLU

!/REPLOT,RESIZE

ALLSEL ,ALL

TUNIF ,20

TREF ,20

! Determina uma temperatura uniforme para todos os nós

!IC , ALL , TEMP ,20

! Temperatura de referência para expansão térmica

! Definição das condições iniciais - temperatura de $20^{\circ} \mathrm{C}$

FINISH

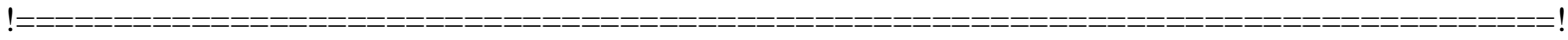

!---> SOLICITAÇÕES E OPÇÕES DE PROCESSAMENTO

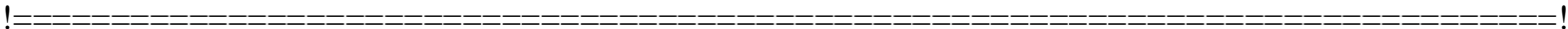

!--- AÇÃO MECÂNICA: DESLOCAMENTO PRESCRITO

/SOLU

NSEL,S,LOC,Z,-Lap+0.001,-Lap-0.001

NSEL,R,LOC,Y,dy+Ygm-0.001,dy+Ygm+0.001 ! Seleção dos nós que passam pela rótula em Z=0.

NPLOT,ALL

*GET,nmestre,NODE,0,NUM,MIN

NPLOT,ALL

F,nmestre,FZ,Carga, , , , , ,

NPLOT,ALL

! Pega o nó mestre (menor numeração de nó da linha). ! Plota os nós

! Aplica um deslocamento prescrito no nó mestre

! Plota os nós

AUTOTS,ON

TIME, 0.1

DELTIM,.01,0.001,.2

CNVTOL,U,1,0.001,2, ,

OUTRES,ERASE

OUTRES,NSOL,LAST

OUTRES,RSOL,LAST

OUTRES,STRS,LAST

OUTRES,EPEL,LAST

OUTRES,EPTH,LAST

OUTRES,EPPL,LAST

!RESCONTRL,DEFINE,ALL,-5,1

ALLSEL,ALL

/REPLOT

LSWRITE,1,

GPLOT

ALLSEL,ALL

/REPLOT
! Automático time step ativado

! Time $=0$

! chute inicial, mínimo time,máximo time

! Controle de tolerância em termos de deslocamento
! CASO 1: Carga Estrutural 
FINISH

!--- AÇÃO TÉRMICA: CAMPO TÉRMICO

/SOLU

*DO,i,1,horas*3600/intloadstep,1

AUTOTS ,1

TIME ,i

DELTIM , 0.25, 0.1,0.5 ! Para 6 seg de intloadstep

CNVTOL,U,1,0.005,2, , ! Controle de tolerância em termos de deslocamento

OUTRES ,ERASE

OUTRES ,NSOL,-3

OUTRES ,RSOL,-3

OUTRES ,STRS,-3

OUTRES ,EPEL,-3

OUTRES ,EPTH,-3

OUTRES ,EPPL,-3

RESCONTRL ,DEFINE,ALL,-3

ALLSEL ,ALL

LDREAD,TEMP,,,i*intloadstep, ,'Endereço onde se localiza o Modelo Térmico mais o nome do arquivo','rth', !carregamento a cada intloadset segundos

LSWRITE ,i+1, ! CASO 2 a ...: Carga Térmica

*ENDDO

ALLSEL,ALL

/REPLOT

!SAVE

FINISH

!--- OPÇÕES DE PROCESSAMENTO

/SOLU

ANTYPE, 0

NLGEOM,1

! Análise estática

LNSRCH ,OFF

NROPT,FULL, , OFF ! Newton-Raphson completo. (ver método)

EQSLV,SPAR, , 0 ! Solver escolhido

PIVCHECK,ON

SSTIF,ON

! Atualiza a matriz de rigidez a cada iteração

NEQIT,20

! Número máximo de equações de equilíbrio

STABILIZE,CONSTANT,ENERGY,0.0001,NO ～! ATENÇÃO: comando usado apenas em modelos com problemas de convergência.

FINISH

!============
!---> SOLUÇÃO 


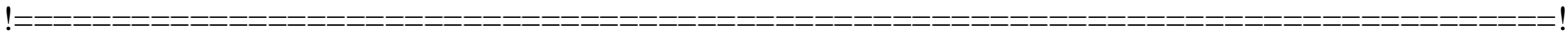

/SOLU

LSSOLVE,1,horas*3600/intloadstep+1,1

! Resolver o modelo

SAVE

FINISH

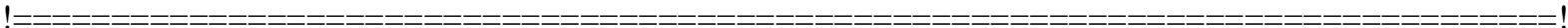




\section{APÊNDICE D - Resultados das análises à} temperatura ambiente: compressão centrada

Neste apêndice, são apresentadas as configurações deformadas dos perfis analisados sob compressão centrada no instante em que os mesmos perdem sua capacidade resistente. Além disso, são apresentados a distribuição de tensões (von Mises) nas chapas das cantoneiras e gráficos que relacionam a força normal de compressão aplicada ao deslocamento axial do topo dos perfis (de onde se obtém a força normal de compressão resistente dos perfis). 


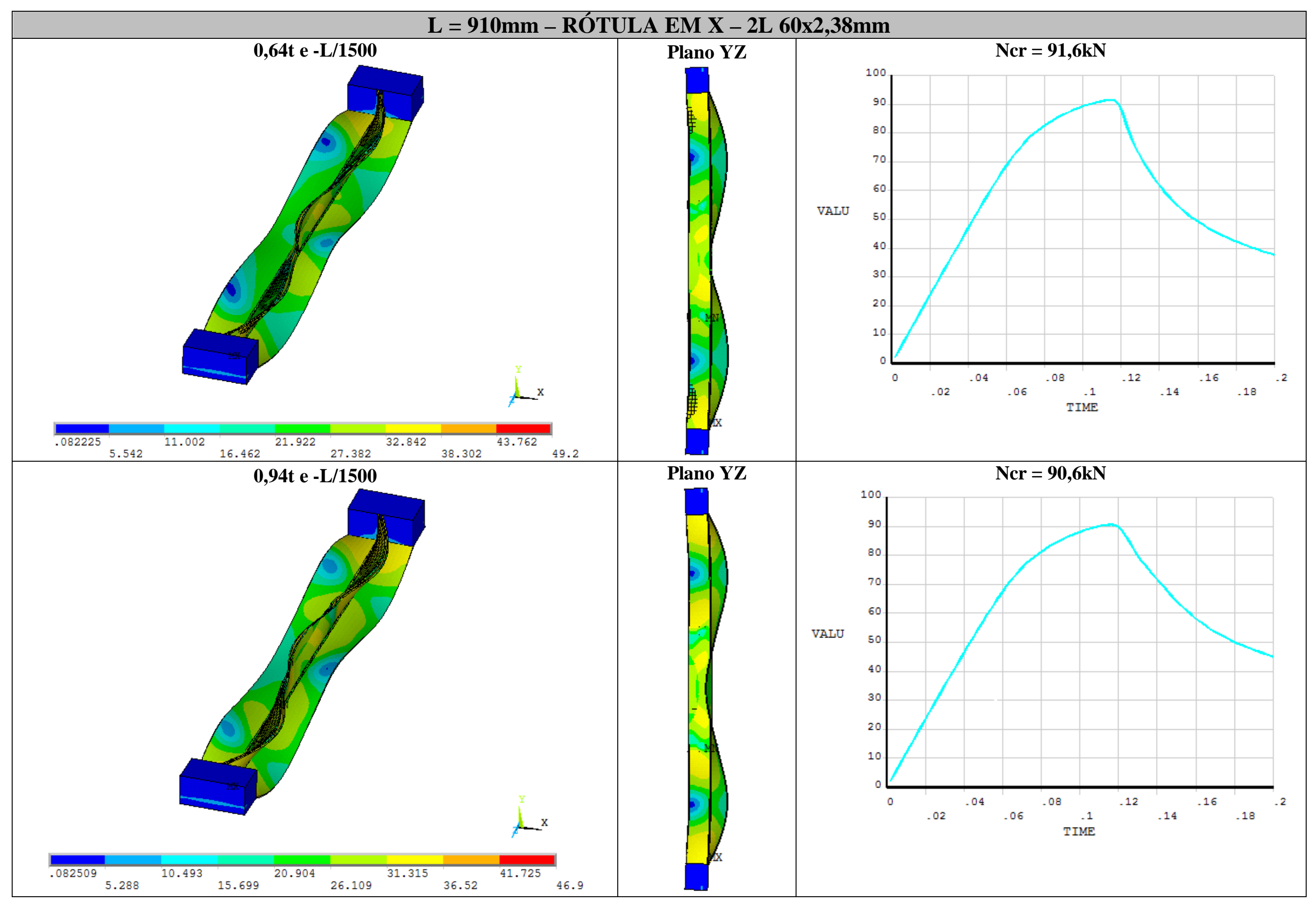


247

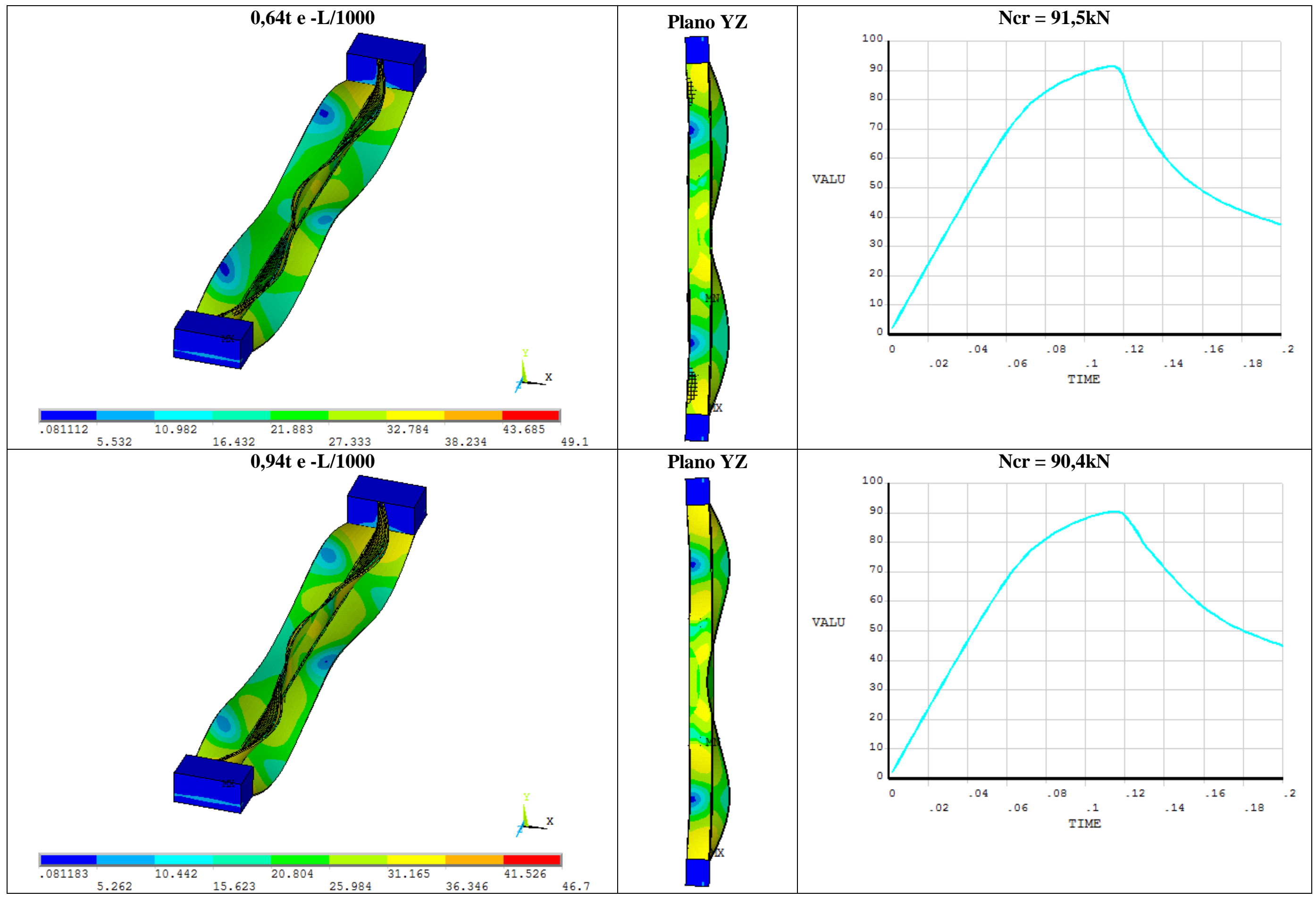




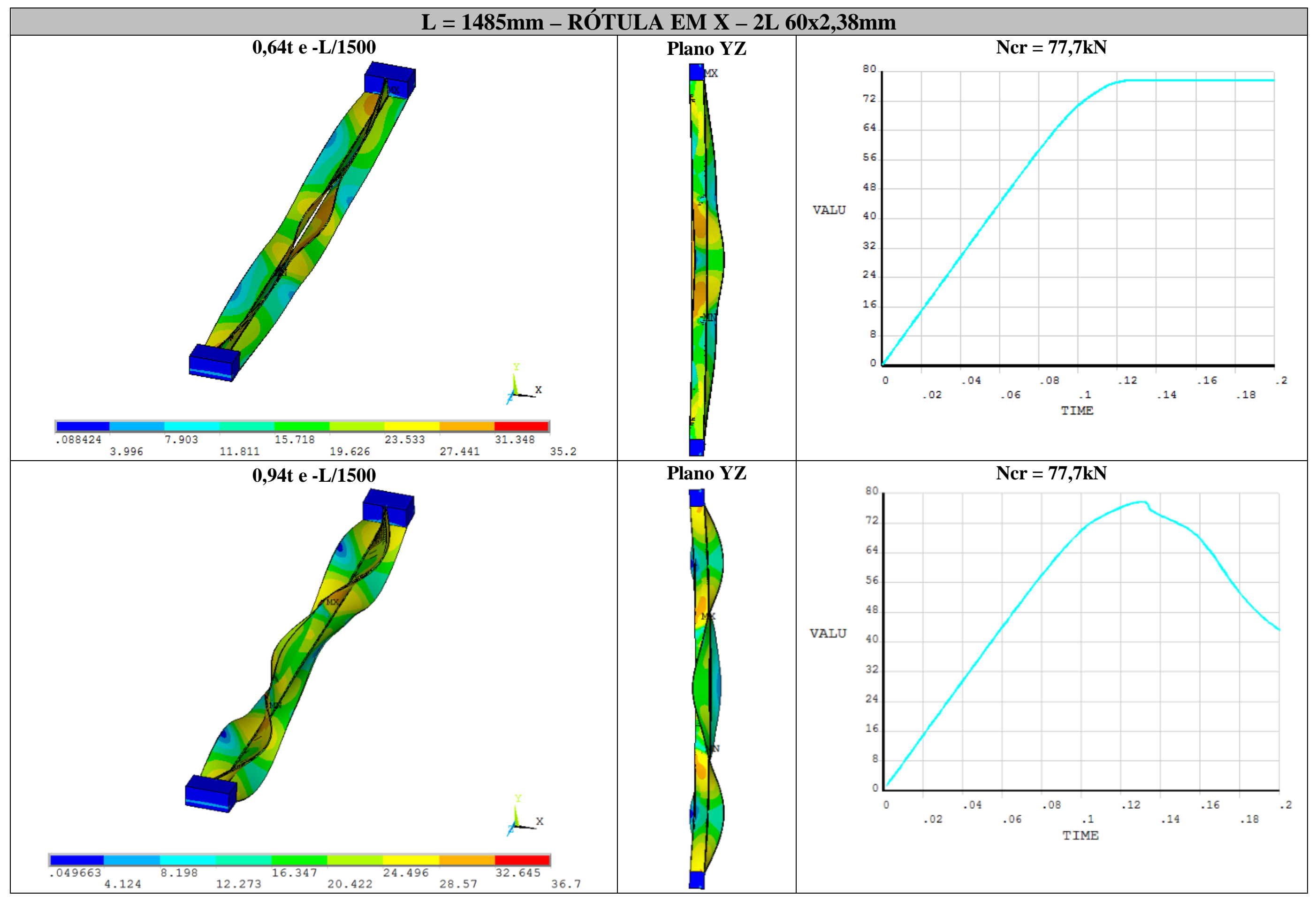




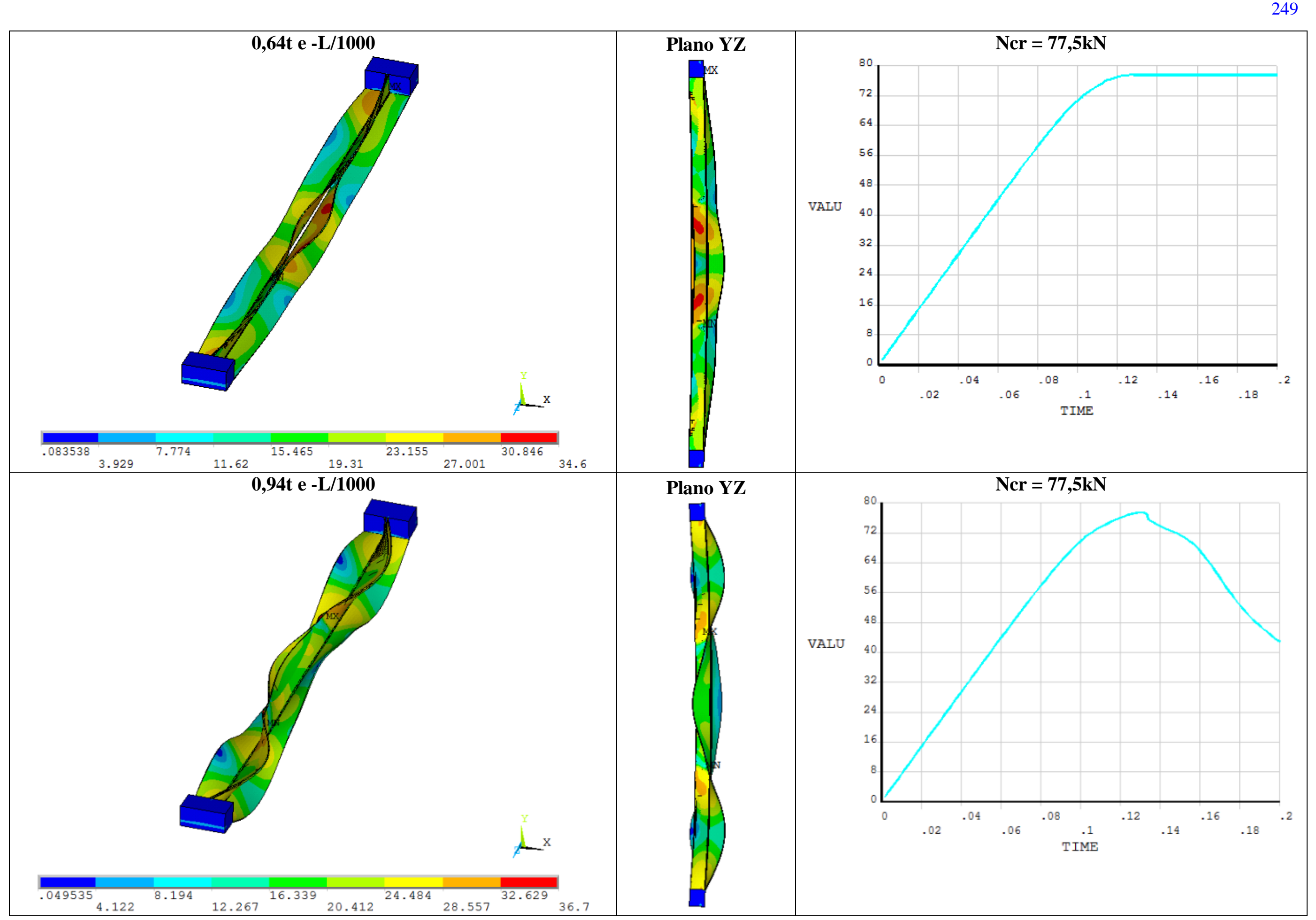




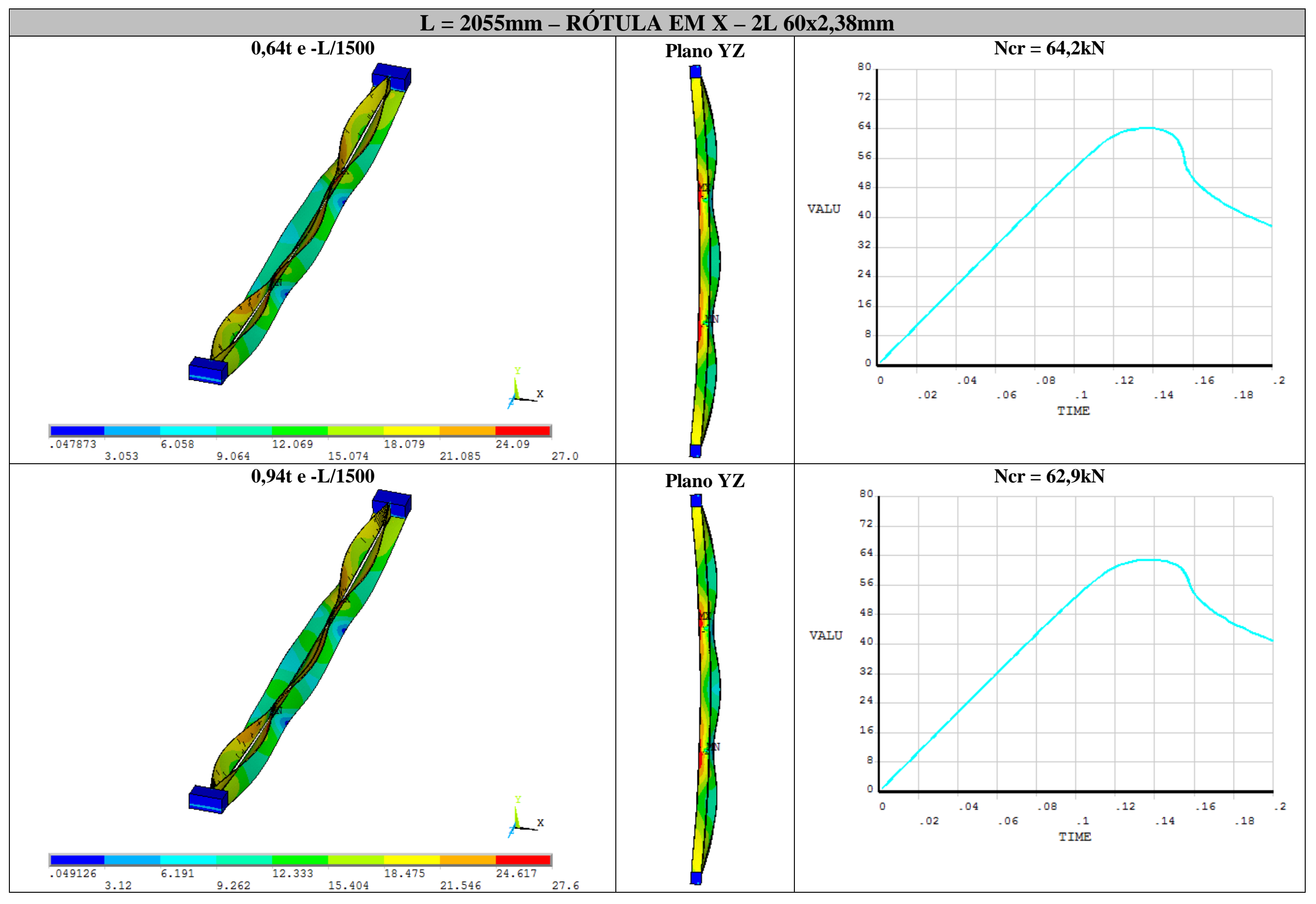


251

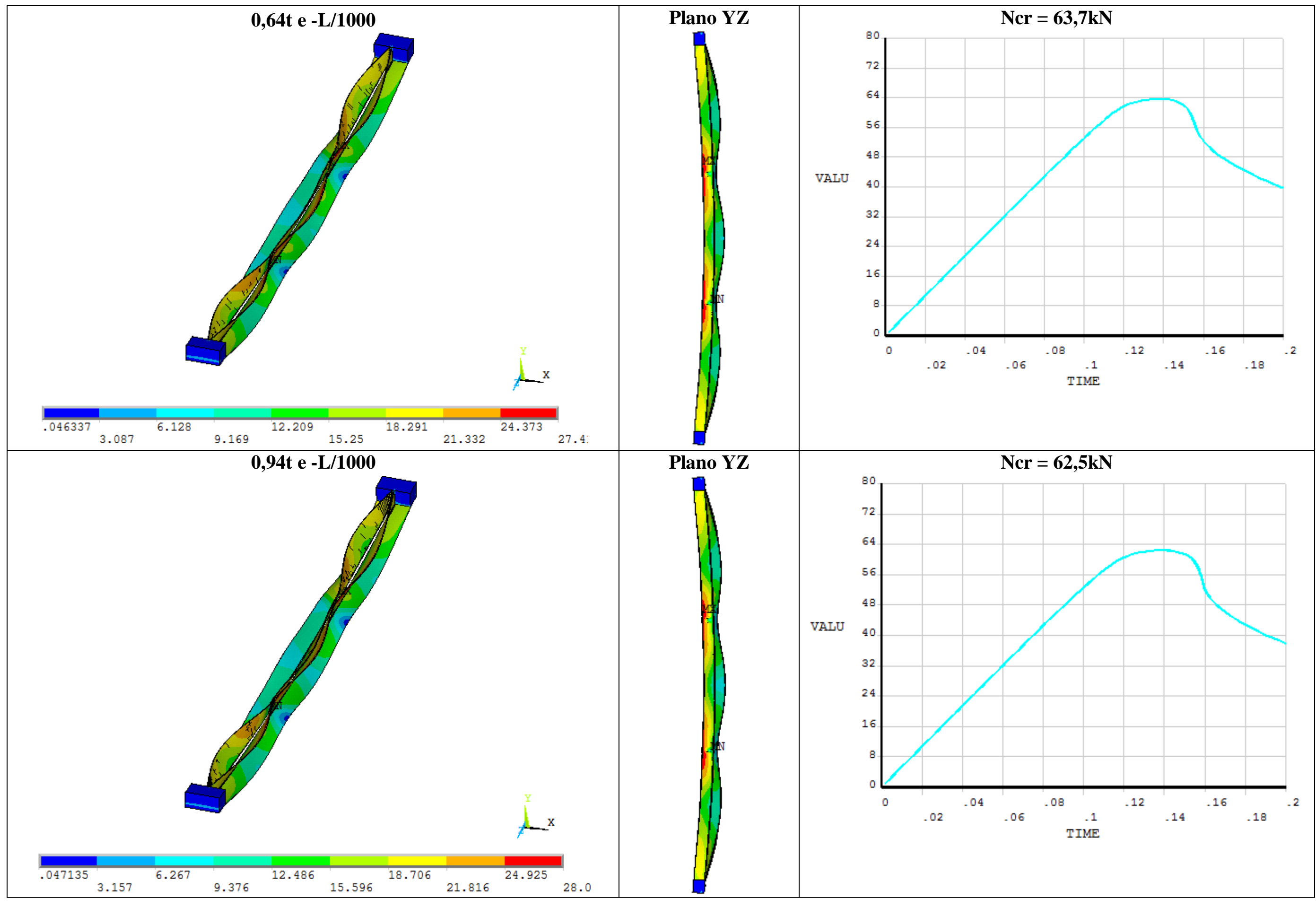




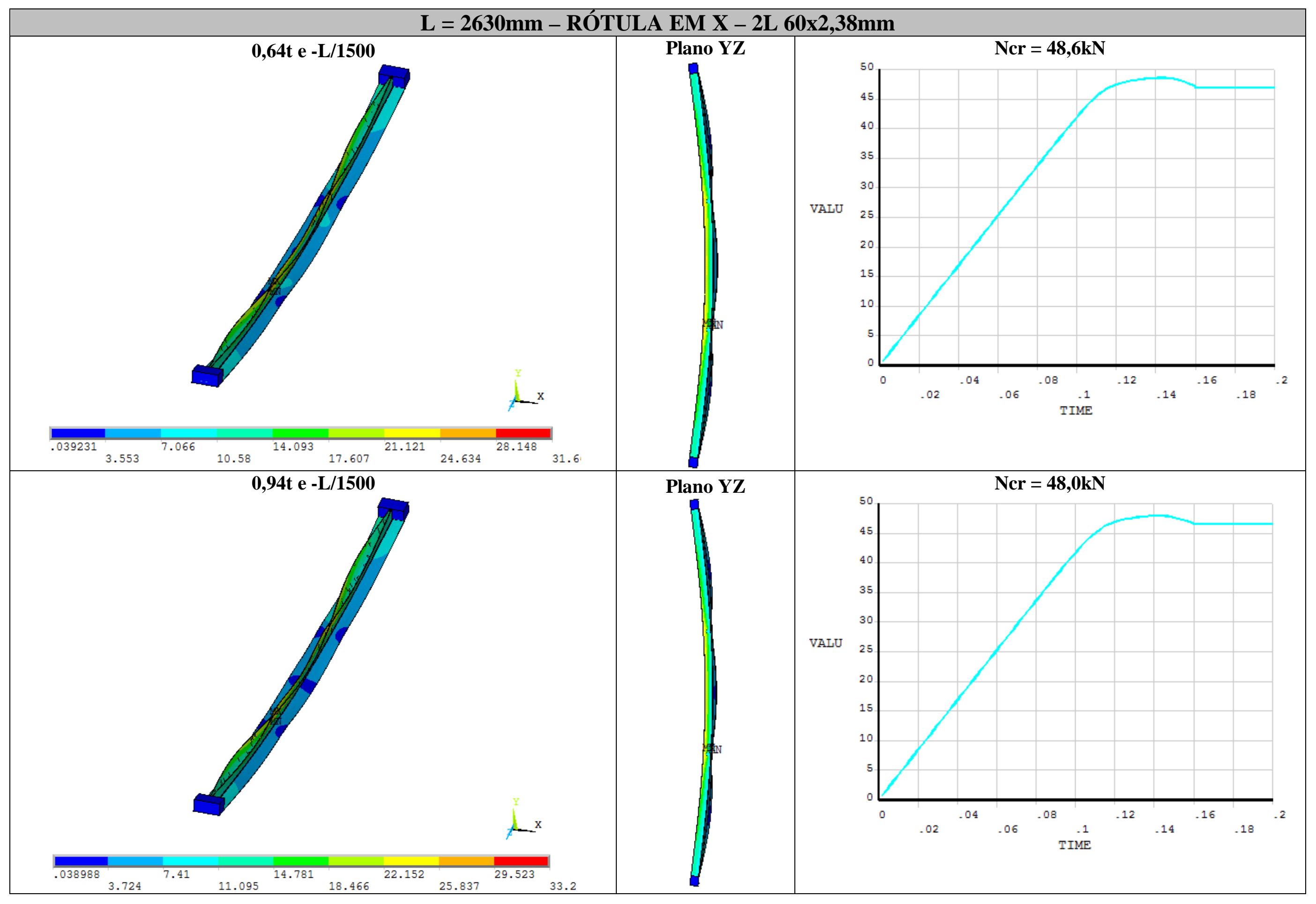




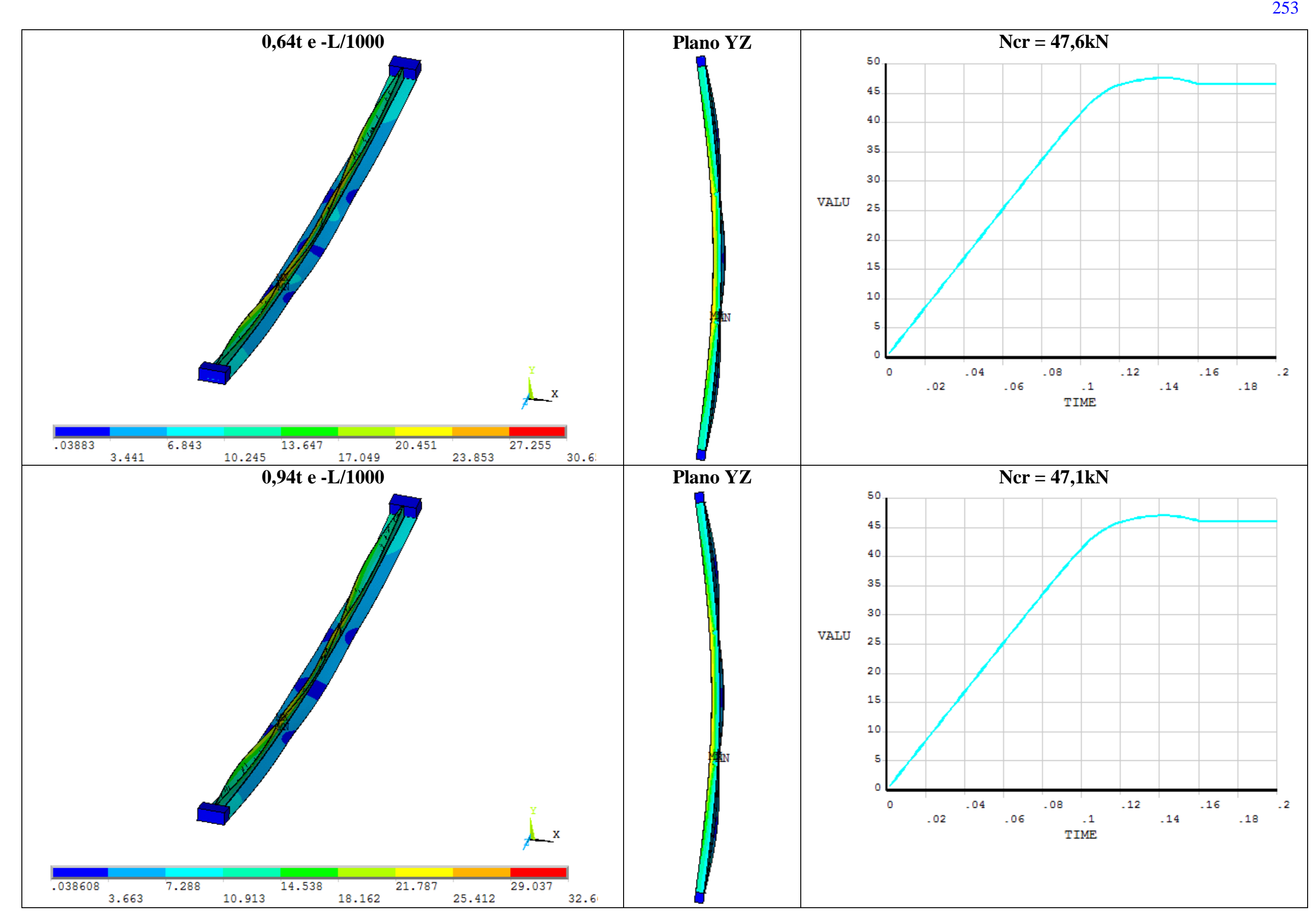




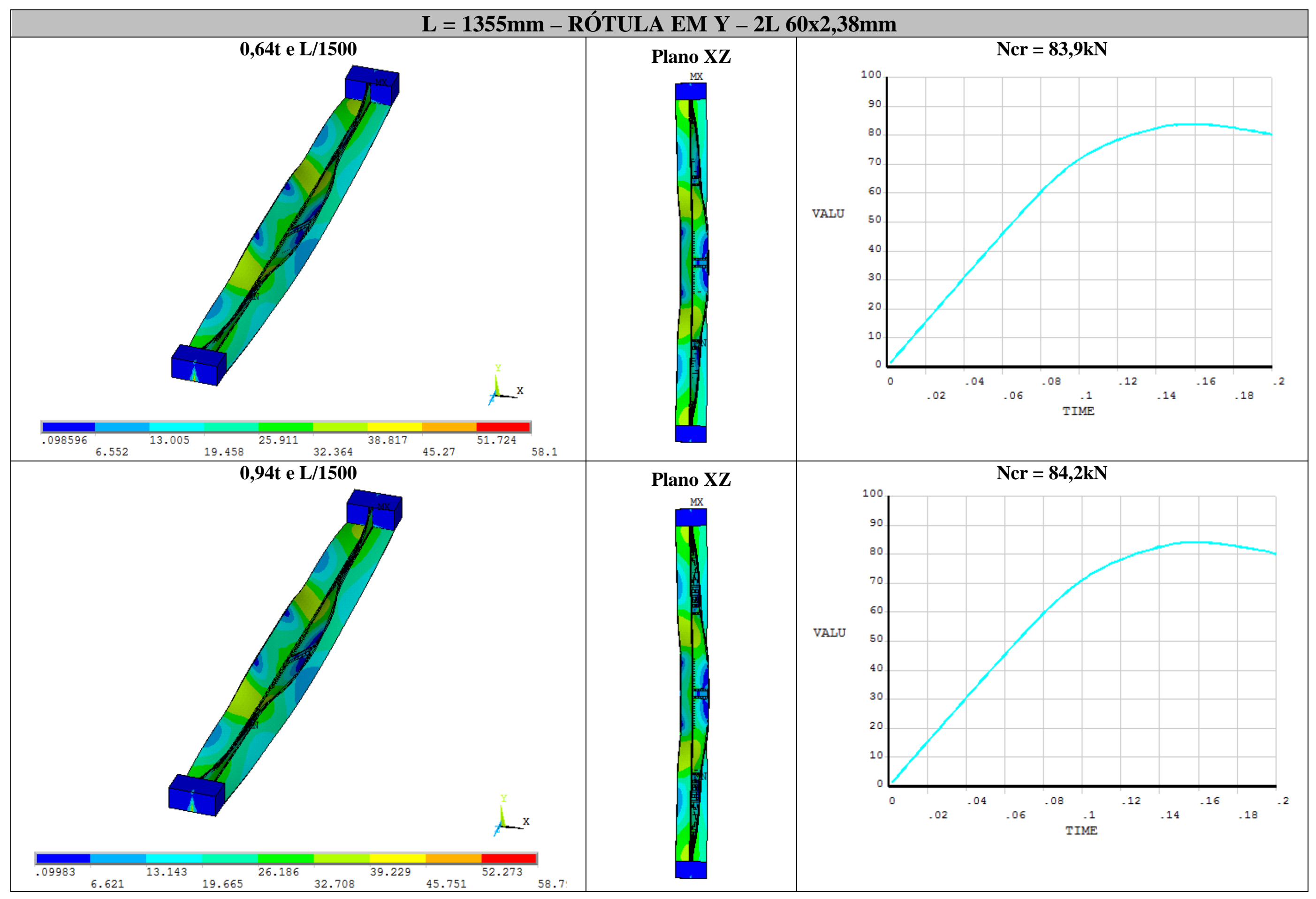




$$
\frac{1}{1} 1
$$




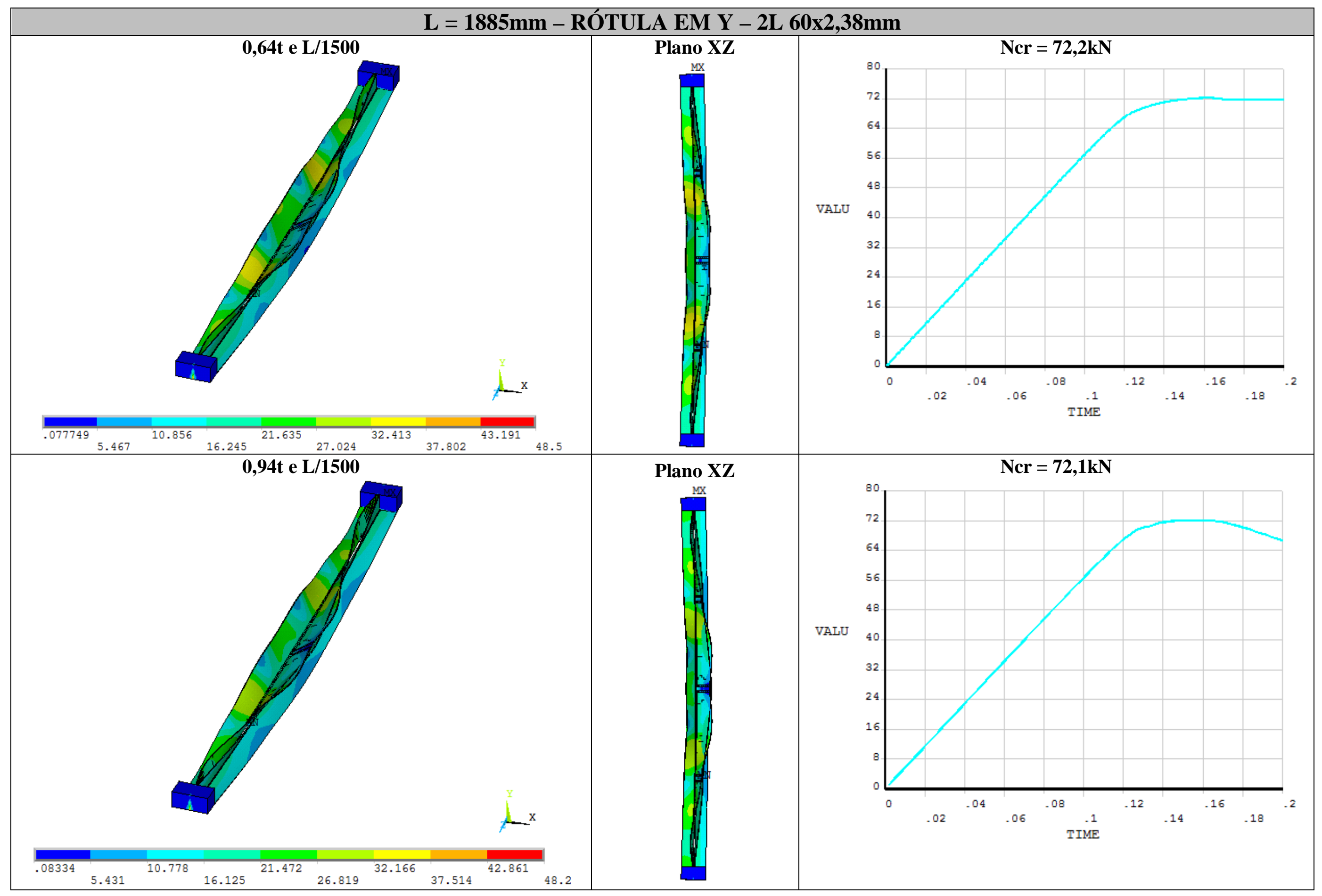


257

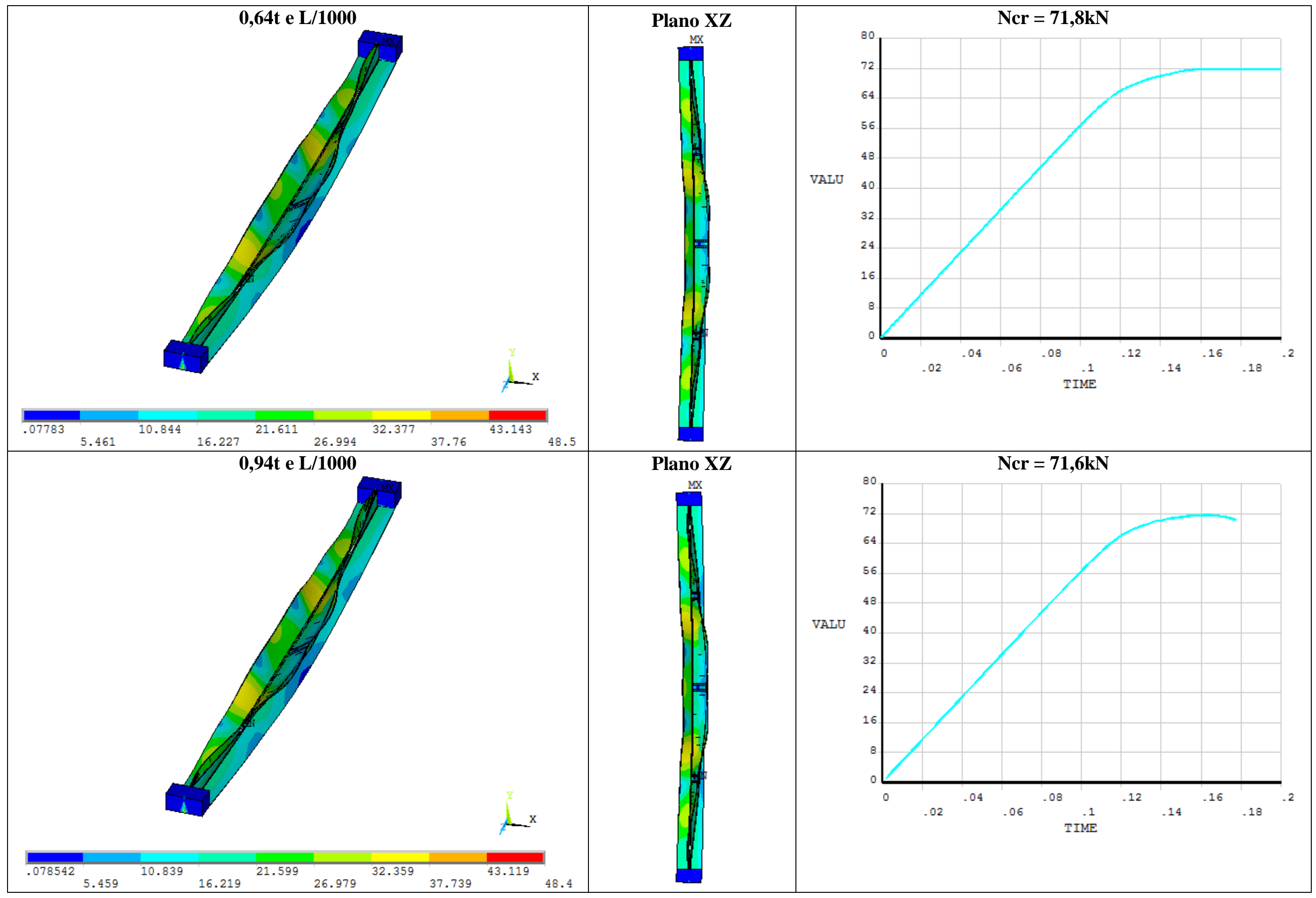




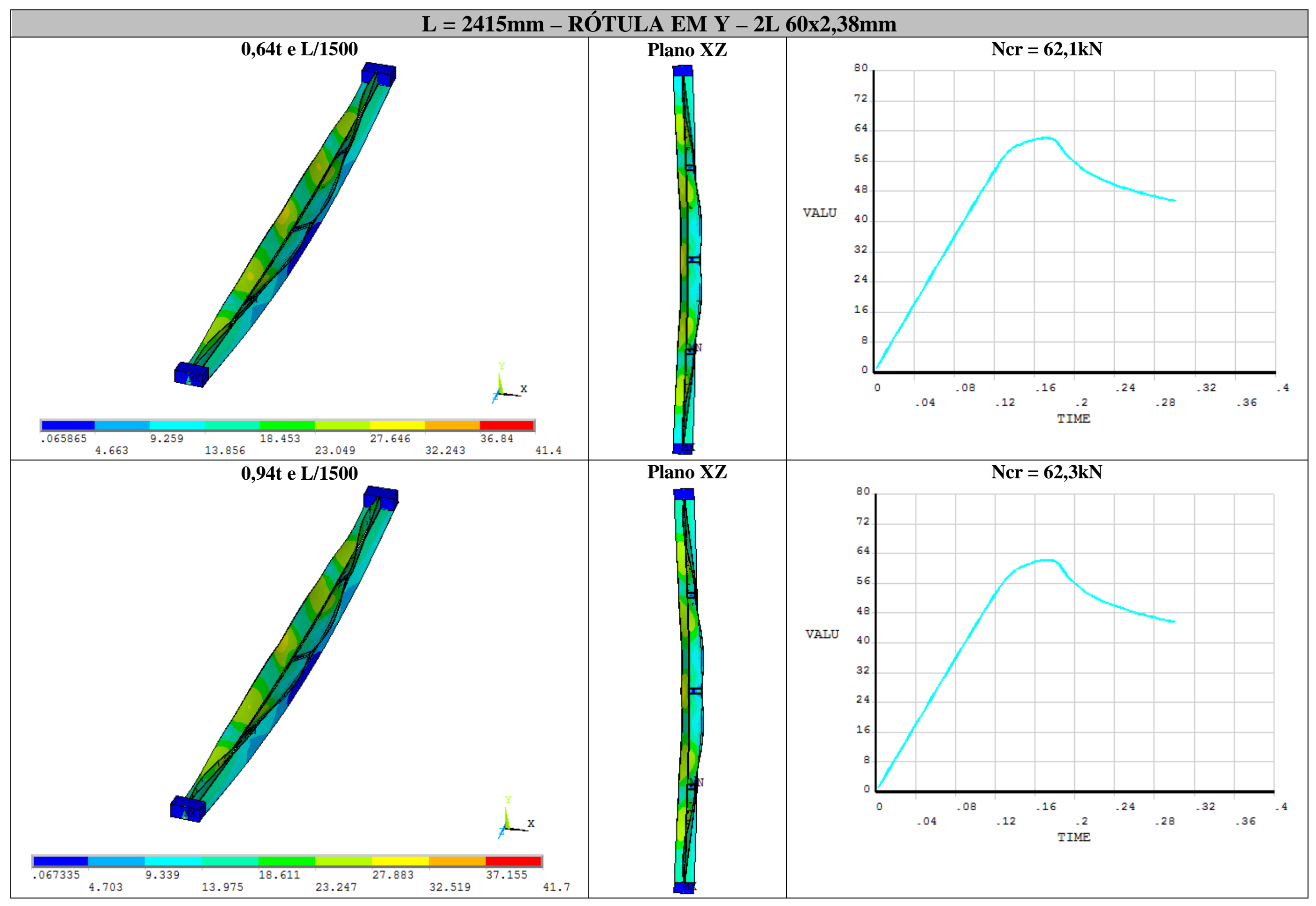


259

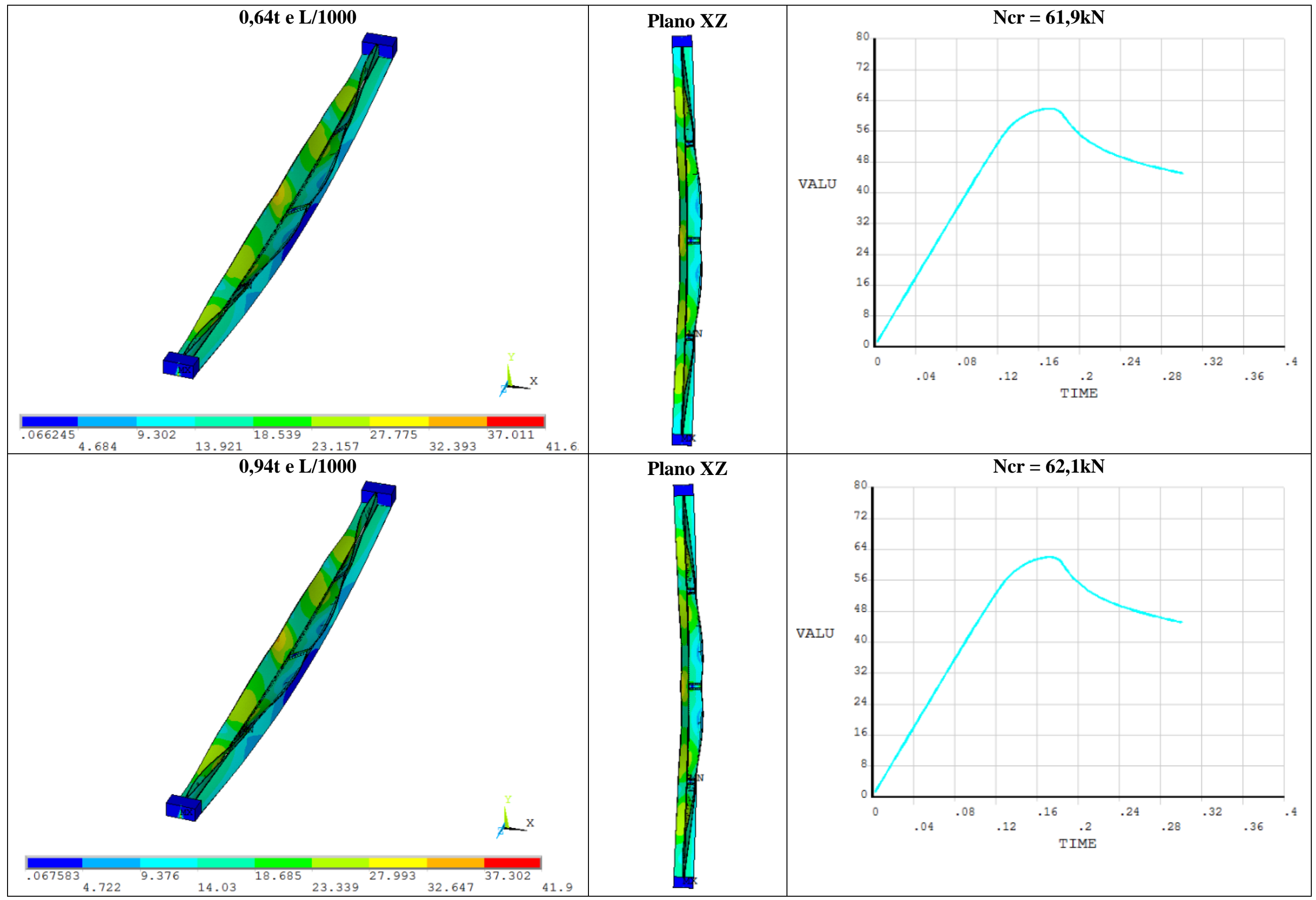




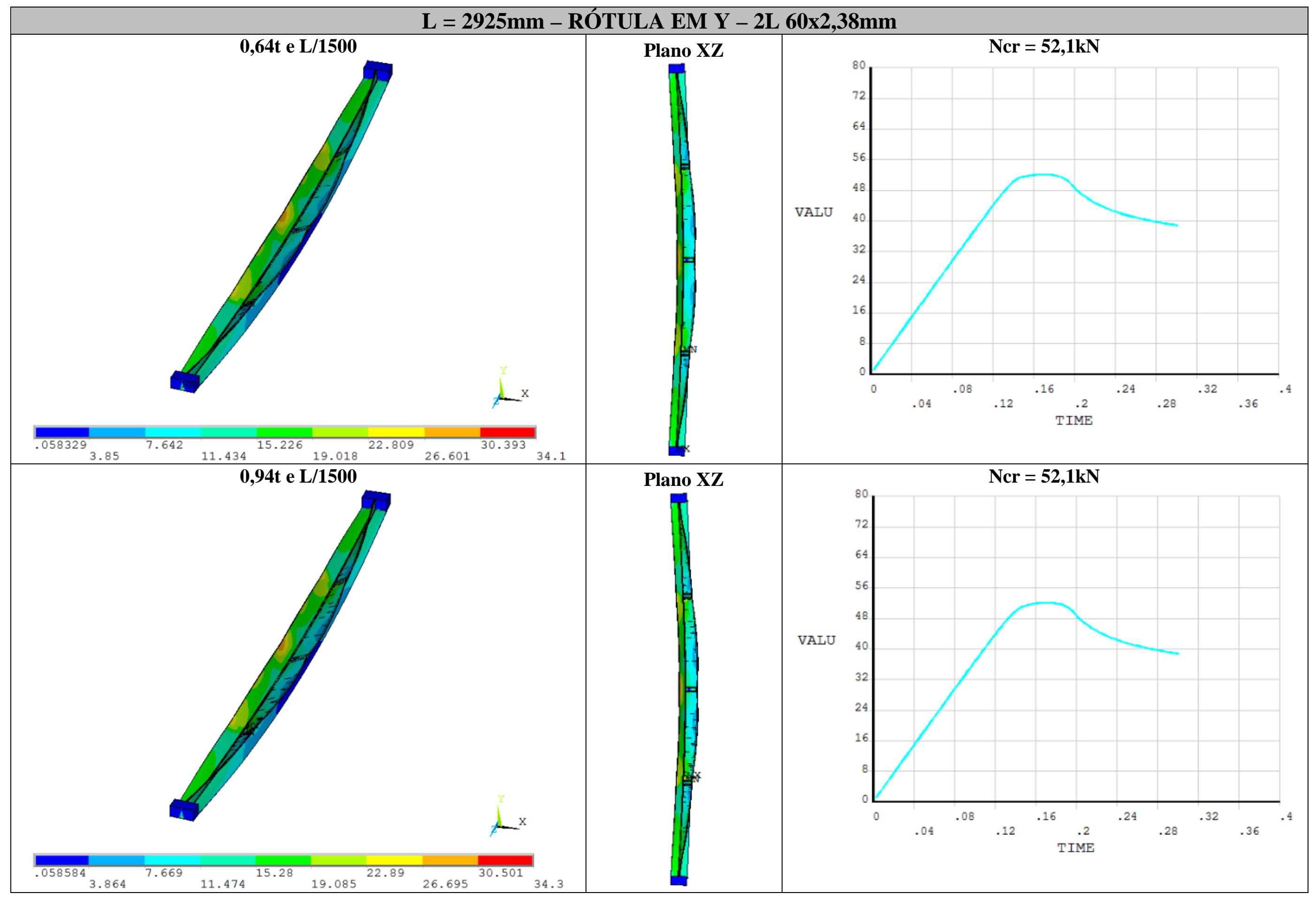




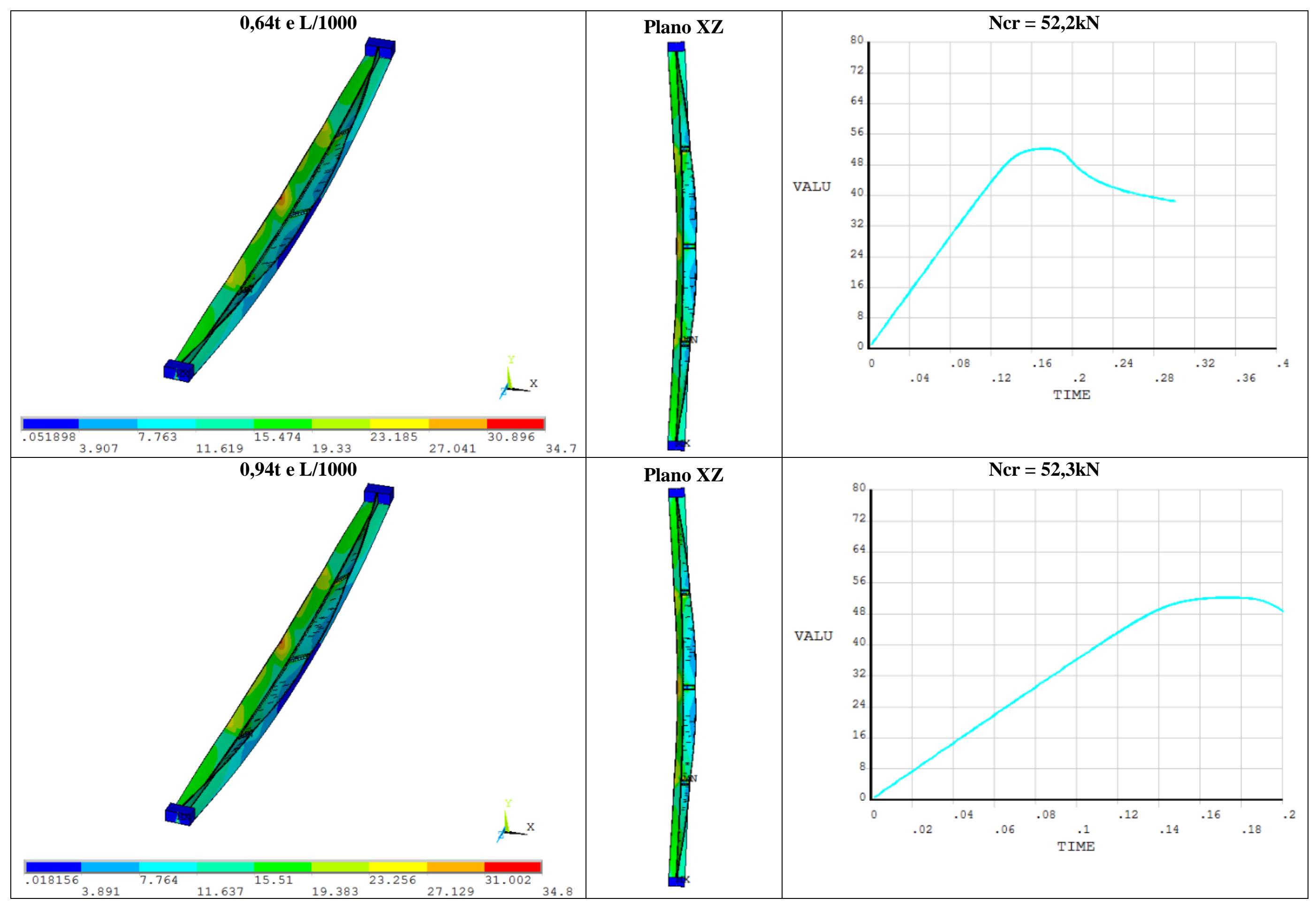




\section{APÊNDICE E - Resultados das análises à} temperatura ambiente: compressão excêntrica

Neste apêndice, são apresentadas as configurações deformadas dos perfis analisados sob compressão excêntrica no instante em que os mesmos perdem sua capacidade resistente. Além disso, são apresentados a distribuição de tensões (von Mises) nas chapas das cantoneiras e gráficos que relacionam a força normal de compressão aplicada ao deslocamento axial do topo dos perfis (de onde se obtém a força normal de compressão resistente dos perfis). 


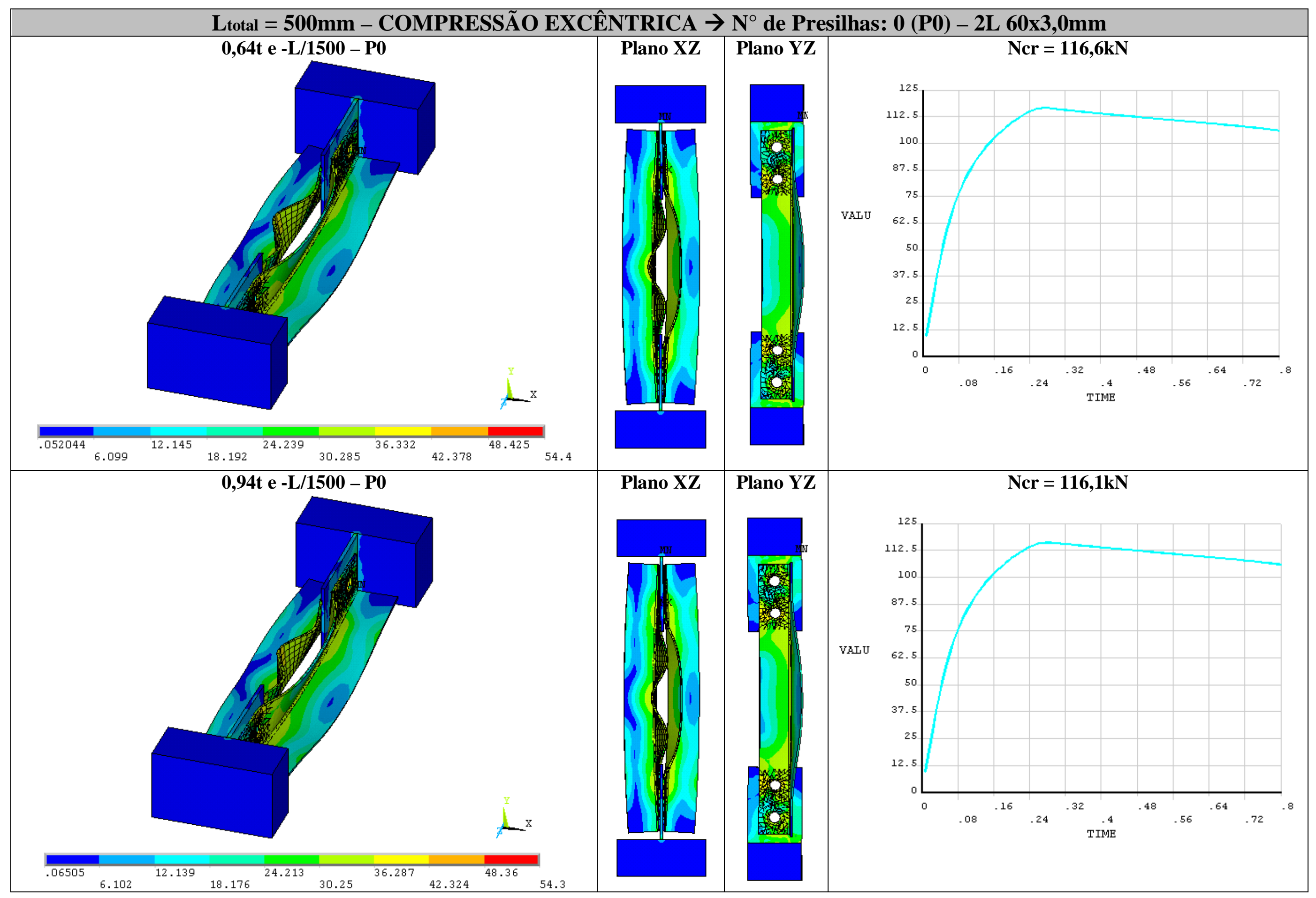




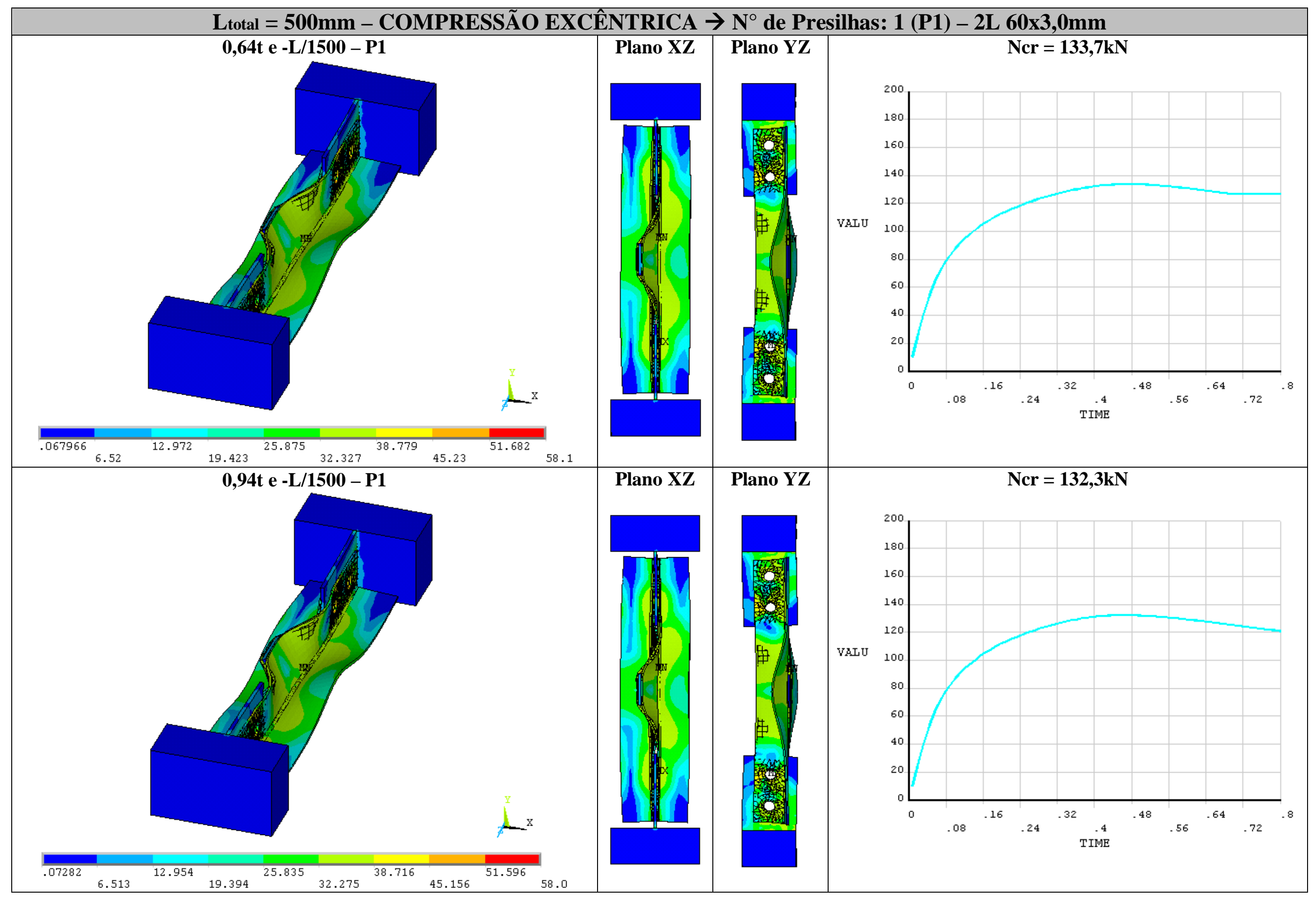




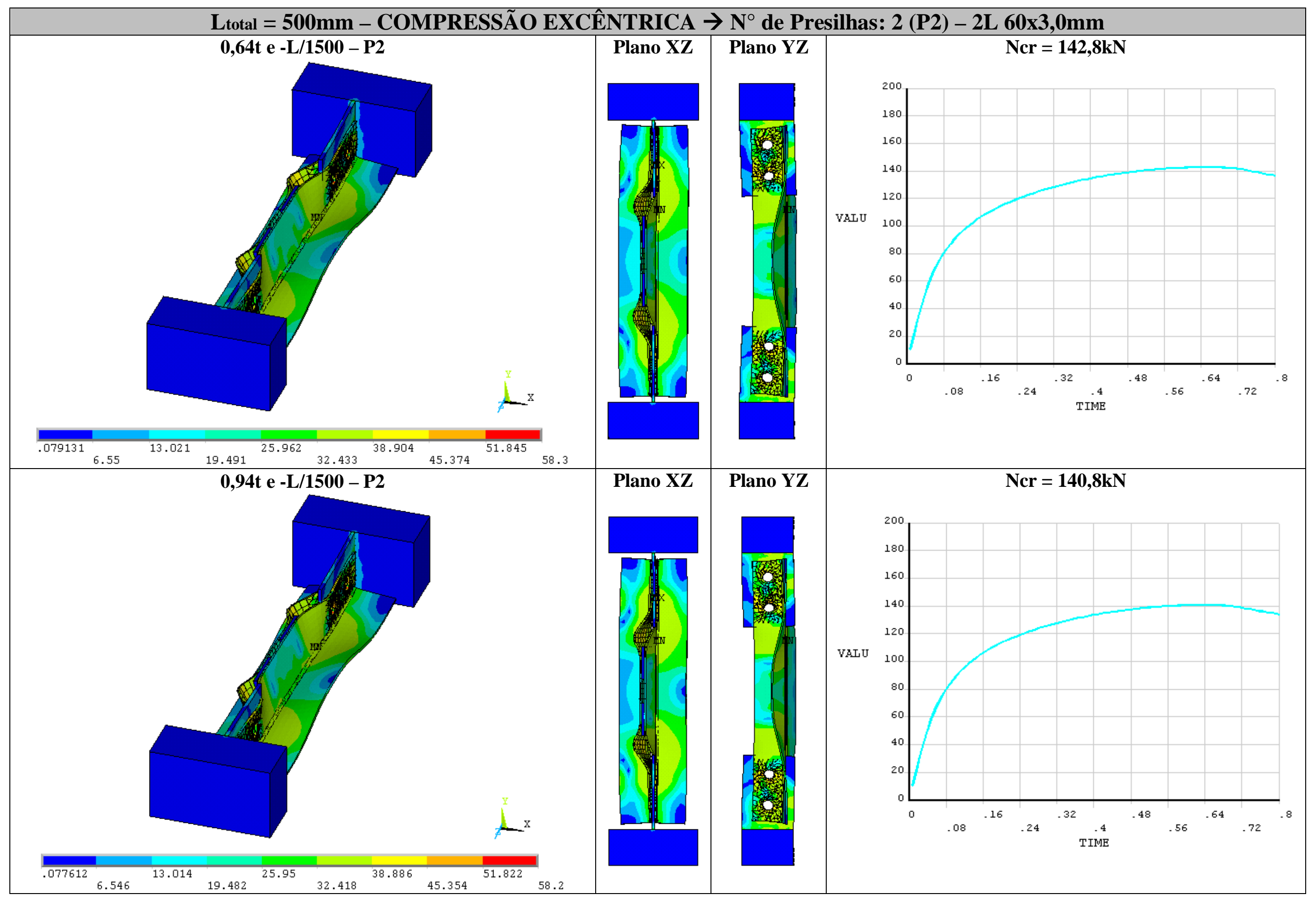




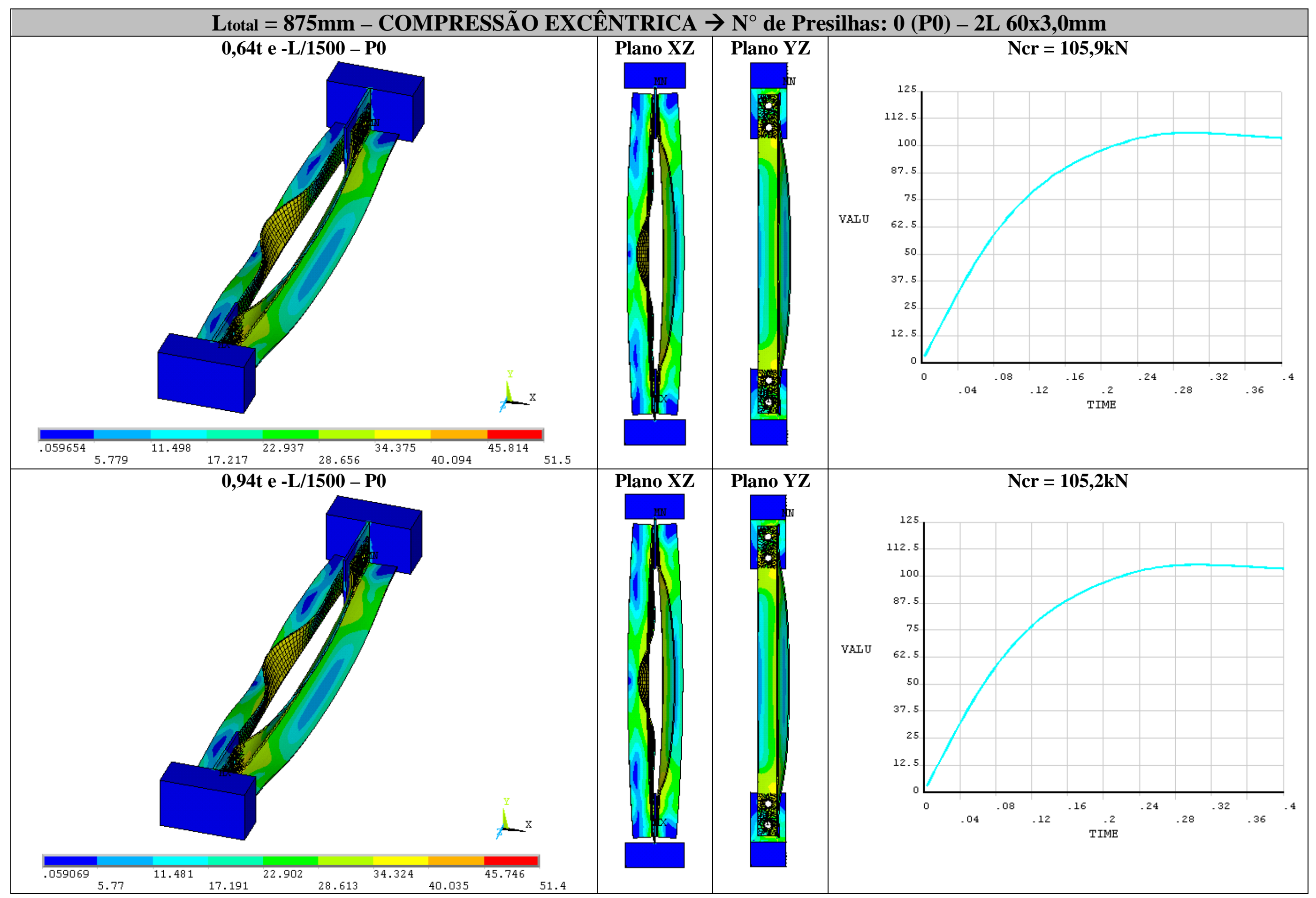




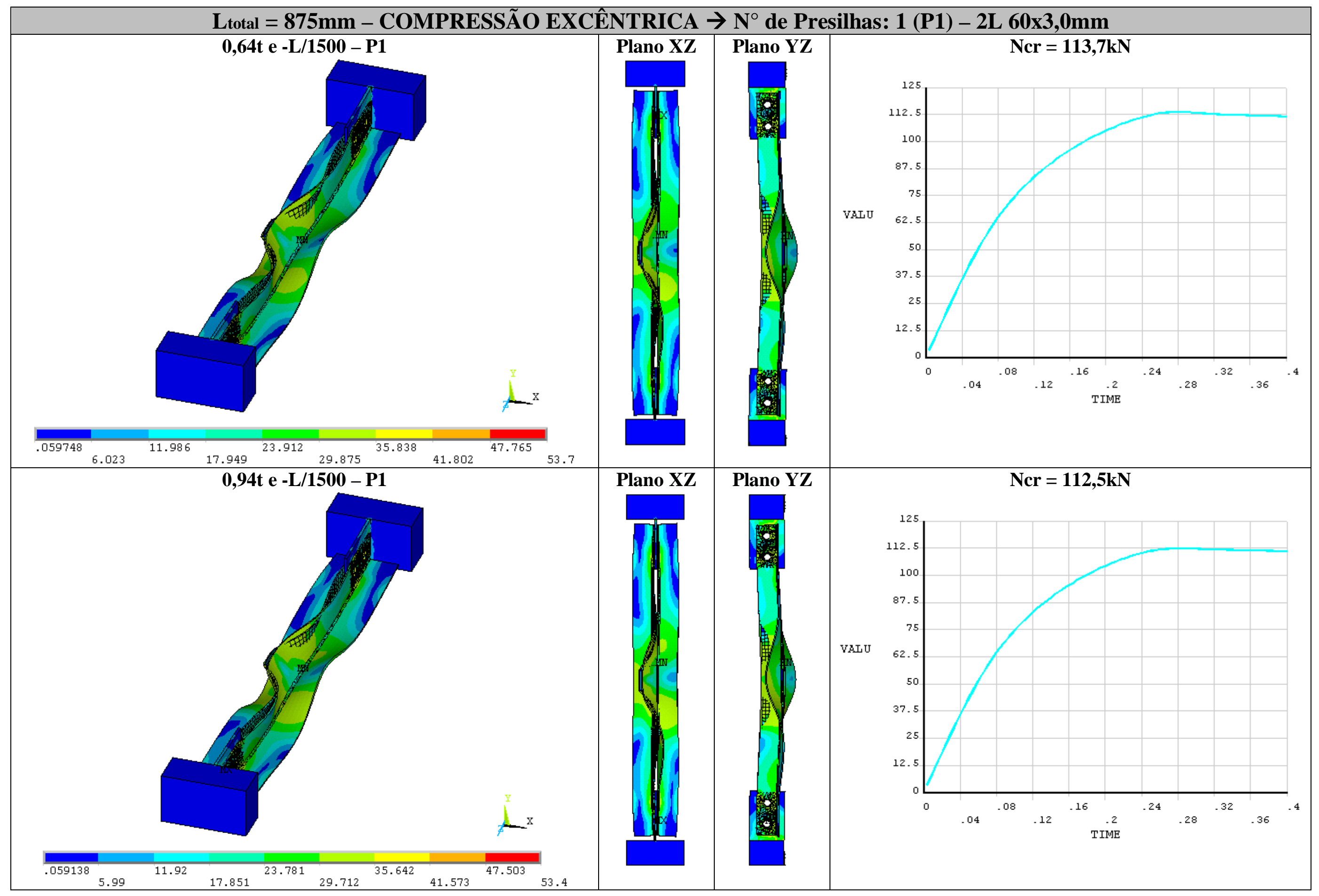




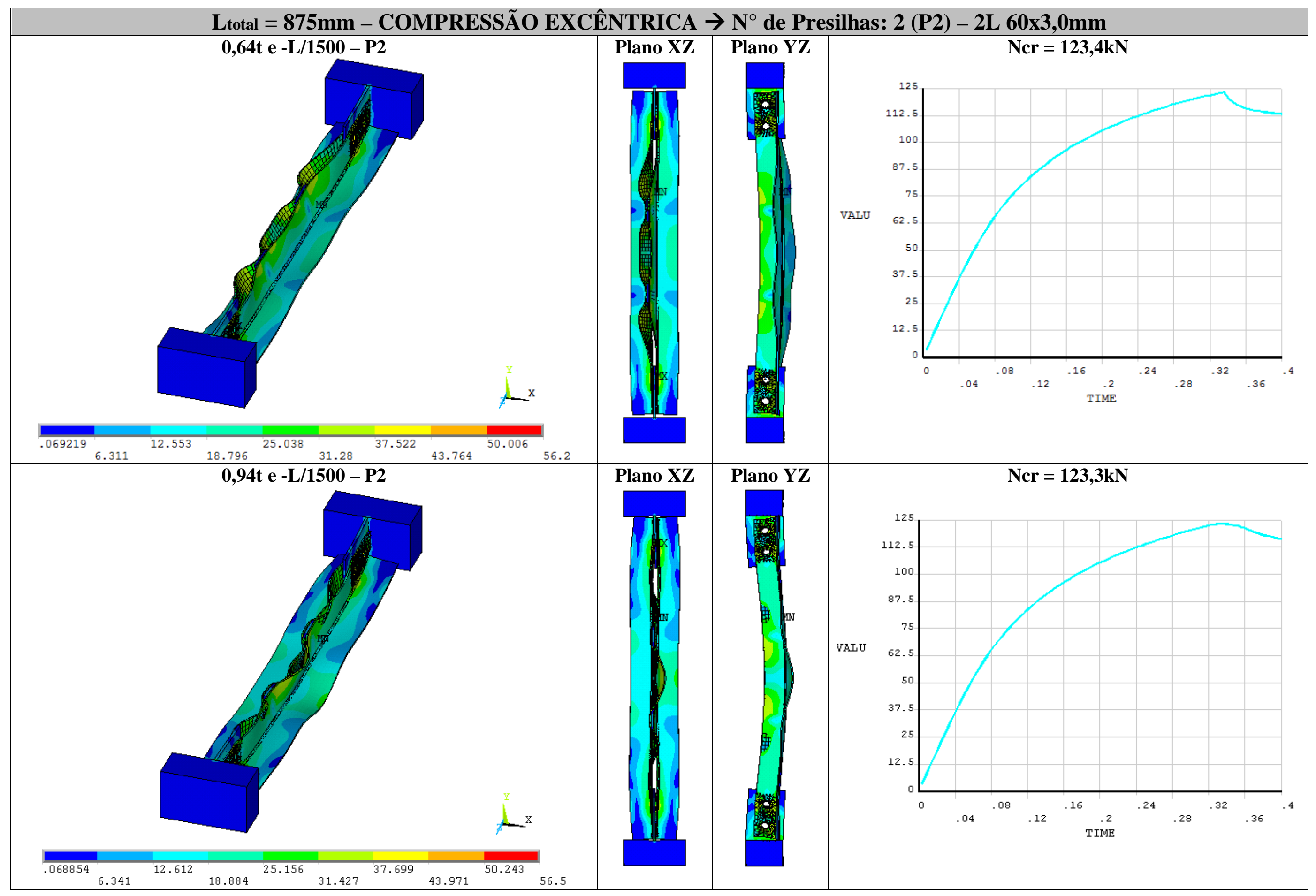




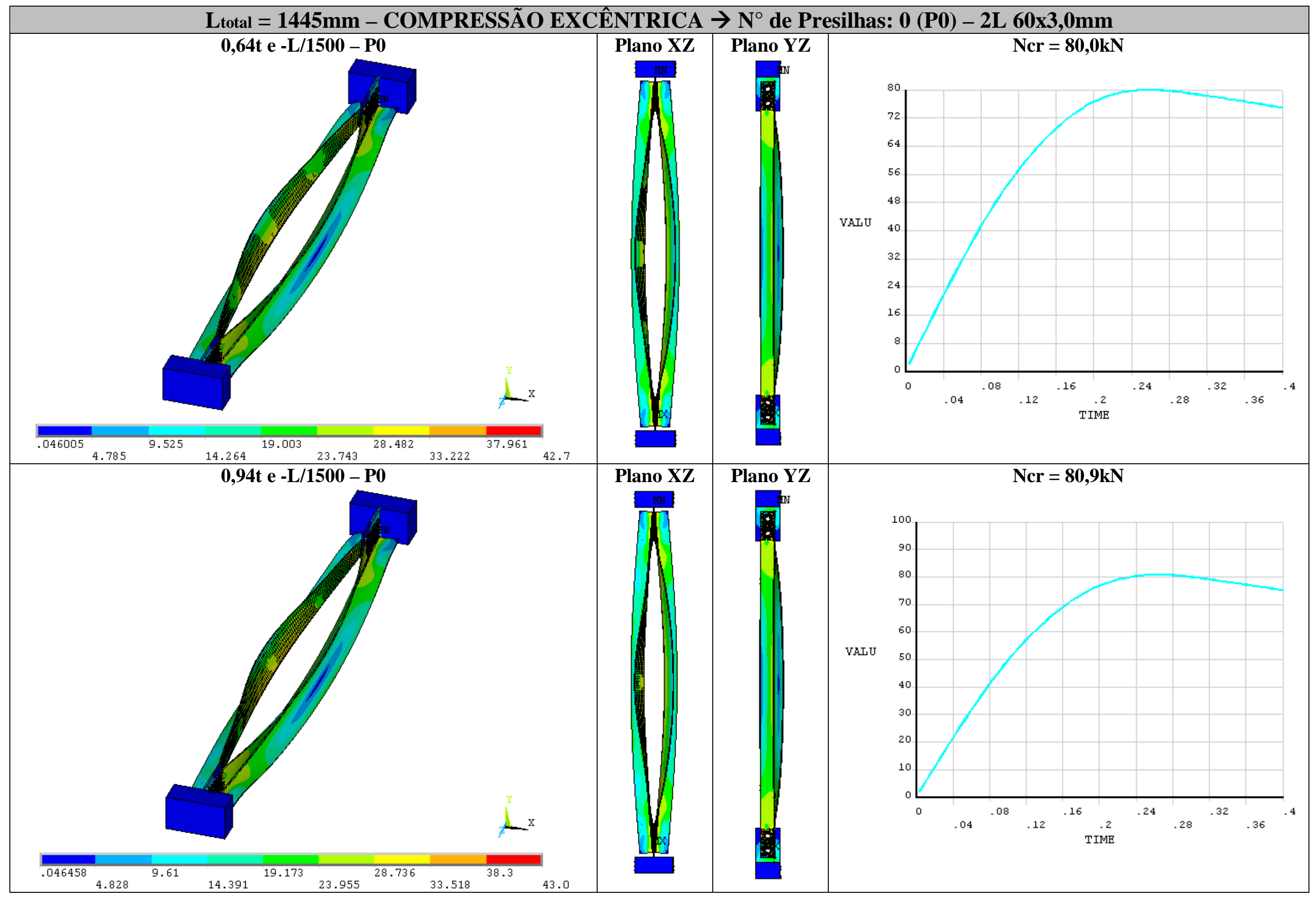




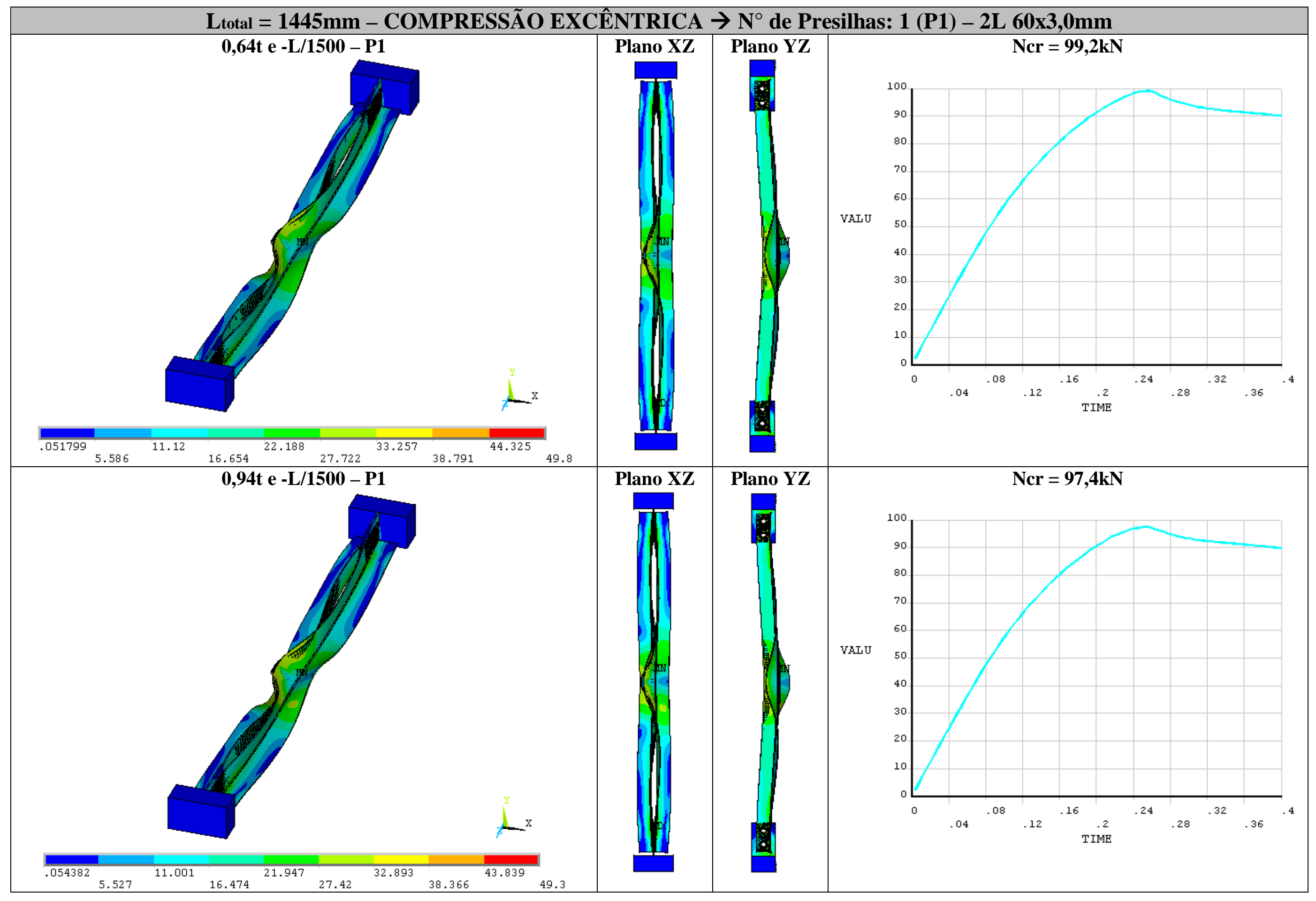




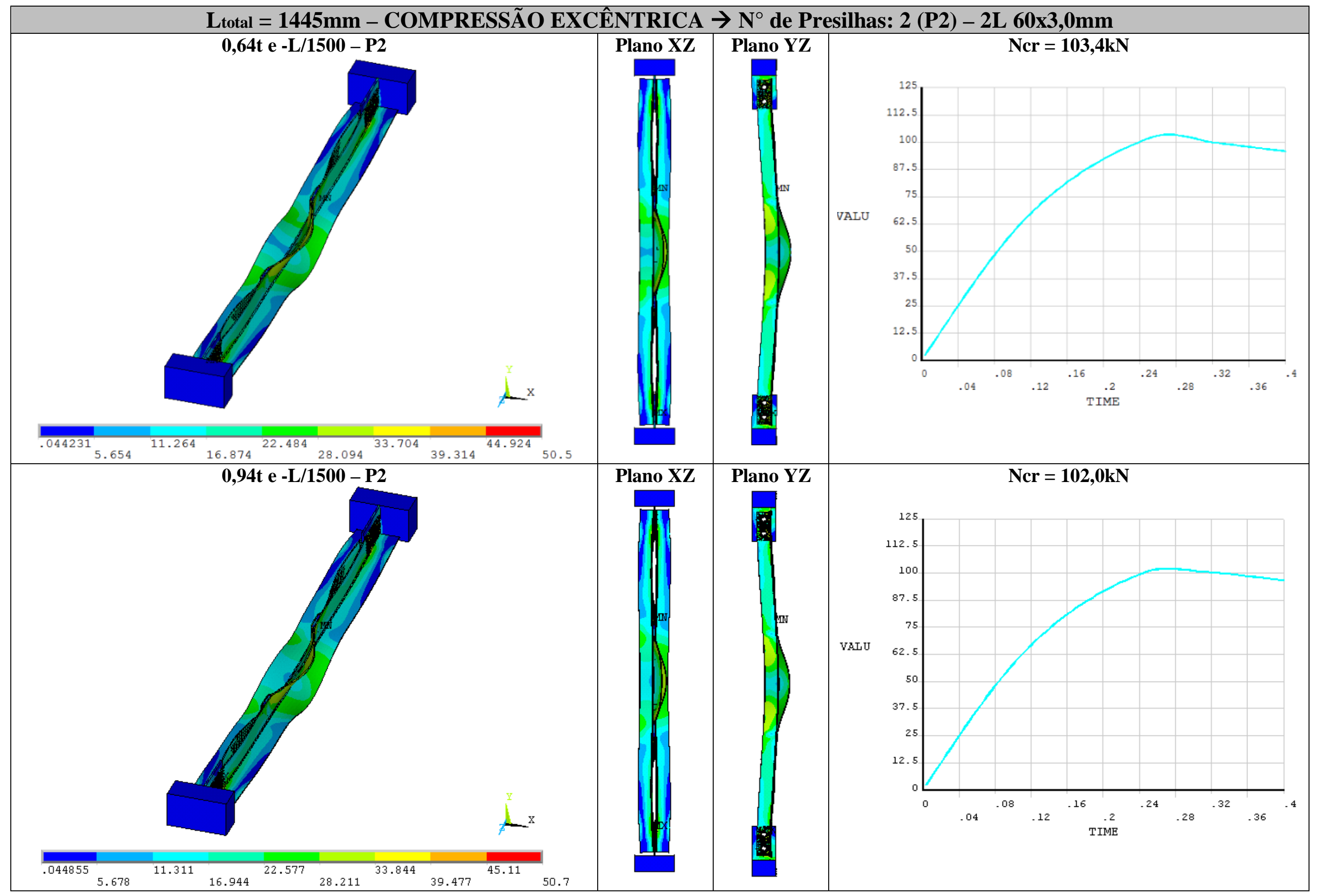




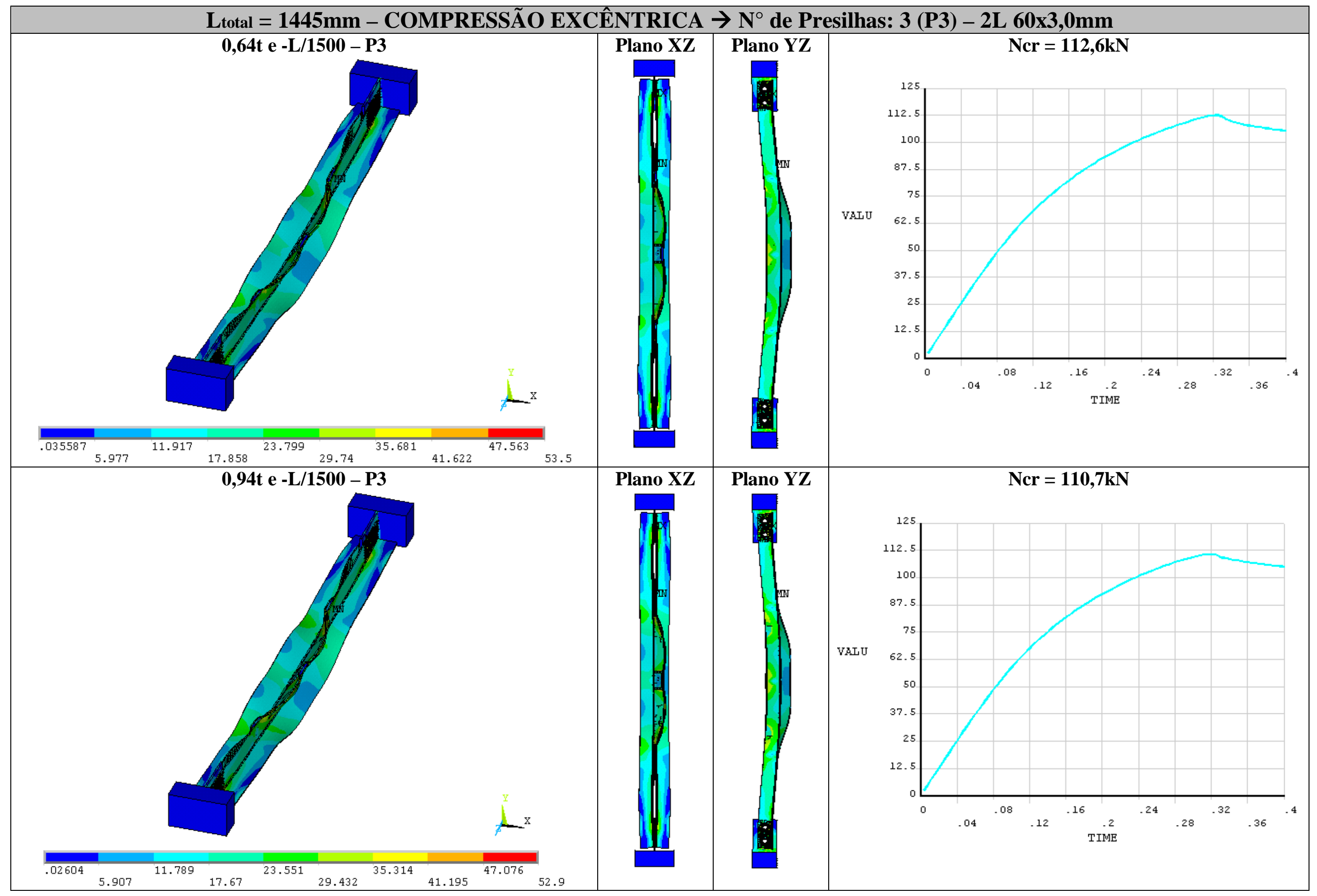




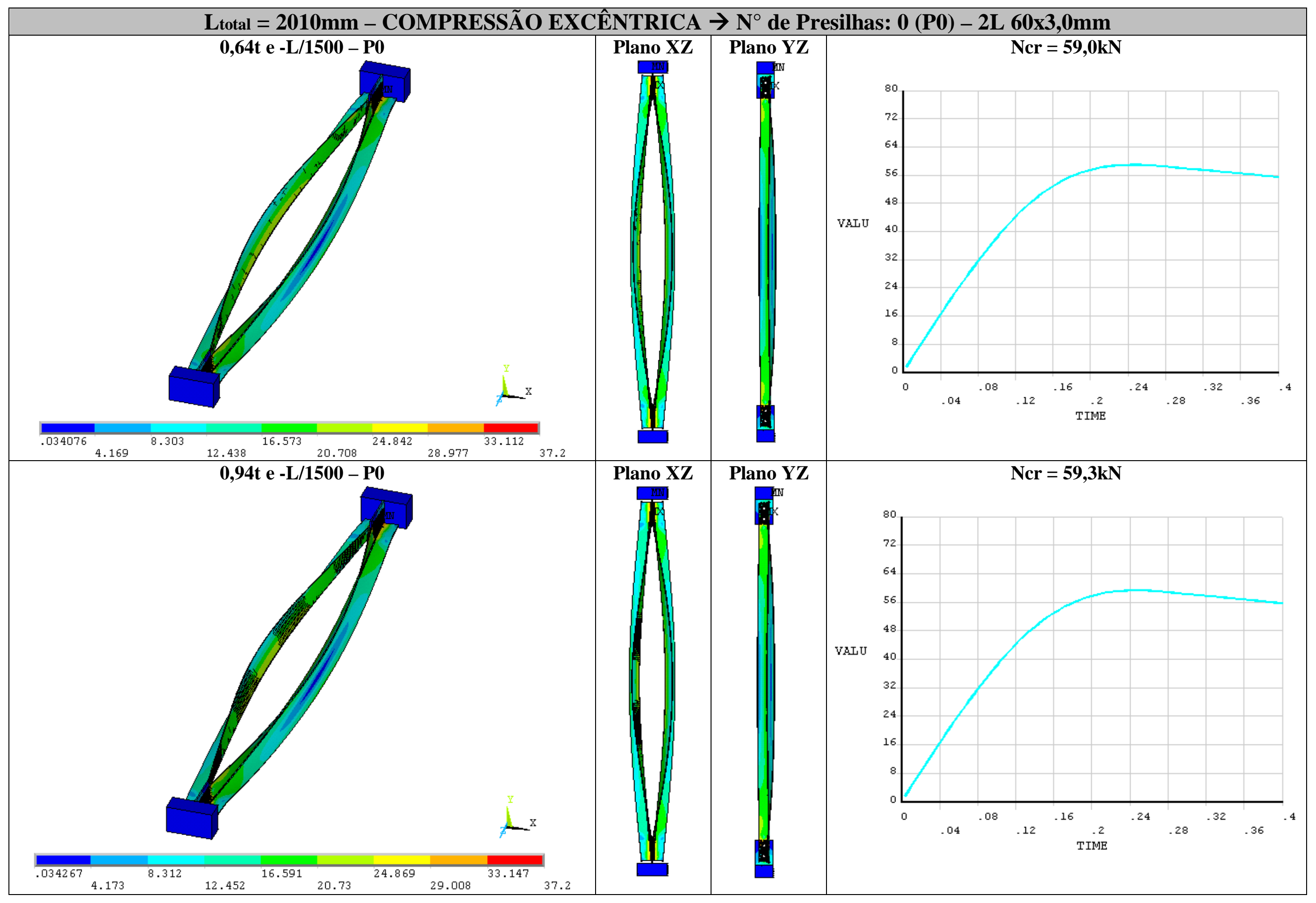




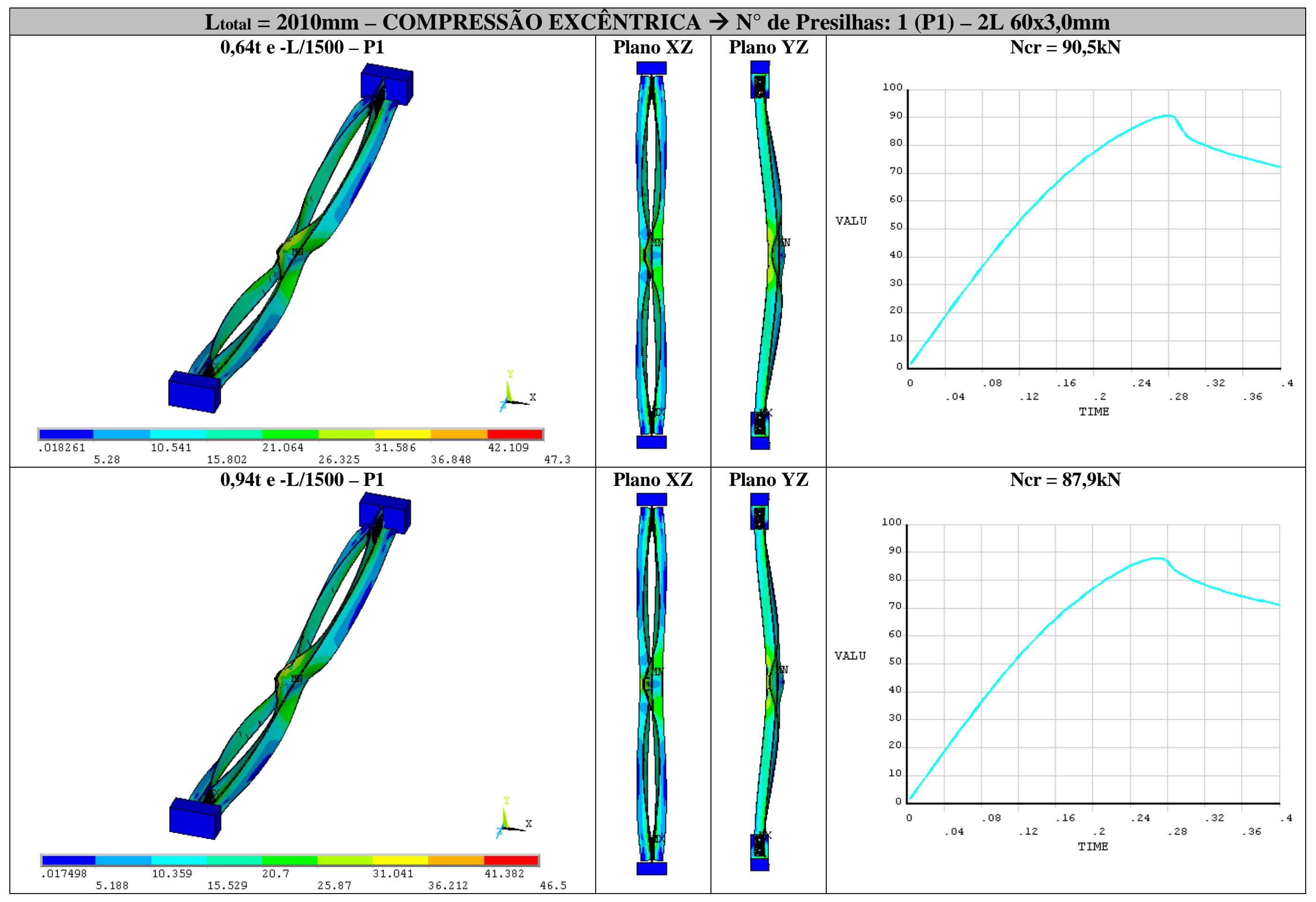




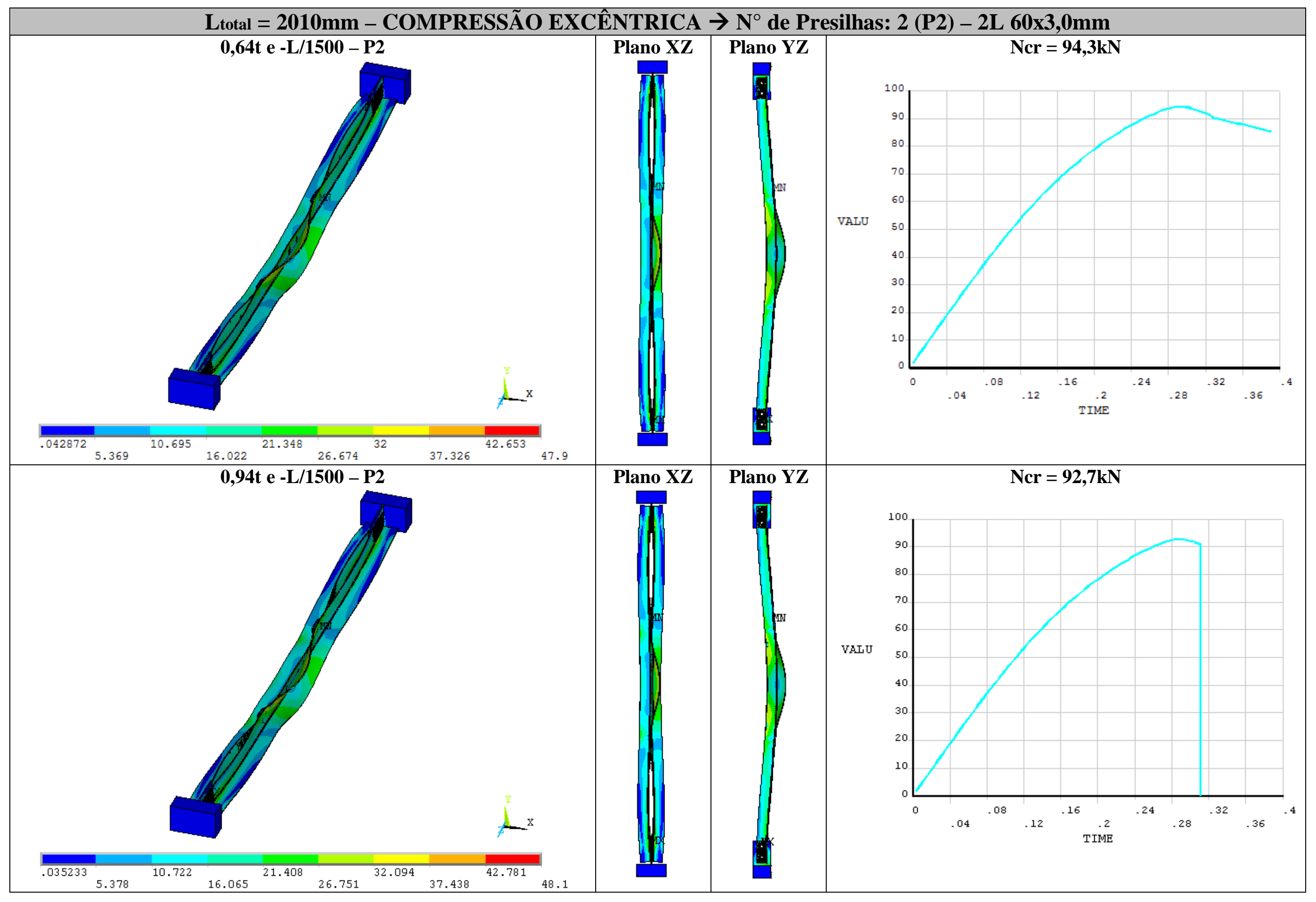




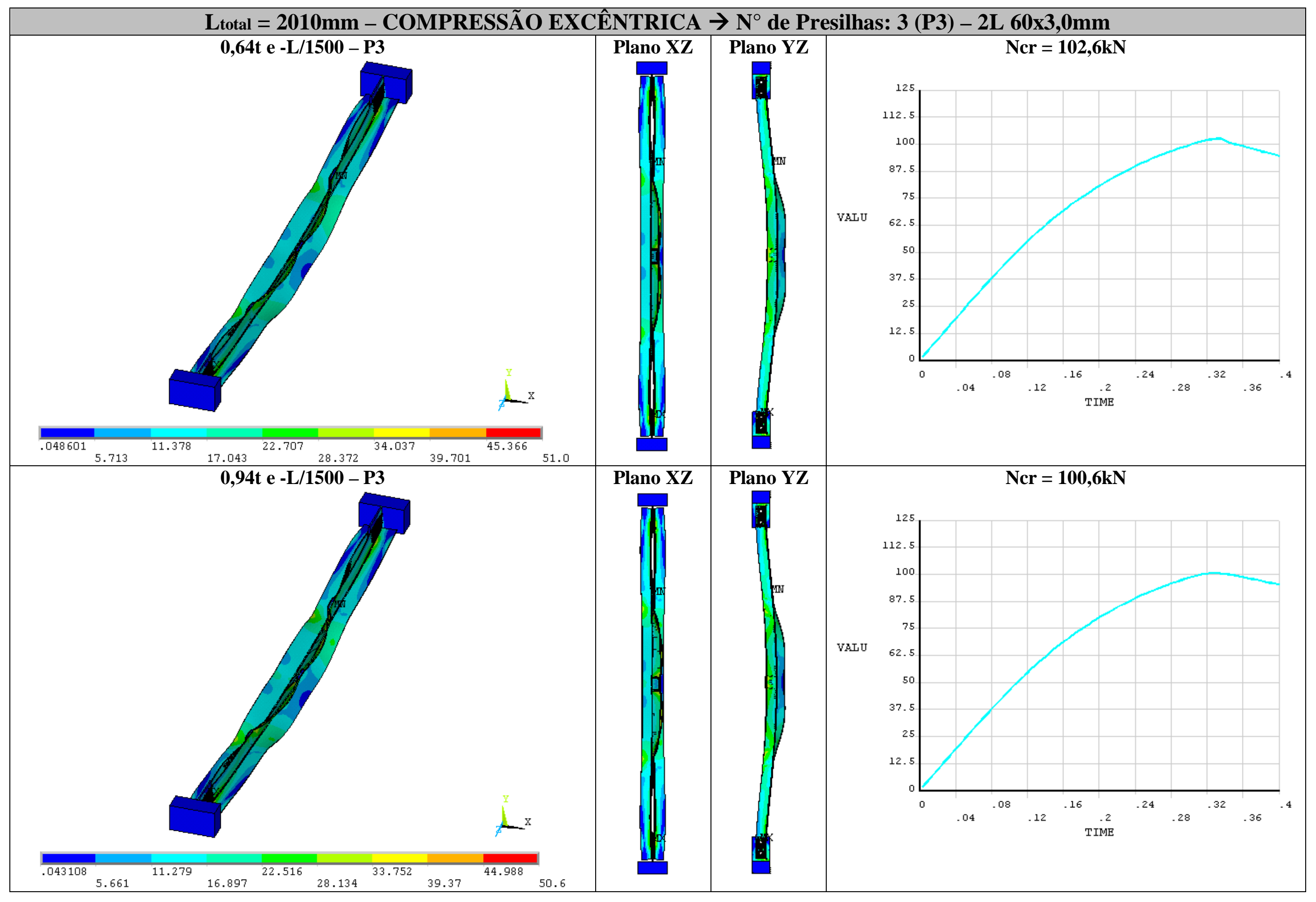




$$
\frac{1}{1}
$$




$$
\frac{l}{l} \|
$$




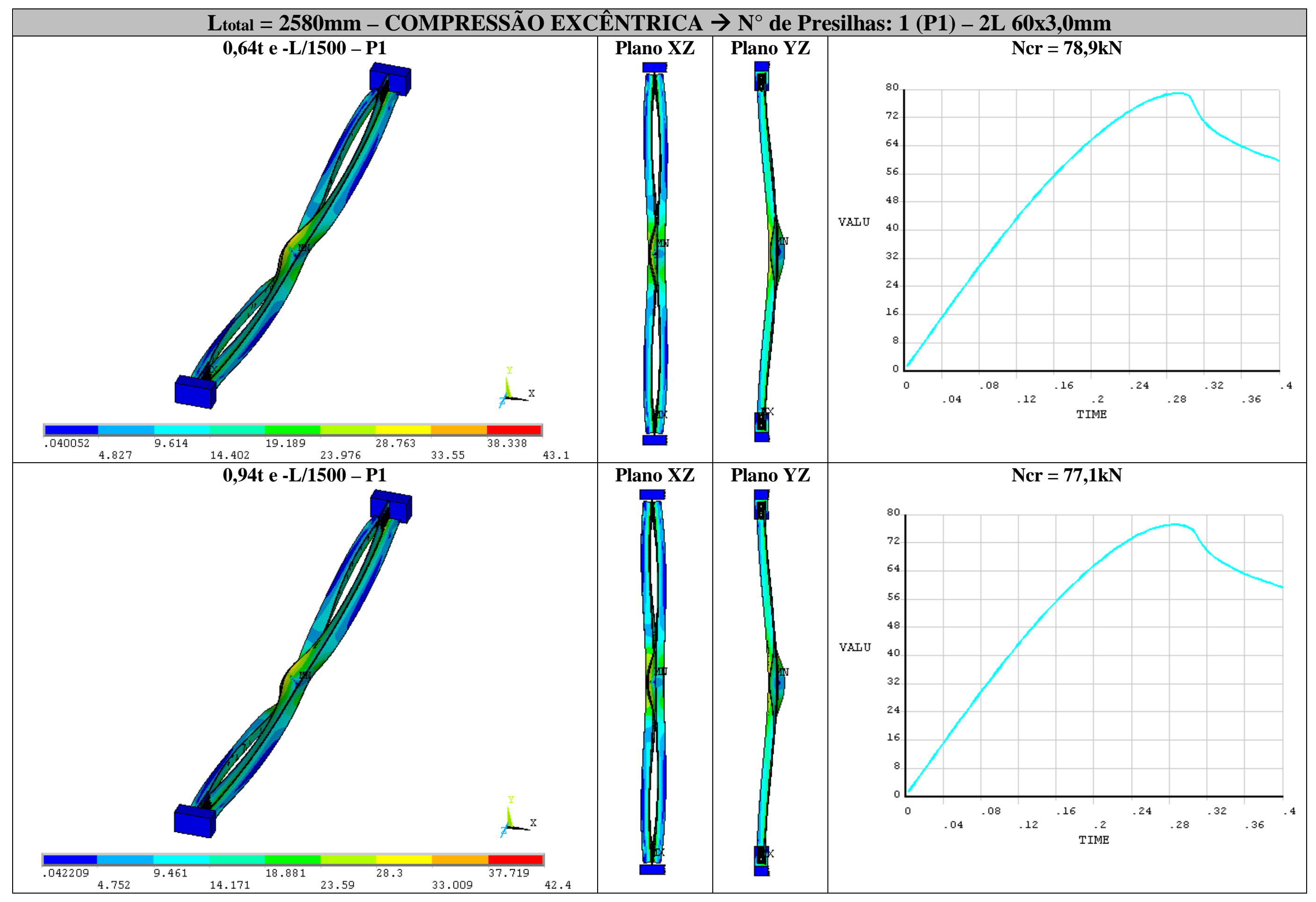




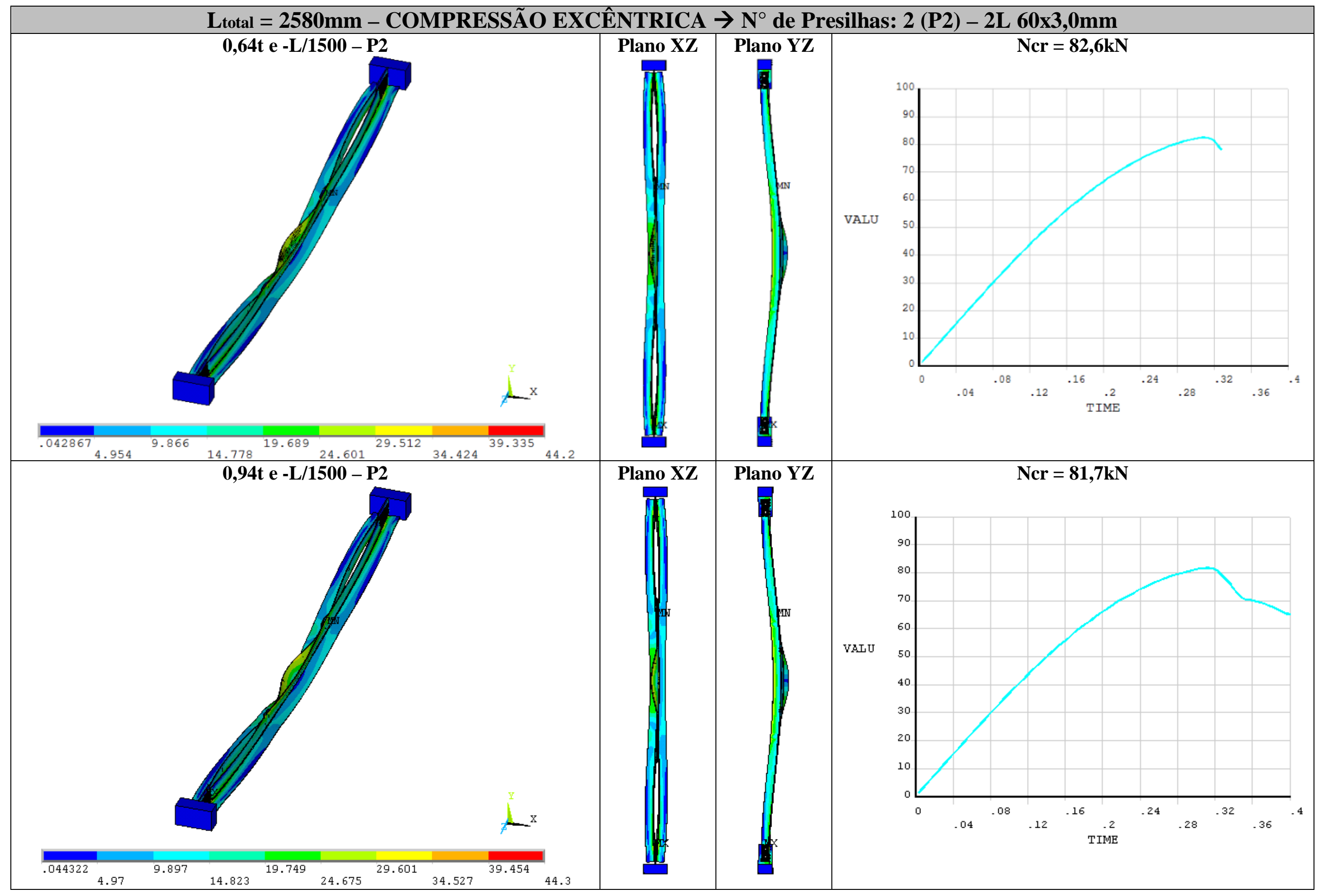




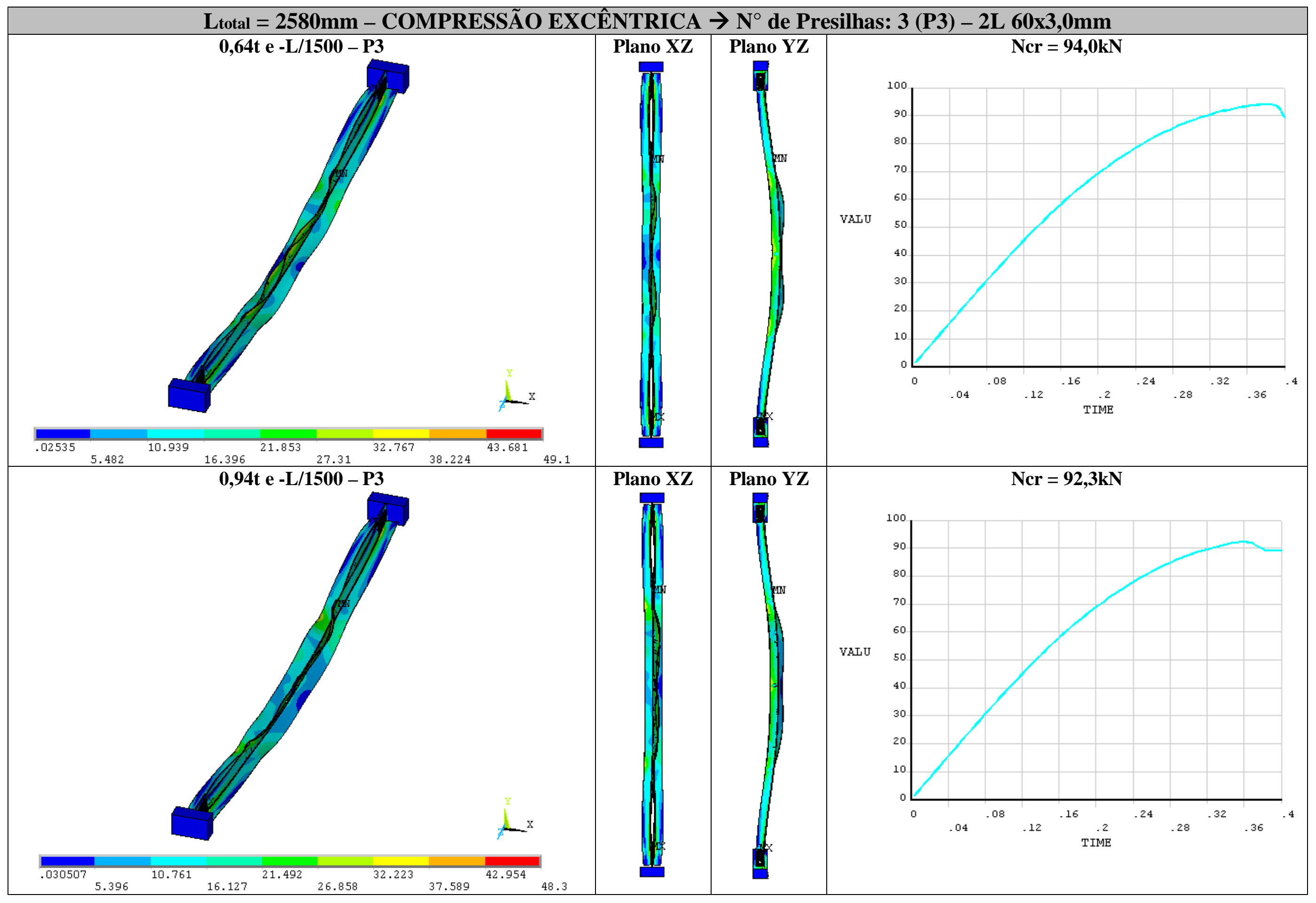


Ltotal $=2580 \mathrm{~mm}-$ COMPRESSÃO EXCÊNTRICA $\rightarrow \mathrm{N}^{\circ}$ de Presilhas: 4 (P4) $-2 \mathrm{~L}$ 60x3,0mm

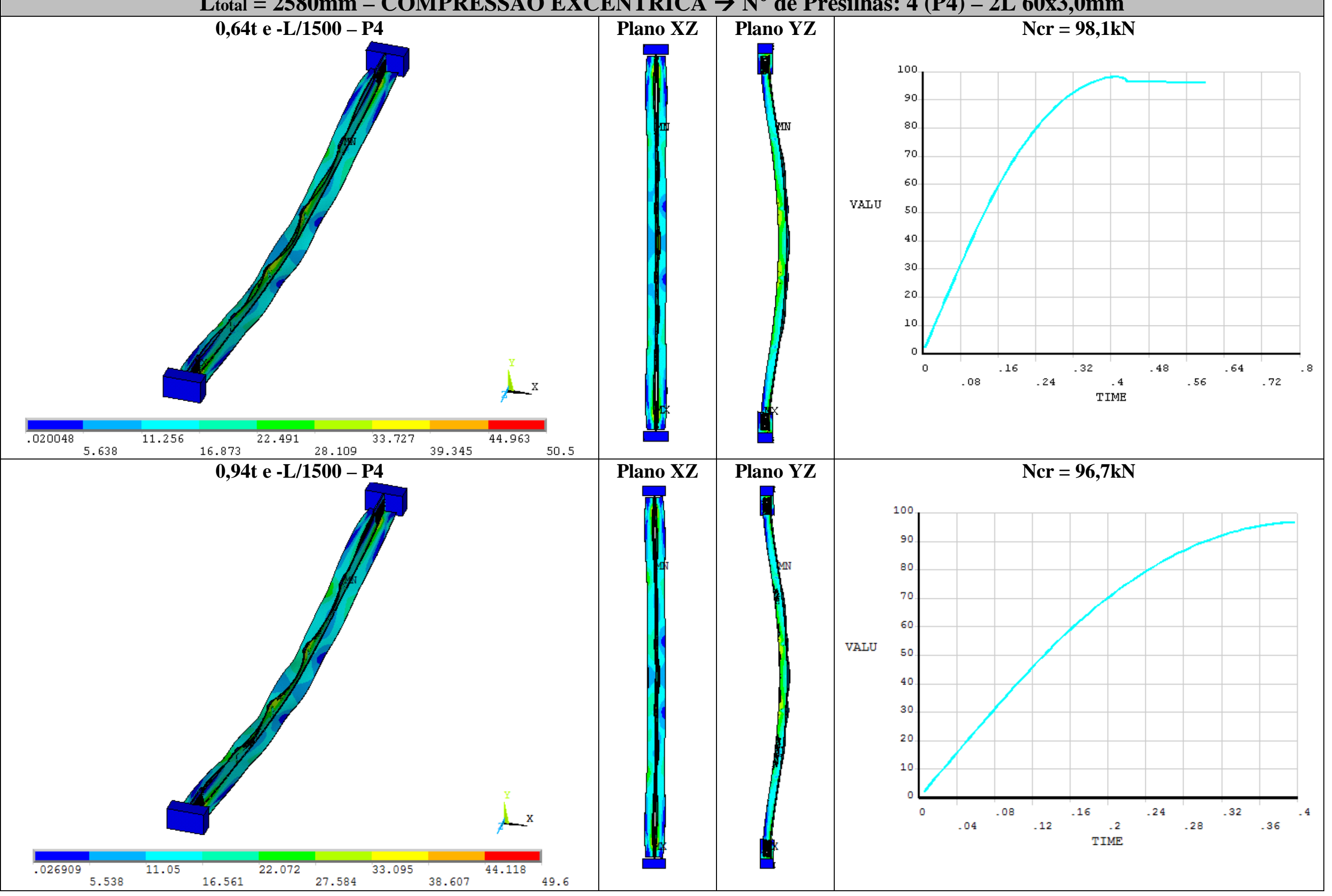




$$
\frac{1}{2}
$$




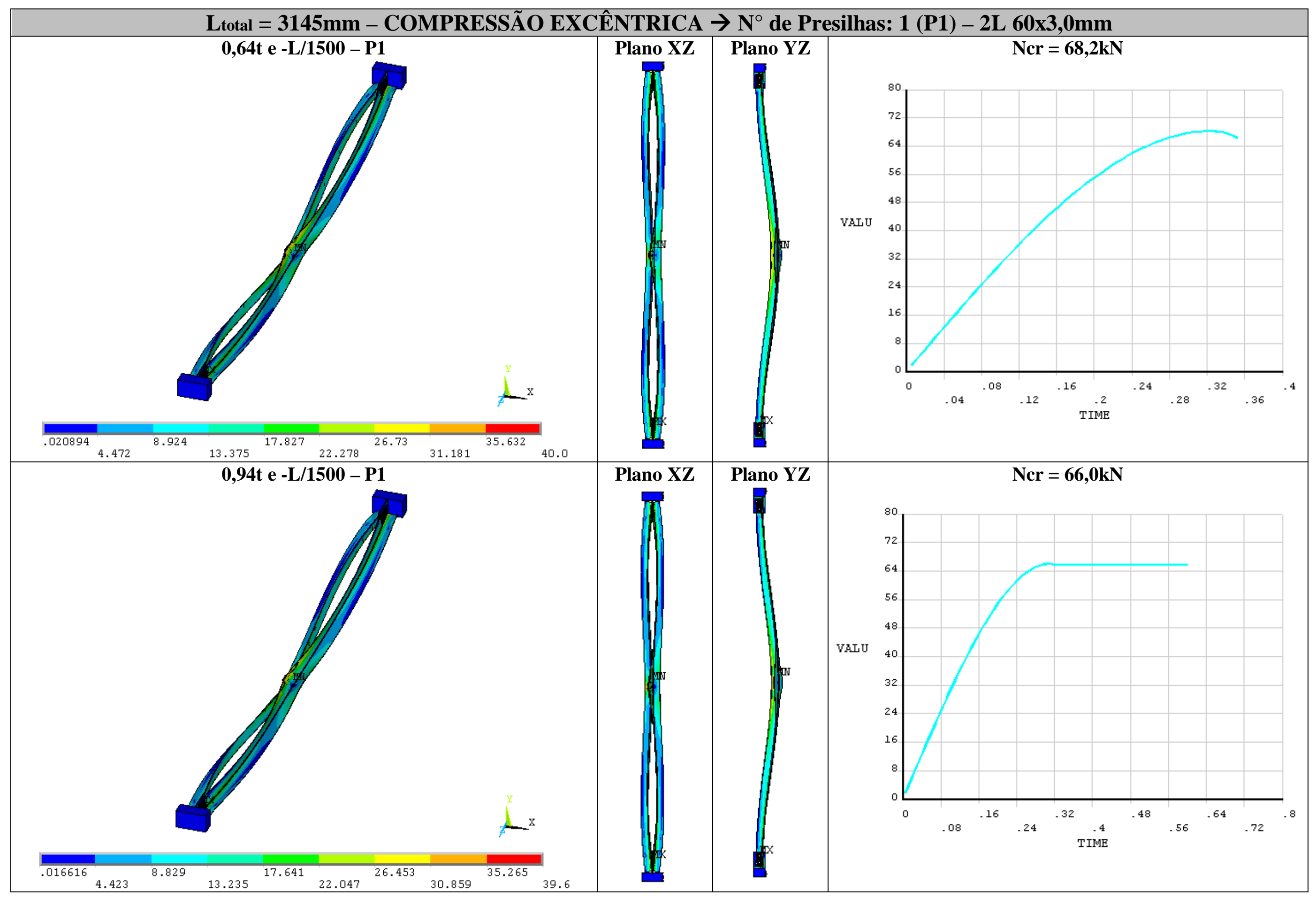




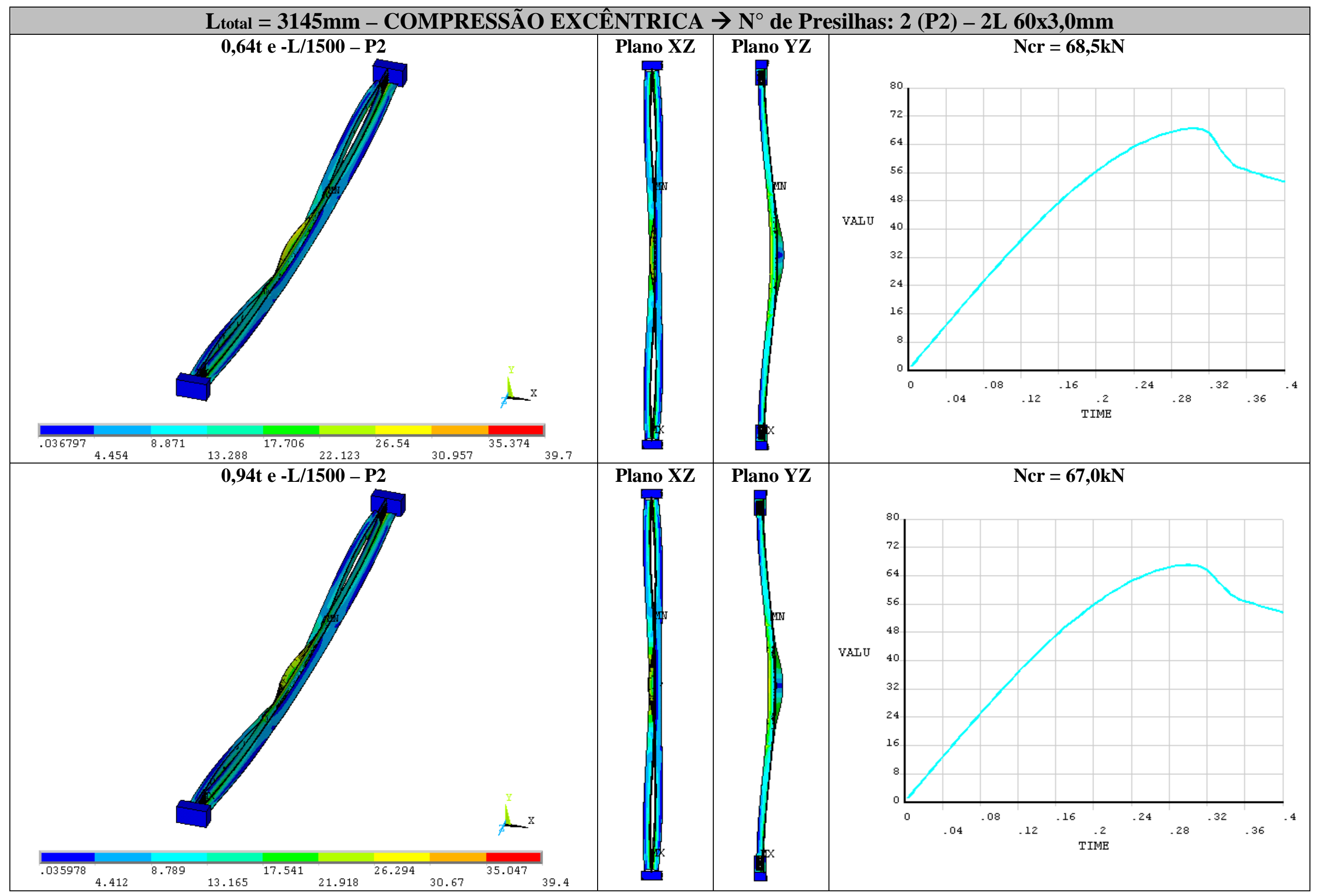




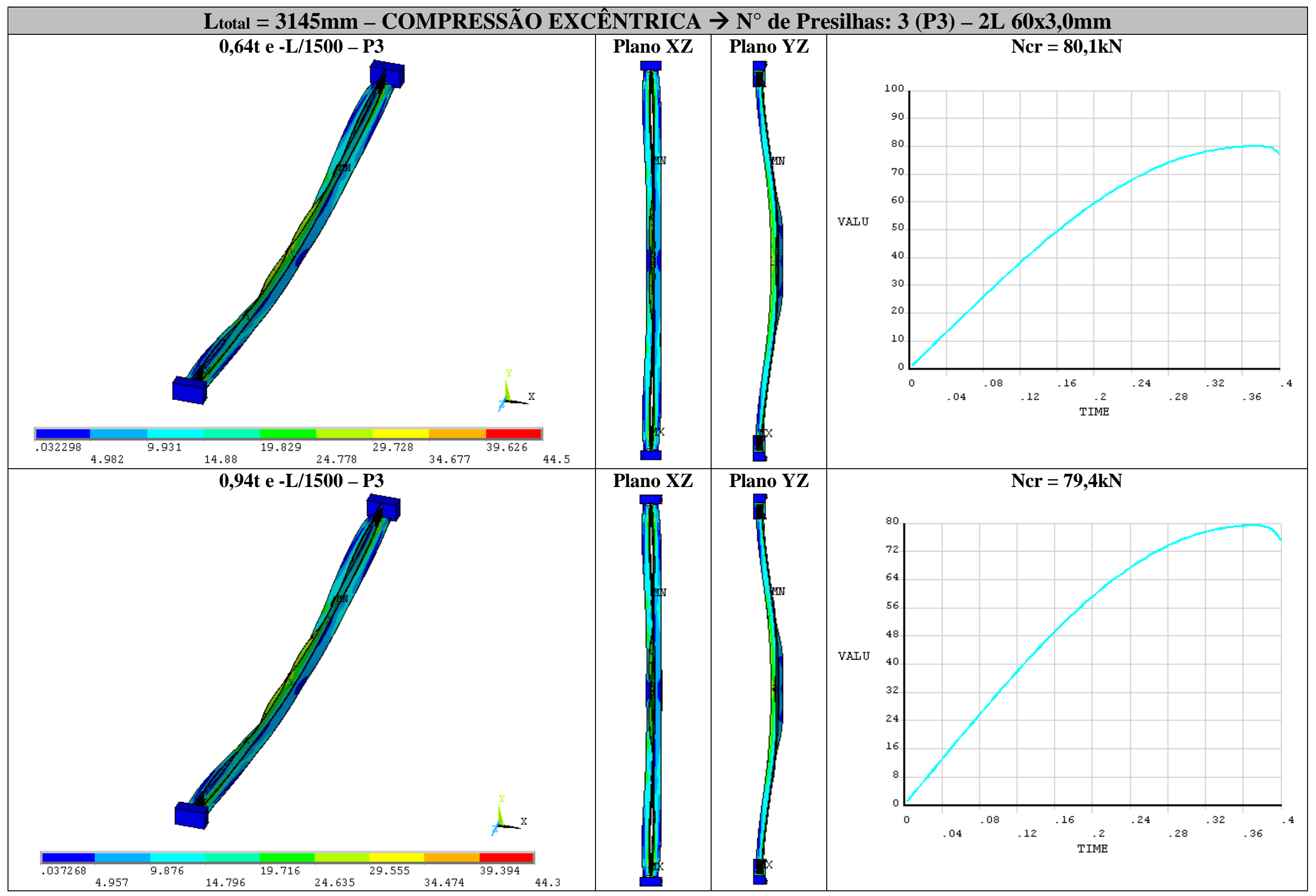




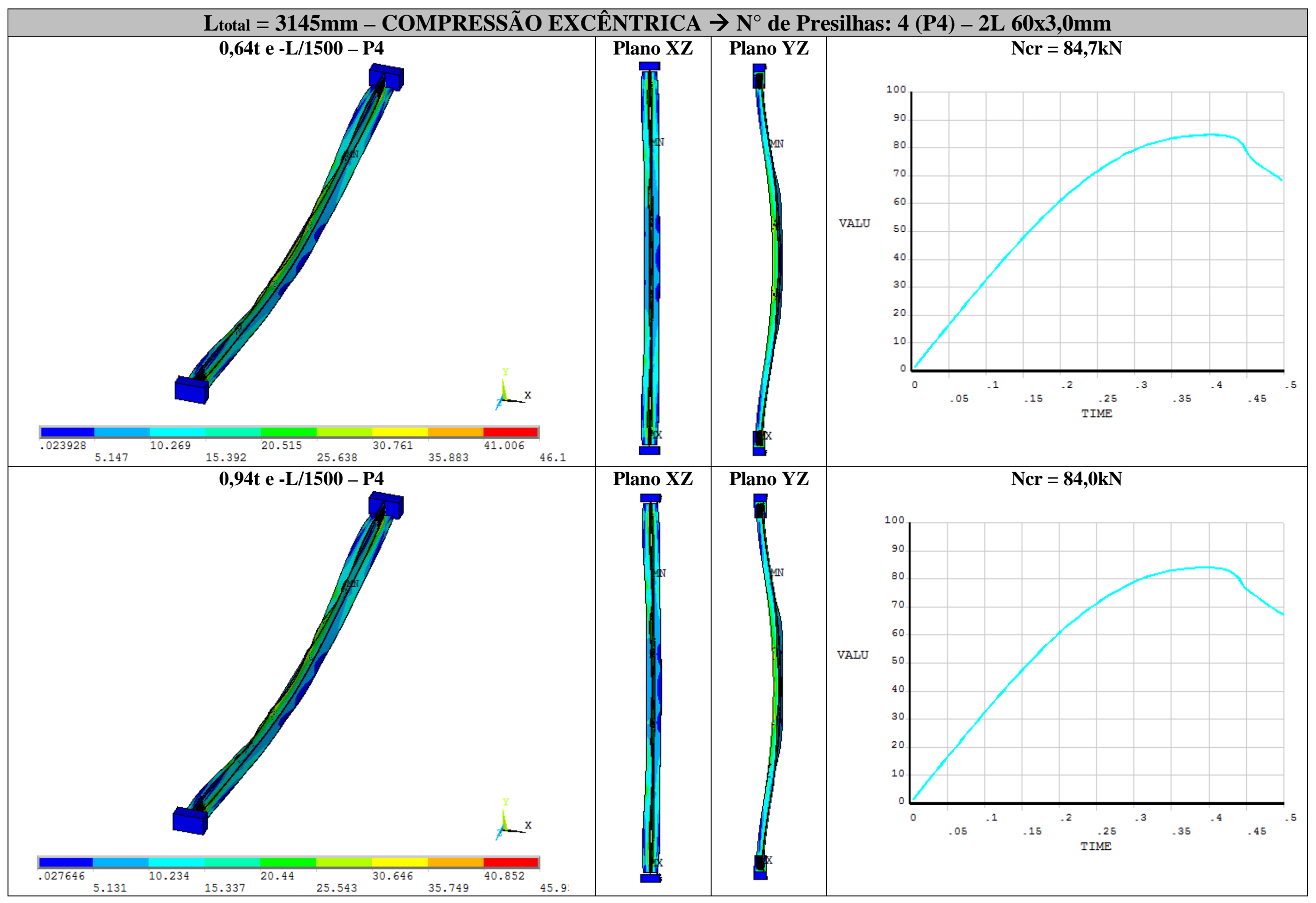




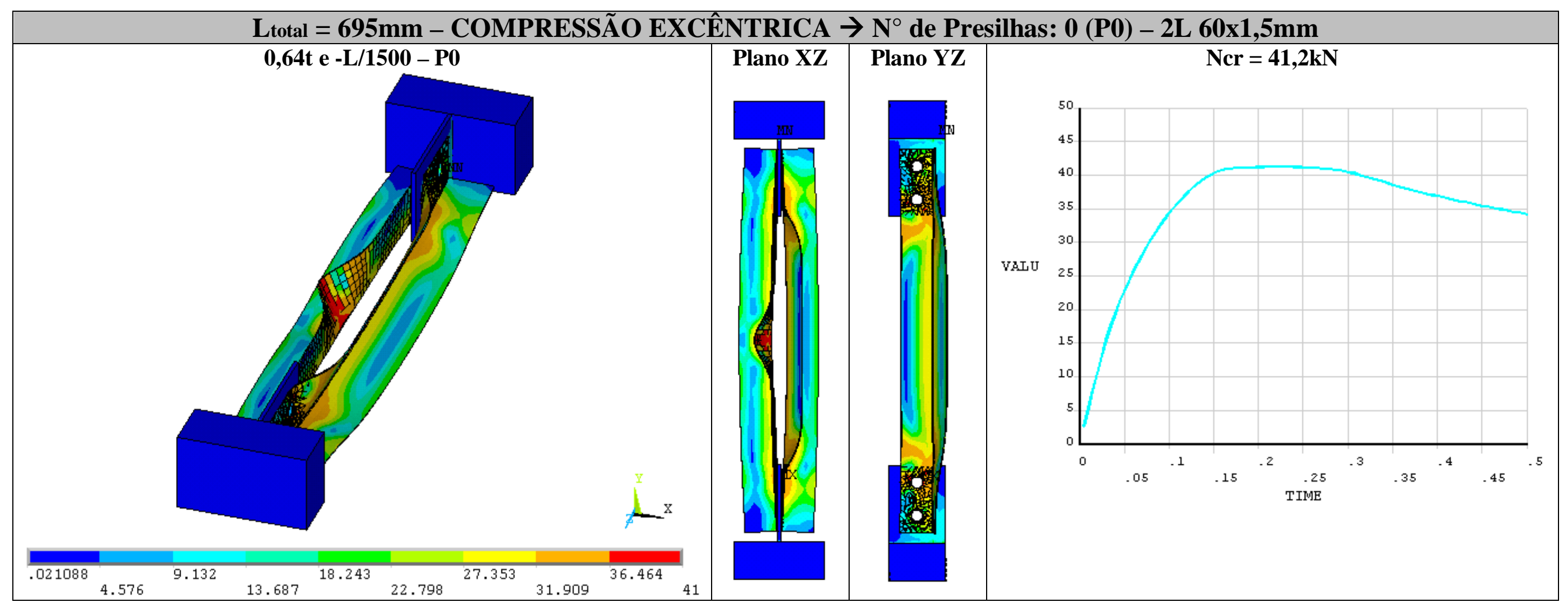




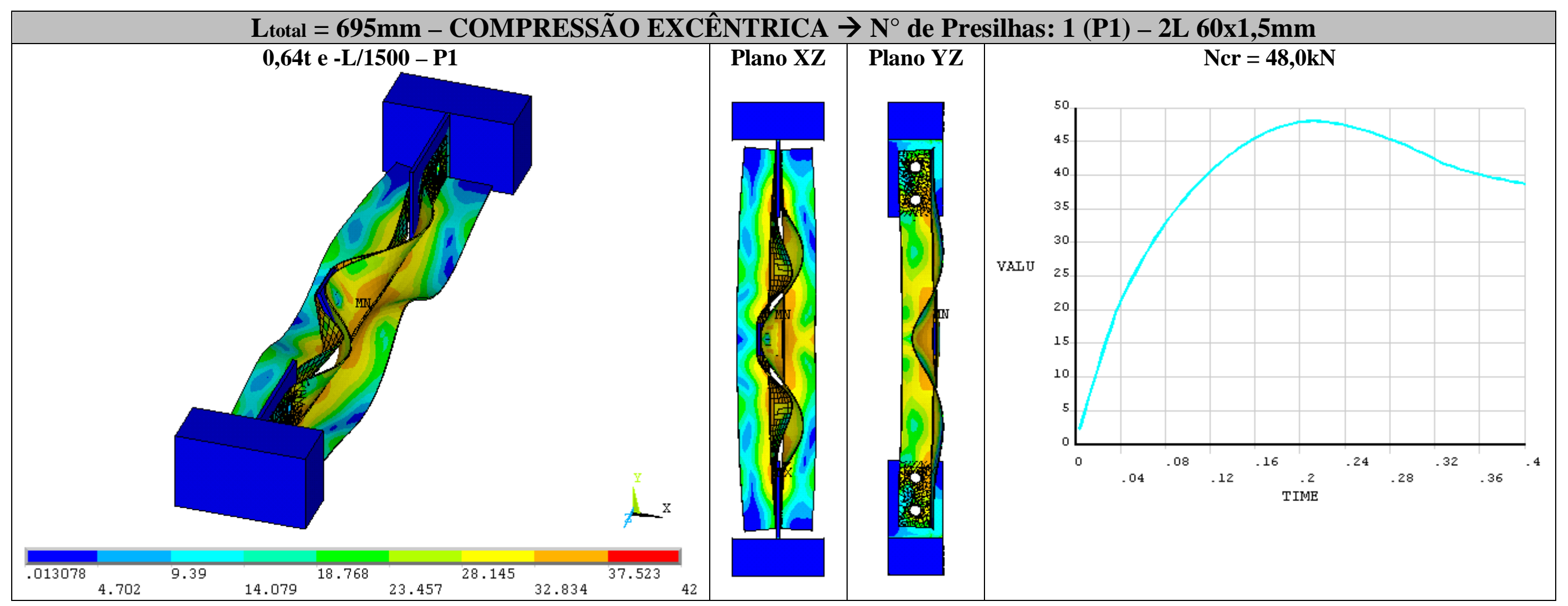




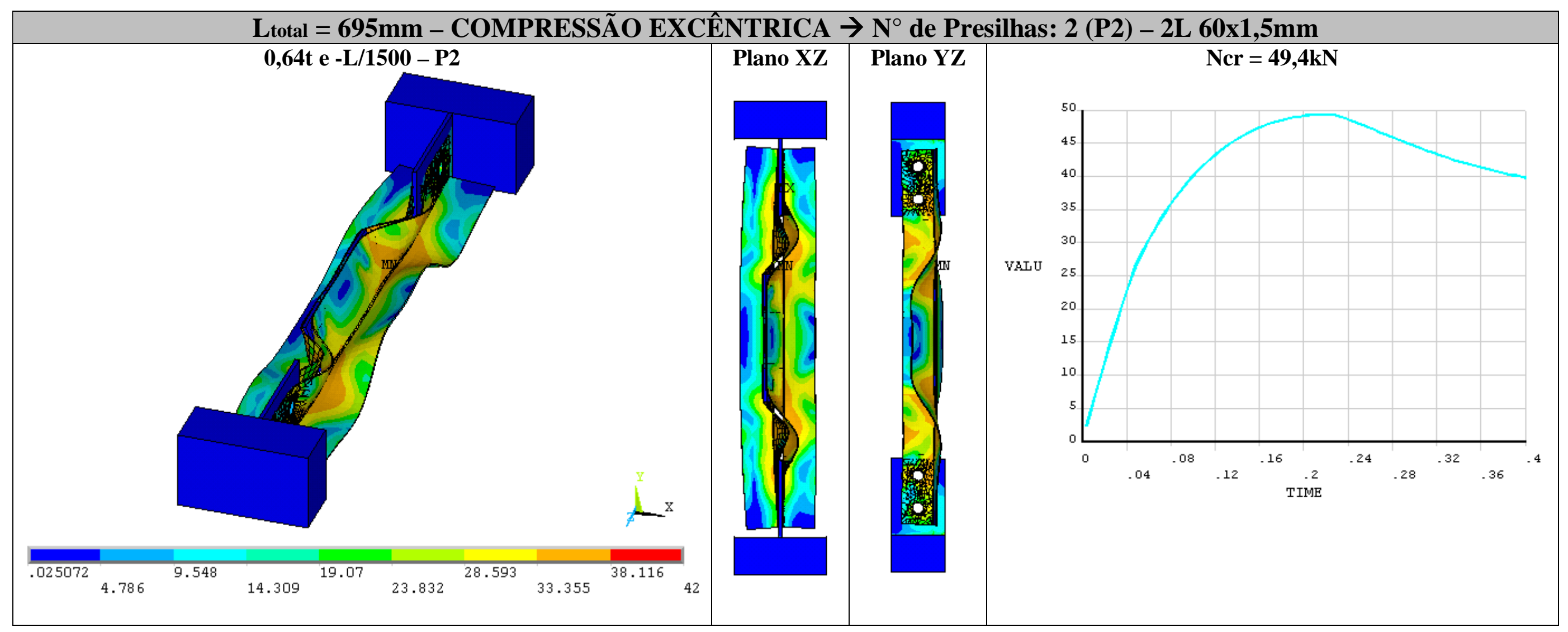




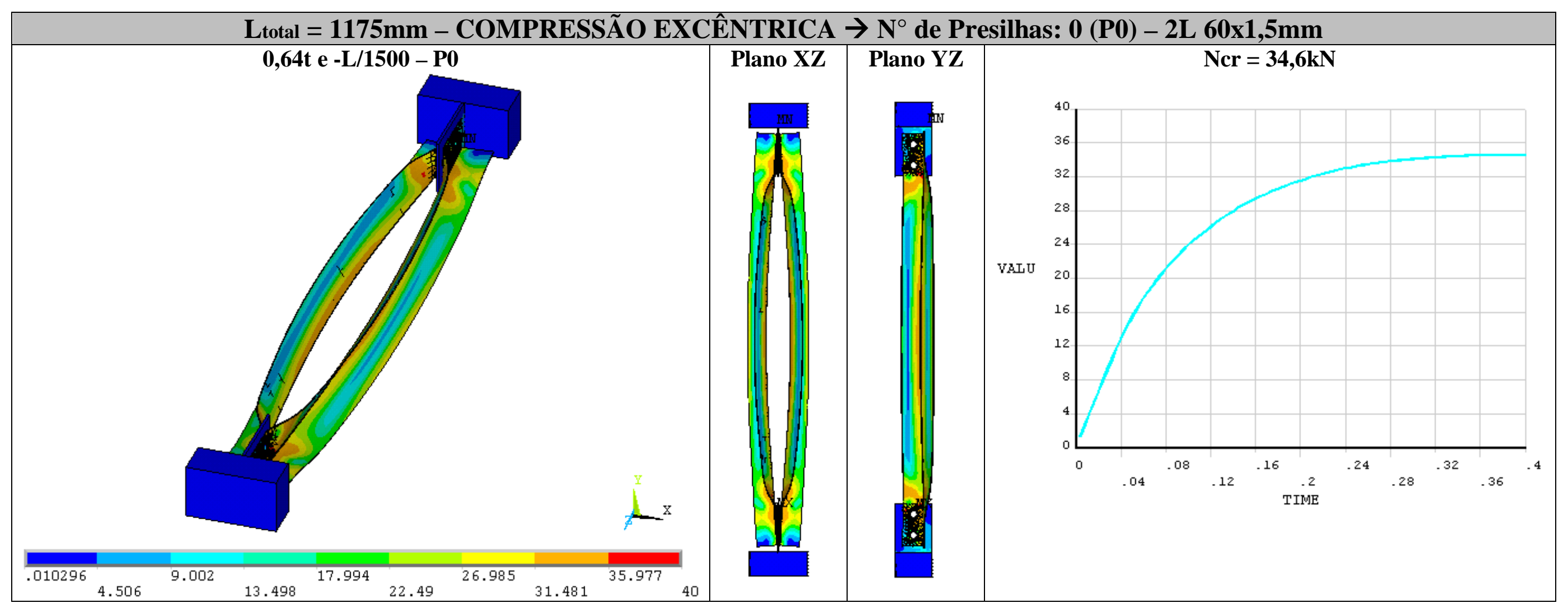




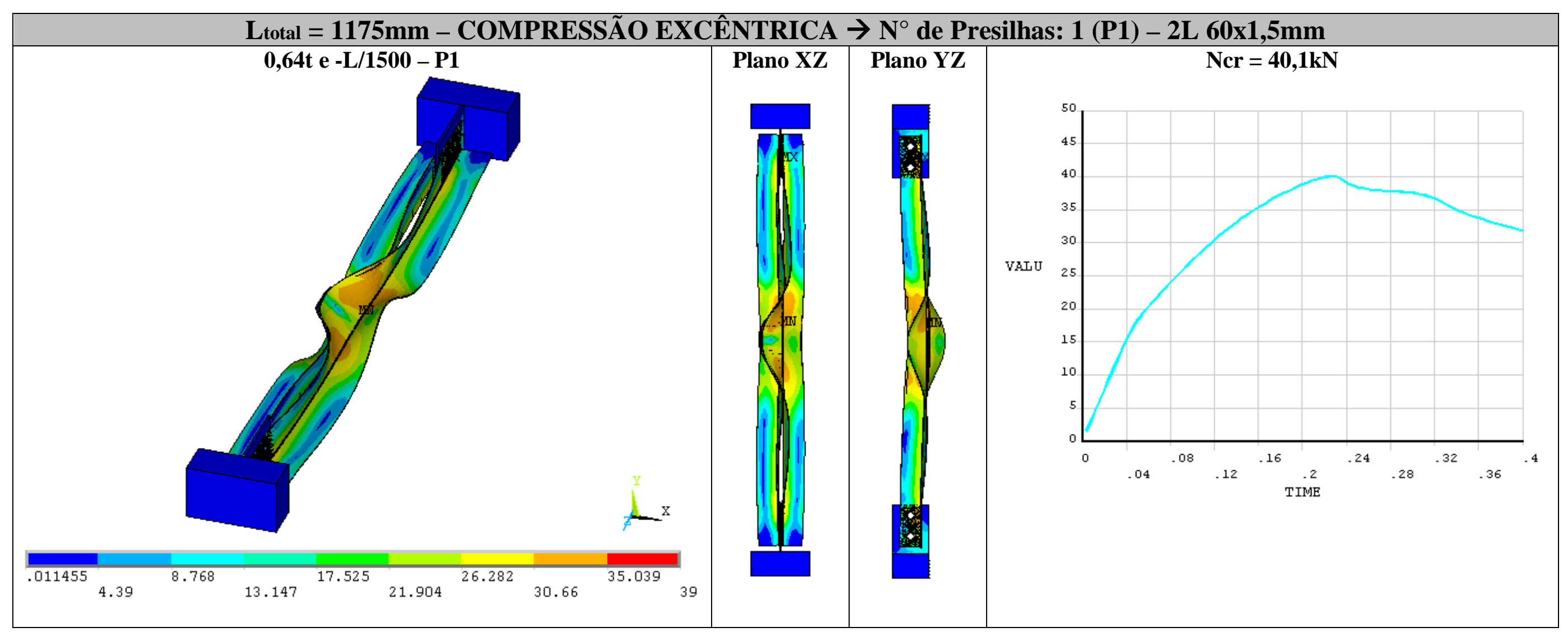




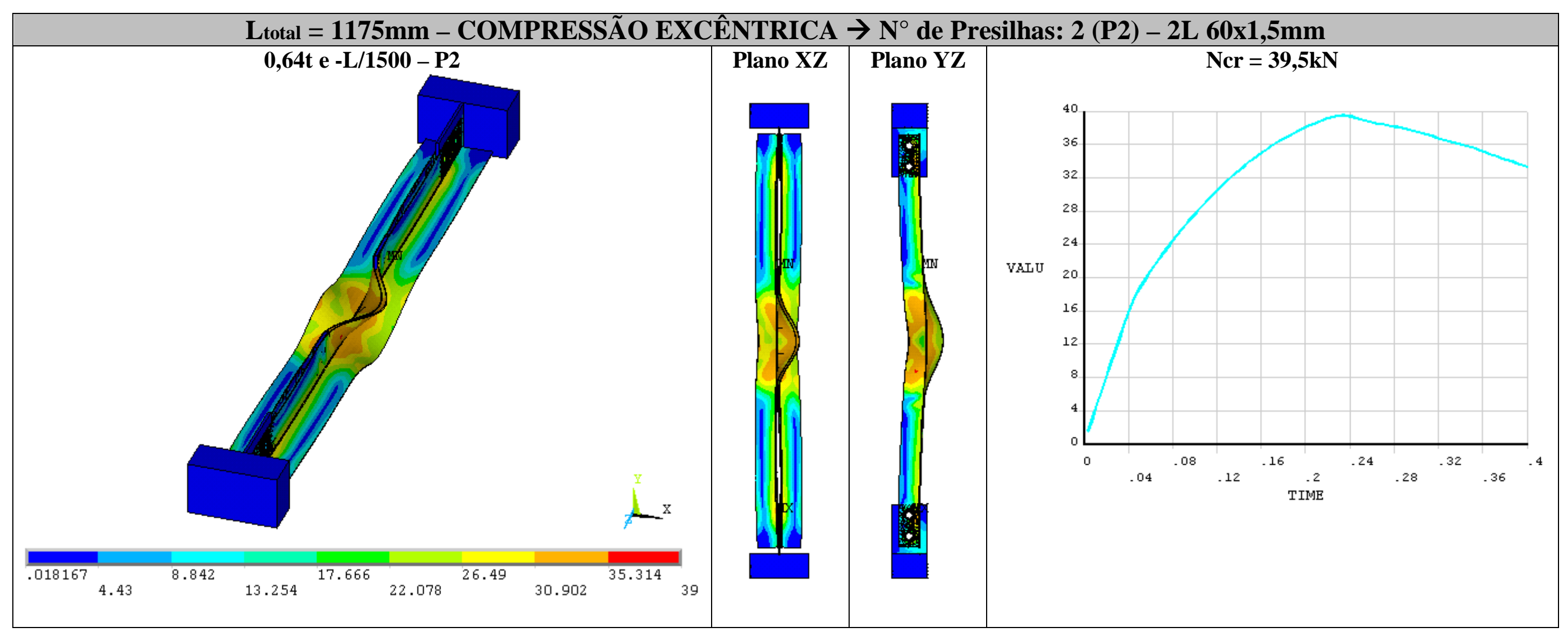




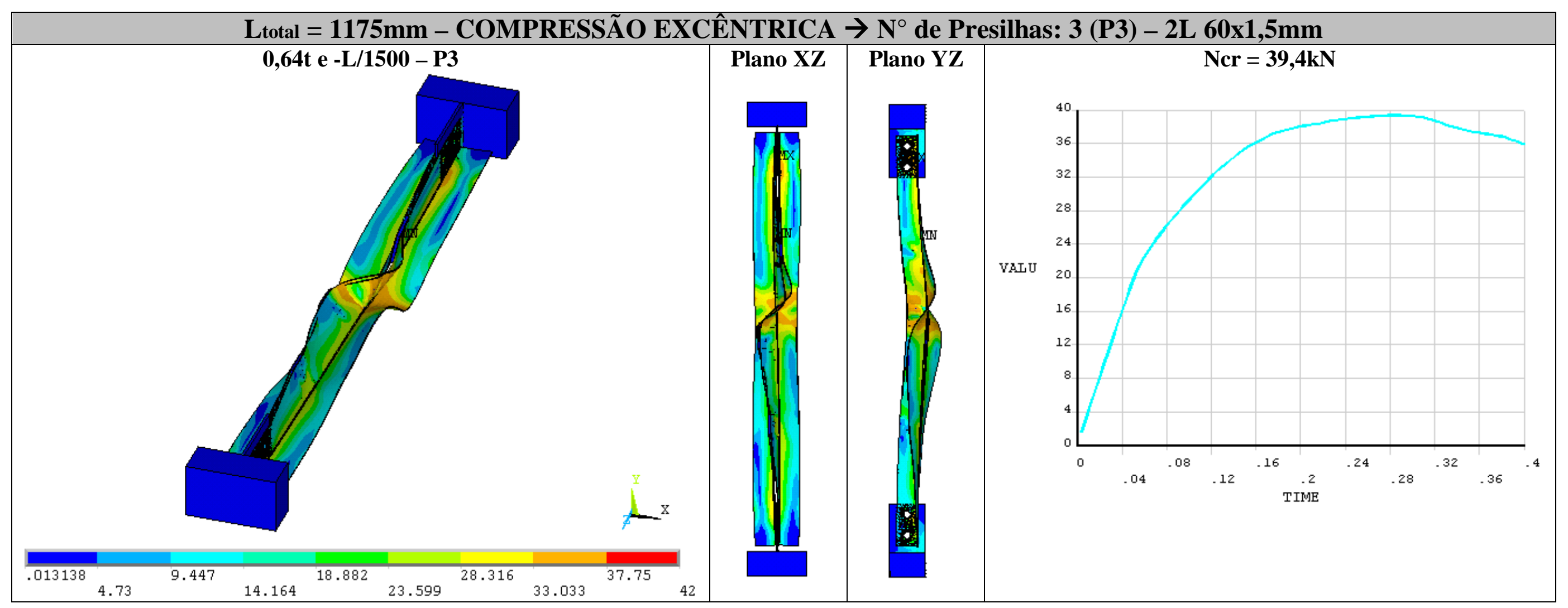




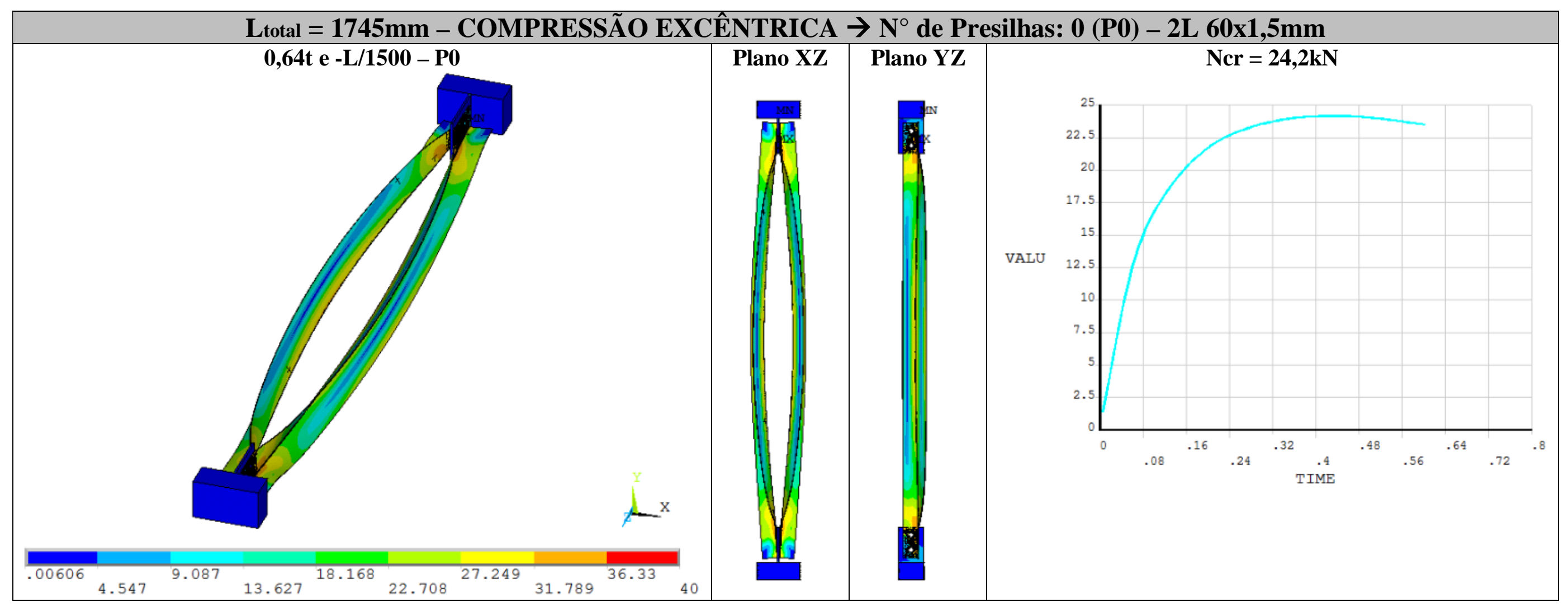




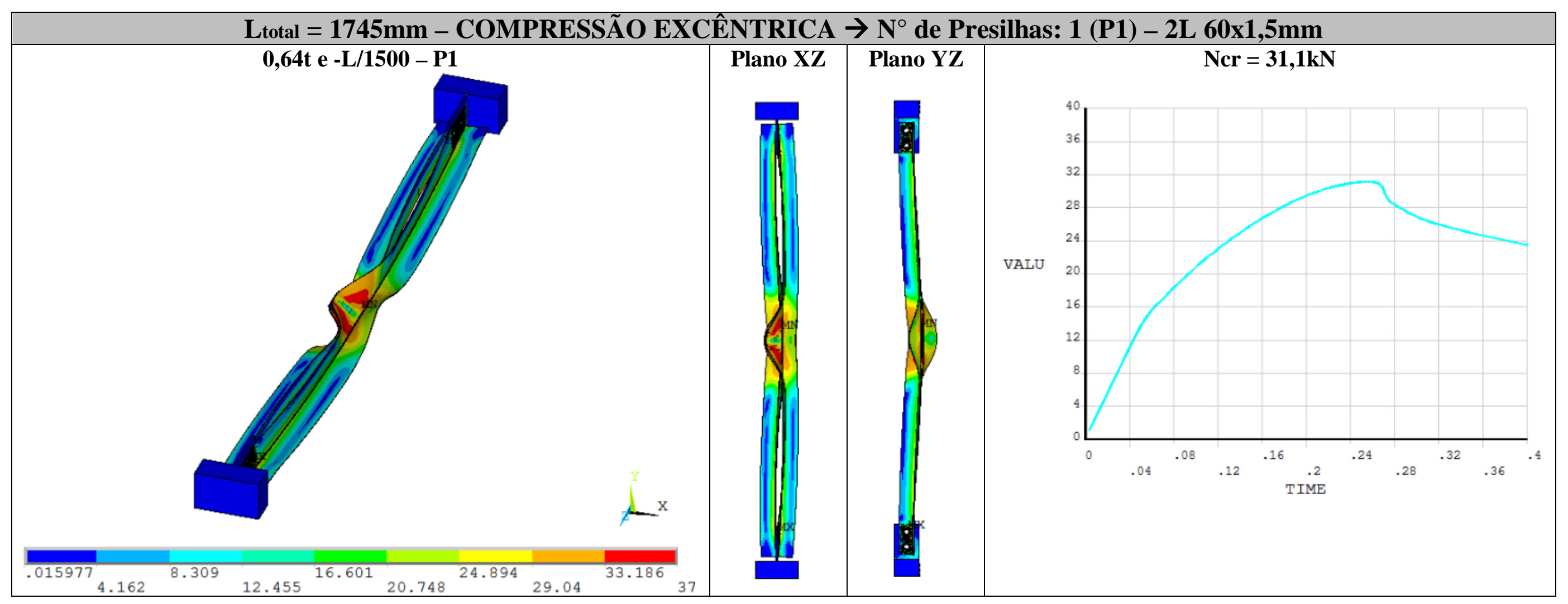




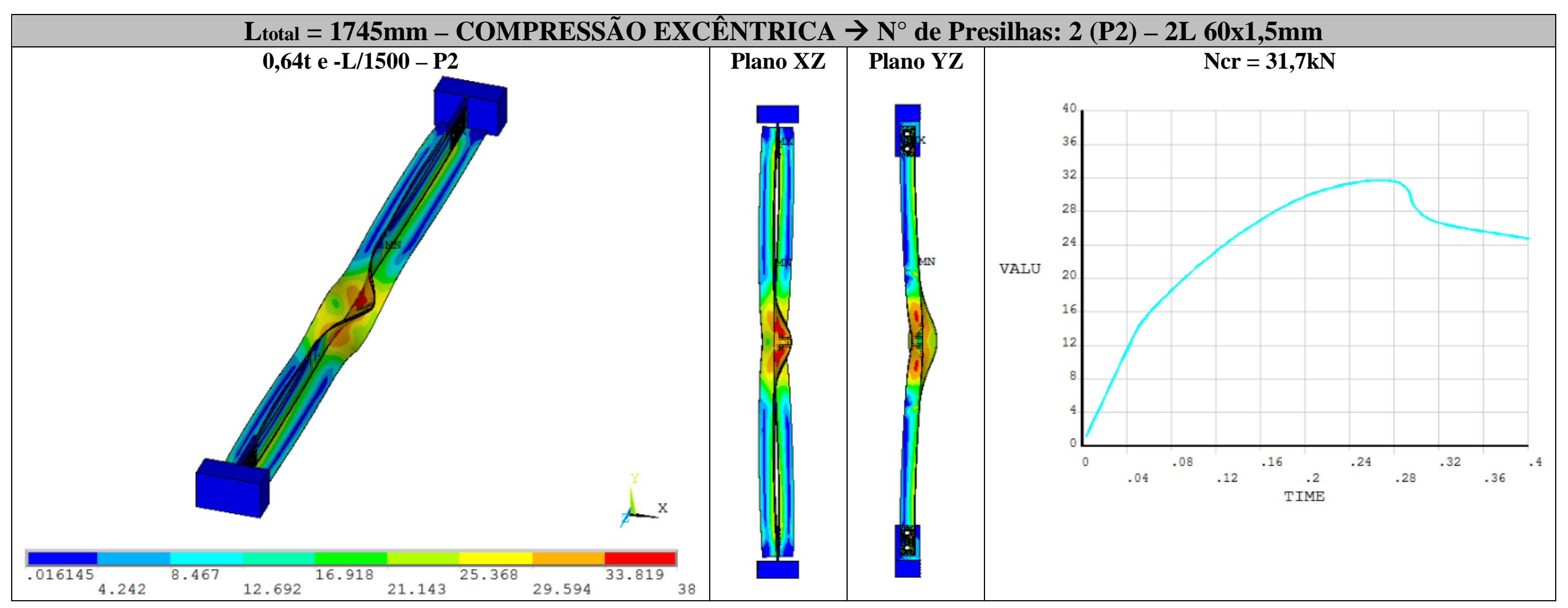




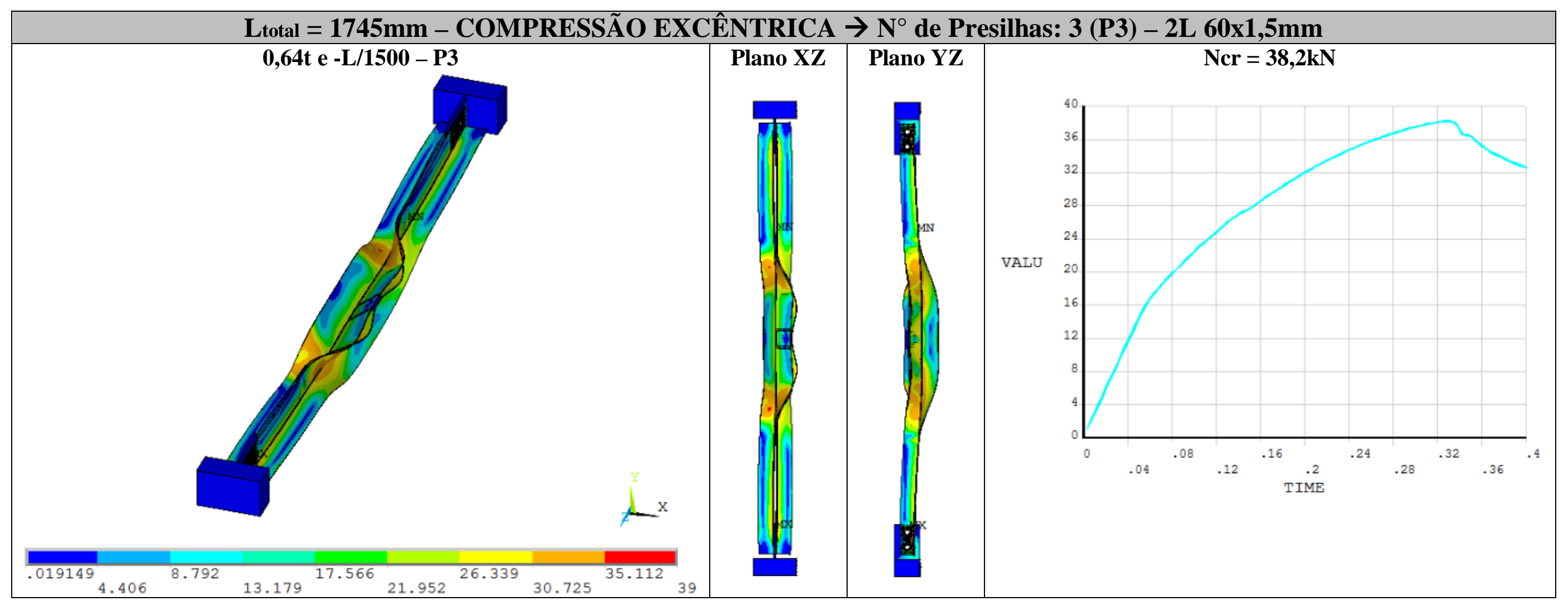




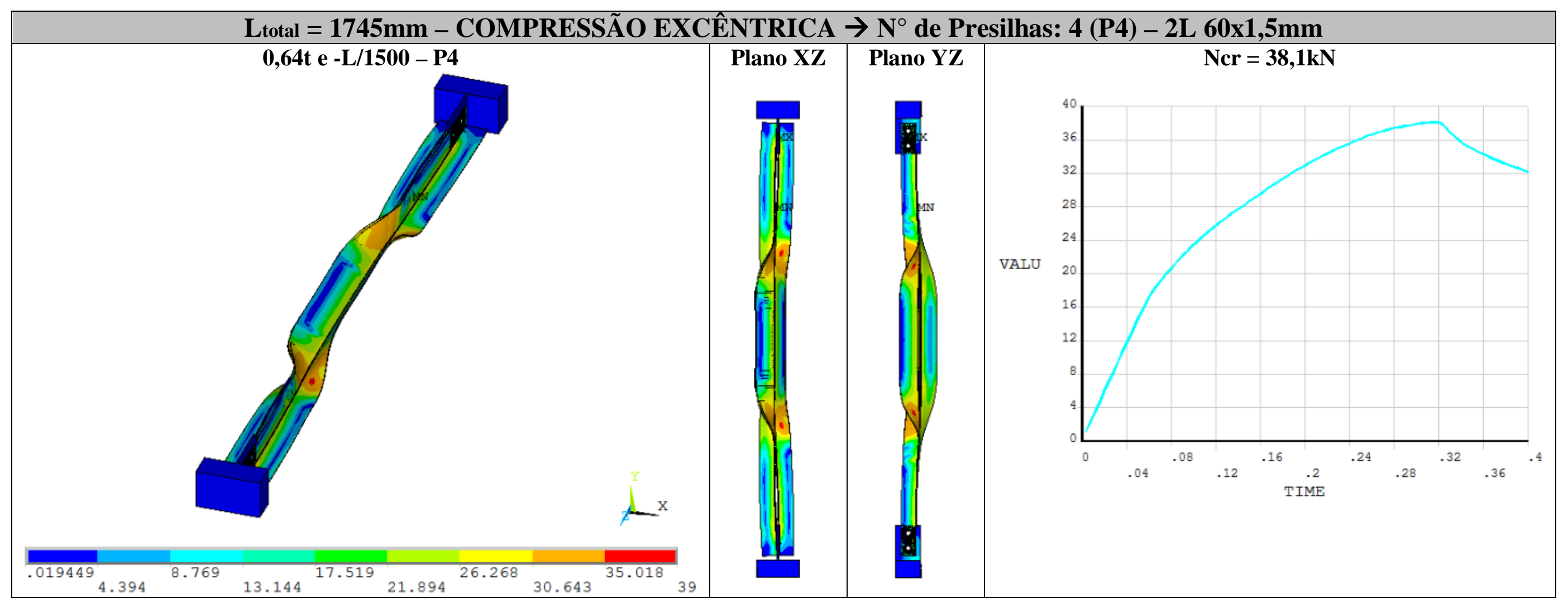




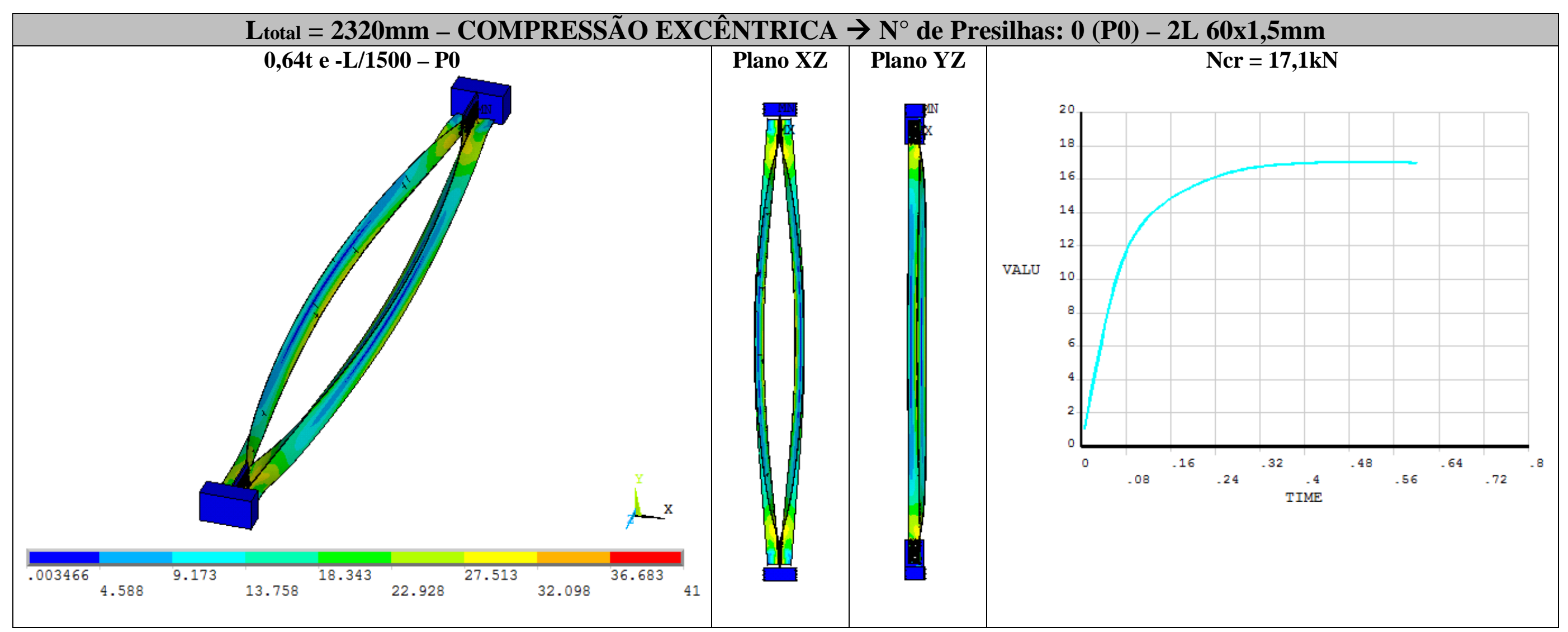




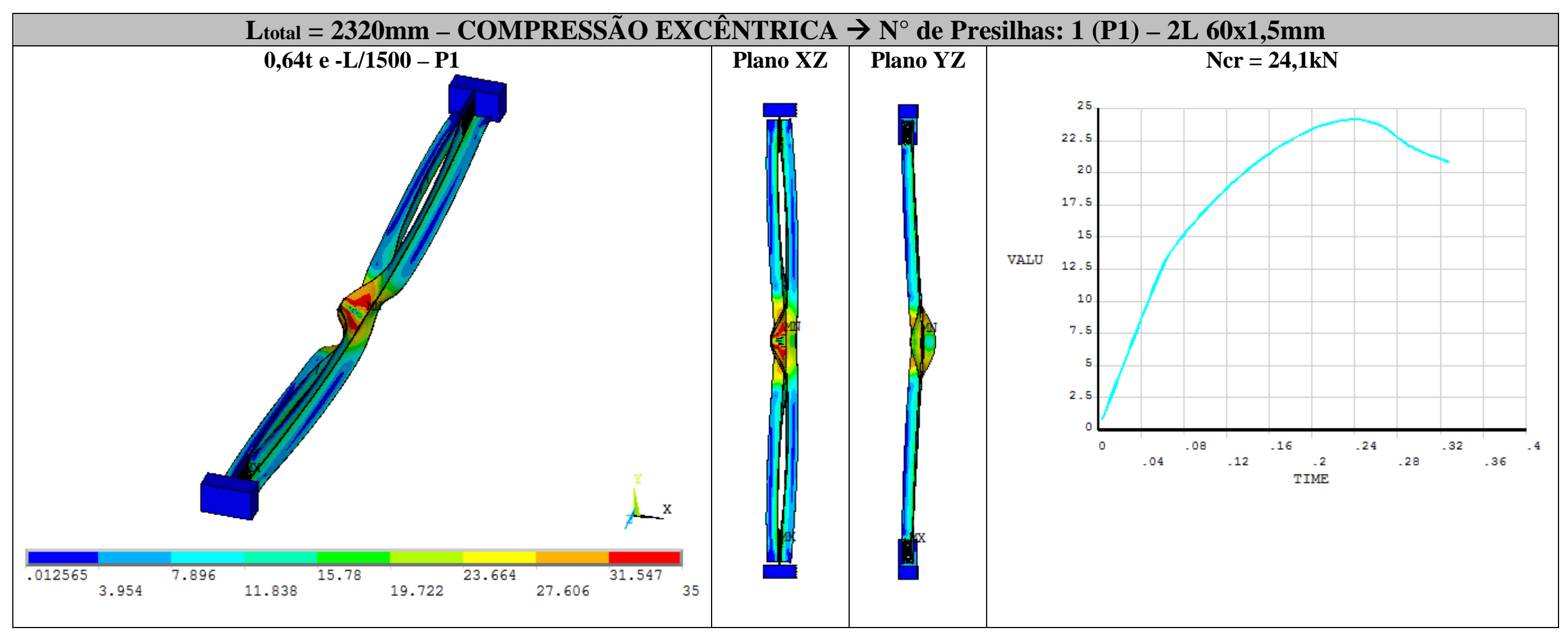




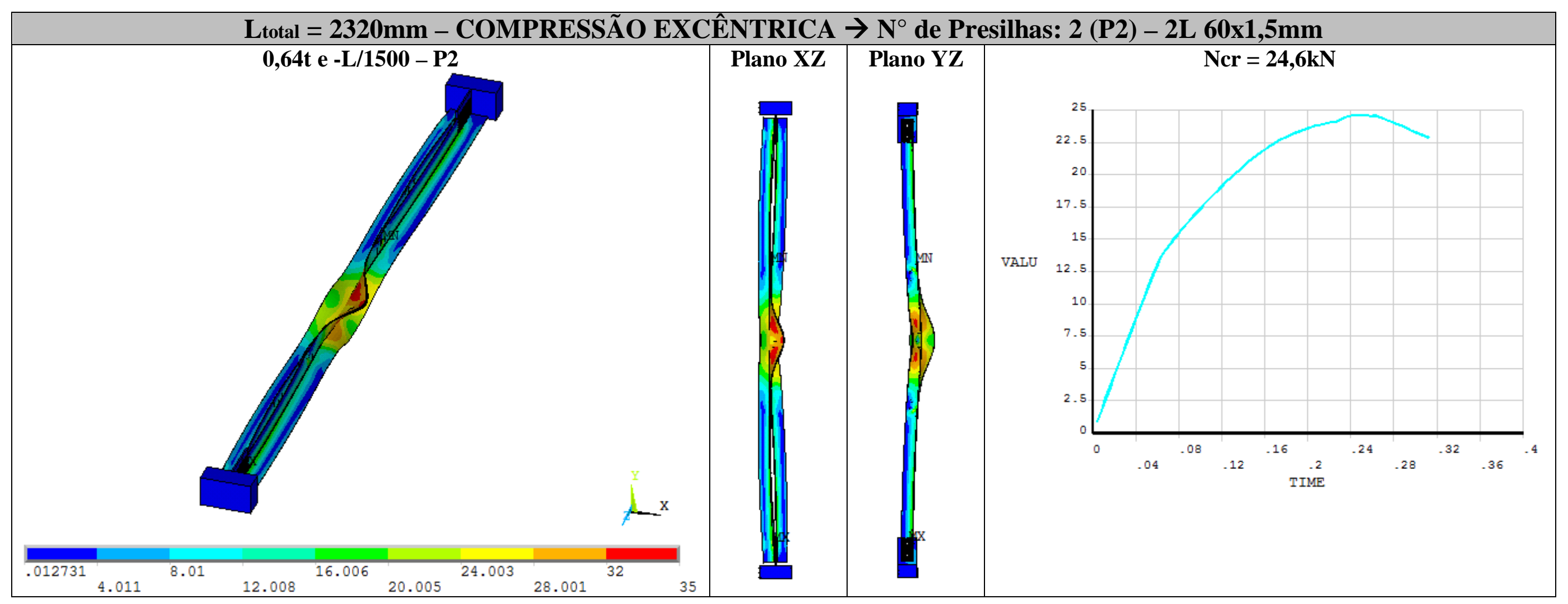




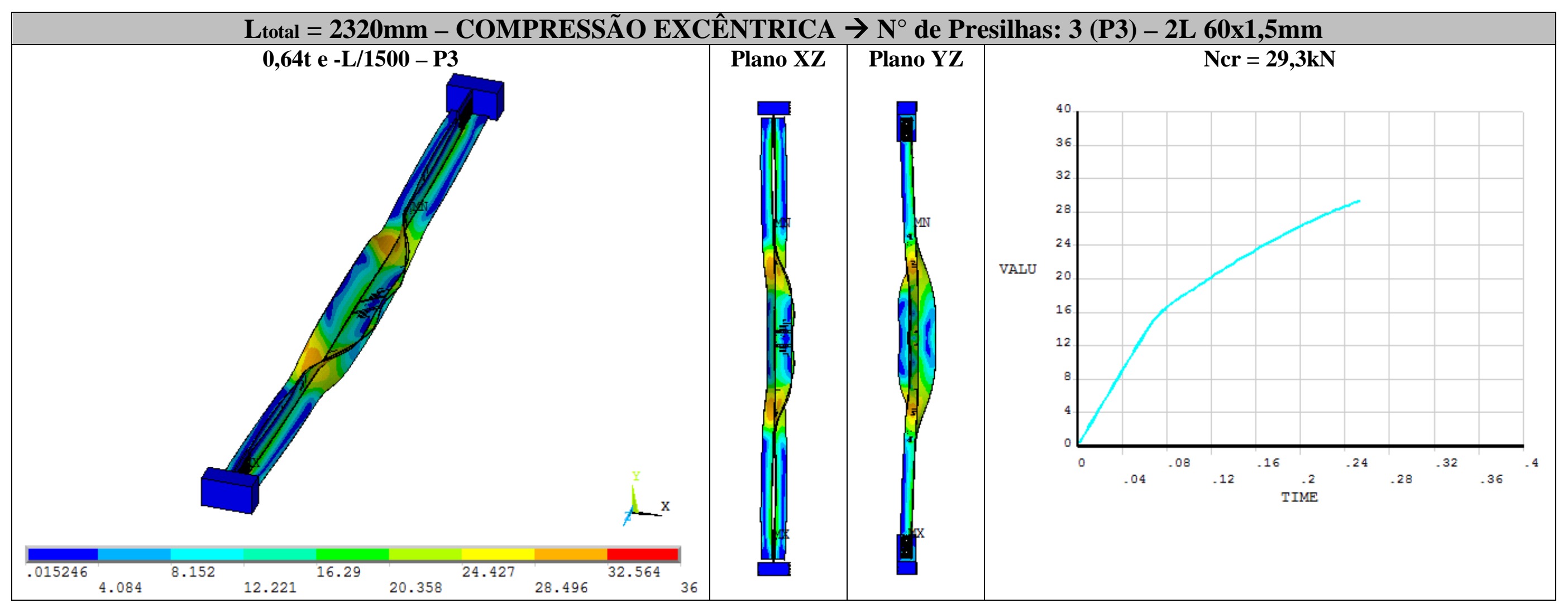




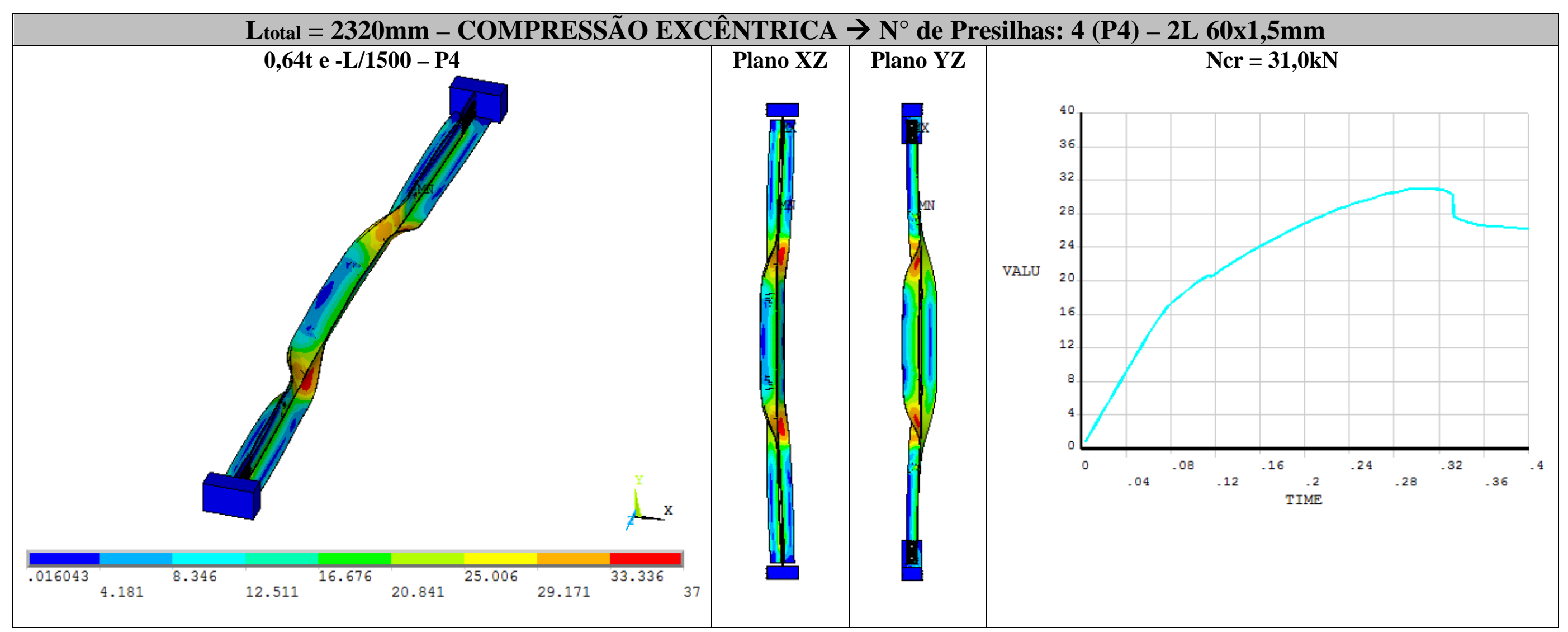




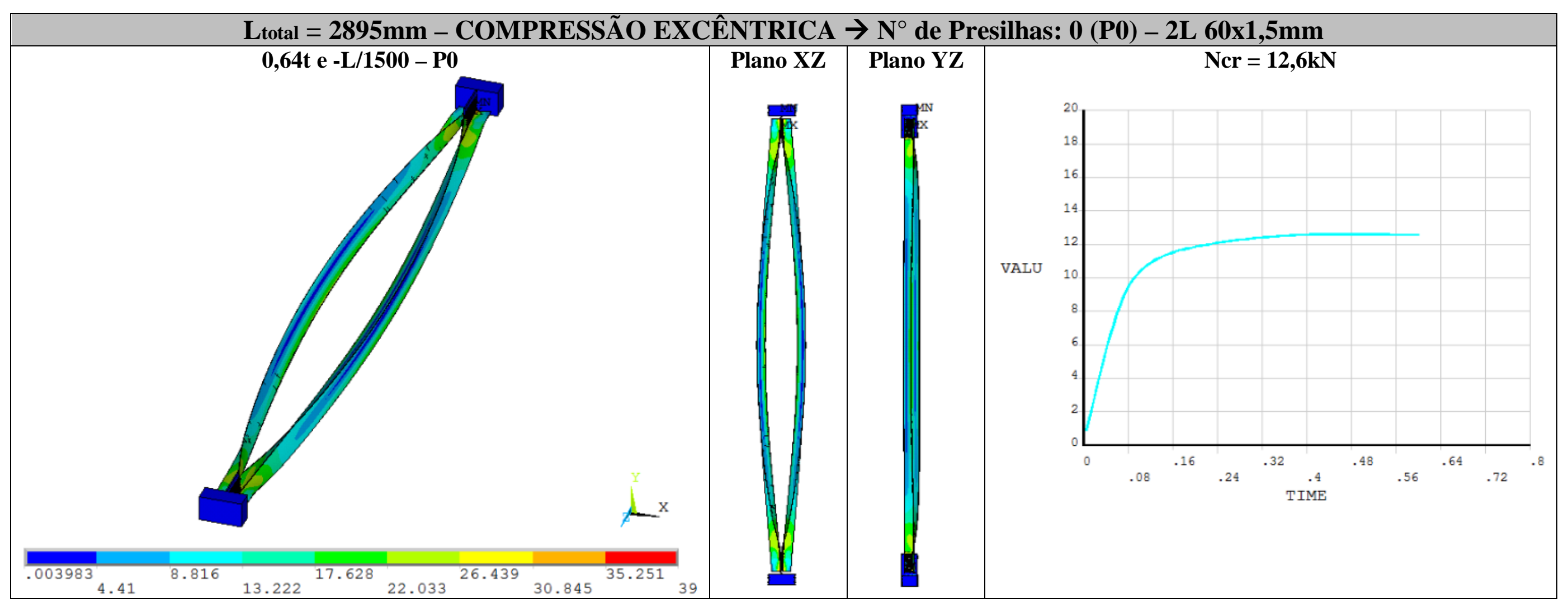




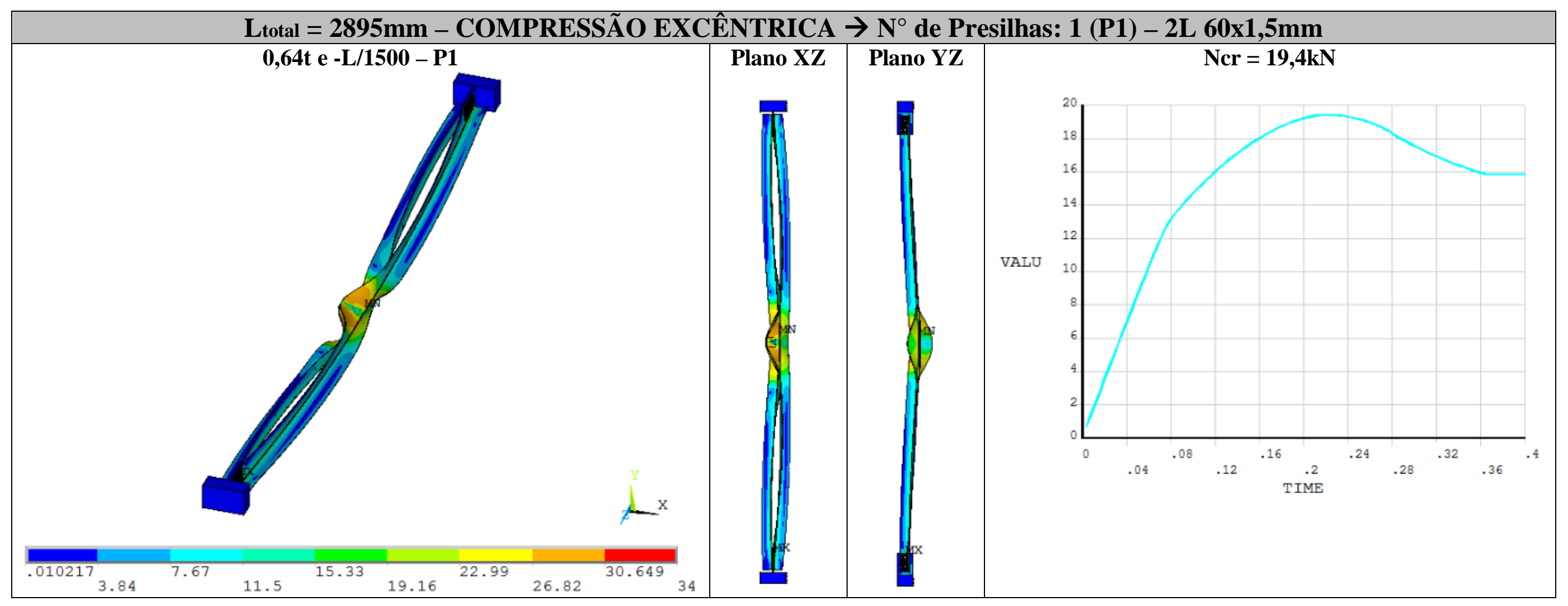




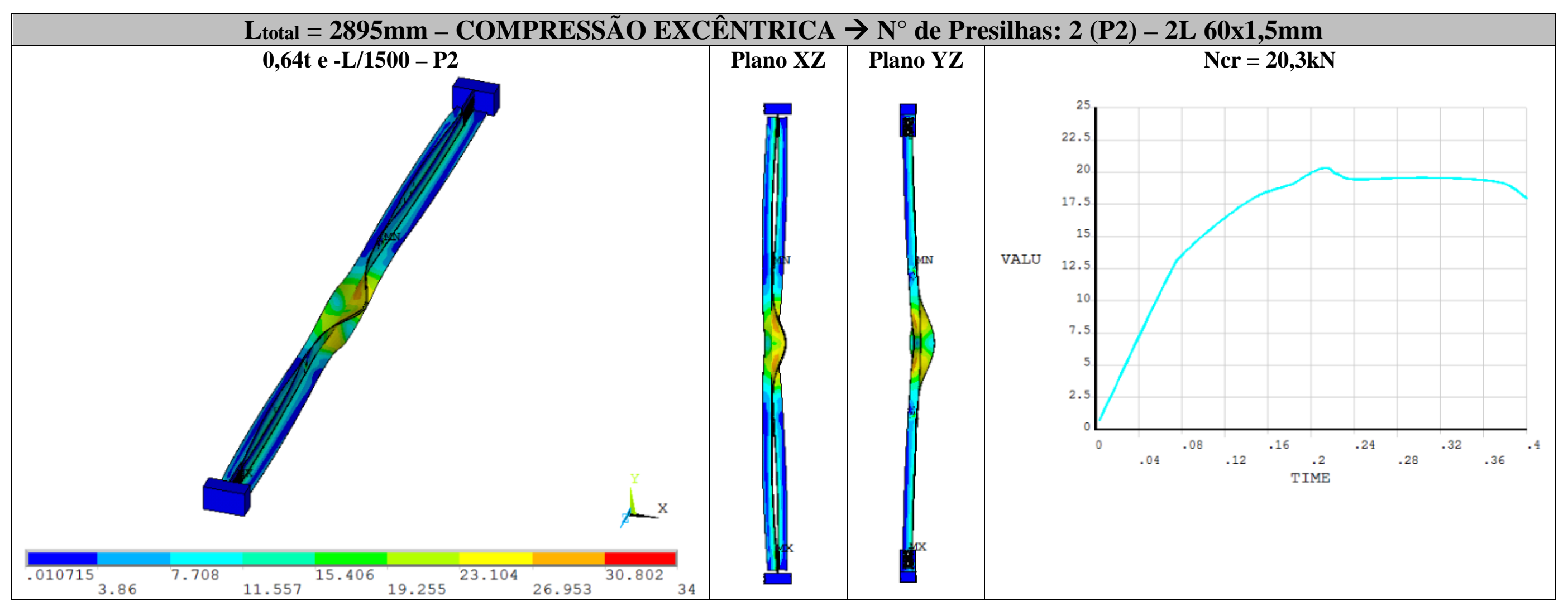




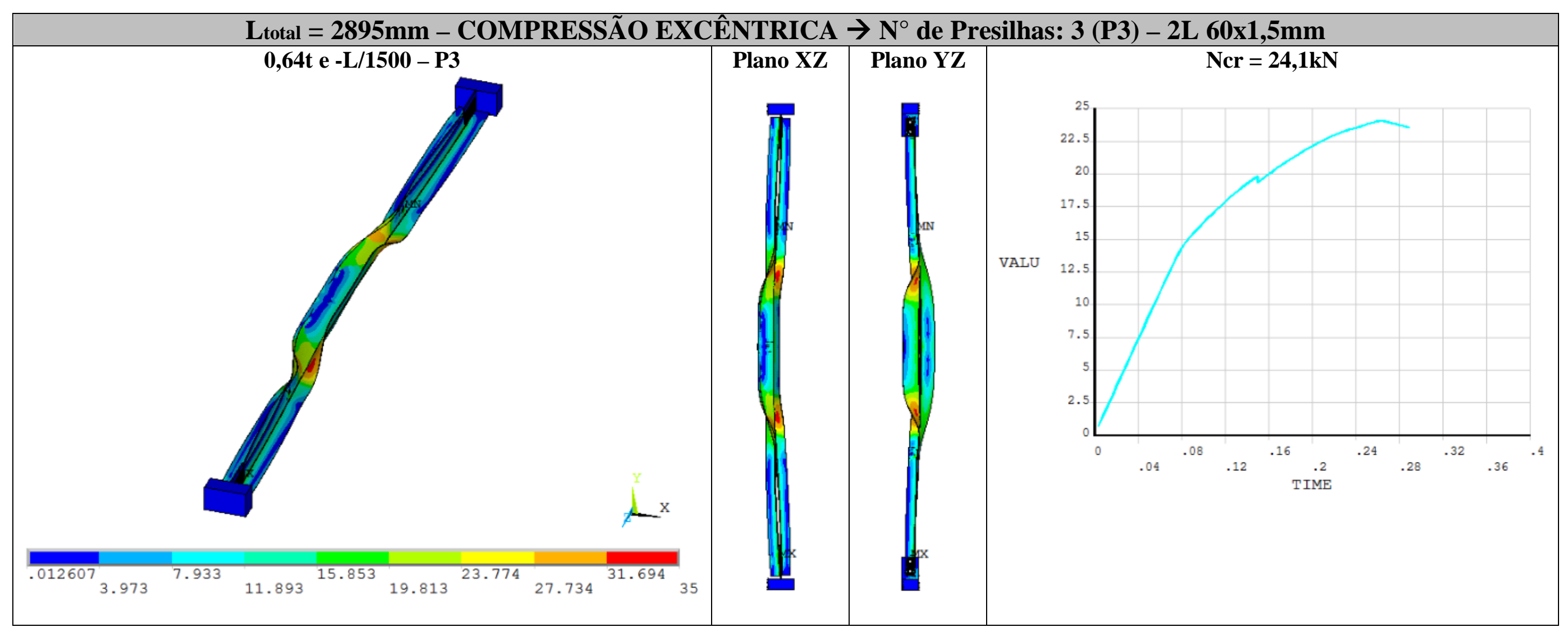




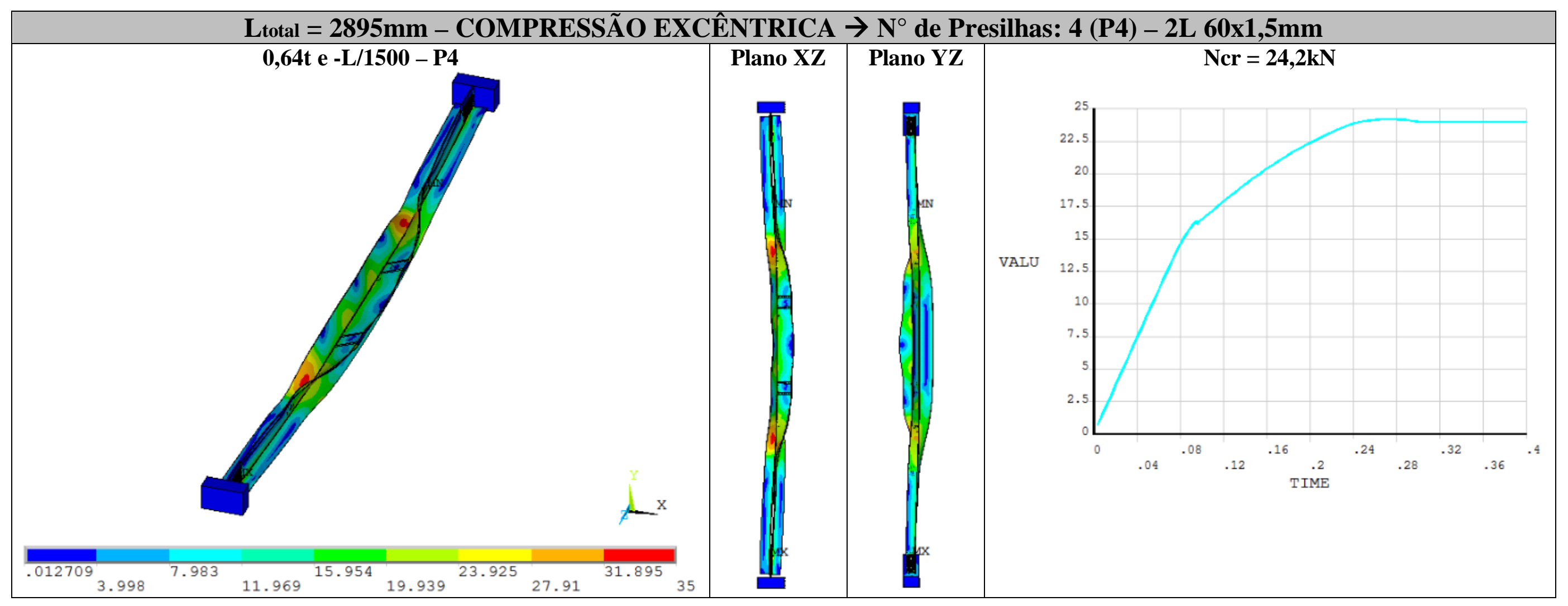




\section{APÊNDICE F - Resultados das análises em temperaturas elevadas}

Neste apêndice, são apresentadas as configurações deformadas dos perfis analisados em temperaturas elevadas no instante em que os mesmos perdem sua capacidade resistente. Além disso, são apresentados a distribuição de tensões (von Mises) nas chapas das cantoneiras, a máxima temperatura atingida pelos perfis antes de ocorrer a falha e gráficos que relacionam o deslocamento axial do topo dos perfis ao tempo de exposição ao incêndio (de onde se obtém o tempo de resistência ao fofo dos perfis). 
311

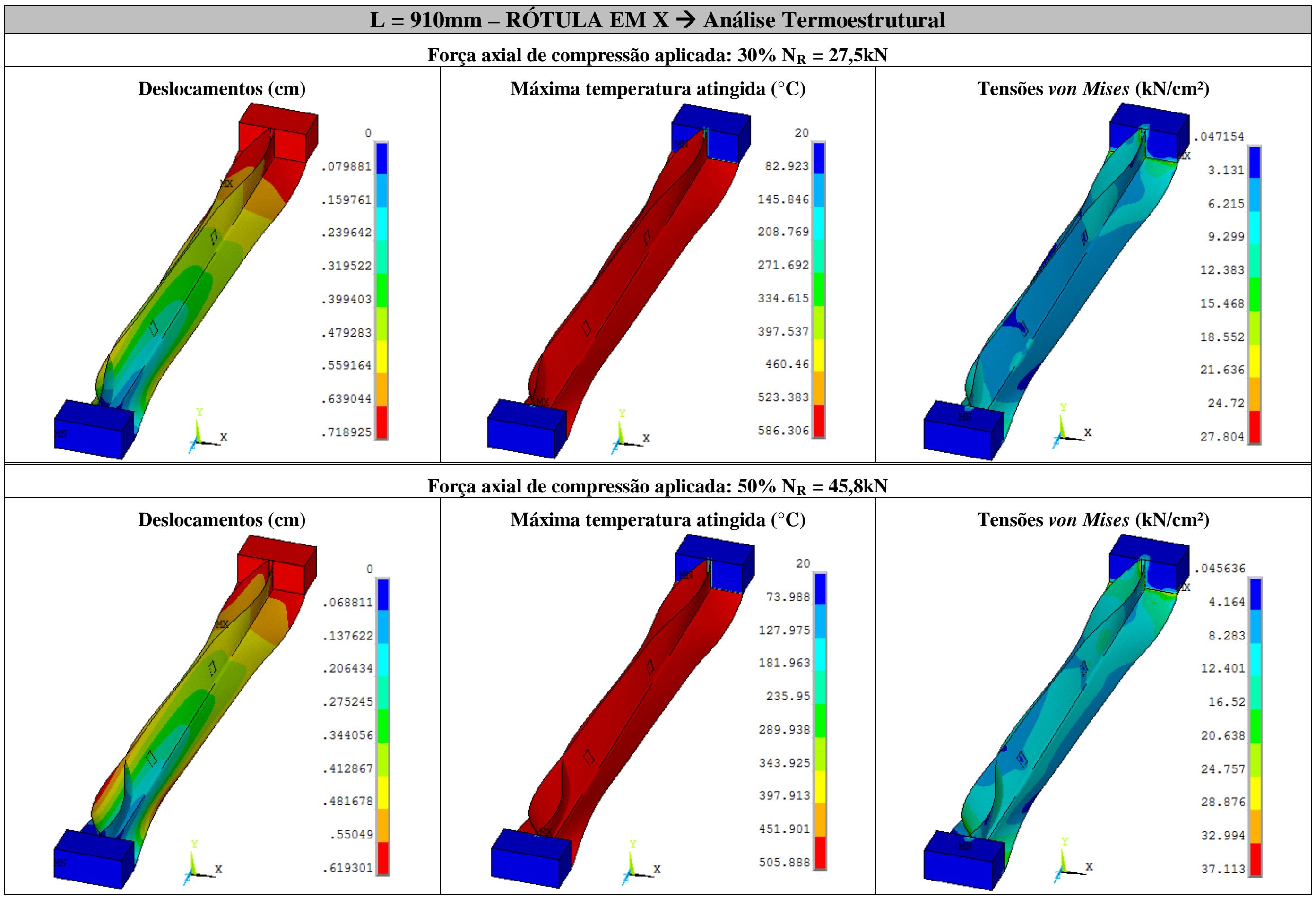




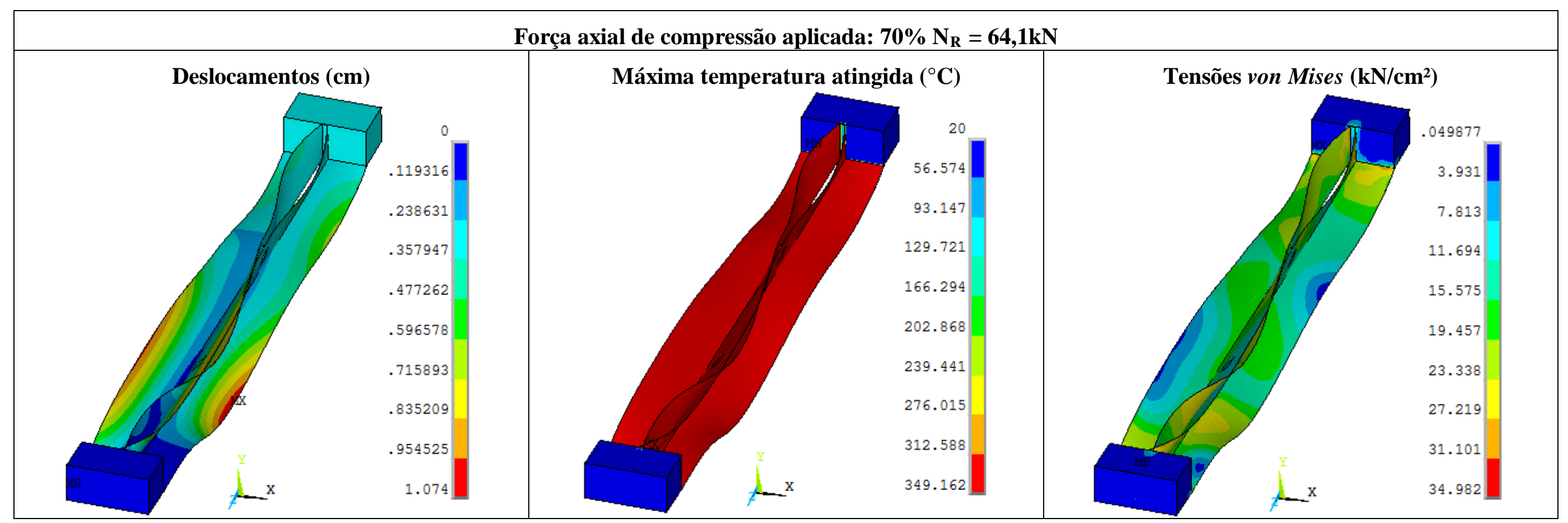




$$
\begin{aligned}
& 7171 \\
& 111 / 1
\end{aligned}
$$




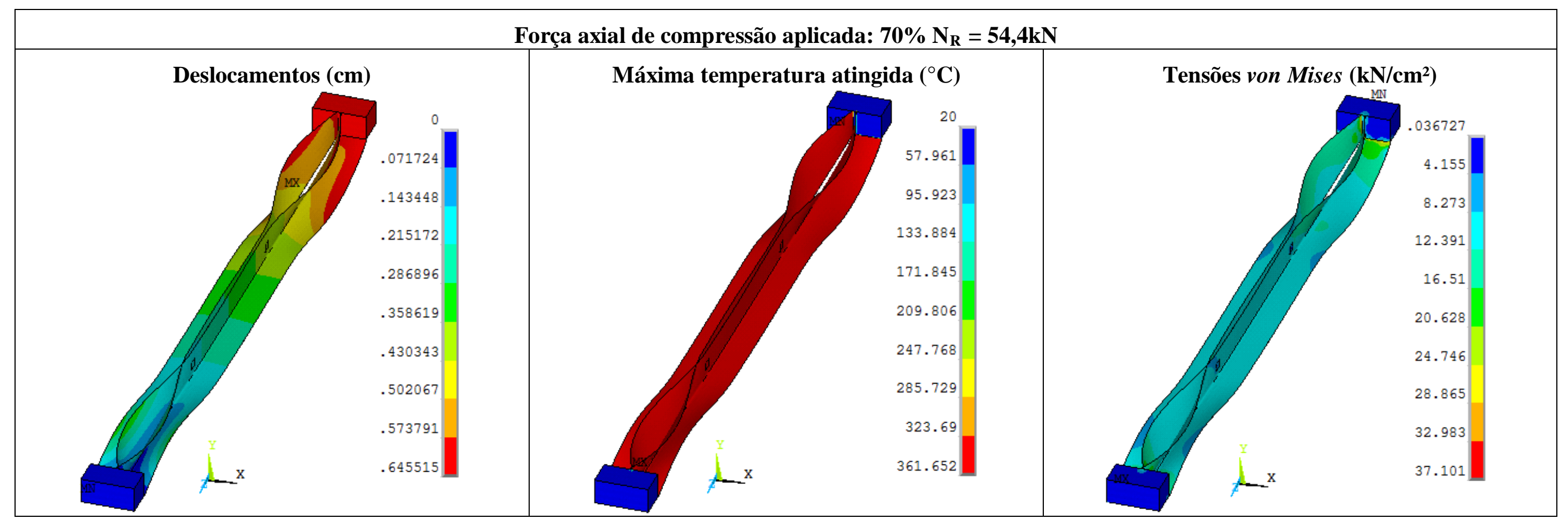




$$
\begin{aligned}
& 7177 \\
& 111 / 1
\end{aligned}
$$




$$
7171
$$




$$
\begin{aligned}
& 7171 \\
& 71111
\end{aligned}
$$




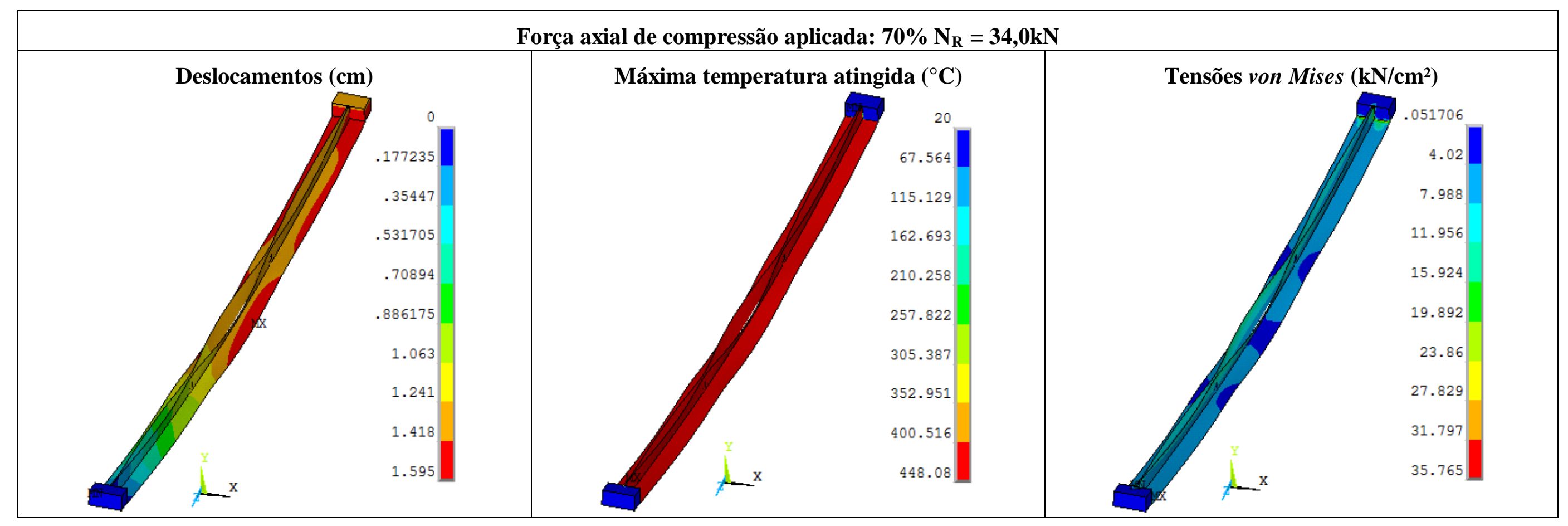

